Universidad deValladolid

PROGRAMA DE DOCTORADO EN FILOSOFÍA

TESIS DOCTORAL:

\title{
CUERPO Y PODER DESDE LOS ALBORES DE LA MODERNIDAD. EL LUGAR DEL PODER CON RELACIÓN A LA CORPORALIDAD HUMANA EN EL SUJETO, LA SOCIEDAD Y SUS ARTICULACIONES
}

Presentada por Alejandro Recio Sastre para optar al grado de Doctor por la Universidad de Valladolid

Dirigida por:

Dr. Fernando Longás Uranga y Dr. Raúl Villarroel Soto 
A Giovanna Rosado Holguín, por la confianza, el amor, la paciencia y la entrega que me ha dado a lo largo de este recorrido. 
Agradecimientos para mis padres $y$ abuelos por haberme apoyado $y$ sustentado durante mi periodo como tesista. También agradezco a mis tutores Fernando Longás Uranga y Raúl Villarroel Soto el interés que han mostrado hacia el tema de mi tesis, así como su sabia, docta e inteligente tutela. 


\section{ÍNDICE}

INTRODUCCIÓN ....................................................................................................... 11

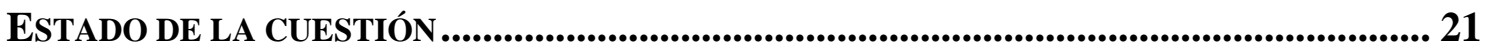

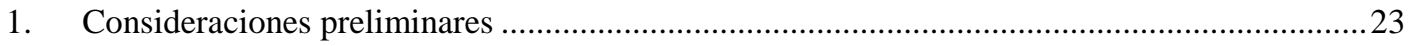

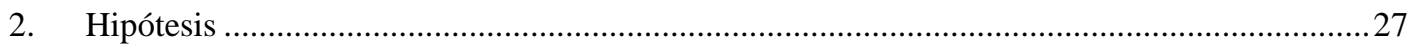

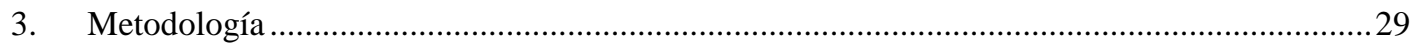

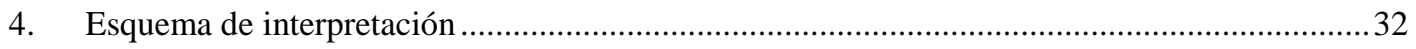

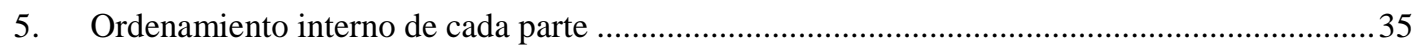

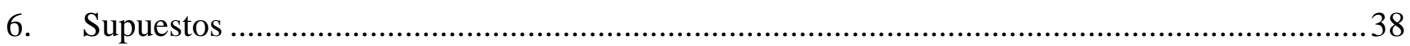

Primera PARTE: Perspectivas filosóficas Sobre el CUERPo en los inicios de la

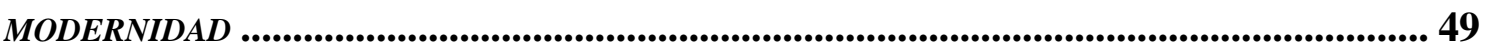

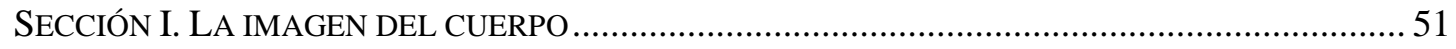

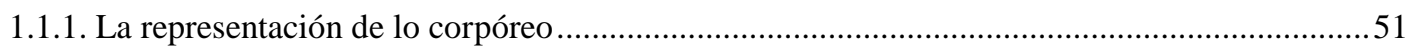

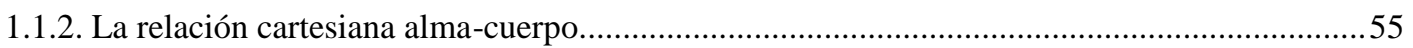

1.1.3. La corporalidad en medio de "la batalla final por el alma humana" .........................................61

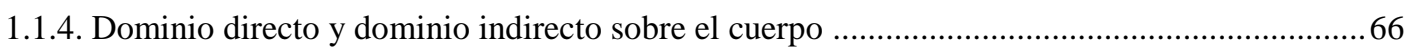

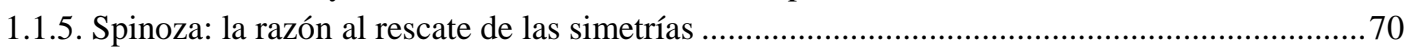

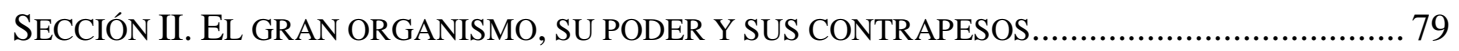

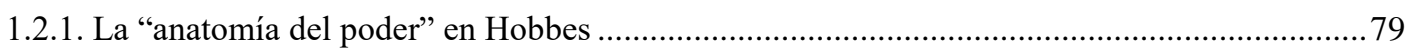

1.2.2. La tendencia humana a formar cuerpos políticos y la analogía entre el individuo y el Estado en

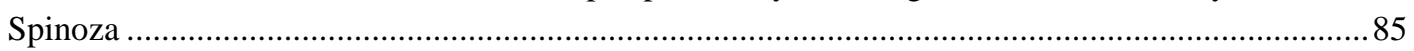

1.2.3. El drama municipal de Fuente Ovejuna interpretado desde la filosofía política hobbesiana...92

1.2.4. Fuente Ovejuna y el problema político del tiranicidio............................................................96

1.2.5. Una interpretación spinozista de Fuente Ovejuna: la potencia política multitudinaria...........103

SECCIÓN III. ESPACIO ESFÉRICO: MÁRGENES DE LA POLÍTICA EN LAS NUEVAS DIMENSIONES

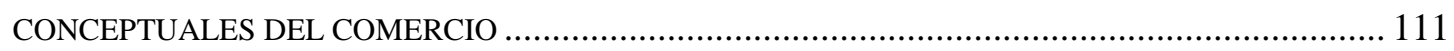

1.3.1. La geografía del poder en la nueva imagen del mundo ..........................................................11

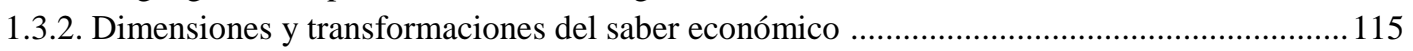

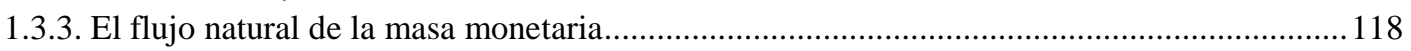

1.3.4. El poder del espacio comercial en la filosofía política de Locke .............................................123

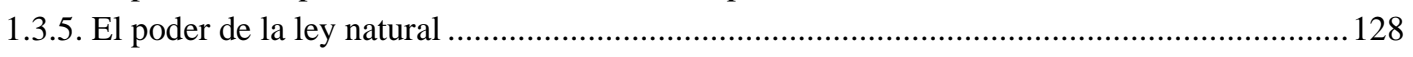

SEGUNDA PARTE: LA CORPORALIDAD EN LA NATURALIZACIÓN Y SECULARIZACIÓN DIECIOCHESCAS DE LOS ESPACIOS POLÍTICO Y ECONÓMICO..................................... 135

SECCIÓN I. LOS MECANISMOS CORPORALES EN LA INDAGACIÓN DE LA NATURALEZA HUMANA

137

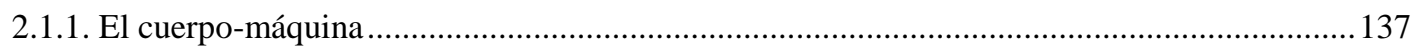

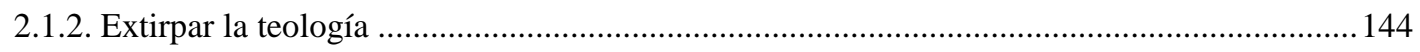

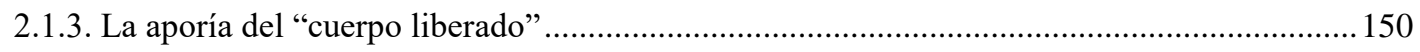

2.1.4. Rousseau: la corporalidad entre el hombre salvaje y el hombre civilizado ............................ 157

SECCIÓN II. DESTRUCCIÓN Y RECONSTRUCCIÓN: PODERES SECULARES PARA EL

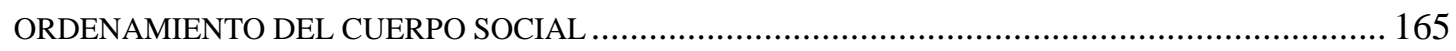

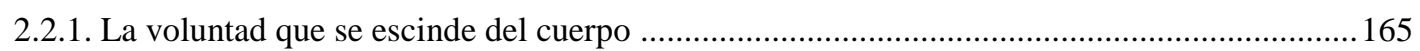

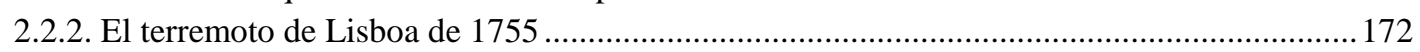

2.2.3. Conmoción y excepcionalidad: los dispositivos del Marqués de Pombal............................... 178

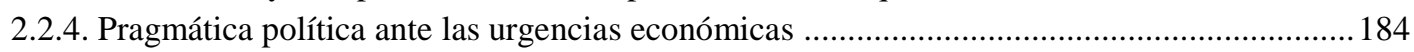

2.2.5. Gobierno como encauzamiento de los flujos de la población ..................................................189 
SECCIÓN III. CUERPOS VIGILADOS: DISPOSICIONES ASIMÉTRICAS EN LA ARTICULACIÓN DEL

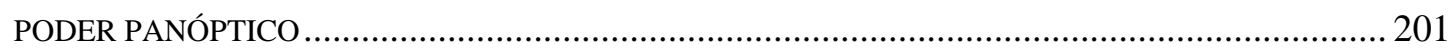

2.3.1. Contexto histórico-local del panóptico ...............................................................................201

2.3.2. La filosofía del panóptico ...............................................................................................204

2.3.3. dióptrica política, asimetría sensual y mecanismos de presión psicológica ...........................2211

2.3.4. Lo corporal bajo el dominio de la utilidad ..........................................................................217

2.3.5. La productividad de la vigilancia en el incipiente capitalismo industrial ............................221

TERCERA PARTE: Planteamientos deCimonónicos ACERCA DEL DOMINIO SOBRE LOS CUERPOS Y LAS REPERCUSIONES POLÍTICAS DE LA POTENCIA CORPORAL .................. 227

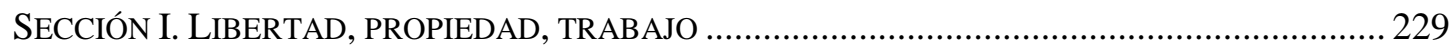

3.1.1. Libertad soberana y libertad del individuo .................................................................229

3.1.2. La emancipación de la individualidad y la defensa del derecho de propiedad privada..........234

3.1.3. La beligerancia del reconocimiento ..............................................................................241

3.1.4. La voluntad libre y la apropiación del cuerpo en el Estado de Derecho: implicaciones políticas de la naturaleza corporal ................................................................................................24

3.1.5. Marx: el eclipse del cuerpo del obrero tras el valor de cambio de la mercancía ...................256

SECCIÓN II. LA FUERZA CORPORAL Y LA POTENCIALIDAD POLÍTICA DEL SOMA SOCIAL...... 265

3.2.1. El cuerpo del pueblo en disputa .......................................................................................265

3.2.2. Marx y el poderío del cuerpo social .................................................................................2 273

3.2.3. Articulaciones físicas y articulaciones incorpóreas de la dominación capitalista ..................2277

3.2.4. Nietzsche: la individualidad degradada del sujeto moderno, el estado como instrumento de supervivencia y el cuerpo delator .......................................................................................28

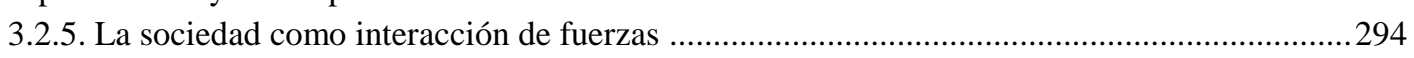

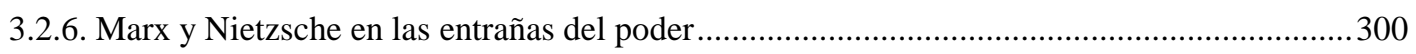

SECCIÓN III. EVOLUCIÓN, PROGRESO, DECADENCIA ............................................................. 307

3.3.1. El evolucionismo y el desarrollo de los organismos naturales y políticos ...............................307

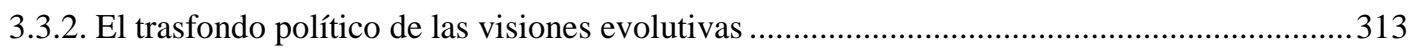

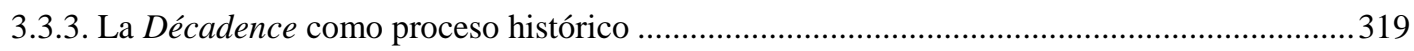

3.3.4. La corporalidad como potencia inmanente en el desarrollo de la vida: críticas de Nietzsche y

Bergson al evolucionismo darwinista ................................................................................ 327

CUARTA PARTE: LO CORPORAL COMO SUJETO DE PODER Y OBJETO DE DOMINACIÓN . 335

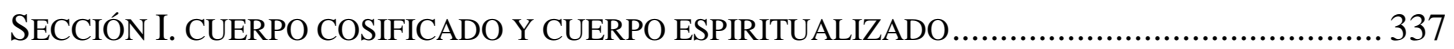

4.1.1. Merleau-Ponty: conciencia y cuerpo en el pensar fenomenológico .......................................337

4.1.2. El cuerpo objetivo es un extraño: redescubrimiento de la corporalidad .................................341

4.1.3. El cuerpo como espacio, como síntesis y como presencia del Otro......................................346

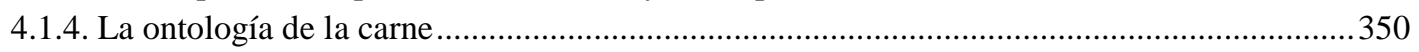

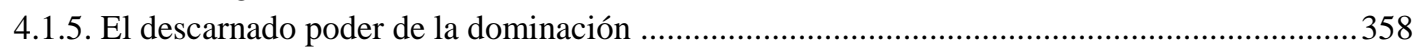

4.1.6. Desfiguración subjetivada de lo corporal en el juego erótico .................................................362

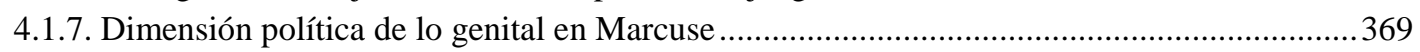

SECCIÓN II. SISTEMAS DE CONTROL FRENTE A LA POSIBILIDAD DE UNA COMPLEXIÓN SOCIAL FUERTE: EL SALVOCONDUCTO DEL INDIVIDUALISMO ECONÓMICO.................................... 377

4.2.1. Marcuse y la dominación híbrida en las sociedades industriales avanzadas ..........................377

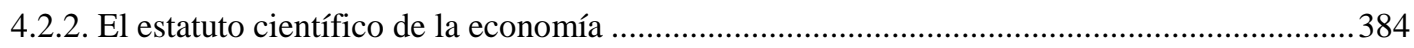

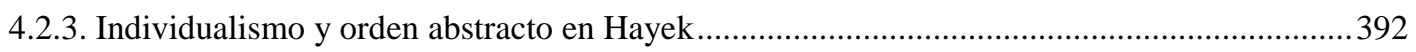

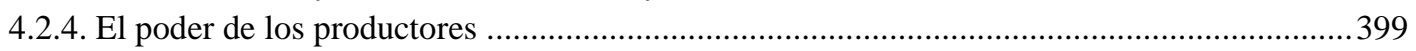

SECCIÓN III. MODULACIONES DE LA RELACIÓN CUERPO-PODER......................................... 409

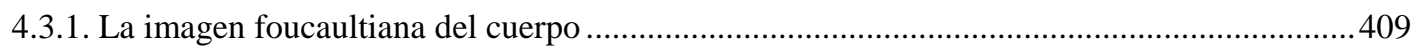

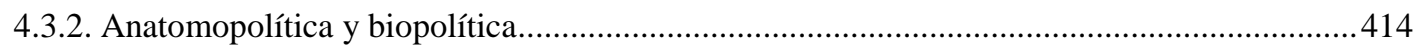


4.3.3. Realización del biopoder: espacios de poder más allá de la jurisdicción

4.3.4. Escisiones de las fuerzas corporales .........................................................................427

4.3.5. La estructura económica del poder ............................................................................... 432

4.3.6. El problema de la desubjetivación y subjetivación de los dispositivos ................................439

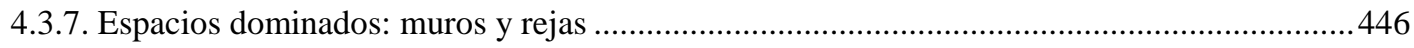

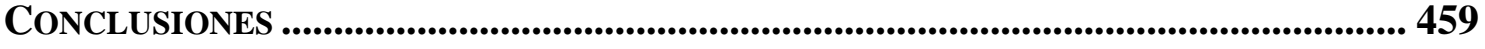

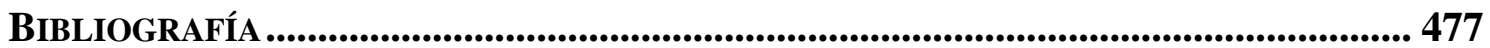




\section{INTRODUCCIÓN}


ntes de iniciar toda reflexión filosófica sobre el cuerpo humano, ya sea "mi cuerpo", el del otro, el de una corporación, el de una sociedad, etc., es preciso situar con pertinente diligencia cuál es la noción que proponemos cuando empleamos términos como "cuerpo", "corporalidad", "dimensión corporal", "fisiológico" o "anatómico". Pues bien, el cuerpo al que nos referimos, con todas las derivaciones terminológicas que lo concretan dentro del discurso, no apunta a un concepto universal, puesto que no vamos a adentrarnos en investigar una supuesta corporalidad que aspira a convertirse en categoría. Nuestra consideración sobre el cuerpo parte de que toda forma de vida requiere de algún tipo de corporeidad, hecho que en el caso de los seres humanos no es distinto. Podría objetarse que la concurrencia familiar, social, política y económica de los individuos forma identidades ficticias que bien caen bajo la analogía de cuerpo pero que en realidad son composiciones de individuos agregados unos a otros, sin embargo, podría responderse que estas concurrencias precisan, necesariamente, de cuerpos que las realicen.

Problema aparte sería saber hasta qué punto los cuerpos humanos se organizan, combinan y sincronizan como si fueran componentes de un organismo vivo o de un todo orgánico-corporal; esta es una cuestión filosófica que no queda al margen de 
nuestra problemática. Entonces, - a no ser que ahora se demuestre lo contrario- toda forma de vida ha de contar con algún tipo de cuerpo. Sin ánimo de elevar esta certeza al grado de categoría, por tanto, establecemos una consideración del cuerpo humano en cuanto ser viviente, ser biológico que crece, se nutre, se tensa, se relaja, intenta reproducirse, siente el daño, siente el placer y termina muriendo inexorablemente.

En concreto, todo cuerpo humano tiene órganos, tejidos, piel, huesos, sangre, etc., pero, además de estos elementos materiales que también pueden formar parte de los cadáveres, las corporalidades humanas portan consigo una biografía, unas experiencias retenidas en la memoria, unos relatos, una individualidad singular y genuina, etc., elementos todos ellos que pertenecen a la subjetividad y que no son apreciables a simple vista ante los ojos de los demás: uno puede andar por la calle y ser visto por los otros como un completo desconocido, un cuerpo que transita por la acera como otro “cualquiera” y que las miradas anónimas no saben "quién” es. Así también, el humano, en cuanto ser biológico y biográfico, en cuanto ente susceptible de ser movido por una dimensión subjetiva que alberga convicciones, deseos, pasiones, ideas, reflexiones, emociones, etc., ese mismo ser humano que puede hacer expresables sus vicisitudes subjetivas a través del rostro, los gestos, la voz, los movimientos de la lengua, etc., pero que también oculta lo que no quiere manifestar ni hacer expresable, convierte a la subjetividad en algo centelleante de cara a la vida exterior donde su corporalidad interactúa con las otredades.

Algunas filosofías primaron la dimensión interior del hombre sobre su ser biológico, trataron de emancipar lo subjetivo y ponerlo a disposición de un espíritu llamado a tomar las riendas de la vida, a dirigir al hombre más allá de su mera dimensión corpóreo-biológica. Otras filosofías, en cambio, apuntaron al cuerpo como lo único existente, como la única sustancia de la naturaleza y causa eficiente de todo lo subjetivo. Por tanto, de forma muy general y escueta, se podría afirmar que algunas filosofías pensaron que la dimensión subjetiva del hombre contenía su verdadera forma de ser, mientras que por el contrario otras sostuvieron que lo subjetivo no es más que un derivado del propio cuerpo.

Las múltiples relaciones de los seres humanos, en las que se ven involucrados sus cuerpos de forma ineluctable y en las que cada individuo arrastra su subjetividad, constituyen un espacio de compromisos y luchas, de concurrencias interesadas o altruistas, de subyugaciones forzadas o voluntarias, de normativas y traiciones: 
consideraremos que todas estas acciones impelidas por conjuntos de cuerpos que comparten un espacio común, todas ellas, constituyen variables que apuntan y nos conducen hacia aquellos aspectos de la vida social que vamos a tomar como "lo político" o la "política". Los cuerpos humanos contienen fuerzas que se intensifican o aminoran según el carácter de las relaciones en que están inmersas, hay un circuito de potencias y un campo de fuerzas capaces de mover o detener a toda una sociedad, de dirigir a poblaciones enteras, de administrar los procesos vitales de los cuerpos, así como de unir y separar a individuos y agrupaciones.

Las corporalidades ocupan un lugar en el espacio donde se desenvuelven las relaciones humanas, tanto en la vida más familiar, privada e íntima como en sus composiciones de índole pública más complejas. Por eso algunos filósofos creen conveniente que las fuerzas de los cuerpos sean reguladas desde instancias externas; instancias necesarias para administrar una dirección sobre el sí mismo o una política sobre los cuerpos que forme una sociedad vertebrada; para ello hacen falta dominaciones que articulen unos instrumentos de control. Otros pensadores vieron que las fuerzas corporales comportan la presencia de un poder inmanente, un poder que subyace a los cuerpos, y que, por tanto, la propia fortaleza corporal implica algún tipo de poder. Partiendo de estas premisas, nuestra hipótesis principal no profundiza exactamente en destacar los aspectos más inadvertidos de esta discusión, sino que tomamos al cuerpo como una potencialidad, partiendo de la base de que efectivamente las fuerzas del cuerpo y de los cuerpos pueden llegar a constituir una forma de poder y que, consecuentemente, son capaces de generar una institucionalidad y constituir así lo político. Pero, ahora bien, sobre esta misma base tenemos en cuenta aquellos discursos filosóficos que procuraron estrategias teóricas y argumentativas por medio de las que se justifica la obstrucción de esa corporalidad que entraña y arraiga un poder: unas estrategias que bien se centraron en el dominio de las subjetividades como forma de impeler un control sobre los cuerpos, o bien tendieron a aprovechar la potencia inherente de estos para construir mecanismos materiales destinados a dominar sobre sociedades e individuos. Los discursos subyacentes a estas estrategias han variado la imagen conceptual del cuerpo natural del individuo, así como también la de los cuerpos congregados en sociedad. Tales discursos instauraron la imagen de una corporalidad y de un soma social pasivos, lo que les inhabilitaba para implantar formas políticas por sí mismos. De modo que vemos en estas estrategias el recurso a disposiciones que cortan 
el canal de fuerzas corporales susceptible de generar algún tipo de novedad, intromisión, irrupción o consecuencia en el campo de la institucionalidad política y económica.

La discusión filosófico-política en torno al cuerpo que pretendemos abrir conlleva el siguiente debate: si las fuerzas naturales de los cuerpos han de ser controladas con el fin de hacer emerger un soma social vertebrado y organizado, ¿acaso no se le está ya concediendo una cierta densidad política a la fuerza corporal cuando se plantea la necesidad de dominarla? ¿Y si el interés por dominar las fuerzas naturales de los cuerpos escondiera en el fondo un cierto temor a que la política institucionalice lo corporal en todas sus facetas, incluidas aquellas que suscitan acritudes impúdicas y aquellas que van referidas a necesidades meramente biológicas de los organismos vivos? Pero, por otra parte, en lo que respecta a la línea filosófica que preconiza un poder inmanente a las fuerzas corporales y que, en cierto modo, reclama su irreversible e irrenunciable presencia en los espacios políticos, se plantean no menos problemas respecto a sus implicancias filosóficas: si la individualidad humana se halla desnuda y expuesta ante las inclemencias de la naturaleza, viéndose por tanto obligada a concurrir en sociedad, si las fuerzas humanas requieren de una unidad que agregue cuerpos, así como de un soma social que haga más resistentes y menos vulnerables a los individuos y a los grupos humanos, entonces ¿será que la sociedad como organismo ha de enajenar gran parte de las fuerza de los cuerpos singulares a favor de subsistir y permanecer como soma social? ¿Qué equilibrios hay entre las fuerzas sociales y las instituciones que de ellas emergen? ¿Cuál es exactamente ese poder que albergan los cuerpos humanos? ¿Cómo se manifiesta? ¿Tiene un origen, o todavía no se ha realizado? ¿Acaso tuvo vigencia en algún momento anterior, a saber, en un momento pre-político? Y de ser así ¿es posible que este poder todavía irrumpa en el orden donde se articulan y complejizan la vida pública y privada?

La primera consideración de la que partiremos para hacer frente a las cuestiones filosóficas que con tanto vigor nos apelan consiste en situar lo corporal en la centralidad de la política. Ninguna decisión procedente de una instancia de poder, es decir, ninguna determinación política podría hacerse efectiva sin cuerpos, del mismo modo que ningún acto de rebelión podría tomar su carácter y expresión sin corporalidades humanas que lo promuevan y secunden. De igual manera, los derechos de explotación y el derecho a ser explotado dignamente sitúan lo económico en el entorno de las fuerzas que emanan de la corporalidad. Lo corporal, entonces, centrifuga el desarrollo de la política y su 
extensión económica, puesto que los cuerpos y sus agrupaciones configuran una constelación de cuya inercia surgen tensiones tras las que se advierten formas de poder. Por ello, consideraremos que las fuerzas del cuerpo se arrojan, se expulsan, se propagan, o, también, se contraen, se retienen y se envilecen como una estrella que languidece. Todas estas determinaciones del poderío subyacente al cuerpo alcanzan una dinámica en un juego de intervalos donde la corporalidad natural de los individuos articula integraciones que dan lugar a nuevos dominios, resistencias, controles, autocontroles inducidos y administraciones de potencias subyacentes a cuerpos individuales y corporaciones sociales.

Pensaremos al cuerpo como punto de referencia, en torno al cual orbitan los elementos de la política: estrategias de control y administración, instituciones, leyes, autoridades, dispositivos, etc. El cuerpo será pensado como una inercia que impulsa y se agencia de las fuerzas que intervienen en las luchas de poder, una inercia hacia la que tienden las voluntades dominantes y las voluntades resistentes, así como las decisiones administrativas y los sistemas de control. A este respecto, nunca lo pudo advertir mejor el profesor José Jara en lo que se refiere a la expresión de Nietzsche: "el cuerpo como centro de gravedad"1. Nosotros no tomaremos como punto de partida concreto la imagen nietzscheana de lo corporal, aunque la imagen del cuerpo como centralidad fehaciente desde la que pensar lo humano coincida plenamente con ella. Posicionar al cuerpo en el centro de las connotaciones sociales, políticas y morales trae consigo priorizar un examen exhaustivo de las imágenes del cuerpo trazadas por la filosofía, en concreto serán revisadas las que se dieron a inicios de la modernidad, es decir, nuestra reflexión no comienza con el punto de inflexión tan importante $-\mathrm{y}$ por nuestra parte celebrado- que dio la filosofía de Nietzsche en su viraje a la vida y al cuerpo, sino que nuestra reflexión se iniciará con el giro moderno a la subjetividad, giro que no pudo por menos resituar la dimensión corporal en relación con el lugar prominente del sujeto.

\footnotetext{
${ }^{1}$ En el libro titulado Nietzsche un pensador póstumo, que lleva por subtítulo El cuerpo como centro de gravedad, José Jara afirma que precisamente la imagen teórica que se desprende de la aseveración de Nietzsche en la que el cuerpo es el <<centro de gravedad>> aparece como una diatriba global contra el filosofar occidental y como una nueva mirada antropológica, una mirada centrada en el hombre en cuanto ser viviente [confrontar en: Nietzsche un pensador póstumo (Barcelona: Anthropos, 1998), 106-107]. Además, el profesor Jara advierte que la alusión de Nietzsche a la centralidad del cuerpo pretende instaurar a la corporalidad como principal actor de la vida, dentro de un sistema donde lo corporal $<<$ adquiere su sentido y puede ser entendido. El cuerpo es el centro de gravedad del hombre dentro del sistema de su existencia, compuesto tanto por elementos fisiológicos como teóricos, morales y valorativos, dando lugar a la vez a su inserción dentro de un pueblo y de una cultura, regional o suprarregional, que serían los horizontes de mayor extensión dentro de los que cabe analizar su situación y acción gravitatoria central〉>, ob. cit., 109.
} 
Pero más allá de una ruptura con la herencia teológica, más allá de las prioridades epistemológicas y del nuevo cariz meditativo de la filosofía moderna, la mera posibilidad de que el cuerpo tomara las riendas de la vida humana era de por sí una posibilidad más polémica de lo que parece. Nuestra idea es que el cuerpo del sujeto emancipado de los modernos guarda un poder intrínseco, un poder que puede emerger desde la inmanencia de las fuerzas corporales; ese era el poder que había que reconocer y detener.

Seguramente a Descartes la situación hipotética de un cuerpo que rigiera la vida del sujeto humano le resultaba como poco irracional, además de desagradable, por eso sitúa al alma racional a ras del cuerpo; es esa misma situación hipotética que Hobbes trasladó al ámbito de las relaciones públicas, y que hace de los cuerpos humanos nada más que individualidades incapaces de establecer por sí mismas un orden civil y una vida social pacífica y segura. Por otro lado, en ese mismo siglo Spinoza sí le reconoció su lugar y relevancia al cuerpo en conjunción con el alma individual e institucional; al menos este célebre filósofo formuló la nada desdeñable pregunta de "cuánto puede un cuerpo", lo que deja entrever un sistema de pensamiento en el que lo corporal adquiere una cocentralidad con el alma en lo relativo a la gravitación de los conceptos políticos.

Tras el siglo XVII, quizá también el materialismo dieciochesco dio los primeros pasos hacia una vida política realizada desde los engranajes naturales de esa "máquina" que los humanos supuestamente tenemos por cuerpo, pero también en ese siglo se dio la distinción rousseauniana entre el mecanismo y la agencia libre que caracteriza al hombre. Mención aparte merece Bentham, cuyo panóptico creó todo un sistema de fisuras dentro de la individualidad que le permitieron calcular el ahorro en medios físicos para vigilar al hombre a costa de perpetuar el poder en su mente, creando de este modo automatismos subjetivos que movieran los cuerpos al son de un poder invisible. Obviamente, en el siglo XIX Marx y el ya mencionado Nietzsche trazaron nuevas imágenes conceptuales de la corporalidad, en el caso de Marx muy a la sazón de Hegel, puesto que en una versión materialista de la dialéctica los cuerpos humanos estaban llamados a hacer aquello que el espíritu no podía llegar a realizar. Por último, en el siglo XX se encuentran los incesantes intentos de Merleau-Ponty por restaurar la unidad entre lo corporal y lo espiritual, a saber, si en su filosofía última, la ontología de la carne, devolvía al hombre a su comunidad intercorporal y a su origen como forma elemental del ser. También los análisis críticos que rehabilitaron en el escenario político al 
olvidado "cuerpo sexuado" llaman nuestra atención y adquieren especial relevancia en Marcuse, quien además, divisó como ningún otro el modo en que la producción de subjetividad mueve y articula los cuerpos en la sociedad según intereses ajenos a los individuos. Y en último término se halla Foucault, quien definitivamente hizo de los cuerpos pensamiento filosófico. 


\section{ESTADO DE LA CUESTIÓN}




\section{CONSIDERACIONES PRELIMINARES}

De entre los incontables problemas que afronta la filosofía, de entre tantos temas irresueltos pero vigentes en el curso de las reflexiones filosóficas, el de la corporalidad se impone como uno de los asuntos más complejos y disputados pues su incesante actualidad resulta irrenunciable. En casi todas las áreas disciplinares de la filosofía la cuestión de lo corporal en la vida humana genera discursos controversiales, así, entonces, el tema del cuerpo en la historia del pensamiento filosófico siempre ha sido uno de los temas más concurridos por parte de autores y sistemas de pensamiento, de tal forma que, y de algún u otro modo, el cuerpo como temática suscita tal complejidad que convoca una considerable variedad de planteamientos en torno a él. La dimensión corporal del hombre en los márgenes de la individualidad y de la sociedad, como también en sus respectivas articulaciones, desarrolla un tiempo y abre un espacio político y económico que configura niveles de reflexión cuya culminación se corresponde con cuestiones pertenecientes a la filosofía política, en tanto en cuanto la corporalidad es una referencia indeleble para el estudio de las relaciones de poder y, muy concretamente, en lo que respecta a la relación cuerpo-poder, ya sea a partir de variables subjetivas, socio-económicas, históricas o de todas ellas a la vez.

Conviene hacer patente, en primer lugar, qué relación existe entre los términos cuerpo y poder puesto que su entrelazamiento conforma la problemática que va a ser pesquisada. Hay una metáfora que bien vale para ilustrar esta relación: En Masa y poder Canetti establece una diferencia fundamental entre la noción de fuerza y la noción de poder cuando plantea la situación del ratón cazado por el gato. El ratón que cae bajo las garras del gato está sometido a la fuerza de su cazador, pero cuando el gato, pudiendo matar ipso facto al ratón, le concede un cierto margen para escapar, sucede que el felino se permite el lujo de jugar con su presa, dado que le atribuye un margen de espacio y tiempo para seguir viviendo, le concede la esperanza de huir y salvarse. Aun teniendo el gato perfectamente controlado al ratón, es precisamente en ese margen espaciotemporal, en ese intervalo en el que todavía el ratón cuenta con cierta esperanza de vida, donde surge el poder ${ }^{2}$.

El poder, de acuerdo con la metáfora que brinda Canetti, sería una fuerza que se contiene a lo largo de una cota de tiempo y espacio. A diferencia de la "fuerza bruta",

\footnotetext{
${ }^{2}$ Cfr. Elías Canetti, Masa y poder (Barcelona: Muchnik Editores, 1985), 277.
} 
que se aplica puntualmente como un acto abrupto y efímero, el poder aparece como una fuerza dilatada. Más allá de la metáfora de Canetti, se podría también suponer una relación entre el ratón y el gato en la que la presa logra ejercer poder sobre su depredador: imagínese al ratón escabulléndose a través de un terreno favorable a su complexión, un terreno que le permite transitar espacios angostos que el cuerpo del gato no puede atravesar. En este caso ¿no podría permitirse también el ratón "el lujo” de jugar con el gato, de hacer exasperar su hambre mientras exhibe el poder que tiene de ocupar lugares donde el cuerpo del felino nunca cabría? Este ejemplo invertido de la metáfora empleada por Canetti para simbolizar el poder da cuenta de la inextricable integración existente entre los cuerpos y el poder. Efectivamente el poder es más que la fuerza, pues el poder mana de ella y la amplía; asimismo, la agencia que concatena las fuerzas, necesariamente, habrá de recaer en un juego relacional de cuerpos que ponga en circulación y procesión sus fortalezas. Si el ratón es capaz de introducir su cuerpo en lugares por los que el cuerpo del gato no cabe, el ratón estaría mostrando una capacidad que le empodera frente a su depredador en tanto en cuanto se está eximiendo de su destino como presa. Este es precisamente el poderío del cuerpo que se pretende poner de relieve, un poderío que la filosofía implícita o explícitamente no ha desconocido, pero que en algunos casos ha sido escindido, desfragmentado y descompuesto en virtud de configuraciones de poder que han sido pensadas como extrínsecas a la corporalidad. Cuando se concibe un poder posicionado hacia el exterior de la inmanencia corporal, la corporalidad pasa a ser valorada como un amasijo o conglomerado de fuerzas que esas instancias de poder externas habrán de controlar, gestionar, regular y dosificar.

La noción de poder que Canetti destaca a través de la metáfora del ratón y el gato ha sido criticada por Byung-chul Han, al considerar que la noción de poder no se reduce solo al ejercicio de la violencia y a la subsunción que esta genera en quien la recibe ${ }^{3}$. Según Byung-Chul Han el poder no solo se extiende sobre el horizonte de la muerte, pues más que matar, el poder ante todo "deja vivir", de modo que Canetti no habría tenido en cuenta los márgenes de vida que subyacen al poder ${ }^{4}$. Pero esta crítica resulta un tanto desorbitada si se presta atención al hecho de que el poder surge dentro de una relación dada en los intervalos de la vida, una relación entre el ratón y el gato que lidia con la muerte en tanto en cuanto vivir también implica morir -y el "dejar vivir" ya

\footnotetext{
${ }^{3}$ Cfr. Byung-Chul Han, Sobre el poder (Barcelona: Herder, 2016), 43.

${ }^{4}$ Cfr. Han, ob. cit., 44.
} 
supone abrir un intervalo con respecto a la muerte que amenaza todas las formas de existencia humana-.

El poder emerge en medio de relaciones entabladas entre seres mortales como lo son los seres humanos, así que pensar el poder en la vida es pensar el poder desde los cuerpos. La potencia de la muerte se vuelve un recurso con que oprimir, coaccionar, reprimir, replegar y debilitar las fuerzas de los cuerpos; la intensificación, el estiramiento y el empuje de la vida son características propias de ese poder corporal que se despliega y encoge ante el acecho del momento ineluctable de la muerte. Entonces, más que considerar un poder fundamental, estructurado internamente y manifiesto en diferentes instancias ${ }^{5}$, habrá que hacerse cargo de un poder cuya simiente parte de la corporalidad y florece a medida que los cuerpos van trazando nuevos y diferentes itinerarios según se van desarrollando las relaciones humanas, que tienen un contenido político en casi todas - por no decir todas- sus configuraciones. Desde la forma de entender el gobierno de sí mismos hasta el complejo histórico institucional y gubernamental se suceden aquellos intervalos donde cuerpo y poder, según el posicionamiento del segundo, dejan apreciar determinaciones muy diferentes que no aluden a un poder estructural, sino que, más bien, impone la exigencia de seguir su composición genética y la aspiración de localizar sus raíces. Se entiende, por tanto, que el poder varía según la relatividad de los cuerpos; no hay, consecuentemente, una estructura del poder que pueda erguirse de forma estable. Tampoco cabe suponer, al modo en que lo hace Han, un tipo de poder jerárquicamente superior a otra u otras formas de poder, a saber, un <<poder absoluto>> alcanzable solo <<en el momento en que la libertad y el sometimiento coincidan del todo $>>^{6}$. Un poder de esta envergadura va a ser considerado solo bajo la circunstancia de una estrategia de dominación centrada en la dimensión subjetiva humana, estrategia de dominación que presupone una subjetividad escindida de lo corporal y en virtud de la cual el cuerpo es dirigido según la voluntad de un sujeto teóricamente libre. Si bien es cierto que esta forma de poder inmaterial resulta muy efectiva, puesto que trae consigo dificultades a la hora de ser localizada y fácilmente se funde con la libertad, no es menos cierto que las figuras de poder que se dan bajo esta coyuntura estratégica no se muestran necesariamente superiores a las figuras de lo que sería una estrategia de dominación material, tendente a

\footnotetext{
${ }^{5}$ Cfr. Han, ob. cit., 9-10.

${ }^{6}$ Han, ob. cit., 17.
} 
corporalizar dichas figuras. A la luz de este último fondo estratégico de dominación, las formas de poder que de él surgen van a ser tratadas y valoradas en el mismo nivel que las figuras de poder subjetivadas e incorpóreas, sin imponer jerarquías entre ellas; ya que tanto el poder más sutil y subjetivado como el poder más virulento y objetivado trazan estilos de dominación que cuentan con importantes ventajas, así como también con serios inconvenientes ${ }^{7}$.

La historia del pensamiento filosófico y político moderno y las reflexiones que se dieron en torno a determinados itinerarios, representaciones y acontecimientos de la historia permiten acceder a unas imágenes del cuerpo en las que se detectan distintas posiciones del poder; dichas posiciones delatan una regimentación y regulación del cuerpo de los individuos y de la corporalidad social. Es dentro de esa historia moderna y en sus sucesivas transformaciones contemporáneas donde se recoge la historia de esa desfiguración de las concepciones y representaciones de los cuerpos, una historia que ha transfigurado la dimensión corporal humana en virtud de mantener latentes unos sistemas de dominación y de resistencia, unos regímenes de control y de liberación, o unas correlaciones de fuerza desfragmentadas y reunificadas sucesivamente. Las dilataciones, contracciones, retenciones y afianzamientos de la potencia corporal hacen ostensible cómo la modernidad y la contemporaneidad acudieron a ese cuerpo al que no siempre se le reconoció su poder en cuanto forma política. Es en ese lapso de tiempo que atraviesa cuatro siglos donde se dan algunos de los planteamientos filosóficos que contribuyeron a desfigurar la corporalidad en su imagen, mas no en su posición céntrica; una desfiguración que se produjo bien porque las fuerzas del cuerpo fueron escindidas de su poder, bien porque ya no había en ellas un punto de anclaje desde el que pensar lo político en cuanto inmanencia corpóreo-vital.

\footnotetext{
${ }^{7}$ La inspiración de estudiar estrategias de dominación sopesando y contrastando las formas de poder que a ellas subyacen procede del estilo en que Jeremy Bentham expuso las ventajas y pormenores del panóptico, un edificio factoría del ingenio del filósofo británico y de su hermano. Fueron las cartas y comentarios del ilustre pensador y jurisconsulto inglés acerca de este edificio de hacinamiento, vigilancia y control de donde fue extraída la idea de valorar las estrategias de dominación a través de un cálculo en el que se diera debida cuenta, por un lado, de los medios coactivos y represivos directos y, por el otro, de los métodos para imponer un régimen de control sobre la imaginación humana como forma de perpetuar el poder en la subjetividad de los individuos. Bentham valoró los pros y las contras del panóptico como espacio de reclusión e instrumento rentable de vigilancia, para ello se valió de una serie de cálculos teóricos que habrían de ser aplicados para lograr una dominación efectiva a la vez que eficiente. La forma en que el fílósofo llevó a cabo el milimetrado cálculo del instrumento de dominación que propuso, permitió dar cuenta de lo útil y necesario que resulta mensurar el alcance y las limitaciones de las configuraciones de poder con que los hombres son interceptados y controlados. De ahí la decisión de "mensurar" las dos estrategias de dominación que serán propuestas en este trabajo, un procedimiento que implica tratar de manera sistemática la capacidad, ventajas y desventajas de los dos tipos de figuras de poder que serán analizadas y, en buena medida, ponderadas desde un prisma teórico-filosófico.
} 


\section{HIPÓTESIS}

El problema filosófico que se va a abordar viene determinado por la cuestión del cuerpo humano conceptualmente representado como el objeto por excelencia de la dominación, de lo que se deriva, a su vez, que la corporalidad de los individuos es susceptible de encarnar algún tipo de poder. Si se entiende que la dimensión corporal humana precisa ser controlada y dominada, entonces, asimismo, también ha de suponerse que las fuerzas inherentes al cuerpo humano tienen posibilidades de llegar a comportar un poder nada desdeñable en lo relativo a la realización de la política.

Estas dos cuestiones imponen la necesidad de tratar el tema de la relación que guarda el cuerpo humano con el poder, lo que implica tomar como asunto problemático la vinculación entre ambos términos dentro de determinados planteamientos filosóficos que se han ido sucediendo en la historia de las ideas, concretamente, en aquellos que se han desenvuelto a lo largo de la modernidad y en buena parte de la contemporaneidad. De este modo se tratará de elucidar qué tipo de relación existe entre la corporalidad y las formas de poder que acaecen en el seno de la vida humana, partiendo de que la filosofía ofrece discursos en los que se puede detectar esta relación, en cuyo contenido participan los diferentes tipos de acontecimientos sociales y representaciones culturales devenidos a lo largo de la historia. Para hablar con mayor precisión, se atenderá al lapso de tiempo que ocupan los siglos XVII, XVIII, XIX y XX.

Primero, el poder encarnado en el cuerpo y, segundo, el cuerpo como objeto de dominación, tal como fue adelantado en un inicio, son dos cuestiones planteadas que contienen una vinculación necesaria a través de la que es posible vertebrar un estudio acerca de la relación entre la corporalidad y el poder. Así, entonces, de la primera cuestión se deriva la segunda, pero, a su vez, la primera cuestión no podría completarse sin la presencia de la otra, en la medida en que si hay necesidad de dominar a la corporalidad será en razón de que esta contiene unas fuerzas capaces de contravenir el orden instaurado o proyectado por algún tipo de instancia dominante. Al tratar de demostrar que las formas de dominación tienen que tomar al cuerpo como su objeto por excelencia, también, puede advertirse que las fuerzas de los cuerpos humanos son susceptibles de conformar un poder en la medida en que tienen posibilidad para erigirse como sujeto político y, de este modo, intervenir como agente activo en el espacio político. Por consiguiente, si el dominio del cuerpo requiere de algún tipo de sistema de presión para dirigir a personas y poblaciones, habrá que suponer, en consecuencia, que 
la dimensión corporal de los individuos reunidos en sociedad alberga en su inherencia algún tipo de potencia suficiente como para incidir en el terreno político, ya sea como una potencia de hecho o como un contrarresto de otros poderes.

En resumen, la dominación sobre los seres humanos halla su punto fáctico y, por ende, su referencia, en la dimensión corporal de los individuos. Por consiguiente, será también en esta dimensión donde resida la posibilidad de resistir a los poderes que actúan desde una exterioridad con respecto al cuerpo natural del individuo o al conjunto de cuerpos que componen la sociedad.

Consecuentemente, el asunto central a tratar cobra relevancia en el marco de la filosofía política en tanto en cuanto la temática principal versa sobre el gobierno de los cuerpos. Al haber considerado tanto la dominación sobre los cuerpos como la potencialidad política que reside en sus fuerzas, se ha procurado hacer ostensible la complejidad subyacente al ejercicio de gobernar los cuerpos. Las estrategias establecidas para llevar a cabo el gobierno de los cuerpos traen consigo la presunción de que la corporalidad contiene fuerzas y de que estas fuerzas pueden resultar útiles para la aplicación del poder establecido o, contrariamente, ofrecer algún tipo de contrapeso capaz de desequilibrar y obstaculizar a este poder. Ha de suponerse, por tanto, que en su origen toda dominación sobre lo corporal tuvo que arruinar la posibilidad de que los cuerpos por sí mismos se resolvieran como una forma de poder político; los sujetos sometidos a un régimen de dominación ven escindida su dimensión subjetiva de su dimensión corporal, tal es así que los dominados no tienen una plena disposición de sus cuerpos o, simplemente, ven amenazada la posibilidad de hacerlo.

De este modo, el problema que se divisa en el marco de la lucha política por el cuerpo humano tendría una doble articulación: por un lado, el cuerpo tiene que aparecer como un objeto para hacerse accesible a las instancias que pretenden dirigirlo, controlarlo y administrarlo, pero, por otro lado, el traslado del cuerpo al lado del sujeto restaura el poder de los seres humanos en su esfera más unitaria, sin dicotomías entre lo corporal y lo subjetivo, haciendo que los hombres dispongan de sus fuerzas de acuerdo al dictado de sus decisiones. 


\section{Metodología}

La materia puesta a escrutinio en la tesis se corresponde con las imágenes conceptuales $^{8}$ del cuerpo presentes en la filosofía moderna y contemporánea. Estas imágenes son, por tanto, el contenido de análisis en torno al que se desarrolla la discusión sobre las relaciones cuerpo-poder.

Partimos suponiendo que en las imágenes del cuerpo es posible detectar una determinada posición del poder y que hay posiciones estratégicas que implantan una dominación sobre la corporalidad a partir de instancias extrínsecas a ella. Consideraremos, además, que en las representaciones culturales y en las concepciones filosóficas del cuerpo se pueden localizar figuras de poder, es decir, formas en que se ejerce la dominación o se le opone resistencia. La posición que toma el poder con respecto a los cuerpos desvela las estrategias que permiten otear el rastro de algún tipo de fuerza dominante o, en su defecto, de alguna estrategia por medio de la que un cuerpo o grupo de cuerpos ofrecen resistencia a una determinada dominancia.

Nuestro ejercicio interpretativo intuye que las relaciones de poder moldean las imágenes conceptuales del cuerpo, imágenes de las que se valen los filósofos para explicar sus dilucidaciones sobre la condición corporal humana, con todo lo que ello conlleva. La función que cumplen las imágenes culturales ${ }^{9}$ del cuerpo es instrumental, pues contribuyen a recortar la silueta del cuerpo en los distintos contextos históricos, lo que permite acceder al concepto de corporalidad atendiendo a la panorámica histórica que lo envuelve. Pero si atendemos al contenido de las relaciones cuerpo-poder detectable, como se ha venido afirmando, en las imágenes conceptuales y representaciones de la corporalidad, conviene también dar cuenta de cómo en las estrategias de dominación sobre el cuerpo los filósofos establecieron una forma relacional asimétrica entre lo corporal y otro término destinado a su control y dirección.

\footnotetext{
8 Con "imágenes conceptuales" se apunta únicamente a las representaciones filosóficas del cuerpo humano, es decir, al modo en que los pensadores de índole diferente configuran una determinada concepción de la corporalidad. Esta configuración por medio de la que se representa al cuerpo necesariamente se asocia y predispone las diversas coordenadas antropológicas desde las que los filósofos interpretan la condición corporal humana.

9 Con "imágenes culturales" se pretende establecer una distinción fundamental con las imágenes conceptuales. Una imagen cultural abarca una totalidad de representaciones de los cuerpos humanos dentro de un contexto histórico, una civilización y unos movimientos artísticos y literarios concretos, de tal forma que este tipo de imágenes hacen referencia a lo fáctico y no exclusivamente al ámbito de lo conceptual, pues las imágenes de la corporalidad se hallan también dentro de representaciones simbólicas cuyos canales de expresión son los hechos. Las imágenes culturales contribuyen a ambientar las imágenes conceptuales que la filosofía ha elaborado del cuerpo $\mathrm{y}$, por tanto, son una fuente que coadyuva a complementar los itinerarios históricos en que se ve representada la corporalidad humana.
} 
Ciertos autores utilizan conceptos que manifiestan y justifican la necesidad de dominar el cuerpo humano, bien a nivel de uno mismo como a nivel social. Conceptos como alma, ley natural, conciencia o Estado, en determinados casos, ocultan formas de poder en las que operan discursos filosóficos que hacen las veces de figuras de poder. Estas figuras son la cubierta de una estructura de dominación, de tal manera que en la relación cuerpo-poder tiene lugar una asimetría entre ambos términos, donde el primero tiene que caer bajo el dominio del segundo precisamente por los caracteres que le han sido atribuidos.

Con base en esto, hemos de concretar que las imágenes del cuerpo integradas en las formas culturales y en los planteamientos filosóficos provienen de una comprensión de lo corpóreo en general mientras que, a su vez, conducen a representaciones y concepciones de la corporalidad humana en particular, cuya resolución filosófica adquiere una complejidad específica en el pensamiento político. Para efectuar estos parámetros, se ha tenido a bien tomar como vértice central de la investigación aquellas concepciones que la filosofía ha realizado sobre el cuerpo humano en el lapso de tiempo que va del siglo XVII al siglo XX, asimismo, serán tenidas en cuenta ciertas representaciones culturales del cuerpo y el contexto histórico en que se inscriben, siempre con el propósito de trazar una periferia que complemente las imágenes conceptuales del cuerpo.

Conviene dar cuenta de dos aspectos formales que constituyen la estructura de la tesis. El primer aspecto se refiere a la división de la tesis en cuatro partes, cada una de ellas en correspondencia con cada uno de los cuatro siglos que son tratados; el segundo aspecto tiene que ver con la regulación interna de las mencionadas partes, formadas sin excepción por tres secciones cada una y cuyo orden de sucesión atiende a razones estructurales del discurso en todos los casos:

i) La decisión de llevar a cabo un estudio que se correspondiera con la etapa histórica que comprende la modernidad y la contemporaneidad es que con ello se imponen unas acotaciones objetivas a la materia de estudio y se especifica un periodo de tiempo que, pese a su magnitud, permite hacer visibles toda una serie de variaciones acerca de la relación cuerpo-poder, a partir del giro conceptual que lo corpóreo en general y la corporalidad humana en particular experimentaron desde inicios de la modernidad. De este modo, resulta viable y abarcable la realización de un recorrido histórico pautado por los planteamientos filosóficos que se dieron en los siglos XVII 
y XVIII por parte de la modernidad y de los siglos XIX y XX en lo que respeta a la contemporaneidad. En este sentido se consideró lícito seguir un orden historiográfico acorde a la manera más objetiva de organizar el estudio de las imágenes conceptuales del cuerpo: la división cronológica por siglos. Cabe señalar, sin embargo, la presencia de una pretendida excepción: en la tercera sección de la primera parte se ha escogido un suceso histórico que acaeció en el siglo XVI pero que representa un punto de inflexión necesario en la conformación de la noción de realidad desde la que se desarrollaron los planteamientos políticos y económicos del XVII.

ii) La regulación temática impuesta a cada una de las épocas estudiadas sigue unas pautas comunes. Así, entonces, no es casualidad que cada parte esté compuesta por tres secciones, la razón de ello es que, según la sucesión ordinal de cada sección dentro de su parte respectiva, se aborda un tema correspondiente a una determinada fase de la exploración acerca de las relaciones cuerpo-poder: $1^{\circ}$ situación de la imagen del cuerpo natural del individuo, $2^{\circ}$ organización de los cuerpos en sociedad y $3^{\circ}$ articulación de los cuerpos. De este modo, cada momento equivale a un grado mayor de complejidad en la formación de las imágenes de la corporalidad. En consecuencia, cada primera sección de cada una de las partes versará sobre la imagen del cuerpo en el seno de la subjetividad ${ }^{10}$, lo que supone llevar a cabo un ejercicio reflexivo a tenor de las propuestas filosóficas en torno al "gobierno de sí mismo"11; cada segunda sección de cada parte tratará sobre la organización de los cuerpos en su entorno social, ámbito del que se desprenden imágenes que hacen alusión a la población como cuerpo; finalmente, en lo correspondiente a la tercera sección de cada parte, será allí donde se alcance el mayor grado de complejidad, pues las relaciones cuerpo-poder van a ser vistas a partir de la interacción entre los cuerpos naturales de los individuos y los cuerpos sociales. El grado correspondiente a la articulación de los cuerpos es considerado el más complejo porque en él se producen

\footnotetext{
${ }^{10}$ El término "subjetividad" hace referencia a la dimensión donde se desarrolla el pensamiento humano, es una forma de dar cuenta de ese plano interior de los hombres, donde se instala un determinado aparato conceptual que determina los juicios, apreciaciones, concepciones y puntos de vista de los individuos. Se entiende que la noción subjetiva del cuerpo es un elemento importante de la representación de la corporalidad, dado que el sujeto humano se comprende en su cuerpo y elabora una comprensión de su dimensión corporal mediante la que implanta una manera de dirigirse a sí mismo, es decir, de establecer un régimen de gobierno de sí.

${ }^{11}$ Conviene matizar que con "gobierno de sí mismo" estamos refiriéndonos al orden de decisión, preferencia y control que cada cual tiene sobre su individualidad, de tal forma que un individuo puede verse como cuerpo, espíritu, sujeto, integración espiritual-corporal, etc., en función de un modo determinado de valorar su individualidad y de justificar la dirección de su vida.
} 
discursos de poder merced a las correlaciones de fuerza por las que interaccionan los diferentes sujetos políticos.

\section{ESQUEMA DE INTERPRETACIÓN}

La interpretación de las relaciones cuerpo-poder a partir de las imágenes conceptuales y culturales de la corporalidad constituyen la actividad fundamental de la exposición, en concreto, se van a interpretar las posiciones del poder con respecto al cuerpo poniendo el foco de atención muy especialmente en las imágenes proporcionadas por la filosofía. Las posiciones del poder con respecto al cuerpo son fundamentalmente dos, una externa y otra interna, aunque, no obstante, en la posición externa cabe distinguir dos figuras sustancialmente distintas: una incorpórea y otra corpórea.

Consecuentemente, consideraremos que el poder puede posicionarse fuera de la corporalidad o dentro de esta, es decir, el poder puede bien constituirse de forma extrínseca al cuerpo o de manera intrínseca a este. La operación que escinde al poder del cuerpo constituye, necesariamente, un régimen de dominación sobre la dimensión corporal humana que, por tanto, erige una figura de poder que se cierne sobre la corporalidad, ya sea directa o indirectamente. El cuerpo humano es dirigido, expiado, controlado y administrado por medio de fuerzas que se instauran en su exterior. Así, de este modo, se entiende que hay unas asimetrías operando en la política sobre los cuerpos, en tanto en cuanto localizamos un poder que sale de la dimensión corporal de individuos y sociedades para erigirse sobre ellos. Ahora bien, esta forma de dominación se concreta en dos estrategias diferentes:

1. Por un lado, se distingue un régimen de representación que recurre a elementos puramente abstractos y, por ende, inmateriales. Estas formas abstractas moverían los cuerpos nada más que por medio de su inmersión en la subjetividad del individuo, produciendo una relación asimétrica entre una determinada figura de poder y el cuerpo sobre el que se debe cernir su dominio, o lo que es lo mismo, el sujeto habrá de dirigir su cuerpo de acuerdo a los designios del poder al que aparece vinculado. Esta forma de entender el poder propone un tipo de dominación indirecta sobre el cuerpo, que se desenvuelve a través de la suposición de que existen instancias no materiales de las que, consecuentemente, surgirían figuras conceptuales de poder exclusivamente inmateriales, no tangibles ni visibles, y solo concebibles en el nivel 
del pensamiento humano. Sin embargo, el punto de referencia sigue siendo el cuerpo, ya que si los cuerpos no actúan según las directrices de este "poder incorpóreo", entonces, no se consuma la dominación. La incursión del poder a través de la subjetividad tiene que implantar controles y movimientos sobre la dimensión corporal de los hombres en términos fácticos, de lo contrario, el dominio sería inexistente. Es obvio que esta forma de poder es muy eficiente y económica, puesto que solo requiere hacer permanecer un aparato conceptual funcionando en el pensamiento de los individuos para moverlos de una determinada manera; pero el problema de esta forma indirecta e inmaterial de dominar a los cuerpos es que los pensamientos y conceptos son invisibles, ya que estos se encuentran en la dimensión subjetiva de los individuos, a la que no hay un acceso sensible así como tampoco hay manera alguna de contactarla de forma directa. El contratiempo de ejercer el dominio por medio de la subjetivación es, entonces, que al no haber modo de acceder directamente al pensamiento de los otros -y aun hoy en día no se ha inventado técnica o artefacto que lo consiga- el dominador o los dominadores nunca podrán cerciorarse de que la dimensión subjetiva de los dominados se encuentra completa y fielmente sumida.

2. Por otro lado, hay una configuración de la dominación externa a la corporalidad que se resuelve y articula de forma corpórea. La configuración de esta forma de dominio implanta un orden de poder directo sobre el cuerpo de los humanos, en la medida en que se ejerce una presión sobre sus cuerpos por medio de mecanismos de fuerza provenientes de un aparato corporal capacitado para poner en marcha tales fuerzas y hacerlas disponibles a los dominadores de manera fáctica. La presencia física de un mecanismo de presión en cuya corporalidad se alberga su propia capacidad para causar efectos sobre el cuerpo de los individuos también afecta a la subjetividad humana, pero de un modo distinto a como lo hacen las instancias de dominación incorpóreas, ya que en este caso el poder se hace evidente en cuanto que alcanza una presencia material, desde la que se proyectan modos de coacción y coerción potencialmente inminentes para el sujeto dominado. La ventaja de esta forma de ejercer la dominación es que anula directamente cualquier tipo de resistencia opuesta por los dominados; ahora bien, su desventaja es que se precisan muchos medios materiales para desplegar un poder de este tipo. La construcción de un cuerpo de poder implica un desgaste físico, e incluso, un derroche de energías que bien puede 
hacer añicos esta estrategia si hay una resistencia física de alta fortaleza y/o duradera. Por eso siempre tenderá a buscar elementos intimidatorios que penetren la subjetividad de los individuos; sin por ello perder de vista que la configuración corpórea del poder se advierte como una causa de intimidación, pues no hay nada más importante que los sujetos sepan de la presencia y disposición de poderes susceptibles de actuar sobre ellos de manera inmediata o casi inmediata.

En lo que se refiere a la posición intrínseca del poder con respecto al cuerpo, conviene apreciar una inmanencia del poder en la corporalidad, es decir, el poder surge, emerge, nace de la naturaleza corporal que inexorablemente acompaña a la condición humana. El cuerpo alberga unas fuerzas naturales, consideración que se hace común también a las proyecciones de la dominación sobre el cuerpo, ya que, si el cuerpo tiene que ser dominado es porque ofrece una serie de resistencias a los sistemas puestos en marcha para dirigir a hombres y sociedades. La postura filosófica que concibe el poder en la inmanencia del cuerpo es aquella que, precisamente, no ha generado una escisión de las fuerzas corporales con respecto al ordenamiento político, en otras palabras, no rechaza que las fuerzas corporales a nivel individual y social se hagan partícipes del espacio donde se desarrollan las relaciones de poder. La inmanencia del poder en el entorno de los cuerpos reconoce que la dimensión corporal humana contiene una politicidad, por tanto, no toma al cuerpo como objeto de dominio, sino que lo convierte en sujeto, lo que conlleva que la corporalidad abandone el lado del objeto para pasar a ser sujeto político o, al menos, una parte integrante e inextinguible de este. Esta posición del poder, inmanente a la corporalidad, implica que no se produzca ningún tipo de cosificación del cuerpo y que en el seno del sujeto no haya divisiones insalvables entre la subjetividad y lo corporal, pues ambos pasan a formar parte de una mismidad, lo que en un sentido político y social se traduciría en que el cuerpo de la sociedad no es un soma pasivo o meramente mecánico que tenga que ser dirigido o administrado desde instancias exteriores, sino que esta aglomeración de cuerpos contiene unas fuerzas con capacidad para erigirse como un poder en el terreno político.

Las dos posiciones del poder mencionadas, junto con las dos estrategias de dominación mentadas en el caso de la posición extrínseca del poder, se resumen de manera gráfica en el siguiente esquema: 


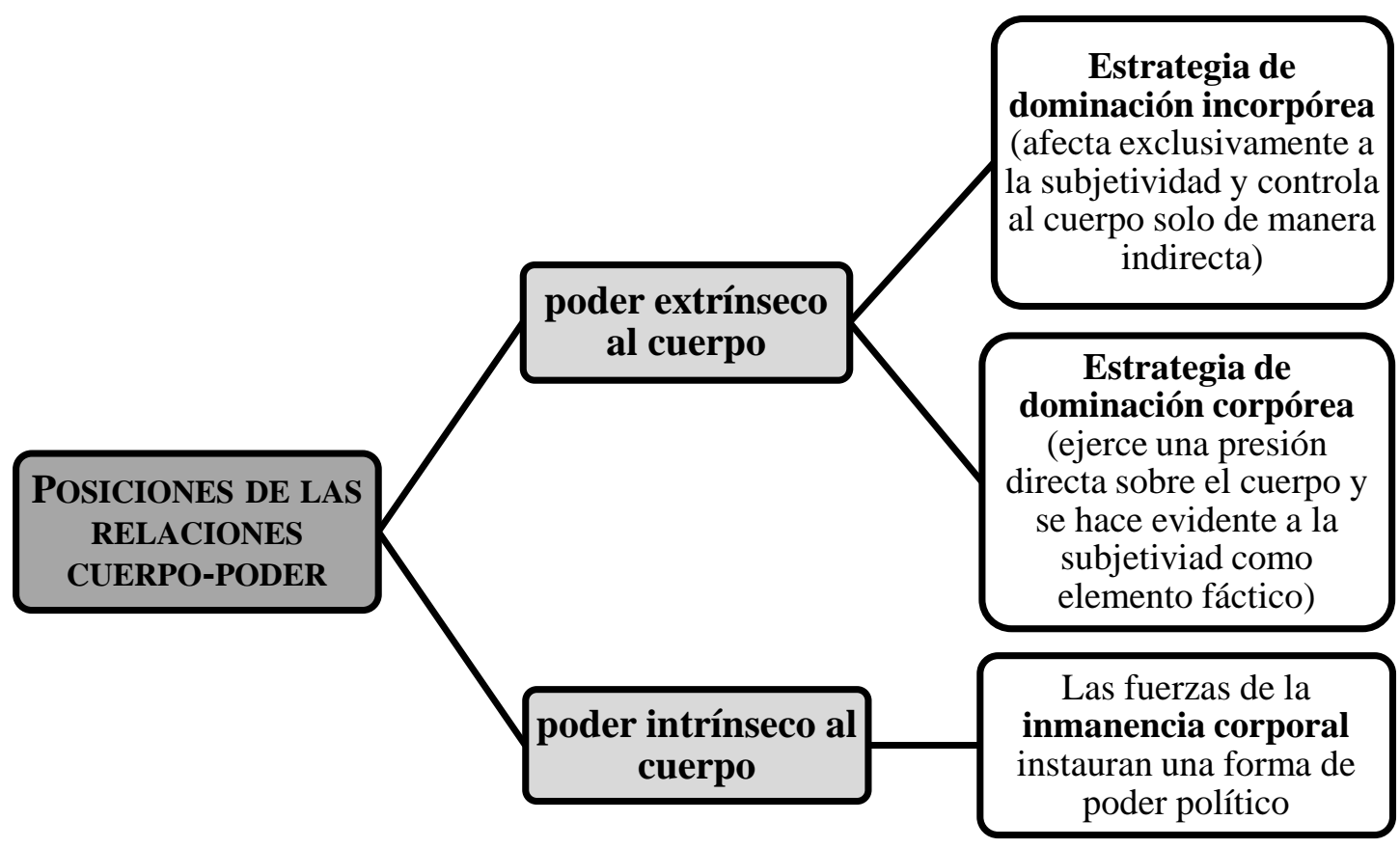

\section{ORdenAmiEnto InTERnO DE CADA PARTE}

La organización temática de cada una de las cuatro partes que componen la tesis guarda una coherencia interna y sigue unos parámetros temáticos que marcan una regularidad a lo largo del discurso. Cada parte se divide en secciones y cada sección se divide, a su vez, en series. Se tercia pertinente aclarar que la distribución de las series no sigue un orden sujeto a pautas predeterminadas, de manera que el número de series por sección y su extensión son relativos a los asuntos que se abordan en cada momento, con arreglo a las exigencias de la coyuntura temática. Además, conviene detallar que en rasgos generales algunas series tienden a ser exposiciones monográficas dedicadas a la exposición de uno, dos, o tres autores a lo sumo; otras series se centran más en abordar contrastes y contraposiciones acerca de un asunto en más de un autor (obviamente estas suelen suceder a las anteriores), por último, hay series que cumplen una función más bien transitiva y sintética dentro de la sección, pues son empleadas con el fin de comunicar o explicitar un tema considerado clave en el conjunto discursivo de la sección. Estas series no establecen rigurosamente una tipología que las diferencie claramente, dado que a lo largo del texto pueden implementarse fragmentos expositivos, comparativos o transitivos con cierta ambivalencia.

De vuelta al orden de las secciones dentro de cada una de las partes, tal y como se puso de relieve anteriormente, el lugar ordinal de cada sección en las partes de la tesis 
equivale, respectiva y sucesivamente, a la situación, a la organización y a la articulación de las distintas corporalidades que intervienen en las relaciones de poder. La situación del cuerpo va en correspondencia con las primeras secciones de cada parte, la organización de la corporalidad social con las segundas y la articulación de la dimensión político-corporal con las terceras. Esta manera de organizar las secciones responde a un criterio de clasificación de la temática general que concierne al tratamiento de las relaciones cuerpo-poder en diferentes niveles del discurso. El criterio, en concreto, consiste en partir de cuestiones más simples para ir avanzando hacia cuestiones de calado más complejo.

Entonces, las primeras secciones de cada parte ocupan la perspectiva del cuerpo visto desde el sujeto, es decir, se centran en el cuerpo humano en cuanto que individualidad y atienden a cómo, tras la subjetivación del cuerpo, operan formas de poder que tratan de determinar la visión del "sí mismo". Las segundas secciones de cada parte se centran en los cuerpos sociales en cuanto que acumulación y sincronización de un conjunto de seres humanos que asocian sus cuerpos para formar una unidad política; en último término, en lo relativo a las terceras secciones, las interacciones entre individuos y formas sociales de organización nos permitirán ver, desde una panorámica más amplia, el modo en que los cuerpos constituyen un espacio político y de qué manera no pocos filósofos han calculado o problematizado sobre el dominio y las posibles resistencias derivadas de él. Cabe matizar que a partir de las segundas secciones, allí donde el asunto comienza a complejizarse, los factores espaciales que rodean a la organización y articulación de los cuerpos pasan a adquirir una mayor relevancia al sobrepasar la esfera de la subjetividad, lo que no implica que la subjetivación del cuerpo quede desplazada a un plano marginal, simplemente, se contrasta con las condiciones objetivas de organización social en un segundo momento para, en un tercer momento, llegar a articularla en el espacio donde se construyen, legitiman y actúan los diferentes poderes.

Veamos con un mayor grado de amplitud cuáles son los asuntos más relevantes en cada uno de estos niveles de discusión, que orientan el desarrollo temático de la tesis y que sientan las pautas regulativas de la sucesión tríadica de las secciones:

I. La primera sección de cada una de las partes irá enfocada a tratar la cuestión de la imagen conceptual del cuerpo humano, en complementación con las representaciones culturales donde lo corporal ha estado implicado directa o indirectamente en un determinado marco histórico, pero siendo en especial la concepción filosófica del 
cuerpo el punto central de la problemática a discutir. En este tipo de secciones se aborda de manera sistemática la forma subjetivada que adquiere la corporalidad en el seno del sujeto, ahora bien, si nos hacemos cargo del sujeto en cuanto a su cuerpo se refiere, es porque en un primer momento conviene hacer del individuo el "laboratorio de investigación" en que descubrir cómo se produce la subjetivación del cuerpo, bien como objeto de dominación, bien como forma identificativa y constituyente del poder de sí mismo. Por tanto, la mirada del cuerpo natural, ese cuerpo del individuo, permite analizar cómo se producen las diferentes construcciones teóricas de la subjetividad en la filosofía.

II. En cada segunda sección se amplía el radio de investigación, pues esta clase de secciones se ocuparán de la noción de cuerpo en cuanto que agrupación de seres humanos. Los cuerpos de los humanos se ven involucrados en los ordenamientos que establecen sus formas de asociarse, toda organización socio-política y socioeconómica impone una direccionalidad en el movimiento de los cuerpos, de tal manera que la coordinación de los hombres en sociedad se ve compuesta de esa materia común representada por la dimensión corporal de los individuos y cuya unión genera la imagen de un cuerpo más amplio, constituido objetivamente como cuerpo social. Asimismo, se prestará especial atención a las analogías entre el cuerpo natural y el cuerpo social que determinados filósofos han empleado, ya que configuran imágenes privilegiadas acerca de cómo el poder en relación con el cuerpo natural del individuo se proyecta en el concepto de cuerpo social, reproduciendo las posiciones del poder en el ámbito social.

III. Por último, en lo relativo a la tercera sección de cada parte, será observado cómo se produce la articulación de los cuerpos naturales y sociales dentro de un espacio civil y de un espacio económico. Las espacialidades construidas por el poder vienen determinadas merced a la forma en que los cuerpos sociales se han organizado o, al menos, merced a cómo se ha entendido su organización desde la filosofía. Estos espacios hallan su concreción en la contextura histórica de cada siglo, una vez más, el panorama histórico-cultural contribuye a complementar el paisaje conceptual que exploramos. La articulación de las fuerzas relativas a las corporalidades que intervienen en los procesos históricos le otorgan un protagonismo a las interacciones que se producen en la vida corporal de los individuos dentro de los organismos a los que se circunscriben, precisamente, es en el interior de estas articulaciones donde se 
escenifican más prístinamente las figuras de poder, cuyos puntos de referencia y anclaje son las corporalidades articuladas en los regímenes de dominación, con los respectivos focos de resistencia y los respectivos cálculos por parte de las fuerzas intervinientes. Así como la imagen del cuerpo natural del individuo es trasladable a las visiones filosóficas del gobierno del cuerpo social, también, de las imágenes del cuerpo social surgen transformaciones que cambian el modo de subjetivar el cuerpo natural. Así, entonces, los juegos de poder que emergen en las asociaciones humanas producidas en las confrontaciones políticas implementan posicionamientos del poder con respecto al cuerpo.

\section{Supuestos}

Hay dos elementos clave que inspiraron el desarrollo procedimental de la presente tesis, en lo que al esquema interpretativo y a la regulación interna de las partes que la componen se refiere: [A] el esquema procede de la interpretación realizada acerca de las posiciones del poder con respecto al cuerpo en el siglo XVII; y [B] las dimensiones del poder establecidas por Michel Foucault a propósito del tipo de corporalidades que abarca la dominación, lo que por un lado el autor llama anatomopolítica, referido al poder sobre el cuerpo natural del individuo, y lo que se corresponde con la biopolítica, en cuanto al poder ejercido sobre la complexión somático-social de las poblaciones se refiere, además de la combinación de ambas formas de poder.

\section{[A]}

El esquema mediante el que se han distinguido las distintas posiciones del poder con respecto al cuerpo, surge de la interpretación realizada a propósito del modo en que ciertos autores del siglo XVII pensaron la corporalidad. Las posiciones del poder no resultan evidentes a simple vista, precisamente por ello se hizo necesario emprender un ejercicio interpretativo de la imagen conceptual del cuerpo. De dichas imágenes se pueden extraer figuras de poder que apuntan, bien a una u otra estrategia de dominación sobre la dimensión corporal humana, o bien a formas políticas integradas a la corporalidad. René Descartes y Thomas Hobbes van a ser representantes de un tipo de poder ajeno a la corporalidad natural de los individuos y que domina desde un "afuera", mientras que Baruj Spinoza va a representar una noción de la corporalidad en cuya naturaleza se alberga un poder. 
A partir de los planteamientos de Descartes y de Hobbes se halla un poder que actúa dominando a los cuerpos humanos, un poder producido en una instancia exterior al cuerpo natural del individuo; ahora bien, en ambos pensadores la naturaleza del poder es diferente. Descartes establece que el alma humana es un principio inteligible, no material y separado de la sustancia que ocupa el cuerpo. La racionalidad propiamente dicha se encuentra en el alma, de tal modo que los individuos humanos, en cuanto síntesis de alma y cuerpo, llevarán una vida racional siempre y cuando la dirección y el control de la corporalidad sea empeñada por la racionalidad del alma. La noción de poder en John Locke se acercaría más a esta configuración, con la salvedad de que la figura de poder que se desprende de su pensamiento no se corresponde con el alma sino con la ley natural, un principio impersonal a diferencia del alma cartesiana, pero que igualmente es inmaterial y porta consigo racionalidad. Esta forma de entender el dominio corporal, mediante una figura de poder sustancialmente incorpórea no sigue las mismas directrices en el pensamiento de Hobbes, cuya concepción antropológica materialista no admite la existencia de entes incorpóreos. Para Hobbes el dominio del cuerpo natural precisa de la formación de un cuerpo artificial, al que identifica con el Estado. La naturalidad del cuerpo del individuo esconde elementos patológicos nocivos para la convivencia social de los hombres, así, tendrá que existir algún tipo de corporalidad más fuerte, y en la medida en que en ella se concentran las fuerzas de los cuerpos de todos, consecuentemente, será en ese cuerpo artificial donde se produzca un verdadero poder político ya que el poder natural de los sujetos fracasa en la empresa de establecer una sociedad pacífica.

Podría decirse que el origen del poder verdaderamente político en el pensamiento hobbesiano tiene lugar exclusivamente en la corporalidad estatal, pues antes de ella solo había un fragor de individuos que se valían de las fuerzas naturales de sus cuerpos para imponerse los unos sobre los otros, por tanto, era imposible hallar poder político alguno, mas solo una malgama de fuerzas pugnantes, vulneraciones, vanidades e intereses egoístas que daban pie a meras arbitrariedades. El poder del cuerpo natural debía ser reducido para hacer posible el Estado, dado que si el poderío de los cuerpos naturales individuales prevalecía en el orden político sus repercusiones en la vida social serían nefastas. Hobbes no le reconoce un carácter político a ese "poder natural" de los cuerpos, puesto que este pareciera ser únicamente un conjunto de capacidades y destrezas aptas para hacer argucias con que superar a los otros, así como un conjunto de 
fuerzas destinadas a nada más que a la supervivencia, la satisfacción de unos instintos y la acometida de intereses individuales; en este entorno el filósofo británico vio imposible que medrara cualquier "politicidad". Ese poder suscrito al cuerpo natural de los individuos sería incapaz de construir un orden institucional, es un poder pre-político cuya caracterización más se acerca a la noción de fuerzas, destrezas, capacidades y habilidades que a una figura de derecho, es decir, que el cuerpo natural por sí mismo no se resuelve jurídicamente.

En lo que se refiere al poder inmaterial e inteligible de Descartes, conviene tomar la precaución de advertir que este no es un autor de filosofía política como tal, no obstante, sí se considera oportuno elaborar una comprensión prudente del alma humana como un poder, en tanto en cuanto su racionalidad controla los supuestos desmanes del cuerpo natural. Descartes comparte con Hobbes la urgencia de dominar estos desmanes, sin embargo, este último emplazó las fuerzas políticamente irresueltas del cuerpo natural por el poder civil, de modo que en la filosofía de Hobbes la complexión del Estado origina un sujeto civil, mientras que en el pensamiento cartesiano el cogito no aparece de propio como un sujeto civil sino más bien como una subjetividad en la que es posible detectar un régimen de gobierno sobre el cuerpo, un régimen que no sale de los límites de la individualidad, pero en el que sí se hace interpretable la presencia de un sujeto agente de poder en tanto en cuanto hay una relación de dominación del alma hacia el cuerpo.

Así que, por un lado, se encuentra una estrategia incorpórea de dominio sobre el cuerpo natural del hombre, en la que solo a través de la subjetividad se logra instalar en la mente del individuo un aparato conceptual capaz de dirigir su cuerpo, y, por otro lado, se distingue una línea estratégica del poder en la que este se corporaliza para ejercer una presión directa sobre los individuos. No es que esta última estrategia le reste importancia a la dimensión de la subjetividad, es que para la mente de los sujetos el hecho de que el poder se comporte como un cuerpo supone una causa factible de coacción y sumisión, dado que tan solo con insinuar la presencia de una instancia de poder capaz de actuar físicamente, ya genera las reservas y temores necesarios en los individuos para que retengan las fuerzas inherentes a su corporalidad.

En oposición a la situación extrínseca del poder con respecto al cuerpo y a las estrategias de dominación que de ella se bifurcan, la filosofía de Spinoza presenta un poder arraigado en el cuerpo, dado que para este filósofo el cuerpo y el alma no son 
sustancias diferentes sino que comparten una misma sustancialidad. En el pensamiento de Spinoza prevalece una suerte de equilibrio y equidistancia entre lo corporal y el alma, de tal forma que las concepciones spinozistas de ambos términos no se orientarían a presentar una relación de dominación, más bien, la racionalidad plasmaría una simetría cuerpo-alma en el seno del sujeto, pues el sujeto requiere adecuar sus ideas a las afecciones que el cuerpo recibe de la naturaleza así como afectar al cuerpo en adecuación a las ideas del entendimiento. En la teoría política de Spinoza, por tanto, el cuerpo social o la multitud tendrán que combinarse con las instituciones para mantener la estatalidad en cuanto que multitud (cuerpo) y unión civil (reunión de las inteligencias en una sola mente). Spinoza se preocupó por que existieran unos equilibrios entre el poder que subyace a la corporalidad social con respecto a la potestad institucional, con el propósito de que predomine la libertad en el Estado y en vistas a que una organización racional pudiera irse abriendo paso.

Bajo estas premisas se hacen patentes en las filosofías de Descartes, Hobbes y Spinoza imágenes sobre la corporalidad que sitúan al poder de una determinada manera. En resumen, se observa cómo Hobbes tiene una visión corporalista de la dominación, mientras que en Descartes la dominación tiene que darse a través de instancias incorpóreas en las que el poder no se identifica propiamente con un objeto artificial, sino con algo invisible que orbita en un plano externo a la dimensión corpórea. Asimismo, ninguna de estas figuraciones de poder se corresponden con la concepción elaborada por Spinoza, en la que el "poder natural" de los cuerpos no queda escindido ni al imperio del alma ni al gobierno de las instituciones del Estado; la racionalidad se encuentra, y así debería ser, en el vínculo sustancial que integra al cuerpo y al alma, así como el Estado civil no enajena el poderío que por naturaleza tienen los cuerpos, sino que lo recoge y fortalece para que los hombres perseveren mutuamente en su existencia.

Gracias a este plantel extraído de las interpretaciones que se realizaron acerca de los filósofos del siglo XVII pudo llevarse a término el esquema de las posiciones del poder: una intrínseca al cuerpo y la otra extrínseca al cuerpo, además de localizar las dos estrategias de dominación subyacentes a la posición extrínseca. Dicha esquematización pergeña un tratamiento que se hace en la tesis en relación con los restantes siglos, pero, si bien estas posiciones y estrategias de dominación llegan a resultar muy evidentes entre los pensadores del XVII, no siempre ocurre así en los pensadores de épocas posteriores. Los sistemas de pensamiento confeccionados a inicios de la modernidad y 
los contrastes extraídos de ellos guardan un orden al que no le viene mal el calificativo de "geométrico". La esquematización que se ha planteado a partir de la comparación entre las filosofías de Descartes, Hobbes y Spinoza contiene esa misma vocación geométrica: sigue las directrices presentadas por los autores y distingue cada línea posicional del poder y cada arista estratégica de dominación con especial claridad, en ellas se detectan casi automáticamente las distancias y diferencias que hay de un sistema de pensamiento a otro. Ninguna de estas líneas y aristas se confunden entre sí y las triangulaciones consecuenciales derivadas de cada planteamiento cuentan diligentemente con su particular definición. Sin embargo, esta geometría trazada según la esquematización puesta de relieve se retuerce a medida que se va extrapolando a las filosofías posteriores. Algunos autores presentan estrategias de dominación que hibridan la figura de poder inmaterial con la material, otros critican las formas de dominación poniendo el énfasis más puntualmente en la subjetividad que en los mecanismos de presión física y viceversa, así como también hay sistematizaciones del poder que parten de una determinada posición de este para luego virar a una posición diferente. En algunos casos nos encontramos con que ciertos autores suponen un poder implícitamente arraigado en el cuerpo, sin embargo, en otros casos la naturaleza de esta raigambre se hace más explícita; mientras que, por otro lado, hay filósofos en los que se deja interpretar una añoranza por recuperar un poder corporal supuestamente desarticulado en la civilización. Con todo y con ello, en definitiva, esos parámetros geométricos de las posiciones del poder con respecto al cuerpo empiezan a retorcerse ya incluso en la tercera sección de la primera parte, sin por ello arruinar el enfoque esquemático mediante el que se investigan las posiciones del poder con respecto al cuerpo.

\section{[B]}

La influencia de Foucault se hace ostensible en las nivelaciones mediante las que son estudiados los cuerpos y sus pertinentes concurrencias. Un primer nivel es el cuerpo natural del individuo humano y una segunda nivelación se corresponde con el cuerpo social. Foucault establecía que el domino de los cuerpos de los individuos se lleva a cabo por medio de un poder disciplinario, pero, más allá de la terminología y las claves del análisis foucaultiano, se hizo necesario comprender la corporalidad del sujeto humano en márgenes conceptuales más amplios: la individualidad en general. 
La subjetivación de lo corporal implanta la imagen del "cuerpo de uno mismo". La filosofía moderna, a la que la gran mayoría de historiadores del pensamiento califica como un "giro subjetivo", plantea diferentes disposiciones del sujeto en relación con su cuerpo -como se vio en el punto anterior-, lo corporal en el seno de la individualidad adquiere un cariz problemático estrechamente vinculado a un tema político. Dicho tema es político en la medida en que plantea el dominio o potencia de la corporalidad. El cuerpo se presenta como un organismo vivo expuesto a la dominación, al revelarse como un espacio controlable, administrable y gobernable, asimismo, también puede presentarse como un ente capaz de influir en el porvenir político de una sociedad, una entidad cuyas fuerzas tienen una resolución política ya que los cuerpos pueden cambiar una situación institucional determinada.

Foucault planteó el tema del cuerpo natural del individuo en términos de dominación, vio en él un objeto expuesto a unas tecnologías disciplinarias que dividen y gestionan las fuerzas corporales. Pero también en la filosofía del pensador francés se planteaba la cuestión del poder del cuerpo que la disciplina vino a fragmentar para hacerlo controlable. Pese a ello, Foucault no indagó en ese supuesto poder inherente al cuerpo natural y previo a la irrupción de la disciplina; podría afirmarse que una indagación de esta envergadura implica introducirse en un terreno pantanoso cubierto de niebla. No obstante, pese a las dificultades, se acató el reto de poner en marcha una investigación que se encargara del cuerpo en la individualidad como asunto que entraña un problema político, a saber, el cuerpo como potencia cercenada y dividida en fuerzas expuestas a la administración y control de poderes configurados en la periferia de la inmanencia corporal. Por supuesto que un tratamiento de este tipo exige ir más allá de la dominancia y de los términos en que Foucault trabajó la disciplina.

En lo referente a la ampliación dimensional de lo corporal, producida en el nivel de reflexión biopolítico, Foucault estableció que en la biopolítica es donde se articula un poder cuyo despliegue abarca a las poblaciones, es decir, a los cuerpos que caen bajo la identificación de una especie, raza o grupo. Pensar a la población como un cuerpo impulsa la salida de los límites de la individualidad hacia la corporalidad social, lo que supone, por ende, comenzar a hablar y comprender lo social como un soma integrado por cuerpos, cuerpos que son tomados como fundidos en una totalidad corpórea. Cuestión aparte era saber si los diferentes filósofos que se dan cita a propósito de este tema entendían al soma social como una totalidad compuesta de átomos agregados, 
donde - no cabe ninguna duda- estos átomos representan a los individuos. Igualmente se daba el problema de que para otros pensadores la comprensión de la sociedad como una masa o una multitud de átomos agregados no era suficiente en lo relativo a la consideración de un cuerpo civil, o más amplia y específicamente: a la consideración de una sociedad civil o de una comunidad política. Consecuentemente, se reproducía en el cuerpo social algo que ya se daba en el cuerpo natural del individuo: el problema de lo corporal como un poder político por sí mismo o su no reconocimiento como tal. Una consecuencia derivada de este problema era, como en el caso de la individualidad, que la negación del cuerpo como poder implicaba la necesidad de imponerle un orden a la sociedad, ya fuera este orden implantado por medio de una especie de "exoesqueleto" que vertebrara al soma social, ya fuera a través de una espiritualidad o instancia inmaterial que hipostasiara a los grupos humanos otorgándoles su condición política; de este modo y en ambos casos se estaría dando por hecho que la "sociedad física" es un cuerpo cuyo carácter civil y político ha de venirle dado desde un "afuera".

Con arreglo a este tema, cabe destacar un aspecto sobre la concepción de la población que se colige con un asunto tratado por Giorgio Agamben, autor que ha venido realizando observaciones muy reveladoras dentro de la línea de investigaciones biopolíticas, de hecho, ha sido a partir de la última década del siglo XX cuando los trabajos de Agamben resueltamente le concedieron una continuidad a las cuestiones biopolíticas tratadas, exploradas y, en algunos casos, solo anunciadas por Foucault. Agamben interpretó en términos biopolíticos la connotación semántica que en las lenguas europeas tiene el término "pueblo" cuando se pretende designar a las clases más pobres de la sociedad. El autor italiano apunta a una distinción entre el "Pueblo" como identidad política y el "pueblo" como parte de la población excluida de la política ${ }^{12}$, sostiene <<que la constitución de la especie humana en un cuerpo político se realiza por medio de una escisión fundamental $>>$, una escisión biopolítica que situaría al "pueblo" como exclusión del espacio político y al "Pueblo" como inclusión en dicho espacio, ya que el pueblo en su doble sentido sería aquello <<que no puede ser incluido en el todo del que forma parte y lo que no puede pertenecer al conjunto en el que está ya incluido siempre $>{ }^{13}$. A tenor del tema que plantea Agamben se pretende indagar en esta escisión biopolítica operada sobre la población mediante la que se instaura un cuerpo

\footnotetext{
${ }^{12}$ Cfr. Giorgio Agamben, Homo Sacer. El poder soberano y la nuda vida. I (Valencia: Pre-Textos, 2003), 224-225.

${ }^{13}$ Agamben, ob. cit., 226.
} 
político y un soma social excluido del espacio de la política; lo que plantea la imagen de una corporalidad o soma social como mero dato físico. Aunque los intereses suscitados en el tema presentado por Agamben se remontan a una polémica puramente semántica, al margen, y sin el ánimo de continuar profundizando en los orígenes y derroteros del término pueblo, sí cabe la posibilidad de comprender a la población como un cuerpo al que se ha tratado de despojar de su condición política, en pro de justificar una serie de estrategias de dominio sobre él, que implicaban la instauración de poderes externos al soma social. Si se niega a las fuerzas del soma social una resolución en forma de poder, se le niega entonces su corporalidad política.

Gracias a Agamben se hizo posible sustraer una cuestión semántica y conducirla hacia un terreno ontológico-político, en cuanto una manera de acceder a la cuestión biopolítica. La historia del pensamiento político moderno da cuenta de cómo en muchos casos el cuerpo social aparece como una entidad que ha de ser expuesta al dominio del Estado, al control y gestión de unas instituciones elevadas sobre esta entidad y responsables de instaurar una vertebración que le otorgare una identidad política. Las estrategias articuladas para implantar esta dominación recurren, como en el caso del individuo, a sistemas incorpóreos de ejercicio del poder y a sistemas materiales de presión sobre las sociedades, estas últimas implican constituir un poder físico, visible y, consecuentemente, intimidatorio y coactivo. Si bien el análisis de estas estrategias ocupa buena parte de la atención en el examen biopolítico propuesto a propósito de la imagen corporal de las poblaciones, también es cierto que el origen de esas estrategias inconscientemente presupone que hay unas fuerzas subyacentes a la physis poblacional que potencialmente tienen capacidad para cambiar la deriva de la vida pública, pues de hecho estas fuerzas podrían intervenir, transformar o trastocar el tejido políticoinstitucional. Hay un poder intrínseco al soma social que podría resolverse como una corporalidad política, una corporalidad política que la historia hizo contrafáctica en tanto en cuanto se produjo un corte sobre la fuerza corporal de la sociedad apartándola del escenario político; es en relación con esta coyuntura teórica donde se acepta el reto planteado por Agamben de pensar desde <<una política que sea capaz de superar la escisión biopolítica fundamental de Occidente $>{ }^{14}$. Reflexionar acerca de esta escisión suponiendo la presencia de un poder inmanente a las fuerzas corporales, observar la historia a partir de una fisura y comprender cómo la dominación sobre la población

\footnotetext{
${ }^{14}$ Agamben, ob. cit., 229.
} 
consiste en fragmentar la posibilidad de su conversión en cuerpo político, es ya asumir este reto.

Cabe retomar, con el fin de concluir la línea inspirativa foucaultiana, la noción de gubernamentalidad como combinación, complementación y complejización del plano corporal donde operan conjuntamente el poder disciplinario y el poder biopolítico. La gubernamentación recoge y sistematiza las directrices de poder disciplinario y las pone en funcionamiento sobre toda una población, la individuación y especialización del cuerpo se integran en una forma de biopoder que aplica unos planes gubernamentales. Esta forma de entender el biopoder va a ser traducida a una comprensión de las imágenes contextuales en que caen los cuerpos, cuerpos relacionados sobre el espacio de una determinada forma y entre los que se entrelaza un relato histórico que proyecta un porvenir. Los pueblos son conducidos según una planificación gubernamental que acude a las circunstancias históricas de unas corporalidades sociales y de unos individuos integrados en sociedad. Individualidad y sociedad se organizan en un intervalo espaciotemporal sobre el que se instauran unos sistemas de poder.

Los mencionados sistemas de poder hacen visibles sus estrategias en el despliegue de los pueblos en el espacio, los cuales llevan tras de sí una historia, es decir, un relato propagado en el tiempo. Es ahí donde se aprecian los dinamismos de los cuerpos en su complexión política. La gubernamentación impone unas concepciones del cuerpo natural que transfiguran la propia facticidad de lo corporal, estas imágenes conceptuales proceden de una articulación realizada a escala biopolítica y entre los que se dejan entrever procesos de desubjetivación que reinstalan nuevas formas de subjetivación interesantes desde el punto de vista del poder dominante. De este modo, el ejercicio del gobierno sobre el plano espacial atravesado por la historicidad de las poblaciones que lo transitan es donde se halla este tercer nivel de reflexión sobre la corporalidad, una corporalidad "plástica" y moldeable según los poderes que actúan sobre ella, pero que también contiene posibilidades de resistencia; no obstante, es preciso advertir que siempre se está pensado en un cuerpo natural y en unos cuerpos sociales que han recibido una desfiguración por parte de poderes externos, de ahí que urja trabajar con aquellas imágenes que visibilizan concepciones y composiciones desfiguradas de lo corporal. 


\section{Primera PARTE: PERSPECTIVAS}

\section{FILOSÓFICAS SOBRE EL CUERPO EN \\ LOS INICIOS DE LA MODERNIDAD}




\section{SECCIÓN I. LA IMAGEN DEL CUERPO}

\subsubsection{LA REPRESENTACIÓN DE LO CORPÓREO}

Los filósofos del siglo XVII fueron protagonistas de una serie de cambios culturales y científicos que ya venían anunciándose en el siglo anterior. Dentro de este panorama intelectual el tema de las relaciones entre el alma y el cuerpo cobró especial problematicidad y, podríamos decir, ocupó un lugar central en la reflexión filosófica, dado que el modo de comprender esta relación implicaba adherirse a un determinado orden de concepciones antropológicas, epistemológicas, ontológicas e, incluso, teológicas.

A estos cambios se le sumó una nueva manera de interpretar los textos de los pensadores de la antigüedad, lo que trajo consigo una revitalización de sus ideas. Un ejemplo de esta nueva actitud con respecto a la filosofía antigua es diáfanamente apreciable en el tratamiento que Francis Bacon hizo de Demócrito y su doctrina atomista; concretamente, en el quincuagésimo primer aforismo de su Novum Organum Bacon dice que en la antigüedad fue la escuela de Demócrito la que mejor supo investigar las vicisitudes de la naturaleza, dado que no recurría a abstracciones sino que operaba entendiendo las cosas fragmentariamente ${ }^{15}$; seis aforismos después, el autor compara el pensamiento de la escuela de Demócrito y Leucipo con el resto de escuelas de la Grecia Antigua, a propósito de cómo sus contemporáneos estudiaban la naturaleza.

La ciencia moderna comenzó a dar sus primeros pasos en el siglo XVI como modelo de conocimiento capaz de desentrañar aquellos secretos que se escondían detrás de los cuerpos, junto con la toma de conciencia de que la composición de los entes respondía a principios asequibles y accesibles para el entendimiento humano; de manera que la ciencia emergió como medio de transparentación de lo corpóreo, implicando con ello que su método y resultados fueran relevantes para el dominio de los cuerpos, aspecto que se ha ido reforzando hasta nuestros días. Precisamente, Bacon fue uno de los pensadores que mejor supo argüir las ventajas técnicas y materiales que conllevaría implementar la nueva ciencia:

en vano nos jactaremos de progresar sensiblemente en las ciencias en general mientras la filosofía natural no se aplique a las ciencias particulares y que estas sean

\footnotetext{
${ }^{15}$ Cfr. Francis Bacon, Novum Organum (Madrid: Espasa-Calpe, 1933), 21.
} 
conducidas a su vez a la filosofía natural (...). Sin embargo, esta sola ciencia, que bebe en las verdaderas fuentes, es decir, en la observación exacta de los movimientos celestes, la marcha de los rayos luminosos, los sonidos, la contextura y mecanismo de los cuerpos, los impulsos del alma y las percepciones del entendimiento, era la única que podía procurarles sustancia, permitirles vegetar con mayor vigor y crecer más rápidamente. ${ }^{16}$

En paralelo a la ciencia, en el contexto de la pintura barroca se estaban produciendo importantes transformaciones en el modo de representar los cuerpos. Una técnica muy recurrida por parte de los pintores del barroco era emplear manchas de color mediante las que lograban un efecto de indefinición en las determinaciones de los cuerpos que representaban ${ }^{17}$, tratando de imitar la forma en que los seres humanos perciben los objetos naturales mediante la vista. En el estilo depurado del insigne pintor español Diego Velázquez se puede apreciar esta técnica al observar con minuciosidad sus cuadros. Esta técnica de las manchas de color evoca un giro en la concepción perceptiva y una nueva forma de comprender la representación de lo real, parece como si la pintura también hubiese entrado en el nuevo paradigma atomista al entender la representación de lo corpóreo sumando sutiles manchas de colores. En El ojo y el espíritu Maurice Merleau-Ponty sostiene que la pintura moderna precisamente trataba de superar el cerrojo que las líneas le habían impuesto a las cosas. No es que toda disensión entre la alineación o el puntillismo forzara a decantarse por una de las dos opciones estilísticas, sino que había que utilizar nuevos recursos de expresión así como los ya disponibles para generar sistemas de equivalencia con la realidad ${ }^{18}$. Merleau-Ponty dice que la <<concepción prosaica de la línea como atributo positivo y propiedad del objeto en sí>> es precisamente aquello que impugna la pintura moderna, de tal modo que <<el contorno de la manzana o el límite del campo de labranza y de la pradera, a los que se tiene por presentes en el mundo, y sobre los cuales, punteándolos, el lápiz o el pincel no tendrán más que pasar $>{ }^{19}$.

Esta técnica pictórica puede recordarnos alegóricamente al emblema con el que el filósofo británico Thomas Hobbes ilustró su obra política más famosa, el Leviatán, en

\footnotetext{
${ }^{16}$ Bacon, ob. cit., 52-53.

${ }^{17}$ Rafael Bueno Morales, "Velázquez: un pintor científico del siglo XVII. Una aproximación a su técnica en el IV centenario de su nacimiento", Spin cero. Cuadernos de ciencias, no. 4 (1999): 44-46, 44.

${ }^{18}$ Cfr. Maurice Merleau-Ponty, El ojo y el espíritu (Madrid: Trotta, 2013), 54.

${ }^{19}$ Merleau-Ponty, ob. cit., 55.
} 
cuya portada aparece la cabeza de un rey sujetada por un cuerpo compuesto de varios individuos unidos. Quentin Skinner, en Hobbes y la libertad republicana, se ocupa de analizar los emblemas a los que el autor de Malmesbury recurrió para sintetizar en imágenes las aseveraciones más características de su pensamiento político. En concreto, sobre la portada del Leviatán ${ }^{20}$, Skinner afirma que la imagen sugiere que el rey le debe la gloria y la gracia del poder al pueblo que le sostiene; por tanto, las ideas que se desprenderían de este emblema serían que la cohesión humana vertebra las fuerzas del Estado y que, dentro de él, cada individuo hallaría la seguridad y el sosiego necesarios para una vida pacífica y segura ${ }^{21}$.

Obsérvese cómo en el siglo XVII la comprensión de la anatomía humana no sólo abarca los conceptos científicos y las imágenes artísticas, sino también las representaciones del poder, las cuales, en lo concerniente a la teoría política, invocan una suerte de relaciones alegóricas.

Asimismo, cuando John Locke habla acerca de la sustancia material, recurre a la noción de átomo como ejemplo de principium individuationis. El átomo es idéntico a sí mismo tanto en un instante concreto como en la prolongación temporal de su existencia. Igualmente, dice Locke que la unión de varios átomos en una masa que conforma un cuerpo se mantiene constante en el tiempo siempre y cuando no se añadan ni separen átomos de dicha masa; esta asociación de átomos sería lo que definiría la identidad sustancial de un cuerpo material ${ }^{22}$.

Un pintor que supo capitalizar todas las posibilidades artísticas y conocimientos científicos sobre la luz fue Jan Veermer. En el cuadro titulado Conversación se pueden observar los cuerpos de dos personas conversando en dos planos: en un primer plano hay un caballero a contraluz dando la espalda al observador, en un segundo plano se encuentra una mujer en quien la luz incide directamente. El cuerpo y la luz son dos componentes fundamentales en las representaciones pictóricas barrocas, obras que vienen respaldadas por un conocimiento sobre el comportamiento de la luz y la expresión de los cuerpos humanos en movimiento por parte de los artistas. En cierto modo, cabe afirmar que la pintura barroca es una dióptrica puesta en práctica, lo que se

\footnotetext{
${ }^{20}$ Cfr. Quentin Skinner, Hobbes y la libertad republicana (Buenos Aires: Universidad Nacional de Quilmes, 2010), 153.

${ }^{21}$ Cfr. Skinner, ob. cit., 155-157.

${ }^{22}$ Cfr. John Locke, Ensayo sobre el entendimiento humano (Buenos Aires: Aguilar, 1967), 125.
} 
relaciona muy estrechamente con las investigaciones que René Descartes realizó sobre el sentido de la vista y el comportamiento de la luz en la naturaleza.

En la Dióptrica, Descartes realiza una reflexión sin parangón sobre la luz, su principal hipótesis es que la luz es un elemento corporal, pues estaría formada por pequeños corpúsculos luminosos capaces de pasar a través del aire y de otros materiales transparentes $^{23}$. Esta composición corporal de la luz implicaría que inexorablemente se halle sujeta a las leyes físicas, que son las que explican el movimiento de todas las cosas extensas. De este modo, en el pensamiento cartesiano la luz pierde toda connotación mística y toda simbología susceptible de caer en interpretaciones teológico-religiosas.

En un pasaje de la Dióptrica, Descartes sostiene que las imágenes que se representan en el interior de nuestro cerebro no tienen por qué ser iguales a los objetos ni reflejarlos con total exactitud, pues, de otro modo, si se diera una representación calcada, no habría forma de distinguir con debida suficiencia la representación de lo representado, es decir que no existiría distinción entre imagen y objeto ${ }^{24}$. Con arreglo a esta escisión, la mente opera de tal manera que tan sólo necesita algunos rasgos característicos de los objetos representados para identificarlos, de hecho, y aquí se encuentra el ejemplo pictórico al que recurre Descartes, <<vemos que los grabados no habiendo sido realizados sino con una pequeña cantidad de tinta esparcida en diversos puntos sobre un papel nos representan selvas, villas, hombres e incluso batallas y tempestades $>{ }^{25}$. No es el ojo el que perfila la forma de las cosas, es la razón la que interviene en los contenidos sensibles procedentes de los órganos oculares para perfilar la forma de los objetos. Podría decirse, asimismo, que el punto de convergencia entre la filosofía y la pintura del barroco se encuentra, precisamente, en la meditación sobre la representación de los cuerpos y los problemas subyacentes al hecho de conocer solo mediante representaciones: el pintor barroco se preguntará cómo distribuir los colores en el lienzo para conseguir desprender un efecto en la mente del espectador que evoque la realidad, mientras que la pregunta del filósofo será cómo es posible alcanzar un conocimiento seguro y exacto de la realidad si la mente humana no puede contar más que con representaciones.

\footnotetext{
${ }^{23}$ Cfr. René Descartes, Discurso del método, Dióptrica, Meteoros y Geometría (Madrid: Alfaguara, 1981), 60-61.

${ }^{24}$ Cfr. Descartes, ob. cit., 83.

${ }^{25}$ Descartes, ob. cit., 83.
} 
El elemento original del modelo filosófico de Descartes se halla, precisamente, en su perspicaz modo de distinguir aquellas acciones, conceptos y cuestiones que se corresponden con el cuerpo de aquellas que hacen referencia al alma; el filósofo de la Flèche no se conformaba, al contrario que los escolásticos, con mantener una jerarquía entre el alma y el cuerpo en la que todos los acontecimientos físicos o fenómenos naturales fueran explicados a partir de la economía del alma, hundiendo su primigenia raíz causal en decretos divinos. Lo que Descartes trató de establecer es una distinción clara entre aquellos hechos físicos correspondientes a la realidad material, o lo que él llama res extensa, y las vicisitudes originadas por la circulación de las ideas en la mente, que se corresponden con el cogito o res cogitans; ambas se distinguen a su vez de otra realidad, la res divina.

\subsubsection{LA RELACIÓN CARTESIANA ALMA-CUERPO}

Conviene precisar en qué medida el pensamiento de Descartes supone un punto de referencia preponderante dentro de la reflexión filosófica sobre el cuerpo. La filosofía cartesiana aportó una serie de novedades, nociones y aclaraciones en cuanto a la manera de pensar el cuerpo y el alma, así como su relación y limitaciones. Para el filósofo francés la vida humana se caracteriza por la inextricable relación del cuerpo y el alma. Descartes concibe la corporalidad humana como una máquina cuyos movimientos se asemejan a los de un autómata, de igual manera sucedería con los cuerpos de los animales. Pero la diferencia fundamental entre la vida humana y la vida animal radica en que el hombre es un ser inteligente dotado de razón, por lo que los seres humanos pueden ejercer un dominio sobre el cuerpo a través de la mente, esta última, inherente al alma. Aunque, por otro lado, no todos los movimientos del cuerpo son competencia del alma ni tampoco el cuerpo ejerce una completa determinación sobre ella, más bien, existiría una integración coordinada entre ambos; en este sentido el filósofo de la Flèche afirma en la quinta parte del Discurso del método, a propósito de las diferencias entre la vida animal y la vida humana, lo siguiente:

No basta que esté alojada [el alma] en el cuerpo humano, como un piloto en su navío, a no ser acaso para mover sus miembros, sino que es necesario que esté junta y unida al cuerpo más estrechamente, para tener sentimientos y apetitos semejantes a los nuestros y comprender así un hombre verdadero. ${ }^{26}$

\footnotetext{
${ }^{26}$ Descartes, Discurso del método (Madrid: Espasa-Calpe, 1973), 83.
} 
El alma es necesaria para la formación del "hombre verdadero", si el ser humano solo estuviera compuesto de cuerpo su existencia no sería distinta a la de un animal o a la de una máquina. Cuando en la correspondencia de junio de 1643 la princesa Isabel de Bohemia le dice a Descartes que sería más fácil identificar el alma con algo material en lugar de con algo inmaterial en lo que se refiere a explicar el movimiento del cuerpo $^{27}$, el filósofo francés le responde a su discípula que él no trata de despojar al alma de su materia, que perfectamente se puede <<otorgar al alma sin reparos la materia y la extensión dichas, pues concebirla unida al cuerpo no es sino eso>>; pero que no por ello la sustancia corpórea se hace pensamiento, puesto que es preciso distinguir el pensamiento mismo de la materia a la que se ve unido, de tal forma que se podrá <<volver a distinguir fácilmente el alma del cuerpo sin que sea óbice para ello el haber concebido su unión $>{ }^{28}$. Descartes categoriza al alma como "ser pensante", de tal forma que la caracteriza como una sustancia diferente a la extensión, la sustancia inteligible. Si la unión entre el cuerpo y el alma se da de hecho, entonces, las pretensiones de Descartes van enfocadas a establecer criterios de diferenciación entre lo material y lo que se corresponde con la realidad del pensamiento, que es una realidad inmaterial e intangible.

En la obra titulada De las pasiones en general y de la naturaleza del hombre Descartes considera que para discernir con seguridad el dominio de las pasiones conviene distinguir bien las funciones del cuerpo y las funciones del alma por separado $^{29}$. De manera que todo efecto experimentado a través de nuestro cuerpo y cuya causa es atribuible a otros cuerpos pertenece al ámbito de la corporalidad, pero todo cuanto hay en nosotros cuya existencia no pueda ser atribuida a otros objetos corporales pertenece exclusivamente al dominio del alma ${ }^{30}$. Además, el autor afirma que el alma está unida a todo el cuerpo y que su principal propiedad es la indivisibilidad; no obstante, sí que existe una parte en el cuerpo humano donde el alma ejerce una especial influencia de manera más particular que en el resto de los órganos y miembros, se trataría de una glándula ${ }^{31}$ muy pequeña suspendida en medio del cerebro que dirige al

27 Cfr. René Descartes, Correspondencia con Isabel de Bohemia y otras cartas (Barcelona: Alba Editorial, 1999), 33.

${ }^{28}$ Descartes, Ob. cit., 38.

${ }^{29}$ Cfr. René Descartes, Obras completas de Renato Descartes (París: Casa editorial Garnier hermanos, 1921-1938), 162.

${ }^{30}$ Cfr. Descartes, ob. cit., 161.

${ }^{31}$ Cfr. Descartes, ob. cit., 176 
cuerpo gracias a la acción que el alma ejerce sobre ella a la vez que le da cuenta al alma de los estados corporales. Se trata de la glándula pineal. Los movimientos de esta glándula son los causantes de la motricidad corporal, pues la actividad de la glándula interviene sobre los espíritus animados, que son corpúsculos muy sutiles de la sangre responsables de transmitir las directrices motoras del cerebro al resto de las partes del cuerpo $^{32}$; igualmente, el impulso de estos espíritus cuando ascienden al cerebro también puede generar movimientos en la glándula pineal.

La inquietud que conduce a Descartes a reflexionar en torno a la relación activa entre el cuerpo y el alma viene a colación de las pasiones del alma, cuestión sobre la que afirma que, aunque la voluntad no pueda intervenir directamente en dichas pasiones, sí que puede indirectamente influir en ellas mediante las representaciones de las cosas, y las representaciones vienen mediadas por la acción de la voluntad, cuyo dominio recae sobre los pensamiento de las acciones, de modo que la voluntad tiene la capacidad de producir representaciones mediante las que inducir aquellas pasiones que quiere ${ }^{33}$. Dos años antes de la publicación del Tratado de las pasiones, en su correspondencia con el embajador Chanut del 1 de febrero de 1647, Descartes aseguraba que existe una reciprocidad entre el cuerpo y el alma de tal modo que, debido a la intensidad del movimiento del corazón, se generan algunas disposiciones corporales que producen determinados pensamientos así como, igualmente, ciertos pensamientos pueden alterar el estado del cuerpo ${ }^{34}$. La producción de las pasiones en el alma se originó a partir de los primeros momentos en que se efectuó la relación alma-cuerpo, por eso

sucede que las primitivas disposiciones del cuerpo, que de esta forma fueron aparejadas con nuestros pensamientos cuando entramos en este mundo, debieron, sin duda, de vincularse a ellos de forma más estrecha que la que vinieron luego. Y en lo referido al origen del calor que notamos en torno al corazón, o al de las demás disposiciones del cuerpo que acompañan al amor, pienso que desde el primer momento en que nuestra alma quedó unida al cuerpo sintió muy probablemente alegría, y acto seguido amor, y luego quizá también odio y tristeza; y que esas mismas

\footnotetext{
${ }^{32}$ Cfr. Descartes, ob. cit., 165-166.

${ }^{33}$ Cfr. Descartes, ob.cit., 183.

${ }^{34}$ Cfr. René Descartes, Correspondencia con Isabel de Bohemia y otras cartas (Barcelona: Alba Editorial, 1999), 234.
} 
disposiciones del cuerpo que provocaron a la sazón esas pasiones se aparejaron ya siempre de forma espontánea a los pensamientos. ${ }^{35}$

Las pasiones son el resultado de la vinculación sintética del cuerpo y el alma, estas, testifican que en algún momento se produjo esa relación inextricable entre ambos, y que las disposiciones que en ese momento tuvieron lugar prevalecen hasta el punto de que existe una sintonía recíproca de los movimientos orgánicos y los pensamientos. La razón, aun perteneciendo a una realidad diferente de la del cuerpo, tiene en el alma humana su dominio y nutrido campo de actividad. La proyección de una vida racional por parte del sujeto debe contar con las pasiones en el inventario del alma, motivo por el que el filósofo de la Flèche dice al final de su Tratado de las pasiones que aunque los seres humanos poseen placeres exclusivos del intelecto también hay en las pasiones -en la simultaneidad del cuerpo y el alma- placeres que resultan muy agradables para la vida, pero que, si bien, la falta de gobernanza sobre las pasiones o la falta de fortuna provoca gran amargura, la racionalidad de la prudencia enseñará $<<a$ adquirir el dominio de sí mismo y a dirigirse con tan exquisita moderación, que se soportan fácilmente los males y hasta en ellos encontramos alegrías $>>{ }^{36}$.

Pese a todo, Descartes sabe lo problemáticas que pueden llegar a ser las pasiones para la proyección de una vida racional, y es consciente de que en su apreciación acerca de la relación alma-cuerpo, donde el alma es puesta a ras de la corporalidad, las pasiones son el elemento pendular entre ambas sustancialidades de naturalezas tan diferentes pero igualmente implicadas en la vida. En el artículo 48 del Tratado de las pasiones el autor menciona que puede suceder que los espíritus animados impulsen a la glándula pineal para representar en el alma un deseo de la voluntad, y, a su vez, también el alma puede sortear a la cosa deseada anteponiendo su voluntad ${ }^{37}$, no obstante, cualquier sujeto humano, al estar provisto de razón posee la capacidad, independientemente de la fortaleza o debilidad de su alma, de ejercer un dominio sobre sus pasiones. En el caso de algunos animales, entre los cuales ninguno está provisto del ejercicio de la razón, se da la posibilidad de alterar sus impulsos naturales siempre y cuando haya un humano que los adiestre, a lo que Descartes añade que:

\footnotetext{
${ }^{35}$ Descartes, ob. cit., 235.

${ }^{36}$ René Descartes, Obras completas de Renato Descartes (París: Casa editorial Garnier hermanos, 19211938), 264.

${ }^{37}$ Cfr. Ob. cit., 184-186.
} 
Es muy grande la utilidad que reporta el conocimiento de estas cosas, porque si las consideramos atentamente, nuestras pasiones, veremos que si con un poco de habilidad se pueden cambiar los movimientos del cerebro en los animales que carecen de razón, es evidente que mucho más fácil ha de ser conseguir este mismo resultado en los hombres. ${ }^{38}$

La racionalidad es el vértice operativo desde el que el alma domeña al cuerpo. La articulación de la razón se despliega a partir de la constitución cognitiva e inteligible que caracteriza al alma, así, se produce una relación vertical de esta con el cuerpo en la que las pasiones actúan como un catalizador con que el alma puede ejercer su control sobre la corporalidad, aunque en última instancia el sujeto deberá gobernar sus pasiones evitando los excesos y exacerbación a los que muchas veces le fuerzan; por ello Descartes considera esencial que el hombre sea prudente y cuerdo a la hora de dirigirlas $^{39}$. La razón siempre tendrá que prevalecer a la hora de ejercer una gestión efectiva de las pasiones, sinónimo de un manejo racional de la vida.

Aparte, conviene poner de relieve que en el tratamiento cartesiano de las pasiones sobresale un elaborado conocimiento sobre el funcionamiento del cuerpo humano. Al comienzo de la obra Descripción del cuerpo humano y de todas sus funciones ${ }^{40}$ el pensador de la Flèche dice:

$<<$ No hay nada más fructífero que podamos hacer que saber cuidar de nosotros mismos $>41$.

Descartes acusa la falta de pericia de su tiempo en asuntos de anatomía, una disciplina que considera en situación de letargo, cuyo avance estaría viéndose perjudicado debido a una férrea obcecación por explicar todos los menesteres corporales situando su causa en el alma:

A lo que ha contribuido mucho la ignorancia de anatomía y mecánica, pues considerando nada más que el exterior del cuerpo humano, no hemos sido capaces de

\footnotetext{
${ }^{38}$ Descartes, ob. cit., 188.

${ }^{39}$ Descartes, ob. cit., 264.

${ }^{40}$ René Descartes, Oeuvres de Descartes XI [contiene: Le monde, Description du corps humain, Passions de l'ame, Anatomica, varia] (Paris: Léopold Cerf, Imprimeur-editeur, 1909).

$41<<$ Il n'y a rien a quoy l'on fe puiffe occuper auec plus de fruit, qu'à tafcher de fe connoiftre foymefme>>. René Descartes, Oeuvres de Descartes XI (Paris: Léopold Cerf, Imprimeur-editeur, 1909), 223 (traducción propia).
} 
imaginar que tuviese suficientes órganos o mecanismo para moverse a sí mismo de tantas maneras diferentes como vemos que se mueve. ${ }^{42}$

El rechazo que Descartes muestra hacia los planteamientos anatómicos predominantes en su época no sólo denotan una suerte de crítica científica, pues, tras la carencia intelectual denunciada, también el autor deja entrever una falta de independencia a la hora de producir conocimientos científicos y de emprender investigaciones sobre cuestiones del mundo físico; así, el autor alude al concepto teológico de alma como un escollo para explicar determinados asuntos cuyas causas no se remontan más que a las condiciones físicas que determinan los estados del cuerpo humano. De este modo, a lo que se está apuntando muy indirectamente es a la necesidad de promover una ciencia autónoma guiada por la luz de la razón, sin la presencia de tutelajes provenientes de autoridades externas distorsionadoras del camino científicoracional hacia la verdad. Se aprecia también cómo en ningún momento Descartes pierde de vista el poderío que entraña el alma en lo que se refiere al conocimiento y control del cuerpo, pues toda racionalidad surge del alma; el cuerpo es visto como un objeto de observación, estudio y, además, como "campo de batalla" donde se disputan diferentes saberes. El poder del concepto de alma promulgado y promovido por los teólogos consistía, precisamente, en evitar que la razón alumbrara aquellos caracteres y aspectos más desconocidos de la corporalidad.

La única que tiene capacidad para conocer la lógica inherente a las cosas es la razón, de tal modo que hoy en día también en el ámbito de las relaciones humanas las ciencias sociales tratan de aplicar la racionalidad metodológica en la investigación, las relaciones humanas están bajo el foco de la "luz natural" de la razón mediante la que Descartes pretendía entender la lógica interna de las "máquinas naturales" en las que inexorablemente se ve encajada el alma humana y, por ende, también la racionalidad. Bajo esta perspectiva, conviene valorar la preocupación y el tratamiento que el filósofo francés hace de las pasiones como un intento de entender también la estructura de los sentimientos humanos en su puesta en común, es decir, en la interacción de los hombres en cuanto que pasionales. Hablar acerca de las pasiones implica tener que dilucidar cómo reacciona sentimentalmente el hombre con relación a los otros, por ejemplo, en el

\footnotetext{
$42<<$ A quoy auffi a beaucoup contribué l'ignorance de l'Anatomie \& des Mechaniques; car ne confiderans rien que l'extérieur du corps humain, nous n'auons point imaginé qu'il euft enfoy affez d'organes, ou de reffors, pour fe mouuoir de foy-mefme, en autant de diuerfes façons que nous voyons qu'il fe meut>>. Descartes, ob. cit, 224 (traducción propia).
} 
caso de la envidia, que se produce cuando un objeto deseado por un sujeto es poseído por otro sujeto diferente ${ }^{43}$.

El análisis de las pasiones del alma supone llevar a cabo una introspección en el funcionamiento de la psicología humana trasladando el método científico a la materia de los sentimientos, incluso se podría decir también que se emprende una mirada social si nos ceñimos al modo en que las pasiones suelen ir ligadas al tipo de relaciones que el sujeto humano mantiene con otros sujetos humanos, por lo que se inquieren cuestiones referentes a las condiciones de convivencia de las personas a nivel pasional, nivel desde el que de alguna manera se componen enlaces intersubjetivos. No está de más hacer presente en este aspecto la apreciación de Remo Bodei en La geometría de las pasiones cuando, a propósito del rostro frío e indolente del Cardenal Richelieu que con tanta audacia le permitía ocultar sus sentimientos en los encuentros políticos y diplomáticos, afirma que la $<<$ ciencia de las pasiones se vuelve así una "ciencia invisible", que se empeña en la traducción simultánea de lo visible en lo invisible y viceversa $>{ }^{44}$. La ciencia cartesiana de las pasiones no es solo un ejercicio introspectivo del sujeto sino que también se advierte como un esfuerzo por conocer -como diría Bodei- aquellos $<<$ 'pliegues' más recónditos $>>45$ del otro, lo que facilita la articulación de un saber acerca de la dimensión donde tienen lugar las relaciones humanas.

\subsubsection{LA CORPORALIDAD EN MEDIO DE "LA BATAlla FINAL POR EL ALMA HUMANA"}

Huelga observar de qué forma la posteridad ha asumido y discutido la manera en que Descartes concibió la relación alma-cuerpo. En un texto de Richard Watson titulado Descartes. El filósofo de la luz, se describe cómo los planteamientos del filósofo francés iniciaron un duradero y problemático enfrentamiento en el terreno de la epistemología a la hora de tratar la relación entre la mente-alma y el cerebro-cuerpo. Para Watson el cartesianismo fue pionero en el modo de plantear la dualidad disruptiva entre el cuerpo y el alma en una tensión que enfrenta a materialistas y espiritualistas, los primeros han emprendido la "conquista del alma" en vistas a hacer valer el monopolio del cuerpo como centro de toda explicación sobre la realidad humana, mientras, a los segundos no

\footnotetext{
${ }^{43}$ Cfr. René Descartes, Obras completas de Renato Descartes (París: Casa editorial Garnier hermanos, 1921-1938), 249.

${ }^{44}$ Remo Bodei, Geometría de las pasiones (México: Fondo de Cultura Económica, 1995), 142.

${ }^{45}$ Bodei, ob. cit., 142.
} 
les habría quedado más remedio que replegarse ante las incisivas demostraciones científicas. La cuestión es <<averiguar si tenemos alma o no〉> tema en el que $<<$ Descartes preparó el escenario para esta batalla con su dualismo de dos sustancias diametralmente diferentes $>{ }^{46}$. Además, afirma Watson:

La batalla final por el alma humana se generó a partir de dos doctrinas centrales de la filosofía de Descartes. La primera de ellas, que nuestro yo real, es una mente-alma que tiene una existencia independiente del cuerpo, y que esta mente-alma ordena y controla el cuerpo como un fantasma en una máquina. La segunda doctrina crucial de Descartes es que todos los animales (...) son máquinas porque se comportan de un modo u otro porque responden a estímulos externos del ámbito material, (...). ${ }^{47}$

La polémica epistemológica de la que da cuenta Watson tuvo su ebullición y plena latencia durante el siglo XVII y a prácticamente ninguno de los filósofos de la época dejó indiferente. Autores como G. W. Leibniz consideraron que el cuerpo no goza de realidad más allá de las nociones que prefiguran el alma y los conceptos del entendimiento. En el artículo doce de su Discurso de metafísica, Leibniz, a diferencia de Descartes, sostiene que la extensión no se puede reducir a una sustancia diferente de la sustancia cognitiva o res cogitans puesto que la extensión, en la que está involucrado el cuerpo humano, toma forma en la medida en que se halla relacionado con las almas, de tal manera que las cualidades de los cuerpos no existen como identidades más que en la mente humana, y no en un supuesto mundo exterior donde gozarían de autonomía ontológica. Mediante esta operación Gottfried Leibniz subyuga totalmente la sustancia corpórea al alma humana, porque

las almas y las formas sustanciales de los demás cuerpos son muy diferentes de las almas inteligentes, únicas que conocen sus acciones, y que no sólo no perecen, naturalmente, sino que guardan siempre el fundamento de lo que son; lo que hace que sólo ellas sean susceptibles de castigo y de recompensa, y las hace ciudadanas de la República del universo. ${ }^{48}$

De estas palabras del filósofo alemán se deduce que el fundamento del dominio del alma humana sobre la sustancia corpórea reside en la inteligencia, algo que comparte con Descartes aunque, más allá de este, destituye el sistema de las tres sustancias para

\footnotetext{
${ }^{46}$ Richard Watson, Descartes. El filósofo de la luz (Barcelona: Ediciones B, S.A., 2003), 292.

${ }^{47}$ Watson, ob. cit., 302.

${ }^{48}$ Gottfried Wilhelm Leibniz, Discurso de metafísica (Madrid: Alianza, 2002), 65-66.
} 
considerar que la sustancia humana es la única capaz de dilucidar la naturaleza de las cosas y otorgarle identidad, pues solo los hombres son capaces de entender cómo pueden emplear la naturaleza para sus intereses, en virtud de que sólo un alma consciente sabe qué le reportará castigo y qué recompensa; por eso los seres humanos pueden entender lo malo y lo bueno, así como lo beneficioso y perjudicial, a fin de poner las sustancias a su servicio. Leibniz termina por subyugar lo corpóreo a lo inteligible, lo sustancial bruto a lo sustancial sutil e invisible.

En una línea radicalmente distinta a los matices que se pueden reconocer en el pensamiento filosófico de Leibniz y Descartes se hallan las tesis de Hobbes sobre el cuerpo. Hobbes instaura una división principal entre los cuerpos naturales y los cuerpos artificiales: los primeros vendrían dados por la naturaleza, mientras que los segundos serían fruto de los convenios o pactos humanos. Las corporalidades que surgen de los acuerdos son artificiales en tanto en cuanto proceden de la voluntad de los hombres. El filósofo de Malmesbury aplica una concepción de corte corporalista ${ }^{49}$ en el tratamiento de todos los ámbitos de la vida, tanto en referencia a las cuestiones naturales como en referencia a las cuestiones políticas, algo que se evidencia con especial intensidad en uno de los pasajes del Leviatán:

La palabra cuerpo, en su acepción más general, significa aquello que llena u ocupa un determinado espacio o lugar imaginado, y que no depende de la imaginación, sino que es una parte real de lo que llamamos Universo. En efecto, siendo el Universo un agregado de todos los cuerpos, no existe tampoco una parte real del mismo que no sea cuerpo, ni hay cosa alguna que propiamente sea un cuerpo, que no sea, además, parte de ese agregado de todos los cuerpos que es el Universo. ${ }^{50}$

En el pensamiento hobbesiano no se reconoce otra sustancia más que lo corpóreo, por lo que la corporalidad atraviesa todos los ejes de sus planteamientos en materia epistemológica, moral y política, erigiéndose como objeto central de reflexión y principal concepto del filosofar. La razón sería, así pues, una capacidad más que una

\footnotetext{
${ }^{49}$ Es preciso indicar que en la cosmovisión corporalista de Hobbes todas las experiencias humanas están circunscritas a su dimensión corpórea. La imaginación o la razón son más bien facultades que permiten utilizar los datos sensuales para elaborar predicciones, hacer cómputos, crear ficciones, producir objetos artificiales y conformar cuerpos políticos. A lo largo de los cinco primeros capítulos del Leviatan Hobbes insiste en que toda experiencia requiere de sensaciones, y que las sensaciones pertenecen al dominio de la corporalidad humana. El cuerpo es el eje radial sobre el que van tomando forma las distintas experiencias, incluyendo las que van vinculadas a actividades que los individuos realizan en diversos quehaceres y en condición de ciudadanos.

50 Thomas Hobbes, Leviatán (Buenos Aires: Fondo de Cultura Económica de Argentina, 1992), 323.
} 
sustancia con independencia ontológica respecto a lo corporal. Hobbes asocia la razón a la psicología humana y la subordina a los cálculos que los seres humanos tienen que realizar de acuerdo a las necesidades y sustento del cuerpo. De este modo, la operación que lleva a cabo Hobbes en su esquema de pensamiento sigue una vertiente opuesta a las filosofías de Descartes y Leibniz, quienes sitúan a la razón en una sustancia tal como el alma, que se encuentra en un plano incorporal e invisible, además de entregarle plena potestad a la razón para dirigir los aspectos de la corporalidad humana. Mientras Hobbes reduce la vida y la dirección de esta a los principios indicados por las necesidades del cuerpo, Descartes y Leibniz recurren a un principio directriz externo al cuerpo donde se halla en su plenitud la inteligencia desde la que se despliega la razón.

En una línea intermedia entre ambas posturas, incompatibles entre sí, se sitúan las ideas epistemológicas de John Locke, quien, disipando las dicotomías, en el Ensayo sobre el entendimiento humano reconoce que no podemos fácilmente concebir la distinción entre la sustancia del cuerpo de la sustancia del alma ${ }^{51}$. La única manera de establecer esta distinción, según Locke, sería recurrir a los actos de sensación, en los que se podría distinguir en términos prácticos un Yo que recibe los contenidos procedentes de los sentidos, de un cuerpo que actuaría como soporte material necesario para canalizar hacia el Yo pensante el contenido de las sensaciones ${ }^{52}$. La diferencia entre este planteamiento gnoseológico y el de Descartes radica en que Locke le concede un mayor valor a la dimensión de la experiencia en el conocimiento, ya que el autor británico no cree que la filosofía natural, mediante el ejercicio exclusivo de la razón, pueda sustraer el fundamento último que explica las esencias de las sustancias, hasta tal punto que $<<$ la experiencia debe enseñarnos lo que aquí no puede la razón ${ }^{53}$. La razón, por tanto, no sería autónoma a la hora de producir conocimiento, pues la experiencia siempre rellenará aquellos vacíos cognoscitivos que la razón haya dejado a la intemperie.

Locke sospecha que la filosofía natural no puede convertirse en ciencia, puesto que sólo <<somos capaces de alcanzar un conocimiento general muy limitado de las especies de los cuerpos y de sus varias propiedades $>{ }^{54}$. La razón contribuye a aumentar el conocimiento, pero no puede penetrar la esencia de los cuerpos por lo que

\footnotetext{
${ }^{51}$ Cfr. John Locke, Ensayo sobre el entendimiento humano (Buenos Aires: Aguilar, 1967), 109.

${ }^{52}$ Cfr. Locke, ob. cit., 112.

${ }^{53}$ Locke, ob. cit., 188.

${ }^{54}$ Locke, ob. cit., 189.
} 
no es capaz de ofrecer una imagen inequívoca sobre la realidad albergada en ellos. Aunque, por otro lado, sí que gracias a la razón podemos descubrir la existencia de Dios y alcanzar un saber sobre nosotros mismos; a lo que el autor añade:

Por esto es fácil concluir que nuestra verdadera ocupación consiste en aquellas investigaciones y en aquella clase de conocimientos que son más adecuados a nuestra capacidad natural, y nos llevan hacia nuestros más grandes intereses; es decir, a la condición de nuestro estado eterno. De aquí creo que puedo concluir, que la moral es la ciencia y el asunto apropiado de la humanidad en general. ${ }^{55}$

Locke se desmarca así de situar el destino de la existencia humana en adherencia a la ciencia, al contrario de lo que hizo Descartes, pues para Locke la capacidad natural de los hombres va en relación con el conocimiento parcial de sus intereses, que tienen que ver con el problema de Dios, la eternidad, el bien y el mal; problemas vinculados directamente con la moral. No entra Locke a considerar el estatuto de la razón más allá de los asuntos morales, o lo que es lo mismo, su preocupación sobre la cuestión de la moralidad humana tiene que ver con la coyuntura de la convivencia y, por ende, la razón tendrá mucho que decir en los temas que afectan a la política.

Si bien Locke asegura que <<en la identidad personal se funda el derecho y la justicia del premio y el castigo $>>$ y que $<<$ la identidad personal consiste, no en la identidad de sustancia, sino en la identidad de conciencia $>>^{56}$, este no dice, como sí dijera Leibniz, que la conciencia humana tenga el privilegio de atribuirle una identidad ontológica a las sustancias externas al alma, dado que Locke, como ya hemos venido diciendo, desconfía de la razón para extraer un conocimiento esencial sobre la constitución ontológica de las cosas. Dicho de otro modo, la razón no tiene la última palabra sobre la verdad de las cosas porque su funcionamiento ha de remitirse a resolver asuntos que preocupan y conciernen exclusivamente al género humano.

Pero Locke no sólo desarticula esa concepción de la razón autónoma, externa al cuerpo y gobernadora de la naturaleza, también hemos de situar al filósofo de Wrington al margen del pensamiento corporalista de Hobbes, puesto que no le concede al cuerpo tal centralidad, ya que no irgue su ciencia sobre el conocimiento de este; el tratamiento

\footnotetext{
${ }^{55}$ Locke, ob. cit., 189.

${ }^{56}$ Locke, ob. cit., 127.
} 
del cuerpo que realiza es más bien indirecto tanto en su dimensión epistemológica como política.

\subsubsection{DOMINIO DIRECTO Y DOMINIO INDIRECTO SOBRE EL CUERPO}

En la filosofía del siglo XVII se realiza un tratamiento de la razón en relación con el cuerpo a partir de la que es posible vislumbrar dos formas fundamentales de dominar la corporalidad humana: mediante un principio sustancialmente distinto y externo al propio cuerpo, o mediante un cuerpo artificial extrínseco a la corporalidad natural pero hecho de su misma sustancia. Esta forma extrínseca, sea incorpórea o corpórea, se configura como un poder forjado para controlar las pulsiones y las acciones impelidas por la fisiología del individuo.

Descartes y los racionalistas en general están vinculados a la primera forma de dominio, mientras que muy singularmente Hobbes piensa en una forma de dominación inherente a la experiencia corporal. Descartes duplica la realidad y distingue entre la extensión y la razón, donde la razón se posiciona sobre la corporalidad humana para hacer posible un desarrollo inteligible de la vida, el control sobre los movimientos naturales procedentes del cuerpo pertenece a una realidad distinta de lo corpóreo y sensible, sintetizada al cuerpo, pero diferenciada de él, y cuyas directrices no vienen determinadas por la mecánica que rige los movimientos corporales. Hobbes, sin embargo, duplica el cuerpo, pero esta duplicación no viene dada en el orden de la naturaleza, sino que son los seres humanos los que, de acuerdo a la necesidad de dominar sus cuerpos para superar las inclemencias de la vida en la naturaleza, erigen un cuerpo civil que habrá de regular la vida social; la duplicidad que propone Hobbes es artificial pero no extralimita las determinaciones inscritas en la experiencia corporal, en tanto en cuanto única experiencia posible. El Estado es un cuerpo que se siente y percibe, porque su fuerza se hace presente en el contexto de las relaciones humanas que tienen lugar en el espacio público.

En Hobbes importa tener en cuenta ya no solo la concepción de un poder corpóreo sino también el comportamiento del poder en cuanto corporalidad. El poder en Hobbes siempre permanece en disposición física, se comporta como un cuerpo, es un activo de presión sobre los ciudadanos, quienes siempre estarán expuestos al factum de ser intervenidos por una instancia corporal más fuerte que cada uno de ellos. El pensamiento político hobbesiano recurre a la materialización del Estado para retener los 
impulsos naturales de la corporalidad humana, es obvio que este Estado no siempre tiene por qué intervenir directamente sobre el cuerpo, basta con que permanezca en la subjetividad del individuo como un concepto adherido a la mente de cada cual y cuya resolución física (existencia fáctica) comporta la presencia de una potencia perpetua. Lo importante es que el Estado previamente se instituya como un cuerpo y se comporte como tal. Una vez la presencia corpóreo-Estatal es instaurada en la subjetividad de los individuos, el miedo que genera en ellos debiera resultar inextirpable.

Interpreta Bodei que Hobbes instrumentaliza el miedo como forma de dominación porque es el sentimiento que iguala a todos los hombres ${ }^{57}$. La vía más efectiva para inducir el miedo es insinuar la posibilidad de causar la muerte, por tanto, será a través del miedo a la muerte como se logrará disuadir a los hombres de perturbar el orden social establecido ${ }^{58}$. Bodei afirma que esta manera de ver las cosas es completamente distinta de la actitud cartesiana, <<que, considerando con certeza el alma inmortal, tomaba en consideración la diferencia entre un cuerpo vivo y un cadáver semejante a aquella entre un reloj o una máquina que funciona y un reloj o una máquina rota $>{ }^{59}$. Ahora bien, en otro punto de su investigación, Bodei sostiene que desde la panorámica hobbesiana $<<$ el "así quiero, así mando" del soberano ocupa por lo menos una parte de aquel espacio que en Descartes correspondía de cualquier manera a la voluntad del individuo $>{ }^{60}$. En todo caso, la imagen mecanicista del cuerpo proporcionada por ambos filósofos va asociada a los conceptos de limitación, finitud, fuerza física y necesidad, etc., pero, a su vez, su diferencia esencial reside en que Hobbes no contempla ni siquiera la posibilidad de que exista algún otro tipo de sustancia no corporal susceptible de trascender esta batería de engranajes físicos, mientras que en Descartes la sola idea del alma como sustancia diferenciada de la hechura de los cuerpos abre los márgenes de la libertad humana. Aunque, a pesar de todo, no pudo prescindir el pensador francés de recursos para causar la abyección del cuerpo humano desde la acción de la voluntad del cogito, también es cierto que ninguno de estos recursos consistía en causar miedo y conmoción en el sujeto. Para que el sujeto desenvuelva su vida de forma racional, el componente extenso de la síntesis alma-cuerpo ha de ser controlado con la finalidad de que la máquina no restrinja aquella sustancia no corpórea

\footnotetext{
${ }^{57}$ Cfr. Remo Bodei, Geometría de las pasiones (México: Fondo de Cultura Económica, 1995), 89.

${ }^{58}$ Cfr. Bodei, ob. cit., 90.

${ }^{59}$ Bodei, ob. cit., 90-91.

${ }^{60}$ Bodei, ob. cit., 293.
} 
en la que anida la voluntad libre, y que es el único componente por el que el hombre puede diferenciarse de los animales y de las máquinas.

Precisamente en este momento de la discusión encaja el reproche que Skinner lanza contra la idea de libertad en Hobbes: el filósofo de Melmesbury, no exento de cuestionarse sobre el asunto de la libertad dentro del esquema corporal-determinista que plantea, presentó lo que Skinner define como una concepción de la libertad $<<$ descarnada en su simplicidad >> ${ }^{61}$, puesto que Hobbes habría reducido esta noción a nada más que a la ausencia de interferencias externas en los movimientos corporales de los individuos. Según Skinner, la forma en que Hobbes presenta el tema de la libertad no contempla, como sí lo hacen los autores republicanos, la posibilidad de que esta se vea alterada e interferida también por una autoridad que actúe de manera arbitraria; la crítica que se le hace a Hobbes desde la perspectiva de la filosofía republicana -la misma que Skinner respalda- sería que no solo se es libre por el hecho de mantener el cuerpo absuelto de intersecciones físicas, que existen otras formas de coacción aparte ${ }^{62}$. Podría afirmarse, de acuerdo con lo anterior, que Hobbes, fiel a su cosmovisión corporalista, adapta el problema filosófico de la libertad a términos estrictamente corporeizados, de modo que su atención reflexiva vira hacia aspectos que tienen que ver estrictamente con el contacto directo y con el juego de presiones y resistencias corporales.

Uno de los planteamientos políticos que conjuga la libertad y la dominación es el de Locke, el cual -como vimos previamente- parte de que la razón humana no persigue dilucidar la esencia de los cuerpos, sino comprender la moral en cuanto que asunto por excelencia de las relaciones humanas. El dominio indirecto del cuerpo presente en la filosofía lockeana tiene una traducción muy clara a términos políticos que se hace patente en un fragmento del Ensayo sobre la tolerancia. En dicho fragmento el autor asienta la idea de que la fuerza no es un método capaz de cambiar las opiniones de los seres humanos, así, la persecución y la amenaza no sirven para transformar las ideas de los ciudadanos; entonces, cabría utilizar métodos más ambles para que los hombres tornen sus pensamientos, métodos que inspiren confianza y acerquen a los ciudadanos al

\footnotetext{
${ }^{61}$ Quentin Skinner, Hobbes y la libertad republicana (Buenos Aires: Universidad Nacional de Quilmes, 2010), 169.

${ }^{62}$ Cfr. Skinner, ob. cit., 169.
} 
Estado $^{63}$. De modo que para Locke <<las gentes así divididas en diferentes facciones serán mejor controladas si se practica con ellas la tolerancia $>>64$.

La tolerancia sería un instrumento en manos del poder estatal para inocular la paz en el cuerpo social. Al asegurar la libertad de pensamiento y culto en cada individuo o grupo de individuos, se contribuiría, entre otras cosas, a que fuera preferible por todos un régimen tolerante a uno en el que se aplique la persecución ${ }^{65}$. De una forma indirecta, el control social se logra mediante la permisión de una pluralidad de pensamientos en el Estado y no mediante la pugna entre el cuerpo político y las corporalidades sociales, en la que el primero arreste y transgreda el cuerpo de los individuos en pos de imponer el monopolio de un pensamiento oficial.

De otro escrito de Locke acerca de este asunto, concretamente la Carta sobre la tolerancia, se desprende, además, la idea de que la intervención del poder en el cuerpo no es un método de persuasión loable, en la medida en que no contribuye a modificar la forma de pensar de los hombres:

Y tal es la naturaleza del entendimiento humano, que no puede ser obligado a creer algo como resultado de una fuerza externa. Confisquemos los bienes de los hombres, encarcelemos o torturemos su cuerpo: tales castigos serán en vano, si lo que de ellos esperamos es que este hombre cambie su modo interno de juzgar las cosas. ${ }^{66}$

Oprimir y agredir la dimensión corporal humana para cambiar el juicio de los individuos fracasará en su cometido, ya que Locke considera que la persuasión es el método más efectivo para alcanzar tal fin; habrá que acudir al entendimiento, dado que es preciso arrojar <<luz para operar un cambio en la opinión de los hombres; dicha luz no puede en modo alguno provenir de los sufrimientos corporales $>{ }^{67}$. Con base en estas sentencias, resulta lícito afirmar que el modelo político lockeano apela al entendimiento de los hombres para hacer posible la paz social. La tolerancia se convierte en un método de control no corporal, sino mental. La filosofía de Locke no considera conveniente ni moralmente aceptable que la autoridad civil contraponga su fuerza a los cuerpos de los hombres para imponerles una u otra creencia. El filósofo

\footnotetext{
${ }^{63}$ Cfr. John Locke, Ensayo y Carta sobre la tolerancia (Madrid: Alianza Editorial, 1999), 53.

${ }^{64}$ Locke, ob. cit., 54.

${ }^{65}$ Cfr. Locke, ob. cit., 54.

${ }^{66}$ Locke, ob. cit., 68.

${ }^{67}$ Locke, ob. cit., 69.
} 
inglés preconiza un modelo de control ciudadano que no interviene de forma directa a través del cuerpo de los individuos, sino de forma indirecta, a partir del entendimiento y la luz de la razón. El gobernante fracasaría si solo operara mediante la fuerza física e hiciera del cuerpo de sus súbditos el medio desde el que condicionarlos, intervenirlos y dirigirlos. Más bien, sería por medio del entendimiento como se puede promover la tolerancia, articuladora de la estabilidad en la vida social de los ciudadanos.

La forma en que Locke tuvo en cuenta el modo de articular la paz social en el Estado se opone sistemáticamente a las propuestas que Hobbes hizo al respecto, dado que este último concibió al Estado como ese cuerpo físico capaz de imponer la paz en el seno de la sociedad por medio de la fuerza o, al menos, por medio de la sugerencia de que existe una instancia corpórea apta para actuar. Sin embargo, en la filosofía política lockeana la pacificación de la vida pública viene garantizada por la tolerancia en la sociedad civil, el comportamiento de las instancias en que se alberga el poder político no emplea recursos corporales para alcanzar la estabilidad social. La tolerancia se vuelve una táctica con que hacer posible las relaciones cordiales entre los ciudadanos, la asunción de la tolerancia por parte de todos ellos previene la agresión física. Locke hace presente al Estado en la mente de las personas no configurándolo como un cuerpo, sino como una mutua articulación entre la libertad de los individuos y los convenios suficientes que deben instaurar para la regulación de su coexistencia. En consecuencia, las corporalidades humanas no se moverían tanto por la amenaza o la represión como por el convencimiento y el acuerdo. Si todos y cada uno de los ciudadanos logran asumir preceptos como el de la tolerancia, tan útil como necesario para garantizar la convivencia pacífica, el recurso a la agresión y al empleo de la fuerza física se verá mermado tanto en el gobierno de los cuerpos civiles como en su interacción pública.

\subsubsection{SPINOZA: LA RAZÓN AL RESCATE DE LAS SIMETRÍAS}

Mención aparte merece la imagen del cuerpo en la filosofía de Spinoza, cuyas orientaciones sobre la posición de la corporalidad en la vida humana se distancian bastante de las líneas trazadas por los autores anteriormente mencionados. En la Ética demostrada según el orden geométrico Spinoza reniega de una noción de lo corpóreo como algo degradado e indigno y, en consecuencia con ello, opuesto a la infinitud e indivisibilidad de la esencia divina. Spinoza argumenta que la caracterización de la materia como algo divisible y limitado es producto de la imaginación, no así de la razón, y le reprocha la falta de entendimiento a quienes, llevados por su imaginación, 
excluyen a la extensión de la dignidad de la sustancia divina. El filósofo neerlandés considera que los seres humanos, cuando enjuician la materia desde la imaginación, tienden a mensurar los cuerpos imaginándolos como limitados y divisibles, pero que, desde el prisma del entendimiento, la extensión es toda ella infinita e inseparable ${ }^{68}$. Por ello, no existe <<razón alguna para decir que Dios es pasivo ante otra cosa o que la sustancia extensa es indigna de la naturaleza divina, aunque se la suponga divisible, con tal que se conceda que es eterna e infinita $>>{ }^{69}$.

Spinoza deriva su imagen conceptual de lo corpóreo en general y de la corporalidad humana en particular a partir de las definiciones y los principios ontológico-teológicos de los que parte su filosofía. El pensador de Ámsterdam define el término "cuerpo" como <<el modo que expresa de cierta y determinada manera la esencia de Dios, en cuanto que se la considera como extensa $>>{ }^{70}$, es decir, la corporeidad es una modalidad de uno de tantos atributos infinitos presentes en la esencia divina. Alma y cuerpo son dos atributos de una misma naturaleza. A diferencia de la ontología y la antropología cartesianas, Spinoza no establece tres realidades o sustancias diferenciadas, sino que todo cuanto existe en la realidad se correspondería con una sola sustancia, consecuentemente, la unidad del cuerpo y el alma integraría toda ella una mismidad sustancial, y no ya una síntesis de dos sustancias diferentes. De esta forma, las cosas que percibe el alma tienen que pasar necesariamente por el cuerpo, el cual es el objeto de la idea del alma:

Todo cuanto sucede en el objeto de la idea que constituye el alma humana, debe ser percibido por el alma humana, o sea, que de esa cosa se dará necesariamente una idea en el alma. Y así, si el objeto de la idea que constituye el alma humana, es un cuerpo, no podrá suceder nada en ese cuerpo, que no sea percibido por el alma. ${ }^{71}$

Para el filósofo neerlandés el objeto constitutivo del alma humana es el cuerpo y no otra cosa distinta, lo que implica que <<el hombre consta de alma y cuerpo y que el cuerpo humano existe tal como lo sentimos $>{ }^{72}$. Tal es así que, si no fuera por la existencia de la corporalidad, el hombre no podría ser afectado por ninguna idea, ya que

\footnotetext{
${ }^{68}$ Cfr. Baruj Spinoza, Ética demostrada según el orden geométrico (Madrid: Trotta, 2000), 49-51.

${ }^{69}$ Spinoza, ob. cit., 52.

${ }^{70}$ Spinoza, ob. cit., 77.

${ }^{71}$ Spinoza, ob. cit., 86.

${ }^{72}$ Spinoza, ob. cit., 87.
} 
las ideas son producidas por las afecciones. Spinoza afirma que la concatenación de los pensamientos en el alma y la concatenación de las afecciones en el cuerpo son simultáneas y que sus ordenamientos siguen una ambivalencia ${ }^{73}$. Así, entonces, las características de la corporalidad humana determinan el modo en que se producen las ideas en el alma, por tanto, la forma en que los hombres acceden al conocimiento de las cosas viene marcada por sus disposiciones corporales, por lo que $<<$ las ideas que tenemos de los cuerpos exteriores, indican más la constitución de nuestro cuerpo que la naturaleza de los cuerpos exteriores $>>74$.

Las ideas tienen una raigambre corporal ineludible y determinante; en este punto, se observa la principal diferencia entre la filosofía de Spinoza y la filosofía de Descartes, mientras este último pretende desmarcar lo corporal de la intelectualidad, Spinoza no puede entender la formación de las ideas en el alma si no es por medio de las afecciones del cuerpo, de hecho, el alma humana confirma la existencia de la corporalidad por medio de los actos de las afecciones del cuerpo ${ }^{75}$. La propia idea del alma es indisociable de las afecciones corporales, por lo que la corporalidad se revela como objeto del alma ${ }^{76}$. En consecuencia, el alma spinozista no es capaz de formar una idea sobre sí misma a expensas del cuerpo, puesto que $<<$ la idea del alma debe estar unida con su objeto, esto es, con la propia alma del mismo modo que el alma está unida con el cuerpo $>>77$.

En la filosofía de Spinoza se puede apreciar una relación de simetría entre el alma y el cuerpo, al contrario que en la filosofía de Descartes, que da lugar a un planteamiento asimétrico en el que lo corporal cae bajo el dominio del alma. Spinoza critica la forma en que Descartes concibió la relación entre el cuerpo y el alma, destacando que el filósofo de La Flèche establece una diferenciación cualitativa abisal entre el alma y el cuerpo, hasta el punto de verse con dificultades para explicar su contacto relacional. Asimismo, Descartes tampoco habría considerado la proporción que guardan la voluntad y el movimiento del cuerpo, lo que dificulta estimar en qué medida el alma, mediante la glándula pineal, causa movimiento en el resto del cuerpo, por tanto, la

\footnotetext{
${ }^{73}$ Cfr. Spinoza, ob. cit., 246.

${ }^{74}$ Spinoza, ob. cit., 93.

${ }^{75}$ Cfr. Spinoza, ob. cit., 96-97.

${ }^{76}$ Cuando Spinoza dice que el cuerpo es objeto del alma no está utilizando el término objeto en el sentido de una pasividad expuesta al dominio activo de un alma, más bien, cabe interpretar que el cuerpo es objeto del alma en la medida en que es su fin.

${ }^{77}$ Spinoza, ob. cit., 97-98.
} 
potencia del alma y la potencia del cuerpo quedan desproporcionadas la una con respecto a la otra $^{78}$. De las enmiendas de Spinoza al planteamiento cartesiano se desprende el propósito de restaurar la dignidad de lo corporal también en la epistemología, y para ello, el filósofo holandés reivindica la conciliación del cuerpo y el alma como dos facetas de una misma sustancialidad, es decir, como dos igualdades solo diferentes desde un punto de vista atributivo-modal. En la filosofía spinozista no priman las jerarquías ni tiene porqué haber una relación de subordinación del cuerpo con respecto al alma, pues entre ellos ha de lidiar una simetría que facilite su coordinación integral en la totalidad del sujeto humano. La naturaleza de la relación alma-cuerpo propuesta por Spinoza es, para él, en cuanto hombre y filósofo, obvia; pero, sin embargo, dice que nunca antes alguien ha intentado saber acerca de la potencia del cuerpo:

Nadie, en efecto, ha determinado por ahora qué puede el cuerpo, esto es, a nadie hasta ahora le ha enseñado la experiencia qué puede hacer el cuerpo por las solas leyes de la naturaleza, considerada como puramente corpórea, y qué no puede a menos que sea determinado por el alma. Pues nadie hasta ahora ha conocido la fábrica del cuerpo con tal precisión que haya podido explicar todas sus funciones (...). Además, nadie sabe de qué forma o con qué medios mueve el alma al cuerpo, ni cuántos grados de movimiento puede imprimirle y con qué rapidez puede moverlo. De donde se sigue que, cuando los hombres dicen que esta o aquella acción del cuerpo procede del alma que tiene dominio sobre el cuerpo, no saben lo que dicen y no hacen sino confesar con especiosas palabras que ignoran la verdadera causa de aquella acción que no les sorprende nada. ${ }^{79}$

El autor detecta que hay una carencia de conocimientos sobre las vicisitudes y capacidades de la corporalidad, debido en parte a que los hombres se han persuadido de que la dirección corporal corre a cargo del alma. Para el filósofo neerlandés pensar que el alma posee suma potestad sobre los movimientos del cuerpo es fruto de la ignorancia. La reivindicación que Spinoza hace de la corporalidad denota una preocupación filosófica que considera al cuerpo como potencia. Así, entonces, el cuerpo actúa por leyes de la naturaleza que suelen atribuirse a una supuesta dirección del alma sobre

\footnotetext{
${ }^{78}$ Cfr. Spinoza, ob. cit., 245.

${ }^{79}$ Spinoza, ob. cit., 128-129.
} 
este $^{80}$. Aquí se hallaría -según tratamos de demostrar- la premisa básica con que Spinoza reivindica una filosofía del cuerpo que permita perfeccionar el conocimiento sobre la potencia de los seres humanos. Si los hombres no han prestado atención a las capacidades de su potencia corporal es porque se han hecho una idea confusa de la relación entre el alma y el cuerpo, imaginando que la primera maneja a voluntad al segundo, sin antes haber indagado acerca de esta relación. Spinoza pretende descubrir cuál es el poder intrínseco a la naturaleza del cuerpo para así, de este modo, actualizar su idea en el alma a través del entendimiento más que de la imaginación.

Si Descartes echaba en falta un saber más incisivo sobre el funcionamiento mecánico del cuerpo, Spinoza apelaba a la carencia de conocimientos sobre las cosas que puede hacer el cuerpo. Spinoza trata a la corporalidad como potencia: el cuerpo puede, y en la medida en que puede, los hombres han de saber cuánta potencia alberga su dimensión corporal si quieren saber qué cosas pueden hacer. Ver en la dimensión corporal de uno mismo nada más que una cosa sometida a la voluntad, además de ser un error, contribuye a devaluar la potencia que uno mismo alberga, de modo que el cuerpo contiene un poder que los seres humanos han de descubrir y no tomarlo simplemente como una cosa disponible a su capricho; solo de este modo los seres humanos reconocerán el poder inmanente en sus cuerpos y adecuarán sus ideas a esta inmanencia.

Spinoza distingue en el alma una parte perecedera y otra imperecedera. La imaginación se corresponde con la parte del alma que perece mientras que el entendimiento se corresponde con la parte sempiterna, esta última es la más perfecta que puede poseer el alma ${ }^{81}$. El entendimiento dispone al hombre para la acción. La potencia de la razón perfecciona al hombre en la medida en que cuanto más activas son las cosas en la naturaleza más perfectas se hacen. Por lo mismo, cuanto más apto es un cuerpo para recibir afecciones, mayor grado de perfección adquiere. El hombre que no se conoce a sí mismo no actualiza la idea de su corporalidad, lo que contribuye a mantenerle en un estado infantil: <<realmente, quien tiene un cuerpo como un niño o un chico, apto para muy pocas cosas, y muy dependiente de las causas exteriores, tiene un alma que, considerada en sí sola, apenas es consciente de sí misma ni de Dios ni de las cosas $>>82$.

\footnotetext{
${ }^{80}$ Cfr. Spinoza, ob. cit., 129-130.

${ }^{81}$ Cfr. Spinoza, ob. cit., 267.

${ }^{82}$ Spinoza, ob. cit., 166.
} 
El individuo que es afectado por ideas inadecuadas, inciertas y difusas de la imaginación no conoce en su plenitud lo real y, entonces, pierde dominio sobre sí mismo además de romper la proporcionalidad simétrica que hay entre su alma y su cuerpo, de tal manera que lo corporal quedaría en situación de pasividad al perder aptitud ante las actividades que puede realizar. Si la imaginación lesiona la capacidad racional del alma por la que se hace posible el entendimiento de las cosas, también, quiebra el equilibrio por el que se establece una equidistancia entre la potencia del alma y la potencia del cuerpo, toda ella garantizada por la potencia de la razón, que unifica ambos órdenes de potencialidad. Spinoza no balancea el poder ni hacia el lado del alma ni hacia el lado del cuerpo pues en su filosofía no hay una polarización de ambos términos, no busca el autor decantar la dominación hacia ninguno de los dos lados, más bien, persigue instaurar un orden racional en la sintonía alma-cuerpo que configura al sujeto. Precisamente, en el filósofo de Ámsterdam el poder se halla en la inmanencia subyacente al contenido de la relación alma-cuerpo. Este poder se identifica con la razón en cuanto que potencia del entendimiento.

El filósofo neerlandés no ve tensiones dicotómicas entre el alma y el cuerpo, sino que, por el contrario, vincula tales confrontaciones a las inadecuaciones entre la potencia del cuerpo y las imágenes que el alma crea a partir de los afectos. De alguna manera, Spinoza traslada al seno del alma las pugnas que aparentemente se hallan en la forma relacional alma-cuerpo -y que solo son aparentes en tanto en cuanto la imaginación ha representado un alma que rige sobre el cuerpo-. No debe pasar inadvertido que, concretamente, el autor empleé el término "poder" para referirse al dominio del alma sobre los afectos y no sobre el cuerpo ${ }^{83}$. En la obra de Gilles Deleuze dedicada al pensamiento de Spinoza, titulada Spinoza: Filosofía Práctica, es posible confirmar en buena medida este tipo de relación simétrica entre el cuerpo y el alma, ya que Deleuze menciona que

a una de las tesis teóricas más célebres de Spinoza se la conoce por el nombre de paralelismo; no consiste solamente en negar cualquier relación de causalidad real entre el espíritu y el cuerpo, sino que prohíbe toda primacía de uno de ellos sobre el

\footnotetext{
$83<<$ Trataré, pues, de la naturaleza y las fuerzas de los afectos y del poder del alma sobre ellos con el mismo método con que he tratado anteriormente de Dios y del alma, y consideraré las acciones humanas y los apetitos como si se tratara de líneas, planos o cuerpos > . Baruj Spinoza, Ética demostrada según el orden geométrico (Madrid: Trotta, 2000), 126.
} 
otro. Si Spinoza rechaza cualquier superioridad del alma sobre el cuerpo, no es para instaurar una superioridad del cuerpo sobre el alma, que tampoco sería inteligible. ${ }^{84}$

En consecuencia, cuando el pensador de Ámsterdam centra sus investigaciones en el alma, lo hace con el propósito de elucidar las causas que producen las escisiones entre las ideas del alma con respecto al orden causal de las afecciones, y que desembocan en el desconocimiento de la potencia corporal. Las ideas adecuadas son aquellas que ponen en correspondencia las ideas de los afectos con la razón de su causa, por el contrario, las ideas inadecuadas no articulan esta correspondencia y de ellas proceden las pasiones ${ }^{85}$. No obstante, las pasiones son tan naturales como las acciones:

Vemos, pues, que las pasiones solo se refieren al alma en cuanto que esta tiene algo que implica negación, o sea, en cuanto que es considerada como una parte de la naturaleza, que no puede ser percibida clara y distintamente por sí misma sin las otras. Y de esta forma podría yo mostrar que las pasiones se refieren a las cosas singulares lo mismo que al alma, y que no pueden ser percibidas de otra forma. Pero mi objetivo es tratar tan solo del alma humana. ${ }^{86}$

Las ideas enhebran entre sí unos vínculos a través de los que alma y cuerpo quedan coordinados en estado de equidistancia simétrica. El sujeto regula mediante las ideas su potencia, de tal forma que $<<$ la idea de todo aquello que aumenta o disminuye, ayuda o reprime la potencia de actuar de nuestro cuerpo, aumenta o disminuye, ayuda o reprime la potencia de pensar de nuestra alma $>>{ }^{87}$. Cuanto mayor sea la propensión del cuerpo a afectar y a ser afectado por los objetos, más aumentará también la aptitud del alma para percibirlos, y a la inversa, si la corporalidad disminuye su aptitud también lo hará la del alma $^{88}$. A su vez, la corporalidad se compone de partes, guardar la proporción de movimiento y de reposo entre estas partes, contribuye a la conservación del cuerpo y, por ende, de la existencia ${ }^{89}$. Es en el modo de la imaginación donde Spinoza encuentra que se producen las tensiones que disminuyen la potencia corporal, y por la que el alma causa que el cuerpo no alcance la plenitud de sus capacidades. El filósofo neerlandés plantea la sabiduría sobre el alma como una cura de los pormenores de las afecciones, y

\footnotetext{
${ }^{84}$ Gilles Deleuze, Spinoza: Filosofía Práctica (Buenos Aires: Fábula, 2004), 28.

${ }^{85}$ Cfr. Baruj Spinoza, Ética demostrada según el orden geométrico (Madrid: Trotta, 2000), 131.

${ }^{86}$ Spinoza, ob. cit., 132.

${ }^{87}$ Spinoza, ob. cit., 134.

${ }^{88}$ Cfr. Spinoza, ob. cit., 210-211.

${ }^{89}$ Cfr. Spinoza, ob. cit., 211.
} 
dado que <<solo por el conocimiento del alma determinaremos los remedios de los afectos $>>^{90}$, será la potencia inteligible la que arroje precisión sobre el conocimiento de los afectos allí donde las ideas de la imaginación los muestran difusos.

No se trata exactamente de que la razón tenga que dominar sobre el cuerpo, sino de racionalizar la dimensión corporal alineando al cuerpo en un mismo plano con la inteligibilidad, para hacerlo propenso a perfeccionarse. La imaginación puede afectar al alma de un modo en que esta pierda conocimiento sobre la potencia del cuerpo y contribuir con ello a que el sujeto humano pierda conocimiento sobre lo que puede hacer. El hombre que no está cierto de su potencia no controla con tanta perfección la unidad original entre el cuerpo y el alma, ya que su alma imagina cosas que no se adecuan a la realidad, lo que causa la disminución de su potencia. Destáquese cómo lo corporal, alineado con la razón, es imprescindible, según la filosofía spinozista, para que el hombre alcance la plenitud vital. El cuerpo en cuanto potencia cognoscible posiciona al poder en la inmanencia del sujeto humano, más que en una exterioridad ajena a su ser.

La operación reflexiva que realiza Spinoza para otorgarle a la corporalidad humana el mismo estatus que el alma consiste en virar hacia el cuerpo como potencia, es decir, concebir la dimensión corporal del sujeto desde las posibilidades de acción, pensar el cuerpo como forma inmanente de la vida. Desde este punto de vida, la corporalidad no es un mero objeto puesto a disposición de voluntades extrínsecas.

\footnotetext{
${ }^{90}$ Cfr. Spinoza, ob. cit., 246.
} 


\section{SECCIÓN II. EL GRAN ORGANISMO, SU PODER Y SUS CONTRAPESOS}

\subsubsection{LA “ANATOMÍA DEL PODER" EN HOBBES}

En la teoría política de Hobbes y desde la base corporalista que caracteriza a su filosofía, toda forma de poder tiene que proceder de una corporalidad, por eso el Estado emerge como un cuerpo. En Hobbes el poder del Estado no se caracteriza por la inmaterialidad de su figura, sino que, por el contrario, esta figura habrá de ser necesariamente corpórea. El control sobre el cuerpo humano natural y el encauzamiento racional del hombre en sociedad precisa de algún medio de presión que contenga las fuerzas de sus corporalidades, tanto para causar terror como para intervenir directamente en el cuerpo de los súbditos; el poder del Estado se configura como un cuerpo y, de hecho, demuestra que puede actuar como tal.

Al contrario que Descartes, Hobbes no concibe una realidad racional-inteligible al margen del espacio físico-natural, pues entiende que la razón es más una capacidad que una realidad por sí misma, es decir, la razón sería una habilidad gracias a la que los seres humanos son capaces de articular cálculos que les permiten extraer conclusiones; no hay que olvidar que para Descartes existe una realidad al margen de la extensión, una realidad en la que se alberga la razón, la res cogitans, pero tal disquisición resulta inconcebible dentro del pensamiento hobbesiano. Así pues, para el filósofo de Malmesbury la razón sería una facultad mental exclusiva de los seres humanos gracias a la que pueden realizar cálculos a partir de los nombres que conciben, ya sean operaciones de adición o de sustracción. En el Leviatán, Hobbes dice que la razón $<<$ no es sino cómputo〉> y que usamos <<el término caracterización cuando el cómputo se refiere a nosotros mismos, y significación cuando demostramos o aprobamos nuestros cómputos con respecto a otros hombres $>>{ }^{91}$. Si la racionalidad en Descartes pertenecía al patrimonio individual de cada hombre, en Hobbes, lo racional exigirá de unos consensos establecidos en el seno de las comunidades humanas, es decir, que <<en el momento que hay una controversia respecto a un cómputo, las partes, por común acuerdo, y para establecer la verdadera razón, deben fijar como módulo la razón de un

\footnotetext{
${ }^{91}$ Thomas Hobbes, Leviatán (Buenos Aires: Fondo de Cultura Económica de Argentina, 1992), 33.
} 
árbitro o juez, en cuya sentencia puedan ambas apoyarse $>>^{92}$. De este modo, la razón arbitra sobre la heterogeneidad de cómputos susceptibles de entrar en disputa.

Hobbes dedica la primera parte del Leviatán a elaborar una investigación sobre el hombre. El primer punto que trata es epistemológico, y en él establece que toda concepción formada en el intelecto tiene que proceder, por compleja que sea, de los órganos sensoriales ${ }^{93}$; por lo que el autor parte de un punto de vista empirista en la vertebración de su teoría del conocimiento. Las sensaciones y la memoria no conforman un tipo de conocimiento plenamente racional, porque son conocimientos de hechos particulares y concretos que no van a volver a suceder, por tanto, para Hobbes el conocimiento racional se halla en un estrato más elevado y al que es preciso llegar mediante el esfuerzo. Este estrato es la ciencia en la que, mediante la conexión de aserciones, se forman unas hipótesis que explican los fenómenos u ofrecen descripciones anticipadas de estos a partir del conocimiento de sus causas ${ }^{94}$.

Esta misma idea la encontramos en el Tratado sobre el cuerpo, donde el pensador británico afirma que <<la Filosofía se encuentra hoy entre los hombres como se cuenta que en los primeros tiempos se encontraban el trigo y el vino en la naturaleza $>>{ }^{95}$, sin que los hombres hubieran progresado todavía en el arte del cultivo. De la misma manera, aunque todos los seres humanos se vean provistos de razón natural y tengan actitudes para la filosofía, no siempre se entregan todos con el mismo esmero a la tarea de cultivar la razón. Cabe matizar que en la terminología hobbesiana ciencia y filosofía son denominaciones equivalentes, pues referencian lo mismo; la definición que propone Hobbes reza así:

la filosofía es el conocimiento adquirido por la recta razón de los fenómenos o efectos aparentes a partir del conocimiento de alguna posible producción o generación; y de cuál fuera esa producción, a partir del conocimiento del efecto aparente..$^{96} 97$

\footnotetext{
${ }^{92}$ Hobbes, ob. cit., 33.

${ }^{93}$ Cfr. Hobbes, ob. cit., 6.

${ }^{94}$ Cfr. Hobbes, ob. cit., 36-37.

95 Thomas Hobbes, Tratado sobre el cuerpo (Madrid: Trotta, 2000), 35.

${ }^{96}$ Hobbes, ob. cit., 76.

${ }^{97}$ Esta definición de filosofía también se puede localizar en la página 36 del Tratado sobre el cuerpo. El motivo por el que se ha recurrido a la definición de la página 76 se debe a que ha sido considerado que el autor aporta mayor brevedad y concreción al concepto que trata de definir, lo que facilita y abrevia la comprensión sobre qué entiende Hobbes por filosofía.
} 
Para el filósofo de Malmesbury la filosofía se divide en dos bloques: filosofía natural y filosofía civil. El primero se dedica a la investigación de la naturaleza y del movimiento tanto en los objetos como en las sensaciones y las mentes, mientras que el segundo se emplea en el estudio de las sociedades humanas y sus regímenes de gobierno. La filosofía moral puede encontrarse en ambos compartimentos del saber, puesto que, propiamente dicha, la moral se encarga de conocer el movimiento de las mentes humanas en cuanto a sus quehaceres volitivos y, a su vez, a partir del resultado de sus investigaciones puede establecer prescripciones que indiquen cuáles son los comportamientos útiles para la convivencia pacífica entre los hombres; sin embargo, la filosofía moral ni puede ni debe agotar el conocimiento de la filosofía civil pues para comprender la formación de los Estados también es necesaria la tenencia de experiencias sobre el modo en que se comportan los hombres en sociedad ${ }^{98}$. Asimismo, la filosofía civil se divide, por un lado, en ética, que inquiere cuestiones relacionadas con las costumbres, y por otro lado, en política, que se ocupa de los deberes de los hombres con su respectivo Estado ${ }^{99}$.

Bajo el prisma de la filosofía civil de Hobbes, y en lo concerniente a la acepción con que enmarca el término cuerpo, el Estado, entonces, sería un agregado de individuos humanos que han constituido un cuerpo artificial, de tal forma que, como cualquier otro cuerpo, este gozaría de espacio y realidad propia. El filósofo británico, fiel a su esquema científico-político, investiga cuál es la causa de la formación de los Estados, y para ello necesita definir la naturaleza de los hombres llevando a cabo una introspección hipotética de la mente humana.

En el Tratado sobre el ciudadano, consecuentemente con su método, Hobbes intenta elucidar las causas que condujeron a la humanidad a organizarse en Estados. El filósofo de Malmesbury imagina una situación anterior a la sociedad civil a la que llama "estado de naturaleza". El estado de naturaleza es un constructo teórico que permite pensar al ser humano "al desnudo", tal como este se mostraría desprovisto de leyes civiles, de jerarcas y de toda retención institucional y penal. La causa primigenia de que del estado de naturaleza emerja el Estado civil es -como ya fue mencionado- el miedo; según Hobbes $<<$ nadie debe dudar de que los hombres por su naturaleza, si no existiera el

\footnotetext{
${ }^{98}$ Cfr. Hobbes, ob. cit., 79-81.

${ }^{99}$ Cfr. Hobbes, ob. cit., 41.
} 
miedo, se verían inclinados más al dominio que a la sociedad $>{ }^{100}$. Así, la formación de la sociedad civil es la elección preferida por los individuos, antes que vérselas sobreviviendo en solitario en medio de un enfrentamiento constante entre ellos y de una naturaleza hostil. Cada individuo busca <<defender su propio cuerpo y sus miembros de la muerte y del dolor $>{ }^{101}$. El autor encuentra en la autoconservación el primer derecho natural, puntal de la vida humana y completamente racional desde la perspectiva de la individualidad, pues proteger la integridad del propio cuerpo es un interés ineludible ${ }^{102}$. Pero la defensa de este derecho natural también comporta que cada individuo priorice la conservación de sí mismo sobre la de los demás.

La tendencia natural en todo tipo de asociación es la guerra, la naturaleza humana es combativa, cada ser humano busca su placer y vanagloria ${ }^{103}$, por lo que a las asociaciones humanas subyace una situación de confrontación perenne. Para superar esta situación los individuos se ven forzados a alcanzar un acuerdo común, por el que convienen en cumplir unos compromisos y finalidades. Este pacto surge de la racionalidad, pues es un cálculo en el que cada sujeto, al tomar conciencia de su vulnerabilidad, sacrifica parte de su voluntad a costa de una voluntad artificial; dicha voluntad es el Estado, que emerge en vistas a mantener la paz en la sociedad de manera prolongada y estable ${ }^{104}$.

Para Hobbes, los seres humanos prefirieron vivir en el Estado civil a vivir en el “estado de naturaleza", los motivos a los que alude principalmente son:

Fuera del Estado cada uno tiene tanto derecho a todo, que no puede disfrutar de nada, pero en el Estado todos disfrutan con seguridad de un derecho delimitado. Fuera del Estado cualquiera puede expoliar y matar a cualquiera, pero en el Estado sólo uno puede hacerlo. Fuera del Estado nos protegen sólo nuestras propias fuerzas, en el Estado las de todos. Fuera del Estado nadie tiene seguro el fruto de su trabajo, en el Estado todos. ${ }^{105}$

\footnotetext{
100 Thomas Hobbes, Tratado sobre el ciudadano, Leviatán, Vida de Thomas Hobbes de Malmesbury escrita por él mismo (Madrid: Gredos, 2012), 22.

${ }^{101}$ Hobbes, ob. cit., 24.

${ }^{102}$ Hobbes, ob. cit., 29-30.

${ }^{103}$ Cfr. Hobbes, ob. cit., 21-22.

${ }^{104}$ Cfr. Hobbes, ob. cit., 21-22.

${ }^{105}$ Hobbes, ob. cit., 111.
} 
Para que el Estado pueda rendir óptimamente en la administración y disposición de las fuerzas que convergen en él, será necesario que los individuos aúnen sus voluntades, de tal forma que consientan sacrificar parte de su voluntad individual en favor de formar una única voluntad entre todos para garantizar la paz y la seguridad. De este modo el Estado emerge como una persona política ${ }^{106}$. La cabeza de esta persona política debe estar regida por un gobernante, desde el punto de vista de Hobbes, es preferible que el gobierno sea detentado por una sola persona en vez de por una asamblea, ya que las asambleas tienden a enfrentar a partidarios de diferentes bandos, lo que puede terminar por dividir al Estado y derivar en guerra civil. Por eso Hobbes considera más eficiente la dirección unipersonal del Estado y que la cabeza del cuerpo civil esté representada por un único soberano ${ }^{107}$.

Pero no sólo las asambleas representan un problema para la dirección coordinada del cuerpo civil, también la libertad natural se cierne problemática sobre el dominio de este cuerpo. En el esquema antropológico y político del pensamiento de Hobbes los efectos de la libertad natural resultan contraproducentes para la sociedad. La libertad, en su expresión más elemental, se convierte en un componente patógeno para la convivencia gregaria de los seres humanos. Naturaleza humana y derechos naturales por un lado, y cálculo de la ventaja de vivir en sociedad por otro, terminan siendo dos componentes incompatibles en el "estado de naturaleza"; así, Hobbes piensa el Estado como un paliativo contra esta incompatibilidad de fondo entre los derechos naturales y la vida social en un ámbito natural, en el que se carece de un contrapeso que rebase la fuerza del individuo. Según Roberto Esposito en Bíos. Biopolítica y filosofía lo que hizo Hobbes fue situar <<en el centro de su perspectiva el problema de la conservatio vitae $>$, además de ponerla a disposición de <<un poder constrictivo exterior a ella, como es el poder soberano, el principio inmunitario ya está virtualmente fundado $>>108$. Para Esposito, la filosofía política moderna comienza a plantear el tema de las prácticas inmunológicas desplegadas por el poder estatal para conservar y preservar el orden vital de la población bajo su jurisdicción. Al igual que en la vacunación se frenan los ataques patógenos inyectando una mínima cantidad de esa patología con el fin de colapsar su evolución en el organismo ${ }^{109}$, en analogía con el cuerpo natural, el Estado tendrá que

\footnotetext{
${ }^{106}$ Cfr. Hobbes, ob. cit., 69.

${ }^{107}$ Cfr. Hobbes, ob. cit., 119.

${ }^{108}$ Roberto Esposito, Bíos. Biopolítica y filosofía (Buenos Aires: Amorrortu, 2006), 75.

${ }^{109}$ Cfr. Esposito, ob. cit., 92-93.
} 
dosificar su capacidad coactiva y su violencia potencial para reprimir las patologías que se producen en la vida social.

Para retener los efectos nocivos de la libertad, Hobbes encuentra en el Estado el diseño de una estructura de poder capaz de controlar la natural agresividad con que se expresan los derechos naturales. A partir del lenguaje biopolítico de Esposito, podríamos decir que el filósofo británico planteó el Estado como un dispositivo inmunológico. Si el gregarismo humano es fruto de un cálculo de la razón, en cuanto que todos asumen que el objetivo de la autoconservación se logra mejor viviendo en comunidad, la maquinaria del derecho civil tendrá que actuar en vistas a lograr una sociabilización óptima. De algún u otro modo, el Estado es el responsable de transfigurar la virulencia natural con que se desenvuelven las relaciones humanas. De acuerdo con la interpretación que Esposito hace de la política en Hobbes, la razón y el derecho tendrían como punto de encuentro la conservación de la vida, pero ninguna de las dos sería capaz de garantizar esta autoconservación per se, ya que, la condición natural del hombre impide que la vida cumpla su fin primordial ${ }^{110}$. Esposito niega que en la modernidad la vida suplantara a la política, sino que, por el contrario, durante la modernidad comenzaron a pensarse cuáles son las articulaciones de poder externas al cuerpo natural desde las que contribuir a salvar la vida; en palabras del autor:

En efecto: es cierto que todo organismo vital tiene en su interior una suerte de sistema inmunitario natural (...), una vez comprobada su insuficiencia, incluso su efecto contraproducente, se lo debe sustituir por una inmunidad inducida, esto es, artificial, que lleva a efecto la primera y simultáneamente la niega: no sólo porque se sitúa fuera del cuerpo individual, sino también porque tiende a la contención forzada de su intensidad primigenia. ${ }^{111}$

Precisamente, en el marco de una racionalidad sujeta a los objetivos vitales del cuerpo, Hobbes comenzó su reflexión sobre las causas de la formación del Estado civil. $\mathrm{Al}$ encontrar que la razón y la libertad natural por sí solas son incapaces de preservar la seguridad dentro de las relaciones sociales, se inhabilita a la corporalidad natural de los individuos para el ejercicio de la política, pues de algún u otro modo la racionalidad calculadora y la libertad sin límites además de las privaciones corporales contribuyen a desbordar la paz social; solo el cuerpo artificial de un Estado puede implantar una

\footnotetext{
${ }^{110}$ Cfr. Esposito, ob. cit., 92-93.

${ }^{111}$ Esposito, ob. cit., 95.
} 
política que se haga cargo de calcular, liberar, limitar, coaccionar y gestionar los aspectos de la vida de los ciudadanos, es decir, de sus cuerpos. Tal es así que, en el análisis científico de Hobbes, el poder va a jugar un papel esencial a la hora de levantar diques que contengan la capacidad de desborde de la necesidad y la libertad humana en su expresión natural.

El Estado, dentro de este ejercicio reflexivo, es un engranaje causal que articula toda una maquinaria para anticiparse y anteponerse a las patologías inherentes al ser humano y a su precario modo de sociabilizarse en una primera instancia natural. Por ende, dentro de la visión hobbesiana de la política se gesta una corporalización del poder que bien puede denominarse "anatomía del poder", en la medida en que su teoría política concibe al Estado como una corporalidad cuyo funcionamiento se determina por las mismas leyes físicas que rigen sobre todos los cuerpos. La fisicalización de la política se traduce a una corporalización de las instituciones y de los sujetos de derecho, y donde el cuerpo natural humano se convierte en el objeto sobre el que se ejerce el poder. Pero la constitución del cuerpo natural como objeto del poder es un movimiento artificial, que contrarresta la fuerza natural que alberga el cuerpo del individuo, una fuerza que no contiene en sí potencia política alguna. El Estado disuelve el poder intrínseco del individuo mediante la configuración de un poder extrínseco. Una interpretación fisicalista de la política entenderá la interacción de las fuerzas de poder en términos de colisión y movimiento, por lo que los procedimientos de la acción política se justificarán a través de la maquinaria que opera e interacciona en esta correlación de fuerzas; dicha maquinaria no puede ser otra más que el Estado, cuyos engranajes son, a un tiempo, coactivos, protectores e inmunológicos.

\subsubsection{LA TENDENCIA HUMANA A FORMAR CUERPOS POLÍTICOS Y LA ANALOGÍA ENTRE EL INDIVIDUO Y EL ESTADO EN SPINOZA}

En la Ética, Spinoza dice que $<<$ si dos individuos, por ejemplo, de una naturaleza exactamente idéntica, se unen entre sí, componen un individuo dos veces más poderoso que cada uno >>, por lo que los seres humanos, en pro de mantener su ser, encontrarán gran utilidad en reunirse y alcanzar acuerdos, $<<$ de suerte que las almas y los cuerpos de todos formen como una sola alma y un solo cuerpo $>>112$. También, Spinoza identifica el principio por excelencia de la virtud con el conato por el que todo individuo

${ }^{112}$ Baruj Spinoza, Ética demostrada según el orden geométrico (Madrid: Trotta, 2000), 197. 
humano busca perseverar en su ser, un fin que para alcanzarse de manera plena requiere de la unión mutua de los hombres, luego, lo virtuoso será aquello que obre a favor de sostener la vinculación de los cuerpos y las almas como en un cuerpo y una sola mente. Seguir las leyes de la naturaleza es propio de aquellos individuos que actúan con virtud porque entienden y persiguen la utilidad ${ }^{113}$. Como la naturaleza humana va en correspondencia con la racionalidad, y como no hay nada más común para cada uno de los hombres que la razón, entonces Spinoza asevera que para el conjunto de los seres humanos no hay nada más útil que aquel sujeto <<que vive bajo la guía de la razón $>{ }^{114}$. Entre las cosas útiles también cuentan <<aquellas que pueden alimentar o nutrir el cuerpo, de suerte que todas sus partes puedan cumplir correctamente su función $>{ }^{115}$. Es posible apreciar de qué manera en el pensamiento spinozista la racionalidad y la corporalidad se sitúan en una misma dirección, ya que ambos no conforman ejes opuestos entre sí donde lo corporal opaque a lo racional o donde la razón se vea fuera de los márgenes de la vida corporal.

Del pensamiento de Spinoza se desprende la idea de que la razón contribuye a la sociabilidad de los hombres, en la medida en que la razón predispone al cuerpo para la vida en común, a saber, porque según el autor el hombre más útil para la humanidad es aquel que convive valiéndose de su racionalidad ${ }^{116}$. Pero, también, el filósofo neerlandés observa que dentro de las sociedades humanas las relaciones entre los individuos suelen acarrear conflictos; si bien la sociabilidad es el mejor modo de realizar el conato de cada individuo, la sola concurrencia no exime a la vida social de tensiones ni procura por sí misma la racionalidad en la organización social establecida:

\footnotetext{
${ }^{113}$ Cfr. Spinoza, ob. cit., 199-200.

${ }^{114}$ Spinoza, ob. cit., 205.

115 Spinoza, ob. cit., 237.

116 Afirma Spinoza en el "Escolio" de la "Proposición 18" de la cuarta parte de la Ética: <<Nada hay, pues, más útil para el hombre que el hombre>> (Madrid: Trotta, 2000), 197. Pero tanto en la Ética como en otras obras ofrece argumentos que relativizan esta afirmación. En el Tratado político Spinoza asume parte de la concepción iusnaturalista por la que el hombre es caracterizado esencialmente como un ser social, puesto que <<si justamente por esto, porque en el estado de naturaleza los hombres apenas pueden ser autónomos, los escolásticos quieren decir que el hombre es un animal social, no tengo nada que objetarles〉>, (Madrid: Alianza Editorial, 1986), 93. Sin embargo, también admite: <<Dado que los hombres se guían, como hemos dicho, más por la pasión que por la razón, la multitud tiende naturalmente a asociarse, no porque la guíe la razón, sino algún sentimiento común, y quiere ser conducida como por una sola mente〉>, ob. cit. 122. Por ende, la sociabilidad humana en el pensamiento del filósofo holandés cuenta con rasgos singulares que lo alejan de la versión iusnaturalista propia de los escolásticos de la época, y aunque en algunos puntos su teoría política también converge con el pensamiento de Hobbes, igualmente, existen importantes diferencias entre ambos.
} 
Rara vez sucede, sin embargo, que los hombres vivan bajo la guía de la razón; sino que están conformados de tal suerte que la mayoría son envidiosos y se molestan mutuamente. A pesar de ello, a penas pueden llevar una vida solitaria, de suerte que a la mayoría les ha agradado mucho aquella definición, de que el hombre es un animal social. ${ }^{117}$

La sociabilidad humana no lleva aparejada también, y necesariamente, la concordia en las relaciones sociales. Si atendemos a las lecciones que Deleuze impartió en la Universidad de Vincennes sobre el pensamiento de Spinoza (transcritas y publicada bajo el nombre de En medio de Spinoza), concretamente en la clase del 9 de diciembre de 1980 el filósofo parisiense explica que las bases de la filosofía política spinozista son las mismas que las de Hobbes, y pese a que sendos planteamientos terminen por distanciarse, sus puntos de partida son prácticamente idénticos, dado que ambos pensadores habrían considerado al ser humano no en cuanto a su esencia sino en cuanto a su potencia. Para Deleuze, aunque Spinoza habla acerca de la esencia humana, nunca toma este concepto en un sentido naturalista sino que lo acomoda a la idea de potencia, es decir, que la esencia de los seres humanos - como de todos los seres-se define por su potencia $^{118}$; de ahí la fuerza subyacente al conato por el que los hombres perseveran en su ser. El estilo con que Hobbes desenvolvió sus argumentos antropológicos y las consecuencias políticas en que estos derivan implica, según Deleuze, una ruptura con la teoría del derecho natural y un giro hacia una concepción ético-jurídica, en detrimento del moralismo esencialista. El pensamiento de Spinoza estaría también incluido en este giro al ver a los hombres como potencialidad, e insiste en que las divergencias entre ambos filósofos a la hora de pensar lo político están en el proceso de su discurso y no en los fundamentos de los que parten:

Spinoza retoma toda esta concepción del derecho natural de Hobbes. Cambiará cosas relativamente importantes, no tendrá la misma concepción política, pero sobre este punto del derecho él mismo declara atenerse, ser discípulo de Hobbes. ¿Y por qué? En Hobbes encontró la confirmación jurídica de una idea que él se formó en otra parte; una sorprendente confirmación según la cual la esencia de las cosas no era nada

\footnotetext{
117 Spinoza, ob. cit., 206.

${ }^{118}$ Cfr. Gilles Deleuze, En medio de Spinoza (Buenos Aires: Cactus, 2008), 71-72.
} 
distinto a su potencia. $\mathrm{Y}$ es eso lo que le interesa de toda la idea del derecho natural. ${ }^{119}$

En el Tratado teológico-político -como también en la Ética y en el Tratado políticoSpinoza define el derecho natural como el poder por el que todos los seres tienden a perseverar en su existencia ${ }^{120}$. El autor concluye que el <<derecho natural de cada hombre no se determina, pues, por la sana razón, sino por el deseo y el poder $>>121$. Los seres humanos no están forzados a vivir racionalmente, por ello, los móviles que dirigen las acciones de los hombres, ya tengan una raigambre racional o pasional, proceden de su derecho natural, entendiendo por derecho natural todo cuanto el individuo puede hacer. Pero cada sujeto humano solo es una parte de la totalidad que conforma el orden natural del mundo, y como cada cual siempre actuará guiado por el interés de preservar su ser, lo bueno y lo malo solo podrán determinarse de forma relativa y de acuerdo a la parcialidad con que los hombres valoran las cosas; el ordenamiento de toda la naturaleza rebasa el contenido de las razones por las que actúan los humanos ${ }^{122}$. Esta misma idea se encuentra reafirmada en el Tratado político, cuando el autor dice que la racionalidad humana no tiene capacidad para abarcar todo el orden de la naturaleza, ya que <<el hombre es una partícula>> en el cosmos, y por tanto, todo <<cuanto nos parece ridículo, absurdo o malo en la naturaleza, se debe a que solo conocemos parcialmente las cosas y que ignoramos casi por completo el orden y la coherencia de toda la naturaleza $>{ }^{123}$.

Una vez los hombres juntan sus fuerzas para superar las debilidades y carencias que tienen individualmente, transfieren su derecho natural al colectivo que componen. La voluntad de todos termina ostentando el poder que originalmente albergaba cada hombre en cuanto individuo. Los individuos establecen un compromiso mutuo. Este pacto no anula los derechos naturales sino que va a ser el producto de la unidad social la que adquiera los plenos poderes que originariamente reposaban en los individuos, así, de esta confluencia surge el Estado ${ }^{124}$. La finalidad del Estado es preservar la libertad de todos. Los Estados no deberían contribuir a la sujeción de los hombres, ni a volverlos

\footnotetext{
${ }^{119}$ Deleuze, ob. cit., 86.

${ }^{120}$ Cfr. Spinoza, Tratado teológico-político (Madrid: Alianza editorial, 1986), 332.

${ }^{121}$ Spinoza, ob. cit., 333.

${ }^{122}$ Cfr. Spinoza, ob. cit., 333-334.

${ }^{123}$ Spinoza, Tratado político (Madrid: Alianza Editorial, 1986), 89.

${ }^{124}$ Cfr. Spinoza, Tratado teológico-político (Madrid: Alianza editorial, 1986), 334-337.
} 
timoratos y proclives al sometimiento, sino que, por el contrario, la vida civil contribuirá a la liberación de los temores que amenazan la existencia humana:

El fin del Estado, repito, no es convertir a los hombres de seres racionales en bestias o autómatas, sino lograr más bien que su alma (mens) y su cuerpo desempeñen sus funciones con seguridad, y que ellos se sirvan de su razón libre y que no se combatan con odios, iras o engaños, ni se ataquen con perversas intenciones. El verdadero fin del Estado es, pues, la libertad. ${ }^{125}$

La Estatalidad en Spinoza se desarrolla en torno a la coordinación de la multitud, que es el conjunto de cuerpos que componen el Estado y que están unidos no solo a un nivel físico sino también moral. En el Tratado político el pensador neerlandés asevera que la unión de los individuos contribuye al aumento de sus derechos a cambio de ceder el derecho natural particular. Actuando juntos, los hombres ganan más poder, y este poder vendrá concentrado en el Estado, que administra, coordina y regula la potencia de la multitud a partir de un orden legal e institucional acordado ${ }^{126}$. De este modo, la convergencia de las fuerzas humanas no solo tiene una dimensión física, sino que los cuerpos que interactúan deben disponerse de forma racional, como guiados por "una sola mente". Spinoza dice que el derecho procedente de la comunidad y que el derecho que

se define por el poder de la multitud, suele denominarse Estado. Posee este derecho, sin restricción alguna, quien, por unánime acuerdo, está encargado de los asuntos públicos, es decir, de establecer, interpretar y abolir los derechos, de fortificar las ciudades, de decidir sobre la guerra y la paz, etc. ${ }^{127}$

La unidad corpóreo-mental del individuo es análoga a la unidad multitudinstituciones del Estado. La misma equidistancia y coordinación entre el cuerpo y el alma de una persona debe darse también en la personalidad jurídica que constituye el Estado. Spinoza encuentra que la estatalidad es el resultado de la interacción coordinada entre la multitud y la mente colectiva, por tanto, la multitud pasa a formar algo más que un mero agregado de cuerpos en el momento en que sus individuos se vinculan políticamente. Se podría decir que en el pensamiento político de Spinoza la

\footnotetext{
${ }^{125}$ Spinoza, ob. cit., 411.

${ }^{126}$ Cfr. Spinoza, Tratado político (Madrid: Alianza Editorial, 1986), 92-93.

${ }^{127}$ Spinoza, ob. cit., 93-94.
} 
comparación entre el individuo humano y el Estado simboliza el funcionamiento idóneo en las relaciones entre la multitud y los agentes institucionales que participan en el espacio político. Esta analogía arroja luz sobre la manera en que el filósofo neerlandés concibe al Estado. Spinoza recurre a este paralelismo simbólico para dar cuenta de cómo la racionalidad debe vertebrar las relaciones que tienen lugar en el interior del Estado, y de cómo, para que prime la racionalidad, los elementos inteligibles y corporales deben vincularse de forma horizontal y complementaria. Así, entonces,

el derecho del Estado o supremas potestades no es sino el mismo derecho natural, el cual viene determinado por el poder, no de cada uno, sino de la multitud que se comporta como guiada por una sola mente. Es decir, que, lo mismo que cada individuo en el estado natural, también el cuerpo y el alma de todo el Estado posee tanto derecho como tiene poder. Y por lo mismo, cada ciudadano o súbdito posee tanto menos derecho, cuanto que la propia sociedad es más poderosa que él. ${ }^{128}$

Huelga matizar la conveniencia de tomar ciertas precauciones sobre el uso y sentido que Spinoza le concede a esta analogía entre el individuo y el Estado. Tal como sostiene Javier Peña en La filosofía política de Espinosa, el filósofo holandés empleó esta comparación sin tratar de ir más allá de su sentido simbólico ${ }^{129}$. Javier Peña indica que atribuirle a la sociología de Spinoza una lectura en sentido organicista, al estilo del siglo XIX, sería hacer una lectura del autor fuera del contexto en que se realiza su pensamiento. Por tanto, los parámetros seguidos por el pensador habrían sido muy distintos, según Javier Peña, irían más encaminados a ver en la imagen antropomórfica del Estado una estructura con "mente" y "cuerpo" cuyas relaciones se entablarían a tenor de una metodología geométrica, metodología más propia de los conocimientos de física del siglo XVII ${ }^{130}$.

Por otra parte, habiendo asumido las pertinentes precauciones en el uso de la analogía individuo-Estado en la perspectiva spinozista, resulta conveniente destacar el artículo de Luciano Espinosa Rubio titulado La política como física del poder en Spinoza, en el que son investigados, interpretados e incluso ampliados, según el criterio del autor, los componentes análogos presentes en el pensamiento político del filósofo.

\footnotetext{
128 Spinoza, ob. cit., 100-101.

${ }^{129}$ Cfr. Francisco Javier Peña Echeverría, La filosofía política de Espinosa (Valladolid: Secretariado de Publicaciones Universidad de Valladolid, 1989), 232.

${ }^{130}$ Cfr. Peña Echeverría, ob. cit., 233.
} 
Basándose en la literalidad de los textos spinozistas, Luciano Espinosa confirma que la unidad física de los ciudadanos ha de ser entendida en correspondencia con el cuerpo del individuo, y que en el caso del Estado sería la multitud, en cuanto que cuerpo político, la depositaria del poder. Asimismo, el autor propone a modo de hipótesis propia que la mens de Spinoza sea interpretada como la parte del Estado que hace las veces de estructura institucional, y añade, en último término, que la administración pública equivaldría a los afectos pasivos y activos en la medida en que la actividad de los ciudadanos generaría información al estilo en que los afectos corporales producen las ideas del alma ${ }^{131}$. El profesor Espinosa relaciona el conato del individuo con la tendencia de los Estados a preservarse, así, la multitud ha de estar provista de los recursos materiales y medios infraestructurales necesarios para mantener la soberanía del Estado ${ }^{132}$. En lo relativo a la conciencia de sí mismo, habría dinámicas inteligibles en la configuración de las relaciones entre la multitud y las instancias gubernamentales que permiten la observación y la modificación de las instituciones estatales a nivel legal, moral y administrativo, así como en todo cuanto concierna a la permanencia de la soberanía del Estado ${ }^{133}$.

Las relaciones políticas entre el cuerpo social y las instituciones civiles deben guardar el mismo orden simétrico que el alma y el cuerpo en el hombre racional, por lo que la racionalidad del Estado implica la equidistancia simétrica y complementariedad de los elementos corporales e inteligibles que lo conforman. De este modo, la transparencia de los asuntos públicos sería un rasgo de la simetría que debe reinar entre la multitud y las instituciones, dado que la transparencia entre el cuerpo y la mente del Estado emerge como una suerte de práctica política para la libertad de los ciudadanos. En el artículo de Luciano Espinosa se sitúa a la transparencia como uno de los ejemplos propios de "la conciencia de sí" del Estado, de tal modo que el filósofo neerlandés se opondría a los secretos de Estado en tanto en cuanto <<conducen a la servidumbre y a la tiranía so pretexto de proteger la seguridad, e impiden el juicio informado de la multitud $\gg{ }^{134}$. Siguiendo las indicaciones del Profesor Espinosa, en el apéndice 29 del séptimo capítulo del Tratado político, se constata cómo Spinoza critica a quienes toman

\footnotetext{
${ }^{131}$ Cfr. Luciano Espinosa Rubio, "La política como física del poder", Res Publica. Revista de Historia de las Ideas Políticas, 17 no. 1 (2014): 33-57, 46.

${ }^{132}$ Cfr. Espinosa Rubio, ob. cit., 48.

${ }^{133}$ Cfr. Espinosa Rubio, ob. cit., 49.

${ }^{134}$ Espinosa Rubio, ob. cit., 49.
} 
partido a favor de ocultarle información al pueblo en nombre de la seguridad del Estado. El filósofo de Ámsterdam considera que hay prácticas políticas incompatibles con la libertad de los ciudadanos, de modo que la protección del Estado no es un pretexto lo suficientemente fundado como para mantener a la multitud aislada de los asuntos que tienen que ver con las relaciones internacionales, los cuales no dejan de ser también asuntos públicos en la medida en que atañen al conjunto de la multitud. Prácticas de este tipo promoverían una asimetría en las relaciones inherentes al Estado, puesto que permitir que los gobernantes guarden celosamente secretos ante sus ciudadanos va en contra del fin del Estado: la libertad. En consecuencia, asegura Spinoza que <<confiar el Estado a alguien sin condición alguna y, al mismo tiempo, conseguir la libertad, es totalmente imposible>>, y que formular propuestas de esta índole no es más que la $<<$ misma cantinela para quienes desean el Estado absoluto $>>135$.

La imagen conceptual del Estado en el pensamiento político de Spinoza configura un sistema de equivalencias entre el cuerpo social y las instituciones que representan esa unidad que establecen los individuos. Esta concepción de la Estatalidad plantea una gobernanza que busca mantener la simetría de los componentes corporales y elementos inteligibles que participan en la vida social. Spinoza no caracterizó a la multitud como una pasividad expuesta a la dominación, sino que encontró una compartimentación del poder en las relaciones entre lo institucional y lo multitudinario. La corporalidad del Estado alberga una parte del poder en cuanto que este es el resultado de la potestad que la multitud le concede a una o varias instituciones para ser gobernada de acuerdo a unas leyes previamente pactadas, de tal forma que la articulación racional de la política implica el equilibrio entre la fuerza de la multitud y la legitimidad de las instituciones. La posición del poder en el esquema planteado por Spinoza describe un segmento que guarda la proporcionalidad entre la potencia multitudinaria y las instancias reguladoras por las que se sostiene la coordinación de las personas que forman la comunidad. Esta unión no agota la potencia del cuerpo social, sino que emerge de su inmanencia.

\subsubsection{EL DRAMA MUNICIPAL DE FUENTE OVEJUNA INTERPRETADO DESDE LA FILOSOFÍA POLÍTICA HOBBESIANA}

A continuación nos centraremos en destacar e interpretar, bajo la noción de cuerpo civil, ciertas gestualidades políticas que se reflejan en el drama municipal Fuente

${ }^{135}$ Spinoza, Tratado político (Madrid: Alianza Editorial, 1986), 160. 
Ovejuna, de Lope de Vega, donde aparecen algunas escenas que podrían sugerir un cierto contractualismo, visible tanto en los gestos políticos del pueblo -el modo en que los habitantes de la villa llegan a acuerdos a través de reuniones asamblearias en las que todos ellos están presentes- como en algunos símbolos -los habitantes representados por mutuo acuerdo bajo la figura de Fuente Ovejuna-. Esta obra teatral fue compuesta en el año 1613, antes de que Hobbes escribiera el Leviatán.

Fuente Ovejuna está basada en hechos reales, puesto que la obra de Lope es una interpretación poético-dramática de un hecho social acaecido en 1479 en el que una comunidad de labradores y ganaderos de la villa de "Fuente Obejuna"136 asaltaron el palacio de la encomienda ${ }^{137}$. La conexión entre los hechos históricos y la obra dramática seguiría una coherencia política en cuanto que la conducta de la población de "Fuente Obejuna" da muestra del cambio político que se estaba produciendo en la España de los Reyes Católicos, en la medida en que a finales del siglo XV comenzaba a consolidarse la idea de un régimen monárquico asentado sobre el poder de un Estado absoluto; mientras que, por otro lado, en el siglo XVII existía la necesidad de justificar ese orden político que, al menos en España, se había tornado injusto y había deteriorado las condiciones de vida de sus súbditos. A finales del siglo XV y comienzos del XVI algunos pueblos pertenecían a la corona, pero otros aún se hallaban bajo un régimen feudal, es decir, estaban bajo el control y potestad de un señor, lo que implicaba una inseguridad jurídica por parte de sus habitantes con respecto a las poblaciones bajo dominio monárquico. En algunas poblaciones feudales surgieron ciertas rebeliones a causa de la arbitrariedad jurídica con que los señores gobernaban las villas que tenían bajo su jurisdicción, en general, los habitantes de las villas preferían vivir al amparo del régimen monárquico ${ }^{138}$; esta es una idea constante en la obra de Hobbes, pues para el autor británico - como bien cabe recordar- la forma de gobierno más sólida es la que

\footnotetext{
${ }^{136}$ En este caso, hemos hecho referencia a "Fuente Obejuna" con la letra "b" y entre comillas porque, según aclara J.M. Marín, mediante el vocablo "Fuente Obejuna" se alude a la población real que se sublevó en 1476 y cuyos hechos históricos quedaron recogidos en un texto del siglo XVII. En la primera nota a pie de página de la introducción a la edición que estamos manejando, Marín aporta una justificación más detallada sobre el empleo de tal vocablo. Cfr. Juan María Martín, "Introducción"; en Fuente Ovejuna, Lope de Vega (Madrid: Cátedra, 1983), 13.

${ }^{137}$ Cfr. Juan María Martín, "Introducción”; en Fuente Ovejuna, Lope de Vega (Madrid: Cátedra, 1983), 13-14.

${ }^{138}$ Cfr. Martín, ob. cit., 15 .
} 
viene ejercida por un sólo hombre ${ }^{139}$, amén de la seguridad que proporciona vivir como súbdito de un Estado en vez de encontrarse a la intemperie en un estado de naturaleza.

Si bien pareciera que Fuente Ovejuna es una representación teatral en defensa de la monarquía absoluta, queda patentado en ella un tema al que Hobbes recurrirá constantemente en su filosofía política, la formación de personalidades artificiales emanantes de una asamblea y en las que se forma una voluntad política. Cuando los habitantes de Fuente Ovejuna se reúnen en la sala del concejo para tomar una decisión sobre cómo revocar la autoridad del Comendador, el cual abusa flagrantemente de ellos, finalmente, deciden acabar con la vida de su señor, tarea en que se involucran todos los ciudadanos de la villa.

Los habitantes llevan a cabo un acto político en torno a una personalidad política, que es "Fuente Ovejuna", al estilo del Estado hobessiano: una persona artificial que agrupa los cuerpos de las gentes que han decidido subyugarse a su autoridad. Por un lado, en la obra de Lope, los habitantes de la villa tienen que adquirir una personalidad política al margen de la ley, por lo que su acción no vendría amparada por la legalidad $\mathrm{y}$, consecuentemente, todos ellos estarían actuando prácticamente en un estado de naturaleza; no tanto racionalmente como de forma visceral y vengativa, pues se tienen que quitar de en medio a un hombre que se vale de sus poderes para violar a sus mujeres. Por otro lado, esta personalidad política actuará bajo el nombre de Fuente Ovejuna, en vistas a hacer cumplir la ley instaurada por los reyes. O sea, que la acción está fuera de la legalidad pero persigue hacer valer una legalidad vigente. Estos dos movimientos del drama teatral enhebran una trama política ideada por Lope para llevar la autoridad del Estado y el poder de la ley hasta el límite.

Cuando el juez trata de averiguar la culpabilidad material del delito acometido sobre el Comendador, habiendo torturado a trescientos de los habitantes de la villa rebelde ${ }^{140}$, en todos ellos no encuentra otra confesión más que la alusión a Fuente Ovejuna como responsable del delito; anteriormente los habitantes habían ensayado en asamblea cuál sería su actuación en el momento de dar confesión ${ }^{141}$, de tal manera que quedaron sincronizados al estilo de un organismo corpóreo. El autor del delito al que todas las

\footnotetext{
${ }^{139}$ Cfr. Thomas Hobbes, Tratado sobre el ciudadano, Leviatán, Vida de Thomas Hobbes de Malmesbury escrita por él mismo (Madrid: Gredos, 2012), 91-92.

${ }^{140}$ Cfr. Lope de Vega, Fuente Ovejuna (Madrid: Cátedra, 1983), 186.

${ }^{141}$ Cfr. Lope de Vega, ob. cit., 173-174.
} 
confesiones apuntaban, Fuente Ovejuna, al ser un acusado tan impersonal como abstracto y lato, provoca que el juez se vea incapaz de dar con el autor o autores materiales del delito, ya que los testimonios que obtiene no dan cuenta más que de un objeto abstracto e impreciso. El propio juez reconoce en el palacio de los Reyes Católicos su incapacidad para impartir justicia en el caso, así que les cede a los Reyes el veredicto. Finalmente, los Reyes deciden ser clementes con la población al no poder averiguar $<<$ el sucesso por escrito $>>142$ y la villa queda provisionalmente en manos de la autoridad real a espera que la herede un nuevo Comendador. Por tanto, los Reyes resuelven finalmente el conflicto, es el Estado a través de la figura de la monarquía quien cierra la obra y la trama política subyacente al drama de Lope de Vega.

Esta trama política ingeniada por el dramaturgo español gira en torno a la acción contractual con que los habitantes de la villa pasan de ser meros cuerpos individualizados a formar un solo cuerpo artificial y político capaz de desafiar a una autoridad tiránica como de defenderse frente a la justicia, y esta última capacidad se hace manifiesta especialmente cuando, aún bajo la tortura infligida por el juez, cada uno de los torturados dice: "Fuente Ovejuna lo hizo". De algún u otro modo, el dolor de la carne del cuerpo natural de los habitantes no se superpone al pacto que la población ha alcanzado previamente, por el que todos acuerdan culpar de lo ocurrido al sujeto artificial creado, asumiendo una responsabilidad colectiva pero que en términos judiciales resulta conceptualmente disoluta, pues se tercia imposible pensar que cada habitante particular contribuyera al asesinato de un sólo hombre. Así que nos encontramos con que Fuente Ovejuna son todos y a la vez ninguno. Al mismo tiempo, la acusación recae sobre una personalidad civil, sobre un cuerpo institucional que es a la vez tan real como invisible, invisibilidad que hace colapsar a la justicia. Por otro lado, la confesión de los habitantes no deja de ser completamente transparente en relación con el sujeto acusado, en el sentido de que todas las acusaciones reflejan que la muerte del Comendador procede de un consentimiento mutuo, es decir, que la causa de la población de Fuente Ovejuna hunde sus raíces en la voluntad de todas sus gentes.

Este colapso judicial no le permite a Lope entrever otro final posible para su drama más que situar en manos de los Reyes la decisión final, lo que, por otra parte, es el recurso habitual y normal en todos los autores de dramas municipales de la época, así lo exigían las condiciones políticas del momento en el que los reyes gozaban de un poder

${ }^{142}$ Lope de Vega, ob. cit., 189. 
absoluto e impartían justicia supuestamente en nombre de Dios. Véase, sino, en la obra de Calderón de la Barca titulada El Alcalde de Zalamea, cómo, en este caso, es precisamente el Rey Felipe II quien aparece al final del drama para impartir justicia en relación con la falta cometida por el alcalde contra un oficial militar abusador. Es el Rey, por tanto, el "personaje" que resuelve la trama ${ }^{143}$. Ante los ojos del espectador del XVII, la diligencia resolutiva con que entran en escena los reyes a cerrar las tramas de los dramas municipales debía infundir sentimientos de admiración y respeto hacia aquellos que ostentaban el poder y la soberanía. Aunque, quizá otros espectadores más perspicaces y astutos interpretaran en estas situaciones dramáticas la fuerza que adquiere la incontrolable exacerbación de la violencia humana, que cuando el hombre se ve deshonrado y humillado no existe para él otro poder más que el de las fuerzas de su cuerpo en lo relativo a acometer su venganza. La agresividad con que se revela el ánimo vengativo de un hombre contrariado ante cualquier vilipendio rasga la red jurídica de contención que el poder del Estado va enhebrando en torno a las relaciones humanas para disfrazar, mediante la fuerza, el entorno social de paz y armonía.

\subsubsection{FUENTE OVEJUNA Y EL PROBLEMA POLÍTICO DEL TIRANICIDIO}

No debe pasar desapercibido que la lectura filosófico-política de Fuente Ovejuna no se agota en la interpretación basada en el contractualismo hobbesiano, ya que, de algún u otro modo, tal interpretación se sostiene básicamente en la idea de que los habitantes de Fuente Ovejuna forman un cuerpo civil para emprender una acción política y, a la vez, defender a cada uno de los individuos de la comunidad utilizando este cuerpo como coraza a fin de protegerse tras él. Ahora bien, la acción del cuerpo civil de Fuente Ovejuna es sediciosa y se inscribe dentro de una actitud irreverente por parte de los habitantes del pueblo hacia su autoridad. Atendiendo de manera exclusiva a las escenas de sedición en Fuente Ovejuna y a la cubierta estética que subyace a ellas se hace ostensible que el drama lopesco puede invocar ciertas constantes que se hallan en el pensamiento liberal de inicios de la modernidad, en concreto del derecho de sublevación contra los tiranos.

La del tirano es una figura caracterizada y en cierta manera caricaturizada por los autores liberales de inicios de la modernidad, entre ellos cabe contar con el español Juan de Mariana, quien es considerado un antecedente del liberalismo, y con el insigne

${ }^{143}$ Cfr. Pedro Calderón de la Barca, La vida es sueño. El Alcalde de Zalamea (Madrid: Espasa-Calpe, 1979), 214-219. 
Locke; ambos realizaron un tratamiento teóricamente calcado de la cuestión del régimen tiránico y del derecho del pueblo a revertirlo.

Según comenta Christian Hansen Roses acerca del Padre Mariana, este caracterizaba al tirano como un gobernante dispuesto a sobreponerse al orden legal y costumbres del pueblo. Esta forma de gobernar depende de la voluntad y el capricho de un hombre, con las correspondientes arbitrariedades que ello conlleva ${ }^{144}$. Para Mariana <<el tirano siempre procura perseguir a todos y humillarlos a todos injustamente; pero con especialidad toda su furia la dirige contra los hombres poderosos y virtuosos $>$, y a los ciudadanos corrientes <<les agobia para impedirles que se conmuevan con multitud de impuestos que inventa todos los días $>{ }^{145}$. El régimen tiránico se sitúa al margen de la ley, es decir, constituye un gobierno extralegal. Otra característica de la tiranía que Mariana pone de relieve es que en este tipo de regímenes los ciudadanos no podrán reunirse libremente ni hablar en el espacio social sobre cuestiones relacionadas con la república ${ }^{146}$; al pueblo se le vedará el derecho a formar y actuar como un cuerpo, lo que supone un agravio contra la patria imperdonable que sumará y convocará enemigos contra el príncipe, algo que Mariana juzga pertinente en casos de esta índole:

¿qué se deberá hacer cuando no haya facultad para reunirse en un cuerpo la república? Mi opinión y mi juicio es el mismo e igual como cuando la república es oprimida por la tiranía del príncipe: quitada la facultad de reunirse entre sí los ciudadanos, no debe faltar la voluntad de desterrar la tiranía, de vengar los crímenes públicos e intolerables del príncipe y de contener sus detestables esfuerzos, de tal modo que, si atropella lo más sagrado de la patria e interna en el reino, para su auxilio, enemigos públicos, aquel que secundare los votos de la república e intentase quitar la vida del príncipe juzgo que de ningún modo obrará injustamente. ${ }^{147}$

Se precisa poner de relieve, a este respecto, que fueron los pensadores de corte liberal de la modernidad, y no Hobbes, quienes reflexionaron en profundidad sobre los casos en que la revuelta popular y el tiranicidio pueden estar justificados, en tanto en

144 Cfr. Christian Hansen Roses, Ensayo sobre el pensamiento político del Padre Juan de Mariana (Santiago de Chile: Universidad Católica de Chile, 1959), 295.

145 Juan de Mariana, Del Rey y de la Institución de la Dignidad Real (Buenos Aires: Ed. Partenón, 1945), 82-83; cit. por Christian Hansen Roses, Ensayo sobre el pensamiento político del Padre Juan de Mariana (Santiago de Chile: Universidad Católica de Chile, 1959), 299.

146 Cfr. Juan de Mariana, ob. cit., 85; cit. por Hansen Roses. Ensayo sobre el pensamiento político del Padre Juan de Mariana, 300.

147 Juan de Mariana, ob. cit., 108; cit. por Hansen Roses. Ensayo sobre el pensamiento político del Padre Juan de Mariana, 324. 
cuanto el pueblo tendría el derecho de combatir a sus opresores siempre y cuando sea justificada su causa. Locke sostiene que el pueblo debe disponer de los medios para precaverse de posibles tiranos, siendo así que el pueblo no sólo tenga $<<$ el derecho a librarse de la tiranía, sino también el de tomar medidas para prevenirla $>{ }^{148}$. Por supuesto, Hobbes jamás habría admitido tal idea, puesto que dentro de su esquema de pensamiento el tirano cae por sí mismo cuando arruina y disuelve al Estado. Hobbes no esclarece mucho cuál es la diferencia entre el tirano en particular y el mal gobernante en general, ni tampoco se preocupa de las características personales de los gobernantes. Para Hobbes, que el soberano sea alguien incapacitado, corrupto, sanguinario u ocioso no repercute en el funcionamiento regular del Estado, pues <<el poder existe en potencia, y la administración del gobierno en acto $>>{ }^{149}$. La actividad administrativa de un Estado es fundamental para hacer cumplir las leyes, mantener el orden social y la gobernabilidad de los súbditos, en otras palabras, los hombres que rodean al rey así como los funcionarios del Estado deben ocuparse de realizar las operaciones necesarias para mantener en plena latencia la organización de la sociedad civil. En este sentido, la condición personal del rey no resultaría ni definitiva ni determinante para el modo de actuar del Estado; de esta manera, Hobbes evade el problema del tiranicidio y la cuestión de los casos en que es legítimo derrocar al soberano o no, restándole importancia a las condiciones personales de aquel que ostenta el poder.

Por otro lado, cuando Locke habla del derecho que tiene el pueblo a levantarse contra los gobernantes que resultan perniciosos para la defensa de los ciudadanos, también postula una serie de modalidades y condiciones en que una sublevación popular ha de entenderse y considerarse como tal. No basta con que un grupo de personas lleve a cabo tal acto por su cuenta, puesto que se trata de un derecho del pueblo en general, un derecho que, además, no viene sustentado por el propio pueblo sino por el derecho natural, de tal modo que la irascibilidad de las gentes y prontitud en las urgencias por actuar contra los tiranos tampoco han de determinar hasta qué punto es necesario actuar. Más bien, hay un tope límite marcado por la naturaleza en virtud del que las comunidades se verán legitimadas a sublevarse o no. El autor británico dice al respecto:

\footnotetext{
148 John Locke, Segundo Tratado sobre el gobierno civil (Madrid: Biblioteca Nueva, 1999), 183.

149 Thomas Hobbes, Tratado sobre el ciudadano, Leviatán, Vida de Thomas Hobbes de Malmesbury escrita por él mismo (Madrid: Gredos, 2012), 120.
} 
El pueblo puede impedir que se lleve a cabo el mal designio trazado contra él, pero si se llega a realizar, no debe tomarse venganza del mismo en el rey, aunque este sea el autor de la villanía. Tiene, pues, el pueblo en general este privilegio, que no tiene el individuo particular (...). En cambio, el conjunto del pueblo puede ofrecer respetuosa resistencia a la tiranía intolerable, porque, cuando sólo se trata de una tiranía moderada, es preciso que la soporte. ${ }^{150}$

Así, en Fuente Ovejuna el crimen contra el Comendador involucra a toda una comunidad de gentes, que se han instituido como un cuerpo político y que, lejos de actuar de manera aislada y arbitraria, actúan de forma unitaria, manteniéndose unidos incluso bajo tortura. Por otro lado, en las palabras de Locke resulta especialmente llamativo que el pueblo deba tratar con respeto y decoro al rey, pese al daño y vejación que haya podido causar. Mientras el rey mantenga su condición de soberano, el pueblo está obligado a respetarle y obedecerle, salvo que deje de ser rey y, entonces, el pueblo vuelva a ser soberano de sí mismo. Locke encuentra dos razones para derribar a un soberano: por sus intenciones y por sus conductas. En el primer caso, el pueblo puede reaccionar frente al soberano si deliberadamente causa el desastre en su comunidad política, tal como sucedió con Nerón y Calígula; en el segundo caso, porque el soberano se haya subyugado a una nación extranjera habiendo echado a perder la libertad de sus súbditos al entregarle a un tercero la soberanía ${ }^{151}$.

El caso de la obra de Fuente Ovejuna representa un tiranicidio mediante un lenguaje dramático, aunque no se trata de una rebelión directa contra los reyes sino contra una institución que representa al poder soberano, en la medida en que se supone que el comendador es un súbdito y representante de la monarquía. Ahora bien, al comienzo de la obra, Lope ya muestra cómo el Comendador acude al palacio del maestre de Calatrava para promover la toma de Ciudad Real a favor del rey de Portugal, en contra de la reina Isabel de Castilla ${ }^{152}$. Mediante este movimiento en el inicio de la obra el dramaturgo español presenta al personaje del Comendador como un traidor, de forma que todo cuanto le acontezca tendrá una justificación y hará que de antemano el público reconozca al villano desde el comienzo. Antes de la escena sediciosa, el autor prepara al público y se guarda las espaldas frente a sus autoridades. En el sistema de poder de la época, quien usurpara a un comendador ofende indirectamente al monarca, y por ende,

\footnotetext{
${ }^{150}$ John Locke, Segundo Tratado sobre el gobierno civil (Madrid: Biblioteca Nueva, 1999), 192.

${ }^{151}$ Cfr. Locke, ob. cit., 195.

${ }^{152}$ Cfr. Lope de Vega, Fuente Ovejuna (Madrid: Cátedra, 1983), 81-91.
} 
se expone a un duro castigo. La población de Fuente Ovejuna no se rebela exactamente contra la traición cometida previamente por su comendador, sino contra el daño directo que ha sufrido a manos de este; sin embargo, en la obra no podía faltar un paso que a priori demostrara la villanía del Comendador y que, en cierto modo, fundamentara la justificación moral del tiranicidio. El propio Padre Mariana, cuando trata el tema del tiranicidio, primero analiza las razones por las que un gobernante debe ser considerado tirano para después legitimar su muerte, secuencia que se puede apreciar nítidamente en las siguientes palabras del Padre español: <<todos los teólogos y filósofos convienen en que al príncipe que por medio de la fuerza y de las armas ocupó la república, sin derecho alguno y sin consentimiento de los ciudadanos, es lícito quitarle la vida y despojarle del trono $>{ }^{153}$. Es posible observar cómo la estructura argumentativofilosófica mediante la que Mariana respalda el tiranicidio concuerda con la estructura argumentativo-literaria con que Lope encauza la acción dramática de su obra hacia la muerte del Comendador.

Desde un punto de vista lockeano, el tiranicidio de Fuente Ovejuna conservaría las dos razones por las que un soberano merece perder el gobierno: primero, el Comendador ha puesto a la población de Fuente Ovejuna en manos de una potencia extranjera y, segundo, ha dañado sin mayores reparos a las gentes del pueblo al violar a una de sus mujeres. Lo que refleja Lope en su obra es que el cuerpo civil formado por la población en rebelión adquiere legitimidad en el momento en que el Comendador pierde, por dos razones obvias, su autoridad y derecho de soberanía, movimientos del argumento dramático que encajan con los argumentos mediante los que Locke justifica y legitima la sublevación contra los tiranos.

Conviene no desdeñar el hecho de que también en la expresividad filosófico-política liberal de la época se halla el cuerpo como símbolo análogo entre el organismo natural y la organización de la sociedad civil, en los mismos términos en que lo utilizaba Hobbes pero en una constelación reflexiva diferente. Mariana dice que el deber más importante del príncipe es conservar la paz, alejando de la república los males de la guerra.

\footnotetext{
${ }^{153}$ Juan de Mariana, Del Rey y de la Institución de la Dignidad Real (Buenos Aires: Ed. Partenón, 1945), 98; cit. por Christian Hansen Roses, Ensayo sobre el pensamiento político del Padre Juan de Mariana (Santiago de Chile: Universidad Católica de Chile, 1959), 316.
} 
Ejemplifica su idea de salud Estatal en analogía con los organismos vivos: <<lo que es la salud en el cuerpo del animal, eso es la paz en el cuerpo de la república $>{ }^{154}$.

Locke, cuando describe a la comunidad política, también la conceptualiza como un cuerpo, los términos que emplea para hacerlo son los siguientes:

Aunque los miembros de una comunidad política siguen siendo siempre personas distintas y son regidos por las leyes de la sociedad en sus relaciones mutuas y como tales personas, sin embargo, todos ellos en conjunto y con referencia al resto del género humano forman un solo cuerpo; este cuerpo se halla colocado en relación al resto del género humano en el mismo estado de Naturaleza en que se encontraban antes todos los miembros que los constituyen. Por esa razón, las disputas que surgen entre uno cualquiera de los miembros de la sociedad y otras personas que se encuentran fuera de la misma, corresponden a la comunidad entera; el daño hecho a un miembro de ese cuerpo compromete a todo él en la tarea de exigir una reparación..$^{155}$

La articulación del tiranicidio requiere de la existencia de un cuerpo social unificado, que ejerza una presión material sobre el tirano. Pero en los planteamientos de Mariana y de Locke la sola fuerza de un cuerpo político resuelto en rebelión no es suficiente para justificar el tiranicidio, ya que la racionalidad del derecho natural determina los fundamentos últimos legitimadores de las acciones sediciosas. La corporalidad política es un elemento necesario y esencial en las sublevaciones, pero su posición de contrapeso al poder no le viene dada por su constitución corpórea, ni por su potencia, sino por la moralidad contenida en el derecho natural, entendiéndolo como una forma trascendente. El derecho natural, tanto en el pensamiento de Locke como en el de Marina, es una instancia extrínseca a las fuerzas que albergan los cuerpos, tanto naturales como civiles. Los autores liberales justifican las rebeliones y los tiranicidios desde ese derecho natural que expía las acciones gubernamentales y procura los contrapesos frente a los abusos de poder que acometen algunos gobernantes. Esta noción de derecho natural no parte de la fuerza inmanente de los cuerpos, sino que se advierte como un ordenamiento trascendente. Los contrapesos al poder que constituyen los cuerpos políticos requerirán, pues, de un respaldo externo a su propia complexión

\footnotetext{
154 Juan de Mariana, Historia General de España (Madrid: Ed. Gaspar y Roig, 1849), 243-245; cit. por Christian Hansen Roses, Ensayo sobre el pensamiento político del Padre Juan de Mariana, 316-226.

155 John Locke, Segundo Tratado sobre el gobierno civil (Madrid: Biblioteca Nueva, 1999), 134.
} 
física. La idea de derecho natural en los autores liberales del XVII no se ajusta a la versión ofrecida por otros filósofos como Hobbes o Spinoza, que entienden el derecho natural vinculado a la potencia de los seres. Ahora bien, Spinoza se muestra más tolerante con el tiranicidio aunque nunca llegare a verlo como una verdadera solución, necesaria y suficiente, de los problemas políticos.

La Europa del siglo XVII fue testigo del tiranicidio que Oliver Cromwell, en nombre del bando vencedor en la guerra civil inglesa, asestó contra el rey Carlos I. La posibilidad de subvertir el poder monárquico instaurado se hacía patente tras los sucesos acaecidos en Inglaterra. Una de las cuestiones más problemáticas para el pensamiento político del momento era la legitimidad de la sublevación contra las autoridades estatales, así como los límites de la monarquía. Mientras los liberales consideraron que el propio incumplimiento de las leyes naturales conlleva la rebelión contra aquellos gobernantes que osan quebrantar tal orden legal-natural, autores como Spinoza pensaron que el asunto del tiranicidio era mucho más complejo y que en él se aprecian tensiones procedentes de la propia naturaleza corporal de todos los seres humanos. Para Spinoza son los pueblos los que se habitúan a vivir bajo un determinado régimen de gobierno, de modo que no resulta oportuno poner reyes allí donde los ciudadanos no lo requieren, así como también la retirada repentina de un rey, por muy tirano que sea, puede acarrear serios problemas en un pueblo habituado a la sumisión y a vivir bajo el mando de otros. Un tirano que es derrocado por un pueblo de estas características fácilmente puede ser sustituido por otro tirano, al no ser los súbditos capaces de gobernarse de acuerdo con sus propias leyes ${ }^{156}$. El caso histórico al que recurre el filósofo de Ámsterdam para refrendar sus argumentos es, precisamente, la experiencia tiranicida de Inglaterra:

El pueblo inglés ha dado de ello un ejemplo fatal. Ha buscado razones para quitar de en medio, so capa de derecho, al monarca; pero, una vez eliminado este, no pudo menos de cambiar la forma del Estado. Pese a lo cual y tras derramar mucha sangre, se terminó por saldar a un nuevo monarca bajo otro título (como si todo el problema pasara por el nombre [se refiere a Oliver Cromwell]). ${ }^{157}$

Spinoza rehúsa utilizar el lenguaje mediante el que los liberales trataron de legitimar la sublevación y el tiranicidio, no presta tanta atención a las características de los tiranos ni se preocupa de degradarlos mediante la descripción de sus cualidades perniciosas,

\footnotetext{
${ }^{156}$ Cfr. Spinoza, Tratado teológico-político (Madrid: Alianza editorial, 1986), 388-389.

${ }^{157}$ Spinoza, ob. cit., 389.
} 
tampoco ahonda en describir con todo lujo de detalle sus actos vejatorios. Para Spinoza, más bien, el paso de un sistema de gobierno a otro se produce cuando el cuerpo social se halla en disposición y aptitudes necesarias para cambiar su forma de gobierno, pero los cambios de los gobernantes no suponen, a la postre, transformaciones sustanciales. La distancia del discurso spinozista con respecto al discurso liberal se encuentra en que el primero ve en la organización estatal un proceso que parte de la potencia de la multitud; los pueblos, en cuanto que cuerpos sociales, van modificando sus instituciones en virtud de sus capacidades y grado de racionalidad. De forma diferente, los liberales no recurren a la potencia de los cuerpos sociales para justificar los cambios en la forma de gobierno, sino que habría un plano extracorporal que vela por la estabilidad de las relaciones sociales y regula las actividades gubernamentales.

\subsubsection{UNA INTERPRETACIÓN SPINOZISTA DE FUENTE OVEJUNA: LA POTENCIA POLÍTICA MULTITUDINARIA}

El drama municipal de Fuente Ovejuna también admite interpretaciones en clave spinozista. En primer lugar, cabe destacar que el comportamiento de los habitantes de la villa del drama coincide con la descripción que Spinoza hace de la conducta humana movida por las pasiones del miedo y la esperanza. Dice Bodei que Spinoza considera que el miedo es una pasión contraria a la razón y la esperanza un consuelo propio de sumisos, de tal modo que <<miedo y esperanza dominan no solo el cuerpo, sino la imaginación y la mente de los individuos, dejándolos a merced de la incertidumbre y volviéndolos dispuestos a la renuncia y a la pasividad $>{ }^{158}$. Los habitantes de Fuente Ovejuna fluctúan entre el miedo y la esperanza, su revuelta se produce en el momento en que su indignación ante los maltratos del Comendador es mayor que el miedo que sienten hacia él. Precisamente Spinoza menciona que los desagravios de los gobernantes contra sus súbditos tornan el miedo de la multitud en indignación, con los consecuentes estragos sociales que produce la pérdida del respeto al soberano:

Pues, para aquellos o aquel que detenta el poder del Estado, es tan imposible correr borracho o desnudo con prostitutas por las plazas, hacer el payaso, violar o despreciar abiertamente las leyes por él dictadas y, al mismo tiempo, mantener la majestad estatal, como lo es ser y, a la vez, no ser. Asesinar a los súbditos, espoliarlos, raptar a

${ }^{158}$ Remo Bodei, Geometría de las pasiones (México: Fondo de Cultura Económica, 1995), 76. 
las vírgenes y cosas análogas transforman el miedo en indignación y, por tanto, el estado político en estado de hostilidad. ${ }^{159}$

En Fuente Ovejuna el propósito de la sedición es la dignidad de las gentes del pueblo, de hecho, cuando la rebelión se produce, los habitantes ignoran que el Comendador previamente había traicionado al Reino de Castilla. Las gentes de Fuente Ovejuna no actúan por el bien de todo el Reino, solo tratan de restaurar su dignidad vulnerada. El pueblo de la villa actúa más movido por la pasión que por la razón, ya que su unión es solo circunstancial y no perdurable, así lo demuestra el propio desenlace de la obra cuando la población queda parcialmente bajo la responsabilidad de los monarcas hasta la designación de un nuevo comendador. Spinoza tiene en cuenta que las formaciones gregarias de los hombres no necesariamente vienen seguidas de la razón sino de sentimientos que afectan a todos los hombres, de tal modo que $<<$ la multitud tiende naturalmente a asociarse, no porque la guíe la razón, sino algún sentimiento común, y quiere ser conducida como por una sola mente [...], por una esperanza o un miedo común o por el anhelo de vengar un mismo daño $>{ }^{160}$. En Fuente Ovejuna, el pueblo se une por el anhelo de vengar el daño que han sufrido a manos del Comendador $\mathrm{y}$, en un segundo momento, se mantienen unidos solo por la esperanza en que la benevolencia de los Reyes les absolverá.

Se podría objetar que la unión política de los habitantes de la villa no sucumbió a las torturas aplicadas por el juez, pero también en este caso la permanencia del alma y el cuerpo colectivos venía procurada por la pasión de la esperanza. Si hubiesen disuelto su unidad política en el momento de la confesión, entonces, el intercambio de acusaciones entre individuos hubiese terminado por condenar de manera inescrupulosa, arbitraria e ineluctable a muchos habitantes. La opción más esperanzadora, pues, era perseverar en la existencia de la persona jurídica de Fuente Ovejuna para de alguna manera poder burlar el procedimiento judicial y llenar de ambigüedad la autoría material del asesinato asestado contra el Comendador. Estos tránsitos por los que atraviesa la situación anímico-pasional de los habitantes de la villa marca la condición de súbditos de aquellos personajes que conforman el pueblo en el drama, se podría decir que la representación que Lope hace de dichos personajes es una caricaturización del "súbdito" enmascarada tras la tonalidad poético-dramática que reviste toda la obra. Fuente Ovejuna, leída desde

\footnotetext{
${ }^{159}$ Spinoza, Tratado político (Madrid: Alianza Editorial, 1986), 115.

${ }^{160}$ Spinoza, ob. cit., 122.
} 
la óptica política spinozista, podría invocar la sospecha de que detrás del argumento, de los giros dramáticos y de la excelencia estética hay también una crítica socio-política filtrada y nunca del todo develada.

Spinoza sostiene que las uniones humanas dirigidas por las pasiones del miedo y la esperanza son más susceptibles de caer bajo la tiranía y la disolución que aquellas que se apoyan en la racionalidad, afirma que $<<$ la esperanza no es sino una alegría inconstante surgida de una imagen de una cosa futura o pasada, de cuyo resultado dudamos. El miedo, al revés, es una tristeza inconstante surgida también de una cosa dudosa $>{ }^{161}$. La inestabilidad que generan el miedo y la esperanza causan la oscilación de la multitud, e impide que los hombres puedan agruparse a partir de un trazado estable y cimentado en la racionalidad. A propósito de la concepción spinozista sobre estas pasiones, Bodei dice que para el filósofo neerlandés la población suele oscilar de manera pendular entre el miedo y la esperanza, produciendo con ello la inquietud perpetua de la masa social en detrimento de la sabiduría ${ }^{162}$. Añade Bodei que en Spinoza el miedo y la esperanza son

pasiones caracterizadas por la máxima variabilidad de las fluctuaciones, por la inestabilidad, por la constante inconstancia, ellos se hallan en las antípodas de la firmitas, la cual constituye la prerrogativa de hombres valerosos y sabios, que no son guiados ni por el miedo que "nace de impotencia de ánimo", ni por la temeridad que surge a menudo de la inseguridad, de la avidez o del deseo de autodestrucción. ${ }^{163}$

A la luz de los comentarios de Bodei es posible detectar el elemento simbólico que opera en la actitud de la población de Fuente Ovejuna, cuya actividad fluctuante marca los movimientos dramáticos que se suceden desde la sedición de los habitantes hasta la restauración de la institucionalidad monárquica, pues finalmente el pueblo solo cambia la persona del comendador y no el régimen de gobierno. Se podría decir que los habitantes de la villa actúan de acuerdo a las duras circunstancias que les acucian, indignan y trastornan en la inmediatez, pero que la unión política llevada a cabo por ellos no deja de ser circunstancial y, consecuentemente, no perpetúan una institucionalidad en la medida en que su revuelta no busca subvertir el régimen de gobierno, sino solo librarse del yugo de un déspota que, además, resulta ser un traidor.

\footnotetext{
${ }^{161}$ Baruj Spinoza, Ética demostrada según el orden geométrico (Madrid: Trotta, 2000), 140.

${ }^{162}$ Cfr. Remo Bodei, Geometría de las pasiones (México: Fondo de Cultura Económica, 1995), 300.

${ }^{163}$ Bodei, ob. cit., 301.
} 
Javier Peña en Cómo se gobierna la potencia de la multitud hace la siguiente reflexión a tenor de la perdurabilidad de las uniones humanas en el pensamiento político de Spinoza:

Un suceso excepcional, como una agresión externa, una catástrofe natural o una tarea que requiera esfuerzo colectivo y ofrezca expectativas inmediatas de beneficio pueden unir en un momento dado a una pluralidad de individuos, pero nada garantiza que la unión persista más allá de esas circunstancias, si no se estabiliza mediante vínculos institucionales creados mediante un proceso de institución. ${ }^{164}$

La personalidad jurídica de Fuente Ovejuna cumple una función circunstancial y particular, no se perpetúa a lo largo del tiempo, su cometido es que los autores materiales del tiranicidio no sean delatados. La cota de ignorancia institucional sobre la traición del comendador y sobre los autores materiales del asesinato es la que salva a toda la población. No hay que olvidar que los Reyes, en un principio, desconocían que el Comendador era un traidor. Como ya fue analizado previamente, Lope se encarga de descalificar al Comendador en vistas a cuidarse de posibles reprimendas y justificar la rebelión de Fuente Ovejuna, de este modo, la escena en que se delata la traición tiene lugar en un momento preliminar al desarrollo central de la obra, se podría decir, en un momento casi extra-argumental. Sin embargo, es necesario hacer ostensible cómo el componente de ignorancia que cubre a todos los personajes es propiamente el hilo que va enhebrando toda la trama: el pueblo mata al comendador sin saber que es un traidor, el juez no logra averiguar quiénes son los autores materiales del asesinato y los Reyes, además de desconocer en un principio que el Comendador es un traidor, ven cómo ante la imposibilidad de saber sobre la autoría material del crimen no tienen más remedio que absolver a todo el pueblo ${ }^{165}$. En definitiva, el argumento de Fuente Ovejuna es un cúmulo de "desconocimientos" que determinan las acciones de sus personajes. Esta falta de saber en los personajes del drama lopesco puede compararse con la forma en que Spinoza critica a quienes en su época mantenían que en el sistema de gobierno monárquico un solo hombre podía hacerse cargo de todos los asuntos públicos ${ }^{166}$. Una vez más, desde Spinoza, se aprecia un rasgo característico del régimen monárquico filtrado en el drama municipal de Lope, a saber, que un solo hombre o un solo

\footnotetext{
${ }^{164}$ Javier Peña Echeverría, "Cómo se ordena la potencia de la multitud. Instituciones y derecho de la ciudad en la teoría política de Spinoza", Revista Laguna, no. 31 (2012): 45-66, 54.

${ }^{165}$ Lope de Vega, Fuente Ovejuna (Madrid: Cátedra, 1983), 189.

${ }^{166}$ Cfr. Spinoza, Tratado político (Madrid: Alianza Editorial, 1986), 124.
} 
matrimonio es incapaz de saber todo lo que ocurre dentro de un reino, que el control sobre la multitud no debe recaer únicamente en manos de uno o dos individuos, pues los asuntos públicos forzosamente tienen que ser delegados y aun así -el personaje del juez lo demuestra- la multitud cuenta con la potencia suficiente como para cubrir con vacíos cognoscitivos aquello que las autoridades no alcanzan a averiguar, dado que los hombres, gobiernen o no, son seres finitos.

Otro de los conceptos presentes en la filosofía política de Spinoza que pueden hallar su paralelo interpretativo en Fuente Ovejuna va en correspondencia con la imagen de la multitud. Si bien, en el pensamiento político de Spinoza la multitud adquiere un lugar protagonista, en el drama de Lope la multitud es un personaje encubierto, ya que el pueblo de Fuente Ovejuna hace las veces de un personaje implícito en la acción teatral. Los personajes que representan al pueblo, cuando forman un cuerpo político con la personalidad jurídica de Fuente Ovejuna, están poniendo sobre el escenario a un nuevo personaje que propiamente no aparece en el reparto, que no es directamente visible para el espectador, pero que va a marcar el trayecto hacia el desenlace del drama; ese personaje es la multitud resuelta como una corporalidad política con la potestad de eliminar a una autoridad y que agrupa a los individuos en una voluntad común. De este modo, el protagonismo de lo multitudinario en la expresión dramático-política de Lope tiene su correlato en la filosofía de Spinoza, siempre y cuando tomemos a la multitud como el vértice en torno al que se desarrolla la problemática política tanto del filósofo como del dramaturgo. Spinoza asevera que - como cabe recordar-<<el derecho de la sociedad se determina por el poder de la multitud que se rige como por una sola mente $>>$ entendiendo por "una sola mente" <<aquello que la sana razón enseña ser útil a todos los hombres $>167$.

El "protagonista oculto" del drama municipal de Fuente Ovejuna es el pueblo de la villa, este, es un protagonista que no se corresponde con un personaje en particular, su personalidad es fruto de un colectivo, su cuerpo es el de la multitud y su mente es fruto de la unión entre las personas vinculadas por una causa común. La multitud de Fuente Ovejuna se convierte en protagonista puesto que su aparición como identidad política en la escena dramática adquiere la centralidad en el desarrollo del argumento teatral. La representación simbólica de la multitud dentro de los parámetros artístico-poéticos de Lope no deja de reflejar una realidad política: la multitud tiene poder para permutar una

${ }^{167}$ Spinoza, ob. cit., 104. 
situación injusta. Aunque el crimen de Fuente Ovejuna venga provocado por los impulsos pasionales del pueblo, el desenlace de la obra vertebra un nexo de racionalidad jurídica. La impersonalidad de la multitud no le resta protagonismo a su personaje, al contrario, la unión de Fuente Ovejuna protagoniza la acción principal del argumento. Igualmente, en el pensamiento político de Spinoza la multitud aparece como un concepto central, que "protagoniza" los movimientos en el espacio público y en las determinaciones gubernativas.

A pesar de que la vinculación política del pueblo de Fuente Ovejuna tuviera un carácter oscilante, parcial y, en cuanto a su personalidad jurídica, efímero, no por ello en el argumento de la obra su personaje -encubierto- deja de patentar que la multitud tiene capacidad para tornar sus condiciones de vida. Los habitantes de la villa no aspiraban a cambiar el régimen de gobierno que pesaba sobre sus cabezas, tan solo pretendían echar por tierra los excesos de un comendador tiránico. Poniendo entre paréntesis los rasgos propios del gobierno monárquico que bordean la obra de Lope, el solo hecho de mostrar cómo la multitud uniéndose en un cuerpo y una mente supera una situación de inclemencia e indignidad, desvela la cabida de una cuña interpretativa que le otorga cierto peso a la democracia, dado que la acción de la multitud y su interferencia en la esfera del poder es un gesto característico del régimen de gobierno democrático en el sentido en que lo describió y concibió Spinoza. Según el filósofo neerlandés el Estado democrático es la forma de organización política que <<más se aproxima a la libertad que la naturaleza concede a cada individuo $>>168$.

Spinoza concibe la democracia como el sistema de gobierno que le concede mayor grado de capacidad de intervención en los asuntos públicos a la potencia de la multitud, ya que en la democracia todos los individuos serían iguales tal y como lo eran en el estado de naturaleza, y por consiguiente, cada individuo poseería el mismo poder. Como asegura Javier Peña, la democracia spinozista aproxima a los ciudadanos a su situación natural originaria, porque se produce una

recuperación del poder de decisión para el individuo por medio de la colectividad: el individuo recupera su "potentia" porque él mismo es parte de la "potentia" del conjunto, de esa "potentia" entregada a la totalidad. Esta recuperación de la

${ }^{168}$ Spinoza, Tratado teológico-político (Madrid: Alianza editorial, 1986), 341. 
"potentia" individual es la que acerca al Estado democrático al "estado de naturaleza". ${ }^{169}$

El profesor Peña preconiza que la ontología necesitarista de Spinoza se refleja en su pensamiento político, especialmente, en la concepción del Estado, de modo que $<<$ los acontecimientos políticos no pueden ser explicados mediante el recurso a determinados actos individuales o determinados sucesos accidentales; la sociedad es también Naturaleza, y tiene leyes inmanentes a su propio devenir $>>170$. La sociedad spinozista mantendría una estructura política a la que se hallan inscritas las leyes positivas así como el poder y la libertad; se supone que esta estructura habilita la potencialidad del individuo, y no a la inversa. Según las indicaciones de Peña, entonces, se confirma cómo Spinoza no admite formas y voluntades externas a la estructura sociopolítica ${ }^{171}$. < Así como la ontología de Spinoza excluye un universo a la medida del hombre, la Filosofía política rechaza las aspiraciones subjetivas como principio regulador de la sociedad $>{ }^{172}$. La composición sociopolítica del Estado, tanto en su elemento corporal, la multitud, como en su elemento espiritual, las instituciones representativas, articulan la libertad de los ciudadanos cuando rige preferentemente la democracia, cuando los pensamientos y convicciones de los ciudadanos cuentan con márgenes de influencia en el destino de la sociedad civil. La racionalidad gubernamental democrática constituye una estructura política inherente a la sociedad que perfila la libertad en el Estado, aquel Estado que se presenta como el más racional y que refuerza el desarrollo de una ciudadanía activa ${ }^{173}$.

En consecuencia con lo anterior, cabe destacar cómo Spinoza ve en la democracia el modelo de Estado más adecuado al modo en que se produce la política, por medio de la actividad de la multitud, y como <<esta forma de gobierno es la mejor y la que trae menos inconvenientes, ya que está más acorde con la naturaleza humana $>{ }^{174}$, por ello, también equilibra el poder de las fuerzas multitudinarias con la potestad política institucional, en tanto en cuanto la democracia articula una equidistancia entre el cuerpo y la mente del Estado; la misma simetría que la razón procura en las dimensiones del

${ }^{169}$ Francisco Javier Peña Echeverría, La filosofía política de Espinosa (Valladolid: Secretariado de Publicaciones Universidad de Valladolid, 1989), 329.

${ }^{170}$ Peña Echeverría, ob. cit., 371.

${ }^{171}$ Cfr. Peña Echeverría, ob. cit., 371.

${ }^{172}$ Peña Echeverría, ob. cit., 387.

${ }^{173}$ Cfr. Peña Echeverría, ob. cit., 391-392.

${ }^{174}$ Spinoza, Tratado teológico-político (Madrid: Alianza editorial, 1986), 417. 
individuo humano es trasladable al Estado democrático, en cuanto que forma de gobierno más racional. El equilibrio entre lo multitudinario y lo institucional generaría un sistema de reparto del poder emanante de la estatalidad, por el contrario, las desproporciones tendrían lugar cuando el poder de decisión se concentra en un solo hombre o en una sola institución. En vez de depositar toda la confianza y poder de decisión en un solo individuo o en un puñado de hombres, la democracia le concede a la multitud la posibilidad de decidir sobre los aspectos relativos a los asuntos públicos, en los que todos los ciudadanos están implicados por el hecho de pertenecer al Estado. El poder que alberga el cuerpo multitudinario es un principio activo mediante el que se disponen los elementos conformantes del Estado en sintonía con los criterios por los que se rige la sociedad, abriendo la puerta a que ciertas determinaciones estatales puedan ser modificadas al permitirse la libertad de cada cual dentro de los márgenes institucionales de la legalidad. 


\section{SECCIÓN III. ESPACIO ESFÉRICO: MÁRGENES DE LA POLÍTICA EN LAS NUEVAS DIMENSIONES CONCEPTUALES DEL COMERCIO}

\subsubsection{LA GEOGRAFÍA DEL PODER EN LA NUEVA IMAGEN DEL MUNDO}

La representación del cuerpo humano no fue el único concepto que experimentó abruptos cambios en la modernidad. También la imagen del mundo fue transfigurada en virtud de las nuevas aportaciones científicas, de tal modo que la visualización del mundo habitado por los hombres pasó por un vertiginoso proceso de transformación. Ya en el siglo XVI se situaron las bases teóricas y materiales para que el pensamiento, la política y las manifestaciones culturales prosperaran en la superación de las trabas religiosas impuestas a la investigación del cuerpo humano y, en su extensión más general, de todos los cuerpos físicos del cosmos. De este modo, la ciencia moderna comenzó a dar sus primeros pasos en el siglo XVI como modelo de conocimiento capaz de desentrañar aquellos secretos que se escondían detrás de los cuerpos, junto con la toma de conciencia de que la composición de los entes respondía a principios asequibles y accesibles para el entendimiento humano; de manera que la ciencia emergerá como medio de transparentación de lo corpóreo, implicando con ello un mejor dominio de los cuerpos en general.

Con ello, el estatus social del científico cada vez fue adquiriendo más relevancia, en tanto en cuanto el discurso de la ciencia ofrecía imágenes de la realidad alternativas a las que ofrecía la religión y la teología; así, la figura del científico y su discurso se erigieron como un poder alternativo al poder hegemónico que predominó en el discurso teológico de la Edad Media. Los conocimientos científicos comenzaban a advertirse como un factor cada ver más determinante en el poderío de los Estados ya que la ciencia ofrecía posibilidades que la fe, o la sintonía con las autoridades religiosas, no terminaban de proporcionar.

Esta nueva imagen del científico, presto a guiar a la humanidad en las dificultades prácticas y técnicas de la vida, podría simbolizarse en el cuadro de Diego Velázquez El geógrafo o Demócrito, donde el pintor representa a Demócrito con los atuendos y características propias de un hombre del siglo XVII, como si el sabio griego fuera un científico de su tiempo. Pese a ser una versión de Demócrito adaptada al XVII, lo que 
cabe resaltar de este cuadro es la situación en la que se encuentra el científico: aparece junto a una bola del mundo apuntando con el dedo hacia un lugar concreto de la esfera mientras mira a sus espectadores con gesto sonriente, como queriendo mostrar su satisfacción por tener noción de dónde se ubican los diferentes puntos geográficos de la Tierra, o como queriendo transmitir entusiasmo ante alguna peculiaridad geográfica que creyera estar observando en el mapa. Se trata de un científico de cuya imagen se desprende un discurso informado sobre los recovecos de la geografía mundial. El saber sobre la forma del cuerpo de la Tierra es una demostración de poder en cuanto a la orientación, a la apertura de vías de comercio y al conocimiento de los límites y las posibilidades de acción; en medio de esta variable saber/poder se halla el cuerpo como medio a través del cual el poder se manifiesta en la demostración de la verdad, lo que trae consigo un nuevo rol social del científico, cuya figura va a estar asociada a saberes funcionales y útiles para el avance del hombre en la naturaleza. Retrospectivamente, los avances científicos y técnicos impulsados por los Estados están inmersos dentro de luchas por el poder en el panorama internacional trazado por los países europeos.

Cuando se estudia el siglo anterior al XVII se suele mencionar el primer cálculo heliocéntrico de Copérnico como punto de partida de la ciencia moderna y como un ejemplo característico de las transformaciones que se estaban produciendo en el saber, estas, en disputa con el marco de veridicción impuesto por la hegemonía clerical. Sin embargo, cabe hacer especial hincapié en un acontecimiento que tuvo lugar a finales de la segunda década y comienzos de la tercera década del siglo XVI y que no hay que dejar pasar por alto, puesto que en él se ven involucrados la ciencia, el poder y la corporalidad humana. Dicho acontecimiento fue la primera vuelta al mundo de Juan Sebastián Elcano, quien tomó las riendas del viaje emprendido por Fernando de Magallanes en la búsqueda de nuevas rutas comerciales para la Corona española. El primer viaje alrededor del mundo imponía una ruptura con respecto a las imágenes del Mundo proporcionadas por las creencias y los relatos tradicionales. Se trata de una travesía que simboliza un punto de inflexión de la ciencia moderna, como afirma José Gaos en su Historia de nuestra idea del Mundo, uno de los efectos de este viaje para el conocimiento humano trajo consigo

la paulatina desaparición de lo fabuloso de la faz de la Tierra en beneficio de lo puramente positivo: de nuestra idea de la Tierra ya no es parte la idea de la existencia 
en ella de más monstruos que los animales feroces bien catalogados en la Historia Natural, y los monstruos humanos que son los humanos moralmente monstruosos. ${ }^{175}$

La travesía de Elcano demostraba la unidad de la corteza terrestre y anticipaba pruebas sobre la forma esférica del Mundo que habitan los hombres; cualquier saber práctico o teórico, natural o social, técnico o especulativo, que pretendiere operar sobre el Mundo no podría ya obviar los límites y forma del espacio habitado por la humanidad y el resto de seres. El conocimiento de las ciencias, ya fueran humanas o naturales, tendría que proyectarse, ajustarse y adecuarse a los márgenes de la Tierra.

Además, el propio viaje que dio la vuelta al Mundo vino precedido de una serie de causalidades que tienen que ver con las circunstancias de la política internacional de la época: por aquel entonces España buscaba nuevas rutas comerciales que le permitieran acceder a una de las mayores fuentes de riqueza de la época, las especias del oriente asiático. Estas riquezas estaban principalmente en manos de los portugueses, que rivalizaban con los españoles por la hegemonía de los mares. Al comienzo de los diarios de Antonio Pigafetta ${ }^{176}$, cronista de la primera expedición alrededor del planeta Tierra, se puede apreciar lo arriesgado que resultaba para los hombres de la época semejante viaje, lo que implicaba una forzosa discreción por parte del capitán general de la expedición con respecto a su tripulación, en cuanto que ocultaba los propósitos de la misión por temor a motines y para evitar los intentos de persuasión de regresar a España $^{177}$. A lo largo de las crónicas se puede apreciar el ambiente hostil que existía entre España y Portugal por hacerse con las rutas comerciales de ultramar; la propia empresa de Magallanes, el cual era portugués, surgió como un desquite por parte del explorador hacia su rey, al no incrementarle <<su sueldo en medio ducado por mes, recompensa que creía haber merecido bien por los servicios que había prestado a la

\footnotetext{
175 José Gaos, Historia de nuestra idea del Mundo (México D.F: Fondo de Cultura Económica, 1992), 136.

${ }^{176}$ Antonio Pigafetta fue un cronista, geógrafo y explorador italiano natural de la República de Venecia, vivió entre 1480-1534. Sus diarios de viaje fueron publicados en Venecia a título póstumo, en 1536. La presente edición con que venimos trabajando es una traducción del italiano al español realizada por el chileno José Toribio Medina y publicada en 1888, a partir de la edición de Cario Amoretti, editada en 1800.

177 Cfr. Antonio Pigafetta. Navegación y descubrimiento de la India Superior Libro I (Archivo de la Frontera, 2013), http://www.archivodelafrontera.com/wp-content/uploads/2013/05/Antonio-Pigafetta-1con-plantilla.pdf [consultado el 12/10/2015], 6.
} 
corona $>{ }^{178}$. Según comenta Pigafetta, a propósito de la llegada de la expedición a Tadore, fue un amigo y familiar de Magallanes instalado y muerto en Tadore quien le instó a visitar la isla, pues <<existía allí un comercio ventajoso que hacer〉>179.

También Pigafetta trata de desmentir algunas descripciones de los portugueses sobre las características climáticas y geográficas del sureste de Asia, puesto que fue esta nación la que tuvo un mayor dominio sobre esta parte del mundo durante el siglo XVI principalmente, de tal manera que, deseosos de mantener el monopolio de sus rutas comerciales, los portugueses no dudaban en ocultar y tergiversar información sobre el área geográfica que dominaban. Por ejemplo, esta pugna por el conocimiento se hace patente cuando Pigafetta describe cómo en las islas Molucas encuentran a un portugués llamado Pedro Alfonso de Losada, quien reconocía que se habían preocupado de guardar silencio sobre el descubrimiento de estas islas después de diez años habitándolas ${ }^{180}$. Así pues, además de una lectura científica, la primera vuelta al mundo también nos ofrece una lectura en clave política, puesto que tras la demostración de la forma esférica de la Tierra se escondían conflictos por el monopolio de las rutas comerciales transoceánicas y la expansión colonial de las dos potencias de la cristiandad que más sobresalían en ese momento histórico. De alguna u otra manera, la Corona española hacía gala de su dominio planetario al tener bajo su servicio a la primera expedición en dar la vuelta al mundo. Entonces, este acontecimiento histórico tiene como raíz causal una lucha de intereses y de dominación más que un afán por averiguar la verdadera forma de la Tierra, de manera que tras el descubrimiento de nuevos itinerarios geográficos existiría un litigio por el poder.

Así, en la demostración de la esfericidad de la Tierra interactuaron dos términos que constituyeron la variable saber/poder: en lo que respecta al saber, se demuestra la verdad de la hipótesis de que la Tierra es redonda; y en lo que respecta al poder, la necesidad por parte de España de abrir nuevas rutas comerciales y coloniales con que mantener y ostentar su hegemonía. En medio de esta variable se halla el cuerpo humano en dos sentidos: 1) el retorno de las personas al mismo punto del que partieron rodeando la Tierra en dirección oeste como evidencia material de la forma del espacio terráqueo,

\footnotetext{
178 Antonio Pigafetta, Navegación y descubrimiento de la India Superior Libro III (Archivo de la Frontera, 2013), http://www.archivodelafrontera.com/wp-content/uploads/2013/05/Antonio-Pigafetta-3con-plantilla.pdf [consultado el 15/10/2015], 17.

179 Pigafetta, ob. cit., 17.

${ }^{180}$ Cfr. Pigafetta, ob. cit., 19.
} 
y 2) la constatación de que el espacio físico donde habita la humanidad es limitado. La constatación de que el mundo en que viven los seres humanos es limitado, más que trabar a los Estados occidentales, animó a impeler nuevos descubrimientos geográficos, incentivando, a su vez, la adhesión de nuevos territorios. La determinación finita del espacio no fue un motivo de desaliento para las naciones europeas, por el contrario, actuó como método con que sopesar sus propias fuerzas con respecto a las de sus rivales. Desde entonces, además, tomó cada vez más importancia la demostración del poder articulado desde el comercio, pues los combates ya no sólo se librarían en los campos de batalla sino también en la monopolización de las rutas comerciales, fuente de riqueza indispensable para el mantenimiento de los elementos de dominio por parte de los emergentes Estados de Europa.

\subsubsection{DIMENSIONES Y TRANSFORMACIONES DEL SABER ECONÓMICO}

La nueva imagen del espacio que habitan los seres humanos y la capacidad para demostrar la realidad de esta imagen influyeron en el desarrollo del comercio, cuyos márgenes se ajustaron a la nueva imagen de la Tierra. En un mundo esférico las actividades comerciales se expandieron y, por primera vez en la historia, los mercados comenzaron a rodear la superficie de la tierra. La proyección comercial por parte de los Estados europeos occidentales quedó sujeta a un nuevo cálculo que obligó a transformar los esquemas económicos heredados de la tradición medieval. La idea de un mercado con capacidad para bordear un espacio esférico situó el flujo de las actividades comerciales en un circuito casi inagotable de intercambios. Las mercancías podían consumirse o terminarse, el dinero podía cambiar su apariencia y su valor, pero, mientras existiese voluntad por parte de los hombres para intercambiar sus bienes y mientras existiesen dinero y mercancías con que ejecutar los intercambios, las posibilidades de enriquecimiento a partir del comercio resultarían casi inacabables. El circuito del mercado aseguraba la tendencia hacia el infinito de las actividades comerciales.

La reflexión económica del momento, de raigambre escolástica, se desarrollaba merced al problema de la justicia. El tratamiento que se hacía de los temas económicos tenía un fondo moral y político. El economista estadounidense Raymond de Roover en un artículo dedicado a la economía escolástica afirma que fueron los moralistas españoles de los siglos XVI y XVII los que contribuyeron a renovar las ideas escolásticas sobre el intercambio comercial, procedentes de la doctrina de Santo Tomás 
de Aquino. Así, los moralistas españoles se fijaron en el cambio internacional de divisas a raíz de observar las condiciones desfavorables en los tipos de cambio de España con respecto al resto de Europa ${ }^{181}{ }^{182}$. Aunque los moralistas españoles avanzaron en el análisis económico, los presupuestos que determinaban sus ideas, como la doctrina sobre la usura, no les permitieron superar ciertos escollos que se planteaban en el contexto económico de su tiempo. Pese a haber contribuido a mejorar los clásicos cálculos sobre los que se asentaba la economía escolástica, finalmente, esta decayó ${ }^{183}$.

A la luz de la observación de los procesos mercantiles, los moralistas españoles fueron atisbando nuevos problemas económicos. La ampliación del espacio mercantil traía consigo nuevas urgencias teóricas y prácticas que había que solucionar. Tomás de Mercado, economista de la Escuela de Salamanca del siglo XVI, afirma que los comerciantes contribuyen al enriquecimiento tanto material como espiritual puesto que adquieren conocimientos a partir de sus experiencias por todo el mundo. Afirma el economista español que <<son útiles a la república, por la gran noticia de varias cosas que han visto y oído en su peregrinación $>{ }^{184}$. Además, da cuenta de cómo los productos importados a las colonias españolas desde la metrópoli son pagados al fiado (a plazos) en vez de al contado. Para Tomás de Mercado en las operaciones al fiado pueden ocultarse prácticas usureras, y apela a la unidad nacional de las colonias con España para que cambien la forma de estos tratos:

Esta costumbre reprehenden muchas veces los teólogos en estos reinos por la sonancia y apariencia que tiene de mal, y también que, como la ley divina y justicia natural, en que se fundan estas reglas y documentos que hemos dado en el vender al fiado, es una e igual y no variable en todo el orbe, parece muy conforme a razón se reduzca, se regle y nivele por ellas el trato de aquellas partes, que, dado sean

\footnotetext{
181 "Economía escolástica" es el nombre del artículo que fue publicado en inglés en 1955 en la revista The Quarterly Journal of Economics; ver en Raymond de Roover, "Scholastic Economics: Survival and Lasting Influence from the Sixteenth Century to Adam Smith", The Quarterly Journal of Economics 2, no. 69 (1955): 161-190.

${ }^{182}$ Adviértase que para acceder al contenido de este texto la revista exige una clave de acceso, de la que no disponemos, debido a ello solo contamos con la traducción al español del artículo que vamos a tratar. La traducción se encuentra disponible en el noveno volumen de la revista Estudios públicos perteneciente al Centro de Estudios Públicos (CEP) de Chile. Lamentablemente no hemos encontrado el nombre del traductor o traductores al no estar especificado en el mismo artículo. Ver en: Raymond de Roover, "Economía escolástica", Estudios públicos, no. 9 (1983): 89-121, 99.

${ }^{183}$ Cfr. Roover, ob. cit., 102.

184 Tomás de Mercado, Suma de tratos y contratos, ed. Nicolás Sánchez Albornoz, http://www.hacer.org/pdf/Tratos.pdf [consultado el 10/04/2015], 47-48.
} 
remotísimas, todos en fin no sólo somos hombres de razón, sino aun de una patria y nación española. ${ }^{185}$

A raíz de estas palabras, es posible confirmar que la principal preocupación de estos economistas a la hora de tratar asuntos económicos era de carácter moral; no obstante, el fracaso de sus doctrinas pone de relieve la emancipación a nivel fáctico y teórico de la economía con respecto a las directrices morales, proceso que en paralelo se hacía visible también en el arte de la política.

Uno de los economistas escolásticos españoles más destacados fue Juan de Mariana, en cuyo pensamiento político -como se vio anteriormente- y económico se advierten gestualidades propias del modo liberal de pensar. Este prurito teórico (proto)liberal se aprecia, entre otros lugares de su obra, en sus críticas a la moneda de Vellón. Ante la escasez de plata, la corona española comenzó a acuñar un tipo de moneda que contenía menos plata, esta práctica es lo que Mariana llama envilecer la moneda y, según su criterio, dicha práctica supone gravar a los súbditos con un tributo más, porque es una forma mediante la que el soberano extrae parte del valor de las monedas que normalmente funcionan como medio de cambio en las operaciones mercantiles ${ }^{186}$. Juan de Mariana se da cuenta de cómo las decisiones arbitrarias de un gobierno pueden perjudicar el orden de la economía, en concreto, vincula a los regímenes tiránicos como causantes de estas distorsiones en el mercado. El padre español añade, además, que una de las características de las tiranías consiste en que el Estado se apropia de los bienes de los súbditos disponiendo de ellos a su gusto y arbitrio, en la tiranía toda la ciudadanía se ve oprimida y bajo las directrices de un jerarca que cree estar por encima de la ley ${ }^{187}$.

Mariana muere en el año 1624, justo ocho años antes del nacimiento de Locke. En el pensamiento político de ambos autores se pueden apreciar ciertos paralelismos, aunque sus entornos vitales e intelectuales fueron muy diferentes ya que Mariana fue un teólogo escolástico de la Contrarreforma, y Locke era un reconocido intelectual anglicano que participó en actividades diplomáticas, gubernamentales y comerciales; mientras Mariana trataba de salvar el orden teológico tradicional que había imperado durante siglos en Europa, incorporando variantes innovadoras en sus concepciones, Locke

\footnotetext{
${ }^{185}$ Mercado, ob. cit., 126.

${ }^{186}$ Cfr. Juan de Mariana, Tratado y discurso sobre la Moneda de Vellón (Madrid: Instituto de Estudios Fiscales, 1987), 39-41.

${ }^{187}$ Cfr. Juan de Mariana, Del rey y de la institución real Libro Primero (Valencia: CCM, 2009), 38.
} 
estaba tratando de afianzar nuevos principios filosóficos y políticos al margen de cualquier clero, en un contexto marcado por las reivindicaciones de los sectores liberales ingleses. Mariana esperaba compatibilizar el iusnaturalismo tomista con el nuevo orden mundial en que se hallaba inmersa la cristiandad, así lo atestigua su planteamiento económico, fiel y riguroso con respecto a las máximas de la religión católica. Locke, por otra parte, no arrastraba los rigores impuestos por la religión, dado que al profesar el protestantismo supo separar aspectos del panorama intelectual, político y económico de los fundamentos provenientes de la fe, que quedaron reservados más bien a aspectos de la vida íntima. Asimismo, el contexto económico en que se movieron los pensamientos de ambos autores denota una serie de cambios en la forma de apreciar el mercado, erigido sobre un espacio supranacional fuera del control de los soberanos.

De este modo, el mercado iba a constituir un espacio aséptico en el que podían triunfar o fracasar tanto un rey como un comerciante, un espacio que no podía ser moldeado a voluntad de las autoridades gubernamentales pues en él se establecieron relaciones que trascendían los espacios que ocupaban los países. En consecuencia, los Estados no podían decidir los unos por los otros en qué condiciones se iban a desplegar sus políticas económicas, y tampoco el mercado se mostraba tan maleable como los pueblos sobre los que gobernaban.

\subsubsection{EL FLUJO NATURAL DE LA MASA MONETARIA}

Los márgenes en que se desarrollaba la vida y la cultura de los pueblos occidentales del Medievo se ampliaron, como vimos, debido a esa nueva imagen de la Tierra -el Mundo que habitan los seres humanos- que los descubrimientos renacentistas pusieron de manifiesto. El concepto y ejercicio del gobierno se alteró en un entorno mundial mucho más extenso que los límites en que se había desarrollado la cristiandad durante la Edad Media, lo que traía consigo un replanteamiento del poder gubernamental en materia económica, territorial y diplomática. A este respecto, cuando Locke expone sus ideas económicas distingue dos formas de enriquecimiento: una mediante la conquista y otra mediante el comercio. La primera sería la que aplicó Roma, la segunda es la que deberían aplicar todas las naciones europeas, especialmente Inglaterra, dada la situación de equilibrio militar predominante en las relaciones internacionales. Una posición favorable en el comercio supone una estrategia de enriquecimiento que no desgasta a la 
nación en los campos de batalla, asimismo, la actividad comercial supone una solución práctica para el enriquecimiento, ya que,

nadie es lo suficientemente vanidoso como para alimentar el pensamiento de que vayamos a cosechar las riquezas del mundo con nuestras espadas haciendo que el botín y el tributo de las naciones vencidas constituyan los fondos para hacer frente a los gastos del gobierno. ${ }^{188}$

Estos comentarios se encuentran en Algunas consideraciones sobre las consecuencias de la reducción del tipo de interés y la subida del valor del dinero, carta publicada en 1692 en la que Locke critica las propuestas que promovían limitar los tipos de interés y reducir la cantidad de plata en las monedas. El autor afirma que los Estados no deben obcecarse en regir sobre aspectos relacionados con la forma en que los ciudadanos disponen de sus propiedades y dinero, ya que no existen leyes que puedan regular sobre tales asuntos, puesto que si

es imposible dictar una ley que impida a un hombre transferir su dinero o propiedad a quien quiera, también será imposible, mediante un artificio legal, impedir que los hombres, conocedores del poder que ostentan sobre sus propios bienes y de la manera en que estos pueden ser transmitidos a otras personas, adquieran dinero prestado al tipo que sus necesidades le obliguen a aceptar. ${ }^{189}$

La idea que persigue respaldar Locke es que tras las necesidades de los hombres, procedentes de su constitución natural, no hay ley gubernamental que pueda decidir cómo cubrir y proteger sus intereses, dado que cada cual conoce mejor cómo gestionar e intercambiar su dinero y propiedad sin la interferencia de una fuerza ajena a sí mismo.

El filósofo de Wrington preconiza la autorregulación del mercado. Solo dejando que el mercado opere sin obliteraciones pueden procurarse las condiciones para el enriquecimiento de naciones e individuos. Por ende, los precios de las mercancías y del dinero (Locke considera al dinero mercancía a la vez que instrumento de medida del valor) no han de ir fijados por ley, en tanto en cuanto los precios varían en función de la oferta y de la demanda, en consecuencia, <<las cosas deben dejarse en paz que encuentren su propio precio $>190$. Es inútil que los seres humanos se ensoberbezcan

\footnotetext{
${ }^{188}$ John Locke, Escritos monetarios (Madrid: Pirámide, 1999), 63.

${ }^{189}$ Locke, ob. cit., 55.

${ }^{190}$ Locke, ob. cit., 82.
} 
fijando unos precios en función de sus previsiones, ya que, en realidad, los movimientos cambiantes del mercado hacen que el valor de las cosas varíe constantemente. Los indicadores que toma en consideración Locke para ponderar los mecanismos mediante los que se establecen los precios de forma natural son la cantidad de oferta y la cantidad de demanda: el encarecimiento de una cosa se produce cuando hay muchos demandantes y pocos ofertantes, mientras que su abaratamiento se deberá a la abundancia de ofertantes y a la escasez de demandantes ${ }^{191}$.

En otra carta sobre economía publicada en 1696, titulada Más consideraciones acerca de la subida del valor del dinero, Locke se enfrenta a un problema al que Juan de Mariana ya se enfrentó cuando se puso en circulación la moneda de Vellón: el envilecimiento de la moneda (fenómeno que hoy en día se conoce como inflación). En primer lugar conviene indicar que para Locke la plata <<es el instrumento y la medida del comercio en todos los lugares civilizados y en los que se comercia del mundo $>>{ }^{192}$, es decir, que la plata, por consenso unánime, es el elemento que mensura el valor de las cosas que se intercambian en el mercado. En el proceso de acuñación de moneda la plata es mezclada con cobre o plomo para hacer más duras las monedas, evitar que se derritan con facilidad y no incurrir en muchos costes en el refinamiento al venir la plata mezclada con otros metales cuando es extraída de la mina ${ }^{193}$. Pero que las monedas de plata vengan mezcladas con otros metales no justifica el recorte de la plata en el proceso de acuñación, por tanto, cada moneda debe llevar la marca de un sello público con el fin de $<<$ proteger y garantizar la cantidad de plata por la que los hombres se comprometen por contrato $>>194$.

Puede darse el caso de que un Estado decida recortar la cantidad de plata de las monedas que acuña, con el fin de poner más cantidad de dinero en circulación, lo que a ojos de Locke es un fraude para el público, que confía en que cada moneda contenga una determinada cantidad de plata. Locke califica el recorte del dinero como un robo al público que repercute negativamente en la marcha de la economía; entre otras cosas, crea trastornos que desordenan el comercio y reducen el poder adquisitivo del dinero ${ }^{195}$. Multiplicar la cantidad de monedas en circulación, realmente, no contribuye a subir el

\footnotetext{
${ }^{191}$ Cfr. Locke, ob. cit., 88.

192 Locke, ob. cit., 169.

${ }^{193}$ Cfr. Locke, ob. cit., 172.

${ }^{194}$ Locke, ob. cit., 173.

${ }^{195}$ Cfr. Locke, ob. cit., 175.
} 
valor de la plata, de hecho, no existe tal concepto porque ni la plata ni ningún producto pueden subir con respecto a sí mismos, solo con respecto a la cantidad de cosas por las que se intercambian. De modo que una onza de plata siempre será igual a una onza de plata, por lo que hablar de la subida de su valor es una mera ilusión ${ }^{196}$. Pero según Locke siempre han existido tergiversaciones de esta naturaleza:

No es imposible de imaginar, en la ignorancia de épocas pasadas, cuando el dinero era poco y la comprensión acerca de los cambios del mercado era menor, que no era difícil para aquellos versados en el negocio y en la política de la casa de moneda, persuadir al príncipe, especialmente si el dinero era escaso, de que el fallo estaba en el patrón de la casa de moneda y que la manera de incrementar la cantidad de dinero era subir (una palabra que sonaba bien) el valor de la moneda. ${ }^{197}$

Locke califica la práctica de recortar el dinero como una decisión política que, sin embargo, ignora el funcionamiento del mercado; mismamente, existe un sistema internacional de paridad que compara la cantidad de plata que contienen las monedas de cada país, para equilibrar la forma de pago entre los países ${ }^{198}$. La acuñación de moneda se produce al margen del público, sus gobernantes y delegados pueden recortar el dinero sin que nadie se entere, pero bajo los argumentos de Locke podríamos decir, entonces, que en economía las mentiras duran poco tiempo. Además de esta idea, cabe poner de relieve otro asunto más importante en la relación entre la política y la economía en el pensamiento lockeano: la imposibilidad de que la voluntad política de los soberanos moldeé el mercado, pese a que desvirtúen el valor de las monedas acuñadas de forma oculta poniendo en riesgo la confianza que los ciudadanos depositaron en ellos y en el sistema de cambio. La economía no puede ser permeable según la voluntad soberana de las autoridades gubernamentales. En un contexto donde el mercado está rodeando el espacio esférico del mundo los gobiernos se topan con la imposibilidad de dirigir los movimientos de este espacio en proceso de crecimiento y expansión. Locke se da cuenta de la ingobernabilidad de ese espacio mercantil que, propiamente, no cuenta con ninguna instancia gubernamental en la medida en que su vertebración es radicalmente distinta a la del espacio Estatal.

\footnotetext{
${ }^{196}$ Cfr. Locke, ob. cit., 183.

${ }^{197}$ Locke, ob. cit., 213.

${ }^{198}$ Cfr. Locke, ob. cit., 178.
} 
El mercado se rige por unas leyes cuya vigencia y funcionamiento no varían ni oscilan en función de la voluntad de cada cual, ni siquiera del poder de los soberanos es capaz de retocarlas o trastocarlas. Los príncipes no pueden mover el comercio a capricho, cualquier decisión arbitraria no fundada en el conocimiento de las leyes mercantiles actuará como una sinrazón y, pese a los argumentos que puedan aportar consejeros y delegados de instituciones de gobierno, estas, siempre serán sofismas si no se ajustan a la nómica del mercado. Huelga añadir que la carta de Locke titulada Más consideraciones acerca de la subida del valor del dinero iba dirigida a criticar la propuesta de Mr. Lowndes, secretario del Tesoro del rey Guillermo III, quien proponía incrementar la cantidad de dinero a partir del recorte de plata en cada moneda ${ }^{199}$. Para Locke esta práctica solo sería legítima si se informara debidamente al pueblo, que es el que está imbuido en el comercio diario, y más bien no haría falta recortar el dinero sino sacar a circulación monedas más pequeñas para las transacciones más pequeñas. Pero si se deteriora el ciclo legal mediante el que fluye el dinero en el mercado se estará perjudicando y engañando al público $\mathrm{y}$, aunque de manera sutil, quebrantando el derecho de propiedad. El dinero <<es necesario para llevar adelante el comercio〉>, por tanto, <<si falta el dinero, las personas no pueden comprar y el comercio se detiene $>>200$.

Locke funda las orientaciones que propone para el ejercicio del gobierno en sus investigaciones económicas, el saber económico actúa como una guía de las acciones gubernamentales. El gobernante, para mantener la estabilidad, libertad, soberanía y fluidez regular de la masa social, no tendrá que aplicar mecanismo de presión directa sobre esta corporalidad masiva, pues no deberá forzar los movimientos de la población haciendo uso de su poder para dirigir a sus gobernados; los márgenes de acción del soberano vendrán guiados por las directrices económicas que ofrece la política monetaria. En el pensamiento político y económico de Locke, la política monetaria aparece como uno de los mecanismos indirectos más importantes para el gobierno de la población. El flujo monetario y la cantidad de masa monetaria es una de las principales causas del movimiento de los seres humanos en el espacio del mercado, el gobernante comprometido con el derecho natural y resuelto a respetar la libertad de sus conciudadanos limitará sus acciones a los asuntos que le competen y no intervendrá en

${ }^{199}$ Cfr. Victoriano Martín, "Estudio preliminar"; en Escritos monetarios, John Locke (Madrid: Pirámide, 1999), 33-34.

200 John Locke, Escritos monetarios (Madrid: Pirámide, 1999), 177. 
aquellos aspectos de la vida social movidos por autorregulación. El filósofo británico invita a que los gobiernos no vean en la moneda un medio para el enriquecimiento de sus autoridades. La libre circulación de la masa monetaria, según la voluntad de los individuos que participan en el mercado, y la determinación natural del valor de la moneda, mediante la relación entre la oferta y la demanda, son una garantía para que el gobernante mantenga el poder.

\subsubsection{EL PODER DEL ESPACIO COMERCIAL EN LA FILOSOFÍA POLÍTICA DE LOCKE}

En el Segundo ensayo sobre el gobierno civil, justo al final del capítulo que Locke le dedica al tema de la propiedad privada, el filósofo se pregunta por qué el oro y la plata, materiales inútiles en términos de subsistencia, pueden haber tomado la forma de dinero $\mathrm{y}$, en consecuencia, haber adquirido tan alto grado de valor para los hombres, hasta el punto de ser un instrumento indeleble en la articulación de las transacciones comerciales. La respuesta que ofrece el autor a este interrogante es que el oro y la plata son materiales durables que pueden permanecer casi impolutos con el paso del tiempo, es decir, el oro y la plata resisten mejor que otros materiales debido a que su obsolescencia es baja, por ende, su acumulación no repercutirá en pérdidas para quien lo atesore. Además, afirma el autor que el dinero, en forma de oro y plata, fue aceptado por el conjunto de los seres humanos como elemento de intercambio en el comercio por mutuo acuerdo.

El dinero no satisface de forma directa ninguna necesidad fisiológica ni aporta ventajas físicas, por lo que en estos términos no tendría ningún valor; su función es otra: representar el valor que los hombres le otorgan a las cosas. La utilidad del dinero reside en el contexto de las relaciones comerciales. Así, entonces, el material del que está compuesto el dinero no resuelve la subsistencia humana ni sacia al cuerpo, aunque sí que indirectamente en el espacio comercial sirve para que obtengamos los recursos con que contribuir a satisfacer necesidades y deseos. La ventaja del dinero es que está constituido por materiales imperecederos que pueden ser reacuñados constantemente, cosa que no sucede con otros productos que son efímeros, caducos o solo pueden ser consumidos una vez sin poderlos reutilizar. Otro factor determinante en el establecimiento del valor del dinero es la escasez de los materiales -oro y plata-que lo componen ${ }^{201}$. Recuérdese que para el pensador de Wrington las cosas escasas aumentan

\footnotetext{
${ }^{201}$ Cfr. John Locke, Segundo Tratado sobre el gobierno civil (Madrid: Biblioteca Nueva, 1999), 74-75.
} 
su valor, o sea que el oro y la plata son valiosos en la medida en que en el mercado son muy demandados y poco ofertados.

En el pensamiento económico lockeano la importancia que el dinero tiene para los seres humanos, a parte de los factores anteriormente mencionados, encuentra también su causa en la capacidad de los hombres para alcanzar acuerdos. Para Locke el valor del dinero vino de la mano de un consenso tácito por el que los humanos acordaron emplearlo en las relaciones de intercambio. En Algunas consideraciones dice que

la humanidad se ha puesto de acuerdo en otorgar un valor imaginario al oro y a la plata en razón de su durabilidad, escasez y dificultad de ser falsificado y los ha convertido, por consenso general, en la prenda común, por lo que el hombre está convencido de recibir a cambio de ellos cosas igualmente valiosas que aquellas de las que se ha desprendido por una cantidad de estos metales. ${ }^{202}$

En relación con lo que acabamos de ver, cabría, a tenor de la teoría sobre el valor del dinero presentada por Locke, hacernos la siguiente pregunta: ¿Cuál es el agente responsable de llevar a cabo el proceso de acumulación gracias al cual se crean depósitos de valor susceptibles de intercambiabilidad? Pues bien, Locke considera que el trabajo es la actividad que por excelencia acumula bienes y, en consecuencia, la propiedad privada se genera a partir del ejercicio del trabajo sobre la naturaleza. El agente que ejecuta el trabajo es el ser humano, y concretamente el cuerpo se va a corresponder con la agencia material de esta actividad. El pensador de Wrington predetermina que, ya de por sí, cada individuo tiene la propiedad de su propia persona. Esta forma de posesión conlleva concebir la corporalidad como fuerza productiva, ya que para el ser humano <<el esfuerzo de su cuerpo y la obra de sus manos son también auténticamente suyos $>>{ }^{203}$; las actividades productivas tienen en la corporalidad su eje material de acción. Cada ser humano ha de poseer su cuerpo para poder trabajar, lo que en términos fácticos supone poseer las capacidades, fuerzas y destrezas subyacentes al cuerpo y a las habilidades que lo acompañan. Resulta que, según Locke, la posesión corporal es un requisito indispensable en la realización de actividades productivas; los individuos explotan las características de sus miembros y su resistencia física para trabajar y procurarse así sustento y riqueza.

\footnotetext{
202 John Locke, Escritos monetarios (Madrid: Pirámide, 1999), 71.

${ }^{203}$ John Locke, Segundo Tratado sobre el gobierno civil (Madrid: Biblioteca Nueva, 1999), 62.
} 
A este respecto Esposito comenta que en la filosofía política lockeana la corporalidad es el lugar de la propiedad, ya que el individuo posee primordialmente su cuerpo. La apropiación originaria del individuo sobre el cuerpo fundamenta ontológica y jurídicamente el resto de posesiones llevadas a cabo por el individuo, en la medida en que $<<$ al poseer su propia persona corporal, es dueño de todas las actividades; en primer término, de aquella que, transformando el objeto material, se lo apropia por propiedad transitiva $>204$. Esposito vincula la protección que el sujeto hace de su propiedad con una operación inmunitaria, ya que la persona resuelve su conservación expandiendo su espectro de apropiación por medio del trabajo, a costa de, para ello, hacer de su cuerpo un objeto apropiado. Del mismo modo que para el sujeto el objeto apropiado $<<$ forma un todo con su propio cuerpo>>, también <<el propietario se vuelve tal solo en virtud de la cosa que le pertenece y, por tanto, él mismo depende de ella $>>{ }^{205}$.

El trabajo sería la actividad por medio de la que el sujeto subjetiviza, mediante su esfuerzo, las cosas, a cambio de situar la corporalidad en el terreno del objeto, en otras palabras, el individuo objetualiza su cuerpo en tanto en cuanto este es la propiedad necesaria en el ejercicio productivo. Para Locke el trabajo consiste en transfigurar las cosas que vienen dadas en la naturaleza, de tal modo que pasan a ser un producto poseído o una cosa artificial:

Por eso, siempre que alguien saca alguna cosa del estado en que la Naturaleza la produjo y la dejó, ha puesto en esa cosa algo de su esfuerzo, le ha agregado algo que es propio suyo; y por ello, la ha convertido en propiedad suya. Habiendo sido él quien la ha apartado de la condición común en que la Naturaleza colocó esa cosa, ha agregado a esta, mediante su esfuerzo, algo que excluye de ella el derecho común de los demás. ${ }^{206}$

Con base en lo expuesto, el trabajo es una actividad que le agrega algo a la naturaleza, que produce cosas nuevas, puesto que modifica la disposición de los objetos con respecto al orden en que los dispuso la naturaleza. Así pues, el trabajo saca las cosas del estado común natural y, con ello, el producto trabajado pasa a ser una apropiación exclusiva del individuo que realizó esta operación, porque el trabajo deja marcada la

\footnotetext{
${ }^{204}$ Roberto Esposito, Bíos. Biopolítica y filosofía (Buenos Aires: Amorrortu, 2006), 105.

${ }^{205}$ Esposito, ob. cit., 107.

${ }^{206}$ John Locke, Segundo Tratado sobre el gobierno civil (Madrid: Biblioteca Nueva, 1999), 62.
} 
propiedad allí donde actúa ${ }^{207}$. Precisamente Norberto Bobbio aclara que la concepción lockeana del trabajo va asociada también a la comprensión de la propiedad privada. Sostiene Bobbio que en la tradición del XVII había dos doctrinas sobre la propiedad: una era la "ocupación" como forma de posesionarse de una res nullius, es decir, de un terreno o cosa que no pertenece a nadie; y la otra era la "especificación", promovida por Locke, en la que la actividad productiva de la persona extrae propiedad del ejercicio transformativo de la naturaleza ${ }^{208}$. Según Bobbio, Locke, que se había interesado por los escritores iusnaturalistas, propuso que las cosas en el estado de naturaleza más que una res nullius conformaban una res communes, o sea, que pertenecían a toda la humanidad, consecuentemente, la propiedad privada, en cuanto apropiación individualizada, <<ocurría entonces no gracias a un proceso de apropiación, sino esencialmente a través de un proceso de individuación $>>{ }^{209}$. El trabajo es la mediación que hace posible el tránsito de las cosas de un régimen de propiedad común a un régimen de propiedad privada.

De acuerdo a estas nociones es posible deducir que el cuerpo es el agente material de las actividades productivas y que, a su vez, es una propiedad más del individuo al venir asociado a la persona. El cuerpo es una propiedad del individuo y además es un factor en el proceso de producción, por tanto, el cuerpo es el agente material que entra en contacto con la naturaleza en el momento de ejercer un trabajo sobre ella, por lo que de alguna u otra manera la corporalidad humana es la principal herramienta en el proceso de acumulación de propiedades. El esfuerzo y la carga que supone el trabajo son focalizadas en el cuerpo. El potencial productivo intrínseco al cuerpo se convierte, a la luz de la interpretación del esquema conceptual lockeano, en un depósito de valor que cada individuo posee en sí mismo, puesto que el cuerpo es la principal fuente de riqueza $\mathrm{y}$, por ende, un activo económico. El cuerpo entra de esta manera en el dominio del mercado, de ahí que tenga que ajustarse a las leyes que rigen su funcionamiento. Pero no solo el cuerpo natural del individuo va a estar dentro del espacio mercantil, también el cuerpo político que conforma cada uno de los Estados quedará subsumido a la lógica y funcionamiento de este espacio.

\footnotetext{
${ }^{207}$ Cfr. Locke, ob. cit., 63.

${ }^{208}$ Cfr. Norberto Bobbio, Locke y el derecho natural (Valencia: Tirant Humanidades, 2017), 158.

${ }^{209}$ Bobbio, ob. cit., 159.
} 
Locke caracteriza al estado de naturaleza como un momento en que el hombre vive en la abundancia. Cada individuo podía trabajar apropiándose de aquello que necesitaba para su subsistencia, y el valor de las cosas dependía únicamente de su utilidad sin que mediaran instrumentos de medida ${ }^{210}$. En un ambiente donde las tierras y los bienes de la naturaleza no escaseaban, los hombres podían apropiarse de tierras y trabajarlas sin dañarse los unos a los otros debido a que la tierra era un bien que sobraba. Cada hombre trabajaba hasta donde sus fuerzas daban de sí sin poner en peligro la propiedad de los otros, la propia naturaleza había impuesto estos límites, y por eso es que cada hombre trabajaba hasta donde llegaban sus fuerzas. No obstante, afirma Locke que a medida que la población fue creciendo y una vez se adoptó el dinero, las tierras comenzaron a escasear con su consecuente aumento de valor, lo que obligó a las comunidades humanas a establecer acuerdos de régimen interno que regularan la propiedad, asimismo, cada comunidad fijó unas fronteras territoriales ${ }^{211}$. La formación de la sociedad política se produjo a partir de la concesión a la comunidad del derecho natural de cada hombre, componiendo un cuerpo civil responsable de respetar y hacer cumplir la ley natural ${ }^{212}$. Nótese cómo en Locke la formación del Estado civil se debe básicamente a una determinada coyuntura económica que empujó a los individuos a formar un cuerpo político. Pero el interés mutuo de cada individuo en formar un cuerpo político residía en la necesidad de contar con una institución que velara por la propiedad de cada cual, dado que en el estado de naturaleza la salvaguardia de la propiedad resultaba aun imperfecta y, consecuentemente, apremiaba la necesidad de un gobierno comprometido con su defensa ${ }^{213}$.

El Estado en el planteamiento de Locke tiene como finalidad proteger la propiedad privada. Los hombres acordaron constituirse en cuerpo político para defender de una manera más eficaz y segura sus propiedades, este es el origen fundacional, y fin último, del Estado. Pero el comercio y el dinero habrían surgido antes que la sociedad civil. Según comenta Crawford Brough Macpherson acerca del pensamiento político de Locke, <<puede suponerse que los hombres tienen una economía comercial con total

\footnotetext{
${ }^{210}$ Cfr. John Locke, Segundo Tratado sobre el gobierno civil (Madrid: Biblioteca Nueva, 1999), 67.

${ }^{211}$ Cfr. Locke, ob. cit., 72.

${ }^{212}$ Cfr. Locke, ob. cit., 97.

${ }^{213}$ Cfr. Locke, ob. cit., 119.
} 
independencia de que tengan o no una sociedad civil $>{ }^{214}$. Siguiendo la pista de la exposición de Macpherson sobre Locke, hemos de indicar que la estructura económica en las relaciones humanas goza de primacía sobre el Estado, de forma que la sociedad civil es un consenso posterior al primer consenso que mantuvieron los hombres, el de aceptar los contratos comerciales y otorgarle valor al dinero ${ }^{215}$. A este respecto, Álvaro Pezoa pone de relieve que la preferencia cronológica del mercado en relación con el Estado presupuesta por el filósofo británico conlleva también una primacía ontológica. Si lo económico es anterior a lo político, quiere decir esto que el espacio en el que tienen lugar las actividades económicas vertebra la estructura sobre la que la sociedad civil asentará unas leyes y un gobierno. Entiende Pezoa que en el momento en que la propiedad privada pasó a ser un asunto de dominio público, se formó el Estado civil, pues en el estado de naturaleza la propiedad es una cuestión privada. Según Pezoa, lo político en Locke deriva de la preocupación pública por la defensa de la propiedad privada, una preocupación que surge a partir de los intereses privados de cada individuo, por lo que lo político en términos conceptuales estaría sujeto a la dimensión económica $^{216}$.

\subsubsection{EL PODER DE LA LEY NATURAL}

De acuerdo con las interpretaciones de Macpherson y Pezoa sobre la filosofía política de Locke, conviene soslayar la idea de que para el autor británico la sociedad política y el Estado civil se forman sobre una estructura ya determinada con anterioridad, el mercado, en el que se ven involucrados todos los seres humanos en cuanto que poseen un cuerpo con el que trabajar para producir depósitos de valor susceptibles de ser intercambiados. Las leyes que rigen el funcionamiento del mercado van a ser la guía de la actividad política, de tal forma que la brújula del gobierno en la dirección del cuerpo social va a ser el mercado. Por esta razón, las acciones gubernamentales no deben incurrir en prácticas que obliteren los engranajes de la mecánica del mercado y los canales materiales mediante los que el hombre expresa su derecho de propiedad y su libertad para intercambiar los frutos de su trabajo como considere oportuno. El cuerpo estatal, al igual que el cuerpo natural, está sometido a

${ }^{214}$ C. B. Macpherson, La teoría política del individualismo posesivo (Barcelona: Editorial Fontanella, 1970), 182.

${ }^{215}$ Cfr. Macpherson, ob. cit., 182.

216 Álvaro Pezoa, Política y economía en el pensamiento de John Locke (Pamplona: Ediciones Universidad de Navarra, 1997), 219-231. 
unas leyes naturales que no debe pretender quebrantar, como, por ejemplo, desvirtuar las monedas de plata y esperar efectos positivos para el comercio, un acto que sería tan osado como arrojarse desde lo alto de una montaña con la esperanza de que la fuerza de gravedad no provoque la caída. Al igual que existen leyes que rigen los movimientos de los objetos físicos, también, en el ámbito del comercio, hay unas leyes que regulan el valor de las cosas en el orden de las transacciones.

El hombre, en su dimensión corporal, extrae propiedades de la naturaleza a partir del trabajo como un derecho que tiene de suyo, merced a la ley natural. La ley natural es indisociable del ser humano, propiamente, marca las tendencias humanas que han de caracterizar a cada individuo. El comercio es parte de ese despliegue de la ley natural en las actividades humanas. La estructura ontológica del mercado es fruto de la naturaleza e igualmente sus movimientos responden a leyes ineluctables e ineludibles para los hombres. La formación del Estado viene a salvaguardar aquellos derechos naturales que en el estado de naturaleza comenzaban a peligrar, especialmente el de propiedad privada, debido al aumento de la población y al subsecuente incremento del valor de la tierra. Recordemos cómo en Hobbes la formación del Estado también es del interés de cada individuo, aunque en este caso su cometido principal es mantener la paz e integridad individual, no exactamente solo en vistas a proteger la propiedad. El cuerpo político hobbesiano hace patente una anatomía del poder pues el Estado se erige como un cuerpo político que recoge el derecho de cohibir y coaccionar a los individuos para preservar la paz, solo la guerra puede disolver la sociedad civil. Sin embargo, en Locke el cuerpo político no forma una anatomía del poder ya que los derechos y libertades que el Estado va a proteger no se restringen ni determinan por la fuerza del cuerpo Estatal. Para Locke el poder del Estado ha de estar limitado por la ley natural, así, entonces, el poder Estatal no se determina solo por la potencia de su complexo corpóreo, sino por una legalidad inmaterial que no viene reducida a la potencialidad de los cuerpos naturales y políticos. La ley natural lockeana es externa a las posibilidades perceptibles y deseos de los hombres, además, es la verdadera regidora de la vida de todos los individuos y seres.

Desde sus inicios el pensamiento lockeano tuvo presente el tema de la ley natural, cuya noción se advertía como un principio fundamental en el desarrollo de sus teorías, análisis y concepciones, ya fuera en el área moral, epistemológica, económica o política. Las lecciones de 1663 de Locke en Oxford como Censor de Filosofía Moral versaban, 
precisamente, sobre el tema de la ley natural ${ }^{217}$. Resulta conveniente añadir, sin embargo, que el primer Locke mantenía unas inclinaciones políticas y religiosas que no se aproximaban a sus obras posteriores; Pezoa afirma que el joven Locke tendía a simpatizar con la monarquía absoluta, de tal modo que cuando Carlos II accedió al trono que años antes había perdido su padre, Locke se posicionó del lado de quienes sentían alborozo ante este suceso, por consiguiente, cabe matizar que las posiciones políticas de aquel joven pensador se aproximaban más al autoritarismo ${ }^{218}$. En concreto, siguiendo las indicaciones de Bobbio en este caso, es el Ensayo de la tolerancia la obra <<que marca la transición del autoritarismo juvenil al liberalismo de la madurez $>>219$ del célebre filósofo. Aunque Locke fue adquiriendo posturas que abogaban por la tolerancia y las limitaciones de las autoridades políticas, el concepto de ley natural que manifestó inicialmente continuó vigente en su pensamiento, siempre y cuando se ponga de relieve la idea de la ley natural como principio que determina el funcionamiento de la naturaleza y de las relaciones humanas.

En las lecciones de 1663 Locke dice que la ley natural existe por decreto divino, es decir, que una voluntad externa a la voluntad humana y de carácter suprasensible ha sido la responsable de crear esta ley. La ley natural prescribe cómo deben actuar los hombres, de modo que obliga y restringe ${ }^{220}$. Matiza Locke que esta ley no es ni puede ser construida por la razón albergada en cada uno de los hombres, la razón no es hacedora, sino que investiga las leyes naturales ${ }^{221}$. Niega así el autor cualquier tipo de innatismo en la mente de los hombres, por lo que el pensamiento lockeano supone la presencia de una instancia de poder externa al cuerpo humano y a la razón, no es esta una figuración de las relaciones cuerpo-poder calcada del cartesianismo, pero sí cabe reconocer que en ambos filósofos hay principios invisibles e inmateriales que determinan las acciones humanas desde el exterior de la corporalidad. En Descartes la razón gobierna al cuerpo por sí misma, en Locke el dominio corporal se ajusta a los decretos de la ley natural.

\footnotetext{
${ }^{217}$ Cfr. Victoriano Martín, "Estudio preliminar"; en Escritos monetarios, John Locke (Madrid: Pirámide, 1999), 13.

${ }^{218}$ Cfr. Álvaro Pezoa, Política y economía en el pensamiento de John Locke (Pamplona: Ediciones Universidad de Navarra, 1997), 17 y 20.

${ }^{219}$ Norberto Bobbio, Locke y el derecho natural (Valencia: Tirant Humanidades, 2017), 153.

${ }^{220}$ Cfr. John Locke, Ensayos sobre la ley natural (Madrid: Universidad Complutense de Madrid, 1998), 84.

${ }^{221}$ Cfr. Locke, ob. cit., 83.
} 
Para el filósofo británico la ley natural obliga a los hombres, ya sea de forma directa o indirecta. Los imperativos de la legislación y la política se hallan dentro de la forma indirecta: <<todo aquel poder que el resto de los legisladores ejercen sobre otros, tanto el derecho a legislar como el derecho a imponer una obligación para que se obedezca, lo toman prestado solo de Dios, y estamos obligados a obedecerles porque Dios así lo quiere y así lo ordena $>>^{222}$. En Locke la ley natural se inscribe dentro de todos los órdenes de la realidad con arreglo a su procedencia divina. En el arte de la legislación y del gobierno, todas las imposiciones que se articulan en forma de leyes positivas y acciones políticas tienen que responder, de forma indirecta, a los decretos que impone la ley natural, los cuales pueden ser dilucidados gracias a la investigación que los humanos hacen de ellos a la luz de su capacidad racional. La fuerza de obligación que la ley natural arroja sobre los hombres es un tipo de poder que se justifica por la presencia de un ser sobrenatural, suprasensible y omnipotente como es Dios, <<dado que debemos nuestro cuerpo, alma y vida [...] a Él y solo a Él, está bien que vivamos con el precepto de $\mathrm{Su}$ voluntad $>223$. Esta idea de que Dios es el creador de las leyes que rigen la vida y las relaciones humanas la hace patente Locke en varios pasajes del Segundo tratado sobre el gobierno, en uno de ellos se puede advertir cómo el trabajo proviene de uno de estos designios divinos:

Al entregar Dios el mundo en común, a todo el género humano, le ordenó también que trabajase, y al encontrarse desprovisto de todo lo obligaba a ello. Dios y su razón mandaban que se adueñase de la tierra, es decir, que la pusiese en condiciones de ser útil para la vida, agregándole algo que fuese suyo: el trabajo.224

Vemos de qué manera Locke justifica el trabajo como una transfiguración de la naturaleza por medio del que los hombres se sobreponen a la desnudez con que Dios los dejó en el mundo. Ya se dio buena cuenta de la importancia que cobra el concepto de trabajo en el pensamiento del filósofo de Wrington, ahora bien, también conviene dar cuenta de cómo sus concepciones vienen respaldadas por un plano teológico desde el que se invoca la ley natural, plano invisible e incorpóreo. Tal es así que en la filosofía lockeana la ley natural se origina en un estrato teológico, pues es de la voluntad de un ser superior de donde procede; tras ello, la ley natural se desarrolla en un estrato

\footnotetext{
${ }^{222}$ Locke, ob. cit., 137.

${ }^{223}$ Locke, ob. cit., 138.

${ }^{224}$ John Locke, Segundo Tratado sobre el gobierno civil (Madrid: Biblioteca Nueva, 1999), 64.
} 
económico, donde opera de acuerdo a la obligación del trabajo y a la nómica de las relaciones de apropiación e intercambio de propiedades; y desemboca en un estrato social, en el que el Estado arbitra las relaciones entre los individuos según la legitimidad que le confirió la ley natural, pues los consensos humanos se dan en vistas a proteger de una forma eficaz y completa sus propiedades, aquellas que surgen gracias al esfuerzo del trabajo. Vemos cómo la ley natural se desplaza en los distintos estratos de reflexión por los que pasa el pensamiento de Locke.

Con ello, el sistema de dominación sobre el cuerpo en el pensar lockeano se proyecta en el estrato económico. La actividad del trabajo requiere de un cuerpo que sea poseído previamente por el individuo para llevar a cabo ese agregado de valor a la naturaleza. El trabajo es fuerza productiva y, en la medida en que supone un esfuerzo, le otorga un valor adicional a la cosa producida. Este valor adicional quedará subyugado a las leyes del mercado, que responden a la ley natural y, en consecuencia, a la voluntad divina. La caracterización que hace el filósofo de Wrington de la corporalidad estará muy presente en la tradición económico-liberal, en la que el cuerpo queda reducido a la categoría de factor de producción. Las leyes del mercado no pueden ser quebrantadas por los cuerpos políticos, sino que, por el contrario, deben seguir sus determinaciones. El origen y fin de los cuerpos políticos que los hombres convienen establecer persiguen la protección de una noción económica como es la propiedad, pero que asciende al ámbito público para hacerse también un asunto político. Asimismo, el cuerpo natural, en cuanto que agente material de las actividades productiva y, en consecuencia, potencia productiva y causa eficiente de todo depósito de valor, queda aherrojado por las leyes que regulan el mercado; de la misma manera, este aherrojamiento análogamente se hace patente en los cuerpos políticos.

Por tanto, y de acuerdo con las teorías de Locke, el cuerpo político no está pensado para oponer su fuerza y resistencia al cuerpo natural sino, más bien, para reforzar y afianzar la extensión que procede de su fuerza productiva, el cuerpo político solo empleará su fuerza para proteger la propiedad, de acuerdo con la vigencia, propagación y designación que la ley natural tiene en la economía y en la política. Dentro del estrato económico el cuerpo produce el objeto de su propiedad, en el estrato político, posterior y dependiente del anterior, el cuerpo político ha de emplear su fuerza para intervenir en la vida pública únicamente para defender el interés individual por el que los miembros de la sociedad le cedieron sus derechos: la propiedad. La articulación del cuerpo natural 
y el cuerpo político en el espacio de mercado y en el posterior espacio público-político responde al poder de la ley natural, ley que gobierna a los hombres desde un plano invisible e incorporal.

El espacio del mercado dentro de los márgenes del mundo moderno, de la Tierra esférica, potenció las expectativas de comercio y explotación de los territorios del mundo del hombre. Igual que el heliocentrismo unificaba las leyes del mundo sublunar y el supralunar, planteando un universo movido por una misma legalidad natural, en el saber económico se empezaba a experimentar una unidad de los principios por los que se rigen la producción y el intercambio de recursos y productos. El cuerpo humano, en cuanto fuerza productiva, queda vinculado a esa nómica que rige el mercado. Dentro de los límites de un mundo cuya circularidad, sin embargo, le concedía a la explotación y al intercambio de cosas unas posibilidades que tendían al infinito, al estar el mercado funcionando sobre un territorio abarcable y circundante, en el que los cuerpos humanos actúan movidos por las motivaciones subyacentes a la avidez de enriquecimiento, a su vez, contribuían a poner en circulación aquellos objetos y seres que manipulan los cuerpos humanos mediante la actividad transformadora del trabajo. El poder que rige sobre los cuerpos naturales, los cuerpos políticos y los cuerpos producidos mediante el trabajo, se corresponde con la ley natural, que atraviesa dos estratos fundamentales de las relaciones humanas: la economía y la política. 


\title{
SEGUNDA PARTE: LA CORPORALIDAD
}

\author{
EN LA NATURALIZACIÓN Y
}

SECULARIZACIÓN DIECIOCHESCAS DE

\section{LOS ESPACIOS POLÍTICO Y}

\author{
ECONÓMICO
}




\section{SECCIÓN I. LOS MECANISMOS CORPORALES EN LA}

\section{INDAGACIÓN DE LA NATURALEZA HUMANA}

\subsubsection{EL CUERPO-MÁQUINA}

En 1764 aparecía en Lancashire (Inglaterra) una máquina hilandera que reflejaba el inicio de la Primera Revolución Industrial. La llamada Spinning-Jenny era un artefacto que funcionaba mediante una rueda que al girarla ponía en funcionamiento ocho carretes de hilo, tejiendo con un rendimiento nunca antes visto en la industria textil. La Spinning-Jenny ${ }^{225}$ generaba un mayor nivel de productividad y reducía la cantidad de esfuerzo, lo que trajo consigo que la máquina se convirtiera en un bien imprescindible para el desarrollo y prosperidad económica de las sociedades. Pero la Spinning-Jenny no es más que el resultado técnico de un proceso que estaba cambiando la forma de pensar el mundo: el hecho de que esta nueva técnica de hilar surgiera tras la primera mitad del siglo XVIII, y de que la mecanización de actividades tan fundamentales como el trabajo resultara un factor tan inseparable de los seres humanos, indica que la imagen de la máquina proyectaba una mirada sistemática sobre los fenómenos naturales y los organismos vivos, incluidos también los cuerpos humanos. Del mismo modo, determinados planteamientos filosóficos habían instalado una concepción mecanicista y materialista de la naturaleza y la existencia humana.

Ya Descartes consideró al cuerpo humano como un autómata, pero un autómata que requería forzosamente de la presencia del alma para ser dirigido y controlado ${ }^{226}$; si bien, la imagen mecanicista del cuerpo se extendió firmemente al siglo XVIII, en este momento histórico una de las polémicas filosóficas más candentes versaba sobre la naturaleza del alma. Se discutía sobre si solo el cuerpo es el causante de todos los pensamientos, sentimientos, deseos, etc., o si hay elementos no corporales que intervienen en la vida humana de forma definitiva. ¿Realmente necesita la máquinacuerpo de un alma para moverse, acaso no le basta al individuo humano con sus

\footnotetext{
225 En el portal digital de la empresa de diseño "Chulavista", dedicado a la exposición de artículos industriales, tecnológicos y mercantiles, se aprecian dos representaciones de la Spinning-Jenny, una es un grabado de la época en la que una mujer aparece moviendo la manivela con la que se ponía en funcionamiento la máquina y en la otra aparece una fotografía en blanco y negro de la máquina de tejer. Ver en: http://chulavista.es/spinning-jenny/ [consultado el 9/10/2016]. También puede apreciarse el funcionamiento de esta máquina tejedora en el siguiente vídeo de "Discovery Channel": https://www.youtube.com/watch?v=gM6T2mb-C6M [consultado el 10/10/2016].

${ }^{226}$ Cfr. René Descartes, Obras completas de Renato Descartes (París: Casa editorial Garnier hermanos, 1921-1938), 163.
} 
engranajes naturales para dirigirse en la vida así como sucede en el caso de los animales? ¿Procede el entendimiento de los hombres de sus mecanismos cerebrales o, por el contrario, hay un plano incorpóreo, sobrenatural e invisible moviendo de forma racional a los seres humanos?

Cuando Julien-Offray de La Mettrie escribe Recapitulación de los sistemas, revisa, entre otros, el sistema filosófico de Descartes. El autor elogia la advertencia cartesiana acerca de que la esencia de la materia se corresponde con la extensión y que la motricidad de esta es propiedad intrínseca de toda sustancia corpórea, pero, por otro lado, se opone completamente a su concepción del alma ${ }^{227}$. Según La Mettrie el filósofo de La Flèche no encontró el modo de justificar cómo el alma, a la que considera inextensa, pudiera entrar en contacto con sustancias extensas como el cuerpo humano; le reprocha no haber considerado que $<<$ lo que no tiene extensión, no puede actuar sobre lo que la tiene >> ${ }^{228}$. Para La Mettrie el alma no se halla en una dimensión distinta de la corporalidad, sino que, más bien, el término "alma" se corresponde con las actividades fisiológicas y cerebrales del cuerpo ${ }^{229}$. En El Hombre Maquina el filósofo materialista de Caen defiende un monismo corporalista al preconizar la materialidad del alma; el alma lamettrieana no levita sobre el cuerpo del individuo desde un plano extracorpóreo, sino que está incluida en la estructura anatómico-material humana. De este modo, cuando el alma se ve afectada por pasiones e ideas, éstas tienen su influencia en el cuerpo, así como, también, las enfermedades corporales afectan al alma por medio de la imaginación ${ }^{230}$.

Como médico y anatomista, La Mettrie se encarga de refutar cualquier pretensión de justificar la existencia de sustancias diferentes a lo corpóreo. El alma, entonces, no ejerce un control completo sobre todas las partes corporales; de modo que no hay

nada tan limitado como el imperio del alma sobre el cuerpo, y nada más extendido que el imperio del cuerpo sobre el alma. No solo ignora el alma los músculos que le obedecen y cuál es su poder voluntario sobre los órganos vitales, sino que jamás ejerce poder arbitrario alguno sobre estos mismos órganos. ¿Qué digo! Ni siquiera sabe si la voluntad es la causa eficiente de las acciones musculosas, o simplemente una causa ocasional,

\footnotetext{
${ }^{227}$ Cfr. Julien-Offray de La Mettrie, Obra filosófica (Madrid: Editora Nacional, 1983), 174.

${ }^{228}$ La Mettrie, ob. cit., 175.

${ }^{229}$ La Mettrie, ob. cit., 90.

${ }^{230}$ Cfr. La Mettrie, ob. cit., 126.
} 
puesta en juego por ciertas disposiciones internas del cerebro, que actúan sobre la voluntad, la mueven secretamente, y la determinan de cualquier manera. ${ }^{231}$

En El hombre máquina es posible apreciar de qué manera el autor vincula los aspectos que tienen que ver con la psicología humana con determinados movimientos dados por el funcionamiento de la máquina-cuerpo de cada individuo, puesto que $<<$ pensamos e incluso somos personas honradas, al igual que somos alegres o valientes; todo depende de la manera en que está montada nuestra máquina > ${ }^{232}$. Esta relación que guardan los caracteres personales del sujeto con su máquina corporal o cuerpo mecánico haría que la condición humana, en términos tanto físicos como psíquicos, halle similitudes indelebles con la naturaleza animal. El pensador francés se pregunta $<$ ¿Qué era el hombre antes de la invención de las palabras y del conocimiento de las lenguas?>>, a lo que responde que el hombre en su origen no era diferente a otros animales, con el inconveniente añadido de contar con un instinto más débil que el de otras especies $^{233}$.

El pensamiento de La Mettrie no contiene ningún sesgo antropocéntrico, su idea es que los hombres no son tan distintos de los animales, incluso, en el terreno de la moralidad los hombres no son superiores a estos. La finalidad de todo organismo vivo es la felicidad, así sucede tanto en los animales como en los hombres, dado que la hechura de ambos procede de una misma madre: la naturaleza.

La naturaleza nos ha creado a todos únicamente para ser felices, sí, a todos, desde el gusano que se arrastra hasta el águila que se pierde en la nube. Por este motivo, ha dado a todos los animales alguna porción de la ley natural, porción más o menos exquisita, según admiten los órganos bien condicionados de cada animal. ${ }^{234}$

La Mettrie entiende que la ley natural se halla fuertemente arraigada a la corporalidad, de manera que su concepción de la ley natural dista bastante de la versión que proporcionaron algunos pensadores naturalistas, entre los que destaca especialmente Locke. Como vimos, Locke nunca hubiese vinculado la ley natural a los cuerpos o intereses particulares de los individuos. Así, entonces, la forma en que La Mettrie concibe y describe la ley natural sigue una línea diferente en tanto en cuanto la corporaliza y adapta a la finalidad de los organismos vivos, que no es otra cosa más que

\footnotetext{
${ }^{231}$ La Mettrie, ob. cit., 136.

${ }^{232}$ La Mettrie, ob. cit., 213.

${ }^{233}$ La Mettrie, ob. cit., 219.

${ }^{234}$ La Mettrie, ob. cit., 230-231.
} 
conseguir placer para ser felices en la vida. Si bien se puede decir que La Mattrie es un naturalista, no puede ser encajado dentro de un naturalismo en el que se hace admisible la presencia de una nómica incorporal e invisible tras los cuerpos, sino que, más bien, se trata de un naturalismo radicado en los organismos corpóreos, pues es en los cuerpos y en su tendencia a lograr la felicidad donde opera y se demuestra la existencia de la ley natural. Este es un naturalismo de corte materialista-corporalista. Recuérdese cómo en Locke la ley natural no era exactamente un principio deducible o extraíble de los cuerpos mismos, cierto que la experiencia podía arrojar cierta certeza sobre la presencia y existencia de la ley natural, pero la causa de esta legalidad se remonta a un estrato teológico o, lo que es lo mismo, a la voluntad de Dios. En la filosofía de La Mettrie, sin embargo, la ley natural tiene su raigambre en el cuerpo y su aprendizaje procede de <<un sentimiento que nos enseña lo que no debemos hacer, porque no quisiéramos que se nos hiciera a nosotros $>{ }^{235}$, fundándose sus principios en el intercambio de sensaciones entre los organismos vivos y no en voluntades suprasensibles o exteriores a la realidad corpórea.

El concepto de ley natural de La Mettrie no se ajusta a ningún tipo de consideración teológica, es más, el propio autor se opone a las creencias de los teólogos. Consecuentemente, la ley natural no procedería de ningún ser superior o entidad divina, sino que nacería con los organismos vivos, cuyo fin es la felicidad. Los organismos de todos los individuos, ya sean humanos o animales, son susceptibles de sentir placer y dolor, por tanto, la felicidad es posible en todos ellos sin excepción. El tipo de felicidad que promueve La Mettrie tiene que ver con la disposición orgánica del cuerpo, donde también está implicado el cerebro con la imaginación. Como se puso de manifiesto anteriormente, para el filósofo francés la imaginación es una parte del cerebro que desempeña una función muy destacada en los seres humanos, ya que les permite organizarse, aprender, crecer intelectualmente y relacionar signos y palabras con los objetos físicos. De esta forma la ley natural iría asociada a la corporalidad, es decir, a la sensación del placer que recibe el cerebro por medio de los órganos sensitivos y el aporte de la imaginación:

Ya veis que la ley natural no es más que un sentimiento íntimo, el cual pertenece también a la imaginación como todos los demás, entre los que se incluye el pensamiento. Por

${ }^{235}$ La Mettrie, ob. cit., 231. 
consiguiente, no supone evidentemente ni educación, ni revelación, ni legislador, a menos que no se la quiera confundir con las leyes civiles, al modo ridículo de los teólogos. ${ }^{236}$

En su Discurso sobre la felicidad La Mettrie apunta que, al igual que la medicina, en muchas ocasiones la filosofía se compone de palabras bellas pero carentes de significado. Afirma que los frutos de la medicina y de la filosofía se estiman solo cuando la primera cura y cuando la segunda significa algo. Los filósofos habrían condenado ciertas conductas vanidosas y egoístas de los hombres, aunque estas <<solo son leves defectos en la humanidad para quien lo examina todo como un físico $>237$. Asimismo el pensador francés sostiene con gran contundencia que su interés por los seres humanos se debe a que los considera máquinas, ya que de otro modo <<habría poco que estimar en la sociedad $>>238$. A la luz de estas consideraciones podría afirmarse que La Mettrie sitúa en la mecanicidad de los cuerpos humanos el fundamento para entender también en qué términos se producen las relaciones sociales y los juicios morales, es decir, que todas las relaciones humanas se encontrarían, consecuentemente, en el dominio que subyace a la lógica operativa de los cuerpos, en tanto en cuanto la corporalidad y la psicología se hallan en sincronía.

En la medida en que La Mettrie reflexiona a partir de elementos conceptuales determinados por aspectos corporales, emprende la tarea de fundamentar nociones como la de "ley natural" en el funcionamiento de las sensaciones y la imaginación de los individuos, sin introducir figuraciones que evoquen pensamientos acerca de entidades incorpóreas sin soporte empírico. Mediante este ejercicio de reflexión el filósofo francés está virando a la corporalidad como centro de creación de un sistema de pensamiento que reivindica entender al ser humano como cuerpo, es decir, que comprende al sujeto desde una ontología materialista, en tanto en cuanto reduce la existencia humana a lo corporal e identifica al alma con ciertas funciones del organismo inseparables del orden mecánico operante en toda la naturaleza. De este modo, la filosofía de La Mettrie sitúa en el cuerpo de los hombres la fuerza centrífuga desde la que investigar, visibilizar y explicar los caracteres que acompañan a toda la naturaleza humana, en sus acepciones ontológicas, epistemológicas, morales y políticas.

\footnotetext{
${ }^{236}$ La Mettrie, ob. cit., 231.

237 Julien Offray de La Mettrie, Discurso sobre la felicidad (Buenos Aires: El cuenco de plata, 2010), 170-171.

${ }^{238}$ La Mettrie, ob. cit., 172.
} 
Otro de los filósofos del XVIII que le concedieron al cuerpo una centralidad nuclear y sistemática en la elaboración de su pensamiento filosófico fue Paul Heinrich Dietrich Von Holbach, conocido comúnmente como el Barón D’Holbach, quien, al igual que La Mettrie, admite criterios de corte materialistas, mecanicistas y corporalistas. Los principios de la cosmovisión mecanicista y de la ontología materialista de Holbach atezan el terreno sobre el que se asienta su teoría moral y política; buena cuenta de ello ofrece su obra Sistema de la naturaleza.

Según el filósofo franco-alemán la religión apela a seres sobrenaturales e imaginarios para explicar la causa de los fenómenos de la naturaleza. Este procedimiento epistemológico avivó el fervor religioso entre los hombres e introdujo creencias y temores que obliteraron el conocimiento empírico y racional, de este modo, los filósofos y teólogos sostienen sus prédicas suponiendo que existen entidades incorpóreas que causan los fenómenos del mundo. Igualmente, la comprensión y el estudio del cuerpo humano se vieron afectados por las creencias religiosas. Pero, a este respecto, el autor afirmar que todos los cuerpos físicos son regidos por una misma nómica común a todos ellos, sin la posibilidad de que existan órdenes extracorpóreos. Consecuentemente, también la vida humana está regida por un ordenamiento corporal:

Por maravillosos, ocultos o complicados que puedan parecer o sean los modos de actuar, tanto visibles como interiores, de la máquina humana, si los examinamos de cerca veremos que todos sus movimientos, sus diferentes estados y sus revoluciones están regulados constantemente por las mismas leyes que la Naturaleza prescribe a todos los seres que produce, desarrolla, enriquece con facultades, hace crecer, conserva durante algún tiempo y acaba por destruir o descomponer al hacerles cambiar de forma. ${ }^{239}$

El ordenamiento de los cuerpos físicos en el mundo viene determinado por las leyes naturales, cuyo origen se remonta al interior de los propios cuerpos. Así pues, el autor sostiene que de la observación de la naturaleza se puede extraer la evidencia de que la materia se mueve por su propio impulso ${ }^{240}$, y que no hay ninguna causa independiente o distinta de la materia que la hubiese puesto en movimiento ${ }^{241}$. Holbach considera que las leyes de la naturaleza mueven tanto los cuerpos físicos como los sentimientos morales. Todas las corporalidades de la naturaleza presentan distintos tipos de combinaciones y relaciones, ya que de $<<$ todos estos seres diversamente combinados en

\footnotetext{
${ }^{239}$ Barón D`Holbach, Sistema de la naturaleza (Madrid: Editora Nacional, 1982), 162.

${ }^{240}$ Cfr. D’Holbach, ob. cit., 131.

${ }^{241}$ Cfr. D’Holbach, ob. cit., 133.
} 
diferentes proporciones, resultan cuerpos, conjuntos físicos o morales $>>$, asimismo, tales relaciones, cuando se producen entre los seres humanos, forman los distintitos tipos de asociaciones e instituciones, de ahí que Holbach convenga en no <<separar las leyes de lo físico de las de lo moral $>{ }^{242}$.

Holbach reivindica el materialismo como una forma precisa y segura de conocer al hombre al entender que este sistema de pensamiento resuelve urgencias que se presentan entre sujetos y sociedades en cuanto que corporalidades. El prisma teológico desde el que la tradición filosófica ha intentado conocer al hombre sería, por tanto, insuficiente y defectuoso, pues tiende a crear prejuicios y conceptos incognoscibles que más que facilitar el ejercicio del conocimiento tienden a obstaculizarlo ${ }^{243}$. Todas las capacidades intelectuales y morales de los hombres proceden de su cuerpo, puesto que todo juicio se inicia con la sensibilidad ${ }^{244}$, de este modo, la corporalidad ocupa un punto central dentro del sistema de Holbach cuando se trata de investigar, entender y teorizar sobre las facultades intelectuales y morales de los individuos. Se detecta en el pensamiento de este autor cómo hay un desplazamiento del concepto de cuerpo desde la marginalidad en que tradicionalmente había estado hacia la centralidad de la reflexión filosófica; evidentemente, este desplazamiento influye en el desarrollo de las perspectivas morales y políticas de Holbach.

En el planteamiento moral de Holbach la corporalidad es el agente y el objeto de las acciones que se realizan en la vida humana. Todo juicio moral hunde sus raíces en la sensibilidad, por lo que la moralidad queda ineludible e indefectiblemente vinculada con el cuerpo, pues es en la corporalidad donde se localizan los órganos de los sentidos. De este modo, términos como "virtud" son concebidos sobre una base distinta de la tradición teológica. Para Holbach la virtud es la capacidad que tiene el individuo para producir sensaciones de placer a los demás, por lo que la virtud sería útil en la medida en que favorece la convivencia social, mientras que los vicios resultan desfavorables porque vituperan a los otros, por lo que obstaculizan a las asociaciones humanas ${ }^{245}$. La sensualidad se va a convertir en un criterio de peso a la hora de determinar qué es virtud y qué es vicio, en función del placer y el daño que las acciones humanas producen. Los engranajes naturales del cuerpo humano orientan la vida de los individuos y, por tanto,

\footnotetext{
${ }^{242}$ D'Holbach, ob. cit., 146.

${ }^{243}$ Cfr. D'Holbach, ob. cit., 193.

${ }^{244}$ Cfr. D'Holbach, ob. cit., 195.

${ }^{245}$ Cfr. D’Holbach, ob. cit., 199.
} 
el modo en que organizan sus asociaciones. La imagen conceptual de la máquina corporal se introduce en el entorno de la política.

\subsubsection{EXTIRPAR LA TEOLOGÍA}

Al fijar en lo corporal el núcleo de desarrollo de la política, el Barón D`Holbach está considerando que las leyes civiles se derivan de los mecanismos naturales que mueven a los individuos. Estos mecanismos naturales producen que los seres humanos tiendan a asegurarse tres beneficios esenciales para su interés: la libertad, la propiedad y la seguridad. La libertad la define Holbach como todas aquellas cosas que pueden hacer las personas para conseguir su felicidad, habiendo renunciado antes a parte de las posibilidades que por naturaleza poseen, con el fin de que el ejercicio de la libertad no perturbe la felicidad de los demás. La propiedad la define el autor como el goce de los frutos que da el trabajo; y la seguridad, como la garantía que tiene cada ciudadano de poder disfrutar de sí mismo y de sus bienes bajo el compromiso de no dañar a nadie con ello $^{246}$. Por otro lado, la justicia también debe asegurar una equidad entre los individuos, de tal manera que <<impide predominar a unos sobre otros por la desigualdad que la Naturaleza o el trabajo pueden haber introducido entre sus fuerza $>>247$, así que igualar a los individuos consiste en no atribuirle privilegios ni desventajas a nadie, sino en respetar las cualidades que la naturaleza le ha otorgado a cada cual, sin que por ello dejen de ponerse de manifiesto unas desigualdades ineluctables que la política no puede modificar.

El filósofo de Edesheim le atribuye a la religión cristiana la responsabilidad del proceso corrosivo de la política. Para que la ignorancia predominara entre las gentes del pueblo, las autoridades ocultaron la verdad sobre el funcionamiento de la naturaleza e inhabilitaron la experiencia sensible como fuente válida de conocimiento, de tal forma que los individuos perdieran el acceso al conocimiento sobre la mecánica del mundo y de las relaciones humanas, para gobernarlos como a niños ${ }^{248}$. También, los teólogos, filósofos y metafísicos se ocuparon, ya no solo de la inhabilitación cognoscitiva de los sentidos, sino también de imaginar y presuponer la existencia de un plano de realidad diferente al de la naturaleza, es decir, un espacio o dominio inmaterial e inaccesible para los sentidos. El resultado de aplicarle tal escisión teórica a la naturaleza coadyuvó a

\footnotetext{
${ }^{246}$ Cfr. D’Holbach, ob. cit., 205.

${ }^{247}$ D'Holbach, ob. cit., 205.

${ }^{248}$ Cfr. D’Holbach, ob. cit., 211.
} 
desvincular el alma de las leyes físicas, lo que implicó el desgarramiento del sujeto, al imponerle nómicas diferentes a las que regían su cuerpo ${ }^{249}$.

Holbach ofrece una descripción detallada acerca de las estrategias que emplea la religión para dominar a los individuos y al conjunto de la sociedad civil. La estrategia más eficaz para llevar a cabo esta dominación consiste en inocular la idea de un dios todopoderoso y de un mundo sobrenatural en la mente de los seres humanos. Esta operación persigue disociar las leyes físicas del alma, con el propósito de desligar las funciones corporales de las operaciones del espíritu y, de este modo, generar un quiasmo dentro del sujeto en el que lo intelectual y lo moral pertenecerían al dominio de lo sobrenatural, mientras que el cuerpo quedaría reducido a un mero objeto físico. Las autoridades religiosas definieron el alma de tal forma que el sujeto se vio <<impresionado por un agente inconcebible que se ha creído distinto de su cuerpo o de una Naturaleza diferente de la suya $>>{ }^{250}$. Holbach sostiene que todos estos conceptos no demostrados por la experiencia ni evidenciados por la mecánica natural fueron el producto de excesos reflexivos, de configuraciones imaginarias y de quimeras pensadas para constreñir a las personas.

El autor utiliza el término "invisible" para referirse a ese mundo quimérico o a esa divinidad imaginaria concebidos para ejercer un dominio sobre los seres humanos. Ante los males que surgen en la sociedad se utilizó la religión como paliativo del ser humano, pero la religión fue más bien la causa de estos males, en tanto en cuanto los teólogos se obstinaron en controlar las pasiones mediante la invención de historias fantásticas, imaginando seres sobrenaturales y espacios suprasensibles. Esta consideración de Holbach está describiendo un tipo de poder que no ejerce una presión directa sobre los cuerpos humanos, sino que utiliza la capacidad imaginativa de los sujetos para introducir en sus pensamientos ideas que contribuyen a reprimir impulsos corporales y a amortiguar la fuerza de las pasiones. Holbach está presentando la religión como un dispositivo psicológico instalado en las mentes de los individuos con el fin de que estos dirijan sus vidas y cuerpos de acuerdo a los intereses de sus autoridades, tal dispositivo porta unas ideas que van a formar parte del aparato conceptual del pensamiento de los sujetos, de modo que basta reproducir tales ideas para que estos pongan por sí mismos

\footnotetext{
${ }^{249}$ Cfr. D’Holbach, ob. cit., 334.

${ }^{250}$ D'Holbach, ob. cit., 337.
} 
en funcionamiento un mecanismo conceptual de presión sobre sus propios cuerpos. En palabras del autor:

se persuadió locamente que un dique ideal y metafísico, que fábulas espantosas, fantasmas alejados, bastaban para contener los deseos naturales y las inclinaciones impetuosas; se creyó que potencias invisibles serían más fuertes que todas las potencias visibles que invitan evidentemente a los mortales a cometer el mal. Se creyó haber ganado todo ocupando los espíritus con tenebrosas quimeras, vagos temores y una divinidad vengativa, y la política se persuadió locamente de que le interesaba someter a los pueblos ciegamente a los ministros de la divinidad. ${ }^{251}$

El Barón D’Holbach se opone a un sistema de dominación en el que se recurre a instancias invisibles e imaginarias para instalar en el pensamiento de las personas el prejuicio y la superstición, sin refrendar los principios morales, decisiones políticas y leyes jurídicas en cosas visibles, empíricamente evidentes y basadas en el funcionamiento de la realidad natural. Como se hizo patente anteriormente, el autor no desvincula el alma humana de su condición corpórea ni la moral de las leyes físicas, promoviendo con ello la naturalización del sujeto humano y del espacio político. Holbach piensa que el primer paso para recobrar un espacio político guiado por la experiencia de la naturaleza y la razón es desactivar el dominio de la teología, ya que la teología se impuso como centro dominante de saber en detrimento del conocimiento del mundo natural, de tal manera que la filosofía <<descuidó la naturaleza para ocuparse de dioses, espíritus, potencias invisibles, que no sirvieron sino para oscurecer y complicar todas las cuestiones $>>{ }^{252}$. Asimismo, la política también se vio afectada por este ingente dominio de la teología, lo que contribuyó a que los soberanos creyeran que sus derechos de gobierno provienen de una potencia divina y de un mundo invisible a los que ellos representan. Igualmente, la jurisprudencia quedó subsumida a los criterios teológicos, como el comercio y todas las actividades humanas, cuyo desarrollo natural era interceptado y obstruido por los arbitrios de los teólogos 253 .

Holbach localiza en los procedimientos de la teología un estilo de ejercer la autoridad que encuentra en la desactivación del conocimiento de la naturaleza su método más efectivo para ejercerse, por ende, la corporalidad humana queda opacada y eclipsada en beneficio de todos esos supuestos seres inmateriales e invisibles que la doblegan. La

\footnotetext{
${ }^{251}$ D'Holbach, ob. cit., 512.

${ }^{252}$ D'Holbach, ob. cit., 534.

${ }^{253}$ Cfr. D’Holbach, ob. cit., 535.
} 
creencia en la existencia de Dios no sería más que un precepto para que algunos hombres, ávidos de poder, gobiernen sobre otros en nombre de designios secretos procedentes de un Dios imaginario ${ }^{254}$. El rechazo por parte de Holbach a las imposiciones autoritarias de la teología suponía, por aquel entonces, tirar por tierra todo un sistema de dominación milenario muy arraigado a las gentes del momento, aunque, ciertamente, empezaba a dar muestras de debilidad y resquebrajamiento. El sistema filosófico, moral y político que propone Holbach, tal y como ha sido comentado, funda sus principios teóricos en el conocimiento de la naturaleza. En este modelo la práctica política debe orientar a los hombres hacia la felicidad, mediante los conocimientos extraídos de la naturaleza en general y de su complexión física en particular ${ }^{255}$.

Así, la política, que vela por el mantenimiento de las asociaciones humanas, deberá desenvolverse a partir de los engranajes motrices que operan en los cuerpos de los individuos y que son comunes a todos los hombres:

La política, instruida acerca de los verdaderos factores que pueden actuar sobre los espíritus de las naciones, reconocerá que no es necesario recurrir a unos móviles imaginarios mientras existan móviles reales para actuar sobre las voluntades de los ciudadanos y determinarlos a trabajar en el mantenimiento de la asociación; reconocerá que un móvil ficticio solo es apto para retrasar, o incluso entorpecer, el ejercicio de una máquina tan complicada como la sociedad. ${ }^{256}$

Con los ideales teológicos extirpados del individuo humano era posible no suponer entidades ni figuras de poder diferentes al cuerpo; el organismo humano, su composición mecánica, se revelaba como el eje desde el que articular todo orden moral y político. La capacidad económica de la máquina-cuerpo implicaba que la ética y los quehaceres legislativos atendieran a preocupaciones encuadradas en la realidad corporal de los individuos, como lo son las diferentes formas de sensaciones: pensar y medir cuáles son las acciones convenientes para lograr un estado saludable, la búsqueda de placeres y, al contrario, el problema de cómo neutralizar o minimizar las causas inconvenientes que provocan efectos nocivos para el cuerpo y la psique.

En estos aspectos ahondó la reflexión utilitarista de Jeremy Bentham, quien propiamente elaboró la doctrina utilitarista como un método con que enfocar y resolver

\footnotetext{
${ }^{254}$ Cfr. D’Holbach, ob. cit., 539.

${ }^{255}$ Cfr. D’Holbach, ob. cit., 590.

${ }^{256}$ D'Holbach, ob. cit., 598.
} 
cuestiones morales y abordar con rigor pragmático asuntos concernientes al arte de legislar.

Los fundamentos morales de los que Bentham parte prescinden de entidades y mundos suprasensibles para, en su lugar, partir de la experiencia humana. Con ello, el jurisconsulto inglés plantea su filosofía moral y política sin recurrir a los presupuestos y enunciados de la teología, sustituyéndolos por contenidos presenten en la experiencia. Consecuentemente, para Bentham son las sensaciones de dolor y placer las que constituyen la materia de toda teoría moral, así, al comienzo del primer capítulo de Los principios de la moral y la legislación el autor dice que la <<naturaleza ha puesto a la humanidad bajo el gobierno de dos amos soberanos: el dolor y el placer $>>{ }^{257}$, de modo que las acciones y relaciones humanas estarían determinadas por estas dos formas de la sensibilidad y del sentimiento. El dolor y el placer constituyen las sensaciones puntales sobre las que se cimienta la ciencia moral, y precisamente al considerar que ambos elementos son medibles, la moral y la legislación pueden desarrollarse como ciencias, porque su objeto de estudio es mensurable y empírico. El pensador británico enumera una serie de criterios para medir y determinar el valor de los dolores y los placeres: intensidad, duración, certeza o incerteza, proximidad o distancia, fecundidad, pureza, alcance $^{258}$. Tales criterios suponen que los placeres y dolores contienen un valor estimable a partir de unos instrumentos con los que el moralista y el legislador deben contar para ser exactos en sus propuestas y acciones, convirtiéndose en científicos del espíritu, el cuerpo y la sociedad. La moral y la legislación van a quedar, por ende, integradas en el ámbito natural. El método para calcular los efectos de las acciones individuales y de las acciones gubernamentales es el principio de utilidad, las magnitudes con las que va a trabajar este "instrumento de medición moral" son, por tanto, el placer y el dolor.

Desde una visión atea, secular y empirista, Bentham, ya en su primera obra, titulada Un fragmento sobre el gobierno, da muestras de su desconfianza hacia configuraciones conceptuales no fundadas en la experiencia, inconmensurables y carentes de demostraciones empíricas. El pensador británico observa que si las máximas que rigen un Estado se remiten a términos tan poco precisos y ambiguos como son el de "ley

\footnotetext{
${ }^{257}$ Jeremy Bentham, Los principios de la moral y la legislación (Buenos Aires: Editorial Claridad, 2008), 11.

${ }^{258}$ Cfr. Jeremy Bentham, ob. cit., 35-36.
} 
divina" o el de "ley natural", cada ciudadano actuará con arreglo a su entendimiento particular sobre estos principios. Como los gobiernos no pueden admitir tal arbitrariedad, considera Bentham que debe haber un principio que guíe la teoría y la práctica del gobierno: el principio de utilidad $^{259}$.

Para el jurisconsulto británico todo sistema de ética y legislación tiene que orbitar en torno a la utilidad, tal como asevera en Los principios de la moral y la legislación:

Admitiendo que otro principio distinto del principio de utilidad es un principio correcto, un principio que es bueno que el hombre adopte; admitiendo (lo que no es verdad) que la palabra bueno puede tener sentido sin referencia a la utilidad, que diga si hay algo como un motivo cuyos mandatos el hombre debe obedecer; si lo hay, que diga de qué motivo se trata y cómo se lo distingue de aquellos que ponen en vigor el principio de utilidad; si no, que diga, por último, para qué puede servir ese otro principio. ${ }^{260}$

Cuando Bentham distingue entre las sanciones con que los legisladores deben contar para hacer o proponer leyes, encuentra que hay cuatro tipos: físicas, políticas, morales y religiosas. La diferencia entre las sanciones se remonta a la procedencia del dolor y del placer. Las sanciones físicas vienen causadas por procesos naturales $\mathrm{y}$, por tanto, su cauce es estrictamente material. Las sanciones políticas dependen de las decisiones de legisladores, censores y gobernantes, mientras que las sanciones morales integran a toda la comunidad. Estas tres sanciones son susceptibles de experiencia en la medida en que el dolor o el placer tienen cauces materiales de acción y expresión, sin embargo, la sanción religiosa apunta a una fuerza invisible no manifiesta físicamente ${ }^{261}$. Para Bentham, la sanción física es el origen de las otras tres sanciones, inclusive de la religiosa, ya que $<<$ los poderes de la naturaleza pueden actuar por sí mismos; pero ni el magistrado, ni los hombres en general pueden actuar, ni se supone que en el caso en cuestión sea Dios quien actúa, excepto por los poderes de la naturaleza >>262; la razón que arguye el jurisconsulto para subordinar las sanciones religiosas a las sanciones físicas es que la religión está implicada en la vida tanto a nivel político como moral. Observamos cómo la religión no recibe ningún tipo de trato especial ni tiene reservado ningún lugar privilegiado, también observamos de qué manera los juicios morales son

\footnotetext{
${ }^{259}$ Cfr. Jeremy Bentham, Un fragmento sobre el gobierno (Madrid: Tecnos, 2010), 159-160.

${ }^{260}$ Jeremy Bentham, Los principios de la moral y la legislación (Buenos Aires: Editorial Claridad, 2008), 16.

${ }^{261}$ Cfr. Bentham, ob. cit., 32.

${ }^{262}$ Bentham, ob. cit., 34.
} 
atraídos al dominio físico, único lugar donde se efectúan las sensaciones y se articula el balance entre los placeres y dolores.

\subsubsection{LA APORÍA DEL "CUERPO LIBERADO"}

En rasgos generales, es posible detectar en los filósofos materialistas del siglo XVIII una reivindicación de la corporalidad como concepto despojado de toda carga teórica fundada en principios teológicos, metafísicos y rigoristas. Esta reivindicación se erigía sobre el propósito de formular un conocimiento de la naturaleza aséptico, en el que estaría incluido el hombre en cuanto ser corporal y, por ende, natural. El materialismo de estos autores se circunscribía al entorno de vertientes de pensamiento en las que se promovía la emancipación del cuerpo humano con respecto a las autoridades tradicionales. A menudo, algunos autores de esta índole se fijaron en asuntos que apelaban al contacto corporal y que sistemáticamente acudían a las vicisitudes del cuerpo para realizar teorizaciones morales y observaciones que atañen a las relaciones humanas. Los seres humanos precisan de sus cuerpos para relacionarse entre sí, sobre todo, cuando se trata de personas que estrechan vínculos afectivos, como por ejemplo sucede en el ámbito conyugal y familiar.

David Hume fue uno de los pensadores que dio cuenta de sus ideas en torno al tema de las relaciones matrimoniales. El filósofo británico prestó atención a los juegos de dominación que se producen dentro de los matrimonios, porque considera que en este contexto hay una obvia tensión entre los cónyuges por mandar. Para Hume las mujeres tienden a buscar la forma de mandar dentro del matrimonio por culpa de los abusos de autoridad que sus maridos muchas veces cometen contra ellas, puesto que las mujeres no encontrarían especialmente relevante disputar la autoridad conyugal si los varones no fueran abusivos. Por este mismo motivo el pensador escocés dice desear que <<no hubiese pretensiones de autoridad por ninguna de las dos partes, sino que todo fuera llevado con perfecta equidad, como si se tratara de dos miembros iguales del mismo cuerpo $>{ }^{263}$. Se aprecia cómo Hume utiliza una metáfora corporalista para explicar su idea de la reunión de una mujer y un hombre en matrimonio, entendida por el autor como una simbiosis de dos partes complementarias e iguales. Así pues, la unión matrimonial sería interpretada como la formación de un tipo de corporalidad duplicada, resultado de una unión afectiva entre dos individuos que deben alcanzar un estado de

${ }^{263}$ David Hume, Del amor y del matrimonio (Madrid: Alianza Editorial, 2006), 114. 
equilibrio en sus relaciones sin que se produzcan asimetrías conducentes a insidias y rivalidades.

Pero no todas las metáforas corporalistas ni la imagen "dulce" de los cuerpos presentada por Hume en las relaciones amorosas siguen esos mismos derroteros, de hecho, la sexualidad inscrita a las corporalidades y la condición libidinal humana instaba a pensar un enfrascamiento perpetuo por el poder, sin que el atajo escogido por Hume condujera a la resolución de los conflictos y sin que todo enfrentamiento "por mandar" quedara reducido a solamente las relaciones conyugales, sino a todo un amplio espectro de situaciones en que interviene la sexualidad.

Uno de los escritores más representativos, radicales, polémicos y provocativos en el clima reivindicativo de la corporalidad es Donatien Alphonse François de Sade, más conocido como el Marqués de Sade. Sus escritos, en su mayoría comedias y diálogos, hacen gala de una imagen de la naturaleza humana asociada a la violencia y depravación sexual. En una de sus novelas más conocidas, Los infortunios de la virtud, describe con saña y descaro los abusos, flagelaciones y violaciones sufridos por una joven desgraciada que, convencida de seguir los mandatos de la moral cristiana, no encuentra paz y reposo sino más bien todo lo contrario, pues cada vez se ve involucrada en situaciones de mayor precariedad, indignidad y desolación. La joven infortunada, llamada Justine, por confiar en la bondad de las personas y por actuar siempre buscando la virtud, solo tiene peripecias fatales que la degradan y hostigan su integridad moral, aunque, pese a ello, persevera en la virtud como forma de vida.

Sade caracteriza a Justine como una eterna víctima, una mujer incapaz de desprenderse de esta condición debido a que no se entrega a los excesos y crímenes de la vida libertina. El cuerpo de Justine es categorizado como un objeto paciente de agresiones, abusos sexuales, flagelaciones y explotación, estos actos forman parte de esos infortunios por los que constantemente atraviesa la protagonista. Justine ejemplificaría cómo ni la civilización, ni el gobierno, ni la sociedad humana contribuyen a paliar en los hombres la agresividad y el disfrute ante el dolor ajeno. En uno de los pasajes de la obra, la protagonista cae en manos de un estafador llamado Dalville que la explota de la manera más cruel y brutal, desnudándola, golpeándola con un látigo y encadenándola a una rueda que le obliga a girar junto a otras dos mujeres, como si fueran bestias: 
Como cada golpe me arrancaba la piel y nunca había sentido tan vivos dolores, lancé agudos gritos, debatiéndome en mis cadenas; aquellas contorsiones y aquellos alaridos hicieron reír a los monstruos que me observaban, y tuve la cruel satisfacción de enterarme entonces de que si hay hombres que, guiados por la venganza o por indignas voluptuosidades, pueden divertirse con el dolor de los demás, hay unos seres tan bárbaramente constituidos como para degustar los mismos encantos sin otro motivo que la tiranía o la más atroz curiosidad. El hombre es, pues, naturalmente malo, y en todas las situaciones de la vida, los males de su semejante pueden convertirse en execrables placeres para él. ${ }^{264}$

El cuerpo de Justine se convierte en un objeto para sus abusadores, ella padece los excesos de aquellos que se regocijan en el desgarramiento, el dolor y el sopor de la corporalidad del otro. La literatura de Sade recurre a la imagen del cuerpo como objeto para acentuar la degeneración de los hombres, la corporalidad paciente de las víctimas pasa a ser blanco de todo tipo de excesos, a costa de convertir los cuerpos de las víctimas en objetos; pero, a su vez, el cuerpo del verdugo se revela en la literatura sadiana como una fuerza capaz de desacralizar cualquier dignidad. Los libertinos de Sade se introducen en una vorágine de animalidad en la que la dicotomía sujeto-objeto opera paralelamente a la relación verdugo-víctima. Los victimarios, que se corresponden con los libertinos, dan rienda suelta a sus impulsos sexuales e instintos primarios para justificar los daños causados contra los piadosos y virtuosos, quienes exponen su cuerpo como si fuera un simple objeto.

En Filosofía en el tocador Sade recurre a situaciones orgíacas para ambientar diálogos en torno a la dimensión genital de los personajes mientras mantienen relaciones sexuales conjuntas. Las ideas que transmiten los pasajes de esta obra caracterizan al ser humano como un animal desenfrenado en la satisfacción de su libido. El autor se propone en esta obra romper con los tabús sexuales impuestos por la tradición religiosa, por lo que sus personajes estilan una falta de pudor, una perversión y una voluptuosidad que no encuentran ninguna pauta de moderación y contención. Para Sade, la lubricidad es congénita a la naturaleza humana. En una de las conversaciones entre los personajes protagonistas, uno de ellos, Dolmancé, el más pervertido, le dice a Eugenia, una joven virgen que está siendo educada en la fornicación por invitación de Madame Saint-Ange, que la vergüenza es un sentimiento pusilánime que no le hace

\footnotetext{
${ }^{264}$ Marqués de Sade, Los infortunios de la virtud (Barcelona: Fontana, 2016), 98.
} 
justo homenaje a la naturaleza ${ }^{265}$. También, en uno de los discursos de "El caballero", un personaje que participa activamente en las orgías, se puede apreciar cómo este afirma que de haber estado entre los propósitos de la naturaleza que el hombre fuera púdico $<<$ seguramente no lo hubiese hecho nacer desnudo>> 266 . "El caballero", mediante las ideas que expresa en sus diálogos y discursos, representa la naturalización de la nueva República Francesa, cuyas leyes deberán ajustarse a las leyes naturales y cuyo quehacer político habrá de evitar disimular la violencia inherente a las relaciones humanas, que siguen la senda marcada por la naturaleza.

El cuerpo sadiano está enlazado a la naturaleza en su sentido más elemental, la desnudez y el carácter impúdico son características intrínsecas a la humanidad, de tal modo que ninguna persona puede renunciar a las tendencias e inclinaciones hacia las que nos conduce la corporalidad. Las pulsiones e instintos del cuerpo son irrenunciables para los humanos en la medida en que son parte de su constitución natural. En Sade el cuerpo es la punta de lanza desde la que se enfrentan las ataduras a las que el poder tradicional-religioso ha sumido a los seres humanos. Tanto hombres como mujeres deben liberar sus cuerpos de estas ataduras y deshacerse de esos prejuicios que les mantienen paralizados y que reprimen su natural tendencia a buscar el goce por medio del placer sexual, fin para el que la corporalidad es absolutamente necesaria. En el discurso de "El caballero", escribe Sade:

Os pregunto si no es acaso un abominable prejuicio considerar como crimen el que un hombre prefiera para su goce al objeto de cuyo sentimiento la naturaleza lo colocó más cerca. Sería como decir que nos está prohibido amar demasiado a los individuos que la naturaleza más nos ordena que amemos, y que cuanta mayor es la inclinación que ella nos imprime hacia un objetivo, más nos ordena al mismo tiempo que nos alejemos del mismo. Estas contradicciones son absurdas: solo los pueblos embrutecidos por la superstición son capaces de creer en ellas o de aceptarlas. ${ }^{267}$

La corporalidad en Sade, por tanto, es medio y fin del disfrute, de la voluptuosidad y del ocio. La vía para alcanzar este estado al que se aboca el cuerpo es el sexo, puesto que la parte genital es la que habilita la posibilidad de lograr el placer más satisfactorio. Pero Sade no considera que esta satisfacción sea una especie de recompensa procedente del mérito, el trabajo o el estatus civil, sino que, muy por el contrario, el placer sexual

\footnotetext{
${ }^{265}$ Cfr. Marqués de Sade, La filosofía en el tocador (Barcelona: Tusquets, 2009), 112.

${ }^{266}$ Sade, ob. cit., 174.

${ }^{267}$ Sade, ob. cit., $187-188$.
} 
no viene causado más que por el carácter pervertido que anida en el fondo del deseo humano. Los actos de la sexualidad impelen un tipo de satisfacción que no entra dentro de la lógica de las convenciones sociales ni de la lógica productivo-comercial, ya que la satisfacción sexual no viene seguida de prerrogativas públicamente pactadas ni establece un equilibrio compensatorio en sentido comercial. Por otra parte, el cuerpo en el esquema de pensamiento de la obra de Sade es portador de poder, en tanto en cuanto al liberarse de sus opresores tiene que explorar todas aquellas posibilidades que tiene y derrochar su potencia sin mucho grado de medición.

La desnudez en la literatura sadiana es inversamente proporcional al grado de artificialidad y exceso ornamental que alcanzaron las sociedades dieciochescas en todos los contextos de la vida y, también, en lo que se refiere al modo de vestir en público. Richard Sennett, en El declive del hombre público, dedica un apéndice a esta cuestión titulado, muy pertinente y significativamente, "El cuerpo es un maniquí". Sennett dice que la <<persona se volvió una figura en un paisaje inventado; el propósito de la indumentaria no era otorgar seguridad en el conocimiento del otro, sino hacer que la persona fuera capaz de comportarse como si estuviese segura $>>{ }^{268}$. La consecuencia directa fue la conversión del cuerpo en un <<objeto de decoración >> ${ }^{269}$, lo que uniría la escena teatral con el espacio público, la apariencia ostentosa y el relato suscrito a cada vestimenta se sobreponían a la naturaleza corporal, el pudor por la carne exigía recurrir a ornamentos que apartaban a los cuerpos para transformarlos en objetos de decoración, en una especie de maniquí de acuerdo con la consideración de Sennett. El cuerpo natural del sujeto tenía que ser transformado y a la vez apartado del espacio público, todo lo que allí se mostraba indicaba una posición social, exigiendo así un decoro por parte de los otros hacia quien llevaba unos u otros atuendos, se trataba de hacer valer $<<$ la regla de la apariencia en el mundo cotidiano, el cuerpo como maniquí, lo que expresaba este vestuario teatral $>270$. Lo que Sade hace en sus libros es rasgar estas vestiduras del exceso social-artificial $y$, sin salirse de lo excesivo, liberar a la corporalidad de aquellos ropajes que reflejaban la convencionalidad y la superficialidad propias de su tiempo. Las escenas orgíacas evocan una pasión impúdica por el "cuerpo desnudo", había que deshilachar de modo simbólico esos atuendos que al mismo tiempo

\footnotetext{
${ }^{268}$ Richard Sennett, El declive del hombre público (Barcelona: Anagrama, 2011), 91.

${ }^{269}$ Sennett, ob. cit., 95.

${ }^{270}$ Sennett, ob. cit., 97.
} 
aparecían como la alegoría perfecta del sometimiento de los individuos a las sobrecargas de una sociedad desnaturalizada y artificiosa, una sociedad rococó.

La liberación del cuerpo no representaba en el siglo XVIII para los intelectuales un mero problema teórico o una suerte de ocasión para desplegar dotes poéticas o exhibir excelencia literaria, más bien, estaban tratando un problema de especial trascendencia política y social porque estaban cuestionando los preceptos impuestos por la teología y su derivado régimen teocrático y absolutista. La religión, como observó D’Holbach, dividió al sujeto en alma y cuerpo, lo que suponía implantar una agónica separación en la que el cuerpo pasaría a ser un estigma. Para desasir a la corporalidad de la dominación religiosa había que suponerle una capacidad de poderío, es decir, se ubicaba en lo corporal la posibilidad de crear un nuevo orden en la vida, sin que figuras de poder extrínsecas, invisibles e inmateriales crearan ordenamientos basados en principios ficticios y quiméricos.

En lo que respecta a esta cuestión, sobresale el estudio de Marcel Hénaff sobre el cuerpo en Sade, titulado Sade. La invención del cuerpo libertino. Hénaff es un filósofo francés contemporáneo vinculado fundamentalmente con el estructuralismo, su interpretación asocia la forma en que el marqués pensó el cuerpo con la iatromecánica, una corriente teórica de la medicina -que también influyó a La Mettrie- en la que se desalojó al alma de su concepción antropológica, y que redujo sistemáticamente la dimensión corporal humana a nada más que a un compuesto mecánico ${ }^{271}$. Según Hénaff la literatura sadiana no restauró el alma en la corporalidad para la configuración de personajes, puesto que la fuente de todas las pasiones proviene de la irreversibilidad de las pulsiones corporal-lúbricas, de tal manera que el cuerpo se revela como causa eficiente de todos esos sentimientos que aparentemente parecen encontrarse en la subjetividad. En los textos de Sade el sujeto es eliminado y, de ahí, el pensamiento queda doblegado a los parámetros maquinales que operan en todo el organismo ${ }^{272}$. Hénaff aparta la reflexión libertina sobre el cuerpo del prisma economicista liberal, es cierto que para Sade el cuerpo implicaría un consumo fisiológico, pero este consumo no representa una carga, sino la constatación de un estilo de vida hedonista desmesurado, sin posibilidad para un cálculo racional de tipo económico:

\footnotetext{
${ }^{271}$ Cfr. Marcel Hénaff, Sade. La invención del cuerpo libertino (Barcelona: Ediciones Destino, 1980), 27

${ }^{272}$ Cfr. Hénaff, ob. cit., 48.
} 
El libertino hace de su cuerpo una fantástica máquina de consumir, de gastar en la indiferencia absoluta respecto al despilfarro que ello implica, en el rechazo sistemático de todo lo que pudiese tomar la apariencia de una lógica cualquiera de productividad. El goce libertino emerge en la punta de una pirámide de trabajo explotado, de riquezas desviadas, de rentabilidad excluida. ${ }^{273}$

La imagen del cuerpo en Sade irradia una liberalidad que no es fruto de pasiones o elementos subjetivos sino de la mecánica que lo constituye. Esta estructura constitutiva dirige los cuerpos en el contacto sexual y también en la violencia que acompaña al deseo, puesto que el deseo se expresa como necesidad provocada por una insatisfacción que la máquina corporal busca saciar, pero que se torna insaciable en la pulsión sexual, por lo que el deseo genital huelga de una violencia a la hora de realizarse. Así es como el cuerpo se hace incontenible para el hombre, se convierte en poder, un poder que ya no era compartido con el alma, de forma que el cuerpo se instala como principio dominante de la vida. El poder emana de la natural mecánica corpórea que constituye al ser humano. Más allá de la dimensión sexual en la que se enmarca la postura sadiana sobre la relación cuerpo-poder y en la que se observa la imagen de un cuerpo consumidor, que requiere cubrir las avideces procedentes de su composición maquinal, encontramos también que, una vez lo corporal es considerado bajo los parámetros de la máquina, entonces, la imagen del cuerpo también puede asociarse con el rendimiento productivo. Si el uso de una máquina como la Spinning-Jenny traía consigo la multiplicación de la producción, también el cuerpo humano, en cuanto que máquina, resultaba explotable y rentable en términos económicos, pero para ello había que convertirlo en máquina-objeto.

La literatura de Sade contiene un carácter aporético especialmente visible en el entorno de lo corporal. Resulta que si en la inmanencia del cuerpo humano reside un poder, si las fuerzas de la naturaleza mecánico-corporal componen una forma capaz de generar impacto en las relaciones sociales, este poder, para liberar al individuo humano, tiene que desprenderse de cualquier reconocimiento de los otros. Ese cuerpo del libertino, ese cuerpo empoderado a partir de sus propios engranajes naturales, hará uso de sus fuerzas para derribar las superficialidades espurias creadas por la sociedad, socavando así las supuestas virtudes tan contrarias a la verdadera desnudez humana; el hombre sería un ser impulsivo e instintivo a quien le estorbaría todo compromiso de

${ }^{273}$ Hénaff, ob. cit., 164. 
carácter social con los otros. Este ejercicio de liberación precisa de la acción soberana de un poder que emana del mismo cuerpo. Según comenta Georges Bataille en El erotismo, Sade no pierde de vista el hecho de que el hombre soberano termine traicionándose a sí mismo; Bataille formula esta aporía a partir del "hombre soberano" de Sade mediante el siguiente argumento:

La lealtad recíproca entre el soberano y los súbditos descansaba en la subordinación de los súbditos en la soberanía del soberano. Pero el hombre soberano de Sade no tiene soberanía real, es un personaje de ficción, cuyo poder no es limitado por obligación alguna. Ya no hay lealtad a la que deba atenerse este hombre soberano respecto a los que le otorgan su poder. Libre ante los demás, no deja de ser víctima de su propia soberanía. No es libre de aceptar la servidumbre que sería la búsqueda de una voluptuosidad miserable, ¡no es libre de derogar! Lo notable es que Sade, partiendo de una perfecta deslealtad, alcance no obstante el rigor. ${ }^{274}$

El hombre soberano sadiano hunde sus raíces en el poder que irradia su corporalidad, pero este poder, a la vez que le libera, también le somete a la virulencia de sus instintos y a las agitaciones de sus pulsiones sexuales. La máquina corporal de La Mettrie se vuelve agria y demoledora en la literatura de Sade. Igualmente, si en la naturaleza pensada por Holbach el hombre podía resolverse como libre, propietario y seguro, en la naturaleza sadiana el ser humano no se garantiza esas tres demandas básicas, puesto que, como cualquier animal, sus determinaciones corporales no le harán del todo libre, la sociabilidad le hará infeliz y no hallará reposo seguro. Tampoco en Sade los sentidos ofrecen pautas y ley para los hombres, como sí trató de hacer Bentham, puesto que los sentidos siempre traen consigo la prodigalidad y no hay en ellos mesura que pueda dirigir al cuerpo. El hombre soberano es una ficción en la medida en que su soberanía nunca llega a solidificarse en el tejido de las instituciones civiles, pero, como de hecho sucede, y esta es la aporía inserta en la imagen sadiana del cuerpo, la institución implanta excesos sobre la corporalidad que resultan mucho más amargos, inclementes e intolerables que los excesos impulsados por el cuerpo natural.

\subsubsection{ROUSSEAU: LA CORPORALIDAD ENTRE EL HOMBRE SALVAJE Y EL HOMBRE CIVILIZADO}

El retroceso que estaban experimentando los dogmas que durante siglos fueron impuestos por la teología afectó a la configuración de conceptos como el "alma" e,

${ }^{274}$ Georges Bataille, El erotismo (Barcelona: Tusquets Editores, 2002), 180. 
incluso, la propia concepción de lo divino estaba siendo alterada en las disputas metafísicas. La teología tradicional ya no imperaba como dominio central del saber y su gloria pasada se iba desvaneciendo entre los más prodigiosos intelectuales. En medio de esta crisis de la teología, los fundamentos de la teoría moral y de la teoría política tenían que ser reformulados sobre la base de una racionalidad secular. En la filosofía política destacan las aportaciones de Jean-Jaques Rousseau, quien desarrolló el concepto de "voluntad general" atendiendo exclusivamente a los puntos fundamentales que definen al ser humano y que son, por supuesto, extensibles a toda persona. En medio de este panorama la categoría antropológica y política de "estado de naturaleza" contribuía a repensar la concepción de hombre natural y las causas que condujeron al estado de civilización.

La concepción de hombre natural por parte de un autor materialista y mecanicista como La Mettrie recurría a una prueba empírica, basada en los testimonios acerca de personas que desde su infancia vivieron apartadas de la comunidad humana y que gracias a otros animales pudieron mantenerse con vida en el entorno salvaje. Cuando estas personas eran encontradas e incorporadas a la civilización, poco a poco salían de su estado salvaje y comenzaban a tener ideas. El efecto de adquirir una reflexividad e instrucción racional es que los sujetos humanos empiezan a pensar hasta el punto de olvidar los momentos y experiencias que les acaecieron cuando no contaban con la capacidad reflexiva ${ }^{275}$. El autor francés, por medio de estos ejemplos trató de confirmar que la racionalidad, así como la reflexión, solo pueden articularse en la comunidad humana, de modo que el pensamiento hallaría su desarrollo en el seno de una sociedad, o sea, allí donde se dan relaciones humanas, porque en un estado salvaje el individuo sería incapaz de articular ideas. Esta caracterización del salvaje como un ser falto de ideas y la vinculación de la racionalidad con la emergencia de una sociabilidad civilizadora es un tema que fue también planteado por el filósofo Jean-Jacques Rousseau. El matiz fundamental que diferencia el planteamiento de Rousseau del planteamiento de La Mettrie tiene una raigambre antropológica muy determinante porque, precisamente, en el pensamiento de Rousseau la naturaleza humana no se reduce a la categoría de máquina. De este modo, el plexo sobre el que el filósofo ginebrino situó su concepción del hombre no se corresponde con una consideración mecanicista.

${ }^{275}$ Cfr. La Mettrie, Obra filosófica, 168-169. 
Rousseau se desmarca de las versiones materialista-mecanicistas pero admite, en el Discurso sobre el origen de la desigualdad entre los hombres, que la constitución del cuerpo es mecánica, así como en el animal dice ver una máquina dotada de sentidos que le permiten sobrevivir, en los seres humanos encuentra también una mecánica subyacente a los cuerpos, pero $<<$ con la diferencia de que la naturaleza hace por sí sola todo en las operaciones de la bestia, mientras que el hombre concurre a las suyas en calidad de agente libre $>276$; esta "agencia libre" del hombre marca de manera fundamental la visión antropológica rousseauniana. La libertad es la línea fronteriza que traza la diferencia esencial entre los hombres y las bestias, aspecto que a ojos de Rousseau frecuentemente juega en contra de los seres humanos, ya que suelen evadir las reglas naturales al estar la voluntad operativa constantemente allí donde la naturaleza deja de $\operatorname{actuar}^{277}$.

El pensador ginebrino representa al hombre salvaje como un individuo que tiene disposición plena de las fuerzas de su corporalidad, sin embargo, el hombre civilizado pierde parte de su fuerza merced a la industria que se procura a sí mismo ${ }^{278}$. En un hipotético enfrentamiento entre el hombre salvaje y el civilizado, el segundo superaría al primero si contara con los artificios necesarios para obtener la victoria, pero, si ambos se enfrentaran en un combate cara a cara y al desnudo, el hombre civilizado quedaría en clara desventaja, puesto que el hombre salvaje cuenta con $<<$ la ventaja de tener constantemente todas las fuerzas a disposición propia, de estar siempre preparado para cualquier acontecimiento $\mathrm{y}$ de ir siempre, por decirlo así, todo entero consigo mismo $>>{ }^{279}$. Se puede advertir, de acuerdo al contraste de imágenes entre el cuerpo del salvaje con respecto al del hombre civilizado, que el salvaje dispone de su cuerpo solo en la medida en que en él se albergan de una vez todas las fuerzas y habilidades que le mantienen con vida, este cuerpo, fortalecido y polivalente, es transformado por la civilización, tornándose más débil. Las diferencias de complexión entre el hombre salvaje y el hombre civilizado dejan interpretar en el pensamiento rousseauniano una experiencia original de la corporalidad humana, inscrita a una situación natural en la que los salvajes contaban íntegramente con las fuerzas que emanan de su constitución

\footnotetext{
276 Jean-Jacques Rousseau, Discurso sobre el origen de las desigualdades entre los hombres (Madrid: Biblioteca Nueva, 2014), 89.

277 Cfr. Rousseau, ob. cit., 89-90.

${ }^{278}$ Cfr. Rousseau, ob. cit., 82-83.

${ }^{279}$ Rousseau, ob. cit., 83.
} 
corporal, de tal modo que la llegada de la civilización en algún momento escindió esta potencia subyacente al cuerpo natural de los individuos.

Retomando el hilo argumentativo por el que Rousseau niega que la naturaleza humana se reduce a la fisiología corporal, huelga destacar cómo el pensador francés trató de descubrir en la dimensión espiritual de los hombres elementos que contribuyeran a evidenciar la libertad. Si las acciones de los seres humanos se redujeran únicamente a los impulsos que los sentidos y los instintos dirigen, y si estas acciones solo estuvieran determinadas por los movimientos físicos en que están involucrados los cuerpos, entonces, la voluntad libre de los seres humanos no tendría procesión alguna en el espectro de la espiritualidad:

La naturaleza ordena a todo animal y la bestia obedece. El hombre experimenta la misma impresión, pero reconócese libre de asentir, o de resistir; y es sobre todo en la conciencia de esta libertad donde se muestra la espiritualidad de su alma, pues la física explica en cierta manera el mecanismo de los sentidos y la formación de las ideas; pero en la facultad de querer o, mejor, de escoger y en la conciencia de esta facultad, no encontramos más que actos puramente espirituales, de los que nada se explica por las leyes de la mecánica. ${ }^{280}$

La antropología rousseauniana no incorpora el concepto de máquina a todas las realizaciones de la vida humana, no presenta al hombre recluido en su máquina-cuerpo, no al menos en una homogeneidad mecanicista-corporalista que imponga $y$, hasta haga previsibles, todo el conjunto de actividades que los individuos pueden realizar. Al no partir de un corporalismo de corte mecanicista, Rousseau se muestra especialmente crítico con la caracterización que Hobbes hizo del hombre en estado salvaje; le reprocha al pensador británico que expandiera los defectos propios de los hombres civilizados a la condición del salvaje u hombre natural. A ojos del filósofo de Ginebra, Hobbes erró <<por haber incluido inadecuadamente en el cuidado de la conservación del hombre salvaje el deseo de satisfacer una multitud de pasiones que son obra de la sociedad y que han hecho necesarias las leyes $>>{ }^{281}$. Entonces, que exista el perjurio de unos individuos contra otros, que exista la vanidad o la beligerancia entre ellos, no son rasgos congénitos a la naturaleza humana, ni causa de su constitución anatómica, sino que es en las relaciones sociales donde se producen estas distorsiones del carácter humano.

\footnotetext{
${ }^{280}$ Rousseau, ob. cit., 90.

${ }^{281}$ Rousseau, ob. cit., 103.
} 
Al final de su Discurso sobre las desigualdades Rousseau afirma <<que la desigualdad, siendo casi nula en el estado de naturaleza, saca su fuerza y acrecentamiento del desarrollo de nuestras facultades y de los progresos del espíritu humano $>>282$ y añade que $<<$ la desigualdad moral, solamente autorizada por el derecho positivo, es contraria al derecho natural, siempre que no concurra, en igual proporción, con la desigualdad física $>>{ }^{283}$. Si las desigualdades entre los hombres en la sociedad fueran causadas por las diferencias de complexión, entonces, el grado de desigualdad entre los individuos no sería tan pronunciado dentro del estado civil. Al igual que en la literatura de Sade, Rousseau reivindica un tipo de hombre desinhibido de los excesos y cargas impuestas por las convenciones, presiones y dominaciones que surgen en las relaciones sociales, pero Rousseau no ve en el hombre liberado de todas estas determinaciones nada más que un cuerpo-máquina, sino que, por el contrario, ve a un ser dotado de voluntad libre. Pero sería hacer una lectura bastante sesgada de la filosofía rousseauniana si se convirtiera a la sociedad en el blanco de todas las querellas contra la degeneración, corrupción, perversión y maldad del hombre civilizado, siguiendo las matizaciones que el profesor Fernando Longás hace sobre este asunto en La libertad en el laberinto del Minotauro, se tercia oportuno subrayar que el filósofo ginebrino

apunta a un proceso sufrido por el hombre en su devenir como ser civilizado, proceso en el que radicaría el origen del mal, y que consiste en la emergencia de una desigualdad material y moral, distinguible de la desigualdad natural o física, en la medida en que las primeras dependen exclusivamente de una especie de conversión entre los hombres por una suerte de pacto impuro. Tanto el surgimiento de la propiedad como el del Estado guardan relación con el desarrollo de esta desigualdad entre los hombres; sin embargo, su verdadero origen se encuentra en un proceso de "personalización" por el que el hombre originario sale de sí mismo y se transforma en un individuo consciente de sí solo por comparación con los otros. ${ }^{284}$

Este proceso de maleamiento de los hombres se da dentro de los inadvertidos confines del espíritu, allí donde se da paso a las relaciones sociales, de las que emanan contenidos no inscritos de forma condicional a la mecánica física del cuerpo y de la naturaleza. Como bien dice Longás, se trata de un proceso en el que el hombre original se sustrae a sí mismo, haciendo que su carácter inicial quede alterado por aquellas

\footnotetext{
${ }^{282}$ Rousseau, ob. cit., 151.

${ }^{283}$ Rousseau, ob. cit., 152.

${ }^{284}$ Fernando Longás, La libertad en el laberinto del minotauro (Santiago de Chile: Editorial Cuarto Propio, 2005), 107.
} 
rencillas y pormenores subyacentes a la vida social. La voluntad humana puede devenir contraria a la libertad que caracteriza a todos los hombres, no son las determinaciones corporales las que instauran las formas de dominación, sino que es en el seno de las relaciones sociales donde se van generando las desigualdades que derivan en la dominación y la subsunción. Asimismo, subraya Longás que en el pensamiento de Rousseau la sociedad civil extiende ese vasallaje congénito al proceso de formación de la civilización por medio del que se fueron afianzando los yugos de dominación que actúan sobre los hombres, estos, pensando proteger su libertad, permitieron la presencia de formas de poder que lejos de cumplir tal propósito terminaron volviéndose en su contra $^{285}$.

La corporalidad humana se ve afectada por este proceso civilizatorio, el cuerpo del hombre civilizado es más débil, menos dispuesto y preparado físicamente que aquel que pudiera albergar el salvaje -de acuerdo con la reflexión que el autor ginebrino menciona al comienzo del Discurso sobre las desigualdades-. De modo que el cuerpo padece, sufre y se convierte en la víctima de un espíritu desvirtuado por los menesteres y desmanes acaecidos en la concurrencia social de los seres humanos; de la vida pública brotan la ambición de dominación y también la sumisión mezquina, pero el cuerpo por sí mismo nunca tendrá la potencia para remediarlo, es la agencia libre de los hombres la que puede tornar esta situación. Del mismo modo, las asimetrías solo pueden ser producidas por el espíritu, mas, el cuerpo no aparece involucrado en medio de estas correlaciones que conforman tanto al dominador como al dominado, el cuerpo es el receptor paciente de este poder que mora entre los espíritus. En contraste con Sade, Rousseau no contempla la presencia de un poder inmanente al cuerpo, sino que toda potencia subyacente a la voluntad libre aparece escindida de la corporalidad y situada en el entorno espiritual, único lugar en el que la libertad no se pierde entre los engranajes del cuerpo-máquina. Pero, de la misma manera que Sade, Rousseau piensa que los excesos producidos por la civilización alteran y distorsionan la naturaleza humana hasta límites insostenibles.

En el Contrato Social, obra propiamente política, Rousseau afirma que dentro del estado de naturaleza los hombres se hallaban desprovistos de un derecho positivo, tan solo la nómica natural orientaba la vida de los seres humanos, los cuales, se valían del uso de sus instintos sin que sus acciones mellaran o causaran mayores incidencias entre

${ }^{285}$ Cfr. Longás, ob. cit., 116-117. 
ellos. El propósito de Rousseau es investigar cómo pueden ser las leyes civiles en relación con la libertad que por naturaleza subyace a todos los seres humanos; apunta que conocer esta relación le permitirá encontrar el nexo de unión entre $<<$ lo que el derecho permite con lo que el interés prescribe, a fin de que no se encuentren separadas la justicia y la utilidad $>>286$.

Merced a tales consideraciones explica que su idea del derecho es opuesta al poder de la fuerza, en otras palabras, excluye del derecho las leyes que utilizan la fuerza y la pertinente coacción y coerción que esta concierne para legislar sobre los individuos. La fuerza es un poder físico que condiciona a aquel o aquellos sobre los que se ejerce, sin que puedan actuar conforme a su propia voluntad. Entonces, la noción rousseauniana de derecho es distinta de cualquier acto que pueda condicionar a los demás o, lo que es lo mismo, obligar mediante la imposición de necesidades. El derecho, así pues, será obedecido de acuerdo con la voluntad de cumplir el deber y no porque venga encarnado en una entidad que fuerce a hacerlo ${ }^{287}$. Pero la emergencia del estado civil impuso la necesidad de impeler transformaciones fundamentales en los hombres, en tanto en cuanto apartaron de sí ese conjunto de instintos y pulsiones para implantar la razón y el deber moral dentro de su conducta ${ }^{288}$. En la sociedad política los comportamientos propulsados por la naturaleza del cuerpo fueron emplazados por unos principios cuya raigambre no es identificable con nada corpóreo ni resulta asimilable a ninguna instancia material.

En el Discurso sobre economía política el autor asegura que $<<$ el derecho de propiedad es el más sagrado de los derechos de los ciudadanos $>>$, porque todos los hombres necesitan apropiarse de medios con que mantener su vida, así, el derecho de propiedad <<es más importante, en ciertos aspectos, que la misma libertad, bien sea porque, como los bienes sean más fáciles de usurpar y más difíciles de defender que la persona, debe respetarse más lo que es más fácil de arrebatar $>{ }^{289}$. Dado que proteger a seres pasivos como lo son las propiedades resulta más complicado que proteger a los seres humanos, pues cada sujeto tiene un mínimo de posibilidad de defenderse contra hurtos, oprobios y agresiones, Rousseau deduce que es del interés de todos que las leyes protejan las propiedades, dado que son medios necesarios para la subsistencia, razón por

\footnotetext{
286 Jean-Jacques Rousseau, El contrato social (Madrid: Aguilar, 1970), 5.

${ }^{287}$ Cfr. Rousseau, ob. cit., 8-9.

${ }^{288}$ Cfr. Rousseau, ob. cit., 21.

${ }^{289}$ Jean-Jacques Rousseau, Discurso sobre economía política (Madrid: Tecnos, 2001), 34.
} 
la que el blindaje legal de la propiedad sería a su entender un modo de promover la defensa de la vida.

El derecho de propiedad une el deber con el interés, en otras palabras, hace del derecho y de la utilidad una misma cosa, sin embargo, conviene matizar que la noción de propiedad en Rousseau no se halla dentro de los márgenes del pensamiento político y económico liberal, a pesar de que la terminología empleada por el autor sea muy parecida y pese a que algunas ideas puedan asemejarse en su formulación. El horizonte reflexivo rousseauniano en el que se enmarca el concepto de propiedad homologa el valor de las posesiones a la integridad axiológica de la vida, mientras que los pensadores liberales, comúnmente, establecen que el valor de las propiedades viene determinado en función del esfuerzo productivo y el negocio del intercambio. Se podría decir que en el liberalismo el valor de las cosas poseídas es establecido por la especulación sobre los rendimientos útiles del trabajo y del comercio, sin embargo, Rousseau trata de establecer el valor de las posesiones con respecto al interés que estas tienen para perpetuar y dignificar la vida, una vida que en el caso de los seres humanos vendría transformada por la libertad, cuyo fundamento es externo a la mecánica corporal y cuya potencia originaria no se encuentra en el entorno donde vive el cuerpo. 


\section{SECCIÓN II. DESTRUCCIÓN Y RECONSTRUCCIÓN: \\ PODERES SECULARES PARA EL ORDENAMIENTO DEL \\ CUERPO SOCIAL}

\subsubsection{LA VOLUNTAD QUE SE ESCINDE DEL CUERPO}

La antropología de Rousseau y su teoría política conciben un estadio originario del ser humano que la sociedad civil vino a destruir y que contribuyó a la enajenación de los individuos, a la proliferación de desigualdades de las que se siguieron los abusos y las conductas perversas. En el Discurso sobre el origen de las desigualdades entre los hombres se aprecia cómo el filósofo ginebrino especula acerca de cómo pudieron iniciarse en el seno de las comunidades humanas estas insidiosas desigualdades, caudal de conflictos y asidero de maleabilidad espiritual, cuya causa más directa, sin embargo, habría venido de la mano del inevitable mutualismo afectivo, es decir, de la sociabilidad humana y de los irrenunciables vínculos fraternos que los seres humanos establecen cuando se relacionan entre sí:

Tan pronto como los hombres hubieron comenzado a apreciarse mutuamente y la idea de consideración se formó en su espíritu, todos pretendieron tener derecho a ella, y no fue imposible que impunemente le faltara a nadie. De aquí salieron los primeros deberes de la civilización, incluso entre los salvajes, y de aquí que toda sinrazón voluntaria se convirtiera en ultraje, porque en el mal que resultaba de la injuria el ofendido veía el desprecio de su persona, con frecuencia más insoportable que el mismo mal. He ahí precisamente cómo, castigando cada cual el desprecio que se le había manifestado, de modo proporcionado al caso de sí mismo, las venganzas se volvieron terribles y los hombres, sanguinarios y crueles. ${ }^{290}$

La primigenia bondad que subyace a los hombres en su estado natural es destruida por la forma en que se producen las relaciones sociales una vez la civilización irrumpe en sus vidas. No es que la sociabilidad derribe directamente la benevolencia originaria de las relaciones humanas, es que hay un proceso cuya dilatación se va sucediendo en distintas etapas por las que pasa la civilización. Sostiene Rousseau que en un primer momento la ley y el derecho de propiedad instauraron ya una forma de desigualdad, la de rico o pobre; en una segunda etapa fue la institución de la magistratura lo que dio

290 Jean-Jacques Rousseau, Discurso sobre el origen de las desigualdades entre los hombres (Madrid: Biblioteca Nueva, 2014), 123-124. 
paso a la diferencia entre poderoso y débil; y en último término el poder legítimo se tornó en arbitrario trayendo consigo la diferencia entre el amo y el esclavo ${ }^{291}$. Rousseau ve en este proceso la paulatina solidificación de asimetrías que hacen mella en las sociedades de los hombres, convirtiendo la convivencia dentro de la civilización en una tarea cada vez más ardua, ya que esta convivencia se va complejizando a medida que se intensifican y amplían las leyes, los derechos, las magistraturas y las arbitrariedades que acompañan a estas determinaciones jurídicas.

El propósito del filósofo de Ginebra es restaurar esa dulzura benevolente que acompaña a los seres humanos en su forma natural, busca reconstruir aquello que la civilización fue destruyendo. De este modo, el contrato social que propone Rousseau viene a recomponer la vida social humana tras una estela degenerativa prolongada en la historia. El contrato social promueve nuevos acuerdos validados por la libre concurrencia de voluntades.

En El contrato social Rousseau construye un concepto que cimienta teóricamente un pacto por medio del que los hombres habrán de gobernarse sin necesidad de recurrir a la mera fuerza bruta, al simple cálculo de intereses particulares, o a la contingente convergencia de las pasiones, este concepto es el de voluntad general, un principio basal y necesario para otorgarle racionalidad a los acuerdos que los seres humanos establecen para alcanzar unos compromisos comunes, que les permitan organizar la sociedad orientándose libre e igualitariamente. En el mismo instante en que los hombres se asocian siguiendo la voluntad general, se tendrá que formar un cuerpo moral y colectivo compuesto de tantos miembros como votos tiene la asamblea, un cuerpo que recibe su unidad, su alma común, su vida y su voluntad a partir del acuerdo instaurado por la mayoría ${ }^{292}$. El pensador ginebrino supo ver en la agrupación de los cuerpos humanos una indiscutible fuente de poder en la medida en que la organización de los cuerpos desprende una fuerza física capaz de cumplir diferentes determinaciones que, por el contrario, un solo individuo, con su cuerpo natural, nunca podría lograr. Esta misma idea también se halla en Hobbes, pero Rousseau extrae unas consecuencias muy distintas, ya que no ve en el Estado solo un cuerpo y nada más que un cuerpo; el Estado es, ante todo, un alma común, y su poder emana de un pacto, de tal manera que las fuerzas del Estado estarán sometidas a la palabra de ese pacto, único fundamento de su

\footnotetext{
${ }^{291}$ Cfr. Rousseau, ob. cit., 144.

292 Jean-Jacques Rousseau, El contrato social (Madrid: Aguilar, 1970), 17.
} 
poder. Para Rousseau, la vinculación de los cuerpos sería espuria si entre ellos no primara una unidad moral, en este aspecto el pensamiento del autor ginebrino se encuentra más cercano al pensamiento de Spinoza, no obstante, la concepción de voluntad general se erige como una abstracción que levita sobre la corporalidad política resultante. En Rousseau la dimensión corpóreo-somática y la dimensión espiritualmoral de la sociedad quedan separadas, un matiz que Spinoza nunca hubiese firmado.

De vuelta a los contrastes entre Rousseau y Hobbes, cabe hacer referencia a las distintas visiones que ambos tienen del Derecho: Hobbes concibió el Derecho en virtud del ejercicio de la fuerza producida por la suma de todas las fuerzas de los individuos, encarnándose el poder en una corporalidad artificial y política que presiona y retiene de forma directa al cuerpo de las personas; Rousseau, por el contrario, aparta al Derecho de acepciones vinculadas a la fuerza, así, en el momento en que se formaliza la unión voluntaria de los hombres es posible hablar de una corporalidad de derecho. En virtud de tales distinciones, el filósofo ginebrino piensa en una figura de poder que no se constituye como una entidad corpórea, sino que es una figura sustancialmente diferenciada de todo objeto físico, se trata, pues, de un poder que orbita sobre los cuerpos, este poder viene representado por la voluntad general.

Las fuerzas del Estado deben estar regidas por la voluntad general, ya que esta comporta el común de los intereses que vertebra la sociedad política, en otras palabras, es la concurrencia necesaria, y no meramente contingente, del interés de todos y cada uno de los individuos la que forma el cuerpo político. La unidad de la corporalidad política viene garantizada por la perpetuación de la voluntad general, ahora bien, esta voluntad no coincide con la del soberano ni con la de la mayoría, no es comparable a nada que no sea aquello que representa la totalidad de los intereses de la comunidad. La voluntad general no es algo concreto ni puntual, ni puede ser un interés particular, sino que es la abstracción que surge de suponer la existencia de intereses en los que todos los individuos coinciden necesariamente y por igual ${ }^{293}$.

Rousseau no concibe al Estado como una mera agregación de cuerpos humanos componiendo un cuerpo político, para que una corporalidad política se constituya, esta debe contener en esencia una unidad moral, de manera que, cuando uno de sus miembros sea dañado, tal quebranto sea tomado como un agravio contra todos ${ }^{294}$. Si la

${ }^{293}$ Cfr. Rousseau, ob. cit., 27-28.

${ }^{294}$ Cfr. Rousseau, ob. cit., 20. 
agresión del ajeno es vista como una vulneración hacia uno mismo, entonces, se puede decir que existe un vínculo moral, y es entonces cuando la espiritualidad de la sociedad emerge como verdadera unidad de la sociedad civil. La correspondencia entre los miembros de la sociedad y el cuerpo social no se origina en la reunión fáctica de los cuerpos, sino en una instancia abstracta e incorpórea que despliega ese "sistema nervioso" invisible por medio del que los miembros de la comunidad se vinculan entre sí. Rousseau presenta una imagen conceptual de la sociedad en la que los cuerpos naturales de los individuos se difuminan en el todo de la comunidad, una imagen que es entendida por Esposito como una forma de terminología sacrificial ${ }^{295}$. Para Esposito, si bien Rousseau fue <<el primer pensador moderno de la comunidad >>, también fue <<el primero en construir su mito, el primero en pensar la comunidad junto a su mito, y dentro de él, en una maraña que no resulta fácil desovillar >>296. Rousseau habría pensado la comunidad desde una antinomia: el individuo aislado de la corrupción a la que le abocan los excesos de las relaciones sociales se presenta como un ser solitario y pre-político, pues este individuo no tiene todavía una historia y, sin embargo, es a este mismo individuo al que se le exige la formación de una comunidad, una comunidad de la que carece ${ }^{297}$. Así, entonces, dentro del andamiaje argumentativo de Communitas, Esposito sitúa al pensamiento rousseauniano en una suspensión entre el individualismo absolutista (el planteado por Hobbes) y el cosmopolitismo moderno (el nuevo universalismo $)^{298}$.

En un artículo de Javier Peña titulado Rousseau y la idea de comunidad política, el concepto de voluntad general es interpretado como un término a través del que Rousseau habría pretendido trascender la contraposición entre el individualismo y el colectivismo. La comunidad que surge del pacto en torno a la voluntad general procede del derecho de autodeterminación subyacente a personas y grupos humanos y, por tanto,

\footnotetext{
${ }^{295}$ Cfr. Roberto Esposito, Communitas. Origen y destino de la comunidad (Buenos Aires: Amorrortu, 2007), 100.

${ }^{296}$ Esposito, ob. cit., 102.

${ }^{297}$ Esposito señala que <<el carácter constitutivamente aporético del comunitarismo rousseauniano reside en esta premisa: ¿cómo puede semejante unidad relacionarse con el otro? ¿puede derivar una filosofía de la comunidad de una metafísica de la soledad? La absolutez del individuo cerrado en su propia existencia se puede "poner en común": ¿qué tipo de comunidad resultaría? (...). La barrera -que Rousseau en más de una ocasión está tentado a atravesar-pasa entre la exigencia de comunidad (presente en negativo en la descripción crítica de la sociedad existente) y su formulación afirmativa. O bien entre la determinación "impolítica" de la ausencia de comunidad -la comunidad como carencia, falta, deuda inextinguible en relación con la ley que la prescribe- y su realización política〉>, Communitas. Origen y destino de la comunidad (Buenos Aires: Amorrortu, 2007), 98-99.
}

${ }^{298}$ Cfr. Esposito, ob. cit., 104. 
hunde sus raíces en la libertad; asimismo, la igualdad permite que todos los individuos pacten el contrato social en las mismas condiciones, es decir, sin que nadie parta de una situación más o menos ventajosa con respecto a otros ${ }^{299}$. Peña pone de relieve que la voluntad general adquiere una connotación muy abstracta en el lenguaje rousseauniano, dado que si

es un principio inmanente al conjunto de los ciudadanos -como voluntad común construida y definida, en condiciones de libertad e igualdad, mediante la deliberación pública-, no es menos cierto que a menudo Rousseau se expresa de modo que sugiere su hipóstasis frente a los ciudadanos. La voluntad general es indestructible, y subsiste aunque nadie la exprese; $(\ldots){ }^{300}$

Continúa el profesor Peña acentuando aquello que el autor ginebrino expresó en $E l$ contrato social sobre la voluntad general, a saber, que su preexistencia es independiente de la coincidencia de intereses particulares susceptibles de configurar una voluntad de todos, es decir, una voluntad correspondiente a los hombres particulares tomados individualmente, más que la de una generalidad comunitaria. Además, el carácter hipostasiado de la voluntad general -según Peña- procedería de la constatación que hace Rousseau de que, en efecto, no siempre la concurrencia de una mayoría de hombres resueltos a lograr un interés determinado se corresponde con el bien común. Los consensos de una mayoría, entonces, pueden describir una trayectoria tangencial a la voluntad general, ya que dichos consensos podrían ser fruto nada más que de intereses particulares que circunstancialmente se cruzan y agrupan, pero que no se aúnan en torno a un bien común válido para todos los miembros de la comunidad. La voluntad general surgiría de un juicio racional más que de un impulso pasional que emanare de una asamblea de forma contingente. Entiende Javier Peña, consecuentemente, que en la filosofía política de Rousseau hay dos tipos de voluntades operando en el individuo: una es la voluntad que surge de las preferencias que uno mismo tiene en cuanto individuo, o sea, en cuanto ser pasional que proyecta unos intereses particulares, y la otra, la voluntad correspondiente a las preferencias del hombre como ciudadano, que adquiere un carácter de racionalidad en la medida en que

\footnotetext{
${ }^{299}$ Cfr. Javier Peña Echeverría, "Rousseau y la idea de comunidad política”, Isegoría, no. 11 (1995): 126$143,134$.

${ }^{300}$ Peña Echeverría, ob. cit., 136.
} 
vela por conseguir el bien común o, lo que es lo mismo, que prefiere el bien de todos los miembros de la comunidad ${ }^{301}$.

Cabría matizar que Rousseau no rechaza explícitamente todo lo que tiene que ver con la esfera de las pasiones, es más, en el Discurso sobre el origen de las desigualdades afirma que <<el entendimiento humano debe mucho a las pasiones >> pues <<solo tratamos de conocer solo porque deseamos gozar, y no es posible concebir por qué quien no tenga deseos ni temores habría de darse la molestia de razonar $>>{ }^{302}$. Pero, sin embargo, es en El contrato social donde el autor conviene en establecer las diferencias entre aquellos aspectos que afectan al individuo en cuanto hombre y al individuo en cuanto ciudadano, dado que la voluntad general habrá de demarcarse de esos intereses fruto de las pasiones y que son susceptibles de derrumbar la complexión social si predominan sobre el bien común que la sostiene y vertebra.

Rousseau advierte de lo inapropiado que resulta confundir el término "voluntad general" con el de "voluntad de todos", este último se refiere a una suma de voluntades particulares en las que se albergan intereses privados y nunca una suma de las contraposiciones de los intereses; tal y como dice Rousseau: <<quitad de esas mismas voluntades [particulares] los más y los menos que se destruyen entre sí, y queda como suma de las diferencias la voluntad general $>>{ }^{303}$. Del mismo modo, el arrojo pasional de cada individuo puede entrelazarse al de otros individuos originando un movimiento masivo cuya fuerza física haría las veces de un injerto en la corporalidad política capaz de derribar, diluir e in-vertebrar la unión moral. De esta manera, la unidad moral del cuerpo social representa en la filosofía política de Rousseau el pilar básico que mantiene a flote la racionalidad en la organización del cuerpo social, por eso la voluntad general, principio incorpóreo y no sujeto a los intereses particulares, se advierte como un poder escindido del cuerpo social solo en tanto en cuanto aparece como su pilar originario. El hombre rousseauniano, en la dimensión de la comunidad política, debe actuar como un ciudadano movido por la voluntad general para hacer posible un espacio público dirigido según la primacía de la racionalidad.

\footnotetext{
${ }^{301}$ Cfr. Peña Echeverría, ob. cit., 136-137.

302 Jean-Jacques Rousseau, Discurso sobre el origen de las desigualdades entre los hombres (Madrid: Biblioteca Nueva, 2014), 91-92.

303 Jean-Jacques Rousseau, El contrato social (Madrid: Aguilar, 1970), 31.
} 
La voluntad general reduce los intereses que proceden de las particularidades de las inclinaciones y tendencias corporales para dotar al ciudadano de una moralidad, este ya no actuará con base en los intereses a los que su constitución fisiológica le llama, más bien, actuará a partir del deber que la voluntad general le impone. El cuerpo del ciudadano sufre una escisión entre aquello que se corresponde con la voluntad particular, que son los intereses y pasiones individuales, y aquello que corresponde a esa otra voluntad que dignifica al individuo en cuanto ciudadano, pues propiamente le convierte en "ser político", en sujeto miembro de una sociedad civil. La voluntad general produce que la conducta del ciudadano no venga regulada por su naturaleza corporal sino por una voluntad impersonal, incorpórea e intangible. Se supone, bajo esta perspectiva, que la escisión entre voluntad general y voluntad particular es una estrategia secularizada mediante la que Rousseau invoca un principio fuera del orden físico de la naturaleza para justificar y respaldar su idea de una moralidad que ha de ser predominante en las relaciones sociales; si la sociedad es fuente de corruptibilidad en los hombres, en esta también habrá de residir la solución a estos dispendios. La sociedad destruye la bondad humana pero la voluntad general la restaura. La voluntad general es, entonces, un poder tutelar que reconstruye el orden moral del cuerpo social en el seno de su espiritualidad, pues esta tiene que erigirse como el alma del cuerpo político, esa alma que forman los hombres cuando se asocian.

En el Discurso sobre economía política Rousseau desarrolla una ilustrativa comparación entre las funciones vitales del cuerpo natural con respecto al funcionamiento orgánico-social del cuerpo político; el autor declara:

El cuerpo político, individualmente considerado, puede entenderse como un cuerpo organizado, vivo y similar al del hombre. El poder soberano representa la cabeza; las leyes y costumbres son el cerebro, origen de los nervios y sede del entendimiento, de la voluntad y de los sentidos, cuyos órganos son los jueces y magistrados; el comercio, la industria y la agricultura son la boca y el estómago que preparan la sustancia común; las finanzas públicas son la sangre de una sabia economía que, desempeñando las funciones del corazón, distribuye por todo el cuerpo el alimento y la vida; los ciudadanos son el cuerpo y los miembros que hacen que la máquina se mueva, viva y trabaje, de modo que cualquier herida que esta sufra en una de sus partes llevaría de inmediato una impresión dolorosa al cerebro si es buena la salud del animal. ${ }^{304}$

\footnotetext{
${ }^{304}$ Jean-Jacques Rousseau, Discurso sobre la economía política (Madrid: Tecnos, 2001), 8-9.
} 
La analogía entre el cuerpo de un animal y el funcionamiento de la sociedad política no debe interpretarse en términos mecanicistas, sino que, más bien, lo que Rousseau pretendía desprender de dicha analogía es que la corporalidad política en la que concurren los cuerpos de los ciudadanos entraña una moralidad que afina y reafirma los vínculos entre ellos. En vistas a especificar el sentido de la mencionada analogía, conviene destacar cómo el autor también concibió la ineludible importancia que conlleva sostener la vida del cuerpo político, lo que implica gastos de mantenimiento a los que todos sus miembros habrán de contribuir. Afirma que

el fundamento del pacto social es la propiedad y su primera condición la de que todos sean mantenidos en el pacífico disfrute de sus pertenencias. Verdad es que, según este mismo tratado, cada cual se obliga, al menos tácitamente, a cotizar en las necesidades públicas; mas, como dicho compromiso no puede perjudicar a la ley fundamental y presupone que los contribuyentes reconocen la evidencia de la necesidad, resulta que, para ser legítimo, debe ser voluntario, y no mediante voluntad particular, como si fuese necesario el consentimiento de cada ciudadano de modo que cada cual pudiese aportar lo que quisiera, lo cual iría directamente contra el espíritu de confederación, sino mediante voluntad general, por pluralidad de votos y en razón de una tarifa proporcional que impida la imposición arbitraria. ${ }^{305}$

Que la moralidad prime en el pacto social tiene repercusiones económicas, pues si bien el derecho de propiedad es fundamental en el orden legal, también resulta de especial obviedad que la sostenibilidad de la estructura político-corpórea que contribuye a afianzar ese derecho sea incólume, por prescripción de la voluntad general, que es el alma de la estructura corporal formada por la agrupación de los hombres y la que les otorga su condición de ciudadanos.

\subsubsection{EL TERREMOTO DE LISBOA DE 1755}

El Día de Todos los Santos de 1755 Lisboa vivió un acontecimiento trágico que marcó un antes y un después en la historia de la capital portuguesa. Un terremoto de alta magnitud desoló durante la mañana de ese fatídico día gran parte de la ciudad, en la que perecieron miles de personas que vivían o transitaban por ella. Lisboa era uno de los puertos más importantes del continente europeo y, consecuentemente, uno de los focos comerciales más concurridos. Basándose en las crónicas sobre el suceso los sismólogos de nuestro tiempo han estimado que se trató de un terremoto con una intensidad de entre

${ }^{305}$ Rousseau, ob. cit., 44. 
8,5 y 9 puntos en la escala de Richter, por otro lado, la cifra de fallecidos en la capital habría rondado las 10.000 personas $^{306}$.

En el ámbito intelectual, el análisis acerca de las causas que originaron el Terremoto de Lisboa puso de manifiesto las agudas diferencias que existían entre los intelectuales ilustrados y los intelectuales de la tradición teológica del Antiguo Régimen. Cabe advertir, no obstante, que dentro de estos dos frentes de discusión filosófica había muchas ramificaciones, no todos los ilustrados eran ateos ni todos los religiosos se adscribían, por ejemplo, al sistema de la teodicea de Leibniz; tampoco todos los ilustrados defendían el materialismo ni todos los cristianos asumían un pensamiento fatalista. Salvando estos matices, cuando hubo que ocuparse de averiguar las causas que provocaron el movimiento de tierras y mares con la consecuente desolación de Lisboa, hubo dos posicionamientos teóricos: uno veía en las conductas perversas, lascivas y viciosas de los hombres la causa principal del terremoto, fruto de la irritación divina ante tanta inmoralidad, y el otro posicionamiento trató de investigar las causas materiales que produjeron la catástrofe, para demostrar que el origen del fenómeno procedía de condiciones estrictamente físicas en las que nada tenía que ver la conducta moral de los seres humanos, por muy deplorable que esta fuera.

En un estudio sobre el tema del "mal”, titulado Desgracia e injusticia y realizado por José María Enríquez Sánchez, se menciona que el Terremoto de Lisboa de 1755 entra dentro de la categoría de "mal natural" en la medida en que vino provocado por la naturaleza misma y no por una voluntad punitiva de ultramundo. Aparte de los continuados tsunamis que vertieron el mar sobre Lisboa, además, la ciudad sufrió un incendio desde el comienzo del terremoto; así que ese día se vivieron una concatenación de infortunios y desgracias que agravaron la situación de la población allí presente. Enríquez Sánchez matiza que este tipo de fenómenos ya se habían vivido con anterioridad en la capital de Portugal, concretamente en 1531, pero que la diferencia entre un caso y el otro no radica <<en el hecho sino en la construcción teórica y narrativa que lo prosiguió >> ${ }^{307}$. A continuación se pondrá el acento en estos discursos narrativos que se formaron a raíz del acontecimiento y tragedia lisboeta con el objetivo

306 Cfr. Daniel Martín, "El terremoto y 'tsunami' de Lisboa de 1755", Pangeados, http://www.pangeados.com/2012/02/el-terremoto-y-tsunami-de-lisboa-de.html [consultado el 2/11/2016]. 307 José María Enríquez Sánchez, Desgracia e injusticia (Madrid: Sequitur, 2015), 19. 
de hacer patente en qué sentido su influencia orientaría el proceso de protección y reconstrucción de la ciudad.

Uno de los relatos que Enríquez Sánchez destaca es el de Voltaire, quien derrocha pesimismo ante la desgracia acaecida cuando trata de constatar que la naturaleza no está organizada de la mejor manera posible ni se dirige hacia el bien como su fin último, todo ello en contra de los argumentos de Leibniz y Pope, filósofos que encomiaban cualquier mal en el mundo amparándose en la figura de un Dios providente que todo lo hace para causar un bien superior, con independencia de los daños que el hombre pueda padecer durante el proceso. En este planteamiento, el mal tan solo sería aparente, puesto que seres tan imperfectos y limitados como los seres humanos son, ante la grandeza de la gloria divina, incapaces de entender que en el mundo tienen lugar ciertos dolores y daños que hacen relucir todavía con mayor brío el bien, así que nada sería esencialmente malo. Voltaire respalda su objeción a esta postura visibilizando la desolación irreversible de Lisboa, en la que el mal se había hecho evidente por sí mismo, lo que demostraría las inconsistencias de las que adolece el optimismo de los teólogos cuando racionalizan el mal a fin de salvar la bondad de Dios. La inevitabilidad del mal en el pensador francés no le fuerza a asumir un pesimismo de tipo pasivo, sino que le conduce hacia un pesimismo que acepta los males como un hecho palpable y un componente indispensable de la vida, por tanto, es un pesimismo que activa la denuncia hacia quienes creen vivir en el mejor de los mundos posibles ${ }^{308}$. En el Cándido, una de las novelas más famosas de Voltaire, cuando el protagonista Cándido y su maestro, el filósofo Pangloss, llegan a Lisboa, presencian la destrucción que el terremoto ha dejado y la conmoción de la población ante tan trágico suceso. En la novela, Voltaire escenifica cómo, tras la destrucción de las tres cuartas partes de la urbe, las autoridades religiosas de Portugal habían decidido hacer un auto de fe para todo el público con el fin de honrar a Dios, en un tono sarcástico el autor cuenta cómo $<<$ la universidad de Coimbra había dictaminado que el espectáculo de varias personas quemadas a fuego lento y con gran ceremonia era un sistema infalible para impedir que la tierra temblase $>>309$.

En el poema que Voltaire dedicó a la catástrofe de Lisboa, titulado Poema sobre el desastre de Lisboa o Examen de este axioma: <<todo está bien>>, encontramos:

Mil insectos nacerán de mi cuerpo sangriento;

\footnotetext{
${ }^{308}$ Cfr. Enríquez Sánchez, ob. cit., 22-23.

${ }^{309}$ Voltaire, Cándido y otros cuentos (Barcelona: RBA Editores, 1993), 18-19.
} 
Cuando la muerte colme los males que he sufrido

¡Qué gran consuelo ser devorado por los gusanos!

Tristes calculadores de las miserias humanas,

No me consoléis más, amargáis mis penas;

Y solo veo en vosotros el esfuerzo impotente

De un infortunado soberbio que finge estar contento.

Solo soy una débil parte de un gran todo:

Sí, pero los animales condenados a la vida,

Todos los seres sintientes, nacidos bajo la misma ley,

Viven con dolor y mueren como yo. ${ }^{310}$

Estos versos destacan la crudeza con la que Voltaire concibe la vida, además de un desarraigo ante los consuelos religiosos, ya que el autor reduce la existencia a la corporalidad, equiparándose a los animales, haciendo del sentir un motivo para experimentar el dolor y afirmando la muerte como la desembocadura inquebrantable de la vida. Frente a la actitud pesimista y el desconsuelo profundo que el desastre de Lisboa suscitó en Voltaire, encontramos la carta que Rousseau le escribió como respuesta al poema. En la mencionada correspondencia el autor de Ginebra dice que no fue producto de la naturaleza que una cantidad amplia de hombres se reuniera en un espacio reducido, donde se levantaban viviendas entre seis y siete pisos. Según Rousseau, los seres humanos se exponen al peligro concentrándose en grandes ciudades, además, cree que si los individuos que vivieron el terremoto hubiesen abandonado el lugar, no habrían sido víctimas de tanto dolor al evitar la mayoría de las lesiones y fallecimientos que padecieron ${ }^{311}$; pero como $<<$ tuvieron que quedarse allí, obstinarse en permanecer alrededor de las ruinas, exponerse a nuevas sacudidas, porque lo que se deja vale más de lo que se puede llevar $>{ }^{312}$, el entorno urbano se volvió hostil para sus propios habitantes.

Lo que Rousseau le reprocha al poema de Voltaire se asienta en una reflexión sobre la desgracia, el infortunio, la destrucción y la desolación, en la que no se culpa tanto a la naturaleza como a los hombres. Ahora bien, en Rousseau se acusa un desarrollo reflexivo radicalmente diferente al modo en que lo pensaron los religiosos, ya que el

\footnotetext{
${ }^{310}$ Voltaire, Poema sobre el desastre de Lisboa o Examen de este axioma: <<todo está bien>>; en Voltaire-Rousseau. En torno al mal natural, Alicia Villar (Madrid: Alianza Editorial, 1995), 161.

${ }^{311}$ Cfr. Jean Jacques Rousseau, Carta de J.-J. Rousseau a Voltaire. 18-8-1756; en Voltaire-Rousseau. En torno al mal natural, Alicia Villar (Madrid: Alianza Editorial, 1995), 186-187.

312 Rousseau, ob. cit.; en Voltaire-Rousseau. En torno al mal natural, Alicia Villar, 187.
} 
pensador en ningún momento relaciona la decrepitud moral con las tragedias naturales en las que se ven inexorablemente involucrados los humanos, es decir, no concibe un Dios castigador que intervenga ante los excesos y abusos corruptores de la integridad moral y de la vida social. Para Rousseau la tragedia de Lisboa vino motivada por el modo en que se organizan las sociedades humanas en el espacio, puesto que independientemente del fenómeno natural, la destrucción que el terremoto ocasionó en la capital no podía ser responsabilidad más que de los hombres, ellos son quienes se hacinan en ciudades y quienes ante la adversidad prefieren proteger sus posesiones en lugar de poner sus vidas a salvo. Así, el filósofo ginebrino localiza en los seres humanos conductas individuales y sociales que a menudo pueden venírseles en contra en diversas circunstancias, ya que es la propia organización humana la que a veces se torna contraria a la vida de los individuos al haberse expuesto ellos mismos a los peores rigores y males naturales.

Rousseau da a entender en su crítica al poema de Voltaire sobre el Terremoto de Lisboa que la forma en que los hombres se ordenan en el espacio en ciertas ocasiones les expone a los peligros que provienen de ciertos movimientos agresivos de la naturaleza. En la capital portuguesa se concentraba un número suculento de población y de edificios, tal disposición se hizo muy desfavorable cuando tembló la tierra y contribuyó a que los daños se agravaran considerablemente; una población que se dispone de forma más dispersa en el espacio no hubiese provocado tal cantidad de víctimas. De este modo, la distribución de la población se vuelve un factor principal para explicar por qué un hecho como un terremoto puede hacerse tan pernicioso y trágico para los hombres, nada más que por su manera de organizarse y de actuar, nada más que por una vehemencia política y económica que dota a los individuos de un estilo de vida gregario y subordinado a las propiedades que van adquiriendo. El orden de las poblaciones humanas lleva dentro de sí un germen autodestructivo susceptible de brotar en determinados momentos y en situaciones donde la organización social se vuelve desfavorable para la vida de los propios humanos. Una vez más, Rousseau da cuenta de cómo la propia sociedad humana subvierte el orden de lo natural volviéndose desfavorable para los hombres que viven en ella.

Precisamente Kant, en el primero de los tres ensayos destinados a dilucidar el origen natural de los terremotos, afirma que la dirección del movimiento sísmico que afectó a Lisboa se ubicaba a lo largo de la ribera del río Tajo, hecho que habría contribuido a 
intensificar los daños. Según el filósofo de Königsberg los terremotos y volcanes son ocasionados por la inflamación del aire en el interior de las grutas de la tierra, fruto de la combustión del aire que fluye a través de ellas ${ }^{313}$. Kant pretende conocer cuáles son las condiciones naturales de los terremotos para poder prever fenómenos de este tipo con el fin de que los humanos puedan precaverse de ellos. Pero se lamenta el filósofo de que entre los hombres prime

una opinión bien distinta de semejantes casos. Puesto que el miedo les priva de la reflexión, creen percibir en catástrofes tan generales un tipo de mal diferente de aquél frente al cual cabe tomar precauciones, y pretenden atenuar la dureza del destino mediante un sometimiento ciego, con lo cual se entregan a él incondicionalmente. ${ }^{314}$

El mal de los terremotos, así pues, se halla localizado en el interior de la naturaleza y, más concretamente, en el interior de la tierra; mediante esta reflexión Kant desmarca el mal moral de lo que podría ser tomado como un "mal natural", habiendo precisado que estos males son vistos como tales de acuerdo a los efectos catastróficos que causan en el ámbito humano. Igualmente, el autor invoca la necesidad de que los seres humanos sepan conocer los orígenes de estos y muchos otros fenómenos naturales con el fin de tener las herramientas epistémicas precisas para salvar daños y disminuir el sufrimiento que pueden llegar a ocasionar. Sería lícito afirmar que el sabio prusiano está poniendo sobre la libertad del hombre y su capacidad de conocimiento la responsabilidad de defender sus cuerpos de esos elementos dañinos y violentos que subyacen a la naturaleza física.

Y es que el Terremoto de Lisboa, al menos en una línea del pensamiento filosófico dieciochesco, puso de manifiesta la preocupación e interés de muchos autores hacia las cuestiones internas de las relaciones sociales, esos aspectos de la vida humana que tienen que ver con el mundo que se despliega en el interior de las sociedades. A parte de esta catástrofe, resulta significativo ver cómo el literato alemán de principios del siglo XIX Heinrich von Kleist representa en su novela titulada El terremoto de Chile los pormenores de sus personajes en el contexto del Santiago de Chile que fue derruido tras el terremoto que padeció esta ciudad en 1647. En una historia ficticia ambientada en

\footnotetext{
${ }^{313}$ Hoy en día esta versión explicativa de los fenómenos sísmicos está obsoleta y desmentida. La geología actual ha comprobado que los terremotos y volcanes son causados por el choque de placas tectónicas, sin que las grutas del interior de la tierra influyan.

314 Immanuel Kant, "Un texto de Immanuel Kant sobre las causas de los terremotos (1756)", Cuadernos dieciochistas, no. 6 (2005): 215-224, 219.
} 
este momento histórico verídico, un autor romántico como Kleist ya muestra la asunción de que es en el interior de las relaciones humanas donde la moralidad halla su plenitud y capacidad de superación ante los desastres naturales. No se detiene el autor en describir la desolación de la morada urbana, su objeto no es recrearse en la destrucción de edificios o la fuerza sublime de la naturaleza, estos pasajes en su obra tan solo ambientan el entorno donde se producen las conversaciones y las acciones de los personajes, en interacción con una sociedad convulsionada. Kleist entremezcla las acciones más mezquinas y despreciables con las más valerosas: en situaciones caóticas, producto del desgobierno y las consecuentes oportunidades de pillaje, los hombres, ante el miedo y la intolerancia frente a cualquier agresión, emprenden acciones como la que acaeció a aquel <<inocente, que se había salvado atravesando un edificio en llamas〉> y que $<<$ fue precipitadamente capturado por el propietario, y colgado al punto $>>{ }^{315}$; pero también se dio el caso de aquellas <<personas a las que se había prestado normalmente poca atención en la sociedad>> y que, sin embargo, <<habían mostrado una grandeza romana; multitud de ejemplos de intrepidez, de alegre desprecio del peligro, de abnegación y divino sacrificio, de ofrenda ilimitada de la propia vida, como si, igual que un bien despreciable, pudiera recuperarse en cualquier momento $>>316$.

\subsubsection{CONMOCIÓN Y EXCEPCIONALIDAD: LOS DISPOSITIVOS DEL MARQUÉS DE}

\section{Pombal}

Una parte de las autoridades portuguesas, tras el terremoto, era consciente de que las plegarias a la divinidad resultaban inútiles si lo que pretendían era eximirse de los males que tanto hicieron sufrir a los afectados. Las medidas de seguridad que se pusieron en marcha tras la tragedia lisboeta tenían el claro objetivo de aligerar los daños ocasionados y retener cualquier tipo de sedición, vulneración moral o acción ilícita. El noble encargado de proteger a la ciudad y a su población como de iniciar el proceso de reconstrucción, Sebastião José de Carvalho e Mello, Marqués de Pombal, sabía de las urgencias que más acuciaban a los supervivientes tras la desgracia, así como también percibía lo menesterosas que resultaban las soluciones propiciadas por las autoridades religiosas, que incluso llegaban a ser contraproducentes en lo que se refiere a paliar el sufrimiento. En las crónicas sobre la catástrofe, encontramos que una de las primeras medidas impulsadas por el Marqués de Pombal en los días posteriores fue enterrar

\footnotetext{
${ }^{315}$ Heinrich von Kleist, El terremoto de Chile (Girona: Ediciones Atalanta, 2008), 55.

${ }^{316}$ Keist, ob. cit., 56.
} 
rápidamente los cuerpos de los fallecidos, para que la putrefacción de los cadáveres no contagiara la peste por cada rincón. Así, una circular del 5 de noviembre instaba a los prelados de los conventos a que con premura iniciaran los ritos de sepultura para que el contagio de las enfermedades no ocasionara una mayor consternación en la sociedad lisboeta $^{317}$. Los apuros civiles prevalecían sobre los rituales religiosos.

El problema de la putrefacción y de la transmisión de enfermedades preocupaba a científicos y autoridades seculares del siglo XVIII. Alain Corbin, en El perfume o el miasma, encuentra que en la modernidad, y muy especialmente en el XVIII, las percepciones olfativas pasan a ser atendidas en tanto en cuanto se descubre que hay enfermedades que se transmiten por medio del aire, lo que generó una especie de angustia ante los ambientes y cuerpos putrefactos ${ }^{318}$. Dado que en esta obra Corbin emplea un método genealógico para investigar el desarrollo de las imágenes olfativas y la concepción del sentido del olfato desde la etapa moderna hasta el siglo XIX, se hace oportuno poner de relieve cómo la amenaza morbífica del cadáver se traduce a la aplicación de dispositivos destinados a detectar los miasmas del entorno y a salvar el espacio social de las amenazas patógenas oscilantes, de modo que los cuerpos, vivos o muertos, se convierten en una amenaza fáctica. De ahí -señala Corbin- la articulación de métodos de vigilancia olfativa para, ya no solo localizar los cuerpos putrefactos, sino también para instalar una nueva imagen de la amenaza, en este caso, por la vía del olfato; se trata de una vigilancia que consiste en $<<$ la atención permanente a la desintegración de los seres y de sí mismo >> ${ }^{319}$. También, dice el autor que en el siglo XVIII se cae en la cuenta de <<que un aire puro constituye el mejor de los antisépticos, porque las emanaciones que surgen de los cuerpos y la basura encarnan la amenaza pútrida, desamontonar a los individuos, es ya desinfectar $>>320$.

Que una de las primeras órdenes en la Lisboa recién sacudida por el terremoto fuera sepultar cuanto antes los cadáveres, nos ofrece una ligera muestra de que la "cólera divina" no estaba entre los problemas que más inquietaban al Marqués de Pombal, sino que, más bien, su preocupación inmediata se cernía sobre las enfermedades que transmiten los cuerpos en estado de descomposición. Probablemente, para ciertas élites

\footnotetext{
${ }^{317}$ Cfr. Cláudio de Conceição, Notícia do Terramoto (Lisboa: Frenesi, 2005), 33-34.

${ }^{318}$ Cfr. Alain Corbin, El perfume o el miasma (México D.F.: Fondo de Cultura Económica, 1987), 29.

${ }^{319}$ Corbin, ob. cit., 29.

${ }^{320}$ Corbin, ob. cit., 118.
} 
cultas, el objeto de intranquilidad también se correspondía con la imagen de esos cadáveres malolientes e infecciosos dispersos entre las ruinas.

Otro problema que moraba entre las ruinas de Lisboa y al que Pombal tuvo que hacer frente no procedía, en este caso, de la amenaza pestilente de los cuerpos muertos sino de las intenciones de algunos "cuerpos vivos", los cuales veían en la situación excepcional del momento la oportunidad perfecta para agenciarse aquellos objetos valiosos desparramados alrededor de las calles y edificios destruidos -nos estamos refiriendo a los robos-. El 4 de noviembre Pombal envió cartas a los corregidores de las comarcas portuguesas para que identificaran a las personas sospechosas que transitaran por sus tierras. En la capital se aligeraron los procedimientos de ejecución de sentencias para los acusados por robo, estas sentencias venían precedidas de un proceso meramente verbal $^{321}$. Tales medidas implicaban clasificar a la población y mantener latente la vigilia de las instituciones para que las fuerzas del orden y los ciudadanos pudieran anticiparse a cualquier delito. Desde el momento del terremoto se desplegó un dispositivo de control por todos los espacios de la ciudad:

Decreto de la misma fecha, para los corregidores de los barrios de Lisboa, cada uno de sus distritos, examinarán las vidas, costumbres y ministerios de todos sus habitantes; prenderán y multarán a los ociosos, imponiendo a los culpados la pena de trabajar con grillete en las obras públicas de la ciudad. ${ }^{322}$

La articulación de este dispositivo precisaba que cada individuo se mantuviera en vilo, que en cada uno de los espacios de Portugal se localizaran e identificaran los cuerpos de sus transeúntes, que se observaran las conductas de los individuos para detectar posibles anomalías en su comportamiento, etc., así, la sospecha se extendió entre la población, cualquiera podía acusar o ser acusado de cometer robos y ser culpado o absuelto mediante sentencias rápidas, inapelables e indiscutibles. Toda la población quedó sujeta a una presión ejercida sobre su vida cotidiana; en los espacios locales, cualquier detalle podía ser susceptible de contener un riesgo de criminalidad, la alarma permanente y la alerta social imponían un sistema de control social que compensaba el desorden ocasionado por un acontecimiento natural de dimensiones

\footnotetext{
${ }^{321}$ Cfr. Cláudio de Conceição, Notícia do Terramoto (Lisboa: Frenesi, 2005), 42.

$322<<$ Decreto da mesma data, para os corregedores dos bairros de Lisboa, cada um nos seus distritos, examinarem as vidas, costumes e ministérios de todos os seus habitantes; prenderem e autuadem os ociosos, impondo aos culpados a pena de trabalharem com braga nas obras públicas da cidade>>. Cláudio de Conceição, Notícia do Terramoto (Lisboa: Frenesi, 2005), 42 (traducción propia).
} 
catastróficas. Portugal había puesto en funcionamiento los mecanismos característicos de un "Estado de excepción". Precisamente la excepcionalidad es uno de los temas que ocupa Giorgio Agamben, de hecho, una de sus obras lleva por título Estado de excepción. De dicha obra conviene extraer la concepción del estado de excepción como un momento de indeterminación de la ley, indeterminación porque en los estados de excepción no existe ni un afuera ni un adentro de la legalidad jurídica. De este modo Agamben sostiene que dentro del estado de excepción se produce una suspensión de la ley que no lleva consigo la anulación de esta, aserción que se resume en la fórmula: "suspender la norma no implica su abolición", de forma que no hay una disrupción del ordenamiento jurídico en el ámbito anómico generado por la situación de excepcionalidad, en la medida en que la ley tan solo queda suspendida de manera parcial $^{323}$. La agilización de los procedimientos judiciales en la Lisboa posterior al terremoto es un claro ejemplo de excepcionalidad, y en rasgos generales, la situación que vivió la ciudad mantiene una estrecha semejanza con los planteamientos agambesianos.

Otro asunto derivado de la situación excepcional que provocó el Terremoto de 1755 en Lisboa y en Portugal, que, además, resulta analizable desde el prisma agambesiano, tiene que ver con los poderes especiales que adquirió Pombal tras la catástrofe. Resulta que Agamben no concibe la suspensión del derecho ni como una situación dictatorial ni como una vuelta a un supuesto estado de naturaleza. Para salir al paso de estas consideraciones acerca del estado de excepción, Agamben recurre a un concepto propio del derecho romano llamado iustitium en el que un hombre es designado para gestionar y superar una situación de urgencia excepcional; este hombre no tiene, por supuesto, la función de legislar, pero tampoco la de ejecutar o transgredir las leyes, sino que tan solo se encarga de no aplicarlas, en tanto en cuanto el poder que se le asigna es una medida ocasional, es decir, quien administra la excepcionalidad actúa fuera de la legalidad, cuya vigencia ha quedado parcialmente anulada por tiempo indeterminado. El mando del hombre designado para actuar en una coyuntura de urgencia excepcional tiene potestad

\footnotetext{
323 Según las propias palabras de Agamben: <<el estado de excepción no es ni externo ni interno al ordenamiento jurídico, y el problema de su definición concierne precisamente a un umbral, o a una zona de indiferenciación, en el cual dentro y fuera no se excluyen sino que se indeterminan. La suspensión de la norma no significa su abolición, y la zona de anomia que ella instaura no está (o al menos pretende no estar) totalmente escindida del orden jurídico >. Giorgio Agamben, Estado de excepción. Homo sacer, II, I (Buenos Aires: Adriana Hidalgo, 2005), 59.
} 
solamente en la franja de indeterminación de la anomia ${ }^{324}$. Este papel es el que realizó el Marqués de Pombal justo después del terremoto; los poderes de los que fue investido le vinieron dados por el rey de Portugal, había una serie de urgencias muy singulares y muy concretas que no pusieron al país bajo un régimen dictatorial, la monarquía continuaba teniendo plenos poderes, sino que hizo de Pombal una figura de poder instaurada al margen de las magistraturas y de la legislación.

El luto generalizado en Lisboa es, finalmente, el hecho que confirma la presencia de una anomia en medio de un panorama excepcional, de hecho, el despliegue de ritos fúnebres, indiferentemente de la superficie simbólico-religiosa que los acompañaba, cumplían una función -también simbólica- en el terreno civil que contribuía a justificar las medidas de excepción. La secularidad que se asentaba tras toda la parafernalia fúnebre se halla precisamente en ese carácter excepcional que imponía el momento. Este tipo de rituales suponía un material significativo que justificaba en el terreno de la facticidad las aplicaciones excepcionales, pues era necesario crear un ambiente que situara tanto a las instituciones como a la población fuera de lo habitual; siguiendo las palabras de Agamben a este respecto:

Así como en los periodos de anomia y de crisis se asiste a un colapso de las estructuras sociales normales y a un desarreglo de los roles y de las funciones sociales que puede llevar hasta la completa inversión de los hábitos y de los comportamientos culturalmente condicionados, asimismo los periodos de luto se caracterizan generalmente por una suspensión y una alteración de todas las relaciones sociales. ${ }^{325}$

A tenor del estado de excepción que vivió Lisboa tras la conmoción del terremoto hay que fijarse en los dispositivos de seguridad y control que se pusieron en marcha para controlar y organizar al cuerpo social en tales circunstancias, estos dispositivos recuerdan al reglamento del siglo XVIII que Michel Foucault comenta a propósito del tema de "la ciudad apestada" en Vigilar y castigar, justo cuando tiene comienzo el capítulo llamado "El panoptismo" ${ }^{326}$. Las medidas a las que hace referencia Foucault se contextualizan en ciudades atacadas por la peste. El autor configura la imagen de "la ciudad apestada" para caracterizar una situación en la que se ponía en funcionamiento un dispositivo de control intensivo sobre los cuerpos de los civiles para contrarrestar los

\footnotetext{
${ }^{324}$ Cfr. Giorgio Agamben, Estado de excepción. Homo sacer, II, I (Buenos Aires: Adriana Hidalgo, 2005), 98-99.

325 Agamben, ob. cit., 124.

${ }^{326}$ Cfr. Michel Foucault, Vigilar y castigar (Madrid: Biblioteca Nueva, 2012), 227.
} 
daños causados por el contagio de la peste en las ciudades. La permanencia del estado de sitio, la clasificación de la población, la especificación analítica de la vigilancia en cada una de las divisiones de la ciudad y una captación de todo tipo de irregularidades, son formas de control similares al dispositivo instalado por Pombal tras el terremoto. La vigilancia generalizada, el registro, el reparto de funciones de mando a distintos sectores del espacio urbano trazados independientemente de la distribución habitual de las barriadas, las clasificaciones de los vecinos y el examen de los cuerpos forman parte del dispositivo de control dieciochesco descrito por Foucault ${ }^{327}$. Sea un terremoto, sea la peste, o cualquier otra amenaza procedente de la naturaleza, sus daños iban a suponer el reforzamiento de los mecanismos de control y la introducción de nuevas técnicas de gestión y administración de los cuerpos.

Las medidas que Pombal adoptó para paliar los efectos nocivos del terremoto encajan perfectamente dentro del concepto foucaultiano de "dispositivo" debido a que perseguían atrapar a los cuerpos para conducirlos hacia una situación que, incluso, mejorara las condiciones de vida anteriores al desastre. El objetivo de estos dispositivos era reconstruir la ciudad de Lisboa pero, además, crear un nuevo panorama en la distribución y administración del paisaje urbano con el objetivo de mejorar el estado de la ciudad previo al terremoto. Siguiendo la interpretación que ofrece Agamben acerca del dispositivo foucaultiano es posible definir el término "dispositivo" como todo aquello que sirve para <<capturar, orientar, determinar, interceptar, modelar, controlar y asegurar los gestos, las conductas, las opiniones y los discursos de los seres vivientes $>>{ }^{328}$. Al menos la intercepción de apariencias sospechosas tanto en la vestimenta como en los rasgos fisionómicos y el comportamiento de los individuos, y que cualquiera pudiera denunciarlos por estos hechos, cuenta como uno de los dispositivos instalados por Pombal para ejercer el control social, esta era una de esas prácticas propias del cinturón de control que se cernía sobre la población. En medio de situaciones límite, en las que el cuerpo social se ve preso del pánico y la desolación, los dispositivos aparecen como elementos que mantienen y reconstruyen el orden allí donde la acción de los cuerpos tiende a disolver la complexión social; por ello, donde amenazan desastres naturales ya sean inherentes a las corporalidades humanas (epidemias) o externas al ordenamiento de la sociedad (desastres naturales), a las que en

\footnotetext{
${ }^{327}$ Cfr. Foucault, ob. cit., 228.

${ }^{328}$ Giorgio Agamben, ¿Qué es un dispositivo? seguido de El amigo y de La Iglesia y el Reino (Barcelona: Anagrama, 2015), 23.
} 
todo caso acompañan el hambre y los tumultos, apremia crear contrapesos en los que tiene que estar involucrado todo el cuerpo social, sin que ninguno de sus componentes quede aislado de los dispositivos de control. En esta dirección Foucault apunta que $<<a$ la peste responde el orden; tiene por función desenredar todas las confusiones: la de la enfermedad que se trasmite cuando los cuerpos se mezclan; la del mal que se multiplica cuando el miedo y la muerte borran las prohibiciones $>>{ }^{329}$. Aquí se encuentra la clave para interpretar los códigos de emergencia desplegados en el XVIII.

Ya no solo se trataba de proteger a los hombres de una naturaleza que enseña su faceta más hostil, se trataba también de protegerse de la propia naturaleza humana, protegerse de los elementos patógenos internos a los cuerpos de los ciudadanos. Procurar contener las reacciones de los individuos en un contexto de histeria ante el peligro inminente pasa indefectiblemente por retener sus cuerpos; de la misma manera que en Lisboa había que frenar el contagio de la peste apartando, sepultando y aislando bajo tierra los cuerpos muertos, también había que resguardar a los ciudadanos de los impulsos cleptómanos procedentes de los cuerpos vivos. En general, todos los cuerpos representaban una potencial amenaza que había que erradicar afirmando y realizando los mecanismos del poder civil. Uno de los dispositivos más efectivos para disuadir propósitos delictivos era ajusticiar a ladrones asestándoles la pena capital en patíbulos expuestos al público, de modo que una vez mostrada la ejecución $<<$ los cadáveres de los castigados, como permanecían en el mismo lugar del suplicio hasta consumir el tiempo, eran un cambio más elocuente de voz, que persuadía a los vivos de evitar los robos si querían salvar la vida $>{ }^{330}$. Se hace ostensible cómo la corporalidad se convierte en un elemento material indispensable y en una referencia objetiva de la facticidad del poder. Por otro lado, encontramos que el espacio va a representar el escenario táctico donde los cuerpos son dispuestos de acuerdo al lugar que les ha sido asignado por las instancias de poder.

\subsubsection{Pragmática POLÍtica ANTE LAS URgenCias ECONÓMICAS}

Otro asunto que afectaba directamente a la población lisboeta y al que Pombal tuvo que plantar cara era el hambre y el desabastecimiento. Cubrir las demandas básicas de subsistencia exigía llevar a cabo medidas de carácter económico. Los días dos y tres de

\footnotetext{
${ }^{329}$ Michel Foucault, Vigilar y castigar (Madrid: Biblioteca Nueva, 2012), 229.

330 < <os cadáveres dos punidos, como ficavan no mesmo lugar do suplicio até os consumir o tempo, eran uma muda mas eloquente voz, que persuadía aos vivos a evitar os roubos se queriam salvar as vidas $>$. Cláudio de Conceição, Notícia do Terramoto (Lisboa: Frenesi, 2005), 44 (traducción propia).
} 
noviembre Pombal le transmitía al Marqués de Alegrete, presidente de la cámara del Senado, las siguientes indicaciones: el primer día se le encomendó repartir los víveres que llegaban a la ciudad entre sus doce barrios, y en una siguiente circular del mismo día se le ordenó nombrar doce jueces por cada barrio, lo que equivalía a propiciar un aumento de las autoridades distribuidas entre áreas más pequeñas, haciendo así más estrecho el radio de control poblacional y permitir de este modo una vigilancia más específica. En el aviso del día tres se mandaba liberar las tasas impositivas sobre el pescado que se vendiere desde Belém a Santarém (barrios de Lisboa) y anular provisionalmente los aranceles de los productos alimenticios entrantes, la finalidad era motivar la reducción de los precios de bienes de primera necesidad; asimismo, en otra carta, Pombal hacía un llamamiento a los hacendados de las tierras a orillas del Tajo para que entregaran harina y otros productos al presidente de la Cámara ${ }^{331}$.

La gestión económica del desastre de Lisboa también forma parte del operativo de control que se puso en práctica, se aplicaron políticas económicas excepcionales para resolver los problemas de desabastecimiento que comenzaron a darse nada más concluir el terremoto. En un artículo titulado El terremoto de Lisboa de 1755 y la política de regulación económica del Marqués de Pombal José Luis Cardoso comenta que los estímulos que recibió el comercio tras la supresión de tasas y aranceles favorecieron el desarrollo de la economía portuguesa en los siguientes años ${ }^{332}$. Para Cardoso, el proceso de reconstrucción de Lisboa encabezado por Pombal supuso una oportunidad para apartar los signos y supersticiones propios de la tradición teológica y sustituirlos por la celebración de la razón y la autoridad estatal ${ }^{333}$. Huelga añadir que, si bien, la reconstrucción y mejora de la capital y de la economía del país evidenciaban lo que ya decía la teodicea, que tras el paso de la ruina y la conmoción se producen bienes superiores, también es cierto que la procesión de los bienes vino de la mano del mercado, dado que, en ningún momento, los males acontecidos contribuyeron a mejorar la moral cívica; la mejoría de Portugal solo fue valorada en términos económicos, la teodicea dejaba paso a la economía y la fe al mercado, este último se advertía, en consecuencia, como un espacio secular privilegiado en lo que se refiere al cálculo del progreso de la humanidad, una idea que se ha venido prolongando hasta nuestros días.

\footnotetext{
${ }^{331}$ Cfr. Cláudio de Conceição, ob. cit., 34-35.

${ }^{332}$ Cfr. José Luís Cardoso, "El terremoto de Lisboa de 1755 y la política de regulación económica del Marqués de Pombal", Historia y política, no. 16 (2006): 209-236, 215.

${ }^{333}$ Cfr. Cardoso, ob. cit., 232.
} 
Cardoso menciona que el Marqués de Pombal, por la forma en que se ocupó de la administración y la reconstrucción de Lisboa, demostró un pragmatismo claro en la consecución de los objetivos que le fueron encomendados. Si para cumplir con su deber Pombal debía aplicar una jurisdicción liberal, pese a sus convicciones proteccionistas, así lo hizo, siempre en miras a conseguir una recuperación rápida por la vía que mejores garantías ofrecía ${ }^{334}$. Además de hacer un análisis contable de las pérdidas y de los efectos de las medidas que adoptó, el Marqués portugués también calculó hasta qué punto la desacralización de la naturaleza en la época ilustrada iba a permitirle legitimar sus decisiones frente a una población temerosa de Dios y cargada de supersticiones. Para justificar el talante secularista de sus políticas en Lisboa, Pombal primero tenía que convencer a la opinión pública de que las causas del terremoto eran exclusivamente naturales:

Para que el papel del Estado pudiese ser cumplido plenamente, para que los súbditos aceptasen el ejercicio de un poder despótico, pero ilustrado, era crucial entender que el terremoto tenía causas naturales y que, naturalmente, tan sólo el poder secular estaba preparado para actuar con eficacia y resolver la emergencia en que se encontraban tanto el país como su capital. En otras palabras, la catástrofe no podía ser resuelta por intercesión divina, ni en la explicación de su origen, ni en la superación de sus secuelas. ${ }^{335}$

La intervención del Estado en asuntos sociales y económicos en la coyuntura de la catástrofe iba acompañada de una ruptura con el relato tradicional impuesto por la religión, no iba a ser la Iglesia el actor principal en la gestión de la crisis, la responsabilidad de administrar la delicada situación ocasionada por la naturaleza tenía que recaer sobre una fuerza que convivía con la naturaleza, la del Estado, fuerza que ostentaba legítimamente el dominio, cuidado y disposición del cuerpo social en su totalidad. Economía y política iban a ser los dominios de saber cuya aplicación contribuiría a realizar la tarea de rehabilitar, reconstruir y restaurar el orden social en Lisboa, tarea en la que Pombal <<demostró ser consciente del complejo esfuerzo organizativo y logístico que la situación requería $>{ }^{336}$. Por tanto, la reconstrucción de la capital portuguesa tenía que ser dirigida por poderes que conocieran al hombre en su acepción física y psicológica, que permitieran anticiparse a sus acciones y que supieran

\footnotetext{
${ }^{334}$ Cfr. Cardoso, ob. cit., 223.

335 Cardoso, ob. cit., 226.

${ }^{336}$ Cardoso, ob. cit., 229.
} 
organizar el espacio para lograr las condiciones óptimas de cara al control de los cuerpos.

Conviene preguntarse, al margen de las implicaciones del poder estatal en el proceso de restauración de Lisboa: ¿qué clase de poder representaba el mercado en la rehabilitación y reconstrucción de la capital portuguesa? ¿Cuáles eran las posibilidades transformadoras del espacio mercantil en lo referente al encauzamiento de los movimientos de la población? Las respuestas se pueden encontrar en los estudios económicos que muchos pensadores de la época hicieron sobre el comercio, en los que destacaban intentos por demostrar las consecuencias benéficas que traería consigo su fomento.

En Ensayo sobre la naturaleza del comercio en general, obra de Richard Cantillon, a quien se le considera un pensador económico cuyas ideas representan un antecedente de Adam Smith ${ }^{337}$, se hace hincapié en que las actividades productivas previas al intercambio comercial conllevan un crecimiento de los recursos del gobierno, ya que el $<<$ nuevo aumento en el número de empresarios y artesanos de toda clase resultará indispensable para el sostenimiento de las gentes de justicia y de los abogados $>>338$. Asevera Cantillon que a este razonamiento subyace la intención de encontrar una relación de proporcionalidad entre el tamaño de las ciudades y el número de propietarios de tierras que habitan en ellas ${ }^{339}$. Cantillon sostiene que la cantidad de población depende del número de tierras porque la producción de estas proporciona los medios necesarios para la manutención de las personas. El autor introduce explicaciones de sesgo economicista para comprender determinados comportamientos humanos, razón por la que interpreta aspectos relacionados con la natalidad a partir de la observación de las condiciones y circunstancias de los progenitores; los individuos que poseen algún tipo de terreno calculan cuánta producción requerirán para formar una familia ${ }^{340}$. Dentro de la manera economicista de ver las cosas el cuerpo es concebido como una carga de necesidades que hay que cubrir produciendo los bienes requeridos para hacerlo.

\footnotetext{
${ }^{337}$ Cfr. W.S. Jevons, "Richard Cantillon y la nacionalidad de la economía política"; en Ensayo sobre la naturaleza del comercio en general, Richard Cantillon (en Biblioteca de la libertad), http://biblioteca.libertyfund.org/sites/default/files/naturaleza-del-comercio-electronico.pdf [consultado el 29/10/2016], 138.

338 Richard Cantillon, Ensayo sobre la naturaleza del comercio en general (en Biblioteca de la libertad), http://biblioteca.libertyfund.org/sites/default/files/naturaleza-del-comercio-electronico.pdf [consultado el 29/10/2016], 8 .

${ }^{339}$ Cfr. Cantillon, ob. cit., 9.

${ }^{340}$ Cfr. Cantillon, ob. cit., 30.
} 
Cantillon mide el desarrollo de los países a partir del desarrollo de su comercio, asevera que para que un Estado en decadencia reflote necesita que inversores extranjeros depositen su confianza en el gobierno y accedan a prestarle dinero a dicho Estado, esta sería la única forma de aumentar la masa monetaria en circulación ${ }^{341}$. El enriquecimiento de un Estado procede fundamentalmente de su comercio exterior, por ello, es importante perseverar en el fomento de una balanza comercial favorable pues los datos económicos determinan la solidez y solvencia de los Estados ${ }^{342}$. Vemos cómo Cantillon encuentra que en el espacio del mercado se hacen transparentes las fuerzas de los Estados, en tanto en cuanto son visibilizadas sus fortalezas y también sus flaquezas en términos económicos, es decir, el mercado proporciona indicadores que informan de las capacidades de los países y de los efectos de sus políticas económicas, el mercado exhibe las condiciones materiales de las naciones, así, quien entra en su espacio de acción está expuesto a la visibilidad de los otros participantes. Cantillon observa que el mercado puede actuar como un baremo suficientemente objetivo para establecer el valor del oro y la plata, puesto que observar las variantes de este valor en el precio que imponen los Estados distorsiona su valor real al no acoplarse a los parámetros apreciables en el natural intercambio comercial, lo mismo sucedería en lo concerniente al valor de cualquier otro artículo $^{343}$. El autor da cuenta de que sus ideas han sido plasmadas con base en sus experiencias comerciales y que la ignorancia acerca de lo que acaece en el terreno económico suele ser la causa de la mala administración de los Estados:

No sé si habré conseguido convencer con mis razonamientos a quienes no tienen idea del comercio. Estoy persuadido de que quienes poseen una práctica al respecto los habrán comprendido con facilidad, y me explico que se extrañen de que quienes dirigen los Estados y administran las finanzas de los grandes reinos sepan tan poco de la naturaleza de los cambios y prohíban la salida de materias primas y de especies de oro y plata, al mismo tiempo. El único medio de conservarlos es conducir tan bien el comercio con el extranjero que el saldo no sea desfavorable al Estado. ${ }^{344}$

El espacio del mercado vino extendiéndose a lo largo del globo terráqueo desde el siglo XVI. A medida que aumentaban las redes comerciales los Estados eran más

\footnotetext{
${ }^{341}$ Cfr. Cantillon, ob. cit., 71.

342 Cfr. Cantillon, ob. cit., 89.

${ }^{343}$ Cfr. Cantillon, ob. cit., 103-104.

${ }^{344}$ Cantillon, ob. cit., 97.
} 
interdependientes los unos con respecto a los otros, en el siglo XVIII los pensadores económicos y políticos habían detectado esta relación de interdependencia, de tal forma que el sentido de lo político cada vez entrelazaba vínculos más estrechos con el cálculo comercial y los análisis económicos. Los pensadores políticos, en su mayoría, fueron haciéndose conscientes de cómo el destino del soberano iba de la mano del mercado. Hume afirma muy tajantemente a este respecto que $<<$ la grandeza del soberano y la felicidad del Estado van en gran medida unidas al comercio y a la manufactura $>>345$.

Hume observa que entre las gentes de su época existía una suspicacia hacia el comercio en cuanto que se creía que el progreso de los países en los mercados se daba en detrimento de otros, idea que el pensador escocés encuentra errónea ya que, muy por el contrario, el avance comercial de un Estado resulta beneficioso para sus Estados vecinos, porque si un pueblo industrioso está rodeado de países donde abunda la ignorancia, la pereza y la barbarie, entonces, cualquier tipo de relación comercial estable sería muy complicada, dado que no habría con quien entablar relaciones de intercambio en ausencia de bienes susceptibles de intercambio ${ }^{346}$. De ahí que el razonamiento de Hume concluya que el fomento del comercio beneficia a todos los pueblos y gobiernos de manera mutua. Hume trata de confirmar esta visión benéfica del comercio a partir del ejemplo de Gran Bretaña: <<cuando se mantiene una comunicación abierta entre las naciones es imposible que la industria interior de cada una de ellas no experimente un aumento como consecuencia de la mejora de las otras $\gg{ }^{347}$. Así fue como -según Hume-, mediante la adquisición de productos y técnicas extranjeras, los pueblos afincados en las tierras británicas pudieron prosperar y adoptar las mejores técnicas de manufacturación.

\subsubsection{GOBIERNO COMO ENCAUZAMIENTO DE LOS FLUJOS DE LA POBLACIÓN}

En La riqueza de las naciones Smith promueve el libre tránsito del trabajo y el capital, el economista escocés afirma tajantemente que la política económica europea obstruye <<la libre circulación de un empleo a otro >>, debido a esos <<privilegios exclusivos de los gremios $>{ }^{348}$, cuya causa más obvia es el debilitamiento de la circulación del capital:

\footnotetext{
345 David Hume, Ensayos morales, políticos y literarios (Madrid: Trotta, 2011), 248.

${ }^{346}$ Cfr. Hume, ob. cit., 300.

${ }^{347}$ Hume, ob. cit., 301.

348 Adam Smith, La riqueza de las naciones (Madrid: Alianza Editorial, 2001), 198.
} 
Todo lo que obstaculice la libre circulación del trabajo de un empleo a otro, hace lo propio con el capital, puesto que la cantidad de capital que puede ser invertida en cualquier negocio depende muy estrechamente de la cantidad de trabajo que pueda ser empleada en él. ${ }^{349}$

En sintonía con los efectos benéficos que el pensamiento económico smithiano ve en la libre circulación del trabajo y el capital surgía, dentro del campo práctico, la problemática de cómo ejercer un control sobre estos movimientos "liberados". En Seguridad, territorio, población Foucault investiga, entre otros asuntos, las transformaciones de los mecanismos reguladores de la circulación en la Europa del siglo XVIII, que tuvieron lugar gracias al auge del mercado. Dice que la circulación se convirtió en <<un objeto privilegiado de la policía〉> ${ }^{350}$, entendiendo "la circulación" en un sentido más amplio que el mero tránsito de cuerpos y productos:

Pero por "circulación" no hay que entender únicamente esa red material que permite la circulación de las mercancías y llegado el caso de los hombres, sino la circulación misma, es decir, el conjunto de los reglamentos, restricciones, límites o, por el contrario, facilidades y estímulos que permitirán el tránsito de los hombres y las cosas en el reino y eventualmente allende sus fronteras. De allí esos reglamentos policiales típicos, algunos de los cuales reprimen el vagabundeo, otros facilitan la circulación de las mercancías en tal o cual dirección [y] otros impiden que los obreros calificados se alejen de su lugar de trabajo y, sobre todo, marchen del reino. Tras la salud, los víveres, los artículos de primera necesidad y la población misma, todo ese campo de circulación se convertirá en objeto de la policía. ${ }^{351}$

El espacio del mercado se expandía, sí, pero en él tenían que instalarse operativos de control que pautaran la transición del flujo de cuerpos humanos y objetos físicos. Los cuerpos humanos movidos por el trabajo y el dinero, el dinero movido por el intercambio de productos y, en definitiva, todos los cuerpos humanos o no humanos movilizados en el mercado debían fluir de acuerdo a formas de circulación que no desbordaran la soberanía de los Estados, para lo que se requería de una corporación de fuerza como la policía, responsable de controlar la circulación.

\footnotetext{
${ }^{349}$ Smith, ob. cit., 199-200.

${ }^{350}$ Michel Foucault, Seguridad, territorio, población (Buenos Aires: Fondo de Cultura Económica de Argentina, 2004), 374.

${ }^{351}$ Foucault, ob. cit., 375.
} 
A medida que se incrementaba el volumen de la producción y de los negocios, la espacialidad del mercado adquiría un mayor nivel de solapamiento al espacio político, de tal modo que la pragmática gubernamental tuvo que ir asimilando e integrando conocimientos acerca del funcionamiento del mercado. El problema era cómo legitimar la soberanía sobre el territorio en convergencia con las dinámicas mercantiles. Rousseau fue uno de los filósofos que supo detectar la importancia política del territorio en la modernidad, consideró que la posesión del territorio era una condición esencial del derecho a gobernar por parte de los soberanos, puesto que la primera condición para legitimar el poder soberano radicaba en la posesión territorial. Rousseau observó que, mientras los monarcas de la antigüedad se consideraban reyes de su población, los monarcas de su tiempo se consideran, primero y ante todo, poseedores del territorio, ya que de esta manera se aseguraban el dominio sobre sus habitantes ${ }^{352}$.

No es baladí la observación rousseauniana acerca del procedimiento de legitimación del poder soberano en la modernidad, en la medida en que el autor se sitúa ante una forma de gobierno de las poblaciones basada en el hecho de que el gobernante es el poseedor del territorio, y al ser propietario de nada más que del territorio, por extensión, tiene derechos de gobierno sobre la población que allí reside. Desde la perspectiva de Rousseau se da paso a una ontología del espacio político que justifica la regulación de los flujos de las propiedades y de los cuerpos circulantes en los territorios soberanos, incluidos los cuerpos que realizan la agencia de la producción. El espacio mercantil transita a través de este espacio ontológico-político. La presencia del comercio moviliza a las poblaciones en el proceso productivo de los bienes extraídos de las posesiones del territorio soberano, y los introduce en la red comercial trazada a partir del intercambio de productos y dinero. Pero, sin embargo, el mercado puede escapar de la soberanía estatal, ya que el volumen de su espacialidad supera el tamaño territorial de cada uno de los Estados, por lo que las regulaciones soberanas solo podrán ceñirse a los cuerpos que puntualmente ocupan o transitan el territorio de uno u otro Estado, es decir, sería posible eliminar el comercio e incluso prohibir ciertas actividades de producción en un determinado lugar, pero tales decretos quedarían restringidos a los límites fronterizos del Estado soberano que los aplica, sin que puedan abarcar la totalidad del espacio por el que se extiende el mercado.

\footnotetext{
${ }^{352}$ Cfr. Jean Jacques Rousseau, El contrato social (Madrid: Aguilar, 1970), 24.
} 
A propósito del enfoque conceptual que Rousseau hace acerca de la población, cabe atender a los parámetros que estima pertinentes para mensurar la fuerza de los cuerpos políticos, el ginebrino utiliza dos criterios: la extensión del territorio y el número de habitantes. Sostiene que tiene que haber un equilibrio entre las posibilidades de producción y consumo que ofrece la tierra por un lado, y la destreza de los hombres para aprovechar los bienes que da la tierra por otro.

Son los hombres quienes hacen el Estado, y es la tierra lo que alimenta a los hombres: la relación es, pues, que la tierra baste al sostenimiento de sus habitantes, y que haya tantos habitantes como la tierra pueda mantener. En esta proporción se encuentra el máximo de fuerza de un número de gente. ${ }^{353}$

La imagen de la población como una fuerza que actúa sobre el territorio soberano movilizada por el mercado condujo a un nuevo modo paradigmático de concebir la corporalidad social. Foucault dice a este respecto: <<la población como conjunto de fenómenos naturales toma el relevo de la población como agrupamiento de súbditos $>{ }^{354}$. Mediante esta definición lapidaria, el pensador francés está dando debida cuenta del proceso dieciochesco por el que el concepto de población pasó a introducirse en los márgenes de la physis -dada la naturalización de los espacios político y económico promovidos por muchos pensadores de la época-. De este modo la población va a ser entendida como si de un accidente natural se tratara, como si fuera un agente físico más, como si gobernarla consistiera en algo semejante a interponer diques para regular el cauce descontrolado de un río. Observamos por qué para Foucault la policía actúa como ese "dique" interpuesto para contener cualquier desbarajuste en la circulación de la población, es decir, cualquier tipo de perturbación que pudiera perjudicar el orden regulativo establecido. Aquí se halla implícita, consecuentemente, la idea de Rousseau ${ }^{355}$ de que el soberano tiene que poseer el territorio si quiere contar con los medios legítimos para gobernar.

\footnotetext{
${ }^{353}$ Rousseau, ob. cit., 51.

${ }^{354}$ Michel Foucault, Seguridad, territorio, población (Buenos Aires: Fondo de Cultura Económica de Argentina, 2004), 403.

355 La definición que Foucault le atribuye al concepto "población" según la nueva caracterización paradigmática que se hacía de esta entidad en el siglo XVIII no la realiza el autor ni a consecuencia de ninguna observación previa sobre la filosofía política de Rousseau ni en relación con ningún tema específico sobre Rousseau. Esta es una relación que ha sido establecida con base en el análisis de los textos de ambos autores, es una reflexión anacrónica (de un pensador del siglo XVIII y de otro del XX) pero que suplementa la idea de territorio soberano de Rousseau con el concepto de población que interpreta Foucault a raíz de los cambios que están patentándose en la teoría del gobierno del siglo XVIII.
} 
A tenor del problema de la circulación, puede hacerse imaginable cómo el Marqués de Pombal, cuando inició la reconstrucción de Lisboa, tuvo que tener presente que la geografía urbana debía admitir formas adaptadas al incipiente espacio mercantil, formas que articularan una nueva ergonomía social sobre el terreno. En Carne y piedra el sociólogo estadounidense Richard Sennett da cuenta de cómo en el siglo XVIII William Harvey descubrió que el movimiento de la circulación sanguínea en el organismo humano es mecánico y no viene causado por el calor de la sangre, como se creía por aquel entonces. Según Sennett este descubrimiento rompió con las teorías de la medicina y la anatomía clásicas ${ }^{356}$. Esta nueva imagen de la circulación sanguínea impuso un dibujo de la anatomía humana bien diferente. Pero, además, Sennett deduce que la imagen del aparato circulatorio natural es análoga a la forma en que Adam Smith concibió el circuito del mercado, basado en una idea mecanicista de la economía en la que sus móviles, el trabajo y los capitales, se conducen de manera mecánica ${ }^{357}$.

La relación de analogía entre la circulación sanguínea y la circulación mercantil no esconde el hecho de que, tal como sugiere Sennett, los propios <<colegas de Smith hablaran de salud económica en los mismos términos que los médicos utilizaban para la salud corporal >> ${ }^{358}$; allende a la salud en la circulación de la sangre, apunta el autor que se daban palabras como "respiración" para referirse al movimiento de mercancías, o "estimulación" para referirse a la fuerza de trabajo y en clara analogía con el sistema nervioso, etc. El mérito de Smith con respecto a sus contemporáneos, cuestión de la que Sennett da debida cuenta, radica en que el economista escocés acertó a localizar en el homo economicus ${ }^{359}$ la partícula viva responsable del movimiento mercantil ${ }^{360}$.

El plano de la Lisboa reconstruida ofrece un ejemplo de cómo el espacio soberano de las urbes dieciochescas incorporaba el paradigma economicista de la circulación como si se estuviera tratando con un fenómeno natural. Lisboa no solo fue destruida por el terremoto, sino que la imagen de su plano, sus calles estrechas e irregulares (intransitables), sus símbolos religiosos y alegorías medievales no volvieron a

\footnotetext{
${ }^{356}$ Cfr. Richard Sennett, Carne y piedra (Madrid: Alianza Editorial, 1997), 273-276.

${ }^{357}$ Cfr. Sennett, ob. cit., 274.

358 Sennett, ob. cit., 291.

${ }^{359}$ En la serie que viene a continuación se analizará con mayor grado de concreción el término homo economicus a partir del uso y significado que Bentham le dio en sus obras de carácter económico. Las implicaciones del homo economicus en el contexto donde se anticipa este concepto sirve como introducción al modo en que será abordado esta última serie en la que se contrapondrán las visiones políticas de corte individualista-economicistas y las fraternalitas.

${ }^{360}$ Cfr. Richard Sennett, Carne y piedra (Madrid: Alianza Editorial, 1997), 274 y 291.
} 
restituirse, sino que fueron literalmente borradas por otro "fenómeno natural", a saber, el flujo de las poblaciones en el espacio del libre mercado.

\title{
2.2.6. ESTRATEGIAS DE CONTROL SOBRE EL CUERPO SOCIAL
}

A medida que los intelectuales se fijaban cada vez más en la relevancia del comercio para la estabilidad de los gobiernos, del progreso de la humanidad y del bienestar de las sociedades, las urgencias en torno al conocimiento sobre cómo orientar la práctica gubernamental en materia económica se hicieron cada vez más pronunciadas. La necesidad de conocer los parámetros por los que se rigen las actividades productivas y comerciales, saber acerca de su relación intrínseca y de la necesidad de normativizar la pragmática del gobierno en asuntos económicos, motivaron que en el siglo XVIII naciera la economía política. La definición que Bentham le atribuyó a esta disciplina arroja luz de forma muy concisa sobre qué área de saber iba a ocupar dentro de la ciencia social y la jurisprudencia:

\begin{abstract}
A la economía política se aplican los axiomas y principios relacionados con la subsistencia y la abundancia. A la economía política; es decir, a aquellas partes de los códigos civiles y penales, en cuya exposición razonada son aplicables y tienen lugar las consideraciones sugeridas por el arte y la ciencia de la economía política; consideraciones que son distintas e independientes de las sensaciones producidas por la pérdida o la ganancia. ${ }^{361}$
\end{abstract}

Para Bentham la economía política no puede diferenciarse de la legislación, lo que supone que su corpus legal no se distingue del conjunto de leyes que rigen a la sociedad civil. Dos de los objetivos inexpugnables del arte de legislar son la protección del derecho de propiedad privada y el enriquecimiento de la nación como forma de contribuir a maximizar la felicidad del mayor número de personas; la perspectiva utilitarista desde la que el jurisconsulto inglés valora la economía política relaciona la legalidad con la propiedad y el comercio como productores de felicidad, el espacio mercantil, así pues, está presente en el cálculo eudemónico con independencia del modo subjetivo en que los individuos aprecian sus ganancias o pérdidas.

Pero esta nueva disciplina tenía que levantarse sobre los cimientos de una determinada concepción antropológica, ya que el sujeto de la economía política, no es un sujeto epistemológico, moral o político, es un sujeto económico. La extracción de la

${ }^{361}$ Jeremy Bentham, Escritos económicos (México: FCE, 1965), 171. 
idea del hombre económico, habitualmente conocido como homo economicus, va más allá de la forma en que las personas actúan dentro de las actividades de producción y comercio, pues el homo economicus es una configuración ideal que parte del supuesto de que la característica esencial del ser humano es el interés individual. Según Bentham todos los sujetos actúan conforme a unos intereses personales, lo que consiste en perseguir placeres y minimizar dolores, únicos dueños capaces de impeler la acción humana ${ }^{362}$. No podría haber planteamiento económico que pretenda eludir o que tratara de evitar el interés como concepto puntal puesto que, advierte Bentham, <<el sistema de economía que se construya sobre cualquier otra base, se edifica sobre una base falsa $>363$.

En las concepciones económico-políticas de Bentham relucen de manera prístina, por un lado, la intención de fomentar el desarrollo de un espacio apto para la producción industrial y el intercambio comercial como un signo acorde al interés público y, por otro, la noción del homo economicus o, lo que es lo mismo, la psicología prototípica del sujeto que actúa en el mercado y cuyo impulsor es el interés personal, determinación de carácter antropológico que opera en todos los niveles de la vida humana. Estas dos formas elementales del pensamiento de Bentham articulaban un nuevo modo de entender el movimiento de los cuerpos en el espacio político y en el espacio económico, ambos imbricados en una red compleja de relaciones sociales en la que los conceptos clásicos de la política -como el de soberanía o gobierno- se interrelacionan indeleblemente con el mercado. Se trataba de albergar conocimientos sobre el comportamiento de los individuos en el mercado en vistas a orientar la práctica política en la construcción de espacios públicos ergonómicos para el homo economicus.

La figura del homo economicus es un constructo teórico común a muchos pensadores económicos de la época, su imagen es la del hombre individualista que dirige su vida para satisfacer sus intereses. La inercia de los movimientos del homo economicus conlleva que la circulación podía convertirse en un problema. El comercio hacía evidente la circulación de los cuerpos, de las mercancías y del dinero pero, de la misma manera que fenómenos naturales como el Terremoto de Lisboa contribuían a trastocar los movimientos regulares de los cuerpos sobre la geografía urbana, la aglomeración y hacinamiento de cuerpos persiguiendo realizar sus intereses también podía causar

\footnotetext{
${ }^{362}$ Cfr. Bentham, ob. cit., 4 y 13.

363 Bentham, ob. cit., 13.
} 
sobresaltos disruptivos en la sociedad. Ante una situación de histeria, pánico, hambre e incertidumbre, los cuerpos de los homo economicus a fin de perseguir sus intereses iniciarían movimientos irregulares y caóticos, de tal manera que el orden social colapsaría. Entonces, la circulación impelida por ese interés individualista intrínseco a todos y cada uno de los seres humanos corre el serio riesgo de tornarse en un desorden incontrolable, por esa razón se terció urgente, entre otras cosas, una nueva manera de regular y ordenar a la población, una regulación que complementara e hiciera compatibles la satisfacción de los intereses individuales con el mantenimiento del orden público.

Interesa ver de qué forma la sociedad va a adquirir una categorización pendular en la reunión, por una parte, del sujeto individualista que mueve su cuerpo en pro de satisfacer sus propios intereses y, por otra parte, de la regulación en torno a un espacio público intervenido de facto por los parámetros económicos que suponen la particularización del individualismo a través de la figura general del homo economicus. La economía política parte de la imagen conceptual de un cuerpo social atomizado, el individualismo egoísta era el punto cardinal de cada uno de estos átomos que, sin embargo, fluían en conjunto. De modo que a la economía política le estaba asignada la difícil tarea de armonizar el movimiento de estos átomos que, siendo individuales, actuaban en conjunto, y no por una actitud colaborativa o altruista, sino por la confluencia de intereses. Dicha confluencia de intereses podía generar "hordas tumultuosas" de cuerpos dirigidos hacia un mismo fin, una estampida multitudinaria capaz de colapsar el espacio público y derribar cualquier contrapeso Estatal. Por tanto, y consecuentemente, los conocimientos respecto al funcionamiento del mercado ofrecían un caudal de datos con que la economía política habría de buscar las medidas necesarias para armonizar esos movimientos masivos.

Richard Sennett proporciona un ejemplo de los estragos que la masa social encolerizada puede llegar a causar: en el primer año de la Revolución francesa tuvo lugar, el 5 de octubre, el motín del pan, causado por las medidas ineficaces del gobierno a la hora de regular los precios de alimentos de primera necesidad. Concretamente en el caso del pan, el gobierno fijaba un precio, pero los movimientos del mercado resultaban indiferentes e irreverentes a esta imposición y, en la práctica, los precios del pan eran alterados por los comerciantes. Sennett se percata de que en este caso las reclamaciones por parte de la sociedad no iban dirigidas a otro lugar más que al propio gobierno. Una 
multitud en busca de pan se dirigió a las puertas del Estado, representado por la Asamblea Nacional, y quebraron con ese acto cualquier intento de orden público y estabilidad del cuerpo social ${ }^{364}$. Ya no solo un fenómeno natural como un terremoto, sino un tropel de cuerpos hambrientos, ocasionaba desórdenes en el espacio público, sus efectos no llegaron a ser ni mucho menos tan devastadores como el suceso de Lisboa de 1755, pero era constatable que la prolongación de estas hambrunas y el malestar colectivo aparejado a ellas ocasiona otras devastaciones en el cuerpo social.

El régimen del Terror que se produjo en Francia durante los años 93 y 94 del siglo XVIII contiene una mezcla de ese furor colérico por parte de las masas que clamaban por el pan en 1789 y el intento de ordenar este enfurecimiento a partir del Estado como representante único del bien común. El Estado jacobino eleva la concepción de un Estado impersonal y aséptico, legitimado para castigar cualquier intento de subvertir la firme igualdad que debe predominar entre los ciudadanos. Dice Remo Bodei en Geometría de las pasiones que el propio Robespierre se veía a sí mismo como una pieza más dentro de los organismos institucionales revolucionarios, un representante público ejecutor de la voluntad del pueblo y un miembro de la sociedad exento de privilegios, pues para el jacobino nada ni nadie ha de posarse por encima del pueblo ${ }^{365}$. Robespierre era para sí mismo la <<bisagra entre la representación informal de los clubes jacobinos y la representación formal de las instituciones públicas $>>{ }^{366}$. En la lógica jacobina la masa social recupera la identidad política de la que el homo economicus la había privado, promueve la concepción de la sociedad como un todo y no como una amalgama de individuos pendientes de resolver sus necesidades y cumplir sus intereses. Los movimientos masivos no serían, entonces, el producto de la coincidencia de intereses particulares, sino que hay un poder invisible que los dirige y su tutela corresponde a las instituciones públicas. Bodei afirma en relación con esta cuestión que

el interés general es monolítico, no negociable, uno indivisible como la república. No nace de un improbable acuerdo entre intereses particulares, de estipulaciones entre los individuos o del libre juego del mercado (económico y político) de los bienes individuales. Es necesario, dada la ocasión, obligar a los hombres a realizar la voluntad general. Pero el bien común no se podrá conseguir hasta que no hayan sido eliminados los egoístas, cuantos piensan solo en sí mismos: en efecto, los hombres podrán ser libres y

\footnotetext{
${ }^{364}$ Cfr. Richard Sennett, Carne y piedra (Madrid: Alianza Editorial, 1997), 299-300.

${ }^{365}$ Cfr. Remo Bodei, Geometría de las pasiones (México: Fondo de Cultura Económica, 1995), 379.

${ }^{366}$ Bodei, ob. cit., 380.
} 
felices solo si son virtuosos y hermanos, solo si son capaces de solidaridad, si son iguales. ${ }^{367}$

Pero el poder que los jacobinos restauraron en el cuerpo social, si bien procedía de este, pronto iba a desembocar en formas abstractas que enajenaban el poderío intrínseco del pueblo en cuanto corporalidad. La estrategia que llevó a cabo Robespierre para depurar la joven República francesa tiene semejanzas con la abstracción de la voluntad general de la filosofía rousseauniana. Aunque Rousseau rechazaba cualquier tipo de poder que se ejerciera mediante la mera fuerza bruta, la invocación y proclamación de principios como el de "voluntad general" evocan en la práctica política una cierta aspiración a orientar al cuerpo social y aplicarle curas en aquellas taras que contribuyen a degenerarlo. También en este aspecto resultan considerables las palabras de Bodei cuando -entre otros pasajes de su obra- vincula a los jacobinos con Rousseau, dice el autor italiano que la muerte en público mediante la guillotina en el régimen del terror $<<$ representa ya un ritual purificador, la manifestación más inmediata del carácter médico de la revolución, que amputa a la sociedad sus partes enfermas con miras a la salvación del todo $>{ }^{368}$. Asimismo, los propios jacobinos tomaron plena conciencia de la distinción entre la voluntad general y la voluntad de todos, la primera, la única válida para reafirmar la virtud, sería interpretada por una minoría (los tres hombres de la convención) que, sin necesidad de acudir a un acuerdo de carácter mayoritario, supuestamente expresaban el sentir general del pueblo desde su posición de vanguardia $^{369}$. La "salvación del todo" impone un poder que actúe desde fuera del cuerpo social, un poder que no esté circunscrito a las múltiples articulaciones de esa complexión compleja de la sociedad; el Estado se escinde del pueblo al que pretende salvar.

Mientras el poder en Rousseau y en los jacobinos aparecía como una abstracción de la sociedad, abstracción que constituía una forma de dominación invisible, inmaterial e impersonal cuya actividad en el espacio público solo podía darse a partir de la representación, en la teoría político-económica liberal el poder tiende a dispersarse entre los individuos. Pero los liberales no pudieron dejar a un lado las abstracciones, a pesar de que, sin embargo, dichas abstracciones no apuntaban a una instancia común que

\footnotetext{
${ }^{367}$ Bodei, ob. cit., 381.

${ }^{368}$ Bodei, ob. cit., 401-402.

${ }^{369}$ Cfr. Bodei, ob. cit., 403.
} 
aglutinara a todos los cuerpos en una sola masa comunitaria movida al son, a saber, de una voluntad o interés general. Los pensadores de corte liberal partieron de la suposición que establecía un interés individualista en cada uno de los hombres, así, cualquier tipo de interés general solo podía ser el producto de la coincidencia de estos intereses particulares. El problema era cómo producir una coincidencia estable, no abrupta y efímera, que diera paso a una sociabilidad operativa en la institucionalización de acuerdos susceptibles de mejorarse a medida que el comercio y la industria fueran generando avances. La figura abstracta del homo economicus se personaliza y encarna en cada uno de los individuos. Es a través de la regulación pública como la sociedad atomizada vertebra un espacio público a partir de las directrices reflejadas por el espacio económico, en este último actúan los hombres como átomos dispersos que solo la casualidad puede aunar, pero solo por medio del primero la multitud conseguirá vertebrarse, porque verá establecidos unos parámetros básicos extraídos de los datos económicos, datos tomados como objeto del derecho y principio justificativo de todo poder público-Estatal.

De alguna u otra manera, las estrategias para controlar a la sociedad oscilaban la problemática sobre cómo escindir la fuerza física inherente a la corporalidad social de la propia capacidad de legitimación política que dicha fuerza alberga, en otras palabras, había que separar lo natural de lo político, lo masivo de lo Estatal, la fuerza natural producida por la reunión de los cuerpos del poder institucional. Mientras unos concibieron la espiritualidad del cuerpo social como una forma unitaria, representativa e impersonal que implicaba a todos los individuos sin excepción, otros fueron más sutiles en sus operaciones y, tomando a la sociedad como un producto ficticio del lenguaje jurídico, acudieron a las fuerzas de los individuos para filtrarlas en los espacios solapados de la economía y la política. Los primeros tuvieron que hallar anclajes materiales de representación para ese poder incorpóreo que levita sobre la sociedad, los segundos aun estaban por coordinar esas formas materiales e inmateriales intervinientes en el dominio y control de los cuerpos que componen la sociedad. 


\section{SECCIÓN III. CUERPOS VIGILADOS: DISPOSICIONES \\ ASIMÉTRICAS EN LA ARTICULACIÓN DEL PODER PANÓPTICO}

\subsubsection{CONTEXTO HISTÓRICO-LOCAL DEL PANÓPTICO}

Durante el otoño de 1786 Bentham escribió unas cartas destinadas a exponer las líneas maestras del principio de inspección. El jurisconsulto inglés basó su principio de inspección en un tipo de edificio llamado panóptico, destinado a optimizar el ejercicio de la vigilancia en aquellos espacios donde resultaba imprescindible poner en práctica técnicas de control que permitieran el dominio e instrucción de grupos de personas hacinadas en un determinado espacio. Las cartas sobre el proyecto de vigilancia panóptica fueron escritas mientras el pensador de Westminster se encontraba en el estado ruso de Krichev (al sur de Mogilev). En Rusia conoció de primera mano las ideas de disciplinamiento que su hermano, Samuel Bentham, había estado tratando de aplicar mientras trabajaba a cargo del príncipe ruso Grigorii Potemkin.

En un artículo de investigación del profesor de arquitectura británico Philip Steadman titulado El Panóptico de Samuel Bentham, se hace referencia a cómo el hermano del célebre jurisconsulto inglés ideó un plan de vigilancia ante la coyuntura que encontró en Krichev, estado que había sido anexionado por Rusia recientemente y que estaba bajo el mando del príncipe Potemkin. Samuel era ingeniero naval y desde 1780 se había afincado en Rusia. En 1784 se puso al servicio de Potemkin, de quien ganó su confianza, siéndole encomendado supervisar las actividades de fabricación de barcos en Krichev ${ }^{370}$. Samuel Bentham quedó al frente de la administración de este estado en el que halló múltiples problemas de disciplina por parte de los trabajadores que tenía a su cargo, la gran mayoría de ellos de proveniencia campesina.

En otro artículo destinado a investigar los orígenes del panóptico, su autor, el historiador inglés Simon Werrett, nos ilustra acerca de cuáles pudieron ser las causas de la desorganización e indisciplina con las que tuvo que lidiar Samuel en su aventura rusa. No solo la desorganización y la falta de preparación técnica de los trabajadorescampesinos causaban la indisciplina, sino también la actitud autoritaria, desconsiderada

${ }^{370}$ Cfr. Philip Steadman. "Samuel Bentham's Panopticon”, Journal of Bentham Studies 14, no. 1 (2012): $1-30,1-2$. 
y negligente de los lugartenientes que Samuel había seleccionado en Inglaterra suponía un escollo para la buena marcha de las tareas que se precisaban realizar. A estos contratiempos se le sumó el carácter multicultural de la población de Krichev, formada por polacos, rusos, judíos y cosacos, en la que se entremezclaban distintas comunidades religiosas y étnicas que hacían muy difícil la comunicación entre los distintos $\operatorname{operarios}^{371}$.

Para paliar la desorganización en el trabajo se precisaba de una disposición del espacio destinada a ejercer un control eficaz y eficiente de los trabajadores. Para ello Samuel pensó en implantar un sistema de inspección central en el que se utilizara una torre de guardia situada en la parte más alta y en el centro del edificio. Desde esta torre se podría observar a un conjunto de hombres más o menos amplio, con el propósito de reducir esfuerzos en tareas de vigilancia, dado que entre otras cosas, este modelo de control permitía disminuir considerablemente el número de guardias o supervisores. A propósito de la técnica con que Samuel Bentham contempló la solución de los problemas que se le presentaban, cabe mencionar, siguiendo a Werrett, que

se suponía que la institución proporcionaba medios para supervisar la instrucción de campesinos no cualificados, pero la instrucción requería supervisores alrededor, entre los campesinos, para supervisar su trabajo con estrecha perspicacia. Esto no era muy diferente de cualquier otra práctica de taller ${ }^{372}$.

Así, el diseño arquitectónico del Panóptico se alzaba como un símbolo que le hablaba un solo lenguaje a una población culturalmente diversa, el del poder ${ }^{373}$.

Otro asunto que Werrett pone sobre la mesa viene a propósito del entorno político y socio-cultural en que surgió el panóptico; especula que el diseño de esta construcción pudo venir inspirado por la forma arquitectónica de las iglesias ortodoxas que Samuel observó durante su estancia en Krichev. Asegura el autor que no se le ha prestado suficiente atención al hecho de que el panóptico fuera ideado en Rusia. Werrett sostiene, además, que el entorno religioso que Samuel encontró en el país eslavo pudo influir en sus ideas arquitectónicas, ya que en las liturgias ortodoxas se trataba de representar la omnisciencia y omnipotencia de Dios escondiendo a los sacerdotes de los fieles mientras se realizaban los sacramentos. Esta posición de los sacerdotes respecto de sus

${ }^{371}$ Cfr. Simon Werrett, "El panóptico en el jardín: La casa de inspección de Samuel Bentham y la teatralidad de la nobleza en la Rusia del siglo XVIII", Scientia Helmántica 2, no. 4 (2014): 32-59, 42.

${ }^{372}$ Werrett, ob. cit., 41.

${ }^{373}$ Cfr. Werrett, ob. cit., 43-44. 
fieles producía una mirada asimétrica destinada a simular el modo en que operaría la mirada divina. Además, los templos ortodoxos tienen una forma ovalada y en su interior los fieles se encuentran en permanente contacto visual con iconos y mosaicos que sugieren la presencia permanente de Dios. También matiza Werrett que, aunque esta puntual comparación de un edificio religioso con un edificio secular no implica una necesaria relación directa entre ellos, sí resulta llamativo que en dos ámbitos tan diferentes -el religioso por un lado y el industrial por el otro- coincidan formas de vigilancia basadas en la mirada asimétrica, donde actúan unas disposiciones arquitectónicas destinadas a generar en los vigilados el sentimiento de que están siendo observados de manera perpetua ${ }^{374}$.

El entorno político y social en que nace el panóptico se correspondía con las reformas que estaba llevando a cabo la emperatriz Catalina la Grande en el Imperio ruso, quien tenía la intención de introducir un absolutismo ilustrado al estilo de las monarquías de la Europa occidental. Este modelo promovía la secularización del Estado. Dicho contexto histórico presenta -a ojos de Werret- el caldo de cultivo necesario para que miembros de la nobleza rusa como Potemkin encontraran atractivo un proyecto secular de vigilancia en el que, de alguna u otra forma, los símbolos religiosos eran sustituidos por símbolos del poder civil, puesto que en una Rusia ilustrada la expiación de los hombres ya no tendría que ser llevada a cabo por ningún ser divino ni instancia sobrenatural, sino por el Estado y sus instituciones, representados en la silueta de la torre central del panóptico. A este respecto, Werrett afirma:

La Casa de Inspección podría, en consecuencia, ser vista como otra intervención del poder secular dentro del orden religioso en Krichev, y el que encajaba en las aspiraciones de Catalina y el sueño de Potemkin en el sur. Puede parecer improbable que para Samuel Bentham haber inventado una iglesia secularizada en Krichev, a pesar de que los diseños que él preparó con Jeremy en 1786, lleva a una semejanza con la arquitectura de la Iglesia del momento, y Bentham estaba bien informado sobre la Ortodoxia. Durante un viaje a Siberia en 1781, Samuel había recabado información para el gobierno sobre las actividades de los raskolniki o viejos creyentes: una operación de vigilancia emprendida al ejercer el poder sobre el sector de la comunidad ortodoxa. ${ }^{375}$

\footnotetext{
${ }^{374}$ Cfr. Werrett, ob. cit., 52-53.

375 Werrett, ob. cit., 53.
} 
El marco socio-cultural y político en que fue ideado el panóptico y su problemática de fondo es que en el siglo XVIII el poder del Estado estaba desvinculándose cada vez más del poder religioso, lo que implicaba que la autoridad civil comenzara a ganar terreno con respecto a la autoridad tradicional de la religión y la teología. En medio de este panorama secularista la vigilancia panóptica respondía a la necesidad de instaurar una figura de expiación sobre la conciencia de los individuos distinta de la figura de un Dios omnisciente. La configuración de un poder estatal separado de los dogmas religiosos traía consigo urgencias teóricas y prácticas en lo relativo al ordenamiento de la sociedad y a la retención de los impulsos corporales humanos, de modo que técnicas de control como la vigilancia y la expiación trasladaban la figura que representaba el poder de Dios a una figura de poder simbolizada en la presencia permanente del Estado. Con relación a esta cuestión, el Barón D’Holbach advertía de lo estéril que resulta para el dominio de los seres humanos el predicamento de la omnipresencia divina:

En una palabra, ¿no vemos en cada instante hombres persuadidos de que su Dios los ve, los escucha, los rodea, que no por ello se detienen ante el deseo de contentar sus pasiones y cometer las acciones más deshonestas? El mismo hombre que temería las miradas de otro hombre, cuya presencia le impediría cometer una mala acción o entregarse a algún vicio vergonzoso, se permite todo cuando no cree ser visto más que por su Dios [...] Cuando los hombres creen no tener que temer más que a su Dios, no se detienen en general ante nada. ${ }^{376}$

De este modo, es posible mantener que el panóptico de los hermanos Bentham venía a resolver ciertas deficiencias flagrantes en lo que respecta al sistema de control social tradicional. Por mucho que las autoridades religiosas pretendieran intimidar, retener y cohibir a los individuos instalando la figura de Dios en el orden de sus pensamientos, este método resultaba insuficiente para conseguir tales fines. En consecuencia urgía que el nuevo poder civil pusiera en marcha un mecanismo efectivo de vigilancia que fisicalizara la dominación, es decir, se requería un tipo de control fáctico en el que se produjera un juego de miradas de un ser humano hacia otro ser humano, y no de un ser sobrenatural quimérico a un humano.

\subsubsection{LA FILOSOFÍA DEL PANÓPTICO}

En las Falacias políticas Bentham menciona que los abusos en el Estado, aunque sean diáfanos en su vituperio contra el interés público, si cuentan con intereses que los

${ }^{376}$ Barón D`Holbach, Sistema de la naturaleza (Madrid: Editora Nacional, 1982), 517. 
sostengan, solo pueden ser respaldados por argumentos falsos encubiertos por el recurso a la autoridad, pues su $<<$ fuerza es proporcional al número de personas que a ella se suman $>{ }^{377}$, es decir, que la autoridad tiene poder con arreglo a la cantidad de cuerpos que logra reunir. También, en las Falacias, el jurisconsulto se pregunta si los hombres que toman partido por una causa son conscientes siempre de las razones que actúan tras su decisión, problemática interpelación ante la que el autor responde que se precisa contar con un conocimiento de la anatomía y de la fisiología del alma tan avanzado como el que se tiene del cuerpo físico ${ }^{378}$. Pareciera que mediante esta reflexión Bentham está situando lo intelectual y lo físico en dominios paralelos completamente separados el uno del otro pero, lejos de establecer una disrupción de tipo dualista entre ambos dominios, a lo que se refiere el pensador inglés es a que resulta mucho más complicado conocer las causas que motivan las acciones de las personas que las causas por las que los fenómenos físicos son ocasionados, porque las primeras se originan dentro de la mente de cada cual y las segundas en el entorno natural, unas no tienen accesibilidad empírica, las otras en cambio sí. La cuestión que aquí se pone de relieve versa sobre cómo es posible influenciar en los pensamientos, las creencias y las convicciones de los individuos para que actúen de un determinado modo, de lo que se deriva la necesidad de extraer un conocimiento acerca de cómo funciona la psicología humana. El domino de los pensamientos humanos tiene como finalidad ejercer una presión indirecta sobre sus cuerpos, controlar la facticidad de las acciones y movimientos que se emprenden por medio de la corporalidad, este es un problema que está presente en la filosofía de Bentham, problema que el principio de inspección venía a resolver eficazmente, siempre con el horizonte del principio de utilidad de fondo.

El método para que los sujetos sometidos a vigilancia en el interior del panóptico sintieran el acecho sobre sus cuerpos pasaba por instaurar en sus pensamientos la imagen de un guardián que les observa. A su vez, activar un modelo de inspección aplicable a los espacios públicos y productivos iba más allá de los contextos donde se manifiestan los símbolos y predicamentos religiosos. Asimismo, las relaciones de los ciudadanos con las instancias de poder iban a ser fijadas dentro de un espacio en el que los cuerpos quedaban expuestos a las miradas de agentes encargados de guardar el orden, por tanto, se requería de una disposición en la que funcionaran unas asimetrías

\footnotetext{
377 Jeremy Bentham, Falacias políticas (Madrid: Centro de Estudios Constitucionales, 1990), 27.

${ }^{378}$ Cfr. Bentham, ob. cit., 202-204.
} 
necesarias para perpetuar el poder civil por medio del "ver sin ser visto". Todo ello dentro del marco de relaciones que tienen lugar en un entorno político secular.

Aunque la peculiar técnica de inspección que Jeremy Bentham aprendió de su hermano fracasó cuando la pusieron en práctica en Inglaterra, el plan teórico del panóptico envuelve una serie de articulaciones conceptuales en la relación cuerpopoder. En especial, conviene destacar -como punto de partida- dos aspectos fundamentales del tipo de vigilancia panóptica: por un lado, se erige como una forma de ejercer el poder a través de la imaginación de los hombres, por lo que se lleva a cabo un tipo de dominio indirecto sobre los cuerpos; pero, por otro lado, no recurre únicamente a la dimensión subjetiva de los individuos, sino que produce un edificio, crea una estructura material, genera unas condiciones asimétrica en el terreno, todo ello para forzar la subsunción y exposición de los cuerpos con respecto a un elemento arquitectónico como es la "torre central de vigilancia", una instalación que simboliza al poder.

Por esta razón, acudiendo a las veintiuna cartas que componen el Panóptico o la casa de inspección, en cuyo prefacio Bentham dice, entre otras cosas, que el panóptico es <<una nueva manera de imponer el poder de una mente sobre otra con fuerza incomparable >> ${ }^{379}$, es posible apreciar un modelo de inspección que domina de forma indirecta a la corporalidad humana, pero que lo hace por medio de un sistema de presión encarnado en un edificio. La pretensión del principio de inspección benthamita es que los individuos dirijan sus cuerpos de acuerdo a los propósitos de sus dominadores, para ello se requiere perpetuar en la mente de los dominados la figura de poder del vigilante y causar en ellos una subjetivación del cuerpo como "objeto vigilado"; a su vez, sobre el plano espacial, se deberán disponer las condiciones asimétricas necesarias para producirlos.

En el panóptico se hace ostensible un problema filosófico proveniente de la tradición empirista inglesa, ya que la concepción de la mente humana que se desprende del principio de inspección benthamita es la de un sujeto cuya imaginación se pone en funcionamiento con arreglo a los contenidos empíricos que recibe: los hombres no cuentan con formas innatas en la mente. Precisamente el principio de inspección parte de la necesidad de posicionar indicadores perceptivos que produzca la imagen del

${ }^{379}$ Bentham, Panóptico (Madrid: Círculo de Bellas Artes, 2011), 35. 
vigilante en la mente del vigilado, pero, sin embargo, el vigilante no aparece evidenciado sino solo a través de la torre central, esta procura los materiales sensibles por medio de los que se simboliza la vigilancia. Son los componentes simbólicos los que, en última instancia, generan la figura de poder que representa el cuerpo del inspector, cuya potencial presencia se hace permanente en la imaginación de los vigilados. En la carta que Bentham le envió a Garran de Coloun, miembro de la Asamblea Nacional francesa, el 25 de noviembre de 1791, se encontraba la memoria en la que el jurisconsulto británico examinaba, promovía y preconizaba su proyecto; allí el autor se expresaba en estos términos:

La inspección: este es el principio único para establecer el orden y para conservarle; pero una inspección de un nuevo género, que obra más sobre la imaginación que sobre los sentidos, y que pone a centenares de hombres en la dependencia de uno solo, dando a este hombre solo una especie de presencia universal en el recinto de su dominio. ${ }^{380}$

La torre central es el canal sensible por medio del que se introduce el simbolismo de la dominación en las mentes de los vigilados, lo que equivale a emplear los recursos materiales suficientes para generar una simbolización del poder lo más intensa posible. El panóptico perpetúa la mirada del vigilante en la imaginación de los individuos, la manera de producir este efecto consiste en la simple operación de ocultar el cuerpo del vigilante. La mirada del inspector, situado en el interior de la torre central, dota de sentido al espacio interior del panóptico, puesto que el funcionamiento de la vigilancia requiere abstraer esta mirada, hacerla factible de manera mediata pero no inmediata, de modo que su mera posibilidad siempre se mantenga latente en la subjetividad de los vigilados.

Dentro del panóptico es el vigilante quien tiene la potestad de otorgarle una realidad a las faltas y estropicios de los vigilados, de modo que la ontología del espacio vigilado tiene que constituirse a partir de la producción de un juego de miradas asimétrico. Únicamente la percepción del vigilante puede atribuirle una realidad a la situación de los individuos puestos bajo vigilancia: si un cuerpo comete una infracción, si evade la cadena de disciplina, su acción tomará carácter real en el momento en que sea observado por el vigilante. Al igual que en la filosofía del obispo George Berkeley, en la que Dios es el fundamento último que le da soporte ontológico a los objetos

\footnotetext{
380 Jeremy Bentham, El Panóptico [incluye además: El ojo del poder de Michel Foucault y Bentham en España de María Jesús Miranda] (Madrid: La Piqueta, 1979), 35.
} 
sensibles $^{381}$, en el panóptico es la torre de inspección la que le concede su realidad a los objetos puestos bajo vigilancia; las infracciones en el interior del panóptico solo son reales si son percibidas por la mirada del inspector. Así como el "dios berkeleiano" sostiene la existencia de los objetos aun cuando no están siendo percibidos por los sentidos del espíritu humano, la torre central del panóptico sostiene un orden interno regulado por medio de la omnipresencia perceptiva.

La filosofía de Berkeley niega el concepto filosófico de materia, el pensador británico puntualiza que no trata de poner en cuestión la existencia de los objetos sensibles externos al espíritu humano, pero se querella contra la posibilidad de que pueda existir algún tipo de sustancia material o corpórea, ya que esta sería una construcción teórica propia de aquellos que quieren prescindir de $\operatorname{Dios}^{382}$. A pesar de negar lo corpóreo, la operación de Berkeley en pro de inmaterializar las cosas sensibles guarda una estrecha similitud con la forma en que el poder se inmaterializa en el panóptico.

La figura de poder que opera en el interior de este edificio se corresponde con la representación del vigilante, pero esta representación no se muestra directamente a los sentidos de los individuos, sino que se simboliza a través de la torre central, precisamente el elemento que sustrae al cuerpo del vigilante de la mirada de los vigilados es el que sirve como símbolo de poder. El vigilante desaparece, se desmaterializa, se hace invisible, pero su concepto toma presencia y fuerza en la dimensión subjetiva de los vigilados. El panóptico no es una mera combinación entre un poder corporal y un poder incorporal, sino que es la búsqueda de rentabilizar los medios físicos con que se articula el poder, lo que retrospectivamente implica ingeniar formas de inmaterializar la dominación. La estrategia que encarna el poder en una entidad corpórea pierde parte de su densidad en virtud de una estrategia incorpórea de

\footnotetext{
${ }^{381}$ El obispo Berkeley solo concibe las ideas en virtud de su "ser percibidas" por un espíritu. La sensación es el medio a través del que las ideas adquieren realidad, la ontología de las ideas viene determinada por la percepción. El filósofo británico afirma en el Tratado sobre los principios del conocimiento humano que $<<$ las cosas percibidas por el sentido pueden ser llamadas externas en lo que respecta a su origen, ya que no son producidas desde dentro por la mente misma, sino que son impresas por un espíritu distinto del que las percibe. Asimismo, puede decirse que hay objetos sensibles que existen fuera de la mente, en el sentido de que existen en alguna otra mente distinta de la nuestra. De manera que cuando yo cierro los ojos, las cosas que yo veía puede que sigan existiendo; pero, de ser así, han de estar existiendo en alguna u otra mente>>. Ver en: George Berkeley, Comentarios filosóficos, Ensayo de una nueva teoría de la visión, Tratado sobre los principios del conocimiento humano, Tres diálogos entre Hilas y Filonús, Alcifón (Madrid: Gredos, 2013), 251.

${ }^{382}$ Cfr. Berkeley, ob. cit., 223.
} 
dominación que, necesariamente, tiene que introducir en el orden de los pensamientos del sujeto formas o figuras de poder estrictamente conceptuales, sin resto de materia que las acompañe. Con el principio de inspección Bentham logra darle una simultaneidad a las estrategias corpórea e incorpórea de poder; cuanto mayor sea el alcance del poder incorpóreo más se reducirá el poder corpóreo, esta complementación es la que el filósofo británico proyecta en el panóptico, pues se persigue aprovechar la potencia simbólica que subyace a la imaginación de los hombres para hacerlos controlables en el plano mental. Al mismo tiempo, si no bastara tan solo con eso para dominar, entonces el panóptico brinda la posibilidad de actuar directamente sobre los cuerpos, de tornar lo espiritual en material:

El todo de este edificio es como una colmena, cuyas celdillas todas pueden verse desde un punto central. Invisible el inspector reina como un espíritu; pero en caso de necesidad puede este espíritu dar inmediatamente la prueba de su presencia. ${ }^{383}$

El tipo de dominación que articula el panóptico impersonaliza el poder, ya que, al hacerse invisible, el vigilante se vuelve anónimo. Foucault menciona que en el panóptico tiene lugar <<una maquinaria que garantiza la asimetría, el desequilibrio, la diferencia. Poco importa, por consiguiente, quién ejerce el poder $>>^{384}$. La caracterización foucaultiana del poder panoptista soslaya el componente inmaterial que acompaña a este sistema de dominación. El filósofo francés señala que quienes saben que están siendo vigilados automatizan las operaciones de la dominación en sus esquemas psíquicos, así, el poder se hace presente en la introspección del sujeto. Por esta misma razón para Foucault

el poder externo puede aligerar su peso físico; tiende a lo incorpóreo; y cuanto más se acerca a este límite, más constantes, profundos, adquiridos de una vez y para siempre e incesantemente prolongados serán sus efectos: perpetua victoria que evita todo enfrentamiento físico y que siempre se juega de antemano. ${ }^{385}$

Con "poder externo" Foucault se refiere a las disposiciones físicas que producen las condiciones asimétricas en la relación vigilante-vigilado. Huelga aclarar que esta expresión no anula nuestra idea de que cualquier forma de dominación ha de situar al poder fuera de la corporalidad, ya sea como cuerpo o como otra sustancia radicalmente

\footnotetext{
383 Jeremy Bentham, El Panóptico [incluye además: El ojo del poder de Michel Foucault y Bentham en España de María Jesús Miranda] (Madrid: La Piqueta, 1979), 36-37.

${ }^{384}$ Michel Foucault, Vigilar y castigar (Madrid: Biblioteca Nueva, 2012), 234.

${ }^{385}$ Foucault, ob. cit., 235.
} 
distinta de este. Hay una estrategia que reduce el poder a un concepto abstracto, simbólico, de carácter inmaterial y, por ende, sustancialmente distinto de lo corpóreo, y otra estrategia que contempla la necesidad de que las formas de dominación adquieran algún tipo de complexión susceptible de causar directamente el sometimiento y actuación de los cuerpos humanos. A la luz de esta perspectiva, podríamos decir que al vincular lo externo con lo físico Foucault está haciendo alusión a ese tipo de poder que nosotros consideramos como encarnado en una instancia corpórea.

Resulta relevante añadir un aspecto que concierne exclusivamente a la dimensión subjetiva de los individuos sometidos a vigilancia dentro del panóptico. La cuestión es que la inspección panoptista constituye un modo de subjetivar la corporalidad en la inherencia del individuo. El cuerpo que los individuos puestos bajo vigilancia subjetivan aparece como un "objeto expuesto a la mirada", de modo que se podría decir que la inspección transfigura la experiencia de la corporalidad en el seno del sí mismo. Si la sustracción del cuerpo del vigilante requiere de un elemento físico que lo oculte, la sustracción del cuerpo del vigilado opera en la dimensión inmaterial de la subjetividad, esta se hace posible una vez la corporalidad de los vigilados ha quedado expuesta, sometida y exhibida a la mirada desplegada por la torre central, pero, una vez dispuestas así las cosas, es la imaginación del individuo la que efectuará y mantendrá al poder.

El "cuerpo vigilado" es un objeto de observación, algo visible cuyas acciones son transparentes ante su observador, este es el tipo de cuerpo que habrá de subjetivar el vigilado para que actúen en él los automatismos de la dominación. El cuerpo del individuo bajo vigilancia no es ya un cuerpo en el sentido natural, es un "cuerpo vigilado", es decir, la experiencia corporal se ha visto transfigurada por la intervención del poder.

La subjetivación del cuerpo vigilado contrarresta el poder que la naturaleza corporal alberga. La vigilancia escinde al cuerpo del sujeto, lo representa como un "objeto observable" y lo transparenta para hacerlo accesible al conocimiento y acción de un otro que ostenta el poder, de tal forma que la corporalidad queda anclada en el lado del objeto. Con ello, el sujeto deja de verse a sí mismo en el cuerpo y pasa a ver en él la presencia de un poder ajeno, un poder que fija su mirada en la corporalidad cual si esta se tratase de una entidad objetual, el poder expropia la fuerza corporal del individuo para ponerla bajo su dominio, haciéndoselo saber al propio individuo, quien toma conciencia de que su cuerpo es objeto de vigilancia. 


\subsubsection{DIÓPTRICA POLÍTICA, ASIMETRÍA SENSUAL Y MECANISMOS DE PRESIÓN PSICOLÓGICA}

Pese a que el proyecto de inspección explicado y vindicado por Bentham hace referencia especialmente a una institución penitenciaria, lo cierto, es que también en algunas cartas el jurisconsulto da cuenta de la polivalencia del edificio panóptico, mismamente, su hermano lo concibió como una fábrica de barcos. El panóptico podía ser utilizado para actividades industriales, penitenciarias, educativas y sanitarias, puesto que su aplicación debía orientarse a vigilar a grupos humanos cuyos individuos necesitaran de algún tipo de control: ya fuera para reformar su conducta, inculcarles hábitos y conocimientos, sanarles, cuidar de sus enfermedades físicas o mentales, o para eliminar algún vicio inserto en su condición social o psicológica difícil de aplacar de otro modo diferente que no fuera la coacción y el castigo. Asimismo, los vigilantes, cuidadores o instructores en cada caso, estarían también bajo el poder de la mirada de quien supervisa sus actividades. Bentham afirma, respecto de los usos que puede adquirir el panóptico, que:

No importa cuán distinto o incluso contrapuesto sea el propósito de dicho establecimiento: ya sea castigar a los incorregibles, vigilar a los dementes, reformar a los viciosos, confinar a los sospechosos, emplear a los ociosos, mantener a los necesitados, curar a los enfermos, instruir a los voluntariosos en cualquier rama de la industria o iniciar a la estirpe venidera en el camino a la educación. En una palabra, puede ponerse al servicio de distintos usos, ya sea el de la prisión perpetua, prisión preventiva, penitenciaría, correccional, asilo de pobres, fábrica, manicomio, hospital o escuela ${ }^{386}$.

Tal y como lo evidencia el jurisconsulto inglés, el edificio panóptico resultaba polifacético porque la vigilancia podía implementarse para controlar muchas actividades de la vida social. Aunque, en la mayoría de las cartas de Bentham dedicadas al panóptico este se refiere al principio de inspección aplicado en penitenciarías. De algún u otro modo el espacio penitenciario era el que planteaba una mayor propensión para el uso de técnicas de vigilancia.

Los espacios destinados al encierro penitenciario en el siglo XVIII estaban comenzando a experimentar importantes reformas, y Bentham es uno de los pensadores resueltos a participar en estos cambios con sus propuestas. La representación de los espacios penitenciarios en el imaginario dieciochesco se hace patente en la novela de

${ }^{386}$ Bentham, Panóptico (Madrid: Círculo de Bellas Artes, 2011), 40. 
Alejandro Dumas El conde de Montecristo, cuando el autor describe un tipo de prisión situada en el Castillo de If que responde, de acuerdo a la descripción que aparece en la novela, a ese tipo de cárceles que Bentham rechazaba y que pretendía reformar. Dumas define el Castillo de If como una <<mole informe>> y como <<una prisión terrorífica que provee a Marsella de consejas y tradiciones lúgubres $>>{ }^{387}$. If representa el modelo prototípico de prisión del Antiguo Régimen, con mazmorras hediondas, húmedas y oscuras, sin un sistema de ventilación adecuado y en las que proliferaban enfermedades entre los presos y sus guardianes; cárceles que, además, se hallaban blindadas por vastos muros que daban la impresión de inaccesibilidad social tanto a nivel interior como exterior, en otras palabras, esos muros impedían cualquier tipo de conexión entre la sociedad civil y las prácticas que pudieran darse en el entorno social inherente a la prisión.

En relación con la insalubridad de las mazmorras del Antiguo Régimen, conviene recurrir a la imagen que Alain Corbin proporciona a este respecto en El perfume o el miasma. Corbin dice que en el siglo XVIII las autoridades penitenciarias acusaron la necesidad de implantar drásticos cambios en el modelo de las prisiones, aunque solo fuera por eliminar la putridez concentrada en los suelos de esas mazmorras y calabozos. Estos escenarios pútridos y hediondos, según considera el autor, no pudieron por más que agitar la necesidad de una vigilancia olfativa que, entre otros espacios, encontraba en las prisiones dieciochescas el mejor ejemplo de lugares con una importante putrefacción acumulada ${ }^{388}$. Así, entonces, para Corbin la mazmorra representa un $<<$ modelo a propósito del cual se elabora, desde el siglo XVIII, la interminable y justa diatriba en contra de la habitación insalubre $>{ }^{389}$.

A la luz de la diatriba contra la insalubridad que señala Corbin hay que situar el proyecto del panóptico, un plan elaborado para solventar los problemas de hacinamiento de grupos más o menos amplios de personas. Bentham no se ocupa de una manera explícita y específica del problema de la hediondez, tampoco plantea la necesidad de un sistema de vigilancia olfativa -ese es un problema al que hace referencia Corbin desde un enfoque genealógico del olfato-, ya que las imágenes procedentes del sentido del olfato no acaparan la atención del jurisconsulto. Pero la necesidad de construir espacios

\footnotetext{
387 Alexandre Dumas, El Conde de Montecristo (Buenos Aires: La Página, 2006), 68.

${ }^{388}$ Cfr. Alain Corbin, El perfume o el miasma (México D.F.: Fondo de Cultura Económica, 1987), 32-33.

${ }^{389}$ Corbin, ob. cit., 62.
} 
ventilados como forma de permitir la entrada de aire y disipar los malos olores es directamente análoga al problema de la iluminación del panóptico, un problema que Bentham tuvo que afrontar en la medida en que la visibilidad de los cuerpos confinados es el requisito esencial del principio de inspección. La construcción de complejos carcelarios con aperturas al exterior permitía la entrada de aire, así como la iluminación de tales complejos también requería de aperturas que permitieran entrar la luz solar. Aquí surgía el problema de cómo retener a los reos en sus respectivas celdas dentro de un edificio "abierto". Steadman menciona que Bentham pretendía solucionar este problema construyendo las paredes frontales de las celdas con rejas, lo que permitiría la entrada de luz y la visibilidad de los convictos, además de su retención y seguridad en las celdas. Otra dificultad se correspondía con la iluminación en el interior de la casa de guardia, el problema era cómo iluminar este espacio reservado a los vigilantes sin exponerlos a la mirada de los vigilados. No podía dejarse los guardianes a oscuras. Speadman dice que en 1791 los hermanos Bentham recurrieron a un ingeniero gracias al cual diseñaron una torre de vigilancia con una bóveda en el techo que iluminaba el interior de esta sala, de tal forma que las paredes que la revestían no visibilizaban de puertas hacia afuera a los guardias situados en su interior ${ }^{390}$. Se trataba de abrir el edificio a la entrada de luz preservando la opacidad de los vigilantes.

Todas las vicisitudes mencionadas dan cuenta de cómo Bentham piensa la mirada en términos de dominación, su plan de inspección establece una dicotomía entre el cuerpo visible y la mirada oculta, en el que esta mirada cae verticalmente sobre una corporalidad en situación de visibilidad; así, por tanto, la mirada pasa a ser un elemento de la facticidad del poder. El hecho de que la arquitectura panóptica piense en cuáles son las condiciones lumínicas idóneas para visibilizar los cuerpos vigilados, el hecho de plantear en qué punto ha de posicionarse al vigilante para que no sea visto y para que obtenga un campo de visión privilegiado, introduce el poder en un juego ocular que nos permite interpretar el panóptico como una "dióptrica política” llevada a la práctica.

El panóptico es pertrechado por una concepción asimétrica de la transparencia, en la que actúa el principio de ver sin ser visto y donde los vigilados no saben en qué momento puntual están siendo observados. Los cuerpos han de posicionarse de tal manera que sean susceptibles de ser observados, este es el método de dominación

${ }^{390}$ Cfr. Philip Steadman. "Samuel Bentham's Panopticon”, Journal of Bentham Studies 14, no. 1 (2012): $1-30,15-18$. 
esencial del panóptico, en palabras de Bentham: <<las personas bajo vigilancia siempre sentirán que están siendo vigiladas, o al menos de que hay una gran posibilidad de que así sea > ${ }^{391}$. Para el vigilado, la sola posibilidad de ser visto en un momento puntual es motivo suficiente para verse constreñido, de tal modo que actuará en todo momento como si estuviera bajo la mirada del vigilante.

Aparte de las vicisitudes relacionadas con la articulación de una visibilidad asimétrica, otra dimensión sensitiva que Bentham estima aprovechable para la dirección de la instrucción y control de los reos es la audición. En la segunda carta del Panóptico explica cómo a través de tubos de hojalata conectados a cada celda desde la torre central se haría posible oír a los presos y, a su vez, darles órdenes ${ }^{392}$. El control por medio de la sensibilidad auditiva también advierte una relación asimétrica, ya que los individuos confinados pueden ser oídos sin saber cuándo lo están siendo; igualmente, la voz, como en el caso de la mirada, lleva una orientación vertical unidireccional desde la instancia de mando hacia los dominados. Los sujetos sometidos a vigilancia e instrucción no pueden hacer llegar su voz a las instancias desde donde son vigilados, de la misma manera que su capacidad auditiva tenía que estar expuesta a los sonidos emitidos desde el centro de mando.

El panóptico encierra un propósito mucho más ambicioso del que aparenta, pues el tipo de dominación que pone en funcionamiento trata de disponer la sensibilidad humana de tal manera que se pueda introducir en la mente de los individuos unos símbolos que referencian una determinada figura de poder. Los sentidos de la vista y del oído son utilizados con el objetivo de instalar una semiótica del poder dentro de la conciencia de las personas, y hacer presente en ellas la figura del vigilante, hecho que nos lleva a pensar en el panóptico como una maquinaria de la sensualidad. El modelo de inspección panóptica funda su capacidad de dominio y control somático en la posesión de la sensualidad visual y auditiva, dado que la vista y el oído van a ser los canales a través de los que se constriñe la mente de los individuos haciendo que interioricen la figura de su dominador y que la perpetúen en sus pensamientos. Este constreñimiento psicológico por medio de los sentidos visual y auditivo requiere de una producción previa de asimetrías evidenciadas en el orden de la relación entre el cuerpo vigilado y el vigilante oculto, este último tiene un acceso total a la sensibilidad de los primeros.

\footnotetext{
${ }^{391}$ Jeremy Bentham, Panóptico (Madrid: Círculo de Bellas Artes, 2011), 60.

${ }^{392}$ Cfr. Bentham, ob. cit., 45-46.
} 
No es casual que la vigilancia a través de la vista y el oído sean las dos dimensiones sensuales que Bentham tiene en cuenta para la transmisión semiótica del poder. Resulta relevante destacar, a tenor de este aspecto, las palabras de La Mettrie a propósito de la sensibilidad visual y auditiva: <<el nervio óptico y el nervio acústico son únicos, uno ve los colores, el otro oye los sonidos, ya que solo los nervios motores llevan al alma la idea de los movimientos $>{ }^{393}$. Esta consideración de La Mettrie era muy común entre los filósofos y anatomistas del siglo XVIII, así que no es de extrañar que Bentham se fijara en la necesidad de ejercer un control de estos dos sentidos tan imprescindibles para la formación de las ideas en la mente, cuyo acceso y aprehensión se advertía necesario en pos de ejercer una dominación más eficaz. En concreto, tal y como se ha venido diciendo, el panóptico pone en funcionamiento una mecánica sensual del poder en la que la producción de condiciones asimétricas regula los engranajes de dominación. La asimetría panoptista sitúa fuera del espectro perceptivo de los vigilados al agente encargado de su vigilancia, se trata de obliterar el acceso perceptivo al vértice desde donde es ejercido el poder de control e instrucción.

Un filósofo empirista como Bentham, a través de la mecánica panóptica, está aplicando en el contexto de la dominación unos conocimientos sobre la sensibilidad humana que le permiten manipular las condiciones psicológicas de los hombres para introducir en ellos la idea de la vigilancia mediante imágenes sensitivas productoras de figuraciones de poder. Se puede apreciar en qué medida la corporalidad humana, concebida como una máquina, habilita la implantación de una estrategia de dominación que localiza en el funcionamiento de los sentidos una manera de conocer la dimensión perceptiva y psicológica humana a través de la que se aplicarán sistemas de control somático.

Una vez señalados estos aspectos relativos al dominio sensual en el panóptico, conviene retomar el tema de la apertura a la luz -y a la ventilación- del modelo arquitectónico penitenciario benthamiano, puesto que esta apertura también cuenta con un correlato en sentido político. Para producir asimetrías políticas Bentham entiende que el edificio penitenciario debe ser transparente para todos menos para los presos que allí residen, de modo que cualquier miembro de la sociedad civil podría acceder a la torre central; dice el autor que las puertas del panóptico deben estar <<abiertas de par en

${ }^{393}$ Julien-Offray de La Mettrie, Obra filosófica (Madrid: Editora Nacional, 1983), 107. 
par a los ojos de los curiosos: ese gran comité abierto del tribunal del mundo $>>394$. Según Bentham, en todo establecimiento público ha de darse esta apertura siempre y cuando sea útil y oportuna para los intereses generales. En consecuencia, puertas para dentro, la asimetría entre la posición de vigilantes o curiosos con respecto a la posición de los vigilados refleja una transparencia en una sola dirección, sin posibilidad de invertirse. He aquí la manera en que la transparencia asimétrica se convierte en un poderoso mecanismo de control que involucra a toda la sociedad, en tanto en cuanto tiene capacidad para simbolizar mediante esa torre de vigilancia a toda la sociedad, lo que implica una presión moral y psicológica -de corte subjetiva- para el vigilado, pues dentro de esa torre podría estar cualquier ciudadano.

De cara al público, la institución panóptica es transparente y abierta, pero para la población encerrada en el interior de la institución es completamente opaca, ninguno de sus miembros puede saber nada sobre quién cierne su mirada sobre sus cuerpos, así que el régimen de control del panóptico, cuyo eje esencial de intimidación es la ocultación, ya sea de guardias o ciudadanos en general, implanta en los vigilados la sensación permanente de estar siendo vistos sin la posibilidad de comprobar que lo están siendo. Mediante esta técnica de vigilancia la figura del poder, representada en la torre central del panóptico, se hace presente en los pensamientos de los individuos, la silueta de la torre de guardia es interiorizada en la conciencia de los vigilados con la intención de que las corporalidades confinadas operen de acuerdo a los intereses de sus dominadores. Por ende, el panóptico es una técnica de intimidación a través de mecanismos de control indirectos sobre el cuerpo, pues es por medio de la presión psicológica del individuo como se logra que este mueva su cuerpo con relación al poder que les controla, y ese poder puede provenir de la figura de cualquier miembro de la sociedad civil que por mera curiosidad se halle observando en el interior de la torre de inspección. Es por esta razón que la transparencia interna del panóptico es un procedimiento de apertura civil, en tanto en cuanto se expone una institución a la vista de cualquier ciudadano. No obstante, el vigilado en cualquier caso nunca sabrá por quién está siendo observado; esta es la forma esencial de la transparencia asimétrica.

\footnotetext{
394 Jeremy Bentham, Panóptico (Madrid: Círculo de Bellas Artes, 2011), 67.
} 


\subsubsection{LO CORPORAL BAJO EL DOMINIO DE LA UTILIDAD}

Si se reduce la categoría de lo "humano" a la dimensión corporal del individuo, entonces, los seres humanos quedan expuestos a la consideración de máquinas, todos sus sentimientos, deseos y organización política estarían sometidos a los automatismos de sus engranajes anatómicos y a sus impulsos sensible-fisiológicos, así como también a sus movimientos productivos, es decir, a la capacidad que tiene el cuerpo de actuar como una máquina en menesteres laborales. El cuerpo, entonces, genera expectativas productivas, posibilidades para extraerle de forma sistemática rendimiento económico, exponiéndolo a la explotación. Bentham trató de compatibilizar este orden productivo inserto en las fuerzas corporales con los principios éticos del utilitarismo. La utilidad económica subyacente a la corporalidad tenía que comportar, además, unas consecuencias beneficiosas para la gran mayoría de individuos que forman la sociedad.

En rasgos generales, la obra de Bentham dedicada al panóptico hace gala de una visión política liberal y de una ética utilitarista que conforman el grueso de sus argumentos a favor del principio de inspección. Además, el autor da cuenta de un estudiado y meditado cálculo moral y económico correspondiente a los pros y las contras subyacentes al sistema de vigilancia que presenta: 1) en relación con las cuestiones morales, podemos apreciar cómo Bentham insta a pensar el Panóptico como una herramienta capaz de controlar cualquier negligencia o abuso dentro de un proceso de instrucción o cuidado de una determinada población de individuos hacinados por necesidad; 2) con respecto a las cuestiones económicas, el jurisconsulto se ocupa de garantizar la viabilidad de este modelo de vigilancia apelando a asuntos tales como la optimización de la productividad, la eficiencia de la vigilancia, la minimización de los costes del proyecto y sus márgenes de beneficio.

Entonces, a través del panóptico y de la propuesta de reforma de la ley penitenciaria, Bentham persigue hacer del apresamiento una práctica útil para la sociedad. De forma que se hacía necesario poner en marcha un cálculo utilitario que solventara el problema de incurrir en copiosos costos para las arcas públicas en asuntos penitenciarios, ya que durante el encierro los condenados tenían que ser provistos de alimento y otros medios fundamentales para la vida, lo que suponía destinar unos recursos determinados a cubrir sus necesidades más básicas. 
A lo largo de las cartas que componen la obra Panóptico, Bentham ofrece razones para justificar y promocionar el instrumento de vigilancia que propone, con el fin de reformar el sistema penitenciario de la Inglaterra de su época y de instaurar un principio de inspección eficiente tanto en un sentido técnico como económico, cuyo telón de fondo tiene en el principio de utilidad su principal aval y basamento.

El sistema de control panóptico se adapta a los cánones de la ética utilitarista concebida por Bentham en la medida en que el fin de su aplicación es causarle el menor daño posible a la mayoría de individuos. Bentham considera que el principio de inspección articulado sobre la idea arquitectónica del panóptico resulta rentable para la sociedad civil, motivo por el que en el panóptico y en el principio de inspección relucen los cánones más característicos de su ética utilitaria, pues se trata del principio de utilidad aplicado al contexto del control de las poblaciones. Encerrar a aquellos que han quebrantado la ley o que reniegan de sus obligaciones civiles es una necesidad indefectible para mantener la justicia y el orden social, de tal forma que el encarcelamiento siempre se practicará en vistas a promover la mayor felicidad posible.

Para Bentham, lo útil es aquello que confiere algún tipo de ventaja, placer, beneficio o dicha a un individuo o grupo de individuos, asimismo, en tanto en cuanto el dolor aleja de la felicidad, contribuir a disminuir o disolver aquellos objetos o actos dañinos promueve también la felicidad ${ }^{395}$. El jurisconsulto inglés formula el principio de utilidad bajo los parámetros conceptuales que contienen el sentido que le otorga a lo útil. El principio de utilidad debe dilucidar la forma más precisa para que los hombres alcancen la felicidad, lograr este fin requiere minimizar el dolor y maximizar el placer. Cuando se trata de aplicar el principio de utilidad a las comunidades, Bentham advierte que en ningún caso debe pasar desapercibido que todos los seres humanos son agentes de sus propios intereses, de tal forma que la comunidad tiene que ser tomada como un constructo conceptual y no como una entidad real. Bentham define a la comunidad como <<la suma de los intereses de los diversos miembros que la componen $>{ }^{396}$ y llama a ser precavidos con las ambigüedades a las que puede conducir este concepto si se superpone la abstracción que denota a los intereses particulares de los individuos;

\footnotetext{
395 Cfr. Jeremy Bentham, Los principios de la moral y la legislación (Buenos Aires: Editorial Claridad, 2008), 12.

${ }^{396}$ Bentham, ob. cit., 12.
} 
porque, si se olvida que lo comunitario no es más que el cómputo de intereses individuales, la comunidad no sería más que un mero concepto vacuo.

La felicidad de los individuos depende, primeramente, de los intereses de las personas en particular y, en un segundo momento, de las cuestiones relacionadas con la felicidad de los otros. En consecuencia, todos los sujetos tienen intereses para consigo así como obligaciones con los demás en tanto en cuanto no deben dañar a nadie ni interceptar sus intereses ${ }^{397}$.

La ética privada concierne a cada miembro, es decir, a la felicidad y las acciones de cada miembro, de cualquier comunidad que se trate; y la legislación no puede concernir a más. Hasta aquí, la ética privada y el arte de la legislación van de la mano. El fin que tiene, o deberían tener en cuenta, es de la misma naturaleza. Las personas a cuya felicidad deben atender, así como las personas cuya conducta deberían ocuparse en dirigir, son precisamente las mismas. ${ }^{398}$

El principio de utilidad equilibra los intereses individuales con la suma de los intereses que forman parte de la comunidad humana, por este motivo se propaga desde la ética particular hacia la legislación. La validez del principio de utilidad tiene lugar a nivel de la felicidad individual como al nivel de la felicidad producida en el trato social o en el contacto público de los ciudadanos. Se desprende del principio de utilidad benthamiano una clara vocación social, ya que va orientado a establecer prescripciones sobre la conducta de los individuos con el fin de garantizar la estabilidad, la paz y la seguridad en la vida que articulan los hombres en sociedad. También, el principio de utilidad pone en marcha un cálculo destinado a prever las causas de posibles conflictos que surgen a raíz del choque de intereses en las relaciones humanas. El sistema de ética que propone Bentham convierte la reflexión moral en una ciencia donde se suponen unas exactitudes prácticas en la forma en que los seres humanos se relacionan y se dirigen en la vida, por extensión, la política también recibirá el tratamiento de ciencia.

Bentham quería que las actividades que se realizaran dentro del panóptico fueran productivas y que, además, contribuyeran a instruir a los reclusos; por este mismo motivo, en el panóptico nada de mazmorras o celdas insalubres y de entornos lúgubres donde las actividades laborales resulten imposibles de realizar. Consecuentemente, la demanda por parte del filósofo de Westminster en materia penitenciaria pretendía

\footnotetext{
397 Cfr. Bentham, ob. cit., 292.

${ }^{398}$ Bentham, ob. cit., 293.
} 
persuadir a las autoridades de la época de que es legítimo aprovechar el rendimiento laboral de los presidiarios, pues el trabajo contribuiría, además, a instruirlos de cara a reinsertarlos en la sociedad. Por otro lado, las cárceles no deberían ser muy distintas de cualquier otro edificio público, puesto que mediante técnicas de vigilancia efectivas se lograría imponer la coerción de la población presidiaria de un modo tan solvente que no sería ya necesario empeñar muchos esfuerzos en mantener un copioso número de vigilantes y en construir abultados muros.

El espacio penitenciario debía resultar provechoso en términos económicos, una razón más por la que Bentham consideraba conveniente introducir actividades productivas entre los presos, a fin de hacer provechosa su permanencia en prisión extrayendo rendimientos económicos de su encierro. La explotación de los presos suponía reducir los costos de su mantenimiento y del edificio penitenciario, además de generar un cierto margen de beneficio, por lo que los espacios carcelarios perfectamente podían ser gestionados por empresarios. Para que el trabajo resultase productivo y para que contribuyera a la inmersión de los presos en el contexto de la vida laboral era preciso que el interior de las cárceles fuera como el interior de una industria, así que ni pasos estrechos ni habitaciones oscuras caben en el proyecto benthamita, la claridad y la luz debían ser administradas en el ordenamiento espacial del edificio a fin de facilitar la articulación de la vigilancia y permitir una producción lo más óptima posible. Así, en el curso de los argumentos mediante los que el jurisconsulto británico refrenda el panóptico como un proyecto viable económicamente se hace patente el balance del principio de utilidad: minimizar cargas o daños y maximizar bienes o placeres en vistas a producir la mayor felicidad posible. En este caso, dentro del cálculo utilitario convergen variables de marcado sesgo economicista con principios provenientes de la filosofía moral.

La primera cuestión que Bentham afronta en relación con las vicisitudes económicas del panóptico es el régimen de propiedad bajo el que debía caer, lo que conducía al pensador británico a tener que aclarar quién se haría responsable de la población presidiaria y de los beneficios que presumiblemente pudieran llegar a generar. Como la gestión más óptima de las penitenciarías debía dejar su jurisdicción en manos privadas, al empresario le serían cedidos por contrato tanto el cuidado de los presos como el derecho de propiedad sobre el producto de su trabajo, por lo que el empresario también 
debía asumir la responsabilidad de cubrir los gastos pertinentes ${ }^{399}$. Pero este contrato, aunque le concediera mayor margen de decisión y acción al explotador privado a la hora de obtener rendimientos óptimos, requeriría, no obstante, de unos compromisos contraídos que garantizaran los derechos más básicos de los presos, dado que dentro de esta coyuntura contractual era necesario prevenir cualquier tipo de abuso ${ }^{400}$. Concretamente en la carta XII se puede apreciar de manera ostensible cómo una de estas cláusulas obligaba al empresario a pagar una determinada cantidad de dinero por cada uno de los reos fallecidos. La implementación de este cobro buscaba incentivar al administrador privado para que diera un trato adecuado a los convictos ${ }^{401}$. Por otro lado, cabe mencionar que también en el siglo XVIII era muy común que los carceleros recibieran dinero por cada uno de los presos bajo su cuidado y supervisión, tal como se aprecia en el El Conde de Montecristo cuando el carcelero que guarda la celda del protagonista trata de persuadirle para que se alimente, en vistas a no sufrir una pérdida en su honorario si muriera ${ }^{402}$. La idea de Bentham de cobrar al empresario por cada preso muerto al año sigue esta misma lógica de incentivos económicos, sólo que en este caso sería una amonestación económica y no un pago. En todo caso, el cuidado de los presos quedaba supuestamente garantizado gracias a un sistema de incentivos económicos mediante los que se apelaba al interés individual de los responsables de esa población presidiaria que, bajo su condena, pasaban a ocupar una posición de dependencia.

\subsubsection{LA PRODUCTIVIDAD DE LA VIGILANCIA EN EL INCIPIENTE CAPITALISMO INDUSTRIAL}

La necesidad de complementar el incipiente orden político y económico capitalista con una ética material y eudemónica tal como es el utilitarismo, motivaba las contribuciones de Bentham en lo que se refiere a la búsqueda de soluciones para las urgencias bullentes en el contexto donde se hallaban inmersas las sociedades europeas del momento. En el plan de inspección panóptico y en la reforma penitenciaria se aprecian planteamientos que apuntan a problemas propios del incipiente nuevo orden económico del momento -el capitalismo de la Primera Revolución industrial-, que estaba causando cambios muy repentinos en la organización de los espacios sociales. De

\footnotetext{
399 Cfr. Jeremy Bentham, Panóptico (Madrid: Círculo de Bellas Artes, 2011), 75.

${ }^{400}$ Cfr. Bentham, ob. cit., 77.

${ }^{401}$ Cfr. Bentham, ob. cit., 98-99.

${ }^{402}$ Cfr. Alexandre Dumas, El Conde de Montecristo (Buenos Aires: La Página, 2006), 72.
} 
esta manera, uno de los fines que perseguía Bentham con el principio de inspección era contrarrestar los perjuicios que, bajo su punto de vista, causaba la Ley de Pobres. Al comienzo del prefacio del Panóptico, Bentham escribía:

La moral reformada, la salud preservada, la industria reforzada, la educación generalizada, las cargas públicas aligeradas, la economía asentada, por así decirlo, sobre una roca, el nudo gordiano de la Ley de Pobres no cortado sino desatado, ; todo gracias a una idea arquitectónica! ${ }^{403}$

La Ley de Pobres consistía en garantizar el techo, el alimento y el trabajo de los sectores más desfavorecidos de la sociedad. Con el fin de ilustrar de forma más expedita en qué consistía esta ley, cabe destacar al antropólogo y crítico económico Karl Polanyi, quien en La Gran Transformación examina los efectos que la Ley de Pobres causó en la organización social del trabajo en Inglaterra. Polanyi asegura al respecto que esta ley <<se ocupaba de lo que llamaríamos los desempleados y los inempleables (aparte de los ancianos y los niños) $>>404$. Menciona el autor que la Ley de Pobres permaneció en Inglaterra desde la tercera década del siglo XVI y que su presencia se hizo latente hasta después de la Primera Revolución industrial, aunque no estuvo exenta de reformas en todo este transcurso de tiempo. Polanyi matiza que las leyes de pobres que se promulgaron iban dirigidas, en realidad, a la gente común, por lo que no solo englobaban a los sectores más miserables de la sociedad sino a los que eran considerados como personas privadas de ocio debido a sus bajos salarios. La Ley de Pobres concedía asistencia social a todos aquellos que no contaban con capacidades ni recursos suficientes para sobrevivir. En el caso de las personas asistidas que pudieran trabajar, si habiendo recibido las consecuentes ayudas de alojamiento y comida seguían sin empleo, entonces podrían perfectamente ser condenadas por haraganería ${ }^{405}$.

Apunta Polanyi que Adam Smith fue uno de los críticos más duros de la Ley de Pobres. Según Smith, la Ley de Pobres generalizaba el inmovilismo entre los campesinos y dificultaba que los capitalistas pudieran hallar trabajadores a los que ocupar con empleos más productivos ${ }^{406}$. En palabras del propio economista escocés:

En todas partes es más sencillo para un comerciante acaudalado el obtener el permiso de negociar en una ciudad gremial, que para un pobre artesano el trabajar en ella. La

\footnotetext{
${ }^{403}$ Jeremy Bentham, Panóptico (Madrid: Círculo de Bellas Artes, 2011), 35.

${ }^{404}$ Karl Polanyi, La gran transformación (México D.F.: Fondo de Cultura Económica, 1992), 38.

${ }^{405}$ Cfr. Polanyi, ob. cit., 39.

${ }^{406}$ Cfr. Polanyi, ob. cit., 40.
} 
obstrucción de las leyes gremiales a la libre circulación del trabajo es algo común, creo, en todas partes de Europa. Pero la deriva de las leyes de pobres es, en la medida de mis conocimientos, peculiar de Inglaterra. Consiste en la dificultad de un pobre para conseguir la residencia o incluso el permiso de trabajo en cualquier otra parroquia que no sea la suya (...). Pero la dificultad de obtener la residencia obstaculiza incluso la de los peones. Quizás valga la pena describir el origen, desarrollo y estado actual de este trastorno, quizás el mayor de todos los de la política de Inglaterra. ${ }^{407}$

Smith consideraba, por tanto, que la Ley de Pobres suponía un escollo para el desarrollo económico dado que dificultaba la movilidad y diversificación de la mano de obra; resulta especialmente llamativo que emplee la palabra "trastorno" para referirse a los efectos que causa esta ley, como si la sociedad fuera un cuerpo afectado por una patología, a saber, la holgazanería y el parasitismo. El razonamiento smithiano contra la Ley de Pobres apela a los efectos que esta generaba en la mayoría de la población, por lo que su argumento no deja de ceñirse a un tratamiento de la sociedad como un cuerpo, de hecho, utiliza el término "cuerpo social" cuando se refiere a la distribución de los productos trabajados y a la justicia que hay en que los distribuidores de estos bienes reciban un beneficio que les permita cubrir sus necesidades ${ }^{408}$. La crítica que Smith emprendió contra la Ley de Pobres articulaba un discurso que otros pensadores liberales posteriores compartirían y completarían, entre ellos Bentham, aportando nuevas pruebas de sus efectos perniciosos.

En la obra de Polanyi también tiene lugar una valoración sobre el panóptico de Bentham, precisamente tal valoración viene a colación de la rémora que el pauperismo y la pobreza estaban generando en la Inglaterra de la Primera Revolución Industrial, y que ralentizaban las actividades productivas y comerciales al asegurar el sustento de personas que potencialmente podían ser trabajadores industriales. Es en este punto donde Polanyi comenta el plan del panóptico, cuyo objetivo habría ido enfocado a paliar los efectos más nocivos de las leyes de pobres. El objetivo que se traía entre manos Bentham -según Polanyi- consistía en emplear a los indigentes a gran escala. Dice Polanyi que el panóptico aplicado para dar subsidio y trabajo a los pobres suponía un ambicioso plan destinado a solventar el problema social de la pobreza, que influía negativamente en todos los recovecos de la sociedad, pero que la ambición más anhelada en el plan benthamiano consistía en convertir a los campesinos desposeídos en

\footnotetext{
${ }^{407}$ Adam Smith, La riqueza de las naciones (Madrid: Alianza Editorial, 2001), 200.

${ }^{408}$ Cfr. Smith, ob. cit., 126.
} 
mano de obra para la floreciente industria ${ }^{409}$. Con base en estas indicaciones de Polanyi, se puede poner de relieve que el proyecto del panóptico contenía en su matriz fundacional una vocación económica muy pronunciada, de la que cabía esperar rendimientos positivos para el conjunto de la sociedad, rendimientos provenientes del ámbito productivo y comercial.

Los quehaceres que venía a desempeñar el panóptico eran dos -a la luz de las expectativas que su creador le atribuyó-: uno económico y otro terapéutico, ambos interrelacionados entre sí. De facto, se hace patente la forma en que Bentham pretendía aplicar el panóptico en el ámbito laboral, ya no solo para emplear a indigentes, sino para contribuir con su producción a intensificar los rendimientos económicos de los individuos apartados del orden regular de la sociedad, lo que generaría utilidad social en general, asimismo, el jurisconsulto inglés esperaba paliar la patología de la pobreza y el pauperismo en cuanto escollos provocados por la Ley de Pobres, que estaría perjudicando al mercado debido a la ralentización que causaba en el desarrollo de las actividades productivas. La Ley de Pobres, al paralizar la economía, ocasionaba perjuicios sociales que Bentham pretendía remediar con su plan de inspección. La retención de los campesinos en el medio rural en detrimento de la industria era una tendencia que, de alguna u otra forma, el panóptico estaba destinado a revertir.

El modelo panoptista guarda en sí la ambiciosa cometida de promover una organización del trabajo a escala social, pues ponía el acento en la posibilidad de modificar el ordenamiento social mediante la intensificación y mejoramiento de las actividades económicas. Bentham entendía que un mercado laboral eficiente es una condición necesaria para mejorar el comercio, y el mejoramiento del comercio era una forma de contribuir a incrementar la felicidad social. Pero el incremento de la felicidad o bienestar de la mayoría de la población requería, además, aplicar una vigilancia a gran escala para intensificar la producción. En el panóptico la vigilancia extiende una cadena disciplinaria que aherroja las corporalidades humanas para extraer rendimientos útiles de su capacidad productiva. Por otra parte, el panóptico se presenta como una forma de terapéutica social en la medida en que va dirigido a erradicar o amortiguar aquellos vicios generalizados, hábitos perniciosos e ineficiencias económicas que afectan a las poblaciones, y que perturban el flujo óptimo del comercio, lo que afecta en la

${ }^{409}$ Cfr. Karl Polanyi, La gran transformación (México D.F.: Fondo de Cultura Económica, 1992), 159160. 
consecución de la mayor felicidad para el mayor número de personas posible. De este modo, de acuerdo a la lógica utilitaria, el panóptico se advierte como una técnica para minimizar daños e incrementar placeres. Podríamos decir que el principio de inspección es concebido como un instrumento para curar las patologías sociales, ahora bien, el proceso de esta curación requiere de un método que reduzca aquellos daños con que estos agentes patógenos deterioran el cuerpo social, como es el caso del estancamiento al que abocaba -según el criterio benthamita y liberal- la Ley de Pobres.

El panóptico pone en funcionamiento una mecánica del poder partiendo de la imposibilidad de dominar a los hombres mediante figuras como Dios y el alma en el contexto de los Estados seculares y de la economía industrial. Pero, igualmente, el despliegue de elementos materiales de poder que aseguraran una presión directa sobre el cuerpo de los hombres suponía un exceso demasiado pródigo para la optimización económica de los recursos disponibles, en consecuencia, la subjetivación del "cuerpo vigilado" era un paso crucial en la aplicación de la dominación panóptica. Así, en vez de inocular figuraciones inmateriales e invisibles en el aparato conceptual de los seres humanos, el panóptico instala la silueta de una torre de vigilancia que para el vigilado se hace opaca, hecho que genera en su mente una incertidumbre encauzada a provocar en él una actitud sumisa. De esta manera, la psicología del sujeto sometido a vigilancia se ve afectada por una mera posibilidad, la de estar siendo visto por un guardia o, a saber, por cualquier miembro de la sociedad civil, un determinado público, incluso, algún familiar. Vemos que en esta operación la figura de poder se oculta tras la imagen de la torre central del panóptico, cuya presencia física instaura la simbolización del poder vigilante en la mente de los individuos.

Entonces, el panóptico se erige como un sistema de presión que necesita de elementos mínimos (económicos) de representación del poder en el entorno material, puesto que el principio por el que se domina a los cuerpos no precisa de un contacto directo con ellos, sino que es en la disposición de los cuerpos en el espacio mediatizado por el poder donde se producen las asimetrías que permiten una dominación cuyo agente de acción permanece oculto e invisible, incluso este podría estar ausente de tal forma que en el interior de la casa de guardia no hubiera cuerpo alguno, porque el único cuerpo que debe permanecer en la mente de los vigilados es el de su propia corporalidad bajo inspección. 
TerCera PARTE: Planteamientos DECIMONÓNICOS ACERCA DEL

DOMINIO SOBRE LOS CUERPOS Y LAS REPERCUSIONES POLÍTICAS DE LA POTENCIA CORPORAL 


\section{SECCIÓN I. LIBERTAD, PROPIEDAD, TRABAJO}

\subsubsection{LIBERTAD SOBERANA Y LIBERTAD DEL INDIVIDUO}

En el siglo XIX, a raíz de los principios políticos que inspiraron las dos grandes revoluciones de finales del siglo XVIII, la Revolución Americana y la Revolución Francesa, la libertad se erigió en puntal conceptual de la reflexión política y filosófica en tanto en cuanto considerada como el derecho fundamental de los seres humanos. La articulación conceptual de la libertad se desarrolló en dos sentidos complementarios: 1) la idea de la autodeterminación de los pueblos y 2) la limitación del poder estatal y social con respecto a los derechos intrínsecos a la dignidad del individuo humano.

A partir de las dos últimas décadas del XVIII en adelante nacieron nuevos países y nuevas formas de gobierno bajo la proclama de la libertad como principio elemental. La Revolución Americana constituyó la aparición de un nuevo país, Estados Unidos de América, y la Revolución Francesa derribó al Antiguo Régimen, ambos hechos inspiraron revoluciones, guerras de independencia y movimientos de liberación en diversas partes del globo terráqueo. De esta forma, los nuevos Estados latinoamericanos que nacieron en el siglo XIX basaron sus actas fundacionales, constituciones y códigos civiles en las repúblicas que les precedieron; sus máximas cardinales consistían en garantizar la soberanía frente a terceros Estados y tiranos, así como velar por la libertad de cada uno de los ciudadanos. Si se toma como referencia el contenido político de las actas que aparecieron durante el proceso de independencia de las colonias españolas en América, y en medio de un ambiente hostil de guerra, agitación social e incertidumbre política, se aprecia cómo la idea de libertad que venía desarrollándose en las revoluciones Americana y Francesa, cobraba una sistematicidad pragmática a la hora de plasmarse sobre las declaraciones de independencia de los países latinoamericanos.

A modo de muestreo, es posible localizar en el Acta de la Declaración de la Independencia Argentina de 1816 la forma en que el Congreso de las Provincias Unidas, tras reunirse en Tucumán, declaró su emancipación de la Corona española de acuerdo a la voluntad del pueblo ${ }^{410}$. En el Estatuto provisional de Argentina del mismo año se declara que $<<\operatorname{los}$ derechos de los habitantes del Estado son la vida, la honra, la

\footnotetext{
${ }^{410} \mathrm{Cfr}$. El Redactor del Congreso nacional, Acta de la Declaración de la Independencia de argentina (1816). N. ${ }^{\circ} 6$., http://www.historiadelderecho.es/h\%20dcho/docencia/hce/TEXTOS/AMERICANAS/LATINOAMERIC ANAS/ARGENTINA.pdf [consultado el 10/01/2017], 1-2.
} 
libertad, la igualdad, la propiedad y la seguridad $>>$, siendo la libertad definida como $<<$ la facultad de obrar cada uno a su arbitrio, siempre que no viole las leyes, ni dañe los derechos del otro $>{ }^{411}$. Igualmente, se reconoce a cada ciudadano como miembro de la soberanía popular ${ }^{412}$, es decir, cada individuo en la medida en que goza del reconocimiento de unos derechos civiles es parte del conjunto soberano que conforma el pueblo.

También, a modo de muestreo, en la Proclamación de Independencia de Chile de 1823 se puede apreciar que la sublevación contra el Imperio español se justificó apelando a la voluntad de autodeterminación política del pueblo, que solo podía venir garantizada por la existencia de un Estado independiente de cualquier tirano o potencia extranjera. En esta proclamación se manifiesta que España, habiendo usurpado los derechos del Nuevo Mundo mediante la fuerza durante más de trescientos años y habiendo fracasado previamente quienes se opusieron a esta situación, tendría que poner fin a su dominación ya en el siglo XIX debido a la resuelta disposición de los pueblos de América a alzarse contra sus opresores. Advierte la declaración que los rebeldes encontraron oportuno abrir un Gran Registro para que todo ciudadano en calidad de su libertad sufragara a favor o en contra de que el gobierno proclamara la independencia de Chile, y que ante la determinación a favor, el gobierno provisional en calidad de ostentador del poder habría de resolverse a declarar la plena soberanía del país, tanto de hecho como de derecho ${ }^{413}$. La voluntad del pueblo, bajo este procedimiento plebiscitario, cuenta con cauces de expresión para transmitir una decisión política que habría de ser ejecutada con el fin de realizar la opción respaldada por la mayoría.

En la Proclamación, la libertad es definida como el "más alto designio natural", razón por la que la independencia política se encuentra identificada con el concepto de libertad natural. En esta declaración se asocia la soberanía con la natural dignidad de los pueblos, de modo que promueve la idea de libertad en vínculo con el sentido que arroja el término autodeterminación. La cuestión que cabe preguntarse es: ¿Cuáles son las bases teóricas desde las que se suponía que podía implementarse la libertad de un conjunto soberano (independiente) de personas con respecto a la libertad que dignifica a

\footnotetext{
411 Dr. Antonio Sáenz, Presidente; José Mariano Serrano, Diputado-Secretario, Estatuto provisional, "Sección primera. Del hombre en sociedad" (1816), 1-3.

412 Cfr. Dr. Antonio Sáenz, Presidente; José Mariano Serrano, Diputado-Secretario, ob. cit., 4.

${ }^{413}$ Luis Valencia Avaria, La Declaración de la Independencia de Chile (Santiago de Chile: Imp. El Esfuerzo, 1943), 12-16.
} 
los individuos en particular, en la medida en que son reconocidos como seres autónomos, independientes y capacitados para autodeterminarse al igual que los Estados? El discurso que Benjamin Constant pronunció en el Ateneo de París en 1819 testimonia, en buena medida, qué se estaba entendiendo a propósito de la concepción de libertad individual.

Constant afirma que en la antigua Atenas el individuo <<estaba mucho más sometido a la supremacía del cuerpo social $>{ }^{414}$, por tanto, entre los modernos de su tiempo el objetivo primordial <<es la seguridad en los disfrutes privados; y [los modernos] llaman libertad a las garantías concedidas por las instituciones a esos disfrutes $>{ }^{415}$. Los contrastes entre la liberad de los antiguos y la de los modernos reside en que los primeros vieron en la soberanía del conjunto de la sociedad el punto culmen de su libertad, mientras que los segundos, además, entienden la libertad ligada a la autodeterminación del individuo en su entorno privado. La forma en que Constant diferencia la libertad entendida como soberanía política - la libertad nacida en la antigüedad- a la libertad surgida en la modernidad, se combinaron en esas declaraciones de independencia y constituciones de los nuevos Estados. Constant estableció unas diferencias en torno a las nociones de libertad que tienen su base en esa primera libertad conseguida por los antiguos, pero que requiere completarse, perfeccionarse y desarrollarse en el plano de la individualidad:

La libertad individual, repito, es la verdadera libertad moderna. La libertad política es su garantía. Por consiguiente, la libertad política es indispensable. Pero pedir a los pueblos de nuestros días que sacrifiquen, como los de antes, la totalidad de su libertad individual a la libertad política, es el medio más seguro para apartarles de la primera y, cuando eso se haya logrado, no se tardará en arrancarles la segunda. ${ }^{416}$

En el discurso que Constant pronunció en 1820, tiene lugar una de las más claras y manifiestas oposiciones a la ley de excepción como ejemplo de arbitrariedad autoritaria. El pensador francés argumenta que la tradición jurídica que ampara las arbitrariedades de los gobernantes bajo la excusa de la excepcionalidad trae consigo consecuencias nefastas para la libertad individual, advierte de los abusos y desmanes que pueden llegar a cometer las autoridades en nombre de la urgencia que conllevan las circunstancias

\footnotetext{
${ }^{414}$ Benjamin Constant, Escritos políticos (Madrid: Centro de Estudios Constitucionales, 1989), 267.

415 Constant, ob. cit., 269.

416 Constant, ob. cit., 278.
} 
excepcionales $^{417}$. En su discurso, Constant alega que la ley de excepción aplicada en Francia durante el periodo del Imperio napoleónico, y previamente aplicada por la Convención, le obligó a exiliarse de Francia; dicha ley promovía la detención de cualquier individuo de manera confidencial así como permitía su asilamiento indefinido, sin garantías de comunicabilidad; dice el propio Constant, con aflicción:

En aquel entonces me marché de Francia, porque los señores prefectos de policía y Bonaparte me podían detener basándose en "iniciativas confidenciales" y según su convicción no comunicable. No esperaba encontrarme de nuevo a la merced de estas "iniciativas confidenciales" y de esta convicción no comunicable, bajo un gobierno constitucional. ${ }^{418}$

Constant clama porque los individuos mantengan intactas unas garantías legales que no deterioren o lesiones sus libertades. Por ello, cualquier arbitrariedad del Estado que afecte a los individuos, ya provenga de un gobernante que no escatima su tiranía o, de forma menos flagrante, arbitrariedades provenientes de la aprobación de un gobierno constitucional son, para Constant, acciones abusivas que ningún Estado moderno debería tolerar.

La imagen de la libertad que patentan las declaraciones de independencia decimonónicas que se han mostrado se conforma, a grandes rasgos, con los conceptos de soberanía, dignidad natural, autonomía y respeto de la individualidad del ciudadano. La laxitud de esta imagen de la libertad en sus resoluciones trajo consigo la problemática de cómo articular las libertades individuales en el marco de la sociedad y el Estado, dicha problemática supuso reformular algunas de las figuraciones de poder de la escena social, política y económica, pues había que hacer del individuo una figura de poder que revistiera a las personas de unos derechos propios e inquebrantables. Por un lado, era preciso limitar el poder estatal para amortiguar los posibles excesos y abusos provenientes de aspiraciones tiránicas y de la fuerza pública, mientras que, por otro lado, era necesario que la individualidad ostentara un poder que implicase la presencia inherente de derechos y obligaciones en todos y cada uno de los miembros de la sociedad civil.

En el breviario de Norberto Bobbio titulado Liberalismo y democracia el pensador italiano da cuenta de los parámetros más determinantes del pensamiento liberal acerca

\footnotetext{
417 Cfr. Constant, ob. cit., 247.
}

${ }^{418}$ Constant, ob. cit., 250-251. 
de las nociones de Estado e individuo, nociones presentes desde un punto de vista pragmático en las legislaciones del XIX y que aún hoy continúan vigentes en casi todas las constituciones de manera nuclear. Para Bobbio, uno de los autores más prototípicos de la manera liberal de pensar fue Thomas Pain, que con anterioridad a la Revolución americana ya afirmaba que la sociedad nace con el fin de paliar las necesidades que tienen los seres humanos, los cuales se asocian para procurarse los medios con que facilitarse la subsistencia y sobrevivencia, mientras que el gobierno es fruto de la maldad humana ya que se requiere de una instancia superior en fuerza a los individuos para retener sus conductas viciosas y perversas ${ }^{419}$. La argumentación de Paine le resulta lo suficientemente válida a Bobbio como para atribuirle al liberalismo la preferencia por el Estado mínimo, es decir, que el poder del Estado no cuente con la densidad suficiente como para llegar a abrogar las iniciativas individuales de forma arbitraria o tiránica. Bajo estos preceptos, Bobbio sostiene que el nacimiento del Estado liberal supuso

la formación de Estados neutrales o agnósticos con respecto a las creencias religiosas de sus ciudadanos (...) y con la exigencia de la disposición libre de los bienes y de la libertad de intercambio, que señala el nacimiento y el desarrollo de la sociedad mercantil burguesa. ${ }^{420}$

Buena parte del pensamiento liberal decimonónico afinó la conciliación entre la individualidad y la sociedad, estableciendo limitaciones en el ejercicio gubernamental que no quebraran la libertad y los derechos individuales; conscientes de la inferioridad del individuo ante el poder del Estado, pero también cerciorados de la necesidad del Estado como ordenamiento político fundamental para la sociedad, muchos liberales de la época vieron en la positividad jurídica el modo de proteger, garantizar y articular la libertad de los individuos, además de procurar medios legales con que proteger a los ciudadanos de posibles abusos y tiranías provenientes de gobernantes, jueces y cargos públicos.

La pretensión del recorrido que acaba de comenzar dentro de la presente sección no es otra más que mostrar las distintas posiciones del poder con respecto al cuerpo en la justificación filosófica de la libertad, resuelta en la configuración del derecho de propiedad privada como derivación de un factum que la hace practicable, a saber, esa libertad que los hombres albergan por naturaleza. Entre la libertad y la propiedad se

${ }^{419}$ Cfr. Norberto Bobbio, Liberalismo y democracia (Buenos Aires: Fondo de Cultura Económica, 1989), 22.

${ }^{420}$ Bobbio, ob. cit., 23. 
halla el trabajo, actividad que se presenta como una integración de ambas en cuanto forma de apropiación y de liberación, lo que no exime al concepto de trabajo de tensiones teóricas bastante agudas.

\subsubsection{LA EMANCIPACIÓN DE LA INDIVIDUALIDAD Y LA DEFENSA DEL DERECHO DE PROPIEDAD PRIVADA}

En Del espíritu de conquista y de la usurpación Constant describe el pasado de la humanidad como una vorágine de agresiones y violencia producidas por las guerras, única forma que tenían los Estados de enriquecerse. Esta actitud beligerante corresponde a etapas que el filósofo de Lausana cree que la modernidad debe superar, pues en las nuevas sociedades modernas el comercio debe alzarse como mediador de las relaciones entre los pueblos y los hombres: $<<$ La guerra es por lo tanto anterior al comercio. La una es impulso salvaje, el otro cálculo civilizado $>{ }^{421}$. El autor dice que el despliegue de fuerzas físicas en las guerras no tiene sentido en el contexto moderno, puesto que la guerra habría perdido todo su atractivo así como también su utilidad en la medida en que no genera ningún tipo de beneficios y, por ende, practicarla no supone ya ningún interés ni motivo de orgullo para los hombres ${ }^{422}$. Según Constant, el fin $<<$ de las naciones modernas es el sosiego, el bienestar, y como fuente de bienestar, la industria $>{ }^{423}$, además, las guerras implican tanto desgaste para las arcas de las naciones que hasta la victoria sale demasiado cara en el contexto moderno.

En el capítulo XV de los Principios de Política titulado "De la inviolabilidad de las propiedades", Constant dice que la propiedad privada no es un requisito indispensable en todas las sociedades humanas, puesto que existen y pueden existir regímenes políticos en los que la propiedad como tal no sea reconocida como derecho; de esta forma, el autor estaría situando el derecho de propiedad privada bajo el consentimiento de la sociedad civil ${ }^{424}$. No obstante, matiza el pensador de Lausana que considerar a la propiedad privada fruto de la convención social no le resta reconocimiento en cuanto a su carácter inviolable y necesario se refiere, que no por incluirla en el terreno de la convencionalidad se promueve e incita la abolición del derecho de propiedad $^{425}$. A

\footnotetext{
${ }^{421}$ Benjamin Constant, Del espíritu de conquista y de la usurpación (Madrid: Tecnos, 2008), 18.

${ }^{422}$ Constant, ob. cit., 20.

${ }^{423}$ Constant, ob. cit., 18.

${ }^{424}$ Cfr. Benjamin Constant, Escritos políticos (Madrid: Centro de Estudios Constitucionales, 1989), 139.

${ }^{425}$ Cfr. Constant, ob. cit., 140.
} 
diferencia de los naturalistas liberales, que sitúan este derecho en el orden de la naturaleza humana, Constant lo posiciona en el dominio de la positividad jurídica.

Constant encuentra que para prohibir la propiedad privada es necesario impedir el trabajo, igualmente, propuestas como repartirlo a partes iguales entre los miembros de la población terminarían por desvirtuar las ventajas que aporta. La propiedad privada impulsa el progreso porque incentiva a los seres humanos ${ }^{426} \mathrm{y}$, dado que surge en el marco de las relaciones sociales, su reconocimiento jurídico se gesta en el seno de la sociedad. Sin embargo, la sociedad no posee ese mismo poder jurídico sobre la integridad de la persona, es decir, sobre su libertad y su vida. No obstante, Constant enlaza el desarrollo y defensa de los derechos inherentes al individuo, que no dependen del reconocimiento social, con el derecho de propiedad privada, pues más que un complemento, la propiedad privada es necesaria para dignificar la vida y posibilitar la libertad de cada individuo. Así, entonces, el filósofo francés encuentra que el poder social sobre la propiedad debe limitarse a favor de la libertad e integridad de cada una de las personas. Las decisiones arbitrarias sobre la regulación del derecho de propiedad afectan también a la existencia humana y a la libertad, consecuentemente, a quien se le expropia algún tipo de propiedad hará todo lo posible para defenderse del expolio que sufre, lo que provocará que el expoliador, para defenderse de la respuesta del expoliado, tenga que verse forzado a cohibirlo ${ }^{427}$. Por tanto, vemos el estrecho vínculo que Constant establece entre el derecho de propiedad privada y la libertad, el primero es social, la segunda es individual, pero ambos están conectados. La intervención social de la propiedad habrá de cuidarse de no dañar los aspectos personales de la vida humana, cuya libre realización material dependerá del acceso, uso, producción y posesión de propiedades.

Se podría decir que Constant piensa la libertad más como un naturalista que como un positivista, pero que el derecho de propiedad lo piensa justamente al contrario -como positivista- al no encontrar un vínculo natural entre la propiedad privada y la constitución ontológica del hombre. La libertad sí puede formar parte de la naturaleza humana, pero la propiedad no, porque no acompaña al individuo por naturaleza. El problema latente en la filosofía política de Constant es hasta qué punto, si la libertad requiere de la propiedad privada para dignificar la vida del individuo, puede el derecho

\footnotetext{
${ }^{426}$ Cfr. Constant, ob. cit., 140-141.

${ }^{427}$ Cfr. Constant, ob. cit., 141-142.
} 
de propiedad emerger y sostenerse en la sociedad, dado que su razón de ser pende del hilo de la convencionalidad.

Fernando Longás en La libertad en el laberinto del minotauro proporciona algunas pistas en lo referente al modo en que el filósofo de Lausana salió al paso de esta problemática. Según Longás, Constant hace de la libertad un cobijo en el que el individuo se defiende del entorno social que le rodea, la libertad es vista como un derecho protector frente a la sociedad civil más que como un cimiento de la vida social $^{428}$. Propiedad y libertad se pliegan al dominio de la privacidad, lo que <<constituye la última y radical transformación en la representación que el hombre tendrá, desde la perspectiva liberal, de su existencia y de sus posibilidades de vida $>>429$. De este modo, Constant habría desintegrado la relación que el liberalismo de corte naturalista establecía entre la libertad y la propiedad. De acuerdo con las directrices que ofrece Longás, podría decirse que Constant no hizo reposar la relación libertadpropiedad sobre una base moral y política, sino económica, una base radicalmente diferenciada de los dominios mencionados; la versión decimonónica del liberalismo pergeñado por Constant <<quiso hacer de la libertad individual algo diferente al poder político y terminó por convertirla en un poder económico > ${ }^{430}$.

Frente a las propuestas socialistas incipientes, Constant se convenció, y así se esforzó en transmitirlo, de los retos que el liberalismo debía superar para no suspender las libertades adquiridas por los individuos. La convención social, en un clima donde el socialismo cada vez se advertía más pujante, resultaba bastante volátil en el aseguramiento del derecho de propiedad privada, precisamente por ello el filósofo de Lausana tenía que apoyarse en un concepto de libertad fundado en la naturaleza humana, independientemente de que el derecho de propiedad privada residiera en el ámbito de la convencionalidad o no. Se precisaba que la sociedad asumiera una legislación y un estilo de gobierno que reforzara esa concepción de la libertad, puesto que solo dicha concepción podría impulsar una convencionalidad que no pusiera en peligro el derecho de propiedad privada. La sociedad se vuelve un potencial enemigo de la libertad, siempre y cuando el conjunto de los hombres se resolviera a no respetar el derecho de propiedad, cuya defensa o no recae en el seno de la sociedad misma. El

\footnotetext{
${ }^{428}$ Cfr. Fernando Longás, La libertad en el laberinto del minotauro (Santiago de Chile: Editorial Cuarto Propio, 2005), 91.

${ }^{429}$ Longás, ob. cit., 92.

${ }^{430}$ Longás, ob. cit., $94-95$.
} 
desarrollo íntegro de la libertad requiere que no se opongan trabas a la posesión, de lo contrario, la libertad de los individuos se vería frustrada.

En Principios de política aplicables a todos los gobiernos Constant sitúa en los propietarios las cualidades y excelencia políticas idóneas para la dirección de las sociedades humanas. Establece un íntimo nexo entre el poder y la propiedad, pues considera que <<poner el poder en la propiedad no es la misma cosa que poner la propiedad en el poder. Las riquezas tienen influencia y consideración en la medida en que no son adquiridas súbitamente > ${ }^{431}$. El poder que se consigue por la posesión lícita de la propiedad conlleva la legitimación política, pero, por el contrario, las propiedades que se adquieren mediante el uso fraudulento del poder no confieren licitud política a quien ha aprovechado una situación de superioridad para enriquecerse a costa de su posición. La propiedad usurpada no procede del esmero en el trabajo y la pericia en el comercio, sino del robo y la agresión. En las sociedades modernas la toma de posesión de propiedades debe producirse a partir de cauces pacíficos, no por ello absueltos de la competencia en el trabajo y el comercio. Asevera Constant que <<en una sociedad bien organizada, el talento conduce a la propiedad $>>$ porque quien $<<$ se enriquece mediante su industria o sus facultades aprende a merecer lo que adquiere $>>432$. El trabajo procura en la escena productiva y comercial el éxito a la hora de obtener propiedades, requisito necesario para participar en la toma de decisiones dentro de la vida pública.

El trabajo en el conjunto de la sociedad vendría regulado por la forma en que se relacionan los agentes que participan del proceso productivo y comercial, no por las autoridades estatales ni por las organizaciones políticas. El trabajo, entonces, es una actividad que requiere del esfuerzo individual pero que se desenvuelve en un entorno social. Medidas de calado político como establecer el precio del trabajo por ley no beneficiarían ni a los trabajadores ni a los patronos. El único estándar orientativo fiable para determinar tal precio es la competencia, en palabras de Constant:

Existe una causa eterna de equilibrio entre el precio y el valor del trabajo, una causa que actúa sin coerción, de manera que todos los cálculos sean razonables y todos los intereses sean satisfechos. Esta causa es la competencia. Pero se la rechaza. Se obstaculiza la

\footnotetext{
${ }^{431}$ Benjamin Constant, Principios de política aplicables a todos los gobiernos (Madrid: Katz, 2010), 200.

${ }^{432}$ Benjamin Constant, Del espíritu de conquista y de la usurpación (Madrid: Tecnos, 2008), 90.
} 
competencia con reglamentos injustos y luego se quiere restablecer el equilibrio con otros reglamentos no menos injustos, que hay que mantener mediante castigos y el rigor. ${ }^{433}$

Tras la determinación del valor del trabajo, cuyo estándar objetivo de valoración es el salario, estaría actuando la competencia como una forma natural e independiente con respecto a las intenciones, voluntades e intereses de las autoridades políticas. Para Constant la intervención política en asuntos laborales obstruye el flujo natural de la competencia. El trabajo ni se corresponde ni va en relación con lo político, este pertenece al dominio de la economía porque es una actividad estrictamente económica y no política. Lo político tiene que mantenerse al margen y no inmiscuirse en aspectos relativos al valor del trabajo, para que su precio sea asignado en función de la coyuntura competitiva de la economía.

A ojos de Constant, la intervención política en las vicisitudes económicas quiebra las expectativas de beneficio que los hombres ponen en su trabajo, así, para que la libertad sea efectiva, los Estados deben dejar la propiedad privada en paz. El trabajo ocupa un dominio distinto del dominio político, por eso el autor recalca

que el efecto de la intervención de la autoridad, por lo que respecta a la intervención de la producción, a veces tal vez necesaria, nunca es positivamente ventajosa. Cabe resignarse a ella como a un mal inevitable; pero siempre se debe tender a circunscribir ese mal en los límites más estrechos. ${ }^{434}$

Constant construye una figura de poder que inserta en la individualidad humana, una figura a través de la que reclama la primacía del individuo soberano sobre sí mismo en sus asuntos privados. El ciudadano solo podrá responsabilizarse de los menesteres públicos en la medida en que constate que sus posesiones son el usufructo de una dedicación y esfuerzo. Podría decirse que Constant instaura una figura de poder asociada a una concepción individualista, fundada en la idea de que el individuo dirige su vida y su cuerpo en función del aparato conceptual que prefigura la forma de su individualidad.

El derecho de propiedad, más que la materia de las propiedades, se convierte en un principio abstracto indisociable del individuo, cuyo estatus civil se erige con arreglo al título jurídico de propietario que lo representa lo que, en la práctica le otorgaba, no solo unas posibilidades más amplias con respecto a los desposeídos, sino también una

\footnotetext{
${ }^{433}$ Benjamin Constant, Principios de política aplicables a todos los gobiernos (Madrid: Katz, 2010), 267. ${ }^{434}$ Constant, ob. cit., 296.
} 
posición social y unos derechos de explotación que bien podían comportar un privilegio. El individualismo que acompasaba al aparato conceptual de la individualidad implantaba un poder en el seno del ciudadano particular, un poder que lo protegía de los posibles excesos manantes de la arbitrariedad subyacente a los acuerdos y convenciones sociales. El poder inserto en la individualidad, entonces, era una estrategia de defensa que bien merecería el calificativo de "contra-poder". De este modo, un autor como Alexis de Tocqueville, que en los años subsiguientes a la Revolución francesa vivió las revoluciones de 1830 y de 1848, decía, en el esbozo de 1847 para un proyecto de manifiesto "Sobre la clase media y el pueblo", que la Revolución francesa de 1789 mantuvo el derecho de propiedad privada pese a haber derogado otros muchos derechos junto a los privilegios, pero, inmerso en el contexto de su presente revolucionario, advierte:

Que los propietarios no se hagan ilusiones sobre la fuerza de su situación, y que no imaginen que el derecho de propiedad es una fortaleza inexpugnable simplemente porque hasta ahora nunca ha sido asaltado, ya que nuestra época no se parece a ninguna otra. Cuando el derecho de propiedad no era más que el origen y el fundamento de muchos otros, se podía defender sin esfuerzo, o mejor dicho, nadie lo atacaba. ${ }^{435}$

La actitud de Tocqueville ante el clima revolucionario que respiraba Francia previamente a 1848 no le inspiraba -debido al tono reservado y prudente de sus declaraciones- un gran fervor revolucionario, sino que, más bien, el pensador francés manifiesta una clara preocupación e incertidumbre ante los desmanes que la exaltación revolucionaria pudiera ocasionar contra el derecho de propiedad privada. En el discurso que pronunció el 12 de septiembre de 1848 en la Asamblea Constituyente, mientras se discutía sobre el derecho al trabajo durante la elaboración del proyecto de la Constitución, Tocqueville advierte sobre los perjuicios que generaría atribuirle al Estado la responsabilidad de proporcionar empleo a los ciudadanos, porque semejante supuesto traería consigo la conversión del Estado en director de todas las actividades productivas y distributivas de los recursos. La casi omnipresencia que adquiriría este Estado sumiría la iniciativa privada y las actividades económicas a la dirección política, los organismos estatales decidirían sin ningún tipo de contrapeso sobre los asuntos económicos, como son la asignación de recursos, las horas de trabajo, la cantidad de trabajadores o qué y cuánto producir; en consecuencia, tanto el desarrollo industrial como el destino de los

\footnotetext{
${ }^{435}$ Alexis de Tocqueville, Igualdad social y libertad política (Barcelona: Página indómita, 2015), 231.
} 
productos quedarían bajo el dominio total del Estado. Si se tratara de aplicar una alternativa más flexible a este comunismo y tan solo se interviniera el trabajo, repartiéndolo entre los ciudadanos para eliminar el paro, igualmente el Estado tendría que convertirse en el único organizador y responsable de la producción, controlando sus ritmos y soterrando la competencia salarial ${ }^{436}$. Según Tocqueville, este tipo de prácticas debilitarían la libertad y afectarían considerablemente al desarrollo económico de Francia y de cualquier otro país donde fueran aplicadas.

A tenor de las cauciones presentes en las intervenciones de Toqcueville en la asamblea constituyente francesa, cabe destacar también que una de las preocupaciones vertebrales de La democracia en América se relaciona con el poder de la mayoría. El autor observa que en el modo de ejercitarse la democracia estadounidense está implícita la posible deriva hacia la tiranía de la mayoría sobre los derechos del individuo. En una parte de la obra, Tocqueville reflexiona acerca del poder sobre el pensamiento: asegura que, aunque el pensamiento comporte un poder invisible, ya que ni la peor tiranía puede detener la libertad de pensamiento, en las circunstancias estadunidenses resulta que, en el momento en que la mayoría se expresa, sus sentencias y encomiendas resultan irrevocables, de tal modo que todas las opiniones divergentes quedan silenciadas. El carácter problemático de esta conducta del poder abrumador de la mayoría sobre la libertad de los individuos convertiría a la democracia americana en una potencial tiranía, diferente incluso de la monarquía absoluta, dado que $<<$ no hay monarca tan absoluto que pueda reunir en su mano todas las fuerzas de la sociedad, y vencer las resistencias, como puede hacerlo una mayoría revestida del derecho a hacer las leyes y ejecutarlas $>>437$.

El temor que Constant y Tocqueville manifiestan expresamente a la figura de dominación que ven inserta en el Estado se funda en el hecho de que este pudiere albergar la capacidad suficiente como para sobrepasar los derechos de los individuos, tanto en el ámbito material de la propiedad, del trabajo y del comercio, así como también en el de las creencias, las opiniones e, incluso, de la intimidad. Solo contemplar la posibilidad eventual de que el estado dirija la política económica, que se viera legitimado para organizar las actividades productivas y se arrogara el derecho de entrometerse en asuntos que tienen que ver con el mercado, como lo son la cuantía de

\footnotetext{
${ }^{436}$ Cfr. Tocqueville, ob. cit., 242-243.

${ }^{437}$ Alexis de Tocqueville, La democracia en América (Madrid: Orbis, 1985), 115.
} 
los salarios o el precio de los productos, representaría la pérdida parcial o total de la libertad de los individuos.

\subsubsection{LA BELIGERANCIA DEL RECONOCIMIENTO}

La filosofía política liberal en el siglo XIX puso de relieve la necesidad de mantener unas relaciones de paz entre las naciones, pueblos e individuos para incrementar el espacio del mercado y, de este modo, construir contextos en los que el individuo lograre hacer posible una emancipación plena con respecto al control estatal y a las obligaciones tradicionales de la comunidad. Sin embargo, en el caso de los procesos de independencia de las naciones americanas se aprecia una contextura histórica beligerante en la que surgieron rivalidades indelebles. El logro de la soberanía nunca podría haberse consumado sin que las recién nacidas repúblicas hubieran obtenido el reconocimiento de otros Estados soberanos.

En Ruptura y reconciliación, un compendio de investigaciones históricas recogidas con el fin de dar cuenta sobre las vicisitudes que atravesaron los países latinoamericanos para ser reconocidos como Estados soberanos, se menciona cómo este reconocimiento de independencia era un asunto crucial para las colonias en emancipación, pues significaba una suerte de fortaleza a la hora de afianzar las fronteras entre los nuevos países vecinos. En medio del mosaico de países que estaban surgiendo en Latinoamérica, el reconocimiento suponía <<un respaldo en las disputas que los distintos gobiernos tenían con sus respectivos vecinos por el trazado de los límites fronterizos $>{ }^{438}$. Esta situación general de las repúblicas surgidas del antiguo Imperio español en América sitúa la concepción del reconocimiento como objeto de pugna y disputa, lo que, a su vez, pone en relación la noción de reconocimiento con la de libertad política.

La caracterización política del reconocimiento fue una línea maestra en la filosofía de Georg Wilhelm Friedrich Hegel, cuyo origen tiene una raigambre ontológica y antropológica fundamental para la comprensión de la libertad. Desde un punto de vista dialéctico y al margen de los criterios filosóficos del liberalismo, Hegel mantuvo la idea de que el porvenir histórico de la Europa de la Revolución francesa suponía una superación histórica de la civilización anterior y una resolución objetiva de la libertad.

${ }^{438}$ Carlos Malamud, et al., Ruptura y reconciliación (Madrid: [como coeditores] Fundación MAPFRE y Santillana Ediciones Generales S.L., 2012), 16. 
En la Fenomenología del espíritu Hegel articula las nociones de libertad y trabajo en una relación de autoconciencias que considera universal a todo el género humano; el pensador alemán realizó un ejercicio dialéctico que trataba de explicar la forma general de las relaciones de reconocimiento, donde la libertad humana aparece como el valor en disputa. Concretamente es en el capítulo IV de la sección "A" de la mencionada obra donde el autor desarrolla la dialéctica de la autoconciencia, en la que aparecen las figuras del señor y el siervo: la primera figura emerge como una forma de dominio, es decir, como una instancia de poder, mientras que la figura del siervo ocupa la polaridad del dominado. Ambas figuras surgen de la tensión inicial entre dos autoconciencias que pugnan por reconocerse libres la una en la otra. Hegel define la autoconciencia como "ser para sí", una subjetividad indeterminada en su ser y característica distintiva de la conciencia humana, dado que $<<$ la conciencia es inmediatamente lo contrario de la determinidad en que está puesta $>{ }^{439}$. Pero como cada autoconciencia es puro "ser para sí", cuando una autoconciencia se pone frente a otra surge el conflicto por el reconocimiento en la medida en que ninguna de las dos, en principio, permite ser para la otra, sino que aspiran a ser reconocidas en cuanto a su esencia se refiere: el "ser para sí" en cuanto libertad. En consecuencia, el reconocimiento por la libertad causa un litigio inicial en el seno de las relaciones entre los individuos; la resolución de dicha tensión desembocará en una forma relacional asimétrica, en tanto en cuanto una de las polaridades autoconscientes se instaurará como parte reconocida mientras que la otra polaridad quedará como parte "reconociente" $" 440$.

La autoconciencia se enfrenta a otra autoconciencia por el reconocimiento, ambas luchan por la libertad, por algo abstracto y diferente de cualquier cosa dada en la naturaleza. El reconocimiento se da solo a pesar de la vida, o sea, solo en la medida en que se pone en riesgo la salud e integridad corporal gracias a la que los hombres permanecen vivos, luego, el contacto pugnante de las autoconciencias pone en liza la libertad solo en cuanto que merece la pena morir por ella. Esta es la única forma de hacer verdadera la libertad porque es la única manera de concederle la posibilidad de ser en el ámbito natural de las determinaciones y contingencias. El carácter mortal de la lucha por el reconocimiento verifica que la libertad vale lo suficiente como para perder la vida por ella:

\footnotetext{
${ }^{439}$ Georg Wilhelm Friedrich Hegel, Fenomenología del espíritu (Valencia: Pre-Textos, 2006), 287.

${ }^{440}$ Cfr. Hegel, ob. cit., 290.
} 
La relación de ambas autoconciencias viene, pues, determinada de forma que ambas se acreditan cada una ante sí misma y la una frente a la otra mediante la lucha a vida o muerte. -No tienen más remedio que entablar esa lucha, pues la certeza de ser ellas mismas, es decir, la certeza de ser cada una de ellas para sí, tienen que levantarla a verdad (...). Y es solo en el exponer y en el arriesgar la vida en lo que se acredita la libertad. ${ }^{441}$

El riesgo de la vida equivaldría a poner por delante el reconocimiento antes que la corporalidad. Si el cuerpo es el sustento físico que garantiza la vida, entonces, al otorgarle un mayor valor al reconocimiento se está suponiendo que la objetivación de la libertad está por encima de lo que vale el cuerpo en cuanto que objeto físico de la naturaleza; la destrucción del cuerpo a costa de luchar por el reconocimiento sería la prueba física de un valor metafísico, a saber, el de la libertad como algo no dado en la naturaleza y que, por consiguiente, debe ser producido en el seno de las relaciones entre humanos. Se podría decir que el cuerpo vivo se convierte en objeto canjeable por la libertad, aunque este canjeo solo pueda darse dentro de las relaciones en el mundo físico, pues a un nivel metafísico la libertad es pura indeterminación, de tal forma que resulta intangible, intransferible y no equiparable a nada corporal. Pero la muerte no tiene que consumarse para que se produzca el reconocimiento, de hecho, la lucha a muerte es la manera que tienen de medirse las dos autoconciencias enfrentadas; esta es una beligerancia mortal insinuada pero que no debe consumarse, no debe llegar hasta la destrucción corporal, porque si el cuerpo de alguno de los dos contendientes es destruido, si la muerte se lleva a término, entonces, toda posibilidad de reconocimiento se habrá desvanecido.

La autoconciencia que temió por su vida se somete con el propósito de no morir y mantener la integridad de su cuerpo, de esta autoconciencia nace la figura del siervo. Por otro lado, el señor es la autoconciencia que se resolvió a luchar pese a la muerte, que no tuvo como su preferencia perpetuarse biológicamente, sino que se elevó sobre sus condicionamientos corporales para conseguir el reconocimiento de su libertad. Para el pensador alemán, el siervo, derrotado y despojado de la libertad, es la parte de la relación dialéctica que queda relegada al trabajo. El siervo hace aquello que resulta costoso para los seres humanos y que supone tener que emplear esfuerzo, incurrir en un desgaste físico para transformar la naturaleza y así apropiarse de ella. De este modo $<<$ el siervo, en cuanto autoconciencia en general, se refiere a la cosa o se relaciona con

${ }^{441}$ Hegel, ob. cit., 291. 
la cosa también negativamente y la suprime o la supera $>>442$. El siervo actúa como esa conciencia dependiente de la naturaleza, una forma de autoconciencia no esenciada todavía en el "sí mismo" sino, a saber, arraigada a su ser biológico, a su corporalidad como vida.

En la introducción que el pensador de origen ruso Alexander Kojève escribe a sus Lecciones sobre la Fenolenología del espíritu el hombre es definido como el único ser <<consciente de su realidad y de su dignidad humanas, y en esto se diferencia esencialmente del animal, que no supera el nivel del mero Sentimiento de sí $>>443$. Kojève convierte el término "deseo" en una categoría central en su interpretación de la dialéctica del señor y el siervo. Distingue entre el deseo animal, que es mero sentimiento de sí, del deseo humano, que es el deseo de otro deseo, pues las relaciones entre los hombres implican un desear el deseo de otro. El ser humano aparece en el mundo en la inherencia de su realidad corpórea, es decir, su vida no es distinta de la de un animal puesto que tiene deseos que inicialmente permanecen anclados al mero sentimiento de $\mathrm{sí}^{444}$. El factor distintivo del ser humano, aquello que lo diferencia de lo meramente animal, es trascender su animalidad desiderativa cuando descubre la multiplicidad de deseos entre sus semejantes, tal como dice Kojève:

El hombre solamente puede aparecer sobre la tierra, por tanto, en el seno de una manada.

Por eso la realidad humana solamente puede ser social. Pero para que la manada se convierta en una sociedad no basta la mera multiplicidad de deseos; hace falta, además, que los Deseos de todos los miembros de la manada versen -o puedan versar- sobre los Deseos de los otros miembros. ${ }^{445}$

Kojève interpreta la figura del señor hegeliano como un poder condenado a desgastarse a lo largo del proceso dialéctico, el poder del señor reside en que puede matar, esa posibilidad es la que pesa en el siervo, ahora bien, la realización de la historia no la hacen los guerreros expuestos a la extinción de su ser, por eso el señorío no transforma el mundo ni cambia por sí mismo. El siervo, sin embargo, transforma el mundo mientras su señor disfruta de las cosas trabajadas, él conoce el proceso por el que puede producir cosas nuevas ${ }^{446}$. Consecuentemente, Kojève sostiene que el trabajo

\footnotetext{
${ }^{442}$ Hegel, ob. cit., 295.

${ }^{443}$ Alexander Kojève, Introducción a la lectura de Hegel (Madrid: Trotta, 2013), 51.

${ }^{444}$ Cfr. Kojève, ob. cit., 52.

${ }^{445}$ Kojève, ob. cit., 53.

${ }^{446}$ Cfr. Kojève, ob. cit., 69.
} 
no es solo un proceso productivo sino un proceso liberador para la conciencia servil, ya que si el esclavo aparecía en un principio como una conciencia dependiente de la naturaleza cuando trabaja al servicio del amo, termina por erigirse en dueño de la naturaleza que trabaja, ya que aprende a negar las cosas dadas. Esta acción-negadora rompe la síntesis primigenia del siervo con la naturaleza, pues sabe negar las cosas naturalmente dadas mediante la potencia transformadora del trabajo. El siervo termina señoreando la naturaleza de la que en un principio dependía; pero no solo transformando lo cósico alcanza la posibilidad de conseguir el reconocimiento que en un principio le fue negado, sino que también habrá de experimentar una transfiguración interior de sí para superar su posición original y crear <<así las nuevas condiciones objetivas que le permitirán retomar la lucha por el reconocimiento >>447.

Bajo el influjo de la lectura Kojèveana de la dialéctica de la autoconciencia, Georges Bataille sitúa en la acción humana el eje discursivo de la problemática que se plantea en el desarrollo dialéctico de las relaciones entre señor y siervo o amo y esclavo:

La Negatividad es el principio de la Acción o, más bien, la Acción es Negatividad y la Negatividad, Acción. Primeramente, el Hombre niega a la Naturaleza introduciendo en ella, como un reverso, la anomalía de un "Yo personal puro". Ese "Yo personal puro" está presente en el seno de la Naturaleza como una noche entre la luz, como una intimidad entre la exterioridad de esas cosas que son en sí, y que, como tales, no pueden desarrollar la riqueza de la oposición dialéctica. ${ }^{448}$

Pero la negatividad de la acción se desenvolvería, en un primer momento, en el lado del amo, quien está dispuesto a sacrificarse por el reconocimiento, algo que es radicalmente distinto de cualquier tipo de satisfacción corporal, instinto fisiológico u objeto físico al que se vea inclinado el humano en cuanto a su constitución biológicocorporal. El elemento transfigurador que tiene el hombre inicialmente es la muerte, y el humano solo podrá hacerse soberano, es decir, dueño de sí mismo, cuando se bata a muerte contra otros. Bataille da cuenta del denuedo en que incurre cuando ofrece su particular interpretación de la figura del amo -o señor- identificándolo con el soberano, en la medida en que entiende que toda autoconciencia, todo ser humano y no un animal, demuestra su soberanía en el momento en que reduce al otro a esclavo -no a cadáver-

\footnotetext{
${ }^{447}$ Kojève, ob.cit., 75.

${ }^{448}$ Georges Bataille, Para leer a Georges Bataille (México D.F: Fondo de Cultura Económica, 2015), 432.
} 
449. Además, afirma Bataille que <<de cualquier forma, se ha constituido un poder en las manos del soberano. La soberanía deja entonces de ser lo que fue: la belleza impotente que, en los combates, sólo sabía matar $>{ }^{450}$.

En el lado del esclavo la soberanía reside en la actividad del trabajo, pues quien ejerce la agencia del trabajo dispone las cosas naturales en objetos aptos para el consumo. Pero el objeto de consumo pertenece al amo y es él quien lo disfruta. El esclavo tiene que abstenerse de consumir lo que produce, tiene que reprimir su deseo de consumo, aunque, precisamente el $<<$ desapego con respecto al objeto de deseo es todo lo contrario de la actitud animal (como la actitud del perro con respecto al hueso) $>>451$. La soberanía humana del esclavo se articula a través de su renuncia al producto trabajado, esta renuncia es anómala, ya que no es la conducta normal de un animal, dado que solo el hombre puede renunciar a lo que desea. Por el contrario, el carácter soberano del señor se demuestra en la conquista de la soberanía del otro, al despojarle de la posesión del producto de su trabajo. Entonces, la soberanía bajo la interpretación de Bataille es una forma de poder que se articula en la pugna de la posesión y la desposesión, el deseo y la abstención. La soberanía es poseída por el amo que, a su vez, se la expropia al esclavo, pero, igualmente, el esclavo también entra en la confrontación por la posesión de la soberanía cuando rechaza poseer el objeto resultante de su trabajo, cuando logra detener su natural impulso biológico hacia la cosa preparada para ser consumida.

De la interpretación de Kojéve y Bataille se desprende que los seres humanos, cuando entran en una pugna puramente humana, se confrontarán por algo que es distinto de las condiciones o cosas que pueda dar la naturaleza, puesto que no son ya objetos materiales como la comida o el cobijo los motivos que subyacen a los enfrentamientos propiamente humanos, sino que va a ser la libertad el principio que motive toda lucha. La libertad no es ni un objeto físico ni un mero producto elaborado en el mundo de la naturaleza, es el contenido abstracto de la subjetividad que hace esenciales a los hombres como seres "para sí". La libertad sale a ese mundo objetivo en que se producen las relaciones humanas por medio de una tensión donde hay un contenido de

\footnotetext{
${ }^{449}$ Cfr. Bataille, ob. cit., 432.

${ }^{450}$ Bataille, ob. cit., 433.

${ }^{451}$ Bataille, ob. cit., 435.
} 
intersubjetividad que habrá de alcanzar unas objetividades en forma de jerarquías e instituciones que van a desplegarse en la historia.

Hegel supo ver en la libertad aquel principio por el cual los seres humanos pueden emanciparse de su condición meramente biológica para convertirse en seres históricos capaces de crear sus propias determinaciones a partir de los contenidos dados en sus relaciones, por ello, las confrontaciones por la libertad no se resuelven en la anulación física de la otredad, haciendo de su cuerpo un cadáver, sino logrando su reconocimiento, forma de penetrar el terreno de su subjetividad y trastocarlo. Finalmente, la intervención del reconocimiento implanta un orden subjetivo que contribuye a desfigurar el carácter natural del hombre en cuanto ser corporal; la corporalidad humana se expone a la negatividad con que el sujeto histórico niega la naturaleza de lo dado y transfigura el contenido de su devenir.

\subsubsection{LA VOLUNTAD LIBRE Y LA APROPIACIÓN DEL CUERPO EN EL ESTADO DE DERECHO: IMPLICACIONES POLÍTICAS DE LA NATURALEZA CORPORAL}

El elemento formal en torno al que se articula la dialéctica de la autoconciencia de Hegel es la libertad. La libertad es el movimiento más esencial del ser humano en tanto en cuanto cada sujeto es un ser para sí mismo. El "ser para sí" es en su subjetividad indeterminación, sin embargo, esta forma primigenia de libertad tendrá que objetivarse en el ámbito de las determinaciones, es decir, en el contexto de la naturaleza. Merced a estas consideraciones en torno a la libertad, la filosofía política del pensador alemán sitúa al Estado como la instancia última en que la libertad adquiere objetividad, allí donde las subjetividades se amparan en unos principios universales y se cierra la beligerancia por la libertad que se da en el seno de las relaciones humanas. En los Principios de la Filosofía del Derecho el autor sostiene:

El Estado, en cuanto realidad de la voluntad sustancial, realidad que esta tiene en la autoconciencia particular elevada a su universalidad, es lo racional en sí y por sí. Esta unidad sustancial es el absoluto e inmóvil fin último en el que la libertad alcanza su derecho supremo, por lo que este fin último tiene un derecho superior al individuo, cuyo supremo deber es ser miembro del Estado. ${ }^{452}$

Hegel identifica la realización plena de la libertad con el Estado de Derecho, única instancia legítima desde la que los individuos adquieren derechos y deberes en cuanto

${ }^{452}$ G.W.F. Hegel, Principios de la Filosofía del Derecho (Barcelona: El edhasa, 1999), 370. 
que miembros de una comunidad política que reconoce su libertad, pero este reconocimiento no implica la emancipación de los individuos y, a diferencia de los filósofos liberales, Hegel encuentra que para realizar la libertad el Estado habrá de trascender a la individualidad.

El Estado es un espíritu objetivo y la libertad es su sustancia por excelencia. El individuo solo puede objetivar su libertad dentro del Estado, fuera de él pierde el reconocimiento de libertad que este le otorga pues, según Hegel, la libertad queda enconada en la dimensión subjetiva del individuo si no encuentra un plexo universal sobre el que objetivarse. La racionalidad se corresponde con la unidad entre lo universal y lo individual (particular), en materia política esto significaría que la voluntad particular ha de ajustarse al contenido de la sustancia universal de la libertad, así como a las determinaciones que se le imponen en forma de normas universales ${ }^{453}$, a saber, que la indeterminación por la que la subjetividad humana se hace digna de la libertad encuentre limitaciones que sean válidas para todos y cada uno de los miembros del Estado. Para que en el Estado realice la libertad, el derecho debe primar en el orden de las relaciones entre los sujetos, debido a que en el derecho se determinan las leyes que imperan de forma universal sobre todos los individuos y sus asociaciones. Hegel admite como mérito propio de Rousseau el haber instaurado la voluntad como el principio por excelencia del Estado, ya que la forma y el contenido del Estado es pensamiento. Pero, sin embargo, le reprocha a Rousseau haber situado la voluntad individual como el origen de la voluntad general, haciendo de ella nada más que la comunidad abstracta de las voluntades individuales ${ }^{454}$. El filósofo alemán le achaca a estas abstracciones los desmanes causados por aquellos Estados revolucionarios que pretendieron instaurar una supuesta racionalidad destruyendo todo lo anterior, precisamente

por ser abstracciones sin idea, han convertido su intento en el acontecimiento más terrible y cruel. Contra el principio de la voluntad individual hay que recordar que la voluntad objetiva es en su concepto lo en sí racional, sea o no reconocida por el individuo y querida por su arbitrio particular. ${ }^{455}$

Afirma Hegel que la libertad no consiste en el libre albedrío, a pesar de que muchas veces, erróneamente, ambos términos sean tomados en sentido unívoco. El filósofo

\footnotetext{
${ }^{453}$ Cfr. Hegel, ob. cit., 370-371.

${ }^{454}$ Cfr. Hegel, ob. cit., 372.

${ }^{455}$ Hegel, ob. cit., 372-373.
} 
alemán desvincula la noción de libertad del área de la contingencia, la libertad no es mera elección según las preferencias del sujeto, sino que es justamente la posibilidad de renunciar a las determinaciones impuestas por el objeto de nuestra voluntad natural. La voluntad libre o independiente se corresponde con la autodeterminación del Yo, que no consiste únicamente en el hecho de poder escoger entre una cosa u otra, sino en la independencia con respecto a las determinaciones de la naturaleza ${ }^{456}$. La libertad, en un primer momento, está sumergida en la subjetividad, es la esencia de la autoconciencia como tal, por lo que la libertad se origina en el dominio de la conciencia y no en el de la naturaleza. De las cosas no puede extraerse libertad alguna, sino solo determinaciones, de modo que las cosas no son por sí mismas libres ni objetos jurídicos ${ }^{457}$.

Si la esencia humana consiste en ser voluntad libre, las personas entrarán en relación con los objetos exteriores a la conciencia poniendo su voluntad en ellos, un derecho que todo humano tiene y que propiamente constituye el derecho jurídico de propiedad privada. La propiedad para Hegel es una forma única y exclusiva de la humanidad, de manera que lo humano consiste también en hacerse propietario ${ }^{458}$. Se podría decir, bajo el prisma desde el que el autor define el concepto de propiedad y siguiendo la estela de sus argumentos en lo que a la libertad se refiere, que en el Estado de Derecho la propiedad privada tiene que ser una determinación de reconocimiento universal para que la libertad pueda realizarse de manera plena.

La coseidad se caracteriza por no tener voluntad en tanto en cuanto no tiene un fin. La esencia de las cosas es ser exteriores en sí mismas, no tienen una voluntad interna que las diferencien con respecto a otros seres y que las mantenga en una relación infinita consigo, es lo mismo que sucede con la animalidad, que es una mera vida exterior, nada más que un cuerpo biológico, una exterioridad en sí, carente de "ser para sí". Lo animal es, por tanto, una forma de vida reducida a su corporalidad pues no ha realizado el movimiento del "ser para sî" de la voluntad libre. En consecuencia, Hegel diferencia a los objetos con respecto a las personas principalmente porque los primeros son pura exterioridad relativa y las segundas pueden relacionarse consigo mismas y con otras cosas de manera infinita; así entonces el filósofo alemán caracteriza la apropiación como

\footnotetext{
${ }^{456}$ Cfr. Hegel, ob. cit., 94.

${ }^{457}$ Cfr. Hegel, ob. cit., 125.

${ }^{458}$ Cfr. Hegel, ob. cit., 128.
} 
manifestar ante las cosas la grandeza de mi voluntad y mostrar que estas no son en y por sí, no tienen un fin propio. Esta manifestación acontece cuando doy a la cosa un fin diferente del que tiene inmediatamente: en cuanto es mi propiedad y le doy a lo viviente otra alma de la que tenía, le doy mi voluntad. ${ }^{459}$

De las afirmaciones de Hegel se desprende la idea de que es por medio de la propiedad como los hombres trascienden la forma de la posesión natural, que es aquel modo de posesionarse de algo solo por supervivencia o deseo - un poseer instintivo y meramente animal-. Para que la libertad opere sobre la posesión ha de ser la voluntad la que anteponga sus propias determinaciones sobre la naturaleza de las cosas poseídas, ya que las cosas no tienen por sí mismas finalidad alguna, es, por tanto, la voluntad la que le atribuye algún tipo de fin a los objetos; la sustancia indeterminada de la voluntad libre proyecta sobre las cosas finalidades. Hegel afirma que la voluntad libre se corresponde con el idealismo porque no acepta las cosas dadas, sino que pretende modificarlas. Asimismo, la actitud opuesta sería el realismo, que acepta lo dado por sí y tal como es ${ }^{460}$.

Según Hegel, la propiedad no debe restringirse a la sola facticidad de poseer, puesto que la posesión está circunscrita al interés particular que la persona pone en su posesión. Sin embargo, el derecho de propiedad se circunscribe más bien al dominio de la voluntad libre, que determina el objeto de la posesión en cuanto es su propiedad, independientemente de cuál sea el interés concreto que la voluntad ponga en aquello que posee. Desde la perspectiva de la necesidad, <<la propiedad aparece como un medio siempre que se coloque a aquella en primer lugar $>>$, pero, en el terreno del derecho, $<<$ la libertad es su primera existencia, un fin esencial por sí $>>461$. Con base en esto, el fundamento del derecho de propiedad es la libertad, y nunca podría ser la necesidad pues la voluntad libre quedaría anulada; mientras que la posesión natural viene determinada exteriormente por las necesidades que acucian al individuo, la posesión que encuentra su determinación jurídica en la propiedad ha de venir determinada desde la esencia que define al individuo humano como un ser libre, a saber, un ser cuya forma esencial consiste en la libertad.

\footnotetext{
${ }^{459}$ Hegel, ob. cit., 128-129.

${ }^{460}$ Cfr. Hegel, ob. cit., 129.

${ }^{461}$ Hegel, ob. cit., 129.
} 
Roberto Esposito, en Las personas y las cosas, alude al pensamiento hegeliano como un ejemplo más de la tendencia, por parte de la filosofía occidental, a situar lo cósico bajo el dominio posesivo de las personas mientras que, a su vez, lo personal iría adquiriendo una mayor raigambre en el ámbito de las cosas. Esposito se propone demostrar en su obra que la persona es un dispositivo de poder el cual entra dentro del terreno de lo apropiable, partiendo ya del hecho de que la corporalidad es tomada como la posesión de un "sí mismo". Entonces, lo corporal queda involucrado, por ende, en el espectro categórico de la propiedad ${ }^{462}$. El autor identifica la relación cosas-personas con la problemática de la filosofía política hegeliana, puesto que, y aunque Hegel despreciara el Derecho privado por sus dificultades para llevar a su plenitud las relaciones espirituales, sí puso la posesión de sí mismo como pilar jurídico fundamental del derecho de propiedad. Asegura Esposito a este respecto que en la filosofía del derecho el poseerse a uno mismo <<es el único tipo de posesión tan perfecta como para servir de modelo para todos los otros tipos de propiedad $>>463$.

Para Hegel la posesión de sí mismo comienza a experimentarse en el mundo natural por medio de la corporalidad; el "Yo viviente" mantiene su existencia como exterioridad con respecto al cuerpo, pero el Yo está sintetizado al organismo que habita. El individuo, en cuanto persona, está incluido en la síntesis que la voluntad indeterminada (subjetiva) ha ejercido sobre la vida y el cuerpo, esta voluntad es la manifestación del Yo. Vida y cuerpo son los elementos que tiene la voluntad libre. Los animales no pueden ejercer esta síntesis triangular -entre el cuerpo, la voluntad y la vida - porque no diferencian su vida de su corporalidad, dado que no cuentan con una voluntad distinta de sus estímulos e instintos. Cualquier individuo humano, si así lo quisiera, podría dañar su propio cuerpo, podría incluso darse muerte si lo deseara, precisamente porque tiene una voluntad diferenciada de su cuerpo:

$<<$ Tengo estos miembros, e incluso la vida, solo porque yo quiero; el animal no puede mutilarse ni matarse, sí en cambio el hombre $>>^{464}$.

El régimen de propiedad por parte del Yo sobre el cuerpo es la característica singular por la que los humanos se distinguen de los animales; el cuerpo pone determinaciones pero no condiciona la voluntad de los hombres. El individuo sabe que puede

\footnotetext{
${ }^{462}$ Cfr. Roberto Esposito, Las personas y las cosas (Buenos Aires: Eudeba, 2016), 50-51.

${ }^{463}$ Esposito, ob. cit., 50.

${ }^{464}$ G.W.F. Hegel, Principios de la Filosofía del Derecho (Barcelona: El edhasa, 1999), 131.
} 
autodestruirse si así lo quisiera y que, mientras conozca esta radical opción, la persona se encuentra a sí misma como libre. La libertad que porta el individuo se hace patente en la posesión de su cuerpo, solo en tanto en cuanto hace de este su propiedad y lo controla como tal. Hegel explica:

El cuerpo no es adecuado al espíritu por ser una existencia inmediata; para que sea su órgano dócil y su medio animado, es necesario que este lo tome en posesión. Pero para los otros soy esencialmente libre en mi cuerpo tal como lo poseo inmediatamente. ${ }^{465}$

Pero, además, el pensador alemán cae en la cuenta de que el cuerpo, al ser parte necesaria de la vida, compone la síntesis del ser viviente, de tal manera que el alma no está exenta de sentirse en el cuerpo y por medio de él. En la síntesis cuerpo-alma, la corporalidad, en cuanto existencia viviente, no debe ser tratada como <<una bestia de carga $>466$, quiere decir esto que lo corporal es una propiedad "especial" para la voluntad, dado que en el cuerpo el alma humana siente de forma inmediata y, tan pronto como el alma puede utilizar el cuerpo para lograr unos fines, si lo reduce a un objeto más de su inventario, finalmente, podrá hacerse sufrir a sí misma al abusar de ese su ser viviente. En este punto es posible interpretar una suerte de advertencia que Hegel realiza a propósito del régimen de propiedad que el alma instaura sobre el cuerpo, ya que el autor parece tomar conciencia de que el alma humana puede hacer uso de su cuerpo para varios fines y que esta instrumentalización de la corporalidad podría llegar a repercutir negativamente en la propia persona si se cree que el cuerpo es explotable ilimitadamente y sin repercusiones, o que los excesos concupiscibles desaforados, u otro tipo de sobrecargas impuestas al cuerpo desde la libertad del alma, no tienen consecuencias. Así como lo corporal se corresponde con el objeto de posesión y el espíritu subjetivo con el sujeto poseedor, Hegel considera que el primero no es un simple objeto natural sino la extensión física del alma del individuo, su punto de referencia en el mundo objetivo y aquello con que se relaciona.

El Yo despliega una regimentación sobre el cuerpo y solo en la medida en que el cuerpo le pertenece de propio puede exteriorizar ese régimen de propiedad, es decir, el Yo hace su humanidad manifiesta a través de su cuerpo, demuestra que existe "alguien" controlando esa "cosa corpórea" que porta consigo. Pero el cuerpo no refleja inmediatamente la realidad y actualidad de la libertad. Una persona puede tener el

\footnotetext{
${ }^{465}$ Hegel, ob. cit., 132.

${ }^{466}$ Hegel, ob. cit., 132.
} 
cuerpo encadenado y maniatado sin por ello perder la independencia de su voluntad, que es el sentimiento interior de la libertad en sentido subjetivo; pero esta persona, al no tener la posesión plena de su cuerpo, no podría, de facto, ser libre. El Yo se ve afectado por la violación y el quebranto del cuerpo en que se halla, ya que si el cuerpo es dañado lo es en cuanto que propiedad.

No es lo mismo dañar al cuerpo de alguien que a una de sus propiedades externas; en ellas no tiene la persona puesta su voluntad de forma inmediata, pero en su corporalidad sí la tiene ${ }^{467}$. Hegel trata de "humanizar" el dominio sobre la corporalidad en dos sentidos: uno, en la relación que el Yo mantiene con su cuerpo y, otro, en la relación de uno mismo con respecto a los demás. La persona aparece ante los otros como un cuerpo, hecho que no le exime de poder ser tratado como una bestia o una cosa, pues las bestias y las cosas también son cuerpos. Ahora bien, Hegel plantea este problema apelando al derecho que los seres humanos tienen de ser libres. Ciertamente, lo humano no se reduciría únicamente a la dimensión corporal, a lo que es el individuo en cuanto objeto; la libertad del individuo humano incluye también a su corporalidad en las relaciones sociales, si se coacciona a los cuerpos de los individuos se ejerce una presión inmediata sobre su libertad. La imagen conceptual del cuerpo en el pensamiento hegeliano actúa como una mediación que liga íntimamente la dimensión subjetiva de las personas con su dimensión exterior. No obstante, aunque el cuerpo sea la propiedad más especial que pueda tener el "ser para sí', que aparece integrado inextricable e irreversiblemente a su cuerpo en cuanto ser biológico, en las relaciones con los otros la corporalidad no deja de ser un contenido mediato de lo intersubjetivo, un objeto cósico dignificado por una autoconciencia que en virtud de su derecho de propiedad lo eleva a una categoría que trasciende la naturaleza bruta de lo biológico; esta trascendencia no la hace ni la da el cuerpo por sí mismo sino que la hace y la da la libertad.

La apropiación corporal es la forma de posesión más perfecta por parte del individuo humano, ya que el Yo está directamente vinculado con el dominio de su cuerpo al encontrarse en su interior y ser su actor directo $^{468}$. La inmediatez del cuerpo para la autoconciencia hace que los seres humanos demuestren su libertad ante los otros por medio de esta exterioridad en la que está inmerso su ser esencial: el "ser para sí". Únicamente por medio de la posesión de su cuerpo el hombre hace patente en la

\footnotetext{
${ }^{467}$ Cfr. Hegel, ob. cit., 132-133.

${ }^{468}$ Cfr. Hegel, ob. cit., 138.
} 
realidad lo que verdaderamente conforma su esencia, que es la libertad de la autoconciencia $^{469}$.

La dominación sobre el cuerpo se resuelve en una relación asimétrica entre la corporalidad, que es la parte subordinada, y la espiritualidad, que es la parte dominante. Esta asimetría ha de evidenciarse en el cuerpo del sujeto, puesto que solo un hombre libre puede presentarse con pleno dominio y control sobre los impulsos, inclinaciones y facultades que acompañan a su condición biológico-corporal. Solo apropiándose de su cuerpo el individuo humano muestra que tras esa masa somática hay un Yo, un "ser para sí" libre. La asimetría en la relación categórica cuerpo-espíritu no es inmediata a la mirada de los otros, el dominio del espíritu sobre el cuerpo se exterioriza cuando la corporalidad del individuo desprende la evidencia de que está siendo controlada por un Yo, que el cuerpo percibido está arredrado por el espíritu que lo posee, el espíritu libre de una autoconciencia.

Entonces, si el ser humano se caracteriza por algo más que por su condición biológica, si los individuos son más que su cuerpo, si a todo hombre subyace un "ser para sí” que lo eleva sobre la mera contingencia en que se halla su corporalidad, ¿cómo sería posible detectar esa verdadera esencia humana que hace de todo hombre un ser libre? A raíz de este planteamiento surge la problematización que Hegel hace en torno a la esclavitud. Para el autor stuttgartense, la justificación de la esclavitud se apoya en el argumento que reduce la esencia humana a naturaleza corporal, constituyendo al hombre ontológicamente como nada más que un cuerpo. Ahora bien, la existencia humana no se adecuaría a esta reducción antropológica, pues la noción de voluntad libre, eje sobre el que Hegel funda el Derecho, presupone la esencia de la libertad en toda forma de humanidad. Pero la libertad no se da en la naturaleza al modo de un objeto físico, la libertad no viene dada en el cuerpo como un órgano, sino fuera de él y como abstracción incorpórea e invisible, por ende, la libertad tiene que realizarse en la vida. El Estado objetiva la libertad no ya como un deber ser, sino como una universalidad que se puede realizar, que puede hacerse objetiva ${ }^{470}$.

En los Principios de la Filosofía del Derecho Hegel aborda la cuestión del trabajo en términos políticos y económicos, y no como en la Fenomenología del espíritu, donde realizó una génesis de índole metafísica de la cuestión. Desde el prisma de la Filosofía

\footnotetext{
${ }^{469}$ Cfr. Hegel, ob. cit., 141.

${ }^{470}$ Cfr. Hegel, ob. cit., 142-143.
} 
del Derecho el trabajo es tenido en cuenta como la actividad que prepara aquellos materiales dados de forma natural para el consumo. Entonces, el hombre, cuando consume y acopia los productos que se elaboran en la sociedad, indirectamente está relacionándose con la forma que tiene el trabajo dentro de su cultura ${ }^{471}$. Para Hegel, pese a que la participación en la riqueza general es accesible a todos los individuos, no todos van a contribuir a ella de la misma manera ni en las mismas condiciones:

La posibilidad de participación en el patrimonio general, es decir, el patrimonio particular, está condicionada por una base inmediata propia (capital) y por la habilidad. Esta por su parte se halla condicionada por aquélla, pero también por las circunstancias contingentes, a cuya multiplicidad da lugar la diversidad en el desarrollo de las condiciones corporales y espirituales, ya de por sí desiguales. Esta diversidad se muestra en esta esfera de la particularidad en todas direcciones y en todos los estadios, y, unida con las demás contingencias y arbitrariedades de otro origen, tiene como consecuencia necesaria la desigualdad de los patrimonios y las habilidades de los individuos. ${ }^{472}$

Significa esto que para Hegel la desigualdad de riquezas entre los hombres se justifica por las diferentes disposiciones naturales en cuanto a capacidades y destrezas se refiere. Sería un abuso intelectual pretender la igualdad en el terreno contingente de las posesiones de los individuos, de sus aptitudes corporales y de sus destrezas intelectuales; la igualdad solo es un supuesto del derecho cuando considera a las personas en abstracto, pero el ámbito del sujeto abstracto no alude ni forma parte del entorno en que se producen las contingencias que dan lugar a una desigualdad de las posesiones por parte de los individuos y de las familias.

Las aptitudes corporales y destrezas intelectuales no pertenecen al dominio del derecho sino al de la naturaleza, y como no es correcto atribuirle a la naturaleza las nociones de justicia o injusticia, <<porque la naturaleza no es libre y por lo tanto ni injusta ni justa $>{ }^{473}$, no es posible hablar de una igualdad material, corporal o intelectual. El deseo moral de que todos los hombres puedan contar con las posesiones suficientes para cubrir sus necesidades es un asunto <<distinto de la posesión y pertenece a otra esfera: la Sociedad Civil $>>{ }^{474}$. El trabajo es la consecuencia directa de la riqueza, pero como el trabajo es ejercido por individuos con cuerpos y capacidades

\footnotetext{
${ }^{471}$ Cfr. Hegel, ob. cit., 317.

${ }^{472}$ Hegel, ob. cit., 319.

${ }^{473}$ Hegel, ob. cit., 134.

${ }^{474}$ Hegel, ob. cit., 134.
} 
diferentes entre sí, la cantidad de riqueza acumulada por cada uno de ellos es naturalmente desigual, y esta desigual distribución de la riqueza producida crea las clases sociales. Cada persona se posicionará en una clase social en función de sus características, la clasificación de los individuos en clases sociales no sería más que un efecto residual de las diferencias naturales ${ }^{475}$. Estas diferencias no son objeto del derecho, que ha de tomar a todos y cada uno de los individuos bajo el concepto uniforme y universal de la libertad.

\subsubsection{MARX: EL ECLIPSE DEL CUERPO DEL OBRERO TRAS EL VALOR DE CAMBIO DE}

\section{LA MERCANCÍA}

Hegel atribuyó a las contingencias del cuerpo la causa de las desigualdades entre los seres humanos, algo que el Derecho ni podría ni debería remediar. Cuando Karl Marx critica la filosofía hegeliana, acusa un menosprecio por parte del pensador stuttgartense de las condiciones físicas sobre las que se apoyan las relaciones que tienen lugar en el Estado de Derecho; a ojos de Marx, Hegel elabora una investigación de carácter jurídico y político suponiendo la existencia y presencia de un espíritu que guía el desarrollo de la humanidad, dicho de otro modo, el protagonista central del pensamiento político de Hegel estaría levitando sobre las condiciones materiales en que se originan las relaciones sociales, punto de partida de las determinaciones jurídicas y políticas. Marx le reprocha, al que fuera su maestro, que con la presunción de este espíritu pretendiera explicar el desarrollo de las relaciones sociales sin virar a las condiciones materiales de producción, fuente originaria de la estructura política. En palabras de Marx:

Tanto las relaciones jurídicas como las formas de Estado no pueden comprenderse por sí mismas ni por la llamada evolución general del espíritu humano, sino que radican, por el contrario, en las condiciones materiales de vida cuyo conjunto resume Hegel, siguiendo el precedente de los ingleses y franceses del siglo XVIII, bajo el nombre de "sociedad civil”, y que la anatomía de la sociedad civil hay que buscarla en la economía política. [...] en la producción social de su existencia, los hombres contraen determinadas relaciones necesarias e independientes de su voluntad, relaciones de producción que corresponden a una determinada fase de desarrollo de sus fuerzas productivas materiales. ${ }^{476}$

\footnotetext{
${ }^{475}$ Cfr. Hegel, ob. cit., 320.

${ }^{476}$ Karl Marx, Introducción general a la crítica de la economía política/1857 (Córdoba, Argentina: Ediciones Pasado y Presente, 1974), 76.
} 
Marx analiza las condiciones de trabajo en las incipientes sociedades industriales de su época. Justo cuando da comienzo el tercero de sus Manuscritos de economía y filosofía comenta que la esencia subjetiva de la propiedad privada se origina en el trabajo, tal como reconoció la Economía Política nacida de Adam Smith y los ilustrados. La propiedad privada dejó de ser una condición objetiva externa al hombre para incrustarse en sus contenidos subjetivos, como siendo la energía que impele el desarrollo de la industria y alienta la acumulación de riqueza ${ }^{477}$. Pero la Economía Política terminó sepultando al hombre en la medida en que su principio, el trabajo, <<es más bien la consecuente realización de la negación del hombre al no encontrarse ya él mismo en tensión exterior con la esencia exterior de la propiedad privada, sino haberse convertido él mismo en la tensa esencia de la propiedad privada $>>{ }^{478}$.

En el primer capítulo de El capital el filósofo de Tréveris centra sus reflexiones en el valor de las mercancías, o sea, los objetos que produce el trabajo. Distingue, por un lado, el valor de uso y, por otro, el valor de cambio. Según Marx, el valor de las mercancías viene determinado por su valor de cambio, que representa el trabajo requerido para su producción. El trabajo es una actividad en la que se ve implicado el esfuerzo, lo que involucra necesariamente al cuerpo humano. Las actividades productivas requieren de un desgaste fisiológico, psíquico y vital en general. Según el tiempo de trabajo y la cualificación de quienes lo ejercen, el valor de la mercancía producida va determinándose; asimismo, en el momento en que unos hombres trabajan para otros, el trabajo advierte su ineludible carácter de relación social ${ }^{479}$.

Las relaciones sociales le atribuyen valor a la mercancía, esta aparece como un objeto físico limitado y, por tanto, cuenta con unas posibilidades determinadas; las condiciones físicas de la mercancía constituyen su valor de uso, pero este no es el valor que le atribuyen las relaciones sociales, sino, más bien, las utilidades que presenta en cuanto a sus condiciones materiales. La mercancía no difiere de las cosas naturales en relación con su valor de uso, sino que es por medio de las relaciones sociales como adquiere un valor de cambio, que es un valor añadido, en la medida en que el valor de cambio es social y no natural. Ese valor que se le agrega a la mercancía es lo que Marx llama fetichismo, una figura inmaterial e invisible externa a las condiciones naturales de

\footnotetext{
477 Cfr. Karl Marx, Manuscritos de economía y filosofía (Madrid: Alianza Editorial, 2013), 163-164.

${ }^{478}$ Marx, ob. cit., 164-165.

${ }^{479}$ Cfr. Karl Marx, El capital. I (México D. F: Fondo de Cultura Económica, 1946), 37.
} 
las mercancías, una figura que se constituye en el orden de las relaciones sociales de los seres humanos: <<la forma mercancía y la relación de valor de los productos del trabajo en que esa forma cobra cuerpo, no tiene absolutamente nada que ver con su carácter físico ni con las relaciones materiales que de este carácter se derivan $>>{ }^{480}$. El trabajo es una actividad que implica un gasto de tiempo, de energías físicas y de capacitaciones, ese gasto en el que interviene el cuerpo como agente material necesario para el proceso de producción no se ve directamente representado en el valor de cambio. El valor de cambio no viene dado por el esfuerzo que los cuerpos le dedican a las labores productivas, sino que su asignación depende exclusivamente de las relaciones entabladas por los propietarios de los medios de producción. Marx dice al respecto:

El descubrimiento científico tardío de que los productos del trabajo, considerados como valores, no son más que expresiones materiales del trabajo humano invertido en su producción, es un descubrimiento que hace época en la historia del progreso humano, pero que no disipa ni mucho menos la sombra material que acompaña al carácter social del trabajo. ${ }^{481}$

A ojos del pensador alemán, los economistas burgueses tergiversan los términos en que se da el valor de cambio de las mercancías. El valor de cambio es una relación social según la cantidad de esfuerzo empleado para producir una cosa, pero las cosas producidas no pueden contener sustancia material alguna más allá de lo que son físicamente. Los sistemas económicos previos al capitalismo y el propio sistema capitalista no habrían sabido ver que el valor de las cosas representa una relación social de producción. La naturaleza no aporta noción alguna sobre el valor de las cosas, son las relaciones humanas las que atribuyen valor, como si tuviera lugar un desdoblamiento invisible de los objetos ${ }^{482}$. Marx, con aguda y perspicaz ironía, hace el siguiente comentario:

Hasta hoy, ningún químico ha logrado descubrir valor de cambio en el diamante o en la perla. Sin embargo, los descubridores económicos de esta sustancia química, jactándose de su gran sagacidad crítica, entienden que el valor de uso de las cosas es independiente de sus cualidades materiales y, en cambio, su valor inherente a ellas. Y en esta opinión lo confirma la peregrina circunstancia de que el hombre realiza el valor de uso de las cosas

\footnotetext{
${ }^{480}$ Marx, ob. cit., 38.

${ }^{481}$ Marx, ob. cit., 39.

${ }^{482}$ Cfr. Marx, ob. cit., 44-46.
} 
sin cambio, en un plano de relaciones directas con ellas, mientras que el valor solo se realiza con el cambio, es decir en un proceso social. ${ }^{483}$

Los economistas tratan al valor de cambio como si fuera una propiedad química intrínseca a la naturaleza de la cosa, mientras el valor de uso de los objetos tiene lugar en la inmediatez de la utilización de estos, no haría falta aquí un intercambio que determine su valor de cambio. Marx afirma que el uso de las cosas no requiere relaciones sociales, sino una relación inmediata sujeto-objeto, pero que en la determinación del valor de cambio es preciso que haya dos o más sujetos que se relacionen entre sí. En el mercado, el propietario de la mercancía ve en ella un valor de cambio, pero para quien quiere obtenerla ve en ella un valor de uso. La consecuencia de esta diferencia al valorar las mercancías causa que en el mercado los productos vayan cambiando de manos solo en función de su valor de cambio, así, concluye Marx que para que se realice el valor de uso antes debe haberse realizado el valor de cambio $^{484}$.

El dinero es el producto fundamental para que el valor de cambio sea equivalente a todas las mercancías. En el intercambio comercial se desdobla la mercancía y el valor: la mercancía se transforma en dinero, pero, previamente, el trabajo ha ejecutado una acción productora $^{485}$. Para Marx, es un error ver en el dinero un signo del valor: se ha creído que el dinero es un fenómeno externo a la mercancía y erigido en representante de su valor, pero toda mercancía por sí misma es un signo que indica la cantidad y el tiempo de trabajo empleado en producirla ${ }^{486}$. En el proceso de producción los hombres se comportan como átomos sueltos, razón por la que los seres humanos pierden completamente el control sobre su producto, en cierto modo, ninguno sabe cuánta cantidad se produce y cómo se le asigna valor, tampoco son conscientes de la manera en que los productos se transforman en dinero. El fetichismo del dinero es el mismo fetichismo que opera en las mercancías, lo que ocurre es que la parte visible es el dinero en la medida en que se cree que él por sí mismo es el que le atribuye valor a las cosas ${ }^{487}$.

En el sexto capítulo del primer libro de El capital Marx da cuenta de cómo los rendimientos útiles del trabajo pasan a formar parte del capital:

\footnotetext{
${ }^{483}$ Marx, ob. cit., 47.

${ }^{484}$ Cfr. Marx, ob. cit., 49.

${ }^{485}$ Cfr. Marx, ob. cit., 50.

${ }^{486}$ Cfr. Marx, ob. cit., 53-54.

${ }^{487}$ Cfr. Marx, ob. cit., 55.
} 
Al incorporarse la capacidad viva de trabajo a los componentes objetivos del capital, este se transforma en un monstruo animado y se pone en acción "cual si tuviera dentro del cuerpo el amor". Como el trabajo solo crea valor bajo una forma útil determinada, y como toda especie de trabajo útil requiere material y medios que tengan un valor de uso específico (...) el trabajo solo puede ser absorbido en la medida en que el capital adopta la forma de los medios de producción específicos requeridos para procesos laborales determinados, y solo bajo esta forma el capital puede succionar trabajo vivo. ${ }^{488}$

Un instrumento no se hace capital solo por las características de su valor de uso, sino en la medida en que tiene un propietario que lo pone a disposición del rendimiento productivo. El martillo con que trabaja el obrero no le pertenece como propiedad, a quien le pertenece es al propietario capitalista, quien pone a disposición de su trabajador ese instrumento para utilizar la capacidad productiva del obrero que lo utiliza; asimismo, la fuerza productiva que sale de las entrañas del trabajador se convierte en el instrumento del capitalista. Este modo de apropiación equivale a posesionarse indirectamente del cuerpo del obrero, ya que de la fuerza de su trabajo, cuyo origen es físico, es posible el incremento de la propiedad del capitalista.

El filósofo de Tréveris encuentra que en el capitalismo el trabajo tiene un precio, dado que la actividad por la que se procesan los productos ha de solidificarse en la mercancía. Las mercancías son el objeto inorgánico resultante del proceso vivo del trabajo. La capacidad laboral, junto a las condiciones y características del obrero, forman parte del valor de cambio de su actividad; las aptitudes y capacidades de los productores se hacen reemplazables, como las mercancías ${ }^{489}$. La agencia productiva en el capitalismo reside en la vida orgánica de los obreros, y como seres vivientes tienen la posibilidad de apropiarse del valor de su trabajo, aunque, si el valor del trabajo es apropiable, esto significa que también puede ser expropiable. Marx se fija en los "sweaters" de las empresas de Londres, cuya traducción al español sería "expoliadores de sudor". Los "expoliadores de sudor" entregan trabajo a un empresario según el salario habitual, pero a los trabajadores que lo ejecutan les paga menos de este salario, arrogándose parte de la cantidad del salario que les correspondería ${ }^{490}$. La acumulación de capital actúa a partir del esfuerzo -sudor- obtenido del cuerpo de los trabajadores

\footnotetext{
${ }^{488}$ Karl Marx, Resultados del proceso inmediato de producción. Libro I. Capítulo VI Inédito de El Capital (México D.F: Siglo XXI Editores, 2009), 40.

${ }^{489}$ Cfr. Marx, ob. cit., 141.

${ }^{490}$ Cfr. Marx, ob. cit., 145.
} 
para alcanzar una forma incorpórea: capital. El cuerpo del trabajador sigue ocupando el lugar de una máquina y la masa social permanece en su posición activa al servicio de un objeto que tiende a invisibilizarse en el valor de cambio, cuyo contenido no es más que una relación sucinta de intercambio en el mercado. Para Marx, el trabajo es una actividad y no una mercancía, una actividad que requiere de la energía de un cuerpo, así como de su salud y tiempo de vida, pero el capitalismo lo sitúa al nivel de las cosas intercambiables, a la altura de las mercancías, equiparando la actividad productiva con la pasividad objetiva de las cosas. El cuerpo, en cuanto agencia de trabajo, se convierte en un objeto traficable en la medida en que el capitalismo trafica con el trabajo.

En La ideología alemana Marx mantiene que es en las actividades y relaciones materiales donde se originan las representaciones de la conciencia, de manera que el desarrollo de las fuerzas y relaciones productivas ponen la base sobre la que emergen las ideas; el problema aparece cuando lo ideal termina por emerger como si fuera el fundamento de las condiciones reales en que se articulan las relaciones de producción:

La conciencia no puede ser nunca otra cosa que el ser consciente, y el ser de los hombres es su proceso de vida real. Y si en toda la ideología los hombres y sus relaciones aparecen invertidos como en la cámara oscura, este fenómeno responde a su proceso histórico de vida, como la inversión de los objetos al proyectarse sobre la retina responde a su proceso de vida directamente físico. ${ }^{491}$

El capitalismo, en cuanto que sistema vertebrado por una ideología, oculta la parte corporal del conjunto de los trabajadores, oculta aquello de físico que la existencia humana tiene y pone el valor inherente a las fuerzas productivas del cuerpo en una instancia externa. De este modo, si en el mercado la mercancía se hace visible como objeto físico, lo que realmente le concede su valor es el precio de intercambio que allí adquiere. Ahora bien, este precio o valor de cambio de la mercancía, que es invisible, artificial e incorpóreo, es un añadido creado en las relaciones de producción que oculta el modo en que se dan dichas relaciones. Por tanto, lo único que se hace visible en el cuerpo de la mercancía es su valor de cambio y no su utilidad práctica -sus posibilidades de uso-, esta utilidad no establece su valor, sino que la corporalidad de la mercancía se vuelve nada más que un signo del valor de cambio, aquello que verdaderamente le importa al propietario que la pone en el mercado. Así, el precio como contorno que envuelve a la mercancía eclipsa a los cuerpos vivos que la han fabricado.

${ }^{491}$ Karl Marx, La ideología alemana (Madrid: Akal, 2014), 21. 
El valor de cambio aparece como si fuera un indicador objetivo fruto de las relaciones de intercambio en el mercado y no de las relaciones de trabajo. En el análisis marxiano de la mercancía y su fetichismo se aprecian con especial flagrancia las asimetrías que se generan en la relación propietario-productor, traducidas a la invisibilización del cuerpo del productor por el producto. El producto no es más que la entidad visible del valor de cambio, valor que según las leyes de la economía burguesa se da a partir de procedimientos neutrales inscritos en el contexto del intercambio mercantil. La dominación asimétrica de las relaciones capitalistas de producción se traslada al juego entre la visibilidad y la ocultación según el poder que los propietarios ejercen sobre los trabajadores, la mercancía se visibiliza en la medida en que a su propietario le interesa mostrar el valor de cambio que esta adquiere en el espacio comercial, mientras que el cuerpo del trabajador es eclipsado. La mercancía encarna el valor de cambio en el mercado. El objeto mercantil impersonaliza la relación trabajomercancía, de tal forma que el vínculo personal entre quienes realizan la agencia productiva con respecto al objeto resultante es neutralizado, con el fin de amortiguar y ahuyentar la posibilidad de que el productor pueda apropiarse del valor del objeto producido.

El cuerpo de la mercancía y su valor de cambio cubren las mutilaciones, rasgaduras y quebrantamientos sufridos por los trabajadores; esta es la consecuencia política que se deriva de la separación entre el valor de cambio y el valor de uso de la mercancía. Las actividades laborales son envueltas por las oportunidades de beneficio que ofrece el valor de cambio en el contexto del intercambio comercial, tanto ofertantes como demandantes verán en la mercancía, no un producto elaborado, no el resultado de un trabajo, sino solo un precio más o menos ventajoso para sus intereses. Los objetos entran en una pugna con los cuerpos humanos, no solo en el espacio comercial de las mercancías, sino también en el espacio laboral de la producción. Precisamente Alain Corbin en el segundo volumen de Historia del cuerpo, obra que dirigió y coordinó junto a otros historiadores y pensadores, asegura que fue entre 1839 y 1840 cuando los filántropos e investigadores comenzaron a ver en el accidente industrial un accidente laboral ${ }^{492}$. El accidente laboral <<violenta los cuerpos con una intensidad particular en

\footnotetext{
${ }^{492}$ Cfr. Alain Corbin, "Placer y dolor: en el centro de la cultura somática"; en Historia del cuerpo. (II) De la Revolución francesa a la Gran Guerra, Alain Corbin, Jean-Jacques Courtine, Georges Vigarello (dir.) (Buenos Aires: Taurus, 2005), 243.
} 
los dos últimos tercios del siglo XIX >>, dado que la revolución del carbón y el vapor $<<$ engendra máquinas que pueden causar heridas atroces $>>493$.

Corbin da cuenta de cómo en las fábricas se confrontaban directamente el cuerpo natural del individuo con la máquina, ya que los equipos de seguridad promovidos por la ley del 12 de junio de 1893 en la III República francesa, resultaban incómodos para los obreros pues no permitían ejercer los trabajos industriales con el grado de movilidad requerido para ello. Corbin plantea, a tenor de esta circunstancia, una cuestión fundamental -que no puede ser omitida aunque solo en una frase sea mentada- en tanto en cuanto $<<$ a la hora de establecer una biopolítica, el cuerpo del obrero sigue siendo un lugar donde se ejerce el poder sobre uno mismo $>>494$. El cuerpo del obrero en el XIX es un problema biopolítico en la medida en que la cuestión de la disposición y aptitud de las corporalidades para el trabajo afectaban a toda una masa poblacional cuyos individuos, además, se veían en la obligación de lidiar con una tecnología tan eficiente como peligrosa, una maquinaria productiva nunca antes vista. El poder inherente al cuerpo del trabajador, el poder de la fuerza de trabajo, de pronto se encontraba a disposición del funcionamiento de las máquinas, lo que imponía unas directrices en el desarrollo del trabajo y le restaba relevancia a la potencia productiva del cuerpo natural humano. Los obreros tenían que manejar esas nuevas máquinas haciendo gala de su capacidad en el proceso productivo, pero, a su vez, ese manejo implicaba fundirse en el "cuerpo" de nada más que una máquina, de modo que el trabajo y su producto quedaban despersonalizados. El trabajador veía imposibilitada la expresión de sus destrezas subjetivas a través del proceso productivo, al no poder plasmar sus habilidades sobre el objeto fabricado. La singularidad del trabajo se veía opacada por la impersonalidad de la máquina pues, en buena medida, cualquiera podía hacer las veces de "engranaje humano" de las máquinas. Algo similar sucedía entre el cuerpo del obrero y el cuerpo de la mercancía, ya que el cuerpo de la mercancía suponía una despersonalización con respecto al cuerpo vivo que la fabricó, una despersonalización que se consumaba en el espacio aséptico del mercado, donde el valor de cambio absorbía y fundía el trabajo corporal en la mercancía.

El trabajo, en cuanto valor, quedaba disuelto por el valor de cambio de la mercancía $\mathrm{y}$, con ello, la personalidad del obrero era omitida, así como también la máquina

\footnotetext{
${ }^{493}$ Alain Corbin, ob. cit., 243-244.

${ }^{494}$ Alain Corbin, ob. cit., 246.
} 
anulaba la singularidad y concreción subjetiva que acompaña al trabajo humano. El dominio de uno mismo, en el caso de una buena mayoría de la población, pasaba necesariamente por las ingentes horas dedicadas al trabajo junto a las máquinas.

Marx fue un filósofo pionero al trasladar aspectos que se consideraban propios del juego económico al terreno de la dominación política, hizo de las relaciones mercantiles un entrelazado relacional de poderes, a saber, el poder que se desprende de los cuerpos que llevan a cabo la fuerza de trabajo y los poderes que resultan del valor creado por el trabajo. El filtro de distorsión de la fuerza productiva como poder que nace de los cuerpos es el mercado, un espacio que desvirtúa ese poder inmanente a la fuerza de trabajo, que hace invisibles las llagas que rasgan los cuerpos de los obreros en los procesos productivos, para depositar todo el poder subyacente a la fuerza de trabajo en el valor que adquiere la mercancía nada más que como producto de intercambio, valor establecido entre los dueños de los medios de producción. La escisión que halló Marx entre el cuerpo del obrero y el "cuerpo" surgido de su actividad productiva, el de la mercancía, es la escisión tras la que se puede seguir el rastro de un poder inherente a la corporalidad, un poder cercenado por el producto que brota del desgaste corporal, del sufrimiento y de la energía física y mental empleada durante la producción. La mercancía monopoliza todo el poder valorativo de la producción a expensas del poderío inmanente a la fuerza de trabajo de los cuerpos humanos; finalmente, la cosa producida es la que cosifica al cuerpo productor, es la que divide el poder de los cuerpos a través de un juego de intercambio mercantil. 


\section{SECCIÓN II. LA FUERZA CORPORAL Y LA POTENCIALIDAD POLÍTICA DEL SOMA SOCIAL}

\subsubsection{EL CUERPO DEL PUEBLO EN DISPUTA}

El pensamiento político decimonónico se aproximó al concepto de poder dentro de la doble articulación entre el individuo y la sociedad. Muchos pensadores advirtieron que la masa social, al formar una corporalidad colectiva, era susceptible de albergar una fuerza al igual que cualquier otro cuerpo natural. Los cauces procedimentales por los que se habría gestado este cuerpo social masificado, formado por la acumulación de cuerpos individuales, condujo a muchos filósofos de distintas sensibilidades y vertientes de pensamiento a plantear el carácter problemático de la fuerza social y en qué medida esta se relaciona con los individuos. Resulta muy ilustrativo a este respecto el ensayo de John Stuart Mill titulado Sobre la libertad, que reivindica los derechos individuales frente a quienes justifican la omisión del individuo merced a la predominancia de la fuerza colectiva. Mill toma partido a favor del individualismo y preconiza que el individuo goce de derechos que le permitan ser independiente del poder estatal y de las imposiciones sociales, fortaleciéndose por sus propios medios $<<$ siguiendo la tendencia de fuerzas interiores que hacen de él una cosa viva $>{ }^{495}$. Además, el autor británico sostiene:

Quienquiera que piense que no debe fomentarse la individualidad de deseos e impulsos, deberá sostener, del mismo modo, que la sociedad no tiene necesidad de naturalezas fuertes, que no es mejor por el hecho de contener en su seno un gran número de personas con carácter, y que no es deseable el que hombres de tipo medio posean gran cantidad de energía. ${ }^{496}$

Las reivindicaciones millianas se sitúan dentro del amplio espectro del pensamiento liberal, pero conviene advertir, a raíz de las matizaciones que aporta Bobbio, que Mill mantuvo muchas diferencias con pensadores políticos liberales como Tocqueville, cuyas concepciones hundirían sus raíces en la tradición continental ${ }^{497}$. Sin embargo, Bobbio también afirma que todo liberalismo implica, por excelencia, una manera de pensar individualista, aspecto que es común a Mill y a Tocqueville -y también a Constant-. El

\footnotetext{
495 John Stuar Mill, Sobre la libertad (Buenos Aires: Aguilar, 1962), 125.

${ }^{496}$ Mill, ob. cit., 127.

${ }^{497}$ Cfr. Norberto Bobbio, Liberalismo y democracia (Buenos Aires: Fondo de Cultura Económica, 1989), 61-64.
} 
individuo aparece separado del cuerpo orgánico de la sociedad pero no aislado, sino que la individualidad debe desarrollarse independientemente de la presión social de la colectividad y de las preferencias mayoritarias, tanto en materia de creencias $\mathrm{u}$ opiniones como en materia económica. De esta manera, el individuo toma las riendas de su vida al margen de las imposiciones provenientes del poder social y estatal. Según Bobbio, el pensamiento individualista liberal promueve un atomismo en cuanto que supone que la esfera del individuo es una partícula indivisible, y no una partícula dentro de una totalidad ya compuesta. El individuo, de acuerdo con la imagen que presentaría el liberalismo, es una totalidad en sí, una unidad completa ${ }^{498}$.

Por otra parte, y cambiando de ángulo, conviene precisar que, aunque en el pensamiento de Hegel se aprecie una inquina manifiesta hacia lo masivo, no por ello debe confundirse al filósofo alemán con un partidario del individualismo filosófico ni del liberalismo político. Más bien, el pensamiento hegeliano tendería hacia posiciones contrarias al individualismo, las holísticas, ya que bajo su punto de vista la organización social en torno al Estado se realiza a partir de las familias y de la sociedad civil como unidades indisolubles: la familia es la <<sustancialidad inmediata del espíritu, la familia se determina por su unidad sentida, el amor >>, y en ella la persona no es <<por sí sino como miembro >> ${ }^{499}$; mientras que la sociedad civil es, por otra parte, el ámbito en el que se relacionan las personas, teniendo en cuenta que cada persona tiene para sí su fin particular, es decir, necesidad y arbitrio, pero solo alcanzará la persona a realizar estos fines relacionándose con otras personas en quienes también se albergan finalidades particulares $^{500}$. Sin embargo, advierte Hegel que en la sociedad civil la universalidad tiene que limitar a la particularidad si se pretende alcanzar el bienestar ${ }^{501}$. Ahora bien, a diferencia de los Estados antiguos y asiáticos, en el Estado de Derecho la independencia de la particularidad cobra realidad, empero, si bien es cierto que en las antiguas sociedades patriarcales las costumbres se corrompieron -siempre según lo que comenta Hegel- debido a que la reflexión autoconsciente generó la independencia de la particularidad, igualmente es cierto que esta independencia debe ser encauzada hacia una forma universal, o sea, hacia el Estado de Derecho. En el Estado de Derecho lo particular se desarrolla como forma universal de la libertad, compartida esta por todos

\footnotetext{
${ }^{498}$ Cfr. Bobbio, ob. cit., 51-52.

${ }^{499}$ G.W.F. Hegel, Principios de la Filosofía del Derecho (Barcelona: El edhasa, 1999), 277.

${ }^{500}$ Cfr. Hegel, ob. cit., 303.

${ }^{501}$ Cfr. Hegel, ob. cit., 304.
} 
los miembros que componen la sociedad y en la que la libertad de uno no impera sobre la de todos, sino que, por el contrario, la libertad de todos se pone como lo objetivo y forma universal. Por tanto, la ley del Estado de Derecho es universalmente válida y fundamental para todos los individuos ${ }^{502}$.

Cuando una masa social desciende a un tipo de existencia por debajo de los cánones normales de la dignidad humana, dice Hegel que se forma la plebe. La plebe es una masa formada por individuos pobres, en cuanto que no cuentan con el honor de subsistir por sus propios medios y trabajo. No es que Hegel contemple una asociación necesaria entre la plebe y la pobreza, sino que es la plebe la que tiende a la pobreza al vivir sus individuos apegados a la subsistencia y a la indignidad frente a los ciudadanos de otras clases sociales. El filósofo alemán rechaza que el problema de la pobreza se solucione sufragando a la plebe mediante contribuciones impositivas procedentes de las clases más opulentas, ya que los pobres en ese caso no se verían en la necesidad de trabajar, puesto que tendrían asegurado un cierto nivel de bienes sin tener que procurárselos por medio del trabajo. El autor elogia la medida que tomó Escocia a este respecto, país que habría dejado a los pobres expuestos a la vergüenza pública, abandonándolos a su suerte para salvar la honra del trabajo y sortear el derroche del erario público en cubrir la vagancia desvergonzada ${ }^{503}$.

Entonces, se aprecia que la masa plebeya de la que habla Hegel viene categorizada con atributos plenamente descalificativos, su postura a favor de la práctica escocesa da a entender que, si bien, la pobreza es una masa de gente que contiene una fuerza inherente capaz de causar el socavamiento de las arcas públicas y el declive de los valores honorables del trabajo, esta fuerza, al no verse incluida en ninguna de las formas institucionales y en ninguno de los órganos del Estado de Derecho, no constituye una composición social aceptable para la racionalidad política. La imagen de pobreza se corresponde con la masa contingente de individuos menesterosos que por sí mismos no pueden constituir organización racional alguna. Tras esta imagen hegeliana de la pobreza es posible detectar una preocupación por la presencia de la plebe, dado que todo cuerpo masivo posee una fuerza física y, en el caso de la masa plebeya, se trataría de una fuerza no consciente e innecesaria dentro del marco institucional del Estado de

\footnotetext{
${ }^{502}$ Cfr. Hegel, ob. cit., 305-309.

${ }^{503}$ Cfr. Hegel, ob. cit., 359-361.
} 
Derecho, al no venir controlada por ninguna racionalidad; además, su sola existencia no estaría eximida de aparecer y colapsar el complejo orgánico estatal.

La manera legítima, a ojos de Hegel, de velar por la subsistencia e incremento de la riqueza reside en el trabajo, esta actividad se organiza en torno a las corporaciones. En la corporación los sujetos buscan satisfacer necesidades concretas. El poder público vigila a las corporaciones, puesto que estas realizan fines particulares. Es la corporación una forma en que cada grupo social mire por sus intereses. La corporación es una concreción de la sociedad civil, pero, ya que la sociedad civil en su totalidad está más alejada de los individuos puesto que no realiza directamente sus necesidades particulares, pone las bases necesarias para que cada cual pueda realizar sus intereses particulares en la corporación ${ }^{504}$.

Hegel considera que el pueblo no puede constituir una personalidad civil, puesto que lo político se corresponde con una concreción que se eleva a la universalidad. La clase política, a la que Hegel llama clase universal, es una corporación que ostenta los quehaceres del gobierno, en consecuencia su fin es lo universal, de manera que esta clase no puede presentarse como una cosa atomística, dividida conforme a los intereses de los particulares que la componen. Para el filósofo stuttgartense el individuo tomado de manera particular no constituye un átomo de la sociedad, por lo que nadie participa a título individual en el ejercicio legislativo. Cada individuo es miembro de alguna familia así como de la sociedad civil, su disposición original viene dada por su pertenencia a algún tipo de organización social, por lo que quienes realizan los quehaceres legislativos, aun siendo las leyes universales, no pueden hacerlo más que perteneciendo a una corporación ${ }^{505}$. Entonces, para Hegel no existe una identidad política universal que pueda representar en su totalidad al pueblo, ya que el pueblo por sí no representa nada, este, no es más que una amalgama informe de individuos:

Lo que se suele comprender como pueblo, la multitud de individuos, es por cierto un conjunto, pero solo como una acumulación, como una masa carente de forma, cuya acción sería precisamente por ello elemental, irracional, desenfrenada y terrible. Cuando respecto de la constitución todavía se oye hablar de pueblo, de ese conjunto inorgánico,

\footnotetext{
${ }^{504}$ Cfr. Hegel, ob. cit., 364-365.

${ }^{505}$ Cfr. Hegel, ob. cit., 455.
} 
se puede ya saber de antemano que no hay que esperar más que generalidades y equívocas declamaciones. ${ }^{506}$

Hegel le atribuye al término "pueblo" connotaciones que aluden a la irracionalidad y a lo inorgánico, así, las poblaciones entendidas como multitudes o agregados misceláneos de individuos conlleva presuponer su incapacidad a la hora de vertebrar una organización representable en el seno del Estado de Derecho. El autor, en sus Lecciones sobre historia de la filosofía universal, utiliza el término compuesto de "espíritu del pueblo" como concepto sustancialmente distinto del pueblo entendido en cuanto plebe, es decir, en cuanto mera aglomeración somático-masiva de multitudes. Concretamente, en la distinción que Hegel hace entre la materia y el espíritu se deja entrever la bifurcación existente entre la noción de "pueblo", entendido como materia masiva, y la noción de "espíritu del pueblo", entendido como una identidad libre y racional: si la materia es para Hegel una pluralidad de singularidades que tiende por inercia a un centro en la medida en que es pesada, el espíritu solo consta de un centro en tanto en cuanto lo tiene dentro de sí, de forma que tiende a un centro que está en sí mismo; mientras la materia tiene su sustancia fuera de sí, el espíritu tiene su propia sustancia y se esencializa a través de ella como ser independiente, como libertad que no requiere de otra cosa para existir ni es movida por la inercia física ${ }^{507}$. El espíritu se da sus propias determinaciones, el espíritu actúa como mediación de sí mismo. <<Producirse, hacerse objeto de sí mismo, saber de sí, es la tarea del espíritu. De este modo el espíritu existe para sí mismo. Las cosas naturales no existen para sí mismas; por eso no son libres $>{ }^{508}$.

El pueblo que actúa como un conjunto de cuerpos naturales de individuos acumulados no funda un Estado, ni puede constituir organismos institucionales con que determinarse a sí mismo y atribuirse una unidad política. Dice Hegel que el espíritu es el que le da una dirección y organización política al pueblo, puesto que la religión, la ciencia, el arte y la historia de un pueblo son formas objetivadas del espíritu, este, $<<y$ no la naturaleza física del pueblo (como la derivación de la palabra natio de nasci podría sugerir), da al pueblo su carácter $>{ }^{509}$. Hegel contrapone lo meramente

\footnotetext{
${ }^{506}$ Hegel, ob. cit., 456.

${ }^{507}$ Cfr. G.W.F. Hegel, Lecciones sobre la filosofía de la historia universal (Madrid: Alianza Editorial, 2004), 62.

${ }^{508}$ Hegel, ob. cit., 63.

${ }^{509}$ Hegel, ob. cit., 69.
} 
biológico, a saber, las determinaciones procedentes desde el nacimiento, a la espiritualidad. Es debido al espíritu que un grupo de cuerpos humanos se hacen miembros de un Estado, coparticipes de un orden político que no viene dado como determinación natural sino como auto-determinación, por ende, como forma dada libremente. Es por ello que la libertad deberá consistir <<exclusivamente en conocer y querer los objetos sustanciales y universales, como la ley y el derecho; y en producir una realidad que sea conforme a ellos -el Estado $>>^{510}$. El Estado es querido por la libertad en la medida en que es la determinación objetiva puesta por el espíritu de un pueblo; todo grupo humano libre y con identidad política propia habrá de organizarse en torno a un Estado.

Los adjetivos con que Hegel caracteriza al "pueblo físico" dan cuenta de cómo asocia conceptualmente lo masivo con lo inorgánico y, por ende, con lo no-político, dado que la masividad se corresponde con un conjunto de individuos que no adquiere forma propia debido a que sus componentes no constituyen una forma orgánica. Lo masivo sería, entonces, una contingencia no-consciente, un agregado de cuerpos movidos por los impulsos y tendencias primarias de los individuos en multitud, de la que no se desprende racionalidad alguna. Los cuerpos naturales de los individuos reunidos en facciones o en grupos accidentalmente establecidos son incapaces de fundar un Estado, ha de haber una espiritualidad tras ellos que porte cultura. Para el autor es una peligrosa falsedad <<suponer que solo el pueblo tiene razón y conocimiento y que solo él ve lo justo; pues cada facción del pueblo puede erigirse en todo el pueblo. Lo que constituye el Estado es el conocimiento culto; no es pueblo >>511. El pueblo es una "totalidad inorgánica", es contenido del Estado en cuanto su materia, pero no en cuanto su esencia. El concepto de pueblo se orienta a definir generalidades irracionales en el lenguaje jurídico que no han adquirido forma propia ni se han adecuado a la forma objetiva de la libertad, porque Hegel no considera libertad alguna allí donde los individuos son dirigidos nada más que por la inercia de un tropel de cuerpos amasados.

Cabe destacar, al margen de las consideraciones hegelianas, cómo el individualismo extremo de Stirner negó la posibilidad de que cualquier tipo de constructo social pudiera ser catalogado bajo el carácter de cuerpo. En su crítica contra el liberalismo social, Stirner insiste en que no puede existir algo así como un "todos" y alude con saña a la

\footnotetext{
${ }^{510}$ Hegel, ob. cit., 136.

${ }^{511}$ Hegel, ob. cit., 125.
} 
falta de consistencia "corpórea" que tiene este constructo teórico-conceptual; el autor argumenta:

¿Quién es esa persona que os llama "todos”? ¡Es una "sociedad”! ¿Acaso es corpórea? Nosotros somos su cuerpo. ¿Vosotros? Pero si vosotros no sois ningún cuerpo. Tú, es cierto, tienes un cuerpo, también tú, y tú, pero vosotros juntos solo sois cuerpos, no un cuerpo. Así pues, la sociedad unida tendría cuerpos a su servicio, pero ninguno único y propio. Ella no será, como la nación para el político, más que un espíritu, y el cuerpo en él solo apariencia. ${ }^{512}$

Stirner promueve la disipación de la dimensión social del individuo tanto en su forma espiritual como corporal, de ahí que rechace la posibilidad de una corporalidad social o política, ya que, en coherencia con lo que nos muestra la naturaleza, lo único que existe es el cuerpo del individuo y la propiedad espiritual que el Yo hace suya. La ilusión de un cuerpo social se origina en los vínculos que entrelazan los individuos cuando se relacionan entre sí y se asocian, por tanto, imaginar la existencia de una corporalidad social no sería más que una mera alucinación que pone a los cuerpos individuales al servicio de algo no físico e inexistente. Pensar la posibilidad de que una cosa corporal gregaria tenga o pueda tener existencia propia perseguiría tratar de implantar una dominación sobre el individuo, el cual termina perdiendo la posibilidad de darse un orden y una propiedad, quedando así sumido al Estado y a la sociedad; el primero se arroga el orden y la segunda la propiedad ${ }^{513}$.

Si en Stirner sobresale un individualismo extremo, que le llevó a renegar de la idea de sociedad y a rehuir de la analogía entre el cuerpo natural y el cuerpo social, en Marx, sin embargo, hallamos una firme reivindicación de la corporalidad social como identidad política: una personalidad colectiva. Además, Marx niega la posibilidad de que la individualidad sea capaz de articular su propio orden de pensamiento al margen de la colectividad, de hecho le reprocha a Stirner que trate de desvincular el desarrollo de los hombres del desarrollo de la sociedad en la que necesariamente viven inmersos ${ }^{514}$.

El individuo no se hace a sí mismo, sino que se hace a través de las relaciones sociales que entabla en su contexto vital, por lo que $<<$ los individuos se hacen los unos

\footnotetext{
512 Max Stirner, El único y su propiedad (Madrid: Valdemar, 2004), 159-160.

${ }^{513}$ Cfr. Stirner, ob. cit., 161.

${ }^{514}$ Cfr. Karl Marx, La ideología alemana (Madrid: Akal, 2014), 185.
} 
a los otros, tanto física como intelectualmente, pero no se hacen a sí mismos, ni en la disparatada concepción de san Bruno ni en el sentido del "único", del hombre "hecho $>>515$. En consecuencia, para Marx, no es el individuo el que se opone de forma natural a los poderes que fluctúan en el entramado estatal, sino que tiene que ser la masa social la que ponga a disposición de la mayoría las fuerzas contra los poderes opresores. El desarrollo de la historia tiene una raigambre colectiva porque viene efectuado por conjuntos de seres humanos que se relacionan los unos con los otros, dicho desarrollo $<<$ no se halla subordinado a un plan de conjunto de individuos libremente asociados $>>$, sino que $<<$ parte de diferentes localidades, tribus, naciones, ramas de trabajo, etc. $>>516$.

En este aspecto se podría decir que, al igual que Hegel, Marx está del lado holístico en sus consideraciones políticas y sociales, ahora bien, el filósofo de Tréveris se posiciona en las antípodas con respecto a las concepciones hegelianas cuando trata de trazar la imagen conceptual de la masividad. Aquello que Hegel denominaba "plebe", en Marx va a adquirir una potencia política, ese soma social, esa masividad, va a ser pensada por el filósofo de Tréveris como una fuerza social susceptible de adquirir un cuerpo político, de ocupar el poder del Estado. Precisamente Agamben sostiene respecto del pensamiento de Marx que la lucha de clases $<<$ no es otra cosa que esa guerra intestina que divide a todo pueblo y que solo tendrá fin cuando, en la sociedad sin clases o en el reino mesiánico, Pueblo y pueblo coincidan y no haya ya, propiamente, pueblo alguno $>{ }^{517}$. El Pueblo entendido como "cuerpo político" y el pueblo entendido como "plebe" tienen connotaciones semánticas muy evidentes en la consideración de la masa social como un soma in-político, un soma que no puede aspirar a las elevadas y selectas labores del gobierno, sino que ha de recibir la vertebración de una institucionalización política procedente de una configuración no interna a la fuerza corporal concentrada en la multitud. Marx se va a oponer a esta escisión practicada sobre la sociedad, que se hace evidente en la filosofía política hegeliana, así como también en la priorización liberal del individuo, o en la totalidad que lo individual representa en Stirner. Consecuentemente, la filosofía marxiana aspira a identificar la fuerza del soma social con el cuerpo político, a reconciliar al pueblo con el poder que le fue arrebatado.

\footnotetext{
${ }^{515}$ Marx, ob. cit., 31.

${ }^{516}$ Marx, ob. cit., 63.

517 Giorgio Agamben, Homo Sacer. El poder soberano y la nuda vida. I (Valencia: Pre-Textos, 2003), 227.
} 


\subsubsection{MARX Y EL PODERÍO DEL CUERPO SOCIAL}

Marx, tal como expone en su crítica de la filosofía del derecho hegeliana, explica la oposición conceptual que aprecia en el pensamiento de Hegel entre el tropel de individuos que conforman la masa social con respecto a la forma orgánica y ordenada que representa al Estado. Los intereses pertenecientes a la plebe no serían más que un conglomerado masivo-irracional de individuos reunidos accidentalmente. Los individuos agrupados en masa no deberían -según Marx interpreta los planteamientos de Hegel- articular deseos y opiniones en contra del ordenamiento estatal. El Estado habría asumido que en su orden orgánico también brota la agrupación de los hombres de manera amontonada, como dispuestos irracionalmente, sin un objetivo, sin una vertebración organizada de su corporalidad social.

Para Marx, en el Estado hegeliano lo masivo puede ser aceptado, pero nunca podrá llegar a convertirse en un poder, es decir, el Estado habría de impedir que el pueblo termine encarnando un cuerpo vertebrado y susceptible de generar una organización independiente ${ }^{518}$. Marx interpreta que Hegel observó cómo en la masividad social reside una fuerza, una fuerza con el potencial suficiente como para volverse problemática y peligrosa de cara al poder estatal, siempre y cuando esta adquiriera una identidad política con capacidad para desalojar la forma orgánico-política impuesta por el Estado y sustituirla por una organización acorde a los intereses de la mayoría social. Al Estado lo que le convendría, entonces, es mantener controlada esta fuerza masiva, no tratar de anularla, sino, más bien, perpetuar su composición inorgánica como única manera de neutralizar su potencialidad política, para que así no pueda rivalizar en el espacio de la organicidad institucional pública como fuerza-masiva políticamente organizada. La mejor manera de controlar la corporalidad social todavía invertebrada en la masa informe del pueblo radicaría en perennizar su no-organización.

Comenta Marx que Hegel presenta a la familia y a la sociedad burguesa sumergidas originalmente en la naturaleza, y que el Estado procede de ellas, pero que lo hacen de una manera inconsciente, es decir, todavía como contenido material y no formal, como irracionalidad latente en la materialidad de las formas naturales y originarias de las agrupaciones humanas. No obstante, la racionalidad del Estado se eleva sobre la familia y la sociedad burguesa con el fin de organizarlas, estas son el contenido material con

\footnotetext{
${ }^{518}$ Cfr. Karl Marx, Crítica de la filosofía del Estado de Hegel (Madrid: Biblioteca Nueva, 2010), 145.
} 
que opera el Estado. Familias y sociedad burguesa: ambas conforman el cuerpo del Estado y el objeto de su dominio. El Estado se alza como principio racional diferenciado de su composición natural. Los componentes corporales del Estado se ordenan conforme a su racionalidad -espiritual-, es decir, conforme a su figura formal ${ }^{519}$.

El Estado se despliega en las diferencias de la realidad, pero siempre con base en su manifestación formal. El Estado tiene a lo orgánico como su forma por excelencia, de tal modo que las diferencias que se dan en la realidad son el resultado de este proceso de la idea, que organiza la diversidad de lo real de acuerdo a formas racionales ${ }^{520}$. La validez - autoridad- del Estado halla su apoyo en el hecho de que persigue un fin que es real, no una ficción o una posibilidad meramente contingente, dicho fin es el interés general. El interés general es una abstracción de los intereses particulares que se realizan en pura confluencia. El contenido abstracto se realiza en el mundo en forma de concreciones, concreciones de esta realización sobre lo material, sobre entes corpóreos. Pero este modo de realizarse, en cuanto que parte de un principio diferenciado de lo dado de manera natural, se lleva a cabo en la articulación de los distintos poderes que surgen en las concreciones ${ }^{521}$.

Un reproche que Marx le hizo a la filosofía de Hegel en general, detectable a lo largo de sus textos filosóficos, es que en el pensamiento hegeliano prima lo abstracto sobre lo material, de tal modo que la observación de la naturaleza no tendría otro fin más que ser $<<$ el acto confirmatorio de su abstracción de la contemplación de la naturaleza, el acto genérico, conscientemente repetido por él, de su abstracción $>>^{522}$. La naturaleza, en cuanto entidad material, quedaría deambulando en la nada como una cosa carente de forma: <<la naturaleza separada, distinta de estas abstracciones, es nada, una nada que se confirma como nada, carece de sentido o tiene solo el sentido de una exterioridad que ha sido superada $>{ }^{523}$. Estas palabras de Marx presentes en los Manuscritos, realizadas a propósito del "saber absoluto" en Hegel, pueden trasladarse a la consideración de la plebe como una entidad surgida naturalmente, proveniente de asociaciones que los seres humanos llevan a cabo en función de sus necesidades e

\footnotetext{
${ }^{519}$ Cfr. Marx, ob. cit., 70.

${ }^{520}$ Cfr. Marx, ob. cit., 76.

${ }^{521}$ Cfr. Marx, ob. cit., 81.83 .

${ }^{522}$ Karl Marx, Manuscritos de economía y filosofía (Madrid: Alianza Editorial, 2013), 252.

${ }^{523}$ Marx, ob. cit., 253.
} 
impulsos instintivos; tras estas agrupaciones naturales no operarían las abstracciones con que el Estado ordena a la sociedad y, por tanto, la población entendida como ente somático carecería de poder, pues no tiene forma política.

Consecuentemente, Marx se muestra crítico con la predilección del sistema de filosofía del derecho de Hegel por privilegiar lo abstracto e ideal sobre lo concreto y real. Los argumentos del filósofo stuttgartense habrían revestido la materialidad social de una estela espectral de idealidad sin una raigambre corporal definida. Este halo de idealidad que cubre los cuerpos creando una pantalla de ficción en las relaciones sociales garantiza una determinada forma de dominación, un poder inmaterial caído sobre el cuerpo social. Marx hace patente su argumento en contra del pensamiento de su maestro cuando trata y caracteriza la figura del monarca en la Filosofía del Derecho; afirma que

hemos oído que la subjetividad es sujeto y el sujeto necesariamente individuo empírico, Uno. Ahora nos enteramos de que en el concepto de la singularidad directa se encierra la característica de la naturalidad, de la corporeidad. Lo único que Hegel ha demostrado es algo evidente: que la subjetividad solo existe como individuo corpóreo y que, naturalmente, donde hay un individuo corporal hay nacimiento natural. ${ }^{524}$

En la monarquía, el nacimiento del soberano, el hecho de haber nacido en el seno de la familia real, garantiza el derecho a gobernar y justifica la transmisión hereditaria del poder. La potestad para gobernar el Estado es una cuestión de índole puramente carnal, pues es la physis en cuanto que nacimiento del cuerpo del monarca la que le otorga su derecho de gobierno, el soberano en la monarquía se impone nada más que por la procedencia -genética- de su cuerpo. Así, por tanto, considera Marx que no hay aquí ninguna racionalidad sino poder físico del cuerpo del monarca, quien impone su linaje como derecho político, pues su ascendencia como criterio de poder físico-natural no pasa por el filtro de una racionalidad plenamente consistente ${ }^{525}$. Marx encuentra que en el proceso para legitimar el poder del monarca se da una apropiación por parte de la idea del cuerpo del rey ${ }^{526}$. La idea escinde la corporalidad monárquica de la constitución biológica del soberano, por lo que la legitimación de la figura (abstracta) del rey no es

\footnotetext{
${ }^{524}$ Karl Marx, Crítica de la filosofía del Estado de Hegel (Madrid: Biblioteca Nueva, 2010), 103-104.

${ }^{525}$ Cfr. Marx, ob. cit., 104.

${ }^{526}$ Cfr. Marx, ob. cit., 105.
} 
más que una estela ficticia (inmaterial) posada sobre el cuerpo de un individuo que se ve convertido en rey por herencia:

El carácter hereditario del monarca se desprende de su concepto. Debe ser la persona específicamente diferente de toda la especie, de todas las otras personas. Y ¿cuál es la diferencia más sólida y fundamental de una persona con todas las otras? El cuerpo. La suprema función del cuerpo es la actividad sexual. El supremo acto constitucional del rey será por tanto su actividad sexual: mediante ella hace un <nuevo> rey y perpetúa su cuerpo. El cuerpo de su hijo es la reproducción de su propio cuerpo, la creación del cuerpo de un rey. ${ }^{527}$

El sistema hereditario de la monarquía lo traslada Hegel -según Marx- a la formación del Estado en el contexto de la sociedad burguesa. La transmisión de los derechos de la propiedad privada hace que cada burgués se convierta en la práctica en un "pequeño monarca". En el mayorazgo, así como en la monarquía hereditaria, la transmisión del poder soberano o propietario se mantiene a lo largo de los cuerpos nacidos generación tras generación. Marx asegura que el hombre nace biológicamente desprovisto de propiedades y estatus, el nacido no es más que un cuerpo humano, pero que son las relaciones sociales las que le hacen heredero de unas tierras y le conceden un rango en la sociedad, ya que estas cosas solo pueden otorgárselas el consentimiento social. El objeto de tal consentimiento no radica en un sitio diferente de la corporalidad del individuo, puesto que < <la dignidad corpórea del hombre o dignidad del cuerpo humano (más explicitado: dignidad del elemento natural y físico del Estado) se presenta de forma que determinadas dignidades sociales, las más dignas, pertenecen a determinados cuerpos $>>528$. No es que los cuerpos ostenten naturalmente esta dignidad social, más bien, esta dignidad le viene asignada a los cuerpos por un poder externo a su propia naturaleza. En este punto se aprecia cómo Marx distingue entre lo natural y lo social, pues resulta que todos los seres humanos son naturales en cuanto que son cuerpos; este es el punto de igualación de los hombres; pero, por otro lado, es en el entorno de las relaciones sociales donde se establecen las diferencias entre los distintos individuos, el elemento de igualación natural de la corporalidad queda de esta forma relegado en conformidad con la jerarquía que imponen las relaciones sociales. Como sucede con el cuerpo de la mercancía, Marx considera que lo social le asigna y añade

\footnotetext{
${ }^{527}$ Marx, ob. cit., 112.

${ }^{528}$ Marx, ob. cit., 191-192.
} 
poder a los cuerpos humanos, este tipo de poder creado en las relaciones sociales no está en la inherencia biológica de los cuerpos humanos.

Marx da cuenta de cómo para establecer clases sociales, asignar propiedades y determinar rangos de mando, es necesario añadirles a las corporalidades humanas algo que no estaba dado en su constitución biológica, algo que les viene dado por una "especie" de fuerza incorpórea que posiciona a las personas en la sociedad unas con respecto a otras, y que les asigna unas obligaciones y deberes en sus relaciones. El poder que lleva a cabo tales asignaciones es invisible e incorpóreo, su influencia sobre los cuerpos no se ejecuta desde una instancia física, no articula un tipo de presión directa sobre los cuerpos, pero sí se puede decir que ostenta una fuerza ficticia, ya que mueve a los cuerpos de los individuos de acuerdo a unas determinadas predisposiciones. El cuerpo humano queda así subsumido por una fuerza ficticia externa a su corporalidad y ajena a la fuerza física de la corporalidad; se instaura un tipo de poder que, si bien resulta abstracto e invisible, tiene como su mediación objetiva a la dimensión corporal de los hombres. El orden de este domino solo se hace palpable y posible cuando cada uno de los cuerpos se dispone en el estamento que le corresponde dentro de una estructura sistémica impersonal en la que se dan relaciones jerárquicas, comportándose cada uno de ellos conforme a la posición social que ocupa.

\subsubsection{Articulaciones físicas y articulaciones incorpóreas de LA DOMINACIÓN CAPITALISTA}

El modelo de dominación impersonal que el joven Marx encontró en la filosofía del derecho de Hegel, guarda estrecha sintonía con la manera en que caracterizaría posteriormente el dominio del capital sobre el trabajo. En los análisis críticos de sus obras de madurez, Marx concibe al capital como una figura de poder impersonal, incorpórea y abstracta, que controla a los cuerpos humanos posicionándolos jerárquicamente a partir del ordenamiento trazado por las relaciones productivas. La imagen del capitalista para Marx es la del capital personificado. El capitalista hace las funciones del capital, este es su cuerpo agente, quien succiona el producto del trabajo; mientras, por otro lado, el trabajo se personifica en el obrero, quien realiza el esfuerzo físico y mental, quien está en contacto directo con la materia del proceso productivo, aunque el producto finalmente siempre es apropiado personalmente por el capitalista en cuanto que agente físico del capital. En esta relación, el capital se advierte como una figura de poder independiente de la corporalidad, la imagen del capitalista es la de la 
personificación del capital, no es este una representación del capital sino su cauce de acción encarnado en el cuerpo de un hombre que explota a otros hombres para sustraer y acumular la riqueza que generan. Además, los cuerpos de los explotados son los que ejecutan el esfuerzo productivo que en último término se convierte en capital. A su vez, el dominio del capital sobre el trabajo no es más que una abstracción de esa relación en la que el capitalista absorbe el valor del trabajo de sus obreros:

La dominación del capitalista sobre el obrero es por consiguiente la de la cosa sobre el hombre, la del trabajo muerto sobre el trabajo vivo, la del producto sobre el productor, ya que en realidad las mercancías, que se convierten en medios de dominación sobre los obreros (pero solo como medios de la dominación del capital mismo), no son sino meros resultados del proceso de producción, los productos del mismo. ${ }^{529}$

El obrero fabrica su propio objeto de dominación, abotarga al capital. Tras los términos de "trabajo muerto" y "trabajo vivo" se encuentra la caracterización que Marx hace del capital como un objeto inerte que domina sobre lo vivo, un objeto abstracto e incorpóreo que pone bajo su yugo los cuerpos de los obreros, absorbiendo el valor de los resultados obtenidos a partir de la energía corporal empleada en las acciones productivas. Esta relación entre el capital y el trabajo convierte al objeto, que es el capital, en sujeto pasivo, y al sujeto, el ser humano, en una máquina de producción, es decir, en un objeto puesto en funcionamiento por el capitalista, quien propiamente es el objeto gerente del capital.

El capitalista cuenta con la legitimación de la violencia para subyugar a los cuerpos que conforman la sociedad ${ }^{530}$. El capital se autovalora con la creación de la plusvalía, el contenido racionalizado por medio del que opera la lógica acaparadora del capital y que se encarna en la imagen del capitalista, el cual acapara el valor que subyace a la producción social, hace del capital el dueño del valor de la fuerza productiva de la sociedad. La plusvalía es, en palabras de Marx, un <<contenido absolutamente mezquino y abstracto, que desde cierto ángulo hace aparecer al capitalista como sometido exactamente a la misma servidumbre respecto de la relación del capital, aunque también de otra manera, que el polo opuesto, que el obrero $>{ }^{531}$. El cuerpo del capitalista, por consiguiente, se revela como el representante físico del capital, de ahí

${ }^{529}$ Karl Marx, Resultados del proceso inmediato de producción. Libro I. Capítulo VI inédito de El Capital (México D.F: Siglo XXI Editores, 2009), 19.

${ }^{530}$ Cfr. Marx, ob. cit., 19-20.

${ }^{531}$ Marx, ob. cit., 20. 
que ocupe el polo pasivo en la relación capital-trabajo, porque está del lado del sujeto pasivo u objeto abstracto por el que se define el capital. Por otro lado, el obrero ocupa la posición activa en cuanto que su cuerpo está en perpetuo movimiento, no es el obrero un representante del capital, sino su objeto de dominación. Este tipo de dominación, que solo puede efectuarse si el obrero se subsume al capitalista, expropia el valor que le corresponde a la fuerza de trabajo del obrero, lo que le relega a la sumisión servil. El mando que ostenta el capitalista, así como su capacidad para sustraer el valor del trabajo, se lo confiere el capital -igual que el consentimiento social admite la herencia del poder en el cuerpo biológico del rey nacido-. El capital es una cosa que solo puede actuar por medio del cuerpo del capitalista pero que se crea a partir de la actividad productiva ejercida por el cuerpo de los trabajadores, a quienes domina indirectamente por medio de la plusvalía impuesta por el capitalista.

La absorción del valor de la fuerza de trabajo y la conversión de las actividades laborales a un valor monetario son el motor del capital y su modo de incremento. El capital se nutre de las energías que guardan los cuerpos humanos, por tanto, Marx identifica la acumulación y la concentración de capital con $<<$ la facilidad de apropiarse en grandes masas del plustrabajo de otras personas, y la consiguiente incapacidad en que se hallan estas mismas de formular pretensión alguna respecto a su propio plustrabajo $>{ }^{532}$. La incapacidad que indica Marx, por parte de la masa social trabajadora, para defender la plusvalía del trabajo habría ido gestándose a lo largo de siglos, durante un proceso histórico en el que, en un comienzo, la burguesía no poseía todavía el poder de los medios de producción, de modo que la acumulación y concentración de capital permanecían aun sesgadas. En lo que Marx considera el preludio de la etapa capitalista, justo cuando comenzaron a desmoronarse paulatinamente las relaciones de producción feudales, se produjo la disolución de las asociaciones gremiales, el desalojo de los señores feudales de sus propiedades y la expropiación de las propiedades comunales, todos ellos factores detonantes del proceso capitalista, cuyo inicio cronológico vendría datado en el último tercio del siglo $\mathrm{XVI}^{533}$.

Para Marx, el sistema capitalista requiere de $<<$ la sujeción servil de la masa del pueblo, la transformación de este en un tropel de gentes a sueldo y de sus instrumentos

\footnotetext{
${ }^{532}$ Marx, ob. cit., 158.

${ }^{533}$ Cfr. Karl Marx, El capital. I (México D. F: Fondo de Cultura Económica, 1946), 608-609 y 611.
} 
de trabajo en capital $>{ }^{534}$. Para llevar a término esta conversión de la masa social, se precisaba expropiar a los individuos de sus medios materiales de subsistencia, así como arrancarles de su esfera comunitaria tradicional; había que hacer del individuo un ser desposeído tanto de sus medios de producción como de las fuerzas que adquiría en asociación con otros individuos. La población campesina entró a formar parte de una masa de personas asalariadas a medida que se les iba expropiando y expulsando de sus tierras mediante leyes que legitimaban el uso de la violencia. Las comunidades campesinas se disolvieron y sus integrantes se dispersaron, al no poseer las tierras que les mantenían unidos en sus actividades tradicionales de trabajo, gracias a las que se mantenían con vida. Los individuos que formaban parte de esta población campesina pasaron a actuar como átomos segregados. Los cuerpos comunales en que se organizaba la población rural estaban en plena descomposición, Marx observa cómo la subsunción de las sociedades tradicionales al capital requirió de operaciones que fragmentaran la complexión que estas sociedades formaban en torno al trabajo.

De esta forma se creó una masa de individuos que no poseían nada más que sus cuerpos, es decir, su única posesión era la fuerza intrínseca a la condición de su ser corpóreo. Los campesinos, condenados al vagabundaje, solo eran propietarios de sus cuerpos y del valor de su fuerza de trabajo, pero este valor no lo tasaban ellos mismos. Siguiendo la lectura que hace Marx -y siendo más incisivos en la cuestión de los cuerpos de los asalariados- se podría decir que a los campesinos que tenían su sustento en las tierras comunales se les reconoció la libertad en el nuevo Estado burgués pero, al haber sido expropiados de sus medios de producción, esa libertad no podía residir ya en otra parte más que en la fuerza de su cuerpo, esta fuerza debía ser encauzada hacia el ámbito productivo-comercial. Estos cuerpos dirigidos por personas libres, pero desprovistas de propiedades, tenían que hallar la forma de sustentarse, lo que las empujaba al mercado laboral.

No basta con que las condiciones de trabajo cristalicen en uno de los polos como capital y en el polo contrario como hombres que no tienen nada que vender más que su fuerza de trabajo. Ni basta tampoco con obligar a estos a venderse voluntariamente. En el transcurso de la producción capitalista, se va formando una clase obrera que, a fuerza de educación, de tradición, de costumbre, se somete a las exigencias de este régimen de producción como a las más lógicas leyes naturales. La organización del proceso

${ }^{534}$ Marx, ob. cit., 613. 
capitalista de producción ya desarrollado vence todas las resistencias; la existencia constante de una superpoblación relativa mantiene la ley de la oferta y la demanda de trabajo a tono con las necesidades de explotación del capital, y la presión sorda de las condiciones económicas sella el poder de mando del capitalista sobre el obrero. ${ }^{535}$

Se supone que el valor de las fuerzas de trabajo operantes en el mercado laboral vendría determinado por la ley de la oferta y la demanda, que presumiblemente debía ser una ponderación aséptica. Marx apunta que en la práctica eran los propios burgueses quienes tasaban el precio del trabajo apoyándose en el poder del Estado, los burgueses imponen una legalidad en las instituciones estatales para regular el precio del trabajo en función a la plusvalía que pretenderían obtener de las fuerzas productivas. El valor del trabajo vendría así aherrojado por la lógica del capital y no por supuestas leyes naturales asépticas y neutrales con respecto a los intereses humanos. Marx dice que este proceso tuvo lugar ya desde el siglo XIV, momento en que aún no existía una masa asalariada prominente, ahora bien, mientras siglo a siglo fuere aumentando la población y a medida que le fueron expropiando tierras a los campesinos la concentración y acumulación del capital en manos de la burguesía creció proporcionalmente a la cantidad de bolsas de desposeídos. En un primer momento la demanda de trabajo asalariado era creciente, mientras que la oferta iba lentamente aumentando ${ }^{536}$.

De los argumentos de Marx cabe inquirir una estructura dialéctica en la confrontación entre la fuerza de la masa popular y la fuerza del Estado. La burguesía desde finales del siglo XV y hasta el siglo XIX habría buscado derogar las tradicionales propiedades comunales, institución feudal de origen germánico ${ }^{537}$; ahora bien, a medida que la burguesía fue siendo más influyente en el Estado, la extracción de las tierras comunales fue agilizándose, quedando estas en manos de propietarios privados. Toda esta privatización de la tierra en manos de una clase social en auge pudo ser articulada en tanto en cuanto el cuerpo de esta clase social pasó a ocupar las instituciones del Estado. La burguesía erigió un nuevo orden en las relaciones de producción: el capitalismo, basado en la propiedad privada de los medios productivos. Pero el capital precisaba de masas de individuos despojados tanto de sus medios de subsistencia como de su comunidad tradicional. El uso violento de la expropiación de tierras a la población rural pasó por el uso de las fuerzas que albergaba el Estado, así, el Estado moderno de la

\footnotetext{
${ }^{535}$ Marx, ob. cit., 627.

${ }^{536}$ Cfr. Marx, ob. cit., 627-628.

${ }^{537}$ Cfr. Marx, ob. cit., 616.
} 
clase burguesa pasó a ser el instrumento político del capital; una vez más, encontramos dentro del pensamiento de Marx una actuación indirecta del capital, ahora encarnado en las instituciones políticas -el Estado era la instancia física con capacidad para organizar y movilizar fuerzas físicas que llevaran a cabo operaciones de despojo y acción directa sobre el cuerpo de los individuos-. El capital habría tomado una forma material integrada por el cuerpo estatal y ocupado por la clase dominante en el capitalismo, la burguesía. Pero la forma abstracta e impersonal del capital también se habría mantenido latente, este contaría con una figura corpórea a la vez que con una figura abstracta e impersonal.

En La ideología alemana Marx dice que solo la clase que ostenta el poder del Estado puede hacer pasar su interés de clase como el interés general de toda la sociedad, como si este fuera el interés universal. No obstante, también advierte que la tensión constante entre los supuestos intereses universales con respecto a los intereses mayoritarios siempre va a permanecer latente, razón por la que el Estado es instaurado para actuar como contrapeso de la fuerza que ostenta el interés de la colectividad, que es la clase social dominada y la más abultada ${ }^{538}$. El filtro a través del que la clase dominante le impone sus intereses a toda la sociedad es, consiguientemente, el Estado. Además, Marx entiende que en las relaciones de producción capitalistas la fuerza del trabajo social tiene que ser extraída de los cuerpos que la impelen. El trabajo debe mantenerse fuera del control de la masa social, para ello, el poder que reside en la fuerza de trabajo como conjunto unitario de acción ha de permanecer oculto, dividido, pasar inadvertido para la sociedad:

El poder social, es decir, la fuerza de producción multiplicada, que nace por obra de la cooperación de los diferentes individuos bajo la acción de la división del trabajo, se les aparece a estos individuos, por no tratarse de una cooperación voluntaria, sino natural, no como un poder propio, asociado, sino como un poder ajeno, situado al margen de ellos, que no saben de dónde procede ni a dónde se dirige y que, por tanto, no pueden ya dominar, sino que recorre, por el contrario, una serie de fases y etapas de desarrollo peculiar e independiente de la voluntad y los actos de los hombres y que incluso dirige esta voluntad y estos actos. ${ }^{539}$

\footnotetext{
${ }^{538}$ Cfr. Karl Marx, La ideología alemana (Madrid: Akal, 2014), 28.

${ }^{539}$ Marx, ob. cit., 28.
} 
La división del trabajo divide el poder que de manera natural albergan las fuerzas sociales que participan en las relaciones y procesos de producción. Podría decirse que Marx supone la existencia de un poder unificado y vinculado a la sociedad en su conjunto, un poder que se identifica plenamente con la corporalidad social de la que emanan las fuerzas productivas; pero, debido a las relaciones sociales por las que se divide el trabajo, el poder originario de la sociedad va enajenándose con respecto a los agentes que ejercen el trabajo, de modo que las actividades productivas terminan saliendo del control del cuerpo social que las impulsa. El poder social se fragmenta, el capital saliente del trabajo configura un poder extrínseco a los cuerpos que lo produjeron.

Marx encuentra que la reunión de los cuerpos en la masa social constituye una fuerza corporal capaz de revertir las condiciones de producción impuestas por el capital. El capital le debe su existencia a la fuerza productiva, asimismo, las relaciones articuladas a partir del poder inmaterial del capital solo pueden ser reducidas si termina por imponerse el poder material que alberga el cuerpo social. Dice el pensador que las contraposiciones en la historia se derivan de las contradicciones entre las fuerzas productivas y las relaciones de producción ${ }^{540}$. El juego de relaciones en que caen las fuerzas sociales productoras constituye un sistema que engrana el modo de dominación sobre la masa. Cuando las relaciones de producción no llegan a controlar el contenido total de las fuerzas que participan en el proceso productivo, entonces las relaciones sociales resultan insuficientes para sostener el domino sobre las fuerzas productivas intrínsecas a los cuerpos. En consecuencia, se pone así en marcha una contradicción que conduce a una nueva situación histórica. En palabras de Marx:

Al llegar a un determinado desarrollo, las fuerzas productivas materiales de la sociedad chocan con las relaciones de producción existentes, o, lo que no es más que la expresión jurídica de esto, con las relaciones de propiedad dentro de las cuales se han desenvuelto hasta allí. De las formas de desarrollo de las fuerzas productivas, estas relaciones se convierten en trabas suyas. Se abre así una época de revolución social. ${ }^{541}$

Las relaciones de producción de la burguesía constituyen el último estadio de la producción social; las condiciones de vida de la sociedad, bajo dominio de un determinado tipo de relaciones de producción, genera un antagonismo que solo puede

\footnotetext{
${ }^{540}$ Cfr. Marx, ob. cit., 63-64.

${ }^{541}$ Karl Marx, Introducción general a la crítica de la economía política/1857 (Córdoba, Argentina: Ediciones Pasado y Presente, 1974), 77.
} 
ser resuelto si la fuerza social se cierne contra las relaciones productivas dominantes. Si los proletarios no tienen el control sobre su trabajo, es decir, sobre el valor de lo que producen y sobre sus relaciones laborales, tampoco tendrán control alguno sobre las condiciones en que se desarrolla su vida. Para que los proletarios liberen su trabajo de las ataduras que les vinieron impuestas por las relaciones de producción capitalistas deben oponerse al concepto de individualidad que la persona adquiere en el Estado burgués, puesto que es aquí donde la sociedad le concede una identidad jurídica, abstracta y supuestamente objetiva al individuo; por tanto, el proletariado debe $<<$ derrocar al Estado, para imponer su personalidad $>>{ }^{542}$. En este punto se aprecia diáfanamente cómo Marx opone la masa social al Estado burgués mediante una confrontación de poder que emana de la correlación de fuerzas entre la fuerza física de la sociedad como conjunto masivo contra su configuración ideal, a saber, la de ese individuo emancipado de la sociedad, individuo que es una figura conceptual instaurada por el liberalismo.

En la filosofía de Marx se hace patente de manera constante la intuición de que la fuerza intrínseca a la corporalidad social encarna un poder capaz de revertir la dominación invisible que el capital implanta sobre el trabajo, de ese tipo de poder puramente imaginario e incorpóreo que envuelve a los cuerpos en un halo fantástico capaz de influir en las relaciones de producción como si de un ser corporal se tratara. Los poderes inmateriales y ficticios de la burguesía habrían tendido a la disolución del cuerpo social en individuos supuestamente independientes de la colectividad. Asimismo, en la confrontación entre la sociedad y el Estado, según la lógica marxiana, la pugna por el poder terminaría por inclinarse siempre a favor del agente que realiza el ejercicio material de la fuerza: la masa social como peso de un cuerpo real y no ideal.

La imagen acerca de lo social que proporciona Marx es la de una totalidad en la que se disponen las fuerzas productivas y en la que se vertebran las relaciones de producción. Al rechazar el individualismo de corte liberal, al negar el ideal de un Yo autónomo e independiente con respecto al poder social y al oponerse a la imagen atómica del individuo, Marx emprendió un análisis crítico de la sociedad decimonónica cuestionando los presupuestos y preceptos individualistas que habían determinado el pensamiento político, económico y social. Marx disuelve la figura jurídico-política del individuo en la sociedad, pues considera que es en las relaciones sociales donde el

${ }^{542}$ Karl Marx, La ideología alemana (Madrid: Akal, 2014), 68. 
individuo conforma la conciencia y donde puede tomar forma la individualidad. Pero la individualidad no viene dada naturalmente ni constituye por sí misma un poder; el único poder real, en cuanto que material, anida en el cuerpo social, allí donde se organizan las fuerzas productivas que propulsan el desarrollo de la humanidad.

\subsubsection{NIETZSCHE: LA INDIVIDUALIDAD DEGRADADA DEL SUJETO MODERNO, EL ESTADO COMO INSTRUMENTO DE SUPERVIVENCIA Y EL CUERPO DELATOR}

Otro de los filósofos del siglo XIX que abordaron la vertiginosa correlación entre la fuerza del cuerpo natural-individual y la fuerza de la masa social fue Nietzsche. En uno de los aforismos redactados en el otoño de 1887 -más adelante reelaborado en el verano de 1888- Nietzsche decía que el individualismo se caracteriza por ser <<una especie modesta y aún inconsciente de la "voluntad de poder"; aquí al individuo le parece ya suficiente librarse de un predominio de la sociedad (ya sea del estado o de la iglesia...) $>>^{543}$. Para el filósofo alemán el individualismo sitúa a todos los individuos en un mismo plano, hace de cada uno de ellos un igual con respecto a los otros, pero siempre tomando a cada individuo de forma particular, de modo que aquello que consigue el individuo $<<$ no lo consigue como persona sino como individuo en contra de la colectividad $>{ }^{544}$. Los individuos no se limitan a conseguir su liberación con respecto a la sociedad, sino que una vez lograda su emancipación continúan luchando entre ellos por el poder, pues la consecuencia del individualismo es la formación de organismos y afinidades entre individuos que desembocan en una jerarquía ${ }^{545}$.

Ya en la primera obra que condujera a Nietzsche al reconocimiento académico y literario, El nacimiento de la tragedia, se aprecia un contraste no necesariamente de índole beligerante entre la individualidad y la sociedad, dicho contraste se hace patente en el arte dionisiaco que rompe los cánones cotidianos y regularidades de los individuos. El arte dionisiaco introduce a los hombres en el juego de la embriaguez y el éxtasis, un juego que tiende a absorber y disolver el recuerdo normalizado de la individualidad; añade Nietzsche:

Dos poderes sobre todo son los que al ingenuo hombre natural lo elevan hasta el olvido de sí que es propio de la embriaguez, el instinto primaveral y la bebida narcótica. Sus efectos están simbolizados en la figura de Dioniso. En ambos estados el principium

\footnotetext{
${ }^{543}$ Friedrich Nietzsche, Fragmentos póstumos. Volumen IV (Madrid: Tecnos, 2008), 324.

${ }^{544}$ Nietzsche, ob. cit., 324.

${ }^{545}$ Cfr. Nietzsche, ob. cit., 325.
} 
individuationis [principio de individuación] queda roto, lo subjetivo desaparece totalmente ante la eruptiva violencia de lo general-humano, más aún, de lo universalnatural. Las fiestas de Dioniso no solo establecen un pacto entre los hombres, también reconcilian al ser humano con la naturaleza. ${ }^{546}$

Es en el ditirambo de la primavera donde el pueblo se expresa como género y no como individuo, ni siquiera el pueblo se convierte en un cuerpo en analogía al cuerpo del individuo, más bien se hace "ser natural" cuando los hombres entran en un nuevo contacto con la naturaleza a través de la sátira y el baile ${ }^{547}$. La fuerza embriagadora de lo dionisiaco permite echar a un lado las cargas y obligaciones de la vida diaria para embaucar a la sociedad hacia una escenificación satirizada de los complejos individuales y hacia el furor del baile como catarsis. En esta escenografía catártica dionisiaca < las representaciones concomitantes llegan hasta el símbolo en las imágenes de una humanidad intensificada, son representadas con la máxima energía física por el simbolismo corporal entero, por el gesto del baile >> ${ }^{548}$. Siguiendo el rastro de la fundición del individuo en el soma danzarín y festivo del arte dionisiaco, que presenta Nietzsche desde su primera obra famosa hasta los aforismos del final de su vida literaria -antes de que en 1889 la demencia le inhabilitara completamente hasta su muerte en 1900-, se puede comprobar que, en efecto, el pensamiento de Nietzsche puede ser tomado en cuenta como un detractor del individualismo moderno pero, no por ello, partidario de posiciones políticas colectivistas. La filosofía nietzscheana no renuncia al valor de la individualidad, las agudas críticas que el autor vertió contra los valores gregarios del "rebaño" le alejan claramente de posiciones próximas al socialismo $^{549}$ y comunismo gestados en el siglo XIX -y obviamente también del cristianismo--. Lo que hace Nietzsche es, por un lado, criticar al individualismo como un pensamiento regresivo que envilece al individuo humano y, por otro lado, trata de localizar las facetas de la cultura que corroen y enferman a la sociedad.

El pensador alemán persigue diagnosticar en la figura de la individualidad debilidades que fuerzan al hombre particular a tener que cobijarse tras lo social, pues el

\footnotetext{
${ }^{546}$ Friedrich Nietzsche, El nacimiento de la tragedia (Madrid: Alianza, 2000), 246.

${ }^{547}$ Cfr. Nietzsche, ob. cit., 269.

${ }^{548}$ Nietzsche, ob. cit., 272.

${ }^{549}$ En uno de los fragmentos de abril-julio de 1885 Nietzsche dice que entre otras tendencias políticas le repugna el socialismo <<porque sueña de un modo completamente ingenuo con las estupideces del rebaño de "lo bueno, verdadero y bello">>, Fragmentos póstumos sobre política (Madrid: Trotta, 2004), 171.
} 
individuo moderno arrastra consigo la expresión de la impotencia más que la de la potencia. La agrupación social es un multiplicador de fuerzas para los humanos. En la primavera de 1888, a propósito del tema del egoísmo, Nietzsche escribía:

Principio: solo los individuos se sienten responsables. Las multitudes se han inventado para hacer cosas que el individuo no tiene el coraje de hacerlas.

Precisamente por ello todas las comunidades, todas las sociedades, son cien veces más sinceras y más instructivas sobre la esencia del ser humano que el individuo, el cual es demasiado débil para tener el coraje que requiere sus apetitos... 550

Para Nietzsche, la multitud es un testaferro creado por los seres humanos para ocultar la carencia de valor que tienen en cuanto individuos. La concurrencia de los individuos por la que se forma la sociedad oculta el verdadero carácter beligerante y violento de la naturaleza humana, los fines que persiguen los individuos cuando se coaligan socialmente corresponden a sus intereses, son fines egoístas, puesto que la sociedad potencia las fuerzas de los seres humanos y, por tanto, aumenta su poder.

El filósofo de Röcken no contrapone lo individual a lo social tensionando ambas nociones, sino que trata de descubrir cuáles son los elementos de la individualidad que coadyuvan a retener los instintos del cuerpo humano, a bloquear las fuerzas de la corporalidad en favor de la unión social. El sentimiento de responsabilidad abruma al individuo y envilece su esencialidad, su poder. La reunión de los hombres en multitud trasparenta la esencia humana en su plenitud, motivo por el que la observación de la sociedad le resulta a Nietzsche más fructífera que el estudio de los individuos tomados aisladamente. La formación de las multitudes viene causada por la voluntad de poder en la medida en que la debilidad de los individuos implica la creación de un cuerpo gregario, un cuerpo fuerte y robusto. La multitud se origina a causa de las falencias que portan consigo los individuos. Quien se ve abrumado por el sentimiento de responsabilidad tiene que esconderse tras la masa para darle rienda suelta a sus instintos, a su violencia, obliterando con ello todo sentimiento de responsabilidad. La responsabilidad contiene las fuerzas de los individuos, coacciona su voluntad de poder, acorrala a los cuerpos, debilita la propulsión expansiva de los instintos.

Para Nietzsche, el Estado es un medio del que se valen los individuos en vistas a sobrevivir, de hecho le reprocha a Hegel que concibiera al Estado como fin, pues la

\footnotetext{
${ }^{550}$ Friedrich Nietzsche, Fragmentos póstumos. Volumen IV (Madrid: Tecnos, 2008), 607.
} 
estatalidad nietzscheana es un instrumento para la conservación, para la conservación de una mayoría de individuos fracasados. El Estado no tendría sentido si en él no sobreviviera alguno de los hombres que más destacan con respecto a la masa. Los Estados nacieron debido al instinto de supervivencia de los hombres, su desarrollo histórico se polariza en la lucha del egoísmo particular y el egoísmo colectivo; Nietzsche habla de un "torbellino atómico de egoísmo", lo que hace imposible cualquier teleología en la historia de los Estados, estos permanecen siempre igual: como medio de supervivencia para la masa y para los individuos más destacados ${ }^{551}$.

En la tercera intempestiva, Nietzsche afirma que los filósofos de su tiempo no han de ver el mundo según la perspectiva que asegura el Estado, el filósofo ha de contemplar cómo se destruye la cultura, cómo <<las naciones se separan de nuevo, se combaten las unas a las otras y quieren destruirse >>, en este panorama, las <<ciencias, practicadas sin medida alguna y con el más ciego "laisser-faire", se disgregan y disuelven toda su convicción; las clases y las sociedades cultas se ven arrastradas a una grandiosa y desdeñable explotación financiera $>{ }^{552}$. También, Nietzsche sostiene que los hombres que admiten la autoridad del Estado a la hora de filosofar admiten la renuncia a la verdad. El Estado no persigue ningún fin, no tiene verdad, le basta con elevarse por encima de ella, así, el filósofo del Estado siempre le deberá fidelidad a una instancia superior a la verdad. Los filósofos universitarios no son amigos de la verdad pues, antes que la verdad, habrán de justificar y confirmar todo lo que para el Estado es bueno ${ }^{553}$.

También, el pensador de Röcken se opone a los principios que rigen la economía y los principios del comercio; muestra un gran desprecio hacia los procedimientos de los comerciantes:

La clase comerciante: sabe tasar todo sin hacerlo, es decir, entiende de las necesidades de los consumidores, por lo tanto no de las suyas. En esto tiene un esquema para su tipo de cultura: ¡en todas partes demanda y oferta y de acuerdo con ello el valor de las cosas y los hombres! Esto la hace repugnante para mí. ${ }^{554}$

Igualmente, critica a los socialistas por valorar las inclemencias del pueblo más bajo según el punto de vista sentimental de hombres cultos, puesto que $<<\operatorname{los}$ sufrimientos y

\footnotetext{
${ }^{551}$ Cfr. Friedrich Nietzsche, Fragmentos póstumos sobre política (Madrid: Trotta, 2004), 119.

${ }^{552}$ Friedrich Nietzsche, Consideraciones intempestivas (Buenos Aires: Aguilar, 1949), 200.

${ }^{553}$ Cfr. Nietzsche, ob. cit., 245-246.

${ }^{554}$ Friedrich Nietzsche, Fragmentos póstumos sobre política (Madrid: Trotta, 2004), 147.
} 
las privaciones aumentan con el crecimiento de la cultural del individuo. Las capas inferiores son más obtusas; mejorar su situación significa aumentar su capacidad de sufrir $>{ }^{555}$. Los socialistas promueven la oposición a las tradiciones y a las costumbres, una alianza que sin embargo no produce nuevas capacidades. Los socialistas destruyen valores sin construir los suyos propios. La única aportación loable que Nietzsche le reconoce a los socialistas es que <<entretiene a los hombres y ofrece a las capas más bajas una especie de diálogo práctico-filosófico. En tal medida, es una fuente de energía del espíritu>>556.

El hombre ha de despreciar toda forma de vida impersonal, aquella vida propia de capitalistas, funcionarios y otros estamentos sociales. Todo individuo que tiene poder quiere consagrarse, incluso después de la muerte. El propósito de los individuos que detentan el poder es dominar entre las familias, los estamentos, etc.; persiguen afianzar sus instituciones. Esta avidez de pervivencia por parte de los hombres poderosos es para Nietzsche pura vanidad, no viene precedida de sentimiento moral alguno ni de la búsqueda de lo útil ${ }^{557}$. Los hombres superiores derrochan atrevimiento y arrojo, su poder no requiere de ninguna legitimación estatal, los hombres superiores no necesitan esconderse tras el Estado para actuar. Los Estados y sus instituciones nacieron de la impotencia de los soberanos, la razón de ser de los Estados, por tanto, se corresponde más con la impotencia que con la potencia:

El individuo superior se concede todos los derechos que se permite el Estado: matar, destruir, espiar, etc. La cobardía y la mala conciencia de la mayor parte de los soberanos han inventado el Estado y la frase bien public. El hombre justo ha manipulado siempre el bien público como un medio para cualquier meta. ${ }^{558}$

Es posible advertir en el pensamiento de Nietzsche la suposición de que la multitud, el Estado, la masa, son constructos que invisibilizan, desinhiben e indultan a los individuos. El cuerpo multitudinario trasparenta la voluntad de poder porque en la forma de multitud los seres humanos pueden suprimir su individualidad y los factores que la debilitan, para así desatar de forma anónima la fuerza de sus instintos, impulsos, deseos, etc., todos ellos radicados en la corporalidad. El atrevimiento que muestran los hombres tras la corporalidad social apunta directamente a las carencias que Nietzsche

\footnotetext{
555 Nietzsche, ob. cit., 140.

${ }^{556}$ Nietzsche, ob. cit., 141.

${ }^{557}$ Cfr. Nietzsche, ob. cit., 151.

${ }^{558}$ Nietzsche, ob. cit., 168.
} 
destaca en el sujeto moderno, ese sujeto que supuestamente tiende a individualizarse, a emanciparse, a pensar por sí mismo, pero que ha perdido el rastro de su condición corporal. La figura del sujeto moderno, que hizo sus primeras apariciones en las corrientes de pensamiento del siglo XVII, es cuestionada por la filosofía nietzscheana, donde se escudriñan los puntos débiles de este sujeto y se pone en evidencia su fragilidad. El sujeto moderno es aquel tipo de hombre que termina haciendo en sociedad aquello que le es restringido por sus ideales, la mezquindad de este hombre le conduciría a entregar su cuerpo a la sociedad para pasar inadvertido en las acciones que aparentemente juzga como incorrectas, pero que realiza si se ve con el poder necesario para hacerlas, esto es, respaldado por la multitud o resguardado tras ella. La masa social alberga los cuerpos e impersonaliza las acciones de los sujetos; es en esta masividad impersonal donde el individuo encuentra el ámbito de camuflaje de su cuerpo, por eso los hombres hacen en sociedad aquello que no se atreven a hacer como individuos, porque sus cuerpos se encuentran parcialmente ocultos y protegidos en el tropel ${ }^{559}$.

Nietzsche supone que el ser humano individualizado es cobarde, que falsea su verdadero modo de ser, que el sujeto racional y responsable, el hombre cívico y libre, no es más que una constitución idílica del sujeto moderno, luego, una mera representación y nada más que una apariencia. Este problema del "individuo aparente" se encuentra planteado en la novela de Herbert George Wells El hombre invisible, novela que plantea el problema de la invisibilidad como impunidad. El hombre invisible se centra en describir cómo un científico llamado Griffin, que ha conseguido hacer su cuerpo invisible mediante un experimento, utiliza su invisibilidad para cometer todo tipo de atropellos y actos perversos. Al inicio de la novela de Wells se muestra cómo la invisibilidad no le permite al hombre invisible interactuar normalmente con otros individuos, pues además de temer ser tomado por un monstruo si alguien llegare a descubrir su secreto, este siempre contempla la oportunidad de aprovechar la ventaja que le otorga la invisibilidad frente a los otros. El hombre invisible decide ocultar su

\footnotetext{
${ }^{559}$ Ya en el drama municipal del siglo XVII de Fuente Ovejuna podía verse insinuada la idea de que la masividad como identidad política oculta la responsabilidad personal de las acciones individuales. Pareciera que la multitud adquiría una connotación positiva y "salvífica" en el drama lopesco, siempre viéndolo -como fue visto- desde un prisma moderno. La imagen de un cuerpo social con una identidad política que parapeta a cada uno de los habitantes frente a la justicia, resultó ser en el argumento del drama una estrategia efectiva para que cada uno de los habitantes de Fuente Ovejuna se salvara, eludiendo la responsabilidad personal ante la sublevación y el crimen. La multitud, en este caso, brindaba una suerte de refugio para el individuo; en el caso de la filosofía nietzscheana la multitud cumple funciones similares, pero la imagen que el autor alemán le atribuye envuelve una forma de poder que surge de la cobardía de los individuos.
} 
cuerpo tras todo tipo de atuendos: cubre su cabeza con unas vendas, lleva peluca, se pone unas gafas azul oscuro, un bigote postizo, nariz postiza y se asegura de llevar puestos siempre los guantes. A pesar de que con esa apariencia no podía evitar llamar la atención, al menos lograba que nadie descubriera su secreto más importante ${ }^{560}$. Al comienzo de la novela, el hombre invisible llega a Iping, un pueblo inglés pequeño y tranquilo, cuando acude a la hospedería de la señora Hall, tiene que poner todos los medios para disimular su invisibilidad. Griffin se ve forzado a presentarse como un ciudadano más, tratar de simular que es un hombre corriente. Pero durante las noches va cometiendo una serie de robos $\mathrm{y}$, una vez los habitantes de Iping descubren sorpresivamente su invisibilidad, tiene que escapar del pueblo para continuar su periplo delictivo $^{561}$.

En más de un pasaje de la novela, Wells relaciona la invisibilidad con el poder: uno de los personajes afirma que <<un hombre invisible es un hombre muy poderoso>>562, en otro pasaje el propio hombre invisible dice que cuando pensaba en las ventajas de la invisibilidad terminó por comprender la importancia de gozar de una total impunidad; y en otra ocasión dice que pretende instaurar un Reinado del Terror para dominar a los hombres ${ }^{563}$. El autor de la novela cuenta cómo Griffin se atreve incluso a cometer todo tipo de fechorías debido a que con su cuerpo invisible puede mantener a salvo su identidad y, por tanto, tiene garantizada la impunidad. La invisibilidad desata "la bestia" que portaba el científico, lo que narra Wells en su novela se puede interpretar como una metáfora acerca de esa violencia congénita subyacente al género humano que se pone de manifiesto cuando el individuo tiene la sensación de ser impune y de contar con un poder que puede utilizar a placer. El cuerpo, desde la óptica de esta novela, es una suerte de carga para contener los impulsos más cruentos de los hombres y guardar el orden moral en la sociedad, puesto que la corporalidad, al estar expuesta a la vista de los otros, delata al individuo que realiza actos delictivos y moralmente reprobables. Pero, si cupiera algún modo factible de invisibilizar el cuerpo, cabría también la posibilidad de que los seres humanos dieran rienda suelta a su crueldad. La invisibilidad, en la medida en que oculta la identidad, se revela como una fuente de poder pues otorga inmunidad. Lo mismo sucede con el individuo que camufla su cuerpo entre la multitud o que se

\footnotetext{
${ }^{560}$ Cfr. Herbert George Wells, El hombre invisible (Barcelona: Olmak Trade, 2016), 7-22.

${ }^{561}$ Cfr. Wells, ob. cit., 36-78.

${ }^{562}$ Wells, ob. cit., 51.

${ }^{563}$ Cfr. Wells, ob. cit., 106 y 129.
} 
justifica tras el poder del Estado, que se vuelve parte del cuerpo de la masa para hacerse inidentificable, para protegerse mediante el anonimato.

La responsabilidad de las acciones humanas se trasparenta en los cuerpos de los individuos porque el cuerpo delata, hace identificables al autor o autores de algún tipo de acto o actos, así, la corporalidad expone a los causantes de estos actos; el cuerpo se hace visible ante la mirada pública y, con él, se visibiliza también la identidad de la persona; el cuerpo responsabiliza. Comenta Paul Virilio que fue precisamente a finales del siglo XIX cuanto en occidente comenzaron a darse las primeras técnicas policiales de identificación por medio de las huellas dactilares, afirma que la dactiloscopia marcó la decadencia de las prácticas basadas en los relatos, testimonios y descripciones, puesto que la mirada humana quedó subrogada por la imagen visual del cuerpo como forma más precisa de identificación de los culpables $^{564}$. Las representaciones subjetivas habrían comenzado a desprender desconfianza, ya que se comenzó a considerar que las imágenes procedentes del discurso de las personas no aportaban un testimonio objetivo al estar henchidas de imprecisiones y desvaríos. Virilo dice que pese a $<<$ la utilidad de los confidentes, de los informes circunstanciales de los inspectores, la mirada humana ya no es signo, ya no organiza la búsqueda de la verdad, la formación de su imagen, en este proceso de identificación de individuos $\gg{ }^{565}$. El cuerpo pasa a ocupar el plano de la evidencia, las técnicas destinadas a localizar al culpable tienen en lo corporal su objeto de verificación, ya que el cuerpo es necesariamente el agente material de los delitos. La subjetividad queda así desplazada, resulta menos válida, porque la mirada subjetiva arrastra consigo defectos en el relato de los hechos susceptibles de generar confusión lo que invita a desconfiar del sujeto. Es el cuerpo el que refleja la evidencia de un acto, el que delata la identidad del culpable y el que incrimina al responsable; el testimonio de la verdad recae sobre el cuerpo. La culpabilidad objetiva se localiza, entonces, en el cuerpo que actúa.

En la Genealogía de la moral, Nietzsche aborda de manera laxa el asunto de la culpa, entendida esta también como "mala conciencia". Asevera que el término culpa equivale a la tenencia de deudas. Culpa es "deberle algo a alguien", cuyo pago resulta canjeable solo a través de sufrimiento. El acreedor posee un privilegio, un derecho de señores, el de causar dolor sin posibilidad de contrapartida. El acreedor tiene la potestad de hacer

\footnotetext{
${ }^{564}$ Cfr. Paul Virilio, La máquina de visión (Madrid: Cátedra, 1998), 58.

${ }^{565}$ Virilio, ob. cit., 59.
} 
sufrir al deudor o, por lo menos, de experimentar el regocijo y la satisfacción de ver maltratado a su deudor ${ }^{566}$. La cuestión principal que pone de relieve Nietzsche es que el pago compensatorio de la culpa permite darle rienda suelta a la crueldad del acreedor en lo concerniente al acto punitivo. Así, el sentimiento de la responsabilidad o de la culpa tiene su origen en una relación deudor-acreedor, en la que se halla una beligerancia y una dirección asimétrica de la fuerza, pues una de las partes ejerce el daño mientras la otra lo recibe.

En esta esfera, esto es, en el derecho de obligaciones es donde el mundo de los conceptos morales de "culpa", "conciencia", "deber", "deber sagrado" tiene su cuna de nacimiento, -su comienzo, como el de todo lo que hay de grande en este mundo, se ha visto regado profunda y profusamente con sangre (...). Es también aquí donde por primera vez se dio el engarce perturbador de esa pareja de ideas que tal vez sean ya inseparables, "culpa [Schuld] y sufrimiento". Preguntémonos una vez más: ¿en qué medida el sufrimiento puede ser una compensación de las "deudas" [Schulden]? En la medida en que el hacer sufrir produce bienestar en grado sumo, en la medida en que el perjudicado trocaba el daño, así como el displacer asociado a este, por un contra-goce extraordinario: el hacer sufrir, -una auténtica fiesta, algo que, como decía, tenía tanto más valor cuanto más contrastaba con el rango y la posición social del acreedor. ${ }^{567}$

El pensador de Röcken no juzga desde un punto de vista moral la cruel tendencia festiva de los seres humanos en las ceremonias de castigo, donde son infligidos crueles daños corporales. Nietzsche comenta que la humanidad primigenia, la que creó estas relaciones contractuales, y los deudores, con el fin de generar confianza en los acreedores, ponían alguno de sus bienes como garantía de cumplimiento. Uno de los bienes que, según Nietzsche, los deudores ofrecían como garantía era el cuerpo propio. Cuando la promesa no se consumaba <<el acreedor podía infligir en el cuerpo del deudor todo tipo de vilezas y tormentos, por ejemplo, cortar de él tanto como pareciera adecuado a la cuantía de la deuda $>{ }^{568}$, en consecuencia, la corporalidad se habría convertido en objeto de operaciones compensatorias para el acreedor y en el objeto de aval para el deudor. De modo que el cuerpo delata una falta a través de sus llagas, pues estas, ponían en evidencia el incumplimiento de una deuda. El filósofo sajón está introduciendo al cuerpo en su reflexión moral en cuanto vértice receptor del daño

\footnotetext{
${ }^{566}$ Cfr. Friedrich Nietzsche, Obras completas. Volumen IV (Madrid: Tecnos, 2016), 490.

${ }^{567}$ Nietzsche, ob. cit., 490.

${ }^{568}$ Nietzsche, ob. cit., 489.
} 
compensatorio, puesto que, en último término, el castigo sobre el culpable no puede ir dirigido a otro lugar más que a su corporalidad, pues allí es donde se despliegan las prácticas punitivas, ya que en el soma reside la causa del dolor físico como vértice de sufrimiento.

\subsubsection{LA SOCIEDAD COMO INTERACCIÓN DE FUERZAS}

En el tercer aforismo del prólogo a Así habló Zaratustra Nietzsche cuenta -haciendo de Zaratustra- cómo hubo un tiempo en el que el alma desconfiaba del cuerpo, una desconfianza elevada a la sacralidad pero que no era de gran enjundia para la vida, ya que esa alma quería un cuerpo feo, famélico, enfermo y débil. El alma aspiraba a liberarse del cuerpo y de la tierra, despreciaba todo lo corporal, ahí residía su crueldad con respecto a la vida, la crueldad de un concepto de alma que no puede traer más que miseria $^{569}$. Nietzsche no concibe ningún tipo de desdoblamiento diferencial entre lo corporal y supuestas sustancias incorpóreas, el Yo, el sí mismo, reside en la corporalidad. En un pasaje de Así habló Zaratustra titulado "De los despreciadores del cuerpo" el autor escribe:

$<<$ Detrás de tus pensamientos y sentimientos, hermano mío, hay un soberano poderoso, un sabio desconocido -que se llama el sí mismo. Vive en tu cuerpo, es tu cuerpo $>>^{570}$.

La imagen nietzscheana de la corporalidad, la noción simbólica mediante la que el autor concibe el debilitamiento del cuerpo a raíz de una relación ficticia con un alma desprendida de él, es consecuentemente trasladable a la visión de la sociedad como un organismo vivo cuyos movimientos tienden a desplegar un poder a través del que este organismo logra su supervivencia. Nietzsche se opone a la máxima de economistas y liberales que apelaban al egoísmo privado como fundamento del orden social. Para el filósofo de Röcken el egoísmo individual no es el principio de la sociedad, sino que la sociedad tiene un origen primitivo altruista. La consideración de lo social dentro de la filosofía nietzscheana descansa en una concepción fisiológica, por ello

la célula es más un miembro que un individuo; este se hace continuamente más complejo en el curso de su desarrollo, continuamente se transforma en un grupo de miembros, en una sociedad. El hombre libre es un Estado y una sociedad de individuos. La evolución

\footnotetext{
${ }^{569}$ Cfr. Nietzsche, ob. cit., 73.

${ }^{570}$ Nietzsche, ob. cit., 89.
} 
de los animales de rebaño y de las plantas sociales es completamente distinta que la de aquellos que viven como individuos. Estos, si no perecen, llegan a ser una sociedad; se desarrollan un gran número de campos de actividades y también muchos combates de los impulsos por la alimentación, el espacio y el tiempo. ${ }^{571}$

La de Nietzsche no es una concepción de la sociedad expuesta a la idea de un finalismo. Podría fácilmente advertirse que el pensador en cuestión, al menos, comparte una visión holística con Hegel, al ver en el individuo un miembro de un organismo y no una totalidad atómica en sí mismo, pero, la diferencia principal entre ambos autores recae en que Nietzsche no contempló la sociedad más que como un medio de supervivencia que, cabe recordar, en el caso de los seres humanos constituye el Estado como un instrumento para lograr este fin vital. Igualmente -para quien estuviera tentado de ver en la concepción nietzscheana de la sociedad un interés individual al estilo de los liberales-, cabe matizar que en Nietzsche la individualidad se fortalece y se hace con un mayor grado de independencia en la medida en que entra en un juego de fuerzas que tiene lugar en la sociedad, precisamente dentro de esta interacción el individuo puede hacerse con un poder que le permite sobresalir, aspirar $<<$ a la mayor independencia relativa de sus fuerzas individuales, al combate más grande dentro de unas proporciones: es el ser más discordante, el más variable y el más longevo, el que desea y se alimenta con prodigalidad, el que se excreta y se renueva $>>{ }^{572}$. Nietzsche no estima la individualidad por el interés individual, sino por el poder del individuo, es decir, más que estimar la destreza del individuo en cuanto a los cálculos racionales que este hace a su favor, prefiere valorarlo en cuanto a las cosas que puede hacer.

Lo político y los conceptos que sufragan a la política se hallan inmersos en una lucha por el poder. Nietzsche encuentra que el poder político es deseado por los hombres, bien por las ventajas que procura, bien porque quieren extender sus mismas desventajas y sacrificios a todos, o bien porque no quieren depender del poder adquirido por otros. Este tipo de poder no es más que "poder político", para Nietzsche, un medio de la "voluntad de poder"573. La voluntad de poder es como un protoplasma que integra algo

\footnotetext{
${ }^{571}$ Friedrich Nietzsche, Fragmentos póstumos sobre política (Madrid: Trotta, 2004), 152.

572 Nietzsche, ob. cit., 152.

573 Nietzsche dice literalmente: <<el poder en la "voluntad de poder" es solo un medio: el protoplasma que se apropia de algo y lo integra al organismo, que por lo tanto se fortalece y ejerce poder para fortalecerse>>, Fragmentos póstumos. Volumen IV (Madrid: Tecnos, 2008), 280. Se supone que el uso entrecomillado del término "voluntad de poder" aparece así en vistas a diferenciarlo de lo que Nietzsche considera el poder como medio. Dado que la frase anteriormente citada pertenece al título "sobre el 'maquiavelismo' del poder (maquiavelismo INCONSCIENTE)", donde Nietzsche ofrece una explicación
} 
para hacerse más fuerte, de forma que las diversas formas de poder político que deambulan en torno a las fuerzas que interactúan en la sociedad hacen las veces de materia para la voluntad de poder. <<En qué medida el comportamiento del protoplasma al apropiarse e integrar al organismo da la clave para el comportamiento químico de aquellos elementos entre sí (lucha y fijación del poder) >> ${ }^{574}$.

Conviene acudir al estudio sobre el tema de la corporalidad en Nietzsche realizado por el profesor José Jara y culminado en un libro titulado Nietzsche, un pensador póstumo, que lleva por subtítulo El cuerpo como centro de gravedad, para arrojar luz sobre algunos asuntos acerca de la sociedad y la fuerza corporal en el pensamiento nietzscheano. El esquema general de la obra ronda la centralidad que la filosofía nietzscheana le otorga al cuerpo, de hecho el profesor Jara considera que Nietzsche es un pensador intempestivo precisamente porque pretende devolverle <<al cuerpo su condición de ser el "centro de gravedad" del hombre $>>575$. La condición corpórea $-y$ centrada en la corporalidad- de los seres humanos condujo a Nietzsche, según Jara, a comprender la organización social de acuerdo a las coordenadas señaladas por la correlación de fuerzas en que se encuentran inmersos los cuerpos. Entonces, es imposible sortear la pugna fáctica de las fuerzas corporales en lo relativo a la formación de un gobierno, lo que implicaría tener que acudir a la vida (corporal) como punto de proyección de los movimientos en la sociedad, desdeñando la posibilidad de que haya un ordenamiento teleológico oculto ${ }^{576}$. La centralidad del cuerpo impele la voluntad de poder en cuanto que pujanza de una fuerza corporal hacia otra por alcanzar la hegemonía, en palabras del profesor Jara:

El cuerpo, como ámbito humano específico en que sucede una de las formas del acontecer, cabe considerarlo así como un campo de relaciones de fuerzas que pueden exhibir distintos grados, y en donde la lucha es una de sus concreciones. Por otra parte, en muchísimos lugares señala Nietzsche que esas fuerzas son los elementos configuradores

sobre las diferentes razones por las que individuos y grupos de individuos pretenden y ambicionan estatus y adquisiciones políticas. Ha sido pertinente añadirle a este poder instrumental del que habla el autor el término "político", para buscar una mayor concreción y distinción entre el poder como medio y "la voluntad de poder". Conviene matizar que Nietzsche aborda toda una serie de circunstancias propias de las relaciones, así como características y capacidades de individuos, que involucran formas de organizarse en la sociedad para conseguir aquel poder instrumental que propiamente se corresponde con el "poder político": cfr. Fragmentos póstumos. Volumen IV, 279-280. El poder político es aquel a través del cual se procesa la "voluntad de poder", por tanto, su medio.

${ }^{574}$ Friedrich Nietzsche, Fragmentos póstumos. Volumen IV (Madrid: Tecnos, 2008), 280.

575 José Jara, Nietzsche, un pensador póstumo (Barcelona: Anthropos, 1998), 53.

${ }^{576}$ Cfr. Jara, ob. cit., 322-323. 
de la voluntad, aun cuando a la vez, ella misma, al actuar, se manifieste como una fuerza; es decir, en este caso, como aquella que se sobrepuso a otros con las que pudo estar en relación de lucha. ${ }^{577}$

La configuración de fuerzas por la que se conformarían las relaciones humanas, según interpreta Jara, también son partes constitutivas de la composición del individuo, puesto que en el interior de este se da una pluralidad variable de fuerzas. La subjetividad del individuo es causada por la correlación de fuerzas en que se halla inmerso como miembro de una sociedad, no hay lugar para una subjetividad apartada o escindida de este juego relacional-social. Además, Jara señala que, si bien, hay una igualdad primigenia en la confrontación de fuerzas, una vez definidos los resultados de esta lucha, entra en juego una desigualdad en la composición jerárquica de la dominación, dominación que no es exclusiva ya de la sociedad sino de la propia comandancia subyacente al individuo mismo. Por tanto, Nietzsche habría virado al cuerpo para rastrear el fenómeno del dominio, sumiendo el pensar y la conciencia al peso que ejerce la corporalidad humana dentro de las correlaciones que la rodean ${ }^{578}$. Se podría decir que el cuerpo, y no el individuo pensante, guarda la sintomatología por la que se dilucida la esencia humana entendida bajo la noción de voluntad de poder.

A propósito de la interpretación de sesgo político realizada por Jara alrededor de la noción de corporalidad en Nietzsche, cabe también hacer referencia a la lectura que Deleuze realizó acerca de la filosofía del autor sajón en Nietzsche y la filosofía, acerca, precisamente, de la noción de fuerza. El pensador francés afirma:

El concepto de fuerza es pues, en Nietzsche, el de una fuerza relacionada con otra fuerza: bajo este aspecto, la fuerza se llama una voluntad. La voluntad (voluntad de poder) es el elemento diferencial de la fuerza. De ello resulta una nueva concepción de la filosofía de la voluntad; ya que la voluntad no se ejerce misteriosamente sobre músculos o sobre nervios, y menos aún sobre una materia en general, sino que, necesariamente, se ejerce sobre otra voluntad. El auténtico problema no se halla en la relación del querer con lo involuntario, sino en la relación entre una voluntad que ordena y una voluntad que obedece, y que obedece más o menos. ${ }^{579}$

La voluntad, entonces, no sería equiparable al término "alma" o al término "ley natural", pues se podría decir, a raíz de las interpretaciones de Deleuze, que para

\footnotetext{
577 Jara, ob. cit., 338.

${ }^{578}$ Cfr. Jara, ob. cit., 338-339.

${ }^{579}$ Gilles Deleuze, Nietzsche y la filosofía (Barcelona: Anagrama, 1998), 15
} 
Nietzsche la voluntad no constituye una particularidad sino una relación de fuerzas. La voluntad estaría incrustada en la vida, y más que ser una parte o complemento inherente derivado del cuerpo se trataría de una fuerza contra otra fuerza, constituyéndose de esta manera una pluralidad de fuerzas que entran en contacto en un contexto vital. Ahora bien, podría llevar a confusión que Deleuze considere que la filosofía de la voluntad de Nietzsche no contemple el ejercicio de la voluntad sobre entidades corpóreas, pero, más bien, el pensador francés, a lo que se estaría refiriendo es a que la voluntad tiene que ser la fuerza de algo vivo y no un brote de animación al estilo de la concepción tradicional de alma. Puesto que necesariamente toda forma de vida requiere de una concreción biológica, ya que no se ha visto todavía un ser viviente que pueda prescindir de su cuerpo por simple y mínimo que sea, lo que estaría viniendo a decir Deleuze es que la voluntad consiste en una agencia viva y no en una exterioridad incorpórea. La voluntad reside en la inmanencia de la fuerza corporal, en la inmanencia de un cuerpo vivo y no de entidades orgánicas que alcanzan la vida por una suerte de sustancia extrínseca a su corporalidad. De este modo, la voluntad expande o retrae sus fuerzas en la medida en que coexiste con otras voluntades. La voluntad colisiona con otra u otras voluntades y, en medio de esta colisión, los cuerpos harían las veces tanto de punto agente como paciente en cuanto potencia viviente portadora de poder.

Deleuze interpreta que en Nietzsche la voluntad no actúa sobre una corporalidad sino que el cuerpo recoge la voluntad como totalidad de su fuerza, una totalidad que se vuelve parcialidad dentro de la contienda entre las fuerzas. Este escenario predispondría el actuar de los cuerpos, de modo que <<cualquier fuerza se halla en relación con otras para obedecer o para mandar. Lo que define a un cuerpo es esta relación entre fuerzas dominantes y fuerzas dominadas $>{ }^{580}$. Nuevamente se aprecia cómo en Nietzsche el cuerpo quedaría definido por la vida $\mathrm{y}$, a su vez, la vida solo puede ser entendida en relación con la fuerza corporal que se derrocha dentro de una contienda de voluntades, dentro de un espacio de relaciones sociales. Esto implicaría comprender que la voluntad de poder no es una especie de dote recibida por un cuerpo pasivo sino, más bien, una natural predisposición de la corporalidad a superarse con respecto a otras corporalidades que tienen el mismo afán de superación. La voluntad de poder está en todos los seres vivos y sin excepción en todos los sujetos y grupos humanos. Deleuze interpreta, por otra parte, que esta conjugación pugnante de las fuerzas opera sobre los cuerpos tanto al

${ }^{580}$ Delueze, ob. cit., 60. 
nivel del despliegue de sus fuerzas inmanentes como en la recepción de fuerzas provenientes de otros cuerpos. El cuerpo guardaría dentro de sí una cantidad determinada de fuerzas activas y fuerzas reactivas que se dejan ver en la confrontación por el dominio; por eso dice Deleuze que el cuerpo <<es un fenómeno múltiple, al estar compuesto por una pluralidad de fuerzas irreductibles $>>581$.

Cabe puntualizar un aspecto relacionado con la modalidad literaria de la filosofía nietzscheana o, lo que es lo mismo, con la expresión de su filosofar: el lenguaje de Nietzsche no cae en sutilezas metafísicas ni científicas a la hora de hacer distinciones terminológicas entre la voluntad, el poder y el cuerpo, ya que estos términos guardan una estrecha relación entre sí, de tal forma que, uno por uno, no significarían nada. El marco de referencia último al que Nietzsche se remonta para dotar de sentido el tridente terminológico voluntad-poder-cuerpo es la vida. La vida entendida como el arrojo de fuerza y superación en cuanto que demostración del potencial que subyace a la corporalidad, una comprensión de la vida que lleva en toda su extensión la voluntad de poder como término con que explicar el fenómeno de lo vital desde el punto de vista de su accionarse, desde la corporalidad tomada en su plenitud, no como identidad sustancial y sustantivada que añora encontrar el sentido de su existencia al margen de las vicisitudes y fortalezas del cuerpo - operación del cristianismo y de la modernidad-.

El término cuerpo en Nietzsche va asociado a su comprensión de la vida como voluntad de poder. El cuerpo es voluntad de poder solo en la medida en que la corporalidad viviente ejerce una presión, una fuerza. Nietzsche no es un "pensador forense" del cuerpo, no lo toma como sustancia, o como una entidad comandada por inteligibilidades o voluntades suprasensibles, como si lo corpóreo fuera nada más que una cosa inanimada en ausencia de un principio motriz inteligible. De este modo, Nietzsche rompe con la imagen de ente vinculada a la corporalidad humana, su pensamiento hace pedazos esa significación que una parte de la tradición metafísica moderna le había atribuido al cuerpo, pues todo lo corporal tiene que ir arraigado inevitablemente en los vaivenes de la vida y, por ende, a la creación que la voluntad de poder hace del devenir. Al pretender dilucidar los movimientos que tienen lugar en la

${ }^{581}$ Deleuze, ob. cit., 61. 
pugna por el poder desde la posición central que ocupa el cuerpo en el desarrollo de las relaciones humanas, Nietzsche se convierte en el primer genealólogo de la voluntad ${ }^{582}$.

\subsubsection{MARX Y NIETZSCHE EN LAS ENTRAÑAS DEL PODER}

El pensador sociológico Bryan Turner, en El cuerpo y la sociedad, plantea una sugerente comparativa entre las filosofías de Marx y de Nietzsche en relación con la corporalidad y el carácter político de la sociedad. Turner asegura que en el pensamiento marxiano tiene lugar una ontología de la sociedad y una condición social humana que perdura ante los constantes cambios que los hombres producen en la naturaleza a través del trabajo ${ }^{583}$. En un principio, Turner puntualiza que $<<$ si bien Nietzsche y Marx compartieron algunos supuestos, las implicaciones de sus puntos de vista acerca del conocimiento son evidentemente distintos $>{ }^{584}$. Más adelante, el autor sostiene que la consideración nietzscheana del saber como un elemento exclusivamente práctico <<suministra entonces un vínculo con Marx, quien, en la Ideología alemana, definió al lenguaje como "conciencia práctica" $>>585$. Los sujetos humanos están incrustados en el entramado que forman las relaciones sociales, que se plasma en el conocimiento y que, previamente, había brotado del lenguaje. Lenguaje y conocimiento son el producto de relaciones sociales, cuyo trasfondo es la vida en su connotación material.

En los Manuscritos de economía y filosofía Marx señala que toda la realidad del hombre se fundamenta en la producción, una actividad social. La propiedad privada sensible e inmediatamente apropiable no es más que la expresión física -la manifestación corporificada- de unas relaciones dadas en el seno de la sociedad. Para Marx, todas las transformaciones y revoluciones que se han dado en la historia de la humanidad corresponden a movimientos de la sociedad en torno a la propiedad privada, de forma que la superación de este tipo de propiedad devolvería al ser humano a su existencia originaria, ergo, a su ser social primigenio, en tanto en cuanto la superación

\footnotetext{
582 Atribuirle a Nietzsche el nombre de "genealólogo de la voluntad" viene inspirado en la interpretación que Deleuze hace tanto de su genealogía como de su noción de voluntad. Dice el expositor francés que $<<$ Nietzsche crea el nuevo concepto de genealogía. El filósofo es un genealólogo, no un juez de tribunal a la manera de Kant, ni un mecánico al modo utilitarista〉> Nietzsche y la filosofía (Barcelona: Anagrama, 1998), 9. Además, si a ojos de Deleuze el concepto de voluntad nietzscheano ha de ser entendido dentro de la relación que guardan entre sí dos voluntades en un entorno vital donde está implicado el cuerpo, entonces, es lícito suponer que la voluntad en términos conceptuales sea presentada a tenor del pensar genealógico.

${ }^{583}$ Cfr. Bryan Turner, El cuerpo y la sociedad (México D.F: Fondo de Cultura Económica, 1989), 288.

${ }^{584}$ Turner, ob. cit., 289-290.

585 Turner, ob. cit., 293.
} 
de la propiedad privada implica un movimiento regresivo que anula por completo los elementos enajenantes de la vida humana: Religión, familia, Estado, moral, etc. ${ }^{586}$. Por tanto, el carácter social humano se remonta a un plexo original ontológicamente inalterable. La condición social del hombre persiste incluso en las actividades que realizan los individuos aisladamente, como sucede, por ejemplo, durante la realización de actividades científicas, en las que el científico no puede prescindir ni del idioma en que piensa ni de la finalidad social de sus resultados ${ }^{587}$. La subjetividad emana de las relaciones sociales, las particularidades de los individuos no constituyen al hombre como sujeto, sino $<<$ la existencia subjetiva de la sociedad pensada y sentida para sí, del mismo modo que también en la realidad existe [el hombre] como intuición y goce de la existencia social y como una totalidad de exteriorización vital humana > ${ }^{588}$.

Mientras se hace notorio cómo para Marx el trabajo es el proceso material por excelencia que corporifica los contenidos intercambiados en las relaciones sociales, dotándoles de una (super)estructura social cambiante a tenor de los avatares de las condiciones productivas, en Nietzsche, los agentes que le atribuyen una corporeidad al contenido inserto en las relaciones humanas no se corresponden exactamente con una actividad concreta.

Nietzsche encuentra que toda actividad trae consigo creación, así, los artistas serían los que mejor simbolizan esas acciones creadoras de la voluntad de poder. Ya en el Nietzsche de El nacimiento de la tragedia se puede localizar un pasaje en el que la música es identificada con la voluntad que mueve el mundo en su conjunto (muy influido por Schopenhauer ${ }^{589}$ ): según el filósofo de Röcken podría llamarse <<al mundo tanto música corporalizada como voluntad corporalizada $>>^{590}$, puesto que la música puede ocupar el trasfondo de diferentes manifestaciones artísticas y situaciones que se suceden en la vida. La música que acompaña a la poesía deriva en canto, la música tiene un poder que mueve al mundo y se corporifica en los diferentes escenarios de la vida, es un lenguaje universal. A medida que el pensamiento nietzscheano fue evolucionando y

\footnotetext{
${ }^{586}$ Cfr. Karl Marx, Manuscritos de economía y filosofía (Madrid: Alianza Editorial, 2013), 174-175.

587 Cfr. Marx, ob. cit., 177.

${ }^{588}$ Marx, ob. cit., 178.

${ }^{589}$ Nietzsche afirma que <<siguiendo la doctrina de Schopenhauer nosotros concebimos la música como el lenguaje inmediato de la voluntad y sentimos incitada nuestra fantasía a dar forma a aquel mundo de espíritus que nos habla, mundo invisible y, sin embargo, tan vivamente agitado, y a corporeizárnoslo en un ejemplo análogo>>, El nacimiento de la tragedia (Madrid: Alianza, 2000), 143.

${ }^{590}$ Friedrich Nietzsche, El nacimiento de la tragedia (Madrid: Alianza, 2000), 142.
} 
alejándose de la inspiración de Schopenhauer y Wagner, el autor explora otras conexiones de la voluntad con el mundo, la concepción de un anclaje esencial de carácter ontologicista iba desvirtuándose a favor de una idea más versátil y controvertida de las relaciones que corporifican la sociedad. A este respecto, Clément Rosset encuentra que el pensamiento de Nietzsche no da pie a recurrir a otro mundo, ni siquiera un mundo musical, puesto que lo <<decisivo en la música es que da fe de este mundo: palabra tanto más importante por cuanto procede resueltamente de aquí abajo $>{ }^{591}$. Tanto la música como la voluntad proceden de las entrañas de los cuerpos, ambas extienden y expresan formas de vida.

Persiste en Nietzsche la consideración de que las manifestaciones humanas son creaciones corporificadas de la voluntad, y precisamente porque pueden corporificarse, también tienen capacidad para envolver la vida y retirarla hacia su negación. Como dice en la Ciencia jovial:

En conclusión: la fuerza del conocimiento no reside en su grado de verdad, sino en su antigüedad, en su hacerse cuerpo, en su carácter de condición para la vida. Cuando la vida y el conocimiento parecieron entrar en contradicción, nunca se llegó a luchar seriamente; la negación y la duda eran consideradas allí como locura. ${ }^{592}$

La ciencia moderna vendría marcada por esa rendición de los hombres ante las contradicciones que el conocimiento contrajo con la vida, de tal manera que el conocimiento acabó siguiendo su propia senda, una senda enfermiza y contraria a las necesidades y exigencias vitales. Nietzsche recurre a un ejemplo protagonizado por la música para ilustrar algunas de las incongruencias y carencias que encuentra en el mecanicismo de la ciencia moderna:

¡Pero un mundo esencialmente mecánico sería un mundo esencialmente sin sentido! Supongamos que se aprecie el valor de una música de acuerdo a cuanto de ella pueda ser contado, calculado, traducido a fórmulas - ¡cuán absurda sería una apreciación <<científica〉> de la música de ese tipo! ¿Qué se habría comprendido, entendido, conocido de ella! ¡Nada, precisamente nada de lo que en ella es propiamente $<<$ música $>>$ !... 593

\footnotetext{
${ }^{591}$ Clément Rosset, La fuerza mayor (Madrid: Acuarela Editorial, 2000), 64.

${ }^{592}$ Friedrich Nietzsche, La ciencia jovial <<la gaya scienza 〉> (Valparaíso: Universidad de Valparaíso Ediciones, 2013), 169.

${ }^{593}$ Nietzsche, ob. cit., 319.
} 
La ciencia moderna, mediante su lenguaje y su simbología, no explica los contenidos esenciales de la vida, no es capaz de traslucir todas las intensidades de las fuerzas correlacionadas en la naturaleza y en la vida humana. La insaciable ansia de verdad de los hombres es un impulso creativo y artístico; precisamente, en Sobre verdad y mentira en sentido extramoral, Nietzsche afirma que el lenguaje compromete a los individuos entre sí, lo que configura la verdad como un poder que le arroja sentido a esos símbolos creados, lo que trae consigo la desaparición de la intuición en pro de las abstracciones simbólicas del lenguaje $\mathrm{e}^{594}$. La palabra articula un poderío en la medida en que surge de la propia voluntad de poder. El poder está adscrito a la respetabilidad que los hombres se infunden a sí mismos cuando hacen coincidir las cosas o fenómenos con las propiedades que les atribuyen mediante el lenguaje, de ahí que el lenguaje sea una forma de poder social ${ }^{595}$.

La esencialidad del lenguaje no residiría en la semántica de las palabras ni en la sintaxis de los discursos, tampoco en la coherencia lógica de los argumentos, más bien, la esencialidad del lenguaje tiene un origen político pues su procedencia se remonta a la actividad de la voluntad de poder. Igual sucedería con el estudio de la música y con otras actividades, ocurre lo mismo también con las cosas que investiga la ciencia, que trata de apartar y desconocer la simiente de poder tras el conocimiento y la verdad. Nietzsche equipara el lenguaje al arte, de tal manera que todas las connotaciones creativas artísticas son simultáneas e idénticas a las actividades expresivas del lenguaje. Para el autor, el lenguaje es un impulso humano constructor de metáforas, metáforas que entrañan un poder y que solo pueden proliferar en la vida social, por lo que

Ese impulso fundamental del hombre del que no se puede prescindir ni un solo instante, pues si así se hiciese se prescindiría del hombre mismo, no queda en verdad sujeto y apenas sí domado por el hecho de que con sus evanescentes productos, los conceptos, resulta construido un nuevo mundo regular y rígido que le sirve de fortaleza. ${ }^{596}$

Ese mundo "regular y rígido", esa "fortaleza" del sujeto, emana de la corporalidad social y política que subyace a las relaciones humanas intermediadas por la acción creativa del lenguaje.

\footnotetext{
${ }^{594} \mathrm{Cfr}$. Friedrich Nietzsche, Sobre verdad y mentira en sentido extramoral y otros fragmentos de filosofía del conocimiento (Madrid: Tecnos, 2012), 28-29.

${ }^{595}$ Cfr. Nietzsche, ob. cit., 33.

${ }^{596}$ Nietzsche, ob. cit., 34.
} 
El profesor Raúl Villarroel en La naturaleza como texto dice que el pensamiento nietzscheano <<es una suerte de diagnóstico de la época, una visión que sobrevuela la historia presente, como un pájaro profeta que mira hacia atrás cuando relata lo que ha de venir según su propia caracterización $>>597$. Para Villarroel, Nietzsche fue protagonista de una fuerte oposición contra la conexión entre el sujeto y el ego, tan firmemente promulgada por la filosofía moderna. El "yo" no sería otra cosa más que una creación de un sujeto que no trasciende en su creación, el "yo" es una metáfora más del lenguaje, una referencia atributiva ${ }^{598}$; en consecuencia, el ego cartesiano deja de ser <<una actividad ligada al poder de una cierta inteligibilidad "inocente" del mundo (si se pudiera decir) $>>599$. El profesor Villarroel interpreta que el valor de la verdad que critica Nietzsche va referido a una voluntad de muerte en tanto en cuanto la creación de un mundo verdadero anula las posibilidades de realización de la vida, así, la creación de un mundo verdadero es un supuesto ilusorio, un supuesto que invoca abstracciones que finalmente se vuelven en contra de la vida. Es notorio que Villarroel logra averiguar y advertir cómo en la filosofía nietzscheana las verdades surgidas de las relaciones que los seres humanos entablan gracias al lenguaje pueden oponerse a las funciones e instintos que sostienen la vida, la verdad hipostasia lo real y genera unas ficciones que llegan a distorsionar el desarrollo vital de los hombres, así como también taran y perturban a los organismos más saludables. La tendencia humana a buscar la verdad, que pareciera vincular subjetividad y mundo, es a la vez la tendencia que diluye la subjetividad, dado que el mundo, al no ser apodíctico, es interpretado a partir de múltiples perspectivas ${ }^{600}$. Al no considerar ningún tipo de anclaje trascendental al mundo, Nietzsche pertrecha una irreversible devaluación ontológica de la subjetividad: <<el sujeto no es algo dado sino algo inventado y añadido, algo puesto por detrás $>>{ }^{601}$.

En relación con lo anterior, cobran más nitidez las intenciones de Nietzsche cuando emprende su crítica contra la moral. El autor localiza en la moral de su tiempo la renuncia a la vida, una actitud que viene infestada de patologías, que se regocija ante la existencia miserable y que celebra el abandono del cuerpo; esta moralidad viene henchida de resentimiento, ansias de venganza e impotencia. Para Nietzsche, el origen

\footnotetext{
${ }^{597}$ Raúl Villarroel, La naturaleza como texto. Hermenéutica y crisis medioambiental (Santiago de Chile: Editorial Universitaria, 2006), 123.

${ }^{598} \mathrm{Cfr}$. Villarroel, ob. cit., 126.

599 Villarroel, ob. cit., 127.

${ }^{600} \mathrm{Cfr}$. Villarroel, ob. cit., 136.

${ }^{601}$ Friedrich Nietzsche, Fragmentos póstumos. Volumen IV (Madrid: Tecnos, 2008), 222.
} 
de la moral se dio en medio de la crueldad, la privación, el desgarro de la carne, la contusión, la mutilación, etc., de modo que su fundación no se remontaría a un bálsamo de principios normativos incluidos dentro de la naturaleza humana. De la misma manera que en Marx <<el capital viene al mundo chorreando sangre y lodo por todos los poros $>{ }^{602}$, en Nietzsche la figura de la moral, en cuanto que poder, proviene de relaciones beligerantes en las que el cuerpo y la fuerza se alzan como protagonistas. Por diferentes que puedan ser las líneas filosóficas de Marx y de Nietzsche, en ambas, hay una convergencia cuando se trata de derivar el punto originario de ciertas formas de poder, dado que su estilo de pensar presume que la civilización se sostiene sobre el fango producido por las discordias humanas. Ambos pensadores supusieron que las asimetrías generadas en las relaciones de dominación constituyen un punto de anclaje aislado de los principios sobre los que se asentaron los sistemas de pensamiento moral y político modernos. El instinto agresivo y explotador del hombre sería la simiente sobre la que se fundan las relaciones humanas que dieron paso a los elementos de la civilización.

Nietzsche sitúa el poder en la inmanencia del cuerpo. Lo corporal integra el potencial de la dominación quedando el poder, ya no como una instancia foránea que se encarna en la corporalidad, sino, más bien, asimilando que la fuerza corporal propale los instintos de conservación, expansión y superación propios de la vida y que, por tanto, estos instintos alcanzan también a la composición de la vida socio-política en todas sus manifestaciones. Por su parte, Marx también había encontrado que hay una fuerza inherente a los cuerpos que determinan las relaciones sociales y políticas; el poder más capaz, material y realizable se encuentra en la fuerza corporal, la que constituye la masa trabajadora. Ambos filósofos pretendieron descubrir el origen corporal del poder y, por ende, le concedieron a la dimensión corpórea humana una politicidad surgida en el ejercicio de la dominación, lo que requería necesariamente suponer la presencia de unos cuerpos que impelen y reciben de manera respectiva los movimientos de dominación. La corporalidad humana hace las veces tanto de vértice activo de poder como de centro receptor de dominio. Esta lectura vino acompañada de un ejercicio reflexivo que desdeñó la figura del sujeto moderno y su racionalidad. Marx y Nietzsche, cada uno a su manera y con contrastes irreconciliables en sus respectivos pensamientos, lo que no los hace siempre y necesariamente incompatibles, dieron cuenta de cómo el ejercicio de la

${ }^{602}$ Karl Marx, El capital. I (México D. F: Fondo de Cultura Económica, 1946), 646. 
dominación tiene que gravitar alrededor de la corporalidad humana y no en torno a figuras carentes de corporeidad. 


\section{SECCIÓN III. EVOLUCIÓN, PROGRESO, DECADENCIA}

\subsubsection{EL EVOLUCIONISMO Y EL DESARROLLO DE LOS ORGANISMOS NATURALES Y POLÍTICOS}

Durante el siglo XIX la civilización occidental pasó por una serie de cambios a un alto ritmo de celeridad. El desarrollo de la industria, el ingente crecimiento de los núcleos urbanos, el vasto incremento de la eficacia productiva y el aumento del volumen del comercio, entre otros factores, fueron algunos de los cambios más determinantes en la modificación del estilo de vida de gran parte de la población occidental. Los intelectuales de esta civilización en expansión, pudieron vivir en primera persona un salto tanto cuantitativo como cualitativo del desarrollo en sus sociedades, así como también pudieron contrastar con mayor grado de precisión las diferencias abismales que existía entre su contexto y el de las comunidades tradicionales. La experiencia de las transformaciones que se estaban produciendo hacía evidente el carácter cambiante de la vida y, con ello, la necesidad de observar las condiciones que causan los cambios en la historia, la sociedad, la política, etc.

Charles Darwin trató de explicar las transformaciones que se producen en la historia natural de los cuerpos orgánicos, tanto en los seres humanos como en el resto de seres vivos, tomando como base la idea de que en la naturaleza tienen lugar modificaciones que en muchas ocasiones pasan inadvertidas a la observación humana y que hay unas leyes naturales que están participando en dichas modificaciones. En El origen de las especies, Darwin presenta una imagen del cuerpo vinculada al concepto de plasticidad, pues considera que el organismo de los seres vivos se acopla a los cambios fluctuantes del entorno natural, y que estos cambios alteran las condiciones de vida ${ }^{603}$. De este modo, las modificaciones anatómicas de las especies animales y vegetales en el transcurso de las generaciones vendrían determinadas por un ordenamiento nómico inherente a la naturaleza. Darwin observa que, de la misma manera en que los hombres ejercen actividades selectivas sobre algunos seres vivos con el fin de modificarlos de acuerdo con sus intereses, la naturaleza también es causante de modificaciones en los organismos:

Así como el hombre puede producir un resultado grande en las plantas y animales domésticas sumando en una dirección dada diferencias individuales, también lo puede

${ }^{603}$ Cfr. Charles Darwin, El origen de las especies (Madrid: Espasa-Calpe, 1988), 184. 
hacer la selección natural, aunque con mucha más facilidad, por tener tiempo incomparablemente mayor para obrar. ${ }^{604}$

La plasticidad corporal es una característica que el ser humano comparte con el resto de especies; en El origen del hombre, el naturalista británico defiende que el cuerpo de los seres humanos ha evolucionado según los mismos parámetros que el cuerpo de los demás seres vivos. El análisis observacional de la anatomía humana le sirve a Darwin para refrendar sus teorías sobre el origen animal del hombre. La plasticidad corporal es un rasgo común a todos los seres vivos, por tanto, los seres humanos no ocuparían una posición privilegiada en la Tierra; Darwin sostiene:

El hombre se halla sujeto a numerosas variaciones, insensibles y variadas modificaciones, producidas por las mismas causas generales, sujetas y transmitidas según las mismas leyes, con que idénticos fenómenos tienen lugar en los animales inferiores. La rapidez de su multiplicación ha sido tal, que necesariamente se ha visto expuesto a la lucha por la existencia $\mathrm{y}$, por lo mismo, a la selección natural [...]. El cuerpo humano se halla construido sobre el mismo plan de los otros mamíferos. Pasa por idénticas fases de desarrollo embriogénico. Conserva muchas e inútiles estructuras rudimentarias que en otro tiempo debieron sin duda servirle de algo. De cuando en cuando, y ocasionalmente, presenta en su ser reapariciones de caracteres, que con todo fundamento podemos creer poseyeron también sus progenitores. Al ser el origen del hombre completamente distinto del de los otros animales, todas esas diversas similitudes solo serían vanas decepciones, hipótesis de todo punto ineludible; antes al contrario, esas manifestaciones son perfectamente inteligibles, al menos en cierto grado, si se admite que el hombre y los otros mamíferos son codescendientes de una forma inferior desconocida ${ }^{605}$

El carácter cambiante de la naturaleza determina también el comportamiento moral de los seres humanos, al igual que el cuerpo, la moral también sería plástica y se vería expuesta a adaptaciones y variaciones propiciadas por el desarrollo de la historia natural de los hombres. En La descendencia del hombre y la selección sexual Darwin manifiesta su acuerdo con Kant en la idea de que el sentido moral es la diferencia más determinante de los seres humanos con respecto a los animales; así, el deber moral es extensible a toda la especie humana y, en este nivel, solo los hombres tienen capacidad para dirigirse según su deber, que iría más allá de la sociabilidad meramente

\footnotetext{
${ }^{604}$ Darwin, ob. cit., 132.

${ }^{605}$ Charles Darwin, El origen del hombre (Madrid: EDAF, 1989), 146.
} 
instintiva $^{606}$. Desde un punto de vista evolutivo, el naturalista británico sostiene que la tendencia de la moral humana hacia la universalidad tiene una explicación perfectamente asimilable a la perspectiva evolucionista, puesto que, a medida que los hombres se civilizan, van formando comunidades de mayor tamaño, por lo que $<<$ la simple razón indica a cada individuo que debe extender sus instintos sociales y su simpatía a todos los miembros de la misma nación〉>, una vez <<alcanzado este punto, solo una barrera artificial puede impedir que sus simpatías se extiendan a todos los hombres de todas las naciones y de todas las razas $>>007$. Los argumentos de Darwin acuden a causas naturales para explicar el carácter universalista dentro de la moral, concibe la moralidad como un fenómeno de la vida humana vinculada con el instinto de supervivencia de los humanos más que como una anomalía extraordinaria.

De la misma manera en que el cuerpo natural del hombre habría cambiado debido a un proceso de selección natural, la organización social también habría experimentado sustanciales variaciones en el desarrollo histórico de las civilizaciones. Fue Herbert Spencer quien prestó especial atención a este asunto, explicando los cambios en los organismos sociales mediante una pertinente analogía con los cambios que se dan en los organismos naturales según la teoría evolutiva. Cuando en Los primeros principios Spencer se refiere al término "evolución" aclara que es preciso diferenciar entre los fenómenos producidos por un proceso evolutivo y los fenómenos que alteran el organismo vivo a causa de algún tipo de patología. Las enfermedades instauran modificaciones que producen una heterogeneidad en el organismo, característica que también tiene lugar en la evolución cuando se pasa de una homogeneidad a una heterogeneidad orgánica, con la salvedad de que la heterogeneidad en el caso de la evolución ha de ser genuina, es decir, tiene que haber en ella una singularidad no común a los estados patológicos ${ }^{608}$. Para Spencer, las variaciones evolutivas traen consigo cambios en los que hay un tránsito de lo indefinido a lo definido y de lo simple a lo complejo:

A la vez que un progreso de lo simple a lo complejo, se verifica un progreso de lo confuso a lo ordenado, de lo indeterminado a lo determinado. En todo desarrollo o

\footnotetext{
${ }^{606}$ Cfr. Charles Darwin, Teoría de la evolución (Barcelona: Ediciones Península, 1971), 158-160.

${ }^{607}$ Darwin, ob. cit., 162.

${ }^{608}$ Cfr. Herbert Spencer, Los primeros principios (Granada: Comares, 2009), 237.
} 
proceso evolutivo hay, no sólo una multiplicación de partes heterogéneas, sí que también un incremento en la claridad con que esas partes se distinguen unas de otras. ${ }^{609}$

Spencer, al tratar a las sociedades como si fueran organismos biológicos, entiende que la sucesión de los cambios sociales sigue unos parámetros análogos a la forma en que cambian los organismos vivos, por ello, del mismo modo en que un cuerpo se pudre cuando muere, pasando de un estado regular a un desorden causado por la descomposición, también, cuando se produce un movimiento revolucionario en una sociedad, esta pasa de un ordenamiento determinado y definido a una situación de indefinición e indeterminación. Mediante este paralelismo el pensador británico pretende demostrar que los cambios ocasionados por las enfermedades o por la muerte son radicalmente diferentes de los cambios evolutivos: si bien los primeros contribuyen a generar un aumento de la heterogeneidad en los organismos, no así derivan en determinaciones y definiciones fijas; lo mismo ocurriría en el caso de las revoluciones, que trastocan y descomponen el cuerpo social sin generar evolución ${ }^{610}$.

Los criterios evolucionistas que Spencer utiliza para distinguir las variaciones evolutivas de las variaciones patológicas, tanto a nivel de los organismos biológicos como a nivel de los organismos sociales, son también trasladados a los caracteres psicológicos de los distintos seres humanos. Según Spencer, <<el curso de la evolución psíquica humana en la tierra también confirma la ley; los pensamientos del salvaje no son tan heterogéneos, como los del hombre civilizado, no tiene muchas veces ideas abstractas, cuyos elementos es incapaz de integrar $>>{ }^{611}$. Asegura también que la predisposición psicológica de los hombres civilizados es la que conduce al desarrollo de la ciencia. Los argumentos del autor evolucionista van enfocados a resaltar el papel relevante que la evolución juega en todos los aspectos de la naturaleza y de la vida. Los tránsitos de la homogeneidad a la heterogeneidad son comunes tanto a la física, a la biología, a la sociología como a la psicología, así, y de este modo, los estadios más complejos correspondientes a formas heterogéneas definidas equivalen a formas más evolucionadas, ergo, han experimentado un mayor grado de progreso. Las leyes de la evolución, según como las considera Spencer, son identificables de manera universal en todos los fenómenos naturales, es decir, todos los cuerpos y estados psicológicos que

\footnotetext{
${ }^{609}$ Spencer, ob. cit., 238.

${ }^{610}$ Cfr. Spencer, ob. cit., 238-239.

${ }^{611}$ Spencer, ob. cit., 257.
} 
presenten un proceso hacia la heterogeneidad, complejidad y definición están evolucionando. La evolución se evidencia en los cuerpos, ya sea a una escala celeste, a la de los cuerpos inorgánicos, a la de los biológicos, a la de los cuerpos sociales y, si se aprecia la conducta de los individuos, también a la psicológica; de forma que todos los cuerpos estarían regidos por la nómica evolutiva, que ineludiblemente domina sus movimientos $^{612}$.

El evolucionismo spenceriano, en clave política, induce a pensar el Estado como un poder artificial, un producto humano, susceptible de trabar el natural desarrollo del progreso humano. Al comienzo de la obra El hombre contra el Estado, Spencer ofrece una panorámica sobre la situación política de su presente y determina que la disputa en esta materia oscila entre los conservadores y los liberales, los primeros representarían el modelo de organización social militarista y los segundos el modelo industrialista. El militarismo sería la forma en que se organizan las sociedades tradicionales, que en Inglaterra se corresponden con las zonas rurales, dirigidas por mandos militares y en las que el Estado obliga a cooperar. Por otra parte, el industrialismo sería propiamente la organización correspondiente al liberalismo, de corte urbanita y especialmente preponderante en los grandes centros industriales de Inglaterra, su auge habría comenzado ya con anterioridad a las pertinentes distinciones entre conservadores y liberales. La forma de cooperación que por excelencia definiría al liberalismo es el contrato o, lo que es lo mismo, la cooperación voluntaria. Entonces, el liberalismo tiende a disminuir el poder coercitivo del Estado ya que, mientras el Estado obliga a cooperar a los individuos, el liberalismo no impone esta obligación, sino que deja que cada cual decida y participe como buenamente quiera y pueda en la cooperación; así, entonces, para Spencer el liberalismo aumenta la libertad en tanto en cuanto aporta a cada cual la independencia de cooperar de acuerdo con sus intereses, convenciones o pareceres $^{613}$. En su texto, Spencer elabora una teorización del liberalismo acorde con su propia versión del evolucionismo. El contraste principal entre la política conservadora y la política liberal se halla, según el pensador británico, en cómo es organizado el cuerpo social: conservadurismo y liberalismo no son más que la consecuencia legislativa y gubernamental de dos formas diferentes de asociarse, una más evolucionada que la otra.

\footnotetext{
${ }^{612}$ Cfr. Spencer, ob. cit., 261-262.

${ }^{613}$ Cfr. Herbert Spencer, El hombre contra el Estado (Buenos Aires: Aguilar, 1963), 23-28.
} 
Spencer cree que una de las transgresiones más destacables en el arte de la legislación corresponde al argumento que justifica el nacimiento del gobierno por la naturaleza violenta de los seres humanos. El gobierno nació, según los legisladores, para paliar las agresiones entre los hombres y, por ende, su único método legítimo con que luchar contra estas derivas agresivas no fue otro más que el recurso a la propia agresión. Asimismo, para el pensador británico la protección de los más débiles, es decir, de aquellos más expuestos a la violencia de otros, sería una excusa encubierta tras una actitud benevolente, ya que, en nombre de la protección de los más desprotegidos y vulnerables, el gobierno se toma la potestad para obstruir la libertad de los individuos. El ejemplo más significativo que encuentra el autor radica en la política económica, cuando se le llama "proteccionismo" a lo que no es más que una agresión contra el librecambio $^{614}$. El error que origina las mayores ínfulas entre los legisladores proviene de imaginar a la sociedad como algo artificial, como si fuera <<un producto fabricado, cuando en realidad es una constante evolución $>{ }^{615}$. La ausencia de un conocimiento científico sobre el funcionamiento evolutivo de la sociedad, en la que su estructuración organiza de manera natural a las instituciones, dio paso a que pudiera creerse que

la humanidad es una especie de masa a la que el cocinero puede moldear como quiera, en forma de pastel, bollo o tarta. El comunista cree que el cuerpo político puede ser moldeado a voluntad. Muchas medidas legislativas suponen que las sociedades a las que se impone esta o aquella organización las conservarán en lo sucesivo. ${ }^{616}$

Spencer pone todo su empeño en defender la imagen de la sociedad como un organismo vivo, con órganos interdependientes, de modo que, como dice Burrows Acton, $<<\operatorname{los}$ diferentes órganos están tan estrechamente unidos unos a otros que los intentos hechos para destruir la sociedad con el fin de reconstruirla están abocados al fracaso y pueden revelarse desastrosos $>>617$. El naturalismo biologicista spenceriano pugna contra cualquier intento instituido políticamente para alterar la organización y el funcionamiento de la sociedad, pues cualquiera de estos intentos supondría introducir un orden artificial allí donde deberían operar principios naturales indefectibles. Spencer esgrime argumentos contra aquellos propósitos proclives a modificar el organismo de la

\footnotetext{
${ }^{614}$ Cfr. Spencer, ob. cit., 132-133.

615 Spencer, ob. cit., 135.

616 Spencer, ob. cit., 136.

${ }^{617}$ Harry Burrows Acton, "Empirismo y evolucionismo"; en Historia de la filosofía. Siglo XIX, Yvon Belaval (dir.) (Madrid: Siglo Veintiuno Editores, 1979), 362-363.
} 
sociedad a partir de fuerzas pertenecientes a los cuerpos políticos, sin embargo, no devuelve el poder a la inherencia orgánico-social, sino que traslada este poder a otra instancia exterior ya no corpórea, ya no tan visible como las instituciones políticas, una instancia que aparece representada por las leyes de la naturaleza y que, desde la perspectiva spenceriana, son las únicas legitimadas para moldear la sociedad.

\subsubsection{EL TRASFONDO POLÍTICO DE LAS VISIONES EVOLUTIVAS}

Las sociedades occidentales a lo largo de la etapa decimonónica se vieron afectadas por el impacto de nuevas costumbres y ocupaciones que tenían lugar en los emergentes entornos urbanos. Había una mirada introspectiva sobre los cuerpos que juzgaba la facticidad de las relaciones sociales, los hábitos y los procedimientos desde el prisma del progreso y de la evolución. El incremento de la población en los territorios urbanos y los cambios que este hecho produjo, junto a una técnica y ciencia en desarrollo, también habilitaba imágenes de la corporalidad que llevaban consigo visiones antropológicas y socio-políticas.

Uno de los escenarios donde se pueden apreciar las modificaciones conceptuales y culturales de la imagen social de la corporalidad se hace destacable en los escenarios de exhibición pública de los cuerpos, uno de sus espacios más notable, fue el de los deportes, que se generalizaron en el XIX. Según Georges Vigarello y Richard Holt, la extensión de los deportes vino acompañada de un temor difundido por el evolucionismo a la degeneración racial, muchas altas personalidades <<estaban convencidas de que las razas se enfrentaban por el domino político y económico. Por eso, tener un cuerpo sano y bien preparado parecía cada vez más importante $>{ }^{618}$. Vigarello y Holt sostienen que las técnicas aplicadas en los distintos deportes que nacieron en el XIX permitían combinar la eficacia y elegancia del cuerpo en sus movimientos (golf, tenis, boxeo, etc.) ${ }^{619}$; el domino de la técnica en las distintas disciplinas deportivas imponía una concepción del cuerpo como mecanismo eficaz y competitivo. La potenciación de la individualidad en los deportes, ya fueran en equipo o no, manifestaba aquellos valores

\footnotetext{
${ }^{618}$ Georges Vigarello y Richard Holt, "El cuerpo cultivado: gimnastas y deportistas en el siglo XIX"; en Historia del cuerpo. (II) De la Revolución francesa a la Gran Guerra, Alain Corbin, Jean-Jacques Courtine, Georges Vigarello (dir.) (Buenos Aires: Taurus, 2005), 320.

${ }^{619}$ Cfr. Vigarello y Holt, ob. cit., 335.
} 
que promovía la burguesía decimonónica: decisión, competitividad, eficiencia técnica, auto-control, mando ${ }^{620}$.

Vigarello y Holt vinculan la imagen que el cuerpo adquiría en los deportes con la concepción pública dominante que operaba tras la escenificación deportiva, si bien la profesionalización de los deportes junto a la proliferación amateur de estos se desarrollaba en el espacio público, la exposición de los cuerpos a situaciones dadas en los márgenes reglados donde se producía una competencia traía consigo nuevos usos del cuerpo y nuevas posibilidades de lo corporal. Los discursos evolucionistas proporcionados por la ciencia desplazaban el cuerpo hacia la responsabilidad política de mantener una complexión sana y fuerte, capaz de desarrollar sus aptitudes en un mundo competitivo, un mundo que los diferentes deportes reproducían, como si emularan la naturaleza competitiva en la que todos los seres humanos están supuestamente inmersos. De este modo, los deporten permitían exhibir el progreso de la civilización aprovechando los recursos estéticos de una complexión atlética:

Parecía constatarse la existencia de un progreso plausible en el núcleo de las defensas corporales. El deporte se hizo así demostrativo, signo de modernidad, señal de progreso, (...). Las competiciones de carreras, de salto, de tiro, de lawn tennis [tenis sobre hierba], distribuidas por los pabellones de los expositores o en los bosques de la periferia de París, sirvieron de excusa para hablar de la salud colectiva, su posible avance o declive. ${ }^{621}$

Otro escenario que tuvo como protagonistas a los cuerpos humanos y que se dio a finales del siglo XIX y principios del XX involucraba también a los cuerpos en el trasfondo político de ciertos desarrollos discursivos evolucionistas: dicho escenario es el de los zoológicos humanos. Juanma Sánchez Arteaga comenta en un artículo dedicado a este tema, titulado "La antropología física y los zoológicos humanos", que el etnocentrismo europeo de la época se apoyó en el discurso evolucionista, cuyo desarrollo metodológico permanecía aislado de otros saberes, de forma que el discurso científico se encontraba protegido frente a las críticas procedentes de disciplinas externas a la ciencia positiva ${ }^{622}$. La exhibición de indígenas en zoológicos partía de presupuestos racistas firmemente consolidados en una buena parte de los argumentos

\footnotetext{
${ }^{620}$ Cfr. Vigarello y Holt, ob. cit., 342.

621 Vigarello y Holt, ob. cit., 353.

${ }^{622}$ Cfr. Juanma Sánchez Arteaga, “La antropología física y los 'zoológicos humanos': exhibiciones de indígenas como práctica de popularización científica en el umbral del siglo XX”, Asclepio. Revista de historia de la medicina y de la ciencia 62, no. 1 (2010), 269-292, 273-274.
} 
evolucionistas. Apunta Sánchez Arteaga que en los zoológicos humanos la teoría evolucionista secundaba la apreciación de antropólogos físicos y biólogos que advertían de la más que probable desaparición de grupos étnicos incapaces de competir en la lucha por la existencia frente al hombre civilizado. Para persuadirse de estas estimaciones, los expertos clasificaron a los indígenas como gentes más próximas a los simios que a los humanos, basándose fundamentalmente en las características de sus rasgos fisionómicos ${ }^{623}$; de este modo,

estigmatizadas como verdaderos "hombres-mono" por parte de la ciencia, al lado de enfermos mentales incurables y criminales innatos, las razas inferiores se encontraban limitadas por su naturaleza a permanecer en un estado evolutivo naturalmente arcaico con respecto al europeo. ${ }^{624}$

Los antropólogos físicos y biólogos del momento se valieron de caracteres corporales tan triviales como el grosor de la nariz para catalogar a los indígenas en un lugar determinado de la "escala evolutiva", con consecuencias políticas evidentes si se atiende a la promoción y justificación de la superioridad de la civilización occidental frente a otros grupos humanos -los aborígenes serían incapaces de sobrevivir al no poder competir con las avanzadas técnicas y perfeccionadas habilidades de los hombres occidentales-. De este modo, la exhibición de indígenas en zoológicos humanos imponía ante la mirada de los espectadores occidentales una asimetría entre el observador y el observado, siendo el cuerpo del observado situado en el lugar de un objeto de exposición.

El hombre occidental demostraba su poder al recrearse en el "espectáculo de la naturaleza”. La exposición de cuerpos de indígenas ante la mirada pública reproducía el “espacio natural" en que se debía desarrollar la vida de estos grupos humanos, lo que certificaba una suerte de avances y progresos acaecidos en las sociedades occidentales, tanto los curiosos neófitos como los expertos científicos podían disfrutar de una potentada posición de espectadores. El caso del pigmeo expuesto en el zoológico del Bronx de Nueva York, llamado Ota Benga -el caso con que Sánchez Arteaga inicia su artículo $^{625}$-, es especialmente definitorio, pues este indígena fue confinado junto a un orangután. La situación de Ota Benga en el zoológico caracteriza de manera muy nítida

\footnotetext{
${ }^{623}$ Cfr. Sánchez Arteaga, ob. cit., 275.

${ }^{624}$ Sánchez Arteaga, ob. cit., 276.

${ }^{625}$ Cfr. Sánchez Arteaga, ob. cit., 270-271.
} 
el lugar al que se relegó su vida, cuyo cuerpo fue puesto literalmente en la zôé, es decir, como un cuerpo que no pertenece al bios ${ }^{626}$, una forma de vida que se halla al margen del espacio civil donde se articulan las relaciones políticas.

Los cuerpos exhibidos en los zoológicos humanos fueron emplazados a un tipo de existencia entendida como vida animal, como zôé; a estos cuerpos se les arrancó su condición civil, quedaron apartados de la vida pública y despojados de toda jurisdicción regular. La condición jurídica de estos cuerpos fue suspendida y apartada de toda ley, el objetivo de su confinación y exhibición no se apoyaba en ningún criterio de base legal, sino estrictamente zoético, a saber, la posibilidad de observar y estudiar estas formas de vida aborigen catalogadas entre el simio y el hombre antes de su desaparición final de la faz de la Tierra. Podría decirse, siguiendo el esquema de análisis y crítica de Agamben, que la suspensión del derecho operante en los cuerpos de los indígenas expuestos en los zoológicos humanos es uno de los ejemplos decimonónicos más clarividentes de una inclusión practicada por medio de un contenido considerado como de exclusión:

La política, en la ejecución de la tarea metafísica que la ha conducido a asumir cada vez más la forma de una biopolítica, no ha logrado construir la articulación entre zôé y bíos, entre voz y lenguaje, que habría debido soldar la fractura. La nuda vida queda apresada en tal fractura en la forma de la excepción, es decir de algo que solo es incluido por medio de una exclusión. ${ }^{627}$

Las teorías de Darwin y la extensión científica del darwinismo fueron utilizados, en muchos casos, para ampliar la hendidura practicada sobre la vida política en el contexto y periodo de emergencia de las democracias occidentales. Aquellas otras formas de vida reducidas a organismos supuestamente incapaces de competir con los avances de la civilización y, por tanto, condenados a la extinción, aquellos cuerpos humanos desfavorecidos por la evolución eran exhibidos en los espacios urbanos donde los zoológicos pretendían emular la zôé. El discurso de fondo de esta emulación era demostrar la supremacía de las civilizaciones industriales occidentales sobre otras formas de vida humana y, a la vez, prescindir de los discursos moralistas y legalistas

\footnotetext{
${ }^{626} \mathrm{Al}$ comienzo de El poder soberano y la nuda vida (primer libro de Homo Sacer), Agamben comenta una distinción fundamental entre los términos griegos zôé y bíos. Con zôé, los griegos hacían referencia a la vida común de todos los seres, al hecho de estar vivo; con bíos designaban una forma de vida concreta de un individuo o grupos de individuos. La "vida política", bíos politikós, jamás podría haber sido considerada como zôé, este último puede referirse tanto a dioses como a seres mortales comunes. Cfr. Giorgio Agamben, Homo Sacer. El poder soberano y la nuda vida. I (Valencia: Pre-Textos, 2003), 9-10.

${ }^{627}$ Giorgio Agamben, Homo Sacer. El poder soberano y la nuda vida. I (Valencia: Pre-Textos, 2003), 21.
} 
para celebrar el grado de dominio que han llegado a tener los hombres occidentales en condiciones naturales, los cuales habrían partido, en un pasado muy remoto, de la misma situación que esos indígenas allí expuestos.

Los zoológicos humanos simbolizan la sinergia entre el saber científico procurado por el evolucionismo de corte darwinista y los intereses del poder político dominante. El discurso evolucionista contribuyó, en muchos casos, a implementar un ordenamiento político de los cuerpos basado en sus características. El evolucionismo mensuraba qué sociedades humanas estaban mejor posicionadas en la "tabla evolutiva" surgida de la competencia por la vida, lo que, en el interior de las naciones occidentales, autodesignadas como más aptas para conservarse en la existencia, también se reproducía una competitividad con una escala clasificatoria desde la que se dividían las clases sociales: la posición social del individuo tiene también un origen natural. El discurso evolucionista buscaba confirmar una simbiosis entre la naturaleza y la sociedad en virtud de una competencia que estaba llamada a designar el porvenir de los individuos en su situación social y, también, incluso, aquellos individuos cuyos cuerpos no eran tomados como parte de la sociedad civil.

Consecuentemente, pensar la evolución implicaba, inevitablemente, la pronunciación de un discurso político que se extendía a trasluz de lo planteado dentro de los márgenes teóricos de la ciencia. Así lo puso de relieve Piotr Kropotkin cuando, en 1888, publica un texto dedicado a la teoría de la evolución de Darwin, en el que resalta cómo la burguesía se amparaba en la "lucha por la existencia" para refutar y tratar de socavar al socialismo. Pero kropotkin trata de demostrar que Darwin en ningún momento respaldó la explotación del hombre sobre el hombre sino más bien la cooperación entre humanos, pues las especies se sostienen mejor en la existencia cuando sus miembros colaboran entre sí $i^{628}$. En el Apoyo mutuo, el pensador ruso dice que Darwin, en relación con el término "lucha por la existencia, <<previno a sus sucesores en contra del error (en el cual parece que cayó él mismo durante una época) que suponía la expresión demasiado estrecha de estas palabras $>{ }^{629}$. Los sucesores de Darwin restringieron el significado de la lucha por la existencia para elevarlo a un principio biológico al que el hombre está subordinado y de acuerdo al que ha de actuar en consecuencia si no quiere ser

\footnotetext{
${ }^{628}$ Cfr. Piotr Kropotkin, El apoyo mutuo (Logroño: Pepitas de calabazas, 2016), 395.

${ }^{629}$ Kropotkin, ob. cit., 30.
} 
exterminado ${ }^{630}$. Kropotkin advierte que los conceptos utilizados por el evolucionismo esconden finalidades políticas, unas finalidades que toman la apariencia de ciencia:

La ciencia proclama en voz alta que la lucha de cada uno contra todos constituye el principio dominante de la naturaleza y de las sociedades humanas; y precisamente a esta guerra atribuye la biología actual el desarrollo progresivo del mundo animal. La historia se conduce del mismo modo; y los economistas, en su ingenua ignorancia, consideran que el éxito de la industria y de la mecánica contemporánea son el "asombroso" resultado de la influencia del mismo principio. ${ }^{631}$

Kropotkin le reprocha a la ciencia de su tiempo haber organizado todo un entramado de poder a través del que se promueve el individualismo y el enfrentamiento. Este entramado científico-político se alza sobre la especie humana como una instancia dominante que dirige a los hombres en sus actividades sociales, donde la economía toma relevancia cuando se trata de fundar criterios y designar formas de ejercer el trabajo y administrar los recursos, todo ello bajo el espectro de la competencia. Pero Kropotkin trata de desvelar un orden subrepticio en el desarrollo histórico de las civilizaciones que la ciencia de su tiempo había dejado pasar desapercibido: la colaboración entre comunidades como método más efectivo de supervivencia. Frente a las directrices elementales del evolucionismo asumido por parte de las ciencias naturales y de las ciencias sociales, Kropotkin recalca el apoyo mutuo como una forma que perdura a lo largo del tiempo biológico de las especies y del tiempo histórico de las civilizaciones de la humanidad. El apoyo mutuo es un factor determinante en los procesos evolutivos y verdadero motor de la evolución. En las costumbres de los hombres el apoyo mutuo se ha mantenido intacto, a pesar de todas las inclemencias propiciadas por el Estado moderno contra las tierras comunales y la asociación sindical, así, <<el núcleo de instituciones, hábitos y costumbres de ayuda mutua continúa existiendo en millones de hombres $>>632$.

La operación que realiza el pensamiento kropotkineano para contradecir las versiones evolucionistas de su tiempo recurre a la crítica del sistema de dominio avalado por la ciencia de entonces, basado en la competencia como único factor posible del desarrollo biológico y social. Además, Kropotkin propone una visión de la evolución alternativa, fundada en el apoyo mutuo, al suponer una organización

\footnotetext{
${ }^{630}$ Cfr. Kropotkin, ob. cit., 32.

${ }^{631}$ Kropotkin, ob. cit., 276.

${ }^{632}$ Kropotkin, ob. cit., 311.
} 
cooperativa-colaborativa necesaria para la evolución, y no una organización competitiva; de este modo, el autor achacó a los científicos evolucionistas no haber sido capaces de ver o deliberadamente haber tratado de ocultar y silenciar la relevancia que el apoyo mutuo tiene para el desarrollo de la vida. Los argumentos de Kropotkin a favor de la cooperación colaborativa como forma esencial de la organización social y del avance histórico de la civilización sitúan el concepto de apoyo mutuo como un poder inmanente a los cuerpos sociales, el propio pensador ruso indica que las sociedades de ayuda mutua formadas en los Estados industriales contribuyen a <<crear un cuerpo viviente, en lugar de un mecanismo muerto sometido a la voluntad de los funcionarios $>>{ }^{633}$. Ni el poder de los Estados ni el de otras instancias constituidas en contra de la natural tendencia colaborativa de la vida pudieron soterrar el apoyo mutuo, que es inmanente a la vida social de los hombres y aparece en distintos escenarios históricos. El apoyo mutuo se halla en la filosofía de Kropotkin como un poder originario de las sociedades humanas, poder inextinguible de cualquier forma de vida.

\subsubsection{LA DÉCADENCE COMO PROCESO HISTÓRICO}

Las visiones evolucionistas y espiritualistas resultan irreconciliables, si bien ambas reconocen que el progreso describe una línea continua de trayectoria uniforme, esta linealidad abarca dimensiones muy diferentes dentro de las relaciones humanas y la historia. Nietzsche, al igual que los evolucionistas, asumió unos preceptos corporalistas que, en cambio, no le condujeron a plantear el tema de la historia humana en los términos del evolucionismo, aunque tampoco aceptó ni acató -como por todos es bien sabido- los criterios hegelianos acerca de la historia y el progreso.

Nietzsche concibe el tiempo bajo la forma de un círculo, la forma del "eterno retorno", de modo que tanto la naturaleza como la historia estarían siendo reguladas por unos movimientos cíclicos y no exactamente lineales.

Siguiendo las indicaciones de Rosset a propósito del eterno retorno, resulta destacable que este término no es tratado por Nietzsche nada más que en apenas dos páginas de su extensa obra, sin embargo, varios de sus intérpretes (Klossowski, Deleuze, Heidegger) le concedieron gran relevancia a este tema ${ }^{634}$. Pese a las muchas

\footnotetext{
${ }^{633}$ Kropotkin, ob. cit., 346.

$634<<$ Que yo sepa, en el conjunto de los libros que Nietzsche ha publicado o de los que ha autorizado su publicación, no hay más que dos páginas, y bastante cortas, expresamente consagrada a la cuestión del eterno retorno: el aforismo 341 de El gay saber y el aforismo 56 de Más allá del bien y del mal. De la efectiva escasez de los textos que se les han consagrado, es cierto que no se podría concluir que el
} 
ambigüedades que Rosset detecta en la noción nietzscheana de eterno retorno, su interpretación del asunto trata de confirmar, sobre todo, que el eterno retorno pertenece a la tendencia afirmativa que Nietzsche hace de la vida -el eterno retorno es un eterno decir sí-. El hombre activo y no el reactivo es quien afirma la vida, quien acepta el devenir como si este pudiera repetirse una y otra vez, pero el hombre del eterno retorno no es un ser mejorado ni un ser humano cuya afirmación se dé sobre una mejora, porque esta actitud, según Rosset, sería propia de un optimismo leibnizeano que Nietzsche nunca hubiera aceptado ${ }^{635}$. Rosset se apoya en el tercer aforismo del primer capítulo de Esse Homo, "Por qué soy tan sabio", para sustentar su interpretación del eterno retorno en Nietzsche como una repetición del mundo tal cual es, lo que supondría admitir el regreso de las mejores y de las peores $\operatorname{cosas}^{636}$. En el aforismo que indica Rosset, un aforismo de corte autobiográfico, Nietzsche, dándole rienda suelta a sus delirios, se muestra orgulloso de llevar la sangre de su padre, al que considera descendiente de la aristocracia polaca, mientras presenta a su madre y a su hermana como una antítesis de sí mismo; después de varios reproches y de pronunciar insultos contra su madre y su hermana, como canaille ("chusma" en francés), dice:

ya que entonces uno carece de fuerza alguna para defenderse de gusanos venenosos... La contigüidad fisiológica posibilita semejante disharmonia praestabilita [desarmonía prestablecida]... Pero conozco que la objeción más profunda contra el <<eterno retorno>>, mi pensamiento propiamente abismal, la constituyen siempre mi madre y mi hermana. ${ }^{637}$

Nietzsche alude a la inquina que siente hacia su madre y hermana para achacarse a sí mismo la fatalidad de tener que volver a vivir de nuevo con esas dos personas a las que tanto detesta. He ahí la rotundidad y el peso del eterno retorno, un pensamiento que -tal como dice Nietzsche en La ciencia jovial-, si <<llegara a tener poder sobre ti, así como eres, te transformaría y tal vez te trituraría; frente a todo y en cada caso, la pregunta: “¿quieres repetir esto una vez más e innumerables veces más?”>>638. Desde el “abismo”

pensamiento del eterno retorno ocupa un lugar secundario o desdeñable en la obra de Nietzsche, ya que, por otra parte, el propio Nietzsche da fe, y con bastante frecuencia, de la gran importancia que otorga a este pensamiento, sin que por ello precise su naturaleza exacta >. Clément Rosset, La fuerza mayor (Madrid: Acuarela Editorial, 2000), 103-104.

${ }^{635}$ Cfr. Clément Rosset, La fuerza mayor (Madrid: Acuarela Editorial, 2000), 108-109.

${ }^{636}$ Cfr. Rosset, ob. cit., 110.

${ }^{637}$ Friedrich Nietzsche, Obras completas. Volumen IV (Madrid: Tecnos, 2016), 788.

${ }^{638}$ Friedrich Nietzsche, La ciencia jovial <<la gaya scienza >> (Valparaíso: Universidad de Valparaíso Ediciones, 2013), 270. 
del eterno retorno podría interpretarse este pensamiento nietzscheano como un término con el que el filósofo alemán contradice las concepciones de progreso de su época, pues todo lo nefasto, pusilánime y perturbador de la vida volvería a repetirse nuevamente sin opciones de mejorarlo. Si el devenir es un continuo eterno retorno, si todo se repite, ni la especie humana ni la historia habrán de seguir un proceso lineal de avance constante.

Más allá de que Nietzsche creyera realmente en el eterno retorno o de que solo recurriera a este término con pretensiones alegóricas -cuestión indiferente con respecto al tema que se está abordando-, resulta interesante ver cómo, tras la noción de eterno retorno, hay una actitud filosófica desde la que el autor piensa a los hombres y a las civilizaciones: podría interpretarse el eterno retorno como la expresión comprensiva de la irreversible degeneración humana, puesto que todas las organizaciones civilizadas ideadas por los seres humanos han terminado desvaneciéndose en el tiempo de la historia; por muy novedosa que se precie una época, todas las falencias humanas vuelven a reproducirse y todas ellas arrastran a las civilizaciones hacia el declive y la caída. La sintomatología decadentista de las sociedades humanas del pasado vuelve a aflorar en las civilizaciones presentes, de modo que todos los sistemas civiles están suscritos a un bucle de despropósitos irremediables. Nietzsche afirma que los pensadores occidentales tienden a creer que todo lo que está en el tiempo corre hacia delante, que la evolución sigue una trayectoria ascendente, sin embargo, esta creencia no sería más que una ficción, puesto que

el siglo XIX no es un progreso con respecto al siglo XVI: y el espíritu alemán de 1888 es un retroceso en relación con el espíritu alemán de $1788 \ldots$... La "humanidad" no avanza, ni siquiera existe... El aspecto global es el de un inmenso laboratorio experimental, en el que algunas cosas salen bien, dispersas por todas las épocas, e innumerables otras fracasan, desprovistas de todo orden, de toda lógica, de todo vínculo y de toda vinculación... ¿Cómo tendríamos el derecho de desconocer que el ascenso del cristianismo es un movimiento de décadence? (...) El ser humano no es un progreso con respecto al animal: el tierno retoño de la cultura es un aborto en comparación con un árabe o un corso; el chino es un tipo logrado, es decir, más capaz de durar que el europeo...639

Nietzsche escribe el término "decadencia” en francés -décadence-, con el que enfatiza su visión de la civilización occidental como corrosión degenerativa. El sentido

${ }^{639}$ Friedrich Nietzsche, Fragmentos póstumos. Volumen IV (Madrid: Tecnos, 2008), 626. 
en que aplica el término décadence recoge la analogía entre el cuerpo natural y el cuerpo social. A ojos de Nietzsche, el desarrollo de la humanidad no es muy distinto al de los organismos vivos y, al igual que todos los cuerpos, las civilizaciones portan los mismos ritmos vitales que cualquier organismo natural. No hay un progreso en la humanidad sino una inquebrantable degeneración. La decadencia es un declive inevitable de la vida, todo tipo de impotencia y debilitamiento del cuerpo son elementos constituyentes de los seres vivos, el cuerpo natural envejece y se descompone, así sucede en todos los procesos de la vida, tanto en los biológicos como en los históricos ${ }^{640}$.

El filósofo alemán encuentra cuatro tipos generales de décadence, el primer tipo se corresponde con la inducción del agotamiento a través de remedios aparentes, operación de la que forman parte el cristianismo y el progreso; el segundo tipo es la moral altruista, que despersonaliza y extiende la compasión como signo de debilidad personal; el tercero tiene que ver con la confusión de la causa y el efecto, puesto que negarle a la décadence su principio causal físiológico implica, además, ver los efectos de la decadencia como su origen; y el cuarto, que consiste en identificar la vida con los males que la afligen, un procedimiento que conduce al anhelo de los estados inconscientes ${ }^{641}$.

Nietzsche relaciona la décadence con lo enfermo, lo mórbido y lo débil, la moral y la filosofía occidentales se habrían resignado a estas formas de disminución. La moral y la filosofía quieren la debilidad, de modo que los valores supremos que promulgan contribuyen a exaltar lo frágil y vulnerable. Extenuar la voluntad de poder, los apetitos y los placeres es la tarea de la moral, tarea que solo conduce a renunciar a la vida ${ }^{642}$. La religión también agudiza los síntomas de la décadence, pues la religión alimenta los estados de mayor desafección con respecto a la corporalidad. El cansancio ante la vida, los momentos de degeneración, son enarbolados por la religión; la divinización de estos estados sale a la búsqueda de bienes superiores fuera del mundo, acción que Nietzsche trata como síntomas de trastorno ${ }^{643}$. Filosofía, moral y religión provocan la confusión fisiológica, malentendidos que sitúan a la enfermedad como forma superior, que prefieren la ebriedad y la impasividad del enfermo ${ }^{644}$. Según Nietzsche, los filósofos a

\footnotetext{
${ }^{640}$ Cfr. Nietzsche, ob. cit., 422-423.

${ }^{641}$ Cfr. Nietzsche, ob. cit., 700.

${ }^{642}$ Cfr. Nietzsche, ob. cit., 528.

${ }^{643}$ Cfr. Nietzsche, ob. cit., 529-530.

${ }^{644}$ Cfr. Nietzsche, ob. cit., 530.
} 
lo largo de la historia han detestado la vida, porque llevan consigo el instinto de la décadence, el instinto de la venganza ${ }^{645}$.

Para Nietzsche los seres humanos crean categorías mediante las que condicionan sus vidas, estas categorías hacen las veces de verdades que se imponen a la subjetividad como fundamentos que no pueden ser contradichos. Nietzsche, al igual que los utilitaristas, considera que las categorías con que los seres humanos condicionan sus vidas son cálculos acerca de lo útil, no son las ideas sino la utilidad la que opera tras la racionalidad, pero, en contra de los utilitaristas, cataloga como ingenuo tratar de extraer verdad de esa utilidad: <<el instinto de la utilidad de razonar como nosotros razonamos lo llevamos en el cuerpo, nosotros somos poco más o menos ese instinto... Pero qué ingenuidad, sacar de ahí la prueba de que poseamos por ello mismo una "verdad en sí" $>>646$. De la inclinación a la verdad surge el "hombre bueno" como tirano, aquel que impone los medios que valen para su vida determinada como fines para las vidas de todos los hombres, aquel que instaura sus condiciones de vida como formas únicamente válidas, o sea -tal como sugiere Nietzsche-, como la verdad, el bien o la perfección ${ }^{647}$. A medida que los hombres se aferran a las verdades creadas por otros "hombres tiranos" se van catapultando hacia el declive, dado que renuncian a su estilo de vivir, a crear sus propios valores.

La civilización ha sido caracterizada como el entorno donde se enarbolan el conocimiento, la perfectibilidad moral, la verdad, etc., pero para Nietzsche esta no sería símbolo de progreso sino, más bien, de decadencia; <<la civilización conlleva el declive fisiológico de la raza $>{ }^{648}$. Nietzsche encuentra que la civilización domestica al hombre y que tal domesticación va en contra de la naturaleza. En El crepúsculo de los ídolos asegura que la involución todavía es posible en Europa puesto que, aunque sus pueblos hayan abrazado los ideales de progreso, aun es factible la regresión. Simboliza a los conservadores como cangrejos, porque considera que estos promueven la marcha de las cosas hacia atrás, ahora bien, asevera que cuando las cosas marchan hacia delante se dirigen directamente hacia la decadencia; la décadence es la tendencia que mejor define al <<"progreso" moderno $>>649$. Para el filósofo de Röcken, por mucho que el

\footnotetext{
${ }^{645}$ Cfr. Nietzsche, ob. cit., 571.

646 Nietzsche, ob. cit., 579.

${ }^{647}$ Cfr. Nietzsche, ob. cit., 584.

${ }^{648}$ Nietzsche, ob. cit., 641.

${ }^{649}$ Friedrich Nietzsche, Obras completas. Volumen IV (Madrid: Tecnos, 2016), 679.
} 
conservadurismo intente obstruir el progreso, su única aportación será ahondar aún más en el declive histórico de la civilización.

Nietzsche considera que los intentos por parte de los moralistas de mejorar a la humanidad se corresponden con la doma y crianza del hombre. El propósito de mejorar a la humanidad se habría dado en todas las épocas y no consistiría en nada más que en tratar de domeñar a una bestia, y para ello se requiere de un violento sistema de presión contra su fisiología. Para contrarrestar el bestial carácter del hombre se precisa llevar a cabo un debilitamiento de las fuerzas de su cuerpo, bloquear sus instintos, pulsiones y violencia. Los moralistas se arrogaron el derecho de doma y crianza del hombre, de un animal más sobre la faz de la Tierra. En este razonamiento, Nietzsche estaría partiendo de los mismos presupuestos con que los evolucionistas caracterizaron al ser humano, considerándolo un animal más sin un lugar privilegiado en la historia natural. Pero Nietzsche se percata de que, entonces, si el ser humano es un animal, la moral no puede corresponderse más que con la doma y crianza de esta criatura natural, la doma y crianza de un ser instintivo, biológico, violento e impulsivo. Los moralistas, en cuanto "mejoradores" de la humanidad, lo único a lo que contribuyen es al envilecimiento de las cualidades naturales del hombre, pues tratan de modificar el carácter bestial de los humanos mediante la retención de sus instintos e impulsos corporales. Nietzsche ridiculiza las esperanzas de mejorar a la humanidad por medio de la moral y declara con especial estridencia que

llamar a la doma de un animal su "mejoramiento" es a nuestros oídos casi una broma. Quien sabe lo que sucede en las casas de fieras duda de que en esos sitios se "mejore" a la bestia. Se la debilita, se la hace menos dañina, se la convierte, con el afecto depresivo del miedo, con dolor, con heridas, con hambre, en una bestia enfermiza. ${ }^{650}$

La imagen del humano como un animal trajo importantes orientaciones para la configuración del pensamiento filosófico y científico del XIX. Nietzsche extrajo de esta imagen consecuencias definitivas y muy determinantes para la elaboración de su crítica contra los mejoradores del hombre, contra la moral tradicional y contra el optimismo del progreso. La civilización se corresponde con ese proceso envilecedor de la humanidad, una doma que fractura el poder natural que subyace a los hombres, un poder que no se encuentra en otra parte más que en la inmanencia corporal.

${ }^{650}$ Cfr. Nietzsche, ob. cit., 646. 
La civilización habría tratado de desactivar las tendencias instintivas de los cuerpos humanos con el propósito de proteger a la especie de la aniquilación, de tal forma que para Nietzsche la negación de los comportamientos salvajes en los hombres iría enfocada a superar las dificultades que impone el entorno natural. Pero, tal y como apunta Roberto Esposito en Inmunitas, la reflexión nietzscheana evidenciaría el carácter aporético que implica resguardar la vida a costa del envilecimiento del cuerpo, en la medida en que, al retener las fuerzas naturales de la corporalidad mediante un operativo inmunológico nihilista, también se contribuye a la neutralización de su fortaleza, ya que $<<$ esa defensa de la vida se vale de un instrumento ideal de tipo ascético que al mismo tiempo la niega > ${ }^{651}$. Para Esposito, Nietzsche habría puesto de relieve cómo esta estrategia de inmunización tiene un efecto retroactivo que termina volviéndose contra el hombre, en cuanto que agudiza esas mismas falencias a las que este pretendía sobreponerse en un inicio $^{652}$. A tenor del ejercicio interpretativo del autor italiano, construido desde la latitud de la antropología inmunitaria, es posible darle un mayor sentido y grado de comprensibilidad a esa pesquisa nietzscheana sobre la imposibilidad de progreso en la civilización, a saber, que cuanto mayor sea su avance más se precipitará hacia el colapso, en la medida en que el desarrollo civilizatorio se da a costa de anular los componentes que integran la fortaleza vital.

El cuerpo en la filosofía nietzscheana es presentado como objeto de crianza y domesticación de la civilización. El tiempo de la civilización, es decir, la historia del hombre, se corresponde con un proceso de desfiguración de la corporalidad en cuanto eje natural que caracteriza a los seres humanos como organismos vivos, organismos originalmente indiferenciados del resto de seres vivos. La desfiguración del cuerpo consiste en debilitar sus fuerzas, en disminuir el potencial inmanente a la corporalidad humana. La historia coincide con un proceso que cercena el poder del cuerpo, proceso que desfigura el potencial de las corporalidades vivas que caracterizan a los hombres. Nietzsche plantea cómo el poder originario del cuerpo ha sido transfigurado por la civilización, de manera que la historia de la humanidad es propiamente el reflejo de la dominación ejercida sobre el cuerpo, un dominio que consiste en desarticular el poder inmanente a las fuerzas originarias de la corporalidad.

\footnotetext{
${ }^{651}$ Roberto Esposito, Inmunitas. Protección y negación de la vida (Buenos Aires: Amorrortu, 2009), 126. ${ }^{652}$ Cfr. Esposito, ob. cit., 127.
} 
A este respecto, conviene destacar la forma en que Foucault concibe la genealogía nietzscheana, como investigación del Herkunft (origen-procedencia) ${ }^{653}$ de los errores sancionado por la verdad. Según Foucault <<es el cuerpo el que lleva, en su vida y su muerte, en la fuerza y su debilidad, la sanción de toda verdad y de todo error, como también lleva, e inversamente, el origen-procedencia $>>{ }^{654}$. Foucault trata de advertir cómo Nietzsche sitúa al cuerpo en el "doble filo" de la voluntad de poder, ya que, del mismo modo en que la verdad nace de la voluntad de poder como una forma de dominio, también, esta verdad termina devaluando la vida, pues la verdad se plasma sobre la corporalidad como estigma sancionador dilatado a lo largo de la historia:

El cuerpo: superficie de inscripción de los acontecimientos (mientras que el lenguaje los marca y las ideas los disuelve), lugar de disociación del Yo (al que trata de prestar la quimera de una unidad substancial); volumen en perpetuo desmoronamiento. La genealogía, como análisis de la procedencia, está, pues, en la articulación del cuerpo y de la historia. Debe mostrar el cuerpo totalmente impregnado de historia y la historia arruinando al cuerpo. ${ }^{655}$

Lo corporal se convierte en receptáculo pasivo de la historia, en el soporte sobre el que se plasman una verdad y un error, en el objeto paciente de un poderío-dominante desprendido con respecto al cuerpo activo de la voluntad de poder. El tiempo de la historia civilizada en Nietzsche es la historia de la dominación sobre el cuerpo. La decadencia es un instinto más, un instinto que procede de los impotentes, enfermos y agotados cuando tratan de dominar, la prueba en la que se basa Nietzsche es $<<$ la absoluta inmoralidad de los medios en la historia entera de la moral $>{ }^{656}$. Sería un

\footnotetext{
$653<<$ Herkunft: es el tronco, la procedencia; es la vieja pertenencia a un grupo -el de la sangre, el de la tradición, el que se orea entre los de una misma nobleza o una misma bajeza-. A menudo, el análisis de la Herkunft hace intervenir la raza o el tipo social. Sin embargo, no se trata tanto de encontrar en un individuo, un sentimiento o una idea, los caracteres genéricos que permiten asimilarlo a otros, $-\mathrm{y}$ decir: este es griego, o este es inglés-, como de descubrir todas las marcas sutiles, singulares, subindividuales que pueden entrecruzarse en él y formar una red difícil de desenmarañar. Lejos de ser una categoría de semejanza, tal origen permite separar, para ponerlas aparte, todas las marcas diferentes: los alemanes se imaginan haber llegado al máximo de su complejidad cuando han dicho que tenían el alma doble; se han quedado muy cortos, o más bien tratan de dominar como pueden la mezcolanza de razas de la que están constituidos. Allí donde el alma pretende unificarse, allí donde el Yo se inventa una identidad o una coherencia, el genealogista parte a la búsqueda del comienzo, -de los innumerables comienzos que dejan esa sospecha de color, esa marca casi borrada que no podrían engañar a un ojo un poco histórico-; el análisis de la procedencia permite disociar el Yo y hace pulular, en los lugares y posiciones de su síntesis vacía, mil acontecimientos ahora perdidos〉>. Michel Foucault, Nietzsche, la genealogía, la historia (Valencia: Pre-textos, 2014), 25-26.

${ }^{654}$ Michel Foucault, Nietzsche, la genealogía, la historia (Valencia: Pre-textos, 2014), 30-31.

${ }^{655}$ Foucault, ob. cit., 32.

${ }^{656}$ Friedrich Nietzsche, Fragmentos póstumos. Volumen IV (Madrid: Tecnos, 2008), 571.
} 
contrasentido y una redundancia suponer que hay un origen moral en la historia de la moral, Nietzsche dilucida que el principio de esta historia fue impulsado por un instinto decadentista procedente de la voluntad de poder.

La voluntad de poder, en cuanto forma de poder originaria, propia de la vida, mana de lo orgánico y siempre se halla en sintonía directa con los cuerpos. A medida que los poderes tienden a reaccionar frente a la constante actualidad activa de la voluntad de poder, declinan la vida; este proceso declinante es el movimiento fundacional de la historia de la civilización, aquel que degrada la vida a través de la desfiguración sistemática del cuerpo.

\subsubsection{LA CORPORALIDAD COMO POTENCIA INMANENTE EN EL DESARROLLO DE LA VIDA: CRÍTICAS DE NIETZSCHE Y BERGSON AL EVOLUCIONISMO DARWINISTA}

Una de las corrientes de pensamiento filosófico que más críticas esgrimió contra el evolucionismo darwinista fue el vitalismo. A raíz de las diatribas planteadas por Nietzsche y Bergson, autores considerados dentro de la corriente vitalista, cabe tener en cuenta las claves principales de una oposición a los cánones del evolucionismo tal y como lo formuló la escuela de Darwin, una oposición que se sostuvo en el recurso a un poder inmanente a la naturaleza corporal de los organismos. Si bien es cierto que ninguno de ambos autores sacude al evolucionismo desde la perspectiva concreta de la confrontación de ideologías (liberalismo, socialismo, comunismo, anarquismo, etc.), igualmente, hay una operación dentro de esas críticas que reivindica un poder inherente a la corporalidad, un poder que tendría lugar en las fuerzas y capacidades de los cuerpos naturales en detrimento de poderes abstractos y externos a las dinámicas fisiológicocorporales.

En la teoría evolucionista se hacía palpable un poder implícito que toma forma en el entorno de la lucha por la vida y que se erige bajo la figura directriz de las "leyes de selección natural”.

En consonancia con lo anterior, huelga tomar como punto de partida las líneas generales con que Nietzsche se opuso de manera vehemente a las tesis evolucionistas: en los aforismos titulados "Anti-Darwin" Nietzsche dice que no hay una lucha por la vida tal como el naturalista británico la concibió; solo acepta la presencia de una lucha, pero esta no se produciría en medio de la precariedad y la necesidad; Darwin supuso una naturaleza malthusiana. Según Nietzsche, como la vida es derroche y exuberancia, 
toda lucha se dará por el poder antes que por la sobrevivencia ${ }^{657}$. Además, el filósofo alemán pugna contra los esfuerzos realizados por la escuela darwiniana a la hora de justificar subrepticiamente la domesticación del ser humano. La domesticación no alcanza grandes cuotas de mejora sobre los hombres, puesto que $<<$ hasta ahora no se ha demostrado nada, excepto un efecto enteramente superficial debido a la domesticación $\mathrm{o}$, en todo caso, se ha demostrado la degeneración $>>{ }^{658}$. También, Nietzsche repudia la idea extendida de que son los caracteres de los individuos más fuertes los que se conservan en la naturaleza, dado que normalmente suelen prevalecer los individuos más numerosos y comunes sobre los más potentes y excepcionales:

Mientras no se nos indique la razón de por qué el ser humano es la excepción entre las criaturas, me inclinaré a prejuzgar que la escuela de Darwin se ha equivocado en todas las cuestiones. Esa voluntad de poder en la que yo vuelvo a reconocer la razón y el carácter últimos de toda alteración nos proporciona el medio de saber por qué precisamente la selección no se lleva a cabo en favor de las excepciones y de los casos afortunados: los más fuertes y los más felices son débiles cuando tienen en su contra los instintos de rebaño organizados, la pusilanimidad de los débiles, la preponderancia del número. Mi visión global del mundo de los valores muestra que, en los valores supremos que hoy en día están dispuestos por encima de la humanidad, no predominan los casos afortunados, los tipos seleccionados: al contrario, son los tipos de la décadence -quizá no haya nada más interesante en el mundo que este espectáculo indeseado... ${ }^{659}$

Nietzsche considera "espectáculo indeseado" a la escenificación de los tipos enfermizos de la décadence extendiendo su dominación sobre los casos más saludables de la vida, ese escenario decadentista tiene lugar en todos los recovecos de la naturaleza; los casos afortunados, por el hecho de ser excepciones, no gozan de elevada fecundidad.

En lo que se refiere a Henri Bergson, aunque su obra madura se dio más bien hacia la primera mitad del siglo XX, este autor dialoga intensamente con el evolucionismo decimonónico. Bergson subordina lo inteligible a las necesidades de la vida. Para el filósofo francés, el cerebro es el órgano sobre el que se sostiene el pensamiento, es decir que la actividad mental requiere apoyarse sobre una base biológica cerebral. La vida del

\footnotetext{
${ }^{657}$ Cfr. Friedrich Nietzsche, Obras completas. Volumen IV (Madrid: Tecnos, 2016), 662.

${ }^{658}$ Friedrich Nietzsche, Fragmentos póstumos. Volumen IV (Madrid: Tecnos, 2008), 568.

${ }^{659}$ Nietzsche, ob. cit., 561.
} 
cerebro es el plexo fisiológico que mantiene activa la vida espiritual, dice Bergson al respecto:

No es, pues, propiamente hablando, [el cerebro] órgano de pensamiento, ni de sentimiento, ni de conciencia, sino que hace que conciencia, sentimiento y pensamiento se mantengan atentos a la vida real y sean por consiguiente capaces de acción eficaz.

Digamos, si quieren ustedes, que el cerebro es el órgano de la atención a la vida. ${ }^{660}$

En cuanto al asunto de la evolución, en La evolución creadora Bergson afirma que $<<$ la materia viva parece no tener otro medio de sacar partido de las circunstancias que adaptarse primero pasivamente a ellas; allí donde debe tomar la dirección de un movimiento, comienza primero por adoptarlo $>{ }^{661}$. Lo que el autor quiere decir es que en la evolución de las especies toda modificación adaptativa tiene como punto de partida la inmanencia corporal. Según Bergson, el individuo extrae ventajas de su entorno acondicionando su cuerpo. La adaptabilidad no dependería solo de las características somáticas del individuo ni de las condiciones ambientales en que está inmerso, sino que de cada individuo emana una fuerza que lo impulsa a acomodarse a sus circunstancias. El punto de vista de Bergson no acepta, por tanto, la idea de que haya unas leyes rígidas externas a la corporalidad que expliquen en rasgos generales y comunes el proceso evolutivo de todos los organismos. La capacidad pasiva de adaptación de las especies se presenta como una suerte de morfología variable acoplable a la naturaleza en función de los caracteres germinales que cada organismo va arrastrando de generación en generación. Bergson propone el siguiente ejemplo para ilustrar su explicación de la evolución:

De suerte que podemos preguntarnos siempre si lo que se transmite es el hábito adquirido por el soma del individuo o es, antes bien, una aptitud natural anterior al hábito contraído; esta aptitud habría quedado como inherente al germen que el individuo lleva en sí, como era ya inherente al individuo y, por consiguiente, a su germen. Así, nada prueba que el topo se haya vuelto ciego por haber contraído el hábito de vivir bajo tierra; quizá porque sus ojos estaban en camino de atrofiarse es por lo que el topo ha tenido que condenarse a la vida subterránea. En este caso, la tendencia a perder la vista se habría transmitido de germen en germen sin que nada se hubiese adquirido por el soma del topo mismo. ${ }^{662}$

\footnotetext{
${ }^{660}$ Henri Bergson, El alma y el cuerpo seguido de El cerebro y el pensamiento: una ilusión filosófica (Madrid: Ediciones Encuentro, 2009), 32.

${ }^{661}$ Henri Bergson, Obras escogidas (Aguilar: Madrid, 1963), 499.

${ }^{662}$ Bergson, ob. cit., 506-507.
} 
Para Bergson, el cuerpo es un sistema cerrado que tiende a aislarse de la naturaleza. El cuerpo siempre permanece cambiable, el concepto de corporalidad al que alude implica necesariamente pensar el cuerpo vivo, es decir, el organismo en movimiento. Aunque la vida corporal se pliegue de manera natural, la evolución resulta ineludible y el cambio de una cualidad a otra es un tránsito que todo cuerpo vivo experimenta. En este aspecto, la forma no sería más que un instante, y los momentos que se suceden en el desarrollo de la vida son un conjunto sucesivo cambiante de instantáneas, al igual que en el arte cinematográfico ${ }^{663}$.

Según Bergson, la evolución de las especies no sigue una sola directriz unilineal predeterminada con cada nueva especie que surge; de nuevo, el pensador se opone al modelo evolucionista impuesto por los naturalistas del XIX, quienes habrían puesto a los cuerpos bajo el dominio de una rigurosa linealidad, como si hubiera una mecánica o planificación operante en las variaciones evolutivas. De este modo, compara el estallido de una granada con el movimiento expansivo de la evolución:

El movimiento evolutivo sería una cosa sencilla y podríamos fácilmente determinar su dirección, si la vida describiese una trayectoria única, comparable a la de la bala maciza lanzada por un cañón. Pero tenemos que habérnoslas aquí con una granada que ha estallado inmediatamente en fragmentos, los cuales se han dividido a su vez en nuevas granadas destinadas a estallar, y así sucesivamente. No percibimos más que lo que está cercano a nosotros, los movimientos dispersos de los trozos pulverizados. Partiendo de ellos hemos de remontarnos, gradualmente, hasta el movimiento original. ${ }^{664}$

Así, por tanto, la fragmentación de las especies en el proceso evolutivo sería comparable a una explosión porque se produce al modo de un efecto expansivo. La vida experimenta la resistencia de su materia bruta, o sea, del cuerpo de cada uno de los individuos. Al igual que en el estallido de la granada interactúan la fuerza expansiva de la pólvora y la resistencia de la materia que la contiene, en la evolución el cuerpo hace las veces de esta materia bruta, cuya resistencia tiende a contener el impulso expansivo de la vida. La corporalidad en la concepción bergsoniana de evolución actuaría como una fuerza de resistencia.

Tras los planteamientos bergsonianos acerca de la evolución se puede apreciar un inmanentismo corporal en el que los cuerpos cobran una centralidad con respecto a las

\footnotetext{
${ }^{663}$ Cfr. Bergson, ob. cit., 697.

${ }^{664}$ Bergson, ob. cit., 523.
} 
tendencias evolutivas generales de la vida. Bergson propone una explicación de la evolución que tan pronto está mirando a las circunstancias externas de los cuerpos así como hacia el interior de estos, es decir, hacia su potencia inmanente y a la capacidad de resistencia que albergan las corporalidades. La inmanencia corporal tiene presencia en las variaciones evolutivas de tal forma que no se podrían establecer leyes constantes iguales para todos los seres vivos. No solo son las circunstancias ambientales las que ponen en movimiento la evolución sino también el impulso interior de los seres vivos a la hora de crear y buscar sus propios entornos. En consecuencia, Bergson estaría cuestionando muy duramente la teoría de la selección natural al concederle a las condiciones intrínsecas de los cuerpos una plasticidad flexiva creativa y no subordinada a procedimientos selectivos prediseñados.

En el vitalismo, tanto en el de Nietzsche como en el de Bergson, se reivindican los actos creativos de la vida como formas naturales de actuar que parten de las propias fuerzas intrínsecas al cuerpo de los individuos. En lugar de suponer la supeditación de la vida a leyes generales externas a los cuerpos, el vitalismo, en rasgos generales, evita reglamentar o suponer una reglamentación en los procesos de la vida. Nietzsche vendría a suponer que en la naturaleza no hay una legalidad selectiva, sino que son las tendencias gregarias las que priman en la herencia de caracteres sin que prevalezcan las singularidades de los más fuertes. Por otro lado, Bergson consideraría que ante la variabilidad de la naturaleza, los seres vivos trazan sus propias estrategias para sobrevivir, de acuerdo a una potencia creadora inmanente procedente de las entrañas del cuerpo; se podría decir, en correspondencia con la perspectiva bergsoniana, que en la teoría de la selección natural pareciera que los cuerpos son movidos mecánicamente o de acuerdo con un plan "genético" ya trazado, lo que no se correspondería en ningún caso con el grado de incertidumbre que arroja la naturaleza en determinadas situaciones o en determinados contextos especiales.

La creencia en una evolución progresiva impone directrices en las que se proyecta una trayectoria que forzosamente habría de guiar el desarrollo de los cuerpos. Tanto en la idea de progreso como en la teoría de la evolución se aprecia cómo, en ambos casos, se presupone la existencia de unos márgenes preestablecidos que indican cuál ha de ser el comportamiento de los individuos y los grupos humanos en el tiempo. Pero estas indicaciones directivas saldrían, o bien de un espíritu que levita sobre la naturaleza y traza su propio plan en la humanidad (Hegel), o bien de unas revelaciones hechas por un 
científico que cree haber descubierto unas leyes naturales actuando en secreto a lo largo de la historia zoológica y antropológica (los evolucionistas). Así, el vitalismo y otros planteamientos filosóficos alternativos trataron de devolverle a los cuerpos un poderío que otras filosofías le habían incautado a favor de ordenamientos extrínsecos. 


\section{CUARTA PARTE: LO CORPORAL}

\section{COMO SUJETO DE PODER Y OBJETO DE DOMINACIÓN}




\section{SECCIÓN I. CUERPO COSIFICADO Y CUERPO ESPIRITUALIZADO}

\subsubsection{MERLEAU-PONTY: CONCIENCIA Y CUERPO EN EL PENSAR FENOMENOLÓGICO}

Una de las vertientes filosóficas originarias y propias del siglo XX que resueltamente transformaron la imagen moderna de la corporalidad fue la fenomenología. Uno de los pensadores precursores de la filosofía fenomenológica, Franz Brentano, estableció una clasificación basal en la distinción de los fenómenos: los fenómenos físicos por un lado y los fenómenos psíquicos por otro ${ }^{665}$. De esta forma, por ejemplo, el sentimiento de dolor sería una representación interna que se asocia con determinadas situaciones en las que el cuerpo sufre algún tipo de lesión; según Brentano, entonces, hay una diferencia entre el dolor que pueda afectar a alguna parte del cuerpo y la base representacional del dolor como sentimiento, cuyo origen es psicológico ${ }^{666}$. El pensador alemán encuentra que la diferenciación entre ambos tipos de fenómenos es intuitiva, define $<<$ los fenómenos psíquicos como representaciones, y como fenómenos que descansan sobre las representaciones que les sirven de fundamento; todos los demás fenómenos pertenecen a los fenómenos físicos $>{ }^{667}$.

Husserl comparte esta misma distinción de los fenómenos, de tal manera que lo fenoménico tendría necesariamente una dimensión interna que fundamenta el orden de las percepciones. En ideas relativas a una fenomenología pura y una filosofía fenomenológica Husserl busca un reducto de la conciencia escindido de los contenidos empíricos, ese reducto es la conciencia pura trascendental y es un lugar genuino y exclusivo al margen del mundo físico. El Yo está en constante interacción con las cosas y ahí también está involucrado el cuerpo, pero -se pregunta Husserl- < ¿Cómo se segregan y pueden segregarse la conciencia misma como un ser concreto en sí y el ser de que se tiene conciencia en ella, el ser percibido como un ser que "hace frente" a la

\footnotetext{
${ }^{665}$ Concretamente uno de los párrafos más reveladores de Psicología hace ostensible la diferencia entre los fenómenos físicos con respecto a los psicológicos mediante el siguiente razonamiento: <<podríamos caracterizar fácil y exactamente los fenómenos físicos frente a los psíquicos, diciendo que son aquellos que aparecen extensos y en el espacio. E inmediatamente, los psíquicos serían definibles, frente a los físicos, con la misma exactitud, como aquellos fenómenos que no tienen extensión ni una determinación local〉>, (Argentina: Editorial Schapire, 1951), 18.

${ }^{666}$ Cfr. Brentano, Psicología (Argentina: Editorial Schapire, 1951), 17.

${ }^{667}$ Brentano, ob. cit., 30-31.
} 
conciencia y "es en sí y por sî"? > 668. Afirma el autor que el mundo no es exclusivamente físico sino que es psicofísico; en él circundan seres animados o "realidades animadas", por ello hay una mixtura en los individuos vivos entre lo psíquico y lo físico y, así, al mundo pertenecen <<todas las corrientes de conciencia unidas a los cuerpos animados $>{ }^{669}$. Ahora bien, se pregunta el filósofo alemán cómo es posible conciliar la concepción de una conciencia como un absoluto trascendente, es decir, una conciencia autónoma e independiente de las condiciones físicas del mundo, con una conciencia inmersa en los procesos psicofísicos de la vida ${ }^{670}$.

Una conciencia es humana o animal en la medida en que se vincula con lo empírico, por lo que toda relación empírica sitúa a la conciencia en un espacio y tiempo concretos. El humano adquiere su concreción espacio-temporal en la naturaleza solo si su conciencia viene asociada a una dimensión física. El natural enlace intuitivo-empírico pone a los organismos vivos en interacción con el mundo. Las acciones e interacciones de los seres animados tienen a la conciencia como un ser aperceptivo, lo que implica que en el enlace intuitivo-empírico la conciencia no se da en su forma pura. Conciencia y cuerpo son dos formas distintas, lo que aparece en el mundo es el cuerpo, la conciencia no aparece, es apercibida, no como los objetos físicos, que son inmediatamente perceptibles ${ }^{671}$.

Para Husserl, la conciencia en sí misma es una esencia absoluta, una esencia que aún integrada psicofísicamente no pierde su esencialidad, por ello es aperceptible en el mundo, por ello se distingue esencialmente del cuerpo de los seres vivos y de los objetos inertes. La conciencia es apercibida y, se podría añadir, "pasa desapercibida" en el encuentro entre un ser vivo y otro ser vivo. Husserl considera que la conciencia no aparece en el mundo al modo en que se perciben los objetos físicos, sino que está incluida en una unidad psicofísica de la que solo resulta perceptible un cuerpo. La conciencia es

"apercibida como un algo"; y en esta apercepción sui generis se constituye una trascendencia sui generis: aparece un estado de conciencia de un sujeto-yo idéntico, real en sentido estricto, que da a conocer en él sus propiedades individuales y reales en el

\footnotetext{
${ }^{668}$ Edmund Husserl, Ideas relativas a una fenomenología pura y una filosofía fenomenológica (México D.F: Fondo de Cultura Económica, 1949), 89.

${ }^{669}$ Husserl, ob. cit., 125.

${ }^{670}$ Cfr. Husserl, ob. cit., 125.

${ }^{671}$ Cfr. Husserl, ob. cit., 126.
} 
mismo sentido y del que se tiene conciencia - en cuanto es esta unidad de propiedades que se dan a conocer en estados- como único en el cuerpo que aparece. Bajo la forma del aparecer se constituye así la unidad psicofísica natural hombre o animal como una unidad fundada en el cuerpo, respondiendo a lo fundado de la percepción. ${ }^{672}$

Cuando la conciencia se involucra en el mundo a través del ser animado que tiene como suyo, lo hace solo por medio de una inmanencia viviente, ahora bien, la esencia de la conciencia consiste en ser trascedente. Según ejemplifica Husserl, cuando tenemos una sensación de alegría se dan dos actitudes: la psicológica y la fenomenológica; la primera apunta a la vivencia como expresión que se refleja en la propia corporalidad, lo que supondría expresar el sentimiento de alegría físicamente hacia el exterior como un estado manifiesto, mientras que la actitud fenomenológica es una apercepción de la vivencia absoluta, tal como el sentimiento de alegría es interiorizado y no expresado al exterior, como siendo únicamente internalizado en la conciencia ${ }^{673}$.

La corporalidad, en la filosofía fenomenológica, es una entidad física que recoge y muestra la presencia de un ser viviente; la corporalidad está en el mundo, se hace evidente a otros seres animados y conforma una apertura para la conciencia. En lo relativo a la conciencia pura, el cuerpo no es una neutralidad, sino que viene condicionado, está lateralizado hacia el mundo, se halla dentro de un lugar y momento determinados. Pero la conciencia tiene la capacidad de hermetizarse dentro del cuerpo animado, ocultarse, escindirse de la dimensión corporal y permanecer inaccesible a los otros. La fenomenología establece esta escisión entre el cuerpo y la conciencia, el primero está forzosamente expuesto al conjunto del mundo, la segunda permanece oculta en el interior de este. El planteamiento derivado de la reflexión fenomenológica es asumido, profundizado y desarrollado de manera amplia por el filósofo Maurice Merleau-Ponty, quien, al comienzo del "Prólogo" de su obra Fenomenología de la percepción, dice que la fenomenología <<es el estudio de las esencias y, según ella, todos los problemas se resuelven en la definición de esencias $>>$, de modo que $<<$ la fenomenología es asimismo una filosofía que re-sitúa las esencias dentro de la existencia y no cree que pueda comprenderse al hombre y al mundo más que a partir de su facticidad $>>674$.

\footnotetext{
${ }^{672}$ Husserl, ob. cit., 126-127.

${ }^{673}$ Cfr. Husserl, ob. cit., 127.

${ }^{674}$ Maurice Merleau-Ponty, Fenomenología de la percepción (Barcelona: Ediciones Península, 1994), 7.
} 
Una filosofía que trata de comprender al hombre y al mundo en el terreno de lo fáctico no reduciría las esencias al dominio de la idealidad, consecuentemente, para Merleau-Ponty, la fenomenología es una filosofía de las esencias que se esfuerza por alejarse del idealismo; como también dijera anteriormente su compañero Jean-Paul Sartre en la "Conclusión" de la Trascendencia del Ego $(1934)^{675}$ : que aunque algunos teóricos le hubieran reprochado un supuesto sesgo idealista a la fenomenología, lo cierto es que hacía siglos que <<no se había sentido en la filosofía corriente tan realista >> y que tal <<reproche no tendría más razón de ser, si se hace del Yo (Moi) una existente rigurosamente contemporáneo del mundo y cuya existencia tenga las mismas características esenciales que el mundo $\gg{ }^{676}$. Así, entonces, el sujeto de la fenomenología estaría inserto en el mundo compartiendo las vicisitudes de la vida y de la historia, pues si las esencias tienen su recorrido en la existencia, la esencialidad de la conciencia y la actualidad fáctica del cuerpo se desenvuelven, por tanto, en una misma realidad.

Merleau-Ponty plantea la fenomenología como un "ir a las cosas mismas", no se trata de explicar las cosas sino de describirlas, la fenomenología es una "psicología descriptiva" en la que uno mismo no puede pensarse como un mero objeto biológico, psicológico o sociológico y clausurase en el discurso de las ciencias. El Yo no es lo que la ciencia positiva refleja, no es la imagen del ser viviente zoológico o social de los discursos científicos, estas imágenes proceden de la naturaleza y de la historia en la que los hombres viven como instantes, pero no son esos instantes los que revelan el modo de la existencia del Yo; este es un absoluto dado a una conciencia que organiza las esencias del mundo. Retornar a las cosas mismas significa regresar a un mundo anterior al conocimiento científico, seguir la pista de aquello acerca de lo que el conocimiento habla ${ }^{677}$. Afirma Merleau-Ponty que la fenomenología tiene, como su adquisición más relevante, <<haber unido el subjetivismo y el objetivismo extremos en su noción del mundo o de la racionalidad $>{ }^{678}$. En el pensamiento fenomenológico no hay lugar para espiritualidades al margen de las experiencias ni tampoco para el mundo de los realistas.

\footnotetext{
${ }^{675}$ Merleau-Ponty publicó la Fenomenología de la percepción en 1945.

676 Jean-Paul Sartre, La trascendencia del Ego (Argentina: Ediciones Calden, 1968), 79.

677 Cfr. Maurice Merleau-Ponty, Fenomenología de la percepción (Barcelona: Ediciones Península, 1994), 9-10.

${ }^{678}$ Merleau-Ponty, ob. cit., 19.
} 
El mundo fenomenológico es, no ser puro, sino el sentido que se transparenta en la intersección de mis experiencias y en la intersección de mis experiencias con las del otro, por el engranaje de unas con otras; es inseparable, pues, de la subjetividad e intersubjetividad que constituyen su unidad a través de la reasunción de mis experiencias pasadas en mis experiencias, y nadie sabe mejor que nosotros cómo se efectúa por primera vez, la meditación del filósofo es lo bastante consciente como para no realizar en el mundo y antes de ella misma sus propios resultados ${ }^{679}$.

Precisamente Merleau-Ponty apunta que la retirada fenomenológica hacia la unidad de la conciencia no busca fundamentar la existencia del mundo, sino encontrar aquellas distancias que dan pie a las trascendencias que entrelazan intencionalmente a la conciencia con el mundo ${ }^{680}$.

\subsubsection{El CUERPO OBJETIVO ES UN EXTRAÑO: REDESCUBRIMIENTO DE LA CORPORALIDAD}

En la segunda parte de la novela de Milan Kundera La insoportable levedad del ser, titulada "El alma y el cuerpo" (la cuarta parte se titula igual), el literato comenta cuál fue la inspiración de la que surgió la protagonista femenina de su novela, Teresa, la cual $<<$ nació de una barriga que hacía ruido>> ${ }^{681}$. Teresa simboliza la dualidad cuerpo-alma que, según Kundera, <<ha quedado velada por los términos científicos y podemos reírnos alegremente de ella como de un prejuicio pasado de moda $>{ }^{682}$. A Teresa le sonaban las tripas debido a que había iniciado un tormentoso viaje en contra de la voluntad de su madre para vivir con Tomás, el protagonista masculino de la novela, y a causa del ensimismamiento que le producía el amor hacia él, Teresa apenas comió un sándwich en todo el día. A través de este personaje Kundera contrapone el discurso científico, que reduce todas las variaciones emocionales a movimientos de la materia gris del cerebro, con los efectos producidos por el enamoramiento. Así, los estados sentimentales disolverían eventualmente el monismo materialista propugnado por la ciencia.

Kundera relata cómo Teresa tiene la costumbre de mirarse desnuda al espejo, no por vanidad, sino porque a través de este ritual trataba de descubrirse a sí misma. Cuenta el autor que frente al espejo su personaje pasaba por alto

\footnotetext{
${ }^{679}$ Merleau-Ponty, ob. cit., 19.

${ }^{680}$ Cfr. Merleau-Ponty, ob. cit., 13.

${ }^{681}$ Milan Kundera, La insoportable levedad del ser (Barcelona: Fabula Tusquets Editores, 2005), 47.

${ }^{682}$ Kundera, ob. cit., 48.
} 
que estaba viendo el tablero de instrumentos de los mecanismos corporales. Le parecía ver su alma, que se le daba a conocer en los rasgos de su cara. Olvidaba que la nariz no es más que la terminación de una manguera para llevar el aire a los pulmones. Veía en ella la fiel expresión de su carácter. ${ }^{683}$

Detrás de esa admiración embaucadora por el reflejo de su cuerpo desnudo, se hallaba la dolorosa historia familiar de Teresa, cuya madre, adúltera y presta a disfrutar de manera desenfrenada los goces que su belleza le había brindado, un día se descubrió envejecida frente al espejo y vio cómo esa belleza de la juventud ya se había esfumado. Tras su último adulterio con un estafador que terminó en la cárcel, la madre perdió todo y su hija Teresa fue privada de continuar sus estudios, siendo obligada a trabajar en una taberna y a cuidar de sus hermanos pequeños ${ }^{684}$. Teresa fue retenida por su madre <<en el mundo de la desvergüenza, donde la juventud y la belleza nada significan, donde todo el mundo no es más que un enorme campo de concentración de los cuerpos que se parecen el uno al otro y en los que las almas son invisibles >> ${ }^{685}$. Por esta razón, la protagonista de Kundera trata de descubrirse en el espejo, porque busca su alma en la imagen de su cuerpo, porque está resuelta a encontrar una genuina autenticidad en esta imagen y extraer de ella la prueba de su singularidad diferenciadora.

La filosofía del cuerpo en la etapa del siglo XX atravesó una problemática similar a la del personaje de Kundera, es una etapa donde la ciencia había reducido el cuerpo y el alma a una misma materialidad fisiológica; allí donde el discurso objetivista de la ciencia hacía de los cuerpos una misma cosa, todavía la filosofía buscaba ese componente espiritual perdido. El alma, aquella dimensión interior invisible de los seres humanos, tenía que emerger de alguna manera al exterior para recobrar la corporalidad. Este fue el cometido de la filosofía de Merleau-Ponty, a la que subyace esa añoranza por recuperar la imagen del cuerpo perdido, el cuerpo del "sí mismo", que ya no es solo un manojo de piel, órganos, sangre y huesos, sino que está habitado por un ser invisible para los otros, un ser que no aparece a la mirada pero que tiene su existencia. Ahora bien, lejos de las miradas meramente superficiales, este ser invisible puede llegar a exteriorizarse en las relaciones intersubjetivas, de modo que, finalmente, la corporalidad tiende un lazo entre el mundo interior de los sujetos y el mundo exterior de los otros.

\footnotetext{
${ }^{683}$ Kundera, ob. cit., 49.

${ }^{684}$ Cfr. Kundera, ob. cit., 51-54.

${ }^{685}$ Kundera, ob. cit., 54.
} 
Xavier Escribano, en un artículo titulado Maurice Merleau-Ponty: el anclaje corpóreo en el mundo, menciona que en el pensamiento del filósofo francés se aprecia una contraposición clara entre la actitud fenomenológica y la actitud de las ciencias positivas: especialmente la ciencia empírica busca únicamente dominar el mundo tratando a todas las cosas como objetos, para ello, inventa un mundo dominado que no es el de la "experiencia habitante". La ciencia no busca las esencias, tan solo le atribuye modelos y variables a las cosas, no experimenta el mundo a través del contacto directo con los entes naturales, solo lo hace por medio de la manipulación técnica ${ }^{686}$. También, apunta Escribano que el filósofo francés parte de una ontología contrapuesta a la de Descartes, en la que el cuerpo es un objeto subordinado a una conciencia transparente ante sí misma y sin anclaje físico alguno, ya que la corporalidad es un mero objeto carente de una dimensión espiritual ${ }^{687}$. Para Escribano, el cuerpo merleaupontyano se asocia al concepto de un sujeto corporal, pese a que ello conlleve instalar una

oscuridad en la autocomprensión y en la comprensión del mundo: aparece como un modo de ser "ambiguo" en el que no se discierne con claridad qué pertenece al orden del sujeto o del objeto, de lo activo o lo pasivo, de lo interior o lo exterior, del espíritu o de la naturaleza, que son dicotomías clásicas del pensamiento moderno. ${ }^{68}$

En el Ojo y el espíritu, Merleau-Ponty afirma que el pensamiento del alma se da <<según el cuerpo, no según ella misma, y en el pacto natural que la une a él se estipula también el espacio, la distancia exterior $>{ }^{689}$. Mediante esta afirmación el autor está saliendo al paso de la teoría que Descartes planteó, propensa a hacer más pronunciada la dualidad cuerpo-alma, una dualidad que desgarraba la naturaleza del alma de la naturaleza del cuerpo, en la que su unión parecía solo fortuita y en la que lo corporal quedaba supeditado únicamente a la dimensión exterior objetual; así, el cartesiano que se mira al espejo $<<$ ve un maniquí, un "afuera" del que tiene todas las razones para pensar que los otros lo ven de forma similar $>>690$.

La herencia moderna del cartesianismo profundizó en especificar las diferencias fundamentales entre el cuerpo y el alma, la corporalidad pasó a ocupar el lado del objeto

\footnotetext{
${ }^{686}$ Cfr. Francesc Xavier Escribano López, "Maurice Merleau-Ponty: el anclaje corpóreo en el mundo", Thémata, no. 22 (1999): 67-79, 69.

${ }^{687}$ Cfr. Escribano, ob. cit., 70.

${ }^{688}$ Cfr. Escribano, ob. cit., 71.

${ }^{689}$ Maurice Merleau-Ponty, El ojo y el espíritu (Madrid: Trotta, 2013), 43.

${ }^{690}$ Merleau-Ponty, ob. cit., 34.
} 
y el alma el del sujeto. Pero a medida que la ciencia moderna fue proporcionando explicaciones respaldas por el comportamiento natural de los objetos, el lado del cuerpo fue monopolizando los contenidos de la vida humana. Se rompió el dualismo pero a costa de convertir la totalidad de la existencia en objeto y toda corporalidad en "cuerpo objetivo". La subjetividad quedó reducida y deportada del lugar que había ocupado esa alma invisible e inmaterial de Descartes, destinada a dirigir la corporalidad. La pretensión de Melreau-Ponty consiste, entonces, en recuperar el lado del alma no a costa del dominio del cuerpo sino a través de reconocer la extensión subjetiva que entraña la corporalidad. El autor reivindica pensar el espíritu no en contraposición al cuerpo, sino más bien a partir de ese <<espíritu del que dijo Descartes que estaba extendido en el cuerpo $>{ }^{691}$, una faceta de la espiritualidad que sitúa al alma a ras del cuerpo. Pero aunque el filósofo de La Fléche considerara también esta situación, siempre mantuvo la supremacía del alma en la medida en que suponía que en ella anidaba la racionalidad, siendo reducido lo corporal a nada más que un mecanismo. A este respecto, cabe traer la reflexión del filósofo español Joaquín Xirau sobre la corporalidad, donde se pone de relieve que la representación del cuerpo procurada por los anatomistas no es la del cuerpo propio, ese cuerpo que uno mismo siente y posee. La imagen corporal que presentan los libros y láminas científicas no es más que un constructo hipotético, ya que nadie puede ver las entrañas de su propio organismo ${ }^{692}$. Siguiendo la crítica de Joaquín Xirau, entonces, se puede afirmar que la representación del cuerpo humano es el producto de unas determinaciones epistemológicas y técnicas dadas. La imagen de la complexión humana no fue representada siempre igual, ni la estructura de la corporeidad de la naturaleza tuvo siempre los mismos rasgos, por tanto, el cuerpo que estudian las ciencias no es el cuerpo que estudia el fenomenólogo, ni el cuerpo del sí mismo es el que aparece dibujado en los libros de anatomía.

El cuerpo del que se ocupa Merleau-Ponty en la Fenomenología de la percepción no es el cuerpo-objeto del mecanicismo, a saber, el que recibe estímulos perceptivos por medio de un complejo neuronal que hace llegar información al cerebro. Ese cuerpoobjeto lo aparta el autor para hacer referencia <<al cuerpo cuya experiencia actual poseo, por ejemplo, al modo como mi mano rodea por todas partes al objeto que toca,

\footnotetext{
${ }^{691}$ Merleau-Ponty, ob. cit., 46.

692 Joaquín Xirau, Presencia del cuerpo [traducido del catalán al español por Marta Jorba Grau]; en Cuerpo vivido, José Ortega y Gasset, et. al. (Madrid: Ediciones Encuentro, 2010), 87.
} 
anticipándose a los estímulos y dibujando la forma que percibiré $>>{ }^{693}$. Se reivindica, por tanto, un cuerpo que une la conciencia con el mundo por medio de la percepción, un cuerpo que hace alusión a la afección viva de la experiencia y que aspira a describir las cosas desde esta corporalidad subjetivada, en vez de partir de una explicación reducida a los engranajes causales-sensitivos que estimulan al organismo.

Merleau-Ponty establece que "mi cuerpo" no es un objeto más en el mundo. "Mi cuerpo" constituye los objetos del mundo pero no se constituye a sí mismo como un objeto, en tanto en cuanto gracias a él existen los objetos. La posición del cuerpo conforma un acceso perspectivo a los objetos, estos solo muestran una faceta de sí ya que el cuerpo los percibe a partir de una perspectiva concreta, ahora bien, uno mismo no puede ver su propio cuerpo porque la corporalidad no puede ser captada totalmente desde una perspectiva externa ${ }^{694}$. Siempre que percibimos lo hacemos desde nuestro cuerpo y no hay modo de captarlo desde un punto de vista exterior. Los objetos pueden ser movidos por medio de nuestro cuerpo, ahora bien, el cuerpo de uno mismo es movido de forma directa, está en el lado de nuestro Yo, no requiere ser buscado ni hay que salir a su encuentro, el Yo se mueve de facto con él ${ }^{695}$.

Ser cuerpo o, dicho de manera más amplia, existir en el mundo y salir al exterior nada más que como un cuerpo, que este sea lo único que ven los demás es, para Merleau-Ponty, aquel fáctico que construye una imagen de la propia corporalidad, una imagen externa que representa un cuerpo extraño al "sí mismo". El cuerpo objetivado por la ciencia positiva resulta extraño a la conciencia. El cuerpo es para la conciencia su apertura al mundo, pero también la exterioridad corporal está incrustada en medio de unas relaciones que le asignan unas determinaciones, de tal modo que la corporalidad es puesta como objeto biológico, social, productivo, etc. En torno a la dimensión corporal de sí mismo se generan unos condicionantes espaciales y temporales desplegados por los devenires y avatares de la naturaleza y de la historia; así, el cuerpo representado como un objeto no invoca la experiencia que uno mismo tiene de su corporalidad, puesto que su sola imagen no entraña lo espiritual en sentido subjetivo. La imagen del cuerpo objetivado enajena "mi experiencia corporal" porque secciona la integridad subjetivo-corpórea subyacente al sujeto. El cuerpo objetivado no trasciende, no

\footnotetext{
${ }^{693}$ Maurice Merleau-Ponty, Fenomenología de la percepción (Barcelona: Ediciones Península, 1994), 94.

${ }^{694}$ Cfr. Merleau-Ponty, ob. cit., 109-110.

${ }^{695}$ Cfr. Merleau-Ponty, ob. cit., 111-112.
} 
transforma las condiciones de la existencia, este cuerpo-objeto es extraño a la subjetividad de uno mismo ya que el sujeto humano se caracteriza por trascender lo dado, por tratar de superar las condiciones sociohistóricas en que está inserto; es preciso contar con ese cuerpo interior espiritual para crear nuevas determinaciones existenciales; siguiendo las palabras de Escribano:

El sujeto que nace del mundo, nace situado, y lo biológico, lo familiar, lo económico, lo social, etc. le condicionan, pero no lo determinan en tanto que la existencia humana, siguiendo el paradigma de lo que ocurre con el organismo biológico y el gesto corpóreo, es un continuo movimiento de superación de lo dado, partiendo de ello, pero abriéndose a nuevos significados. Esto es a lo que Merleau-Ponty llama "trascendencia". ${ }^{696}$

La imagen del cuerpo que procede de los condicionamientos y determinaciones exteriores, la forma conceptual y predeterminada que sitúa al Yo con respecto a los otros en un contexto social, económico, político, etc., es un cuerpo extraño a la experiencia que cada uno tiene de su propia corporalidad.

\subsubsection{EL CUERPO COMO ESPACIO, COMO SÍNTESIS Y COMO PRESENCIA DEL OTRO}

En el pensamiento de Merleau-Ponty el hecho de que la corporalidad ocupe un lugar en el espacio supone que el cuerpo sea entendido como un espacio en sí mismo. El cuerpo anuda momentos y experiencias, es una síntesis y una apertura de la conciencia al mundo. La percepción del espacio y la percepción de las cosas no constituyen problemas diferentes, dice el autor que toma como punto de partida una noción que la tradición cartesiana y kantiana ya había puesto de manifiesto: la experiencia del espacio objetivo le atribuye una existencia a los objetos que aparecen en este espacio donde el cuerpo se posiciona y halla su lugar dentro de una objetividad ${ }^{697}$. El cuerpo, en cuanto espacialidad, habilita el espacio inteligible, este último es el que aparece como algo objetivo y que no se deriva de la forma en que se orienta el cuerpo en sus determinaciones posicionales (arriba, abajo, a la izquierda, a la derecha, etc.). La forma universal del espacio, en tanto en cuanto esencia de la espacialidad, solo puede hacerse aprehensible mediante contenidos espaciales, es decir, los de la corporalidad; de modo que el <<espacio corpóreo no puede convertirse de verdad en un fragmento del espacio

${ }^{696}$ Francesc Xavier Escribano López, "Maurice Merleau-Ponty: el anclaje corpóreo en el mundo", Thémata, no. 22 (1999): 67-79, 77.

${ }^{697}$ Cfr. Maurice Merleau-Ponty, Fenomenología de la percepción (Barcelona: Ediciones Península, 1994), 165. 
objetivo más que si en su singularidad de espacio corpóreo contiene el fermento dialéctico que lo transformará en espacio universal >> ${ }^{698}$.

Para Merleau-Ponty, el cuerpo actualiza la existencia de las esencias, por ello la corporalidad es de por sí una posición sintética, pero no una posición que sintetice una totalidad, sino un acceso a la parcialidad de las cosas, a una faceta del objeto, a una perspectiva que hace las veces de puente entre las esencias y las existencias. El Yo no puede desligarse de su cuerpo, de manera que las variaciones por las que atraviesa la corporalidad no son separables de la conciencia:

Pero yo no estoy delante de mi cuerpo, estoy en mi cuerpo, o mejor, soy mi cuerpo. $\mathrm{Ni}$ sus variaciones ni su invariante pueden, luego, plantearse expresamente. Nosotros no contemplamos únicamente las relaciones de los segmentos de nuestro cuerpo y las correlaciones del cuerpo visual y del cuerpo táctil: somos nosotros mismos el que mantiene juntos estos brazos y piernas, el que a la par ve y toca. ${ }^{699}$

El anudamiento en que está enlazado el cuerpo mantiene una variabilidad constante. En la corporalidad interactúan fuerzas naturales que equilibran el manantial de variaciones inherentes a la experiencia. La conciencia tiene capacidad para advertir, anticipar y registrar el modo esencial de los cambios que atraviesan la naturaleza orgánico-sensitiva corporal. El cuerpo aparece como un medio con que otorgarle una significación a las experiencias, si bien, la conciencia actualiza los anudamientos de la corporalidad, no es, entonces, solamente la causación orgánica la que produce la significación en el ámbito de las sensaciones. Consecuentemente, todo mirar tiene tras los ojos del observador una conciencia que constituye los significados, es la mirada la que <<obtiene más o menos de las cosas, según cómo las interrogue, cómo se deslice o recueste en ellas $>>$, por ejemplo, el aprendizaje de los colores $<<$ es adquirir cierto estilo de visión, un nuevo uso del propio cuerpo, es enriquecer y reorganizar el esquema corpóreo $>{ }^{700}$. El cuerpo es el medio por el que se expresa la existencia. La facticidad de la existencia tiene en la corporalidad su lugar de realización, por eso en MerleauPonty el cuerpo actualiza el modo en que los seres vivos presencian el mundo, pero a costa de desvirtuar la experiencia originaria del cuerpo de uno mismo:

\footnotetext{
${ }^{698}$ Merleau-Ponty, ob. cit., 119.

${ }^{699}$ Merleau-Ponty, ob. cit., 167.

${ }^{700}$ Merleau-Ponty, ob. cit., 170.
} 
La existencia corpórea, que pasa a través de mí sin mi complicidad, no es más que el bosquejo de una verdadera presencia en el mundo. Cuando menos, funda su posibilidad, establece nuestro primer pacto con él. Sí, puedo ausentarme del mundo humano y abandonar la existencia personal, pero solo será para encontrar en mi cuerpo el mismo poder, esta vez sin nombre, por el que estoy condenado al ser. ${ }^{701}$

Uno de los problemas fundamentales que aborda Merleau-Ponty de manera sistemática y a través de su esquema de pensamiento fenomenológico es el del Otro. Para el autor, las relaciones humanas se producen dentro de una interacción social que genera una serie de prácticas y procedimientos técnicos, estas prácticas y procedimientos técnicos se inscriben en un contexto cultural. Las experiencias del contexto cultural habilitan una serie de hábitos y trato con las cosas. El manejo de los utensilios es impersonal en la medida en que su uso puede ser realizado por cualquiera, pero, sin embargo, Merleau-Ponty se pregunta cómo es posible que un Yo se apropie de un procedimiento ajeno a su sí mismo. El comportamiento del otro o de los otros hace del cuerpo un objeto cultural, dado que solo se puede advertir uno u otro comportamiento en la medida en que hay unos cuerpos que actúan de una manera determinada. En el ámbito cultural donde se mueven los cuerpos e interactúan los Yos hay una paradoja irresuelta: que la conciencia pueda hacer suyo un pensamiento extrínseco, un pensamiento impersonal que, no obstante, es realizado por individuos concretos, singulares e irrepetibles ${ }^{702}$.

El cuerpo descrito por la biología y la fisiología representa un amasijo de órganos. La imagen de este cuerpo describe tanto a la corporalidad del Otro como a "mi cuerpo"; esta noción de lo corporal surge del discurso empírico de las ciencias, en las que

los hombres y yo mismo como ser empírico, no somos más que mecanismos que se mueven por resortes; el verdadero sujeto no tiene par, esta consciencia que se ocultaría en un fragmento de carne sangrienta es la más absurda de las cualidades ocultas, y mi consciencia, coextensiva con lo que puede existir para mí, correlato del sistema entero de la experiencia, no puede encontrar en ello otra consciencia que inmediatamente haría aparecer en el mundo el fondo, desconocido por mí, de sus propios fenómenos. ${ }^{703}$

El planteamiento del autor cruza la disensión entre el "ser para sí” y el "ser en sí”. El "ser para sí", que es el ser de uno mismo, se encuentra con "seres en sín", que son los

\footnotetext{
${ }^{701}$ Merleau-Ponty, ob. cit., 182.

${ }^{702}$ Cfr. Merleau-Ponty, ob. cit., 360.

${ }^{703}$ Merleau-Ponty, ob. cit., 361.
} 
objetos, pero en las relaciones de un "ser para sí" con respecto a otro "ser para sí" se produce una relatividad en la forma del "ser en sí". Merleau-Ponty afirma que en un primer momento el Otro es a la vista de uno mismo un ente, un "ser en sí", pues este aparece como un objeto-cuerpo a la mirada. Este Otro no refleja inmediatamente la presencia de un "ser para sí" en él, en tanto en cuanto solo mirando su cuerpo no se hace visible esta categoría ontológica suya, mas, pese a todo, lo que exige el Otro frente a uno mismo, cuando se sitúa delante, es que quiere ser tratado como un "ser para sí". La contradicción que reside en esta relación es que Yo tengo que darle una peculiaridad al Otro, que ya no es un objeto más en el mundo, sino un cuerpo que porta un "ser para sí", pero este "ser para sí” no es tangible y, por ende, no es evidente de forma inmediata. Los cuerpos se retiran al mundo objetivo, ese mundo visible donde la corporalidad es pensada, pero no la conciencia, porque la conciencia es impensada, es apercibida, está oculta, reside en un plano vacío de objetividad, no es un objeto físico como tal. La ciencia aporta un discurso sobre el cuerpo en el que este queda escindido de la subjetividad que lo habita, sin embargo, en las relaciones con los otros el Yo supone la presencia de una conciencia en sus cuerpos, nadie sabe cómo es esta conciencia ni puede demostrar empíricamente su presencia, tan solo puede suponerse, sin que pueda ser demostrable empíricamente ${ }^{704}$. El cuerpo del Otro difumina la bifurcación entre el "ser para sí" y el "ser en sí". Otorgarle una conciencia al otro implica rellenar un vacío subjetivo, hace posible una intersubjetividad, algo que la visualización objetiva del cuerpo como mero ente u organismo fisiológico no permite ver.

Precisamos recuperar en los cuerpos visibles los comportamientos que en ellos se dibujan, que en ellos se ponen de manifiesto, pero que no están realmente contenidos en los mismos. Nunca se hará comprender cómo la significación y la intencionalidad podrían habitar unos edificios de moléculas o unos agregados de células, y en esto el cartesianismo tiene razón. Pero tampoco se trata de una empresa tan absurda. Solamente se trata de reconocer que el cuerpo, como edificio químico o conjunto de tejidos, está formado por empobrecimiento a partir de un fenómeno primordial del cuerpo-paranosotros, del cuerpo de la experiencia humana o del cuerpo percibido, que el pensamiento objetivo inviste, pero del que este no ha de postular el análisis acabado. ${ }^{705}$

La forma de percibir los estados anímicos del Otro requiere observar sus comportamientos y conductas corporales, según varíe su fisionomía es posible atribuirle

\footnotetext{
${ }^{704}$ Cfr. Merleau-Ponty, ob. cit., 361-362.

${ }^{705}$ Merleau-Ponty, ob. cit., 363.
} 
alguna actitud, sentimiento o pasión ${ }^{706}$. De este modo, el cuerpo ya no es solo el reflejo de una presencia existencial en el mundo, es además la forma en que un Yo se presenta a una comunidad humana. Las características y estados del cuerpo hacen existir al individuo humano ante los otros, frente a su alter-ego. El cuerpo delata las condiciones más concretas de la existencia, pues, tal como dice el pensador francés:

Todo cuanto "soy" por el hecho de la naturaleza o de la historia -jorobado, guapo o judío-, nunca lo soy por completo para mí mismo, (...). Y lo soy, sin duda, para el otro, pero sigo siendo libre para pro-poner al otro como una consciencia cuyos puntos de vista me tocan hasta mi ser, o, por el contrario, como un simple objeto. Verdad es aún, que esta alternativa es una coacción: si soy feo, tengo la opción de ser reprobado o reprobar a los demás. ${ }^{707}$

Independientemente de cuáles sean esas condiciones que actualizan la existencia, de cuáles sean esas características que hacen ser a un cuerpo de un modo $\mathrm{u}$ otro, la conciencia siempre se moverá en un plano neutral con respecto a estas contingencias y condiciones del mundo, por lo que la conciencia sigue siendo libre respecto de un cuerpo feo, bello, tullido, etc., ya que las caracterizaciones corporales vienen dadas por la sociedad y no por la libertad. El cuerpo pone unas determinaciones pero no absorbe el conjunto de márgenes de posibilidad que tiene la libertad de la conciencia. El lateral ontológico corporal hace irrenunciable la presencia de los hombres en el mundo, de los hombres como seres vivientes con unas determinaciones biológicas y una complexión y condiciones fisiológicas concretas, estas características son inocultables a los demás, se manifiestan irreversible e indefectiblemente, pero no anulan la libertad.

\subsubsection{LA ONTOLOGÍA DE LA CARNE}

En Lo visible y lo invisible Merleau-Ponty dice: <<Tener cuerpo es ser mirado (no solo eso), es ser visible $>>708$. En esta obra el autor vuelve a plantear que al igual que uno mismo puede negarle el acceso al mundo a los otros, estos también pueden hacer lo propio contra uno mismo. El acceso a las cosas mismas es afirmado por un Yo como verdad exclusivamente suya, pero solo porque uno mismo crea o pueda llegar a pensar que la mirada de los otros no ve las cosas mismas, sino tan solo apariencias, paradójicamente, el Yo está negándose también su "ver las cosas mismas”. El Yo puede

\footnotetext{
${ }^{706}$ Cfr. Merleau-Ponty, ob. cit., 367.

${ }^{707}$ Merleau-Ponty, ob. cit., 443.

${ }^{708}$ Maurice Merleau-Ponty, Lo visible y lo invisible (Barcelona: Editorial Seix Barral, 1966), 233.
} 
pensar que también los otros sospechan que su mundo percibido no refleja las cosas tal como son en sí mismas, lo que hace patente la inaccesibilidad al "ser para sí" albergado en cada cual, puesto que el Yo y los otros permanecen herméticos en el mundo que ellos mismos perciben a través de su cuerpo ${ }^{709}$. Merleau-Ponty se pregunta cómo es posible, entonces, la apertura del "ser para sí" al mundo de los otros, cómo es posible una relación que abarque a todo un "Nosotros". Según el autor

basta que la voz se altere, que aparezca lo insólito en la partitura del diálogo, o, al revés, que una respuesta conteste bastante bien a lo que estaba pensando sin haberlo dicho del todo, y de repente irrumpe la evidencia de que también allá se vive la vida minuto a minuto: en alguna parte detrás de esos ojos, detrás de esos gestos, o más bien ante ellos, o, mejor dicho, a su alrededor, viniendo de no sé qué trasfondo del espacio, se trasluce otro mundo particular a través de la trama del mío, y por un momento es en él donde vivo, no soy más que respuesta a esa pregunta que se me hace. ${ }^{710}$

Se produce un trasvase del uno al Otro y del Otro al uno cuando se utilizan las mismas palabras y los mismos instrumentos, y solo esta relación intersubjetiva puede garantizar una conectividad de un "ser para sí" con otro ser de la misma índole. Merleau-Ponty hace plausible la compartición de una sustancia común, una sustancia comunicante de los "seres para sí", dado que el mundo es transmisible entre conciencias que parcialmente y aparentemente permanecen aisladas en los individuos. Asimismo, poder vivir el mundo del Otro y hacerse testigo de un mundo compartido termina transparentando la conciencia, aunque el cuerpo siga siendo ese ente que opaca cualquier acceso directo al mundo que subyace a los otros ${ }^{711}$. Las relaciones humanas se enmarcan en un contexto histórico-cultural en el que se producen unas acciones comunes fundadas en acuerdos, acuerdos que los hombres alcanzan por medio de sus relaciones intersubjetivas. El mundo de la verdad es invisible, habita en el dominio de los espíritus, de tal modo que, aunque <<parece que cada hombre viva en su islote〉>, y que haya disrupciones in-transitivas de un cuerpo a otro cuerpo, los seres humanos son capaces de alcanzar acuerdos, pues cada individuo es <<un frágil amasijo de gelatina viva, y ya es mucho que hayan seguido la misma ontogénesis, y mucho más que, desde

\footnotetext{
${ }^{709}$ Cfr. Merleau-Ponty, ob. cit., 26-27.

${ }^{710}$ Merleau-Ponty, ob. cit., 27-28.

${ }^{711}$ Cfr. Merleau-Ponty, 28.
} 
el fondo de su retiro, se hayan dejado arrollar todos por la misma mecánica social y el mismo lenguaje $>>712$.

En el curso impartido por Merleau-Ponty en el Collège de France durante el año lectivo de 1954-1955, se presenta al Otro no como un constituido-constituyente en cuanto a "mi negación" se refiere, sino como un instituido-instituyente entendiendo que la diferencia entre los términos "constituir" e "instituir" reside en que el primero apunta a un ser que solo "es para mí", ya que tiene sentido solo en un instante concreto, mientras que el término instituir tiene sentido sin "mi presencia", pues lo instituido tiene una anterioridad que se fuga hacia el futuro. La conciencian no le da sentido a los seres que se propagan en la temporalidad, pues estos seres han adquirido su ser anteriormente a "mí"713. En consecuencia, para Merleau-Ponty, en el Otro

[hay] proyección-introyección, productividad de lo que hago en él y de lo que él hace en mí, comunicación verdadera por implicancia lateral: [se trata de un] campo intersubjetivo o simbólico, [el de] los objetos culturales, que es nuestro medio, nuestra bisagra, nuestra juntura -en lugar [de la] alternativa sujeto-objeto. ${ }^{714}$

La relación de la filosofía moderna entre sujeto-objeto resulta a ojos de la filosofía merleaupontyana abrupta, tosca y artificiosa, el problema del acceso a las cosas mismas no se resuelve a través de un cogito o sujeto cognoscente conocedor de los objetos puestos en el mundo físico, motivo por el que en la institución del Otro se crea un canal conectivo que prefigura el modo en que proyectamos una accesibilidad al ser de las cosas. Solo por medio de la relación instaurada con los Otros, de la instauración de un mundo de significados compartidos, se abre la posibilidad de una facticidad común.

A propósito del curso de 1954-1955, huelga poner de relieve que en la "Presentación" realizada por la traductora del texto al español Mariana Larison, se hace mención al carácter transicional que toma este curso dentro del pensamiento de Merleau-Ponty, ya que en él puede patentarse un giro desde un enfoque epistemológico manifiesto en la Fenomenología de la percepción hacia un enfoque ontológico presente en Lo visible y lo invisible ${ }^{715}$; esta última obra, inacabada por parte del autor debido a

\footnotetext{
712 Merleau-Ponty, ob. cit., 31.

713 Cfr. Maurice Merleau-Ponty, La institución. La pasividad: Notas en cursos del Collège de France (1954-1955). I. La institución en la historia personal y pública (Barcelona: Anthropos, 2012), 7.

${ }^{714}$ Merleau-Ponty, ob. cit., 5.

715 Concretamente la autora afirma que el pensamiento de Merleau-Ponty, entre la década de los años cuarenta y los años cincuenta <<entra en una fase de transición cuyo resultado será el desplazamiento del problema fenomenológico del sujeto de la percepción al problema ontológico del ser de lo percibido. Este
} 
que se vio sorprendido por la muerte en 1961, hace ostensible su viraje hacia una perspectiva ontológica cuando dice que la $<<$ concepción del tiempo, del "alma", en sentido husserliano, de la intercorporeidad en tanto que "natural" - Pero todo eso -que recoge, profundiza y rectifica mis dos primeros libros ${ }^{716}$ - ha de hacerse totalmente en la perspectiva de la ontología >> ${ }^{717}$. Bien puede soslayarse que la filosofía merlopontyana recorre una serie de problemáticas presentes antes y después de que su pensamiento experimentara el giro ontológico: la relación con el Otro y la transparencia y opacidad del cuerpo en vínculo con la subjetividad constituyen discursos enhebrados a lo largo de sus meditaciones filosóficas, en las que no se pierde la programática fenomenológica en ninguno de los itinerarios temáticos abordados por el filósofo francés. Asimismo, es posible encontrar en Lo visible y lo invisible un término propio del pensamiento tardío de Merleau-Ponty que tiene lugar a tenor de las líneas maestras de su ontología; este término es el de "carne".

Merleau-Ponty no equipara su concepción de "carne" a nociones espiritualistas ni tampoco materialistas, sino que identifica la carne con el sentido que los antiguos le atribuyeron al término "elemento" (tierra, agua, aire y fuego), designando, así, algo que está inscrito dentro del orden del Ser, pero no inclinado definitivamente hacia lo físico, que aparece entre el espacio y el tiempo, ni tampoco hacia la inmovilidad de la idea. La carne es facticidad, lo que posibilita los hechos, y también es aquello que le atribuye un sentido a lo fáctico ${ }^{718}$. La carne es el plexo que transparenta la existencia de los seres humanos puestos en relación, la carne hace visibles aquellas sensaciones y aquel mundo que se abre a uno mismo como algo accesible "en sí". Precisamente la imagen de un cuerpo cuya carne aparece como una propiedad individualizada en la experiencia del mundo es lo que trata de refutar Merleau-Ponty, de modo que la carne sería más bien el envoltorio ontológico que hace interaccionar a los hombres y que vuelve accesibles las experiencias tanto a uno mismo como a los otros. La carne abre la posibilidad de una intersubjetividad desarrollada a partir de la facticidad del contacto sensorial, única manera de establecer significados compartidos.

último proyecto es el que se delinea en el póstumo e inconcluso libro que conocemos hoy con el título de Lo visible y lo invisible, y cuyos primeros trazos de escritura aparecen en 1959 (es decir, dos años antes de la muerte del filósofo)>>. Mariana Larison, Merleau-Ponty y los cursos en el Collège de France; en La institución. La pasividad: Notas en cursos del Collège de France (1954-1955). I. La institución en la historia personal y pública, Maurice Merleau-Ponty (Barcelona: Anthropos, 2012), VI.

${ }^{716}$ Se refiere a La estructura del comportamiento y a la Fenomenología de la percepción.

${ }^{717}$ Maurice Merleau-Ponty, Lo visible y lo invisible (Barcelona: Editorial Seix Barral, 1966), 208.

${ }^{718}$ Cfr. Merleau-Ponty, ob. cit., 174. 
El cuerpo tiene un anverso cósico y un reverso espiritual, el reverso espiritual del cuerpo le concede al individuo el poder de ocultarle sus pensamientos a los otros, aunque esta subjetividad invisible también puede emerger desde el "sí mismo" hacia los otros, a la vez que estos cuentan igualmente con esa misma capacidad. Al tocar la mano del Otro se extiende la posibilidad de que el sentimiento del Otro en "mí" pueda ser igual al modo en que él me siente a "mí", de manera que este contacto físico supera las barreras de la corporalidad para insertarse en el campo de los significados compartidos, donde lo subjetivo puede exteriorizarse. Las sensaciones ambivalentes producen significaciones ambivalentes entre otredades, estas crean una simetría dentro de la asimetría con que se relacionan los cuerpos y los espíritus: lo único cierto es que uno mismo no puede ver su cuerpo fuera de sí, puede ver el cuerpo del otro, aunque no puede ver el Yo de ese otro, que está oculto tras su cuerpo solo como un supuesto "mío"; esto mismo le sucede también al otro; de ahí que, dentro de estas asimetrías, haya una situación simétrica en la que aquello de lo que uno mismo carece, el verse como cuerpo y el no poder ver el Yo del otro, es de lo que carecen también los otros, y, aquello que uno mismo tiene, la certeza subjetiva de su yo y la visión externa de los cuerpos ajenos, es algo que los otros también tienen.

Si se ha dejado captar por uno de sus fragmentos, queda establecido el principio de la captabilidad, y en el campo hay cabida para otros Narcisos, para una "intercorporeidad". Si mi mano izquierda puede tocar mi mano derecha mientras esta palpa lo tangible, si puede tocarla tocando, capta su palpación, ¿por qué, cuando toco la mano de otro, no estaré tocando en ella el mismo poder de amoldarse a las cosas que he tocado en la mía? Es verdad que "las cosas" de que se trata aquí son las mías, que, como suele decirse, la operación se efectúa por entero "en mi", en mi paisaje, cuando de lo que se trata es de instituir otro. Por el contrario, cuando una de mis manos toca la otra, el mundo de cada una de ellas se abre al de la otra porque la operación es facultativamente reversible, porque, como se dice, ambas pertenecen a un único espacio de conciencia, porque es un solo hombre el que por medio de ellas toca una sola cosa. ${ }^{719}$

La carne abre pliegues que permiten quebrar el narcisismo y el solipsismo de los individuos en tanto en cuanto esta se expande y posibilita la visión de un mundo de sensaciones a través del contacto de los cuerpos, un mundo susceptible de ser compartido, un mundo que se inicia en la inmanencia del Yo pero que trasciende por medio de la intercorporalidad, es decir, por medio de la experiencia elemental de la

${ }^{719}$ Merleau-Ponty, ob. cit., 175-176. 
carne que subyace a todas las cosas, a "mí mismo" y a los otros. El cuerpo de uno mismo, que de suyo es para el Otro nada más que un objeto, y el cuerpo del Otro, que de suyo es un objeto para "mí mismo", rompen este carácter objetual cuando la carne pone en contacto la interioridad del sí mismo con la exterioridad de los Otros y, del mismo modo, la exterioridad de los Otros con la interioridad del sí mismo. La carne vuelve transparente el juego de miradas de las otredades puestas en contacto, de tal forma que se produce una visibilidad en sentido doble: de lo interno a lo externo y de lo externo a lo interno; lo que es invisible para los otros la carne lo hace visible y lo que resulta invisible de los Otros para uno mismo la carne lo torna visible. La noción merlopontyana de carne trasciende la materialidad sin por ello sostenerse como levitando en los cuerpos, pues tampoco es un espíritu, se trata del <<enrollarse lo visible en el cuerpo vidente, lo tangible en el cuerpo tangente, de lo cual tenemos testimonio sobre todo cuando el cuerpo se ve, se toca viendo y tocando las cosas $>>{ }^{720}$. Al concebir la carne como un elemento, Merleau-Ponty evita equipararla bien al cuerpo bien al espíritu, ya que <<sería unión de contradictorios〉>, por ello, pensar la carne como un elemento implica atribuirle la categoría de <<emblema concreto de un modo de ser general $>>721$.

El palpar las cosas se advierte como el sentimiento de una envoltura externa, circunscrita a la superficie de la cosa, esta dimensión extrínseca del ser es lo que propiamente palpa la carne; la experiencia del mundo está lateralizada por el cuerpo, tocamos allí donde se halla nuestro cuerpo, sentimos desde él, así como oímos desde nuestra corporalidad, de hecho, no es lo mismo oír la voz propia que la de los demás. Para Merleau-Ponty se producen hiatos entre lo que uno mismo siente de sí mismo y lo que se siente en contacto con el mundo exterior, pero no hay vacíos de no-ser, mas estos hiatos se encuentran suturados por la carne, esa carne del sí mismo y también la carne del mundo, un mismo elemento para relacionar ambas polaridades ${ }^{722}$. El autor rescata la expresión husserliana "horizonte de las cosas" para referirse tanto al límite exterior de las cosas como a esa interioridad henchida de posibilidades de visión que, a primera vista, pareciera ser eclipsada por el horizonte externo del mundo, pero que es tan solo un límite con el horizonte interno: <<el horizonte como tierra o cielo no es una colección de cosas tenues, o el título de una clase, o una posibilidad lógica de

\footnotetext{
${ }^{720}$ Merleau-Ponty, ob. cit., 181.

${ }^{721}$ Merleau-Ponty, ob. cit., 183.

${ }^{722}$ Cfr. Merleau-Ponty, ob. cit., 183-184.
} 
concepción, o un sistema de "potencialidad de conciencias": es un nuevo tipo de ser: ser poroso, preñado, el ser de la generalidad $>>{ }^{723}$.

La carne se retuerce en los cuerpos, hace visibles a los hombres. La dimensión espiritual de los individuos humanos, que permanecía oculta en sus entrañas, logra extenderse de lo interno a lo externo gracias a la carne. En un principio los pensamientos son retenidos en el hermetismo del sí mismo, en el cobertizo interior del espíritu; estos tan solo pueden exteriorizarse a través de la latencia de una intercorporalidad procurada por la textura de la carne, que revela la forma de la experiencia originaria de los cuerpos, donde lo pensado subjetivamente se hace significado en la medida en que llega a compartirse con los otros:

Solo el ser visible y, por así decir, endeble, es capaz de ofrecer esta textura tan apretada. Existe una idealidad rigurosa en experiencias que son experiencias de la carne: los momentos de la sonata o los fragmentos del campo luminoso se adhieren uno a otro como una cohesión sin concepto, que es del mismo tipo que la de las partes de mi cuerpo, o la de mi cuerpo con el mundo. Mi cuerpo ¿es cosa? ¿es idea? Ni lo uno ni lo otro, ya que es el medidor de las cosas. Tendremos que admitir, pues, que existe una idealidad que no es ajena a la carne, que le da sus ejes, su hondura y sus dimensiones. ${ }^{724}$

La carne concebida por Merleau-Ponty no es una sustancia homogénea destinada a romper dualidades. Hay un anverso y un reverso variables en la ontología de la carne: así como "mi cuerpo" es visible para el Otro, el cuerpo del Otro es visible para "mi”, pero, igual que "mis pensamientos" son invisibles para el Otro, también los suyos son invisibles para "mi". La carne, oculta del mismo modo que también transparenta, sin embargo, lo visible y lo invisible no son dualidades abruptas e insalvables -del tipo ser y no-ser-, puesto que precisamente la carne es el elemento que posibilita la transmisibilidad de sensaciones y experiencias de uno mismo hacia los otros y de los otros hacia uno mismo. La carne comunica a los hombres entre sí, por medio de ella el mundo toma una significación común, en este aspecto, vale tener en cuenta las palabras del profesor Maximiliano Basilio Cladakis, quien interpreta que la noción de carne en la ontología de Merleau-Ponty

no debe comprenderse como una metafísica monista. El ser carnal, que se identifica con el ser natural o ser salvaje, posee ya una dinámica de negatividades y positividades, un

\footnotetext{
${ }^{723}$ Merleau-Ponty, ob. cit., 184.

${ }^{724}$ Merleau-Ponty, ob. cit., 188.
} 
movimiento en el que hay alternancias, en donde lo latente y lo presente se entrecruzan de manera permanente. Por esto mismo, si el monismo hace referencia a un principio que es en-sí, positivo, pura presencia, la ontología merleaupontyana no presenta rasgos en común con él. ${ }^{725}$

Según Cladakis, la carne, en cuanto elemento, logra hacer comprensible una tercera dimensión que permite asociar lo corporal a lo espiritual, retomando la posibilidad de unificar los existentes bajo una sola forma ${ }^{726}$. Así, las dificultades en torno al <<solipsismo, el problema de la multiplicidad de narcisos, deja de ser un obstáculo puesto que, a partir de la constitución de la carne como elemento articulador de la ontología originaria, la intercorporalidad precede a la corporalidad $>>727$. La referencia a la intercorporalidad como noción previa a la consideración del cuerpo de sí mismo evoca la presencia de un origen, un origen que se remonta a la carne. El cuerpo natural del individuo, ese cuerpo subjetivado que el narcisismo mueve retroactivamente hacia un Yo, el Narciso que ve su mundo y se instala con respecto a los otros como cuerpo en virtud del mundo que él mismo ha configurado, sería un resultado fragmentario del origen ontológico intercorporal. El plano en el que existe la carne como elemento no admite la forma del cuerpo como propiedad, ya que el cuerpo natural no es la apropiación de un Yo, dado que su carácter inicial viene puesto como carne, por tanto, como un elemento común a la hechura de otros humanos, de otros seres vivos, etc., de los cuerpos en general que forman parte del mundo.

La ontología de Merleau-Ponty extrae lo corporal del dominio del individuo, dicho con mayor explicitud: el propósito de Merleau-Ponty en su filosofía del ser es hacer con el cuerpo aquello que la fenomenología de Husserl hizo con la conciencia, pues igual que la conciencia no es patrimonio de un solo individuo, el cuerpo tampoco está bajo el poder de un ser individualista que tiene toda su existencia corporal bajo su control. Hay un cuerpo originario que no es una propiedad, que no es un objeto de apropiación ni por parte de uno mismo ni por parte de los otros, sino una sensibilidad conectada de manera intersubjetiva con la "sustancia carnal" del mundo y con una comunidad de hombres; la carne es el elemento que "encarna" a toda la humanidad.

\footnotetext{
${ }^{725}$ Maximiliano Basilio Cladakis, "Merleau-Ponty y la ontología de la naturaleza: intercorporalidad, negatividad y dialéctica", Diánoia 61, no. 77 (2016): 83-108, 104.

${ }^{726}$ Cfr. Cladakis, ob. cit., 102.

${ }^{727}$ Cladakis, ob. cit., 103.
} 


\subsubsection{EL DESCARNADO PODER DE LA DOMINACIÓN}

La ontología merleaupontyana le concede a la carne un cariz empático que contribuye a conectar la dimensión subjetiva y la dimensión corporal de los hombres entre sí y a sacarles del aislamiento en que originalmente se hallan anclados sus pensamientos. Ahora bien, huelga tener presentes aquellas situaciones del siglo XX en las que la humanidad se ha visto descarnada y desolada. Merleau-Ponty no fue indiferente a los trágicos acontecimientos de su tiempo, fundamentalmente los acarreados por la Segunda Guerra Mundial, pero su ontología de la carne no define un desgarramiento causado por la violencia en las relaciones humanas, más bien, todo lo contrario: la carne es el elemento que une a los seres humanos porque es lo común a todos ellos, todos tienen carne; cabe recordar que Merleau-Ponty consideraba la carne como elemento en el sentido de la filosofía presocrática, luego, todo el mundo en última instancia alberga ese carácter espiritual y corpóreo. Merleau-Ponty encuentra en la carne el punto de convergencia entre la espiritualidad y la corporalidad, trata de romper con una tradición que situaba lo corporal en el lado de lo cósico, de los objetos, mientras aislaba lo espiritual en el lado invisible de la subjetividad.

La carne merleaupontyana es un elemento cósmico que aúna la dimensión interna del individuo con su mundo externo y que instituye un Nosotros, pues despliega vínculos intercorporales entre los sujetos previamente a cualquier noción que cada uno de ellos pudiera hacerse del "cuerpo propio". Pero, este elemento ontológico-carnal subyacente al común de los seres humanos, más allá de cómo lo consideró Merleau-Ponty, también aparece seriamente comprometido en ambientes de alta hostilidad y destrucción. La brecha que vulnera la carne no necesariamente se inclina el cascarón subjetivo del Narciso, sino que estas brechas también hacen su aparición visiblemente en la carne ensangrentada y contusionada; este es un aspecto que conviene ver más allá del esquema filosófico planteado por Merleau-Ponty. Por ello, cabe observar cómo la carne vulnerada, dañada, agredida, etc., hace visibles imágenes de cuerpos en estado de destrucción y abatimiento, cuerpos que son golpeados, aislados, maltratados, cuyo poderío ha sido sesgado debido a que se les ha expuesto a situaciones vejatorias, precarias y brutales.

En contexturas de esta índole, el elemento carnal entra en estado de desintegración, dejando de ser un elemento conectivo-empático. La historia del siglo XX contiene itinerarios cuyas secuencias muestran excavadoras apartando cadáveres de personas 
yacidas en campos de concentración, filas de refugiados huyendo de la guerra, soldados hacinados en franjas de tierra sobreviviendo en condiciones paupérrimas, cuerpos esparcidos en paisajes urbanos desolados, etc., es por ello que conviene abrir un acceso interpretativo al tema del cuerpo teniendo en cuenta los abusos que han padecido los seres humanos y el grado de brutalidad que hostigó, atravesó y destruyó sus cuerpos. Consecuentemente, habrá que fijarse en las llagas que rasgan la piel de las corporalidades agredidas, en la fisionomía del sufrimiento, con sus rostros abatidos, aterrorizados y mutilados, en la desfiguración de la complexión humana y en la cosificación de la carne, pues, precisamente, estas situaciones proporcionan imágenes que dan pistas acerca de cómo hubo cuerpos que recibieron sistemáticamente la condición de objetos, siendo despojados de toda su dimensión subjetiva.

¿Cómo llegan los cuerpos a ser objetos? ¿Cómo toman estos la forma cóncava que les vacía de toda interioridad frente a quienes les magullan y descarnan? La operación para que un cuerpo sea tratado como un objeto requiere de la presencia atacante de un poder extrínseco, cuya presión sea ejercida desde una instancia ajena, de tal manera que la simiente de este poder dominador haya proliferado fuera de las fuerzas naturales inherentes a los cuerpos de los individuos. La presión proveniente de un poder foráneo al cuerpo quiebra su poderío originario, así como también diluye toda posibilidad de que los sujetos aspiren a entablar una relación de envergadura intercorporal. Es a través de este procedimiento como se traza la historia de la dominación, una historia que no es invisible, pues el dominio deja huella allí donde se ejerce, ya que necesita hacer del cuerpo un objeto: su objeto por excelencia. La historia de la dominación, por tanto, hace mella en los cuerpos que caen bajo su radio de poder, las magulladuras y cicatrices, los rostros de dolor, el abatimiento y las expresiones faciales desencajadas son testimonios consumados de un poder dominante cuya fuerza apartó a empellones el poderío que todo cuerpo guarda originariamente en su ser.

Es preciso contar con la lectura -en clave estética- que Fernando Fernández Lerma realiza en Algo más que belleza sobre el valor de las mutilaciones y las deformidades corporales producidas por las contiendas militares; afirma que la historia y el pensamiento le conceden a estas heridas y deformidades una categoría moral asociada, según qué caso, a la vergüenza o al orgullo. El autor se fija en el cuadro Aptos para la guerra en un 45\%, también llamada Los mutilados de guerra, obra de Otto Dix presentada en la exposición dadá de 1920 pero censurada y destruida en 1939 al ser 
considerada "Arte degenerado" por el régimen del Tercer Reich. La obra representa cuatro personajes que han sufrido algún tipo de mutilación o deformación, vestidos con los uniformes de los soldados alemanes de la Primera Guerra Mundial ${ }^{728}$. Los personajes del cuadro de Dix aparecen regocijados en su desgracia y como deseosos de volver a la batalla; así, el artista, mediante una imagen macabra, estaría tratando de conjugar una ironía a partir de los contrastes entre las prótesis y las medallas; en palabras de Fernández Lerma:

Tal vez sea esta una de las imágenes más poderosas en las que se establece esta relación entre la mutilación del cuerpo, su fragmentación, y las cualidades morales de los individuos o en este caso de la sociedad o el Estado que los ha convertido en la triste imagen que el pintor representa. Una imagen llena de ironía, en la que los detalles del funcionamiento de las prótesis, como si de una publicación médica se tratara, contrasta con la gloria de los uniformes y el premio de las medallas, como piezas de esta anatomía creada por la guerra. ${ }^{729}$

Asimismo, el autor compara la imagen de los personajes mutilados de Dix con una fotografía de soldados alemanes cuyos rostros fueron deformados en los combates de la Primera Guerra Mundial ${ }^{730}$; el gesto que se desprende de la expresión de estos soldados, o de lo que su desfiguración permite ver, evidencia tristeza y desesperanza. Pareciera como si en la realidad las medallas y el orgullo de posar con un traje militar no compensara la irreversibilidad que conlleva la pérdida de miembros y la deformación fisionómica, más aun, Fernandez Lerma mantiene que Dix estaría haciendo una denuncia $<<$ a través de la mutilación del cuerpo, de ese orgullo malsano en nombre del cual son enviados los hombres a la muerte y que en la República de Weimar tuvo un paréntesis de feroz crítica $>{ }^{731}$. Medallas y trajes militares junto a rostros desfigurados por la guerra vienen a hacer ostensible que, tras los ornamentos del "honor" y la "gloria", se hallan daños irreparables y pérdidas irremplazables. La historia de la dominación ha dejado escenas particularmente ininteligibles, inexplicables, irracionales y hasta extravagantes en el siglo XX. En La insoportable levedad del ser Kundera relata cómo en la Praga de 1968, durante los días de la invasión soviética de Checoslovaquia, afloraron imágenes de

\footnotetext{
${ }^{728}$ Cfr. Fernando Fernández Lerma, Algo más que belleza (Madrid: Biblioteca Nueva, 2015), 53.

${ }^{729}$ Fernández Lerma, ob. cit., 54.

${ }^{730}$ Cfr. Fernández Lerma, ob. cit., 54.

${ }^{731}$ Fernández Lerma, ob. cit., 55.
} 
tanques, puños amenazantes, casas semiderruidas, muertos cubiertos con la ensangrentada bandera roja, blanca y azul, jóvenes que iban en moto a una enloquecida velocidad alrededor de los tanques y agitaban banderas nacionales con largos mástiles, jovencitas con faldas increíblemente cortas que provocaban a los pobres soldados rusos, sexualmente hambrientos, besándose ante sus ojos con viandantes desconocidos. $\mathrm{He}$ dicho ya que la invasión rusa no solo fue una tragedia sino también una fiesta del odio, llena de una extraña (y también inexplicable) euforia ${ }^{732}$.

La historia de la dominación, que hace de los cuerpos objetos y de la corporalidad su objeto por excelencia, brinda imágenes excepcionales: los cuerpos dominados o, en su defecto, aquellos que se hallan bajo la amenaza opresiva e irremediable de un poder externo, dejan de ser el cuerpo de uno mismo. Allí donde el cuerpo es alienado para defender lo ajeno, a riesgo de ser desfragmentado, deformado, despedazado y destruido; allí donde la resistencia resulta impotente frente a poderes de gran robustez, a causa de que su brutalidad pone en grave riesgo la vida, aparecen poderes que son extrínsecos a las fuerzas naturales del cuerpo de los individuos, aflorando casos en que lo corporal es sistemáticamente cosificado. Ejemplos de ello son las mutilaciones exhibidas junto a galardones militares o chicas en minifalda besando a cualquier viandante, fenómenos cuyas causas vienen motivadas por un "uso" determinado del cuerpo, que implica el empleo de lo corporal como objeto contra una otredad invasora o expoliadora. Cuando hay un poder que no puede ser derrotado valiéndose de la potencia inherente al cuerpo de uno mismo, la corporalidad pasa a ser utilizada como una cosa, ya sea por parte del dominador o por parte de la incontrolable desesperación. En consecuencia, el dominio escinde lo corporal de lo subjetivo, logra convertir al cuerpo de uno mismo en un objeto extraño para sí -se llegan a hacer cosas que uno no haría normalmente-, la dominación desintegra lo que la naturaleza da integrado, a saber, la subjetividad de los humanos inextricablemente asociada a la vida corporal.

Pero, además, la dominación también puede ocultarse en la dimensión subjetiva de los hombres una vez que su fuerza física ya se ha propagado. La dominación se sutiliza en lo subjetivo, sale a relucir una vez que el poder hizo mella, pues vierte conceptos de opresión que se prolongan y sedimentan en la subjetividad, creando automatismos de subsunción recogidos silenciosamente en esa opacidad propia de la dimensión interna de los individuos. Hay cuerpos en los que la dominación ejerció una presión física que,

\footnotetext{
${ }^{732}$ Milan Kundera, La insoportable levedad del ser (Barcelona: Fabula Tusquets Editores, 2005), 74-75.
} 
habiéndose detenido, deja sin embargo incubado en el terreno subjetivo cargas de sumisión que ascienden al exterior como actividades habituales. A este respecto, las palabras de Foucault en el inicio de la entrevista con Knut Boesers en 1977 resultan muy reveladoras:

Es un bello sueño que muchos comparten: dar por fin la palabra a quienes no pudieron tomarla hasta el presente, a quienes fueron forzados al silencio por la historia, por la violencia de la historia, por todos los sistemas de dominación y explotación. Sí. Pero hay dos dificultades. Primero, quienes fueron vencidos - en caso de que los haya, además-son aquellos a quienes, por definición, se les ha quitado la palabra. Y si pese a ello hablaran, no lo harían en su propia lengua. Se les ha impuesto una lengua extranjera. No están mudos. No es que hablen una lengua que no hayamos escuchado y nos sintamos hoy obligados a escuchar. Por el hecho de estar dominados, se les impusieron una lengua y ciertos conceptos. Y las ideas así impuestas a ellos son la marca de las cicatrices de la opresión a la que estaban sometidos. Cicatrices, huellas que impregnaron su pensamiento. Diría incluso que impregnan hasta sus actitudes corporales. ${ }^{733}$

Antes de que el pensamiento de Foucault apenas hubiera iniciado su andadura, varios filósofos estaban tratando de "decodificar" el origen de los comportamientos humanos que ocultan la presencia de un poder actuando sobre ellos; las "huellas" que siguieron estos autores conducían a una represión sexual primigenia.

\subsubsection{DESFIGURACIÓN SUBJETIVADA DE LO CORPORAL EN EL JUEGO ERÓTICO}

Uno de los problemas que la filosofía del siglo XX hizo suyos y que motivó nuevos debates antropológicos, sociológicos y políticos, tiene que ver con el erotismo. Las investigaciones psicológicas de Sigmund Freud proporcionaron nuevos materiales de reflexión para la filosofía, tras ellos estaba implícita la necesidad de pensar al hombre, su cuerpo, sus pulsiones y sus relaciones sociales desde perspectivas alternativas a los discursos tradicionales del pensamiento político, social y económico. Una de las obras de Freud que más ecos tuvo en el siglo XX, debido a las interpretaciones políticas que suscitó, fue El malestar en la cultura, en la que el psicoanalista presenta una imagen antropológica donde los individuos habrían venido naturalmente guiados por el "principio de placer" pero reprimidos por la cultura. La proyección psíquica del principio de placer genera severos desbarajustes con respecto a la naturaleza, ya que normalmente la vida humana se halla rodeada de sufrimiento y angustia. Superar estas

\footnotetext{
${ }^{733}$ Michel Foucault, El poder, una bestia magnífica (Buenos Aires: Siglo Veintiuno Editores, 2012), 55.
} 
sacudidas dolorosas implica moderar, e incluso eclipsar, la tendencia natural de los hombres al placer ${ }^{734}$.

Afirma Freud que el sufrimiento tiene tres vertientes y que una de ellas es el cuerpo (las otras dos son el mundo exterior y las relaciones con los otros). El propio organismo está expuesto a la muerte, por tanto, el dolor y la angustia son señales ineluctables de este destino ${ }^{735}$. Entre los métodos que la cultura humana ha creado para evadir y contener el sufrimiento, aunque solo fuera en menor o mayor medida, están aquellos que actúan sobre el organismo, dado que <<todo sufrimiento no es más que sensación, solo subsiste mientras lo sentimos, y solo lo sentimos como consecuencia de ciertos dispositivos de nuestro organismo $>>{ }^{736}$. La comunidad humana puede llegar a hacer dúctil algunos aspectos de la naturaleza y, con ellos, también la psique, así como los impulsos fisiológicos son modificados. Los humanos forman comunidades para superar los obstáculos más nocivos de la naturaleza suscrita a su individualidad, por lo que la cohesión comunitaria siempre ha de resultar más fuerte que el individuo particular, consecuentemente, el poder comunitario $<<$ se opone ahora como "derecho" al poder del individuo, el cual es juzgado como fuerza bruta. Esta sustitución del poder del individuo por el de la comunidad es el paso cultural decisivo $>>{ }^{737}$.

La cultura ejerce una fuerza que restringe el poder que por naturaleza tiene el individuo, de tal modo que el impulso hacia el placer se ve transformado por la intervención de la comunidad. El cometido de la cultura consiste en modificar ciertos aspectos naturales que afectan, afligen y golpean a los hombres cuando se reúnen en comunidad. El despliegue de las actividades que lleva a cabo la cultura para paliar y reprimir las tendencias sexuales de los individuos requiere de un derroche de energías psíquicas que la propia cultura toma prestadas de la sexualidad. Dice Freud que, de este modo, se levanta una estructura económica en la que las fuerzas psíquicas que el individuo emplea en su sexualidad van a ser trasvasadas al ámbito de la producción ${ }^{738}$.

La transfiguración que la sociedad laboral ejerce sobre el cuerpo supuso un tema filosófico en el siglo XX de especial envergadura, en concreto, fue el movimiento artístico de vanguardia del surrealismo el que tomó las teorías freudianas como

\footnotetext{
${ }^{734}$ Cfr. Sigmund Freud, El malestar en la cultura (Madrid: Ediciones Akal, 2017), 20-21.

${ }^{735}$ Cfr. Freud, ob. cit., 21-22.

${ }^{736}$ Freud, ob. cit., 23.

${ }^{737}$ Freud, ob. cit., 45.

${ }^{738}$ Freud, ob. cit., 55.
} 
inspiración para sus representaciones. La historiadora del arte Alyce Mahon en Surrealismo, Eros y política 1938-1968 afirma que el Eros de los surrealistas no es el mismo Eros de Freud, a saber, aquel que había que encauzar hacia la civilización en la vida social. El Eros surrealista desprendía una radicalidad subversiva de la realidad, ya que comprende que el interés de los surrealistas por el deseo y el erotismo iba más allá de la búsqueda de novedosos y provocadores estilos artísticos, sino que tras esa estética se revelaba aquello que la autora llama una "política de Eros", con claros propósitos revolucionarios. La combinación de lo erótico y lo político en el surrealismo pone <<el énfasis en el cuerpo erótico y sexual y en su increíble poder, manifestado en su arte y en sus exposiciones $>>{ }^{739}$. Uno de los pensadores que más vinculado estuvo a este movimiento de vanguardia fue Georges Bataille, quien perteneció al grupo intelectual "Contraataque: Unión de lucha de los revolucionarios", junto a personalidades como André Breton, cuyo asunto primordial fue la psicología del fascismo ${ }^{740}$.

En lo que a la cuestión erótica se refiere, Bataille elabora sus análisis partiendo de un enfoque etológico. Afirma que los movimientos naturales de los organismos vivos tienden al exceso, que la naturaleza es pródiga tanto en la creación de nuevos organismos como también en su destrucción. La vida es una explosión que necesariamente obliga a que unos seres sean sustituidos por otros ${ }^{741}$. Tan solo los seres humanos se preocupan por ejercer sus actividades empleando el menor gasto de fuerzas posible, aunque, asevera Bataille, esta no es una decisión anti-natural, pues la avidez de acumular beneficios es una operación que <<en su globalidad, (...) aspira a la prodigalidad hasta la angustia $>>{ }^{742}$. Además, el autor sostiene:

$\mathrm{Si}$ en las prohibiciones esenciales vemos el rechazo que opone el ser a la naturaleza entendida como derroche de energía viva y como orgía del aniquilamiento, ya no podemos hacer diferencias entre la muerte y la sexualidad. La sexualidad y la muerte solo son los elementos agudos de una fiesta que la naturaleza celebra con la inagotable multitud de los seres, y ahí sexualidad y muerte tienen el sentido del limitado despilfarro al que procede la naturaleza, en un sentido contrario al deseo de durar propio de cada ser. $^{743}$

\footnotetext{
${ }^{739}$ Alyce Mahon, Surrealismo, Eros y política 1938-1968 (Madrid: Alianza editorial, 2009), 16.

${ }^{740}$ Cfr. Mahon, ob. cit., 28.

${ }^{741}$ Cfr. Georges Bataille, El erotismo (Barcelona: Tusquets Editores, 2002), 63.

${ }^{742}$ Bataille, ob. cit., 64.

${ }^{743}$ Bataille, ob. cit., 65.
} 
Para Bataille, el erotismo se conforma a partir del intento del ser humano por escapar de su animalidad, sin embargo, en lo erótico se mantienen determinados aspectos de esta naturaleza animal. Lo erótico no determina una línea fronteriza entre lo animal y lo humano. La impulsión de la sexualidad $<<$ se mantiene incluso tanto en el erotismo que constantemente se lo relaciona con términos tales como animalidad o bestialidad $>>$, tal es así que <<la transgresión de lo prohibido tomó el sentido de un retorno a la naturaleza -cuya expresión es lo animal->>744. La inclinación infantil a la satisfacción sexual no está mediada por la prohibición, es en el momento en que irrumpen las prohibiciones sociales cuando surge el contenido transgresivo de lo erótico, más aun, la transgresión viene organizada por una sociedad laboral y, asimismo, el erotismo es también una actividad organizada ${ }^{745}$.

Lo erótico no es reducible al acto sexual, ni las funciones de los órganos sexuales sumariamente reflejan qué es lo erótico; cualquier animal sexuado posee propiedades y funciones orgánico-sexuales, el erotismo no reside en esas características externas, advertibles simplemente en los actos de los cuerpos. Bataille entiende que los estudios científicos sobre los comportamientos sexuales son el reflejo objetivo de informes realizados desde un punto de vista externo a los actos de la sexualidad. Estos informes no aportan nociones sobre qué es el erotismo, tan solo persiguen proporcionar datos, convirtiendo la sexualidad en una cosa, en un simple objeto de investigación. Bataille considera que la reflexión sobre el erotismo requiere de una interiorización de la experiencia sexual, precisa espiritualizar aquellos elementos orgánicos y psíquicos que participan de la sexualidad ${ }^{746}$.

A ojos de Bataille, el cuerpo como objeto sexual y las funciones genitales no muestran el carácter subjetivo del erotismo, tiene que haber un "cuerpo poético", una corporalidad subjetiva y no meramente un objeto aprehendido por la objetivación científica. El entorno íntimo donde se producen los actos sexuales humanos arruinan cualquier intento por obtener estadísticamente un conocimiento diligente sobre qué es el erotismo, los informes estadísticos, con sus operaciones matemáticas y los promedios que de ellas se deducen no dan cuenta del carácter esencial del sexo, no contemplan el

\footnotetext{
${ }^{744}$ Bataille, ob. cit., 99.

${ }^{745}$ Cfr. Bataille, ob. cit., 114.

${ }^{746}$ Cfr. Bataille, ob. cit., 156-158.
} 
exceso que supone la sexualidad, ni acceden al entorno íntimo en que se dan las relaciones sexuales ${ }^{747}$.

Del mismo modo, la animalidad subsiste en el hombre, su exuberancia sexual, sólo podría considerarse como una cosa si tuviéramos el poder de negarla, de existir como si ella no fuera nada. La negamos en efecto, mas en vano. Incluso la sexualidad, tachada de inmunda, bestial, es lo que más se opone a la reducción del hombre a la cosa: el orgullo íntimo de un hombre se vincula a su virilidad. La sexualidad no equivale en nosotros a la negación de la animalidad, sino a lo que tiene el animal de íntimo e inconmensurable. ${ }^{748}$

Bataille contrapone lo animal a lo humano mediante el carácter económico que dirige la vida de los hombres. En Las lágrimas de $\operatorname{Eros}^{749}$ asevera que <<el trabajo liberó al hombre de su animalidad inicial. El animal se convirtió en humano a causa del trabajo $>>750$. El trabajo no solamente ejerce una transformación de las cosas naturales, el trabajo también cambia al hombre, le hace humano, le hace racional ${ }^{751}$. Al igual que el trabajo precisa de unas operaciones conscientes en busca de una finalidad, también el erotismo requiere de actividades conscientes que alcancen un fin, en este caso la voluptuosidad. Pero el erotismo difiere del trabajo en que es una actividad que no persigue ganancia alguna, en consecuencia, el placer como finalidad se devalúa con respecto a las actividades productivas ${ }^{752}$. Mientras $<<$ la voluptuosidad es el resultado previsto del juego erótico. En cambio, el resultado del trabajo es el beneficio: la ganancia $>{ }^{753}$. Bataille observa que el trabajo y el erotismo siguen una trayectoria inicial de convergencia, ambos persiguen un fin de forma consciente, pero divergen en

\footnotetext{
747 Cfr. Bataille, ob. cit., 159-160.

${ }^{748}$ Bataille, ob. cit., 163-164. 1938-1968 (Madrid: Alianza editorial, 2009), 184-185.

${ }^{750}$ Georges Bataille, Las lágrimas de Eros (Barcelona: Tusquets, 2002), 60.

${ }^{751}$ Cfr. Bataille, ob. cit., 61.

${ }^{752}$ Cfr. Bataille, ob. cit., 62-63.

${ }^{753}$ Bataille, ob. cit., 64.
}

749 Según comenta Alyce Mahon, esta obra guarda una especial relación con la coyuntura sociopolítica nacional e internacional que vivía Francia y con aspectos pertenecientes a la vida personal del propio autor en 1961. <<Bataille mezcló la antropología, el análisis literario, la historia del arte y la indagación filosófica en su estudio del exceso erótico, Las lágrimas de Eros. Bataille examinaba la relación entre el torturador y la víctima en diferentes rituales sacrificiales y sádicos, tanto en las sociedades antiguas como en las modernas, y concluía con un capítulo particularmente macabro, donde describe sacrificios de vudú en África, así como el ritual chino de tortura de los "Cent Morceaux" [cien pedazos]. El autor concluía deliberadamente el libro con ejemplos de violencia extrema. Quería que el lector terminara con una sensación de atrocidad. La resonancia de la obra de Bataille entre los lectores contemporáneos surgía indudablemente, por lo menos en parte, de la incesante violencia de la guerra de Argelia. De hecho, Bataille tuvo muy presente la guerra de Argelia mientras escribía el libro cuando su propia hija, Laurence, fue detenida y encarcelada por protestar contra el conflicto〉>. Alyce Mahon, Surrealismo, Eros y política 
la naturaleza de sus respectivos fines. De este modo, en la perspectiva de la técnica y la ciencia, la sexualidad tiende a cosificarse porque hay un punto de dispersión respecto de los factores que coadyuvan a intensificar, mejorar y optimizar el trabajo con respecto a aquellos elementos que pertenecen a una rémora de animalidad inmanente a la corporalidad humana: su tendencia impulsiva al placer. Este impulso en busca de placer es modificado e incluso distorsionado por el erotismo, pero, a diferencia del trabajo, en el erotismo el cuerpo todavía conserva un componente animal del que mana subjetividad. Sin embargo, la imagen económica del cuerpo hace de lo corporal un objeto de explotación.

En la filosofía de Bataille se pone de manifiesto la presencia de un substrato animal en la vida humana, la experiencia que el individuo tiene de su propio cuerpo ha sido transfigurada por la sociedad, cuya característica esencial es la actividad económica de trabajar. La estructura artificial que surge a partir de la sociedad laboral lleva junto a sí la exclusión de todo componente bestial del humano, no obstante, este componente no es aniquilado sino que más bien termina ocultándose en forma de sustrato subjetivo. El cuerpo pasa a ser objeto de trabajo y, dentro del ordenamiento de las relaciones laborales, este será también objetivado por la ciencia. Las investigaciones científicas sobre las relaciones sexuales muestran -de acuerdo con las críticas de Bataille- esta imagen cósica del cuerpo postulada por la ciencia y que no indaga ni trata de descubrir aspectos subjetivos necesarios para revelar la esencia del erotismo. Bataille apela a la imagen social y científica del cuerpo, tras este cuerpo objetivo estaría invisibilizado ese sustrato animal que todavía perdura en los individuos. La sociedad transforma el deseo animal-sexual en erotismo, la subjetivación del cuerpo dentro de esta operación desfigura la experiencia corporal, las convenciones sociales transmutan la forma del cuerpo y lo tornan útil para ejercer un control fehaciente de las relaciones sexuales, mas el deseo -animal- continúa funcionando en el sustrato subjetivo humano. El deseo sexual es reprimido por medio de la propia cosificación del cuerpo, lo erótico distorsiona el instinto sexual poniendo al cuerpo en el centro de las relaciones sociales.

La represión del deseo animal y la transfiguración social de la imagen del cuerpo es un tema que el surrealista Hans Bellmer plasmó a través de sus muñecas ${ }^{754}$ en los años treinta, en coincidencia con los años en que Hitler tomó el poder. Mahon sostiene que las desfiguraciones perturbadoras de las muñecas creadas por el artista alemán

\footnotetext{
${ }^{754}$ Cfr. Alyce Mahon, Surrealismo, Eros y política 1938-1968 (Madrid: Alianza editorial, 2009), 29 y 53.
} 
pueden interpretarse en el plano sexual y en el político -como símbolos de un erotismo subversivo y sádico, una rebelión adolescente y antiedípica-; pero además, en términos históricamente más específicos, pueden considerarse como un enunciado contra el nazismo. Creada por primera vez en 1933, (..), la sexualidad incontrolada y “degenerada" de las muñecas de Bellmer desempeñaron el papel de afirmación alegórica contra todo lo que representaba el nazismo (...). Si la iconografía nazi enfatizaba el confort de lo femenino maternal, moral y natural (aplicando el diktat del Tercer Reich para las mujeres: Kinder, Kirche, Küche [hijos, iglesia, cocina]), la muñeca de Bellmer enfatizaba el poder siniestro y la amenaza de lo femenino. ${ }^{755}$

Bellmer trataba de rescatar la esencia femenina de la cosificación de su cuerpo, fruto del convencionalismo social, que termina constituyendo imágenes arquetípicas e idealizadas de la "mujer ideal" tras la que se encuentra un propósito por dominar y sumir a la mujer en las actividades de trabajo como cocinar, cuidar a los hijos, cuidar el hogar, etc., actividades a las que la sociedad laboral relegó a la mujer y que no tuvieron -ni tienen todavía a día de hoy- el reconocimiento de trabajo remunerado. Las muñecas de Bellmer se oponen a los cánones tradicionales con que ha sido representado el cuerpo de la mujer. Los cuerpos femeninos han sido representados bajo estrictas proporciones, acompañadas de todo un cupo de valores y roles que están más allá de la apariencia, pues exigen, a la vez, un determinado número de roles sociales impuestos a la mujer.

Fernández Lerma se remonta a los orígenes de la muñeca Barbie, cuya primera réplica era una muñeca de coleccionismo para adultos que comenzó a ser fabricada con motivo de unas viñetas del semanario alemán Bild, que representaban a una mujer rubia, voluptuosa y de bajo nivel intelectual, a la que dibujante y editor llamaron Lili $^{756}$. Fernández Lerma dice que curiosamente este nombre femenino aparece en el título de la canción Lili Marleen, una canción popular de la Primera Guerra Mundial que evocaba a la mujer del hogar, sometida a los deseos del hombre, ya fuera el hijo, el novio o el marido $^{757}$. Fernández Lerma dice que

Lili o Barbie ha sido para las mujeres la imposición de un arquetipo, de un canon de belleza imposible en un mundo de plástico, confort y felicidad. Barbie, con sus medidas,

\footnotetext{
${ }^{755}$ Mahon, ob. cit., 30.

${ }^{756}$ Cfr. Fernando Fernández Lerma, Algo más que belleza (Madrid: Biblioteca Nueva, 2015), 48.

${ }^{757}$ Lili Marleen también fue escuchada por los soldados durante la Segunda Guerra Mundial, sobre todo en la campaña de los alemanes en África, además, los británicos la interpretaron en su idioma. Fernández Lerma extrae la información acerca del recorrido histórico de esta canción de la investigación de Rosa Sala sobre el tema, en El misterioso caso alemán (Barcelona: Alba, 2007).
} 
sus ojos azules y su melena rubia ha supuesto, de manera contraria a otras muñecas con rasgos infantiles, la idealización de una edad adulta occidental, de ociosa supremacía, de erotismo y de lujo. Por una parte, era difícil no querer ser Barbie; por otra, era imposible serlo. El deseo se convierte en realidad a fuerza de anhelarlo y durante las últimas generaciones el cliché se ha convertido en norma y miles de adolescentes han enfermado física y mentalmente por no poder encarnar un ideal. La mujer occidental ha sufrido en la época de su liberación una de las mayores cargas, aceptada, en apariencia, de buen grado. ${ }^{758}$

El autor se refiere a la producción de imágenes como forma de incluir contenidos subjetivos erotizados en la sociedad, unos contenidos que portan un trasfondo prescriptivo, trasfondo que opera a través de los cánones estéticos introducidos en la dimensión subjetiva de los individuos. El "cuerpo plástico" de una muñeca genera todo un dispositivo de dominación pues tras esa "concavidad plástica" se hallan disposiciones que pretenden ordenar las relaciones sociales y posicionar lo femenino con respecto a lo masculino de una determinada manera. La cosificación de la corporalidad femenina y la plastificación de su piel, contribuyen a perpetuar clichés que influyen en las voliciones y mueven los deseos, incidiendo en el trato que ciertas mujeres hacen de su propio cuerpo y que puede llevar a la auto-agresión. El ejemplo de cosificación de la corporalidad tiene su principal auge en la cultura del consumo de la segunda mitad del siglo XX. La vida corporal humana, de una manera cada vez más exagerada, comenzó a girar en torno a ciertos fetiches producidos por el mercado, el consumo de productos pasó a estar mediado casi en su totalidad por pautas publicitadas que incidían en la forma de desear. La creación de cánones y estándares corporales convencionalmente inducidos a través de la subjetividad hizo posible el movimiento uniforme de grandes cantidades de individuos, todos ellos llevados de la mano de contenidos de subjetivación que les fueron introducidos por agentes de interés externos a ellos.

\subsubsection{Dimensión POLÍtiCa DE LO GENITAL EN MARCUSE}

En el año 1937 Herbert Marcuse publica El carácter afirmativo de la cultura, una obra fundamentalmente de temática estética, pero en la que tiene lugar un análisis filosófico de la relación entre el alma y el cuerpo. En concreto, Marcuse critica el tratamiento que la sociedad burguesa le concedió a la dualidad alma-cuerpo. El interés

\footnotetext{
${ }^{758}$ Fernando Fernández Lerma, Algo más que belleza (Madrid: Biblioteca Nueva, 2015), 49.
} 
del autor por esta cuestión, en esta etapa de su pensamiento, tenía una clara influencia marxista, de tal forma que la concepción del alma libre estaría $<<$ al servicio de la entrega ideológica de la existencia a la economía del capitalista $>{ }^{759}$. Para Marcuse, que el alma sea erigida por la sociedad burguesa como dominio esencial de la vida implica la renuncia y subsunción de los sentidos, lo que llevaría aparejada la internalización del placer, es decir, situarlo dentro de la dimensión espiritual humana, sin tener que recurrir al cuerpo como su principio de acción ${ }^{760}$. Páginas antes, el autor hacía referencia a la concepción de igualdad promulgada por la sociedad capitalista, una igualdad concebida de forma abstracta y que, por tanto, ignora las condiciones concretas en que viven los individuos. Para Marcuse, esta forma de entender la igualdad se desvanece en el momento en que solo una parte minoritaria de la población puede acceder a la propiedad de todas las mercancías necesarias para la felicidad. El poderío de la burguesía promovió <<la libertad abstracta para gozar de la libertad individual: disponía ya de las condiciones materiales capaces de proporcionar estas satisfacciones $>>{ }^{761}$.

La noción de un alma igual y libre, entendiendo estas características de forma abstracta, constituye para Marcuse < <un factor útil de la técnica del domino de las masas en la época de los estados autoritarios en que fue necesario movilizar todas las fuerzas disponibles en contra de la modificación real de la existencia social >> ${ }^{762}$. La burguesía utilizó la idea del alma para sostenerse en el poder, este fue siempre su único interés. Las sociedades burguesas liberan a los individuos, aunque conserven la disciplina y el factor condicionante de la prohibición del placer. En este orden social, las clases dominadas no llevan a cabo una servidumbre personal hacia sus dominantes, dado que el uso del cuerpo como instrumento de placer o como medio para procurárselo es tomado como una práctica indigna. Sin embargo, el uso mediato de las capacidades mentales y de las fuerzas corporales para la obtención de beneficios económicos sería visto como una práctica propia de la naturaleza de la libertad. En estos términos, la explotación del cuerpo no iba a ser ya forzada, sino que la propia alma por voluntad libre decidiría hacer unas u otras actividades productivas $^{763}$.

\footnotetext{
${ }^{759}$ Herbert Marcuse, El carácter afirmativo de la cultura (Buenos Aires: El Cuenco de Plata, 2011), 31.

${ }^{760}$ Cfr. Marcuse, ob. cit., 32-33.

${ }^{761}$ Marcuse, ob. cit., 16.

762 Marcuse, ob. cit., 37.

${ }^{763}$ Cfr. Marcuse, ob. cit., 39.
} 
La miseria y la desgracia fueron absorbidas por la cultura para justificar la existencia de un tipo de felicidad desligada de las condiciones corporales y asociada únicamente a la dimensión interna de los hombres: el alma, allí donde la condición humana se dignifica. En este aspecto, Marcuse afirma que los seres humanos

pueden sentirse felices, aun cuando no lo sean en absoluto. La apariencia vuelve incorrecta la afirmación de la propia felicidad. El individuo, reducido a sí mismo, aprende a soportar y, en cierto modo, a amar a su propio aislamiento. La soledad fáctica se eleva a la categoría de soledad metafísica y recibe, en tanto tal, la bendición de la plenitud interna a pesar de la pobreza externa. La cultura afirmativa reproduce y sublimiza con su idea la personalidad, el aislamiento y el empobrecimiento social de los individuos. ${ }^{764}$

El interés de Marcuse por la cultura y la reflexión crítica de sus vicisitudes continuó gestándose en los siguientes años y décadas; fue a mitad de los años cincuenta cuando el pensador publicó Eros y civilización, obra en la que, tal como comenta Bryan Turner, $<<$ se apartó en considerable medida del núcleo ortodoxo del marxismo tradicional al afirmar que el trabajo, lejos de ser la fuente de todo valor, era sencillamente una carga >> 765 y <<adoptó el marco básico de la filosofía freudiana para dar cuenta de los procesos de control social en el capitalismo $>>766$.

Justo al comienzo del primer capítulo de Eros y civilización, Marcuse asegura que la concepción antropológica <<que surge de la teoría freudiana es la acusación más irrefutable contra la civilización occidental -y al mismo tiempo, es la más firme defensa de esta civilización->>, y menciona también que para Freud $<<$ la historia del hombre es la historia de su represión. La cultura restringe no solo su existencia social, sino también la biológica, no solo partes del ser humano sino su estructura instintiva en sí misma >> ${ }^{767}$. Según Marcuse en el pensamiento freudiano la historia de la humanidad no puede desenvolverse al margen de la represión, dado que la cultura ha ejercido una transfiguración psíquica y biológica de los individuos humanos. Los hombres son seres históricos precisamente porque la represión trastocó la estructura biológica e instintiva con la que contaban por naturaleza.

Marcuse interpreta que el término "principio de realidad" de Freud se refiere a una modificación cultural del principio de placer, que es un impulso libidinal y

\footnotetext{
${ }^{764}$ Marcuse, ob. cit., 47.

${ }^{765}$ Bryan Turner, El cuerpo y la sociedad (México D.F: Fondo de Cultura Económica, 1989), 48.

766 Turner, ob. cit., 49.

${ }^{767}$ Herbert Marcuse, Eros y civilización (Barcelona: Seix Barral, 1968), 25.
} 
congénitamente natural de los seres humanos, es decir, todo individuo tiende por naturaleza a buscar la sensación de placer, una sensación cuyo origen reside en la dimensión genital del organismo. Mediante $<<$ la institución del principio de realidad, el ser humano que, bajo el principio del placer, ha sido apenas un poco más que un conjunto de impulsos animales, ha llegado a ser un ego organizado $>>{ }^{768}$. El principio de realidad se advierte como una estructura tanto interna como externa que contribuye a la contención de los impulsos instintivos de los individuos. Freud estableció la existencia de dos tipos de instintos: Eros y Tanatos; el primero es el instinto sexual y el segundo es el instinto de muerte. Para el psicoanalista la pulsión de muerte pasa mucho más inadvertida en la vida, ya que a menudo

tropezamos con dificultades para pesquisarla; por fin, llegamos a ver en el sadismo un representante de ella. Sobre la base de consideraciones teóricas, apoyadas por la biología, suponemos una pulsión de muerte, encargada de reconducir al ser vivo orgánico al estado de muerte ${ }^{769}$.

La dificultad para localizar con suficiente claridad el Tanatos la asume Marcuse cuando asegura que $<<$ Eros es definida como la gran fuerza universal que preserva la vida. La relación última entre Eros y Tanatos permanece oscura $>>{ }^{770}$. No obstante, Eros y Tanatos se combinan en el desarrollo de la civilización en la medida en que la realización de la represión organiza y transforma aspectos del vivir y del morir. $<<\mathrm{La}$ obra de la represión pertenece tanto al instinto de muerte como al de la vida $>>{ }^{771}$.

Para Marcuse, el reconocimiento de Eros es un factor que opaca el instinto de la muerte, puesto que el contenido de Eros, que es una modificación cultural de los instintos libidinales de la sexualidad, desplaza al instinto de muerte fuera de sus márgenes. Pero, sin embargo, dentro de la civilización la pulsión de muerte o instinto de destrucción también se modifica, pasando a ser Tánatos, lo que sucede es que el Tánatos pasa inadvertido fácilmente. La génesis de Tánatos comenzaría con una relación artificial que, por tanto, ha sido puesta en marcha por la cultura: cuando el instinto de destrucción se pone a merced del principio de Nirvana, que es el principio correspondiente a un estado de alivio de las perturbaciones que afectan y angustian a los

\footnotetext{
768 Marcuse, ob. cit., 27.

769 Sigmund Freud, Obras completas (volumen 19). "El yo y el ello y otras obras" (Buenos Aires: Amorrortu, 1992), 41.

${ }^{770}$ Herbert Marcuse, Eros y civilización (Barcelona: Seix Barral, 1968), 39.

${ }^{771}$ Marcuse, ob. cit., 61.
} 
hombres, resulta que la muerte, entendida como destrucción, pasa a ser comprendida también como un estado de conciencia en el que se anulan el dolor y las tensiones latentes de la vida. Si la muerte del cuerpo llegara a término, los deseos y las necesidades quedarían anuladas, el cuerpo no sentiría ni padecería las precariedades de la existencia, y, entonces, la humana confrontación contra el sufrimiento habría obtenido su victoria en la muerte. El principio de Nirvana involucra al instinto de destrucción en un plexo histórico no natural, puesto que representar la muerte como una desconexión del sufrimiento implica que ya existe una cultura en la que se está llevando a cabo una producción representacional sobre la muerte ${ }^{772}$.

El instinto de la muerte tiene su prolongación sigilosa y nada destacada en el desarrollo de las civilizaciones. La muerte no deja de ser un activo en la realización de los procedimientos represivos, por tanto, a ojos de Marcuse, el principio de muerte está implícitamente establecido en la vida de la civilización como un substrato de utilidad:

El silencioso "acuerdo profesional" sobre el hecho de la muerte y la enfermedad es quizá una de las más amplias expresiones del instinto de la muerte -o, mejor, de su utilidad social. En una civilización represiva la muerte misma llega a ser un instrumento de la represión. Ya sea que la muerte sea temida como una amenaza constante, o glorificada como un sacrificio supremo, o aceptada como destino, la educación para el consentimiento de la muerte introduce un elemento de rendición dentro de la vida desde el principio. ${ }^{773}$

La muerte puede ser entendida como una forma de liberación, como una manera de proteger a la comunidad de sí mismo; en la civilización el hecho de morir puede tener muchas connotaciones, significados y razones, pero para Marcuse es el propio recuerdo de las víctimas el que apela directamente a la humanidad, y el hecho que constantemente confirma la imposibilidad de una civilización en la que no existe represión ${ }^{774}$.

Se tercia relevante soslayar que Marcuse se preocupa de seguir el rastro diferencial entre < las vicisitudes biológicas y sociohistóricas de los instintos $>>775$, una diferenciación que, a ojos del autor, Freud no especificó ni explicitó. De este modo, Marcuse construye un término llamado "represión sobrante", para denominar aquellas

\footnotetext{
${ }^{772}$ Cfr. Marcuse, ob. cit., 39-41.

${ }^{773}$ Marcuse, ob. cit., 217-218.

${ }^{774}$ Cfr. Marcuse, ob. cit., 218.

775 Marcuse, ob. cit., 45.
} 
restricciones impuestas en el dominio social, que varían según la forma específica en que una u otra sociedad se organiza. Esta forma de represión va más allá de los requisitos restrictivos necesarios para perpetuar la civilización en la vida de los hombres. Por otro lado, a través del término "Principio de actuación", Marcuse concibe las variaciones que toma el principio de realidad en la historia. El principio de actuación modula variables históricas del principio de realidad ${ }^{776}$. La metapsicología de Freud habría establecido que la existencia humana está expuesta a la ananké, la escasez, una situación que impide satisfacer la natural e instintiva pulsión sexual. La organización del trabajo oblitera la sexualidad pero solivianta el dolor que produce la escasez, ya que gracias al trabajo los seres humanos logran procurarse los medios de subsistencia suficientes para continuar su vida, aunque con ello el principio de placer se demuestre incompatible con la civilización. Para Marcuse, Freud habría tomado la escasez como un hecho dado de forma absoluta, pero no habría llegado a observar cómo la escasez es gestionada de acuerdo a los parámetros administrativos e institucionales con que las distintas civilizaciones hacen frente a esta coyuntura vital. La distribución racionalizada de la escasez no evita la presencia de agentes dominantes, cuyo poderío, instalado dentro del conjunto de relaciones sociales de trabajo, transmuta la esencia del principio de realidad de manera constante; quiere decir el autor que por mucho que los individuos humanos obtengan gratificación a través de los productos que les brinda su tejido productivo-industrial, eficiente y tecnificado, las prácticas de dominación no dejan de actuar. La civilización no puede prescindir de la represión, mas, las formas de dominación que se dan en su interior varían según la composición histórica del principio de realidad ${ }^{777}$.

La civilización incide directamente sobre la corporalidad, para que la represión del aparato instintivo humano se haga posible el cuerpo ha de convertirse en objeto de las operaciones represivas, con el fin de tornarlo en instrumento de producción. Como la sexualidad es un estorbo para las actividades laborales, la genitalidad humana es intervenida por la civilización causando en ella una desexualización de los impulsos. A este respecto, Marcuse afirma:

El placer de los sentidos inmediatos actúa en las zonas erógenas del cuerpo -y lo hace solo por el gusto del placer. Su desarrollo irreprimido erotizaría al organismo hasta tal

\footnotetext{
${ }^{776}$ Cfr. Marcuse, ob. cit., 46.

${ }^{777}$ Cfr. Marcuse, ob. cit., 46-47.
} 
grado que actuaría contrariamente a la desexualización del organismo necesaria para la utilización social de este como un instrumento de trabajo. ${ }^{778}$

El cuerpo se convierte en objeto de trabajo en la civilización. El principio de placer no es completamente anulado, sino desplazado hacia el espacio donde se desarrollan las actividades productivas, por tanto, el instinto sexual es reconducido por parte del principio de realidad. Este <<proceso abarca la separación de la libido de nuestro propio cuerpo para dirigirla hacia un objeto ajeno del sexo opuesto $>>779$, lo que significa que la sexualidad será valorada solo en cuanto a su funcionalidad, en cuanto que la procreación genera nuevos organismos vivos. Lo sexual queda reducido a los márgenes de la procreación como elemento útil del orden civilizatorio. Marcuse observa que la universalización de las leyes se extiende sobre toda la sociedad, sus operaciones sobre el individuo se realizan tanto externa como internamente, en consecuencia, la represión pasa a formar parte de la vida habitual del individuo, la conjugación del dominio veda el componente represivo del ordenamiento objetivo de la sociedad. La dominación desarrolla la sexualidad y la civilización dentro de un orden de cosas, por medio del <<mando del principio de actuación, el cuerpo y la mente son convertidos en instrumentos del trabajo enajenado $>>780$, o sea, tanto la dimensión interna como externa del individuo son puestas a disposición de las actividades organizadas de producción.

Marcuse considera que en las sociedades industriales contemporáneas el trabajo va haciéndose cada vez más ajeno al individuo, de modo que la racionalización técnica de los procesos de producción sería una clara tendencia de ello. Pero esta forma de trabajar mecanizada no forma parte de las expectativas de realización personal, tan queridas como pretendidas por todo individuo. Mientras el trabajo se va desprendiendo de los seres humanos, estos hallan en el tiempo libre su ámbito de proyección para la libertad, de esta forma la represión atenúa sus cauces de acción. La sexualidad en condiciones de no represión, pero dentro de la vida civilizada, constituye propiamente el nacimiento de Eros. El Eros, que procura la satisfacción de los instintos sexuales, en un primer momento anula la razón bajo el principio de actuación, principio a través del que Eros se pone en funcionamiento. El individuo se satisface sexualmente cuando suspende los factores racionales que en condiciones normales orientan y dirigen su vida, no obstante,

\footnotetext{
${ }^{778}$ Marcuse, ob. cit., 49.

${ }^{779}$ Marcuse, ob. cit., 50.

${ }^{780}$ Marcuse, ob. cit., 55.
} 
en un plano que rebasa el principio de actuación, la realización de la felicidad necesita pautas racionales. Lo razonable pasa así a formar parte de la dimensión del Eros, de modo que el principio de placer se prolonga a la racionalidad, y penetra en el orden de la conciencia ${ }^{781}$.

El análisis marcuseano de la civilización tiene en cuenta la génesis de la represión y las formas de dominación que se despliegan, perduran y emergen a tenor de ella. Este análisis parte de un sujeto cuyo cuerpo y cuya conciencia componen una unidad integrada. Marcuse descubre que el ejercicio del poder en la civilización debe desarrollarse a partir de este sujeto unitario: las fuerzas represivas de la civilización no vacilan entre la dimensión psíquica y la dimensión corporal del individuo, se aplican sobre una individualidad no dual, una individualidad integrada en la que las modificaciones sobre lo fisiológico repercuten psíquicamente y las modificaciones sobre la dimensión psíquica influyen en lo corporal. La civilización reprime los instintos y con ello transfigura el organismo, pero también vierte una serie de automatismos represivos en el interior de los individuos; la dominación conforma un aparato conceptual en la dimensión interna de los sujetos a la vez que se materializa en las relaciones sociales de trabajo, como una mole estructural externa que tiene amarrada la genitalidad.

El hombre civilizado de Marcuse no ejerce un poder directo sobre su dimensión genital, no tiene una disposición de su cuerpo que no haya venido determinada por la represión. Incluso la sexualidad liberada, el Eros, no puede sustraerse a la civilización, ya que Eros no conforma una experiencia sexual previa a la irrupción de la cultura. La civilización trae consigo dominaciones que escapan al control de los individuos; tanto las experiencias corporales como aquellas que tocan al interior vienen determinadas por este poder extrínseco a los sujetos humanos. Si Marcuse en los años treinta consideraba que el alma era el dispositivo de dominación de la sociedad burguesa, en los cincuenta vendría a decir que tanto la interioridad - la zona reservada para el alma- como la exterioridad están aherrojadas a los mecanismos impersonales de la producción. Los vértices económicos que dirigen la vida gestionan tanto las fuerzas naturales del cuerpo, que impelen la libido, como el orden de los pensamientos, a saber, los deseos de gratificación.

${ }^{781}$ Cfr. Marcuse, ob. cit., 206-207. 


\section{SECCIÓN II. SISTEMAS DE CONTROL FRENTE A LA}

\section{POSIBILIDAD DE UNA COMPLEXIÓN SOCIAL FUERTE: EL}

\section{SALVOCONDUCTO DEL INDIVIDUALISMO ECONÓMICO}

\subsubsection{MARCUSE Y LA DOMINACIÓN HÍBRIDA EN LAS SOCIEDADES INDUSTRIALES} AVANZADAS

La filosofía de Marcuse tuvo una importante influencia en los movimientos sociales contestatarios y de corte revolucionario que culminaron en el histórico acontecimiento conocido como "Mayo del 68", cuyo foco principal estaba en Francia. El pensamiento marcuseano inspiraba, así como coincidía, con un ambiente de reivindicación política en el que el concepto de Eros era una punta de lanza para el reclamo de cambios sociales. Mahon destaca que Eros y civilización fue traducido durante los años sesenta al francés, al igual que El hombre unidimensional, obra publicada también en la década de los sesenta y traducida a lengua francesa justo en el año 1968. Afirma la historiadora del arte que <<Marcuse indudablemente compartía preocupaciones y temas con los surrealistas $>>$ dado que $<<\operatorname{los}$ surrealistas argumentaban que el impulso de adquirir bienes ha de ser rechazado en pro del impulso del deseo $>>{ }^{782}$.

Uno de los hilos argumentales principales que enlaza la problemática marcuseana en Eros y civilización y en El hombre unidimensional tiene que ver con la erotización del tiempo libre: en la primera obra Marcuse mostró su preocupación por el hecho de que la efectividad de los mecanismos represivos en las sociedades industriales llegara a crear formas aparentes de libertad que, bajo el espejismo de una supuesta contraposición entre la vida privada y la existencia pública, controlara las dinámicas de los individuos durante el tiempo no dedicado al trabajo ${ }^{783}$; asimismo, en la segunda obra, el autor se centra en el tema de la introyección de necesidades en los individuos como forma de control social ${ }^{784}$. Dentro de las sociedades industriales avanzadas, una vez cubiertas las necesidades biológicas básicas, el orden de lo necesario se vuelve superfluo, es decir que su cumplimiento no condiciona la supervivencia del individuo. Marcuse divide las necesidades en "verdaderas" y "falsas", pues entiende que las segundas se gradúan

\footnotetext{
782 Alyce Mahon, Surrealismo, Eros y política 1938-1968 (Madrid: Alianza editorial, 2009), 185.

${ }^{783}$ Cfr. Herbert Marcuse, Eros y civilización (Barcelona: Seix Barral, 1968), 208.

${ }^{784}$ Cfr. Herbert Marcuse, El hombre unidimensional (México D.F: Editorial Joaquín Mortiz S.A., 1968), 26.
} 
según la historia de los hombres y, por tanto, no atienden a la pura obligatoriedad de tener que mantener al organismo con $v^{2} a^{785}$. Las necesidades falsas $<<$ tienen un contenido y una función sociales determinadas por poderes externos sobre los que el individuo no tiene ningún control $>$, mientras que las necesidades verdaderas son las únicas <<que pueden inequívocamente reclamar satisfacciones〉> ${ }^{786}$.

Además, por otro lado, como ya argumentara durante los años treinta en El carácter afirmativo de la cultura, en El hombre unidimensional Marcuse sostiene que la libertad promulgada por las sociedades capitalistas se contradice con la necesidad imperiosa de participar en el mercado, ya que los individuos se ven obligados a elegir entre el trabajo o la mera subsistencia, de tal forma que su margen de elección resulta bastante limitado y estrecho. Si gracias a la eficiencia de la mecanización en las labores productivas los individuos pudieran finalmente liberarse del trabajo enajenado, si todos los hombres satisficieran sus necesidades sin incurrir en muchos esfuerzos y preocupaciones, la racionalidad técnica contribuiría a ampliar la autonomía de las personas para adentrarse en un terreno inexplorado de la libertad ${ }^{787}$. Pero el ordenamiento político de las sociedades industriales avanzadas, según Marcuse, tiende más bien hacia el totalitarismo y no hacia la liberación de los enajenamientos y las alienaciones, no porque en estas sociedades los poderes dominantes recurran directamente a la implantación del terror, sino porque consiguen distorsionar y moldear las necesidades de los individuos en función de intereses externos a ellos.

Para Marcuse el poder político está a expensas de los procedimientos de producción industrial, cualquiera que sea el signo del partido político de turno en el gobierno, este habrá de contribuir forzosamente a mantener el orden social establecido ${ }^{788}$. Entonces, consecuentemente, aunque las máquinas realicen trabajos productivos con mayor eficacia y eficiencia que los hombres, el hecho de que los cuerpos en el mundo laboral actúen como si fueran extensiones de la organización técnico-productiva se halla amparado y sostenido por el orden político, pues únicamente y <<en esencia el poder de la máquina es solo el poder del hombre almacenado y proyectado $>>789$; tiene que haber

\footnotetext{
${ }^{785}$ Cfr. Marcuse, ob. cit., 26-27.

${ }^{786}$ Marcuse, ob. cit., 27.

${ }^{787}$ Cfr. Marcuse, ob. cit., 24.

${ }^{788}$ Cfr. Marcuse, ob. cit., 24-25.

${ }^{789}$ Marcuse, ob. cit., 25.
} 
una forma de dominación que se haga efectiva a través de los ritmos productivos impuestos por la máquina.

Marcuse observa que los proletarios, inmersos en los engranajes articulados por los mecanismos sociales de producción, son la negación del sistema que los explota -lo que ya descubriera Marx-, pero, en el caso de las sociedades industriales avanzadas, no se trata de un tipo de negación explícita sino implícita, mediata y diluida en la división del trabajo de los procesos mecánico-productivos. El tiempo de trabajo que la eficiencia técnico-mecánica resta y obliga a redistribuir las energías libidinales de los individuos, no obstante, y según el razonamiento que el pensador alemán hace patente en Eros y civilización, el principio de actuación por el que los seres humanos son explotados en actividades productivas ya no requiere de una excesiva represión sobrante, luego, el principio de realidad dejaría de ser represivo

conforme la división del trabajo llegara a estar orientada hacia la gratificación de las necesidades individuales libremente desarrolladas; mientras que, en las relaciones libidinales, el tabú sobre el uso total del cuerpo sería debilitado. Sin ser empleado ya como un instrumento del trabajo del tiempo completo, el cuerpo sería sexualizado otra vez. (...) El cuerpo en su totalidad llegaría a ser un objeto de catexis, una cosa para gozarla: un instrumento de placer. ${ }^{790}$

Bryan Turner interpreta que la sexualización del cuerpo en la filosofía de Marcuse se deriva del hecho de que la $<<$ libertad social requiere de la libertad sexual; ambas libertades estaban siendo posibles gracias al cambio económico capitalista〉>, asimismo, la <<amenaza fundamental a estas potencialidades provino de la comercialización y mercantilización del sexo, lo cual hizo redituable a la sexualidad $>>{ }^{791}$. Conviene tener presente, además, cómo el sociólogo británico Anthony Giddens da a conocer, de manera muy sintética, la problemática marcuseana sobre la liberación de la libido a costa de recluirla en la dimensión genital. Sostiene Giddens que para Marcuse -así como también para Freud- el instinto de muerte fue despojado de su relación con la libido en las sociedades tradicionales, pero que la sociedad industrial, al liberar parte del tiempo de trabajo, vuelve a situar al instinto de muerte en la estela del placer sexual. Liberarse $<<$ de la fatiga permite la reerotización no solo del cuerpo, sino de la

\footnotetext{
${ }^{790}$ Herbert Marcuse, Eros y civilización (Barcelona: Seix Barral, 1968), 188.

${ }^{791}$ Bryan Turner, El cuerpo y la sociedad (México D.F: Fondo de Cultura Económica, 1989), 49.
} 
naturaleza $>>792$. Giddens soslaya que Marcuse viera en el Eros un modo de socializar a los seres humanos, las relaciones sociales se ven expuestas a la gratificación, donde la racionalidad represiva ha dejado paso a una racionalidad sensual ${ }^{793}$. Marcuse considera que la civilización no-represiva sigue generando formas de dominación: pese a haber sido eliminada la represión excedente, los cuerpos humanos continúan expuestos a explotación, ya no mediante la extracción de su fuerza de trabajo, sino mediante su potencial sexual en la medida en que la erotización de lo corporal aporta rendimientos económicos óptimos.

Si bien un <<proletario de las etapas anteriores del capitalismo era en verdad la bestia de carga, que proporcionaba con el trabajo de su cuerpo las necesidades de la vida, mientras vivía en suciedad y en la pobreza>>, un proletario de la sociedad industrial avanzada se muestra <<como los demás objetos humanos de la división social del trabajo, está siendo incorporado a la comunidad tecnológica de la población administrada $>794$. Para Marcuse el proletariado de las etapas anteriores del capitalismo era la negación fehaciente del sistema, pero el proletariado industrial del capitalismo avanzado habría disuelto aparentemente su contenido negativo inherente. Mientras los cuerpos de los obreros del primer tipo de capitalismo eran explotados directamente cual si fueran máquinas, haciéndose patentes en ellos las llagas, la suciedad y precariedad de un sistema productivo abrupto, los cuerpos de los obreros en las sociedades industriales avanzadas -mayoritariamente- no presentan señales de opresión, pues la corporalidad ha sido introducida en el sistema técnico-productivo como su extensión y un objeto de placer sexual fuera del tiempo de trabajo.

Las contradicciones del sistema productivo tienden a ocultarse en las sociedades industriales avanzadas, ya no solo porque estas contradicciones se hallen dentro de un sistema que vuelve la fuerza corporal más mediata en los beneficios que resultan de la acción del trabajo, sino, también, porque los obreros cuentan con cierto margen de acceso a las mercancías y a los servicios que ellos mismos producen. Marcuse piensa que la producción mecanizada no libera al hombre por el mero hecho de concederle más tiempo, ya que las sociedades industriales <<antes que oprimir las cosas tienen ritmo, y le pasan su ritmo al instrumento humano -no solo a su cuerpo sino también a su mente e

\footnotetext{
${ }^{792}$ Anthony Giddens, La transformación de la intimidad (Madrid: Cátedra, 2000), 153.

${ }^{793}$ Cfr. Giddens, ob. cit., 153.

${ }^{794}$ Herbert Marcuse, El hombre unidimensional (México D.F: Editorial Joaquín Mortiz S.A., 1968), $47-$ 48.
} 
incluso a su alma >> ${ }^{795}$. El componente erótico, por tanto, también estaría dentro de esta nueva forma de opresión subsumida a los ritmos de la máquina.

Marcuse da cuenta de cómo la producción mecanizada supera la individualización de los procesos productivos, lo que contribuye a echar por tierra la noción marxiana de plusvalía, ya que la máquina, al homologar a todo un cuerpo social a su funcionamiento, vuelve difuso el contraste que Marx veía entre el trabajo vivo y el trabajo muerto. De este modo, la plusvalía resulta inmedible en términos de "trabajo vivo", ese trabajo impulsado por las fuerzas emanantes del organismo ${ }^{796}$. Asimismo, $<<$ no todo el tiempo empleado en y con mecanismos es tiempo de trabajo (...), y no toda la energía ahorrada por la máquina es poder de trabajo>>, puesto que la <<mecanización también ha "ahorrado" libido, la energía de los instintos de la vida $>>797$. Según Marcuse, la libido es envilecida por la mecanización en la medida en que lo sexual pierde sus referentes eróticos heredados de las sociedades anteriores. Los espacios reservados para la vida sexual desubliman los aspectos discursivos de las sociedades tradicionales, los márgenes del romanticismo se ven deserotizados $\mathrm{y}$, con ello, los entornos de placer de la corporalidad son forzosamente contraídos al acto sexual y a su experiencia fortuita, causal y contingente, perdiendo con ello todo su contenido de sublimación.

Por ejemplo, compárese hacer el amor en una pradera y en un automóvil, en un camino para enamorados fuera de las murallas del pueblo y en una calle de Manhattan. En los primeros casos, el ambiente participa e invita a la catexia libidinal y tiende a ser erotizado. La libido trasciende las zonas erotogénicas inmediatas: se crea un proceso de sublimación no represiva. En contraste, un ambiente mecanizado parece impedir tal autotrascendencia de la libido. Obligada en la lucha por extender el campo de gratificación erótico, la libido se hace menos "polimorfa", menos capaz de un erotismo que vaya más allá de la sexualidad localizada, y la última se intensifica. ${ }^{798}$

Mediante esta ejemplificación, Marcuse simboliza en qué términos tiene lugar esa "localidad restricta" libidinal acotada a espacios que no evocan un mundo natural desconocido fuera de los límites de la civilización, pues las experiencias sexuales dentro de las sociedades industriales no se dan fuera de las máquinas y del entorno urbano, no cuentan con un "entorno ideal" de sublimación. No es lo mismo mantener relaciones

\footnotetext{
795 Marcuse, ob. cit., 48.

${ }^{796}$ Cfr. Marcuse, ob. cit., 50.

${ }^{797}$ Marcuse, ob. cit., 93.

${ }^{798}$ Marcuse, ob. cit., 94.
} 
sexuales en un coche que en una pradera, en la intimidad estrecha e incómoda de una tapicería que en la intimidad abierta de un jardín recóndito, perdido de las miradas ajenas y al margen de la ciudad. Para Marcuse la "libertad sexual" cotiza en el mercado, lo sexual pasa a formar parte de la cotidianidad en que se desenvuelven las relaciones humanas, el cuerpo es puesto como objeto de exhibición en las relaciones laborales haciendo las veces de un componente más de negocio, es decir, el cuerpo mercantilizado se revaloriza en las relaciones laborales y comerciales de las sociedades industriales, ya no por su potencial productivo, sino porque su apariencia, agradable e higiénica, se revela como un intercambio que ofrece la oportunidad de ascender en los estratos sociales ${ }^{799}$.

La estructura tecnológico-productiva de las sociedades capitalistas del siglo XX envuelve a la conciencia y a los cuerpos de todos los individuos; la interacción social de estos reproduce los mecanismos de dominación interiorizados subjetivamente. La sociedad hostiga a la conciencia de los individuos introduciendo en ellos pensamientos que no responden directamente a sus intereses inmediatos ni a sus verdaderas necesidades. El logro del poder dominante propio de las sociedades industriales avanzadas ha sido no recurrir de manera sistemática a mecanismos de presión directa sobre los cuerpos. El cuerpo social no se ve quebrantado ni amenazado inmediatamente por un cuerpo de poder constituido, lo que no significa que el poder no se corporalice ni que carezca de cauces de materialización. La dominación en las sociedades avanzadas no muestra sus medios de coacción directamente, no hace visible su aparato terrorífico, este permanece oculto mientras sea la propia sociedad la que siga dirigiéndose de acuerdo a unos cánones de dominación que se les ha introducido a los sujetos. Dice Marcuse:

La tolerancia del pensamiento positivo es una tolerancia forzada; forzada no por una agencia terrorista, sino por el abrumador poder anónimo y la eficiencia de la sociedad tecnológica. Como tal, cubre la conciencia general -y la conciencia del criterio. La absorción de lo negativo por lo positivo alcanza validez en la experiencia diaria, que ofusca la distinción entre apariencia racional y realidad irracional. ${ }^{800}$

Marcuse descubre una faceta del poder contemporáneo muy relevante a la hora de comprender los métodos de dominación que se aplican en sus sociedades. Un aspecto

\footnotetext{
${ }^{799}$ Cfr. Marcuse, ob. cit., 95.

${ }^{800}$ Marcuse, ob. cit., 243.
} 
del poder contemporáneo que se puede entrever en la lectura de los textos del filósofo alemán es la invisibilidad que pueden llegar a alcanzar los mecanismos de dominación: bien porque estos se hagan invisibles en la conciencia de los individuos, bien porque mantengan los medios terroríficos actuando en lugares apartados y alejados, a saber, en Vietnam y en otros países de la periferia occidental. Mientras los individuos autorregulen sus cuerpos a partir de formas conceptuales-inmateriales de poder introducidas en sus conciencias, el control social vendrá garantizado sin tener que desplegar las fuerzas físicas del poder.

La tipología de la dominación que resulta extraíble de la crítica política marcuseana no divide el poder, mas sí bifurca sus dimensiones de acción, ya que este actúa simultáneamente en la dimensión subjetiva y en la dimensión corporal de los individuos. Marcuse aúna la estrategia que recurre a un tipo de poder corporal y la que recurre a un tipo de poder inmaterial. Esta operación reflexiva produce una hibridación de las estrategias de dominación, haciéndose muy ostensible la exteriorización a la que siempre ha de recurrir el poder cuando se trata de efectuar la dominación sobre sujetos humanos y cuerpos sociales. De hecho, Marcuse denunciaba aquellos ejercicios filosóficos estériles en lo relativo a comprender $<<\operatorname{los}$ procesos de conversión e identificación como procesos sociales -p. ej., como una mutilación de la mente (y del cuerpo) infligida a los individuos por su sociedad $>>{ }^{801}$. El poder que emana de las relaciones sociales de dominación, precisamente, genera estas escisiones que afectan al conjunto de la sociedad y que perpetúan unos sistemas de control tanto a nivel interno de los individuos como en la regulación exterior de los flujos sociales.

También se hace destacable la forma en que Marcuse teoriza acerca de la figura de dominación que respecta al instinto de destrucción o muerte. En su razonamiento el filósofo alemán da a entender que la dominación actúa como una totalidad destinada a uniformar lo social en pro de crear un tipo de individuo unidimensional, ya que el instinto de destrucción <<es un amplio componente de la energía que alimenta la conquista técnica del hombre y la naturaleza>>, de modo que el riesgo subyacente al progreso técnico, su potencia devastadora, <<será enfrentado no solo con una resignada aceptación, sino también con una aprobación instintiva por parte de las víctimas $>>02$. La finalidad última del poder dominante en las sociedades industriales persigue ser

\footnotetext{
${ }^{801}$ Marcuse, ob. cit., 222.

${ }^{802}$ Marcuse, ob. cit., 99.
} 
aceptado incluso en su aplicación agresiva, represiva y violenta. Se podría decir -tal como es interpretado en este caso- que la dominación alcanza su punto culminante justo cuando, pese a utilizar métodos de presión directa sobre los cuerpos y pese a poner en marcha mecanismos físico-represivos de destrucción, logra igualmente ser aceptada bajo una forma afirmativa de la resignación.

\subsubsection{El ESTATUTO CIENTÍFICO DE LA ECONOMÍA}

Las tendencias capitalistas del siglo $\mathrm{XX}$ requerían de un dominio de saber que justificara la matriz que ensambla a la población con los mecanismos productivos y el orden de las relaciones de mercado: la economía resultaba para algunos pensadores el saber más apropiado de cara a la realización de esta encomienda. La teoría económica de ciertos sectores adscritos al liberalismo tenía la ambiciosa pretensión de erigirse como una ciencia puntal para la metodología epistemológica de las ciencias sociales, así como el reto de fundamentar una ontología del mercado preeminente con respecto al espacio público. Esta ontología de mercado debía guiar lo que para algunos pensadores políticos y económicos era una manera eficiente de organizar los quehaceres del Estado, era preciso determinar las decisiones de los gobernantes siempre con el fin de evitar su caída en arbitrariedades fatales para la libertad de los individuos y ruinosas para el porvenir de la civilización.

Karl Raimund Popper en Conjeturas y refutaciones, a propósito de la distinción entre ciencias naturales y sociales, recurre a un axioma de física y a otro de economía para ejemplificar de forma ilustrativa el modo en que se diferencian ambas áreas del saber:

El segundo principio de la termodinámica puede adoptar la forma de la siguiente advertencia tecnológica: "No se puede construir una máquina que sea ciento por ciento eficiente". Una regla similar de las ciencias sociales sería: "sin aumentar la productividad, no se puede elevar el salario real de la población trabajadora", o "no se puede igualar los reales y al mismo tiempo elevar la productividad". Un ejemplo de una hipótesis promisoria, en este campo, que está lejos de haber recibido general aceptación -es decir, que se trata de un problema aún en discusión- es la siguiente: "No se puede seguir una política de ocupación plena sin inflación.” Estos ejemplos indican de qué manera pueden adquirir importancia práctica las ciencias sociales. No nos permiten efectuar profecías históricas, pero pueden darnos una idea acerca de lo que se puede y no se puede hacer en el campo político. ${ }^{803}$

${ }^{803}$ Karl Raimund Popper, Conjeturas y refutaciones (Barcelona: Paidós, 1967), 410-411. 
Lo que Popper le pide a la ciencia en rasgos generales es que prescriba qué no hay que hacer, esto supone crear reglas tecnológicas que orienten de manera racional las acciones humanas. Como claro representante del pensamiento liberal, Popper sostiene que en términos políticos su <<tesis es que la miseria humana es el problema más urgente de una política pública racional, y que la felicidad no constituye un problema semejante. El logro de la felicidad debe ser dejado a nuestros esfuerzos privados $>>004$. El Estado no deja de ser un mal que obliga y doblega a los individuos, pero este mal es irreversible en cuanto que permite la convivencia pacífica entre los hombres. Según Popper, el Estado tiene que ser un poder que sobrepase el poder del ciudadano e instituciones, lo que conlleva un riesgo, a saber, que el poder estatal termine por abarcar todos los aspectos de la vida privada, dominando por completo a la sociedad ${ }^{805}$. Para evitar que el Estado termine convirtiéndose en una tiranía de un solo hombre, partido, aparato de gobierno, clase social, etc., es necesario que el liberalismo ejerza una labor de evaluación y transformación de las instituciones con las que opera el Estado, en vistas a $<<$ modificar o reformar las instituciones existentes, más que para reemplazarlas〉>, de tal forma que el liberalismo <<es más un credo evolucionista más que revolucionario (a menos que se esté frente a un régimen tiránico) >>806.

En el pensamiento político popperiano se reflejan muy bien los presupuestos generales del liberalismo. Precisamente la ciencia como forma autorizada de conocimiento con que guiar las acciones gubernamentales y las acciones privadas (poder público y poder privado), va a ir configurando un saber económico que, a partir del conocimiento del mercado, prescribirá cómo ha de determinarse el orden sociopolítico. Hasta aquí, no hay mucha distancia entre los presupuestos de Popper y un filósofo liberal moderno como Locke, quien, por ejemplo, observó que la política monetaria tenía que venir señalizada por el comportamiento del dinero en las relaciones de valor entre divisas, observable en el mercado. En el nivel de este "liberalismo

\footnotetext{
${ }^{804}$ Popper, ob. cit., 432.

805 Con la finalidad de hacer más expedita esta argumentación resulta de mucha ayuda recurrir a las siguientes palabras de Popper: <<Es fácil comprender que el Estado es un peligro constante o (como me he aventurado a llamarlo) un mal, aunque necesario. Pues para que el Estado pueda cumplir su función, debe tener más poder que cualquier ciudadano privado o cualquier corporación pública; y aunque podamos crear instituciones en las que se reduzca al mínimo el peligro del mal uso de esos poderes, nunca podremos eliminar completamente el peligro. Por el contrario, parecería que la mayoría de los hombres tendrá siempre que pagar por la protección del Estado, no sólo en forma de impuestos, sino hasta bajo la forma de la humillación sufrida, por ejemplo, a causa de funcionarios prepotentes. El problema es no tener que pagar demasiado por ella>>, Conjeturas y refutaciones (Barcelona: Paidós, 1967), 420.

${ }^{806}$ Popper, ob. cit., 421.
} 
clásico" la política cuenta con márgenes de acción y niveles de decisión exclusivos con respecto a los discursos científicos, el propio Popper admite que la política se compone de acciones y que la racionalidad de estas ha de ser previamente deliberada y discutida, puesto que hay que determinar qué tipo de Estado es preferible y más aceptable, en cuanto finalidad propia de la política ${ }^{807}$. La ciencia coadyuva al cumplimiento de fines determinados, aunque Popper no los sustrae a la revisión racional, los fines tanto en la política como en otros ámbitos sobrepasan el alcance de la argumentación científica ${ }^{808}$; lo político, entonces, goza de cierta autonomía y poder de decisión sobre las funciones descriptivas de la ciencia, en otras palabras: la ciencia no ejerce una función prescriptiva en la política.

Asimismo, en el siglo XX nació una vertiente adscrita al liberalismo que, sin embargo, profundizó en la formalización de la economía como una ciencia social determinante para el ejercicio de la política. A tal vertiente se la conoce normalmente como neoliberalismo, y hasta el día de hoy ha venido promoviendo unas reglas técnicas, extraídas del saber económico, a través de las que se pretende definir, imponer y sistematizar una pragmática gubernamental que resulte universalmente válida para todas las sociedades. El neoliberalismo da un paso más allá con respecto al uso que los liberales hacían del saber económico, a saber, como guía útil para la práctica gubernamental. Pero el neoliberalismo promovió una ciencia económica que suplantara sistemáticamente a la política, quedando lo políticos diluido en lo económico -y en cierto modo confundido con ello-, amén de la búsqueda de una disposición del cuerpo social acorde a los mecanismos optimizadores del mercado.

Uno de los autores más reconocidos y laureados de la Escuela Austriaca de economía como es Ludwig von Mises, en Problemas epistemológicos de la economía, veía en el historicismo un escollo para la proliferación del conocimiento científico del saber económico. Mises le atribuye a Hegel el nacimiento del historicismo, el cual influyó tanto en el materialismo histórico de Marx como también en la ideología del nacionalismo. Para el economista austriaco el historicismo parte de supuestos ancestrales y seudocientíficos carentes de racionalidad. Los historicistas mantienen que hay una verdadera realidad objetiva tras la subjetividad de cada individuo ${ }^{809}$, así, Mises

\footnotetext{
${ }^{807}$ Cfr. Popper, ob. cit., 428-429.

${ }^{808}$ Cfr. Popper, ob. cit., 430.

${ }^{809}$ Cfr. Ludwig von Mises, Problemas epistemológicos de la economía (Madrid: Unión Editorial, 2013), 94.
} 
encuentra que la única fuente de conocimiento para el historicismo radicaría en unos supuestos designios de la historia que se habrían ido manifestando en el desarrollo social de los hombres a lo largo del tiempo, lo que además permitiría inventar unas leyes de la historia con las que tratan de subsumir la vida de los individuos a las determinaciones de la historia. De este modo, dentro de los sistemas historicistas, la subjetividad termina perdiendo toda validez con respecto a la legitimación de la verdad, pues bajo estos supuestos el hombre individualmente es incapaz de saber cómo va a determinar su vida, si no es en función de los designios de la raza, la clase, el grupo, etc.

Una de las características más propias de los neoliberales austriacos, y de Mises particularmente, es que no ven posibilidad alguna de complementación entre el liberalismo económico y las ideas socialistas ${ }^{810}$; el socialismo, ya sea en su vertiente marxista-comunista, ya sea en su vertiente nacional-socialista o fascista, conduce irreversiblemente a regímenes totalitarios.

Mises sostiene que en un régimen socialista no se puede llevar a cabo ningún tipo de cálculo económico, puesto que en este tipo de regímenes la producción viene controlada por mecanismos estatales centralizados que no permiten la iniciativa empresarial ni la creación de espacios de competencia, por tanto, en un régimen socialista no puede florecer el libre mercado, sin él es imposible establecer una epistemología económica. El funcionamiento del libre mercado precisa necesariamente de la existencia de propiedad privada y del reconocimiento pleno de su derecho, dado que toda forma de <<cooperación social sólo puede basarse en la propiedad privada de los medios de producción. El socialismo -propiedad pública de los medios de producción- hace imposible el cálculo económico, y por ellos no es viable>> ${ }^{811}$.

En contra de las posturas historicistas, Mises afirma que la historia no puede constituir una forma de conocimiento universal sobre la realidad social y económica, ya que el saber histórico <<es siempre expresión de un fenómeno que se ha producido en un lugar y en un tiempo particulares $>>{ }^{812}$. De esta manera, el economista austriaco basa sus pretensiones de alcanzar un método válido para el conocimiento económico en un

\footnotetext{
${ }^{810}$ Un ejemplo de esta tendencia lo podemos encontrar en la siguiente afirmación de Mises: <<El hombre piensa no sólo en atención al conocimiento, sino también en orden a la acción. No sería necesario repetir estas obviedades si no fuera porque una propaganda antiliberal y sectaria, con la apariencia de ciencia, trata vehementemente de negarlas una y otra vez >. Ludwig von Mises, Problemas epistemológicos de la economía (Madrid: Unión Editorial, 2013), 80.

${ }^{811}$ Mises, ob. cit., 81.

${ }^{812}$ Mises, ob. cit., 44.
} 
ámbito neutral, no inmerso en las vicisitudes del pasado, ni construido sobre observaciones de hechos particulares que sólo suceden una vez en un momento y en un lugar determinados. Ese ámbito neutral lo encuentra Mises en la acción humana en el sentido general del término, hallándose esta <<en el mismo plano que el principio de causalidad $>>$, ya que $<<$ se halla presente en todo conocimiento de cualquier comportamiento que vaya más allá de la mera reacción inconsciente >> ${ }^{813}$. Tanto la causalidad, que se conoce a través de leyes físicas, como el comportamiento de los hombres, que se conoce mediante las leyes de la lógica, constituyen formas de conocimiento universal independientes de la contingencia con que se producen los acontecimientos históricos a los que Mises niega la capacidad de constituir un orden nómico y lógico. Por otra parte, lo inconsciente, es decir, aquello que no responde a una lógica perteneciente a la autodeterminación, es competencia de la psicología, que no puede establecer leyes de carácter universal, sino solo conocer reacciones inconscientemente al margen de estados mentales puramente conscientes, en los que se puede investigar una intencionalidad tras una serie de actos cohesionados de acuerdo a una coherencia. Por ello, Mises aspiraba a construir una praxeología, es decir, una ciencia de la acción humana fundada tanto en la experiencia que tenemos de los modelos existentes en el mundo como también en aquellos modelos que surgen en la imaginación y que, por tanto, están aún por realizarse ${ }^{814}$.

La economía es un saber universal que versa sobre la acción humana porque está incluida en la praxeología. Las teorías económicas en particular, y las teorías en general, necesitan de un lenguaje para desarrollarse, lo que implica que las teorías estén compuestas por términos y conceptos determinantes a la hora de dirigir el orden en que se va elaborando el conocimiento a partir de las experiencias que se tienen. Al contrario de los empiristas, el economista austriaco cree que la evidencia empírica ocupa un lugar secundario con respecto a la teoría, ya que los instrumentos teóricos son los que anteponen el aparato conceptual sobre el que se van a procesar las experiencias, y el lenguaje es el instrumento por excelencia en la expresión de las teorías, así, ni siquiera el empirista puede quedarse al margen del uso de estos instrumentos teóricos que ordenan los datos empíricos ${ }^{815}$.

\footnotetext{
${ }^{813}$ Mises, ob. cit., 50.

${ }^{814}$ Cfr. Mises, ob. cit., 51.

${ }^{815}$ Cfr. Mises, ob. cit., 68-69.
} 
Para que la economía pueda constituirse como una ciencia de la acción humana, Mises encuentra necesaria su neutralidad, y para ello su punto de partida en el análisis tiene que ser la acción de los consumidores y no solo la acción de los negociantes. Lo que la economía tiene que hacer es explicar cómo se forman los precios del mercado, de modo que la economía no puede juzgar las acciones humanas desde la perspectiva ética, estética, política u ontológica, sino que su campo de estudio tiene que ser la cataláctica $^{816}$, es decir, la ciencia que se ocupa de los intercambios, y desde la que no se establecen juicios de valor sobre las razones que llevan a los consumidores a actuar, sino que su cometido es ver cómo intervienen de hecho los consumidores en el mercado ${ }^{817}$. Para comprender de forma más descriptiva esta concepción miseana acerca de la pretendida neutralidad de la economía hemos de destacar la siguiente sentencia:

No tiene importancia el que la demanda de armas provenga de hombres que están de parte de la ley y del orden o de criminales o revolucionarios. Lo único decisivo es que existe una demanda de un determinado volumen. La economía se distingue de la psicología por el hecho de que los sucesos psíquicos que han llevado a una acción carecen de importancia. ${ }^{818}$

En vistas a que la economía vertebre un discurso basado en la neutralidad y sea capaz de resistir los escollos interpuestos por los contra-argumentos ideológicos, Mises va a concebir una epistemología que parta de la lógica sobre la que se cimienta la acción humana. La lógica es anterior a la propia acción, por eso la acción de los hombres tiene su asentamiento formal en leyes a priori, sólo a partir de éstas toman forma los contenidos de la experiencia. La doctrina desde la que el proletariado emprendió su lucha contra el liberalismo es la ideología que promueve la lucha de clases, o sea, el marxismo; la burguesía, entonces, entendió que lo que necesitaba para hacer frente al proletariado no era una ideología, sino una teoría científica neutral que atajara los presupuestos seudocientíficos que controlan la conciencia de la clase obrera ${ }^{819}$. La función de la epistemología de la economía es, en este aspecto, abrir un cauce con el que elaborar un sistema de conocimiento capaz de formar una ciencia aséptica con

\footnotetext{
816 Huelga destacar una de las más aclaratorias afirmaciones de Mises acerca de la cataláctica: <<La cataláctica cumplió su función sólo cuando triunfó en este proceso de generalización, sólo cuando atribuyó la formación de los precios al punto en que el actor realiza su elección y pronuncia su decisión: prefiero A a B >>. Mises, ob. cit., 294.

${ }^{817}$ Cfr. Mises, ob. cit., 154-155.

${ }^{818}$ Cfr. Mises, ob. cit., 294.

${ }^{819}$ Cfr. Mises, ob. cit., 277.
} 
respecto a la ideología y la historia.

Otro autor destacado de la Escuela Austriaca es Hayek, el cual elaboró una teoría del conocimiento en economía tomando como punto central el descubrimiento dentro del libre mercado. En Conocimiento y orden espontáneo como proceso de descubrimiento Hayek afirma que el orden económico no se encuentra nunca centralizado sino, por el contrario, se halla disperso y limitado a los individuos que participan en el orden del mercado. De esta manera, según el autor, el problema de la economía en cuanto ciencia no es la forma en que se distribuyen los recursos sino, más bien, cómo los sujetos de una sociedad emplean los recursos que poseen en vistas a obtener el máximo rendimiento posible. Para Hayek el conocimiento científico no representa todas las formas posibles de saber, puesto que hay conocimientos que surgen de circunstancias particulares. La tesis del autor vienés, entonces, es que tras el aprendizaje teórico hay un abanico de posibilidades prácticas producidas en situaciones concretas donde los sujetos realizan descubrimientos y obtienen nuevos conocimientos a partir de condiciones específicas $^{820}$. La ciencia aparece cuando <<nuestros sentidos nos muestran nuevos modelos, ello provoca sorpresa $>>{ }^{821}$, pero sin la ayuda de modelos abstractos sería imposible reconocer los nuevos modelos que proceden de la intuición sensible, según Hayek, existe una correspondencia de representación entre los modelos que proceden de la experiencia y los sistemas abstractos construidos por las matemáticas ${ }^{822}$. A raíz de esta idea es posible encontrar una característica en el pensamiento económico de Hayek diferente a la tónica general de la Escuela Austriaca: la capacidad de las matemáticas para constituir modelos teóricos a partir de los que obtener nuevos conocimientos o nuevas formas de comprender los datos empíricos. Ahora bien, las matemáticas no pueden llevar a cabo predicciones de fenómenos, porque no es ésta la competencia de la ciencia como tal, más bien, el fin de las matemáticas aplicadas a la ciencia consiste en formar descripciones de tipos de modelos con que hacer nuevos descubrimientos ${ }^{823}$.

Hayek menciona a Popper en lo relativo a la importancia que debería cobrar la ignorancia en las investigaciones científica ${ }^{824}$, puesto que Hayek se suscribe a la idea de

${ }^{820}$ Cfr. Friedrich August von Hayek, Selección de textos de Friedrich A. von Hayek (Buenos Aires: Estudios Públicos, 2010), 284.

${ }^{821}$ Hayek, ob. cit., 289.

${ }^{822}$ Cfr. Hayek, ob. cit., 289.

${ }^{823}$ Cfr. Hayek, ob. cit., 293.

${ }^{824}$ En el apartado que lleva por título La importancia de nuestra ignorancia Hayek afirma: <<Tal como lo han señalado Popper y otros: "mientras más aprendo del mundo, y mientras más profundo es nuestro 
que los seres humanos tienen limitaciones ineludibles a la hora de conocer tanto los fenómenos físicos como los fenómenos sociales, consecuentemente, también para averiguar aquellos mecanismos que mueven los mercados conviene comenzar reconociendo limitaciones epistemológicas; de modo que es preciso comenzar por los hechos más específicos y concretos, porque la ciencia económica, más que predicciones, establece parámetros que guían la acción en el mercado ${ }^{825}$. En Derecho, legislación y libertad, Hayek dice que la abstracción permite ampliar el espectro cognoscitivo de los fenómenos en detrimento de las posibilidades de conocer la anticipación de los actos, lo que contribuye a disminuir en cierto modo las pretensiones de moldear el mundo de acuerdo al cumplimiento de ciertos deseos. El autor asocia esta actitud con el liberalismo al afirmar que este <<restringe el control premeditado del orden global de la sociedad al simple acatamiento de aquellas normas generales de cuya existencia la formación de un orden espontáneo depende, orden cuyos detalles ningún ser humano está en situación de prever $>{ }^{826}$.

Hayek lanza una vigorosa diatriba contra el constructivismo racionalista, al que acusa de haber tratado de controlar todas las concreciones que se dan en el ordenamiento social, autorizando una racionalidad restringida a intereses concretos en vez de hacer valer las ventajas de la abstracción. Un ejemplo paradigmático sería, a ojos del economista vienés, la filosofía social de Hobbes, que recurre a la analogía entre el organismo humano y la sociedad para proyectar un orden total sobre las concreciones que se dan en el orden social, reduciendo toda la realidad a una sola forma racional supuestamente válida para cualquier caso particular" ${ }^{827}$. La imagen de la "Gran Sociedad" planteada por Hayek se corresponde con el orden surgido a partir de la capacidad humana de transmitir conceptos abstractos. Solo los conceptos abstractos pueden procurar el avance de la razón, pues si la razón solo opera a partir de casos particulares o situaciones concretas, entonces, cometerá los errores del racionalismo constructivista, que en su empeño por subsumir y orientar todos los procesos según una

aprendizaje, más consciente, específico y articulado será nuestro conocimiento de lo que no sabemos, nuestro conocimiento de nuestra ignorancia">>. Selección de textos de Friedrich A. von Hayek (Buenos Aires: Estudios Públicos, 2010), 293.

${ }^{825}$ Cfr. Hayek, ob. cit., 93-94.

${ }^{826}$ Friedrich August von Hayek, Derecho, legislación y libertad. Una nueva formulación de los principios liberales de la justicia y de la economía política (Madrid: Unión Editorial, 1985), 71.

${ }^{827}$ Cfr. Hayek, ob. cit., 72. 
racionalidad termina por estancar la razón e impedir su desarrollo ${ }^{828}$.

Hayek mantiene que los estudios descriptivos en sociología no suponen una aportación válida para el derecho. La sociología empírica solo toma ciertos casos aislados para establecer relaciones inductivas, pero no utiliza una batería de conceptos teóricos que guíen los datos de la experiencia ${ }^{829}$. Las carencias de la sociología empírica hacen de la economía el único dominio de saber capaz de pertrechar un método lo suficientemente solvente para analizar la espontaneidad con que se comporta la sociedad y los órdenes abstractos que guían el conocimiento sociológico. Así, entonces, la economía para Hayek es esa ciencia social cuyo desarrollo epistemológico y metodológico más se aproxima a la forma de ser general de la sociedad, en tanto en cuanto la <<mecánica que al funcionamiento del mercado corresponde es también seguramente la única susceptible de abarcar todo el ámbito de la sociedad $>>{ }^{830}$. Se hace ostensible cómo el modelo sociológico de Hayek se centra en variables abstractas tomadas de la epistemología económica para aplicárselas al conocimiento de la sociedad.

La economía toma una posición central que la erige como un saber fundamental y dominante en la ciencia social. Esta es una economía cuyo objeto de conocimiento, el mercado, aparece como un objeto impersonalizado y homogeneizado, un espacio que organiza el cuerpo social mediante parámetros espontáneos derivables de vértices abstractos que más que predecir prescriben cómo se realiza la conducta humana dentro de las operaciones económicas. El mercado pasa a ser el espacio que vertebra a la sociedad y de la que se pueden establecer criterios para el derecho, de modo que lo político queda diluido en virtud de elementos formales que la ciencia económica establece. La estructuración de la sociedad, por ende, se llevará a cabo sobre el espacio mercantil como una base imprescindible.

\subsubsection{INDIVIDUALISMO Y ORDEN ABSTRACTO EN HAYEK}

Hayek preconiza un individualismo económico y político, él mismo se considera heredero de la filosofía individualista que prosperó en los siglos XVIII y XIX. Pero no todos los pensadores que han sido clasificados bajo el individualismo filosófico o la línea de pensamiento individualista son aceptados por Hayek. En Individualismo: el

\footnotetext{
${ }^{828}$ Cfr. Hayek, ob. cit., 73.

${ }^{829}$ Cfr. Hayek, ob. cit., 221.

${ }^{830}$ Hayek, ob. cit., 222.
} 
verdadero y el falso, el autor considera que <<ningún término político ha sido tan maltratado como el término "individualismo" $>>831$. El anclaje teórico hayekiano se encuentra en el "individualismo verdadero", denominado así por el propio autor, y cuya línea intelectual habría nacido, según comenta, con John Locke, a los que se suman autores como Bernard de Mandeville, David Hume, Josiah Tucket, Adam Ferguson, Adam Smith, Edmund Burke, Alexis de Tocqeville o Lord Acton ${ }^{832}$. Para Hayek, el "falso individualismo" viene representado principalmente por el racionalismo cartesiano y por la teoría rousseauniana del Contrato social, ambas doctrinas llevarían consigo el germen de la planificación social y de la centralización estatal, que fuerzan un tipo de sociedad totalmente controlada y organizada en función de instancias que, en vistas a mantener un orden racionalizado, no permiten los movimientos espontáneos de los agentes sociales y económicos ${ }^{833}$. De ahí que para Hayek la familia del "verdadero individualismo" promueva como principio práctico fundamental $<<$ la necesidad de una rigurosa limitación a todo poder coercitivo o exclusivo $>>{ }^{834}$. Asimismo, esta limitación del poder estatal se corresponde con la posición que el Estado debería ocupar en el complejo de relaciones sociales: <<el Estado, expresión de un poder deliberadamente organizado y conscientemente dirigido, debería ser solo una pequeña parte de un organismo mucho más rico que llamamos "sociedad" $>>835$.

Hayek prefiere una racionalidad abstracta a una racionalidad que abarque todos los aspectos concretos de la vida; esta última, integrada y encarnada en el Estado, puede llevar a un sistema totalitario que suprima la libertad. En este sentido, razón y libertad han de ir de la mano en las relaciones sociales y en la articulación de la política. De modo que una racionalidad en virtud de la cual sus preceptos suprimen la libertad deriva en irracionalidad. Hayek retoma una problemática filosófica que, como él mismo afirma -y como ya se puso de manifiesto anteriormente en el presente trabajo-, los autores del siglo XVIII y XIX ya plantearon: los límites del poder público del Estado con respecto a los derechos y la libertad del individuo particular. En El espejismo de la justicia social, que corresponde al segundo volumen de Derecho, legislación y libertad, Hayek dice que los teóricos de la "justicia social" promueven un ideal de justicia dirigido a la

\footnotetext{
${ }^{831}$ Friedrich August von Hayek, Individualismo: el verdadero y el falso (Madrid: Unión Editorial, 2009), 49.

${ }^{832}$ Cfr. Hayek, ob. cit., 50-51.

${ }^{833}$ Cfr. Hayek, ob. cit., 58-59.

${ }^{834}$ Hayek, ob. cit., 68.

${ }^{835}$ Hayek, ob. cit., 75 .
} 
sociedad como si esta fuera un todo, mientras echan a un lado a los individuos concretos. Afirma que

la sociedad, en el sentido estricto en que resulta posible distinguirla del aparato gubernamental, es incapaz de actuar según plan específico alguno, por lo que la "justicia social" se convierte en obligación de que sus miembros se organicen de manera que resulte posible asignar partes concretas del producto global a específicos individuos o grupos. Surge así la fundamental cuestión relativa a si es lícito moralmente que el ser humano quede sometido a un poder que intenta coordinar los esfuerzos de todos al objeto de materializar algún específico modelo de distribución que por determinados miembros de la sociedad sea considerado justo. ${ }^{836}$

Hayek hace visible la imagen conceptual de la sociedad como una masa invertebrada e incapaz de adquirir un ordenamiento determinado por sí misma. La sociedad sería vista nada más que como una "avalancha" de cuerpos. Los defensores de la "justicia social" aunarían el concepto de gobierno y el concepto de sociedad, cuando, en realidad, para Hayek ambas son cosas distintas. Toda sociedad precisa de un gobierno que coordine las acciones de los diferentes individuos y grupos relacionados entre sí en un espacio concreto. Pudiera parecer que el modo en que se distribuyen los ingresos en el mercado es injusto, pero los mecanismos que pone en funcionamiento el mercado no fueron previstos por ningún gobernante ni por nadie en particular; estos habrían mantenido mejor la subsistencia de la mayor parte de la población. Por tanto, una desigual distribución de ingresos no es motivo para otorgar prerrogativas a grupos aparentemente perjudicados en detrimento de otros ${ }^{837}$.

El concepto de "justicia social" es, en el pensamiento hayekiano, un atavismo, una aspiración a impartir justicia que proviene de un viejo orden tribal en el que originariamente vivieron los hombres, cuando los grupos humanos eran tan reducidos que solo reunían a unas cuantas familias. La justicia social no es acoplable a las demandas de las sociedades civilizadas, por lo que esta es vista por el autor austriaco como un "señuelo" que desvía a las sociedades de los principios y objetivos que en su momento condujeron a los hombres hacia la civilización; la sola pretensión de aplicar la justicia social responde a un <<burdo intento de satisfacer apetencias propias de los ancestrales grupos tribales que ningún papel pueden jugar en la sociedad actual libre y

\footnotetext{
${ }^{836}$ Friedrich August von Hayek, Derecho, legislación y libertad. Volumen II: El espejismo de la justicia social (Madrid: Unión Editorial, 1988), 122.

${ }^{837}$ Cfr. Hayek, ob. cit., 123.
} 
compleja $>{ }^{838}$. Las sociedades libres propias de los hombres civilizados han de promover individuos libres, con autonomía económica, es decir, individuos que dispongan de los medios materiales con que proveer sus necesidades, apetencias e intereses. La "justicia social” contribuye a que grupos determinados de la sociedad se sirvan de la actividad gubernamental para procurarse privilegios, así, por tanto, es en las sociedades planificadas donde se desarrolla un tipo de economía en la que sus actores no son libres, dado que se les indica constantemente qué hacer. La justicia social puede tomar algún tipo de significación allí donde se rechaza que los ingresos y distribución de la renta no responden a causas fortuitas. Hayek asevera que, realmente, ningún marco de normatividad que respete la libertad del individuo puede ser aceptable para las exigencias de la justicia social ${ }^{839}$. Tras la arenga por satisfacer las necesidades de los más desfavorecidos y ayudar a quienes menos capacidad adquisitiva tienen, el socialismo, bajo el estandarte de la justicia social, ha procurado intervenir en el mercado, aunque $<<\operatorname{los}$ intentos de "corregir" los resultados del mercado según los dictados de la "justicia social" han producido probablemente más injusticias -en forma de nuevos privilegios, obstáculos a la movilidad y frustración de esfuerzos- que alivio de los más necesitados $>{ }^{840}$.

Las sociedades modernas, a las que Hayek llama "Sociedad Abierta" o "Gran Sociedad", no se ajustan a los preceptos establecidos por el socialismo, que impone una ética única fundada en una organización más propia de sociedades tribales que de sociedades civilizadas. La Gran Sociedad progresó debido a que esta ética tribal se fue debilitando y diluyendo. Advierte Hayek que la mayoría $<<$ de la gente sigue resistiéndose a captar la más alarmante lección de la historia moderna: que los mayores crímenes de nuestro tiempo han sido cometidos por gobiernos que contaron con el entusiasta apoyo de millones de personas inspiradas por impulsos morales $>>^{841}$.

El mercado hayekiano es un espacio en el que operan unas reglas asépticas y cuyos mecanismos no responden a intereses que tengan que ver con algún tipo de poder político. Las formas en que son remuneradas las actividades laborales en el mercado no se vinculan con la estimación afectiva o personal de los méritos, tampoco el sistema de recompensas establece correspondencias entre las necesidades que "sienten" los

\footnotetext{
${ }^{838}$ Hayek, ob. cit., 127.

${ }^{839}$ Cfr. Hayek, ob. cit., 130-131.

${ }^{840}$ Hayek, ob. cit., 242.

${ }^{841}$ Hayek, ob. cit., 234.
} 
individuos $^{842}$. Las remuneraciones son de diferentes cantidades no porque unas sean más útiles que las otras para la sociedad, ni porque los servicios prestados posean un mayor o menor "valor social". El valor de las diversas actividades laborales no va en virtud de su aportación a la sociedad, sino que el valor de una actividad está relacionado con el grupo de individuos a quienes satisface y a la cantidad que estos estén dispuestos a pagar por tales prestaciones:

Lo fundamental no es constatar que las humanas valoraciones son siempre dispares, sino percatarse de que los valores que los distintos usuarios atribuyen a los diferentes servicios no son comparables entre sí. Lo único que cabe decir es que unos reciben superiores sumas dinerarias aportadas por un público más numeroso. ${ }^{843}$

Hayek toma de su maestro Mises el término "catalaxia" para referirse al estudio de los intercambios en la ciencia económica, pero, por otro lado, Hayek ve en la catalaxia una manera de comprender las relaciones humanas, ya que, con base en la etimología de la palabra, los griegos empleaban esta noción, no solo para referirse al intercambio, sino también a la transformación del enemigo en amigo. La significación que Hayek le concede al término "catalaxia" se ajusta al contexto de las sociedades de mercado y $<<$ al peculiar orden espontáneo que el mercado genera, ámbito en el cual la gente somete su conducta a las normas relativas a la propiedad, la protección contra el fraude y el respeto de los pactos libremente establecidos $>>844$. Consecuentemente, la catalaxia hayekiana se halla indeleblemente unida a una concepción del mercado como espacio de jurisdicción, es decir, un lugar donde rige una normatividad que permite entablar relaciones entre grupos humanos diversos, con base en unas reglas sobre la propiedad y su intercambio. El funcionamiento del mercado, en tanto en cuanto responde a unas normativas determinadas, es entendido por Hayek como un espacio susceptible de configurar verdades para la regulación jurídica.

El autor austriaco considera errónea la acepción de que los economistas solo hacen sus juicios siguiendo criterios estrictamente economicistas, que todos los asuntos que tratan los juzgan desde un rasero solo económico. Según Hayek, esta crítica que se hace contra los economistas parte de un error conceptual de la economía, pues al ser

\footnotetext{
${ }^{842}$ Cfr. Hayek, ob. cit., 135.

${ }^{843}$ Hayek, ob. cit., 141.

${ }^{844}$ Hayek, ob. cit., 195.
} 
la catalaxia la ciencia que se ocupa de analizar ese único orden general que es capaz de integrar a toda la humanidad, el economista está en su perfecto derecho de insistir en que la debida propiciación de tal orden constituye el criterio según el cual debe ser juzgada cualquier concreta institución social. ${ }^{845}$

La filosofía individualista de Hayek viene sufragada por una serie de preceptos que persiguen superar las limitaciones a las que había estado sujeto el saber económico tradicionalmente. Por un lado, la catalaxia es la forma científica de la economía y sus principios en ningún momento prescinden del fundamento moral que aspira a una sociedad integrada por cada vez más individuos; por otro lado, la catalaxia codifica la lógica operante en el mercado, que es el espacio de interacción propicio para alcanzar la concurrencia de todos los seres humanos, partiendo todos ellos de una igualdad inicial que les permite competir en las mismas condiciones. Hayek parte de la imagen de un individuo humano autónomo y libre, capaz de juzgar por sí mismo lo correcto o lo incorrecto, lo moral o lo inmoral, lo beneficioso o perjudicial, etc. Este individuo emancipado de la sociedad es la figura desde la que Hayek se opone a toda forma de comunitarismo y sociedad comunal. Los individuos deben contar con normativas universales, válidas para cualquiera, y todo gobierno habrá de amparar estas normas, de hecho, el ordenamiento normativo está por encima de las necesidades individuales, puesto que <<la primera obligación del gobierno no es satisfacer las necesidades sino mantener un orden espontáneo que a todos permita desarrollar las correspondientes iniciativas productivas según modalidades para la autoridad siempre ignotas $>>{ }^{846}$. Las prioridades de los individuos no tienen por qué coincidir con las prioridades de una mayoría social o con los intereses de algunos sectores más o menos amplios de la sociedad.

Las sociedades modernas apartan el comunitarismo tribal en virtud de concederle una mayor autonomía a los individuos. Las preferencias concretas pueden ser tan variadas como numerosas, por ello, la regulación de las actividades en la sociedad no han de estar dirigidas por determinados grupos con capacidad para interferir en la política y, a través de esta, trastornar los movimientos espontáneos que acaecen en el mercado. Las determinaciones gubernamentales han de actuar como el mercado, mediante leyes abstractas que no beneficien ni perjudiquen a individuos y cuerpos sociales concretos;

\footnotetext{
${ }^{845}$ Hayek, ob. cit., 202.

${ }^{846}$ Hayek, ob. cit., 20.
} 
por supuesto, las concreciones de estas leyes no satisfacen las demandas de justicia de todos los miembros de la sociedad, pues cada cual puede tener su propia idea de justicia sin que necesariamente esta tenga que acoplarse a la realidad. Lo real no se acomoda a todos los puntos de vista particulares que hay en torno a lo justo y lo injusto, por ello, las rentas y los patrimonios resultantes de las relaciones producidas en el mercado generan unas oportunidades, aprovechadas ya sea por la destreza de los individuos ya sea por la suerte que puedan haber tenido. De modo que $<<$ no hay necesidad de justificar moralmente la correspondiente distribución de los recursos o ingresos. En esta clase de competiciones todos los jugadores reciben "igual trato", lo que es plenamente compatible con la diversidad de los individuales resultados $>>847$.

La metodología y, sobre todo, la forma ontológica que adquiere la imagen del mercado en el pensamiento de Hayek extiende la idea de un espacio comercial movido por intereses individuales cognoscibles, no porque sean concretos sino porque cualquiera que sea la naturaleza de un interés, este responde a unos cánones abstractos preestablecidos en la lógica operativa del mercado. La confluencia de estos intereses funda unos mecanismos formales en la medida en que son mecanismos universalizables, es decir, extensibles a cualquier persona y ámbito de relaciones catalácticas. Los elementos formales del mercado contribuyen a comprender conductas generales provenientes de individuos particulares, todos los individuos en buena medida actúan en sociedad siguiendo este marco normativo no dado necesariamente en los códigos legales, es más, estos últimos deberían adaptarse a estas normas abstractas. La filosofía neoliberal de Hayek va mucho más allá de los asuntos jurídicos y económicos, introduce una "mentalidad" subyacente a cualquier individuo que mira por sus intereses dentro de las oportunidades que se desprenden del mercado. Toda mentalidad individual en un espacio mercantil ha de estar regida por unos cánones formales que explican la conducta de cada uno de los individuos. El mercado, entonces, hace previamente aquello que las sociedades no hicieron en su origen, a saber, situar los fundamentos por los que se tienen que regirse individuos considerados iguales y libres, una igualdad que viene dada abstractamente y que no parte de un sujeto cuyas características son fruto de la contingencia y de los devenires de la vida; asimismo, la libertad solo puede ser considerada en términos universales, cada cual la concretará según estime oportuno y será la suerte o la destreza la que determine su destino.

${ }^{847}$ Hayek, ob. cit., 208. 
Las concreciones de los cuerpos y la dinámica de los cuerpos sociales son sacrificadas en vistas a establecer un orden abstracto y una regulación general universalizable que valga para cualquier sujeto humano, independientemente de sus determinaciones concretas, como si estas, de hecho, no determinaran sus quehaceres en el espacio mercantil. Por tanto, tampoco la procedencia de clase o el sesgo étnico, religioso, familiar o moral de los individuos o grupos de individuos son tomados en cuenta dentro de los preceptos formalistas con que Hayek entiende el funcionamiento del mercado. De manera que el autor supo combinar lo individual y lo general sin incurrir en hipóstasis pero, a su vez, justificando por qué un ordenamiento impuesto y establecido desde el mercado no puede conducir, bajo ninguna circunstancia, a desórdenes sociales en los que individuos atomizados comenzaran a actuar como una multitud descontrolada. La libre competencia y la espontaneidad de los individuos sigue unas pautas regladas por un mercado cuya estructura nómica es universal, ahí Hayek garantiza el orden social sin erosionar esta nómica, evitando formular principios políticos contrarios a las pautas del mercado.

\subsubsection{EL PODER DE LOS PRODUCTORES}

Las sociedades planificadas en el pensamiento hayekiano son aquellas en que la economía está controlada por el Estado, es decir, todo cuanto es producido habrá de venir autorizado, contabilizado y precisado por un órgano central de poder. Si en una sociedad planificada no hay un dominio perpetuo de todas las cosas producidas y de los servicios ofrecidos, su régimen político de tipo totalitario peligraría, ya que una producción no controlada otorga un cierto margen de libertad a los consumidores:

Aunque una sociedad planificada tendría probablemente que emplear con cierta extensión el racionamiento y otros expedientes análogos, el poder del planificador sobre nuestras vidas no depende de esto, y difícilmente sería menos efectivo si el consumidor fuera nominalmente libre para gastar sus ingresos conforme a sus gustos. La fuente de su poder sobre todo el consumo, que en una sociedad planificada poseería la autoridad, radicaría en su control sobre la producción. ${ }^{848}$

Para Hayek, la característica principal y esencial de la planificación Estatal de la economía radica, entonces, en el control de la producción. La condición básica de toda libertad pasa necesariamente por que los consumidores tengan la posibilidad de escoger por sí mismos qué bienes y servicios prefieren consumir. El consumidor libre es aquel

${ }^{848}$ Friedrich August von Hayek, Camino de servidumbre (Madrid: Alianza, 1978), 126-127. 
individuo que cuenta con el poder para elegir entre una variedad de cosas ofertadas en el mercado, por tanto, de nada le serviría a un régimen totalitario que en su espacio soberano deambularan productos no producidos por los órganos Estatales de planificación, porque de ser así ya habría, en parte, cierta libertad para los individuos. La manera más efectiva de prohibir el consumo de un determinado bien o servicio es no producirlo, todo poder político totalitario habría de tener esto en cuenta; así, es en la producción donde Hayek localiza el área fuerte de poder de los Estados con economía planificadas. Si la oferta de productos viene mediada, interferida y planificada por un solo agente productor, los consumidores no serán libres, pero si los productos dependen de diferentes agentes de planificación privados y estos compiten en un mercado sin restricciones, entonces, esa sociedad de productores libres y expuestos a la competencia contará también con unos consumidores libres.

En Hayek la noción de producción viene vinculada con el poder. Quien produce, tiene capacidad para ofrecer aquellas cosas que son deseadas por un grupo más o menos reducido de individuos, por eso mismo, si un poder totalitario pretende reducir la libertad de sus ciudadanos, deberá ejercer un control estricto sobre las cosas producidas. En el curso 1977-1978 impartido por Foucault en el Collège de France, a propósito de los primeros estudios sobre la población en el siglo XVIII, se afirma que fueron los economistas fisiócratas quienes llegaron a la conclusión de que el deseo es el motor de acción de los individuos y que a través de este es posible encauzar sus intereses, de tal modo que la interrelación de deseos sería susceptible de producir el interés general:

El deseo es la búsqueda del interés para el individuo. Por otra parte, aunque este pueda perfectamente ser engañado por su deseo en lo concerniente al interés personal, hay algo que no engaña: el juego espontáneo o, en todo caso, a la vez espontáneo y regulado del deseo permitirá, en efecto, la producción de un interés, algo que es interesante para la propia población. Producción del interés colectivo por el juego del deseo: esto marca al mismo tiempo la naturalidad de la población y la artificialidad posible de los medios que se instrumentarán para manejarla. ${ }^{849}$

El sentido en que Foucault utiliza el término producción va conectado al concepto de interés, ya sea el individual o el colectivo. El filósofo francés descubre que en la interacción social en torno al mercado la producción de intereses depende de relaciones

849 Michel Foucault, Seguridad, territorio, población (Buenos Aires: Fondo de Cultura Económica de Argentina, 2004), 96. 
entre agentes desiderativos, esto significa que las preferencias de los individuos en el mercado, así como también las preferencias políticas, son articuladas por juegos de deseos que producen intereses. Se podría decir que la producción de intereses mediante juegos de deseos es para Foucault una forma de poder, pero una forma de poder generada antes del despliegue físico del mercado y antes de que el Estado ponga en funcionamiento sus medios coactivos. En la producción de intereses, antes de que los cuerpos de los trabajadores ejerzan labores productivas, de que los comerciantes compren y vendan mercancías, de que los productos y el dinero circulen, y de que los consumidores escojan bienes y servicios, antes de todo esto, tiene que haber unos intereses dispuestos en la subjetividad de los individuos, intereses causados por una internalización de avideces generada en las relaciones sociales.

La conexión que Foucault encuentra entre la producción de intereses y el poder viene formulada a partir de la temática histórico-económica sobre la que versa su curso de 1977-1978. Foucault está centrado en el análisis del gobierno en el siglo XVIII, y lo hace a propósito de las teorías económicas de los fisiócratas. Pero en el curso 19781979, publicado bajo el nombre de Nacimiento de la biopolítica, Foucault analiza la corriente de pensamiento político y económico del neoliberalismo, donde menciona a Hayek como un representante de lo que Foucault denomina "neoliberalismo alemán" u “ordoliberalismo" 850 . Para el pensador francés, Hayek habría planteado que en la economía de mercado el Estado tiene que actuar contrariamente a un plan diseñado o preestablecido, dado que el Estado, para que el mercado funcione de manera libre, ha de carecer de unas directrices económicas. El Estado no tendrá potestad alguna para decidir qué tipo de consumo debe aumentar o disminuir, tampoco podrá influir en la distribución de los ingresos, sino que, más bien, el Estado debe sostener, proteger e incluso someterse a las leyes formales de la economía ${ }^{851}$ : < <una ley formal es una ley que va a obligar al Estado no menos que a los otros y, por consiguiente, debe ser tal que cada uno sepa exactamente cómo se comportará el poder público >> 852 .

\footnotetext{
${ }^{850}$ No se profundizará ahora en la clasificación que hizo Foucault del neoliberalismo, en "neoliberalismo alemán" y "neolibelaismo americano", al que también denomina "anarcocapitalismo". Esta clasificación en algunos casos puede resultar dudosa y responde, en cierto modo, a escuelas liberales de distintas vertientes y que aglutina a economistas con puntos de vista teóricos muy diferentes.

${ }^{851}$ Cfr. Michel Foucault, Nacimiento de la biopolítica (Buenos Aires: Fondo de Cultura Económica de Argentina, 2007), 207-208.

${ }^{852}$ Foucault, ob. cit., 208.
} 
Foucault cae en la cuenta de que hay una diferencia fundamental entre el liberalismo del siglo XVIII y el neoliberalismo: el liberalismo dieciochesco tomaba el mercado libre como espacio natural de intercambio, no obstante, en esta concepción, el Estado no estaba exento de participar en la producción, pues se requería de él para hacer posible la propiedad individual de las cosas producidas ${ }^{853}$; en el neoliberalismo, sin embargo, el mercado ya no es concebido como forma de intercambio, sino como competencia. La esencia del mercado para los neoliberales residiría, según Foucault, en la competencia, y su racionalidad económica se basaría en el conocimiento de la competencia en cuanto forma por excelencia del mercado ${ }^{854}$. Consecuentemente, comenta el filósofo francés: $<<$ la competencia solo debe sus efectos a la esencia que posee, que la caracteriza y la constituye. No debe sus efectos benéficos a una anterioridad natural, un dato natural que lleve en su seno. Los debe a un privilegio formal $>>{ }^{855}$. Cabe interpretar, a la luz de esta diferencia establecida por Foucault, que la formalidad de la esencia de la competencia implanta una verticalidad con respecto a los efectos concretos de la producción, es decir, la producción estaría dentro de la competencia en cuanto parte de su esencia, de lo que se deriva que cualesquiera que sean las decisiones sobre qué y cómo producir, en qué cantidad y a quiénes destinar los productos, estas siempre serán decisiones tomadas dentro de parámetros competitivos. La competencia dirige las iniciativas productivas, comerciales, financieras y consumidoras, lo formal se superpone a lo material y lo doblega a su estructura esencial, los cuerpos productores, los "cuerpos producidos", e incluso las necesidades corporales de los hombres quedan supeditadas a los mecanismos competitivos que esencian el mercado. Todo el raudal de productos que caen a los puntos de venta, y que ofrece una amplia variedad de cosas elegibles para los consumidores, es, entonces, la consecuencia por excelencia de la competencia, nunca podría darse el caso contrario. El poder sobre la producción y sobre los cuerpos que participan en ella se encuentra, así pues, en un elemento abstracto tan inmaterial como formal, un aspecto no captable a simple vista, a saber, la esencia de la competencia en cuanto fundamento del mercado.

En esta línea, conviene señalar que para Hayek los fines que los individuos persiguen en el mercado son desconocidos y, por tanto, solo un ordenamiento abstracto podría garantizar una multiplicidad de fines concretos para una amplia variedad de individuos.

\footnotetext{
${ }^{853}$ Cfr. Foucault, ob. cit., 150-151.

${ }^{854}$ Cfr. Foucault, ob. cit., 151.

${ }^{855}$ Foucault, ob. cit., 153.
} 
La política, en consecuencia, debe ir orientada a maximizar el éxito de los individuos evitando emplear medios coactivos para el cumplimiento de las normativas establecidas.

Las metas de dicha política serían, por tanto, maximizar por un lado las oportunidades de éxito en la persecución de los ignorados propósitos de cualquier asimismo ignorado miembro de la sociedad y, por otro, limitar el uso de la coacción (obligaciones fiscales aparte) a la mínima imprescindible para hacer respetar las normas que, aplicadas universalmente, tiendan a mejorar las oportunidades de todos. ${ }^{856}$

La política genera las condiciones formales para que se haga posible el juego cataláctico del mercado, asimismo, la producción queda subsumida a reglas formales universalizables. Hayek da por hecho que los consumidores se mueven por su interés y que sus elecciones son libres, que el orden de necesidades depende, en instancia última, de las inclinaciones preferenciales de individuos movidos por intereses que ellos mismos establecen según unos márgenes de oportunidad. El poder de la producción no depende de nadie en particular, pues los principios que la mueven son impersonales ya que la formalidad reglamentaria en el mercado determina previamente el porvenir de las actividades que en él se realizan; este no es un poder fijado por unos agentes productivos determinados, por el contrario, la competencia crea las variaciones, crea nuevos intereses, necesidades y nichos de beneficio. Las decisiones de los consumidores determinan el éxito o el fracaso de los objetivos planteados por los agentes productivos.

Pero Hayek no elaboró una génesis acerca de los individuos que de hecho actúan en el mercado capitalista, su análisis siempre permanece en la formalidad y tiende a la abstracción. La esencialidad competitiva del mercado que instala su pensamiento como eje central del estudio económico y de los principios políticos no ahonda en el vertido de pensamientos que recibe la subjetividad humana, es decir, su filosofía carece de una indagación sobre la productividad de conceptos introyectados en los sujetos y por medio de los que se mueve su conducta. El individualismo hayekiano escinde al sujeto formal del sujeto social, el primero surge exclusivamente en el espacio del mercado mientras que el segundo se forma en la facticidad socio-política humana; la formalidad del mercado se sustrae a las relaciones políticas que los hombres entablan en su entorno público. Por ello, es preciso contraponer a este sistema de pensamiento neoliberal, que

${ }^{856}$ Friedrich August von Hayek, Derecho, legislación y libertad. Volumen II: El espejismo de la justicia social (Madrid: Unión Editorial, 1988), 204. 
en cierto modo privilegia lo formal sobre la facticidad social, la crítica marcuseana a las sociedades industriales avanzadas.

Tal y como pudo constatarse -en el primer apéndice del presente capítulo- Marcuse encuentra una contradicción en la raíz de las sociedades industriales avanzadas cuando ve que la promulgación de una libertad entendida como autonomización del espacio de vida privado anula, empero, las posibilidades de libertad dentro de los campos en que se desarrollan y entrelazan institucionalmente el Estado y el mercado ${ }^{857}$. Las necesidades entendidas desde el punto de vista del "sujeto privado" cargan a sus espaldas todo un arsenal de represiones y condicionamientos extrínsecamente instaurados que no son contemplados, y que de hecho son obliterados, por las "instituciones de la libertad", de modo que cuanto <<más altas hayan llegado a ser las propias necesidades y satisfacciones del individuo más aparecerá su represión como una fatal depravación>>; lo que a su vez se revela como el perturbador factor desde el que puede llegar a crearse <<el primer prerrequisito subjetivo para un cambio cualitativo; este sería: la redefinición de las necesidades $>>{ }^{858}$. Marcuse desconfía de los universos de necesidades establecidos, puesto que habría necesidades relativizadas según el marco histórico de objetivación en el que se dan, sin que puedan constituir verdaderas necesidades desde el punto de vista del acopio básico de medios para la perseverancia en la vida ${ }^{859}$. El autor realiza el siguiente planteamiento problemático:

En última instancia, la pregunta sobre cuáles son las necesidades verdaderas o falsas solo puede ser resuelta por los mismos individuos, pero solo en última instancia; esto es, siempre y cuando tengan la libertad para dar su propia solución. Mientras se les mantenga en la incapacidad de ser autónomos, mientras sean indoctrinados y manipulados (hasta en sus mismos instintos) su respuesta a esta pregunta no puede considerarse propia de ellos. Por lo mismo, sin embargo, ningún tribunal puede adjudicarse el derecho de decidir cuáles necesidades se pueden desarrollar y satisfacer. Tal tribunal sería censurable, aunque nuestro disgusto no podría eliminar la pregunta: ¿cómo puede la gente que ha sido objeto de una dominación efectiva y productiva crear ella misma las condiciones de la libertad ${ }^{860}$

\footnotetext{
${ }^{857}$ Cfr. Herbert Marcuse, El hombre unidimensional (México D.F: Editorial Joaquín Mortiz S.A., 1968), 262.

${ }^{858}$ Marcuse, ob. cit., 263.

${ }^{859}$ Cfr. Marcuse, ob. cit., 27-28.

${ }^{860}$ Marcuse, ob. cit., 28.
} 
Si Hayek concebía la libertad como posibilidad de elección individual, siendo lo contrario a la libertad un aparato de Estado monopolizador de la producción y, por ende, decisor último de las opciones de consumo, en la problemática de Marcuse el problema de la libertad no se reduce simplemente a la oportunidad de elegir entre una colección de cosas previamente producidas. De la misma manera que la presencia de un órgano de planificación central que se arrogue el derecho de decidir qué es prescindible y qué imprescindible para la sociedad resulta irracional, también, es poco razonable suponer que ante la ausencia de poderes de este tipo los individuos vayan a decidir siempre sobre sus necesidades en ausencia de condicionamientos externos y solo en virtud de su libertad.

Para Marcuse hay unos condicionantes en los individuos susceptibles de determinar sus opciones dentro de un abanico de adquisiciones o preferencias posibles. Marcuse reconoce que en las sociedades industriales avanzadas no es factible un control inmediato de las necesidades de los individuos, pero que a través de la administración de los individuos sí resulta posible permear las relaciones sociales. El poder de una racionalidad total y única para toda la sociedad se articula de forma indirecta, haciendo inverosímil ante la población la posibilidad y la pretensión de ejercer un dominio totalitario sobre ella, solo produciendo esta creencia podrían llevarse a efecto mecanismos de control tendentes a prácticas totalitarias ${ }^{861}$. Un ejemplo sería, según propone el autor, la producción de bienes y servicios, la necesidad de trabajar para consumir, la disposición de alternativas diversas para emplear el tiempo libre y la libertad de competencia, todas ellas, formas de control sobre las sociedades opulentas. Las supuestas libertades con que cuentan los individuos a la hora de escoger entre una cosa u otra para cubrir sus necesidades hace de la noción de libertad, paradójicamente, un medio de represión. $<<$ Bajo el gobierno de un todo represivo, la libertad se puede convertir en un poderoso instrumento de dominación $>>{ }^{862}$.

El modo en que Marcuse piensa la conexión entre la dominación y las necesidades es similar a la forma en que Foucault entiende la relación entre el poder y la producción de intereses; el juego de deseos se da en ese espacio de interacción social que es el mercado. El mercado contiene un poder impersonal, no posee una cabeza de gobierno visible tal como puede suceder en un Estado, pero en él se articulan relaciones sociales

\footnotetext{
${ }^{861}$ Cfr. Marcuse, ob. cit., 29.

${ }^{862}$ Marcuse, ob. cit., 29.
} 
productoras de subjetividad que por medio de deseos mueven a los individuos hacia bienes y servicios ya fabricados. Marcuse ve que, efectivamente, en las sociedades industriales avanzadas hay una gestión de las necesidades indirecta, no aplicada mediante fuerzas físicas, sino a través del control represivo de la subjetividad. Que los individuos cuenten con un abanico más o menos amplio de cosas a elegir, ya no solo dentro del mercado sino también en lo relativo a la elección de gobernantes, extiende posibilidades y márgenes de acción previamente constituidos; ahora bien, por muchas que sean las opciones a elegir, en ningún momento se les otorga a los individuos el poder para crear sus propias opciones, este poder viene determinado por una maquinaria tecnológico-política ya configurada.

Escoger libremente entre una amplia variedad de bienes y servicios no significa libertad si estos bienes y servicios sostienen controles sociales sobre una vida de temor y de trabajo, esto es, si sostienen la alienación. Y la reproducción espontánea, por los individuos, de necesidades superimpuestas no establece la autonomía; solo prueba la eficiencia de los controles. ${ }^{863}$

Las fuerzas inmanentes a la individualidad no tienen cómo fabricar de manera fehaciente los medios con que satisfacer sus propias necesidades y deseos, estos, vienen asistidos por un aparato de producción bien engrasado en los espacios donde se desarrolla la política y la economía. Las observaciones críticas de Marcuse dan cuenta de cómo los individuos pierden el poder de construir los objetos de sus propias decisiones, la libertad promulgada entre las sociedades opulentas queda en una mera "libertad de supermercado", en la pedestre e intrascendente posibilidad de elegir entre una marca y otra de tomate envasado. La sociedad queda expuesta a la dirección de unas fuerzas productoras que, mediante formas sofisticadas de subjetivación, conectan avideces no nacidas en la inmanencia de los sujetos con determinados objetos y actividades laborales interesantes para los poderes dominantes establecidos, esta operación se realiza por medio de una actividad productiva en la que los hombres no participan como sujetos autónomos de decisión sino como objetos pasivos de explotación.

Finalmente, resulta relevante observar cómo en la crítica marcuseana predomina una imagen de la sociedad alineada a poderes externos, como si la sociedad hubiera perdido un poder que originariamente albergaba. Si se retoman las observaciones de Hayek, sin

${ }^{863}$ Marcuse, ob. cit., 29-30. 
embargo, su imagen de la sociedad viene distorsionada por un individualismo que solo recurre a los términos derivados de "social" más como un concepto útil que como una realidad. No existe para el pensador austriaco un cuerpo social ni este podría llegar a existir, el poder pertenece a individuos que interactúan en un marco de relaciones regidas por una catalaxia, cuyo marco normativo es externo a los sujetos físicos que componen la sociedad. La imagen de lo social como una avalancha de cuerpos portadores de fuerzas susceptibles de derribar el sistema político late en Hayek tanto como en la perspectiva crítica de Marcuse, como también en el tratamiento biopolítico de Foucault; en ellos está presente la observación de que, como tal, política y saber económico interactúan con el fin de dirigir una masa supuestamente informe, es decir, una masa social que tuvo que adquirir su forma debido a la organización del tiempo destinado a conseguir la materia de consumo. Lo cierto es que ni Marcuse ni Foucault le niegan a esa masa social su poder original, mientras que Hayek ve en las sociedades atávicas nada más que una congregación de fuerzas cuyas relaciones solo se ajustaban a las urgencias de la supervivencia. La masa social, por tanto, si adquiriera una complexión propia, podría ser un fuerte contrapeso para los mecanismos de dominación externos que la dirigen; de eso se percatan los tres autores.

El entorno productivo es un ámbito privilegiado para dirigir las fuerzas de la sociedad, de esto se dan cuenta tanto Hayek, como Marcuse, como también Foucault. En función de la producción, los individuos son dirigidos. Las dictaduras totalitarias pueden hacer un uso efectivo de la producción para regular la sociedad, pero también en el espacio mercantil se generan instrumentos de subjetivación que mueven a la sociedad de forma indirecta, sin recurrir a una configuración física del poder, o sea, sin poner en marcha una estrategia corpórea de dominación; bastaría entonces con introducir aparatos conceptuales en la subjetividad de los individuos para manejarlos. Por otro lado, la dimensión física de la producción no para de crecer y tal crecimiento, como bien se deduce de la crítica de Marcuse, requiere de una reserva de fuerzas físicas al acecho de cualquier tumulto y presta a actuar allí donde cualquier amenaza se vuelva imparable.

La producción en las sociedades contemporáneas se revela como una fuerza de poder impersonal, con unas manifestaciones corporales que tienden a incrementarse de modo incontrolable a través de su propia lógica. A este respecto, nada desdeñables resultan las palabras de Elías Canetti en su epílogo a Masa y poder, donde asegura que el 
incremento de la producción implica necesariamente el reclamo de más hombres, puesto que cuanto más se produce más consumidores parece necesitarse. <<Todos los hombres deberían llegar a una especie de igualdad ideal, es decir, ser todos compradores solventes y bien dispuestos. Pero ello no bastaría, pues una vez que todos hubieran comprado, la producción todavía querría aumentar >>, además de esta tendencia de la producción "en masa", Canetti apunta una segunda tendencia, aquella por la que se da <<un aumento del número de los hombres. La producción necesita más hombres: mediante la multiplicación de los objetos se vuelve al sentido original de toda multiplicación, la de los hombres $>>864$.

La producción y los índices de productividad y consumo hacen de la economía una tecnología de organización, control y distribución del soma social; la economía se erige como una maquinaria política de dominio sobre esas multitudes, cuerpos agregados y convergencias "atómico-somáticas" tras las que actúan avideces verticalmente inducidas por formas de poder ajenos a los intereses de grupos sociales e individuos. La producción es ese "exoesqueleto" que rodea a la corporalidad social y cuya instalación ha supuesto que la sociedad se comporte como si fuera un soma antes invertebrado. Con independencia de que así fuera exactamente, este "exoesqueleto" le impone unos movimientos, operaciones, funciones y aspiraciones al soma social según los engranajes diseñados por la economía, que implanta una complexión al cuerpo de la sociedad fuera de su naturaleza y vitalidad.

${ }^{864}$ Elías Canetti, Masa y poder (Barcelona: Muchnik Editores, 1985), 464. 


\section{SECCIÓN III. MODULACIONES DE LA RELACIÓN \\ CUERPO-PODER}

\subsubsection{LA IMAGEN FOUCAULTIANA DEL CUERPO}

La noción de corporalidad que subyace a los textos de Foucault viene conformada según una metodología genealógica que le niega todo carácter universal a los conceptos. Por tanto, la imagen del cuerpo extraíble de la filosofía foucaultiana solo puede trazarse a partir de discursos y prácticas que han tenido lugar en diferentes momentos de la historia y que involucran en ella a los cuerpos humanos.

Foucault, en un diálogo con Michel Fontana, afirma que el recurso a la metodología genealógica es fruto de una consideración de la historia como desarrollo de relaciones de fuerzas. Para el pensador francés la historia carece de sentido, lo que no implica que esta sea incoherente. Rechaza la metodología dialéctica y la metodología semiótica, al ver que la primera trata de evadir la naturaleza azarosa de los enfrentamientos humanos y que la segunda intenta sortear la connotación agresiva y sangrienta de estos ${ }^{865}$. En la "Conclusión" de la Arqueología del saber, Foucault señala que su encomienda consiste en $<<$ liberar la historia del pensamiento de su sujeción trascendental>> ${ }^{866}$, además, dice que la arqueología no descubre un "a priori" histórico al modo en que lo exige la fenomenología, pues precisamente la arqueología debe zafarse de las reticencias de la fenomenología hacia una historia destinada a descubrir hechos ${ }^{867}$. Asimismo, para Foucault la historia tampoco es una mera colección de hechos dispuestos de tal modo que en ellos se puedan advertir continuidades necesarias, niega la existencia de leyes previas susceptibles de otorgarle una inteligibilidad, una regulación y una teleología a los hechos históricos. El autor reniega del término "acontecimiento" utilizado por la etnología, así, en su entrevista con Fontana admite que fue el estructuralismo <<el esfuerzo más sistemático para evacuar no solo de la etnología, sino de toda una serie de otras ciencias e incluso, en el límite de la historia, el concepto de acontecimiento $>>668$. Pero Foucault también se desmarca del estructuralismo al percatarse, según comenta en la Arqueología del saber, de cómo

\footnotetext{
${ }^{865}$ Cfr. Michel Foucault, Un diálogo sobre el poder (Madrid: Alianza, 2012), 175-176.

${ }^{866}$ Michel Foucault, Arqueología del saber (Madrid: Siglo veintiuno editores, 1979), 340.

${ }^{867}$ Cfr. Foucault, ob. cit., 341-342.

${ }^{868}$ Michel Foucault, Un diálogo sobre el poder (Madrid: Alianza, 2012), 175.
} 
hace ya mucho tiempo que los historiadores localizan, describen, y analizan estructuras, sin haberse preguntado jamás si no dejaban escapar la viva, la frágil, la estremecida "historia". La oposición estructura-devenir no es pertinente ni para la definición del campo histórico, ni, sin duda, para la definición de un método estructural. ${ }^{869}$

A tenor de los asuntos que competen al método de Foucault, se tercia interesante tomar en consideración las indicaciones que el profesor Luis Sáez Rueda propone al respecto en Movimientos filosóficos actuales, donde hace un breve repaso del pensamiento foucaultiano. Sáez Rueda firma que para el filósofo de Poitiers el estructuralismo acertó al diluir la gramática de la metafísica occidental, aunque, por otro lado, acusó las serias carencias que mostraba a la hora de elaborar un estudio genealógico de las múltiples sendas que recorren la historia, pues tomó los hechos dentro de una historicidad unilineal ${ }^{870}$. También, Sáez Rueda dice que Foucault contribuyó a elaborar una ontología crítica del presente y que su punto de partida coincide, solo en parte, con el de Kant, a saber, porque trató de establecer las “condiciones de posibilidad" de la subjetividad. Pero resulta que Foucault nunca partió de un sujeto trascendental al estilo del filósofo de Königsberg, sino que, muy por el contrario, disolvió al sujeto para introducirlo en un marco de racionalidades lingüísticas y discursivas operantes en la historia ${ }^{871}$. Así, entonces, ni hay configuraciones aprióricas con respecto a la historia ni esta viene impulsada por una racionalidad y un sujeto universales. Razón y sujeto irían formándose a través de los condicionamientos que manan de las contiendas inherentes a las relaciones humanas: las $<<$ "condiciones de posibilidad" que articulan la subjetividad no son elementos trascendentales de la naturaleza humana sino, más bien, conjuntos de prácticas sociales unidas a saberes >>, por tanto, tales condiciones se producen <<en cuanto conjunto de fuerzas generadoras, elementos genéticos de aquello que definen "racional" y "sujeto" $>>872$.

Foucault, como postulado inicial en sus investigaciones históricas, presume que los universales no existen, de modo que, por ejemplo, su investigación acerca de la locura consistiría en ver qué historia se puede $<<$ hacer de los diferentes acontecimientos, esas diferentes prácticas que, en apariencia, se ajustan a esa cosa supuesta que es la

\footnotetext{
${ }^{869}$ Michel Foucault, Arqueología del saber (Madrid: Siglo Veintiuno Editores, 1979), 19.

${ }^{870}$ Cfr. Luis Sáez Rueda, Movimientos filosóficos actuales (Madrid: Trotta, 2009), 421.

${ }^{871}$ Cfr. Sáez Rueda, ob. cit., 421-422.

${ }^{872}$ Sáez Rueda, ob. cit., 422.
} 
locura $>>{ }^{873}$. Entonces, si se tomara como punto de partida la noción de una corporalidad huérfana de todo contenido universal, la imagen teórica resultante de ella solo podría configurarse merced a una serie de prácticas que permitieran pesquisar la silueta de lo corpóreo en una diversidad de acciones moduladas en la historia. Consecuentemente, sin interpelar a $<<\operatorname{los}$ universales utilizando la historia como método crítico >> y suponiendo < la inexistencia de los universales para preguntar qué historia se puede hacer $>{ }^{874}$, se situarán, de este modo, los parámetros preliminares para toda empresa que ose tomarse la licencia de indagar en una posible imagen del cuerpo presente en la filosofía de Foucault. De hecho, desde las propias directrices metodológicas planteadas por el autor es posible acceder cabalmente a ese cuerpo emancipado de los universalismos, mas no por ello vacuo en su contenido onto-genealógico.

De acuerdo con lo visto, es perfectamente razonable suponer que puede desprenderse de los textos foucaultianos algún tipo de "imagen del cuerpo". En vistas a ofrecer una explicación clara sobre por qué sí se considera la presencia de una imagen del cuerpo en el pensamiento de Foucault, urge disputar los argumentos de Turner en contra. Turner es favorable a la idea de que la noción de corporalidad en los textos foucaultianos resulta ambigua y contradictoria. Afirma que para Foucault en las sociedades modernas la configuración del cuerpo es producto de las relaciones de poder, lo corporal sería entonces controlado tanto en la dimensión de la individualidad como en la dimensión de la población ${ }^{875}$. Pero más adelante dice que ocasionalmente Foucault

juzga al cuerpo como una entidad real: como, por ejemplo, en los efectos del crecimiento poblacional sobre el pensamiento científico o en su análisis del efecto de la criminología sobre el cuerpo. Foucault parece tratar el cuerpo como un aspecto unificado, concreto, de la historia humana, el cual es continuo a través de las épocas. Tal oposición, sin embargo, se encuentra en franca contradicción con sus enfoques acerca de las discontinuidades de la historia y con su argumento de que el cuerpo es construido por el discurso. ${ }^{876}$

Las dificultades que Turner encuentra en la filosofía de Foucault en lo relativo al tratamiento de la corporalidad proceden de la metodología y de los criterios epistemológicos que el propio pensador francés empleó. Para Turner, el método

\footnotetext{
${ }^{873}$ Michel Foucault, Nacimiento de la biopolítica (Buenos Aires: Fondo de Cultura Económica de Argentina, 2007), 18.

${ }^{874}$ Foucault, ob. cit., 19.

${ }^{875}$ Cfr. Bryan Turner, El cuerpo y la sociedad (México D.F: Fondo de Cultura Económica, 1989), 61-62.

876 Turner, ob. cit., 76.
} 
foucaultiano iba dirigido a disputar los términos del cartesianismo, y para ello requirió negar tanto la naturaleza del cuerpo como la existencia de la conciencia ${ }^{877}$. El ejercicio interpretativo de Turner transige la presencia de una noción "nuclear" del cuerpo, como si el campo de relaciones de poder que se abre en torno a la corporalidad acusara una tangencia perceptible de forma directa, esto sería tanto como si le exigiéramos a un físico que demostrara la existencia de los átomos mostrando uno de ellos a nuestros sentidos. Turner no cae en la cuenta de que los procedimientos metodológicos de Foucault son solo suposiciones desde las que se emprende una exploración de la facticidad, de modo que la negación de los universales es tan solo una táctica con que el filósofo francés pretende alejarse de las imposiciones conceptuales prefiguradas por los órdenes hegemónicos de la tradición filosófica.

La cuestión es que Foucault no niega la existencia del cuerpo, ni de la conciencia, ni de la locura, etc., más bien, lo que hace es vaciarlos de su contenido universal para prescindir de las imposiciones de la ontología tradicional, de los discursos hegemónicos y de las racionalidades asumidas acríticamente. Foucault observa hechos y acude a los discursos y prácticas que los suturan, tal sutura le permite interpretar la asociación de lo fáctico con los conceptos universales. Foucault hace como si no existieran los conceptos y términos universales para desconectar la facticidad de los amarres con que esta ha sido atrapada, pero, en ningún momento, niega la materia de lo fáctico, ya que sus investigaciones versan sobre los hechos y sobre la historia contada en torno a ellos. Por tanto, la corporalidad será tratada en virtud de esta facticidad envuelta y rodeada por formas hegemónicas cuyos discursos vertebran imágenes de la dimensión corporal humana.

Últimamente, el profesor Byung-Chul Han le ha reprochado a Foucault, a propósito del modo en que entiende el poder disciplinario, que es debido a $<<$ la amplia fijación que tiene con el cuerpo >> la razón por la que $<<$ no se entera suficiente de aquel poder que opera creando hábitos en un nivel simbólico $>{ }^{878}$. Ante la denuncia de una excesiva "fijación" por parte de la filosofía foucaultiana hacia el cuerpo y su supuesto olvido hacia la capa de signos y símbolos que actúan a nivel de la subjetividad y la intersubjetividad, solo cabe afirmar, una vez más, que en la comprensión del método de Foucault conviene tomar lo corporal como un eje central a raíz del cual también se

\footnotetext{
877 Cfr. Turner, ob. cit., 77.

${ }^{878}$ Byung-Chul Han, Sobre el poder (Barcelona: Herder, 2016), 68.
} 
forma toda una constelación de hábitos y símbolos. Lo subjetivo nunca termina de desarraigarse del cuerpo, el triunfo de la productividad de contenidos subjetivos siempre desembocará y dará señales de su éxito en el terreno de la facticidad, allí donde interaccionan cuerpos que hablan, gesticulan, se tocan y utilizan expresiones con que aumentar el espectro del poder. La corporalidad es un centro en la comprensión del poder, de modo que es la propia actuación de los cuerpos, ya sea al nivel de la resistencia o al nivel de obediencia, donde se ponen a prueba esos discursos que penetran la subjetividad y que tienen capacidad para moldearla, no siempre recurriendo al contacto físico directo, pues, más bien, es preferible no incurrir en gastos materiales que le atribuyan un peso ingente y desmesurado a los medios con que opera la dominación. El cuerpo de Foucault no es una "cosa" desprendible del esquema operativo simbólico, de hecho, Byung-Chul Han reconoce que un <<hábito causa una afirmación y un reconocimiento preconsciente del orden dominante que se repite en lo somático $>>{ }^{879}$, si no se repitiera jamás habría una certeza plena de su presencia en un universo semiótico; precisamente la pugna de Foucault fue dirigida contra la consideración de que pueden existir, independientemente de la facticidad, órdenes conceptuales no adscritos a ningún registro explicito o implícito en la vida; como si los discursos no fueran enfocados a generar unos efectos, como si lo subjetivo no "moviera" la conducta habitual de individuos y sociedades.

De la caracterización que Foucault hace del cuerpo en Nietzsche, la genealogía, la historia, como $<<$ superficie de inscripción de los acontecimientos $>{ }^{880}$, se extrae la imagen de la corporalidad en cuanto soporte de unas relaciones desplegadas a lo largo de la historia. En ningún momento Foucault supone un cuerpo al margen de la historia, pues no puede haber una configuración discursiva sobre el cuerpo que no sea histórica, ni siquiera la anatomía "más científica” o la fisiología más descriptiva podrían hacerlo.

De todas formas, pensamos que el cuerpo no tiene otras leyes que las de su fisiología y que escapa a la historia. Nuevo error; está atrapado en una serie de regímenes que lo modelan; está roto por ritmos de trabajo, de reposo y de fiestas; está intoxicado por venenos -alimentos o valores, hábitos de alimentación y leyes morales, todo a la vez-; se forja con la resistencia. ${ }^{881}$

\footnotetext{
${ }^{879}$ Han, ob. cit., 69.

${ }^{880}$ Michel Foucault, Nietzsche, la genealogía, la historia (Valencia: Pre-textos, 2014), 32.

${ }^{881}$ Foucault, ob. cit., 45-46.
} 
En el pensamiento de Foucault el cuerpo varía su imagen según la red de relaciones de poder que recorre la historia. Hay que suponer un cuerpo como entidad vacía para ver en qué medida su imagen conceptual es producto de una correlación de fuerzas articulada en el tiempo histórico. El cuerpo no es una coseidad surtidora de datos empíricos ni una coseidad expuesta a las directrices de una inteligencia externa, es una fuerza viva cuya inmanencia surte de contenidos a racionalidades, conceptos y principios jurídicos.

\subsubsection{ANATOMOPOLIÍTICA Y BIOPOLÍTICA}

En el pensamiento de Foucault se dan dos formas de poder sobre la vida humana, no antitéticas la una con respecto a la otra, y que acceden a lo corporal a partir de dos niveles diferentes: la individualidad-anatómica y la población-especie. En Historia de la sexualidad el autor da cuenta de cómo en un primer momento, a comienzos de la modernidad (siglo XVII), se formó el polo de la anatomopolítica, que presentaba la imagen de un cuerpo mecánico sobre el que se ejerce un poder disciplinario. Así, este cuerpo-máquina quedaba incrustado en sistemas disciplinarios desde los que se imponía un control eficaz y eficiente sobre los individuos. En un segundo momento, Foucault sitúa hacia la mitad del siglo XVIII la formación del polo de poder biopolítico, cuyo eje central de acción iba dirigido al cuerpo-especie que revela una imagen del cuerpo, no correspondiente a la dimensión anatómica del individuo en particular, sino a toda una población. La población despliega una serie de dinámicas que tienen que ver con vicisitudes de la vida y la muerte en todo un "plexo somático vivo" que es controlado por medio de intervenciones sobre los procesos biológicos allí acaecidos ${ }^{882}$.

Las imágenes foucaultianas del cuerpo vienen indefectiblemente vinculadas con el ejercicio del poder, se podría asegurar que las actividades del poder "dibujan" los perfiles de las corporalidades sobre las que se ejerce. Los cuerpos se ven acorralados por una <<gran tecnología de doble faz -anatómica y biológica, individualizante y especificante, vuelta hacia las relaciones del cuerpo y atenta a los procesos de la vida>>, a su vez, la muerte, en cuanto potencia simbolizada en la figura del soberano, <<se halla ahora cuidadosamente recubierta por la administración de los cuerpos y la gestión calculadora de la vida $>>883$. A tenor del dilatado contenido filosófico que hallan los

${ }^{882}$ Cfr. Michel Foucault, Historia de la sexualidad. 1. La voluntad de saber (Buenos Aires: Siglo Veintiuno Editores, 2005), 168.

${ }^{883}$ Foucault, ob. cit., 169. 
términos "poder" y "relaciones de poder" en el pensamiento de Foucault, cabe tener en cuenta la clasificación del poder en tres modulaciones, según las dos imágenes del cuerpo mencionadas y su síntesis respectiva: 1) el poder disciplinario o anatomopolítico, que apunta al cuerpo del individuo; 2) el poder biopolítico, que se dirige a la población en cuanto especie; y 3) el poder que integra las dos formaciones corporales anteriores, el biopoder.

La representación anatómica del cuerpo natural de los individuos precisa de una mirada que contenga un saber/poder, es decir, un saber que saque a la luz las condiciones de posibilidad con que poner en funcionamiento un control, una administración y, en definitiva, un dominio incisivo y eficiente sobre lo corporalindividual. Concretamente es en Vigilar y castigar donde Foucault desarrolló las claves del funcionamiento de ese micropoder cuya conformación tuvo lugar en las decisivas transformaciones que se dieron a finales del siglo XVIII, época que determinaría el umbral entre la modernidad y la contemporaneidad. El sistema penal que floreció y se prolongó a lo largo de la época contemporánea llevó a los jueces a juzgar aspectos de la vida que escapaban del terreno del derecho, pues en las decisiones jurídicas intervienen elementos externos a la propia jurisdicción, tales como, por ejemplo, el peritaje psiquiátrico $^{884}$. Los castigos consistentes en suplicios y en la exhibición pública del culpable supliciado fueron sustituidos por técnicas que recurrían al cuerpo no para desgarrarlo y destruirlo, sino para aprovecharlo económicamente o, al menos, instaurar sobre él un régimen de explotación que lo doblegase y amansase ${ }^{885}$. La corporalidad se vio incrustada en medio de una red de relaciones de poder que iban a movilizar al cuerpo e iban a extraer de él unos signos exigidos por el propio orden político dominante:

Este cerco político del cuerpo va unido, en función de relaciones complejas y recíprocas, a la utilización económica del cuerpo; el cuerpo, en buena parte, está imbuido de relaciones de poder y de dominación, como fuerza de producción, pero, en cambio, su constitución como fuerza de trabajo solo es posible si se halla inmerso en un sistema de sujeción $(\ldots) .{ }^{886}$

\footnotetext{
${ }^{884}$ Cfr. Michel Foucault, Vigilar y castigar (Madrid: Biblioteca Nueva, 2012), 31.

${ }^{885}$ Cfr. Foucault, ob. cit., 34.

${ }^{886}$ Foucault, ob. cit., 35.
} 
Las articulaciones que conforman la dominación disciplinaria planteada por Foucault, componen un tipo de poder externo a la corporalidad que no se materializa siguiendo una ergonomía de las posibles concreciones fisiológicas de una pluralidad de cuerpos distintos entre sí, sino que, muy por el contrario, elabora una forma "imaginaria" y abstracta de la anatomía humana para orientar el control, la administración, la intervención y la movilización de los cuerpos. Esta forma imaginaria y abstracta establece que presumiblemente los parámetros impuestos para ese cuerpo formalizado son válidos para cualquier otro cuerpo concreto. El cuerpo "imaginado" por las instancias de poder orienta las prácticas que se dirigen al dominio de ese crisol variable de cuerpos que presentan tantas diferencias y singularidades entre sí -es muy improbable hallar individuos exactamente idénticos-, cuerpos que, por otro lado, no pueden ser computados ni registrados de manera omnímoda, porque ningún ordenamiento de poder tiene capacidad para saber absoluta y milimétricamente todo sobre las singularidades de los cuerpos a los que domina. El poder tiene que establecer criterios de clasificación generales que permitan gestionar con eficiencia todas las variaciones posibles. Consecuentemente, para instaurar el "cerco político" del cuerpo se requerirá una concepción abstracta de una forma anatómica universal, y que haga las veces de plano general sobre el que guiar las operaciones de control, un plano que procure directrices teleológicas y engarce dominios discursivos con que actuar sobre toda una pluralidad de cuerpos diferentes. El poder anatomopolítico modifica las fuerzas inherentes a la corporalidad de los individuos, así, ejerce una acción hipertrófica sobre la fuerza de trabajo de estos, ya que intensifica sus capacidades laborales a costa de disminuir otras fuerzas. La disciplina implanta una presión ortopédica sobre los cuerpos, trata de disponerlos de tal modo que apliquen los cánones de una anatomía de fuerzas ya preestablecida en abstracto ${ }^{887}$.

Conviene dar cuenta de cómo la biopolítica surgió en la esquemática contextual de la disciplina. El nacimiento de la clínica es la obra de Foucault que mejor simboliza el

\footnotetext{
${ }^{887}$ En la última lámina de Vigilar y castigar, la lámina número 30, Foucault presenta la imagen de un árbol con un tronco torcido atado a un palo. El objetivo del palo recto es procurarle al árbol un crecimiento en dirección vertical, erguida y regular. Lo que el autor francés ve en la imagen de esta lámina es la metáfora de la ortopedia que se le aplica a las deformidades corporales de los niños. Pero la ortopedia también tiene una función estratégica en lo que se refiere al control y gestión de las fuerzas de los individuos, de hecho, los rendimientos óptimos de la producción dependerán de que las fuerzas naturales del cuerpo sean conducidas a una maximización de su capacidad útil, un mecanismo tecnológico-disciplinario que ha de ser entendido como una ortopedia, pues implanta una linealidad uniforme en la aplicación de las fuerzas corporales y, además, requiere de un medio de presión con el fin de que estas fuerzas tengan un uso considerado como correcto.
} 
tránsito del poder anatomopolítico al poder biopolítico, del control sobre los cuerpos individuales al control de las poblaciones: dado que las enfermedades afectan a los cuerpos individualmente a la vez que se convierten en un problema para toda una especie en tanto en cuanto estas proliferan, contagian y, por ende, pueden propagarse hacia todos los recovecos de las sociedades. Foucault sostiene que a finales del siglo XVIII la medicina abandonó el diagnóstico de las enfermedades mediante signos provocados artificialmente sobre el cuerpo del enfermo, pues, a partir de entonces, $<<$ la anatomía patológica prescribe a la clínica interrogar al cuerpo en su espesor orgánico, y hace aflorar a la superficie lo que solo estaba dado en capas profundas $>{ }^{888}$. Se constituye una anatomía patológica que le permite a la mirada del médico acceder a los signos de la enfermedad, de modo que el cuerpo adquirió la imagen de un volumen tridimensional, luego, su imagen, tomó una superficie y una profundidad. La tridimensionalidad corporal permitió suponer y localizar las enfermedades como corporeidades, e incluirlas en las mismas coordenadas dimensionales del cuerpo, la consecuencia de ello fue que el mirar "anatomoclínico" dispusiera los cuerpos en función de las directrices pragmáticas con que la medicina se resolvía a luchar contra las enfermedades $^{889}$.

En la clínica, se tratan a la inversa enfermedades cuyo portador es indiferente: lo que está presente es la enfermedad misma, en el cuerpo que le es propio y que no es el del enfermo sino el de su verdad. (...). En el hospital, el enfermo es sujeto de su enfermedad; es decir que se trata de un caso; en la clínica, en la cual no se trata sino del ejemplo el enfermo, es el accidente de su enfermedad, el objeto transitorio del cual esta se ha apropiado. ${ }^{890}$

Para Foucault, la enfermedad no es tomada directamente en el "espesor del cuerpo", sino que de manera previa se elabora una clasificación de las enfermedades que configura un marco orientativo de la práctica médica ${ }^{891}$. De este modo, la enfermedad adquiere su propia espesura. El autor observa que el médico, cuando localiza el sufrimiento de un órgano u órganos, a la hora de neutralizar sus efectos perturbadores aplica una mirada que <<no se posará sino en un espacio lleno por las formas de composición de los órganos. El espacio de la enfermedad es, sin residuo ni deslizamiento, el espacio mismo del organismo. Percibir lo mórbido, no es otra cosa que

\footnotetext{
${ }^{888}$ Michel Foucault, El nacimiento de la clínica (Buenos Aires: Siglo Veintiuno Editores, 2004), 230.

${ }^{889}$ Cfr. Foucault, ob. cit., 230-231.

${ }^{890}$ Foucault, ob. cit., 92.

${ }^{891}$ Cfr. Foucault, ob. cit., 18.
} 
percibir el cuerpo >> ${ }^{892}$; ahora bien, la mirada anatomoclínica observa la corporalidad en cuanto organismo afectado patológicamente, de tal forma que el volumen espacial de la enfermedad, sus cuadraturas clasificatorias, terminará condicionando la batería de prácticas y disposiciones aplicadas al cuerpo enfermo y su pertinente disposición en el espacio clínico.

En relación con los aspectos tratados por Foucault acerca de los cambios que experimentó la medicina y las repercusiones que dichos cambios produjeron en su trayectoria contemporánea, huelga tener en cuenta el modo en que el profesor Raúl Villarroel explica los análisis foucaultianos sobre la medicina. Para Villarroel, que sigue a Enrico Berlinguer en su punto de vista preliminar, la práctica médica va más allá de los espacios institucionales de profesionalización, especialización y reconocimiento de la medicina en cuanto prácticas ejercidas por médicos ${ }^{893}$; por tanto $<<$ la intervención médica debe ajustarse al espacio de reconocimiento de la compleja multidimensionalidad de lo humano, inaprensible para cualquier esfuerzo explicativo que no contemple su vastedad y pluralidad $>>{ }^{894}$. Villarroel aclara que el matiz hermenéutico desde el que discurren sus argumentos acerca de la filosofía médica pasa por tratar de superar la noción saber/poder foucaultiana aproximándose a una propuesta que comprenda a la medicina como "arte de curar", y que sobrepase los límites que el biopoder y la biopolítica le habían impuesto a su desarrollo histórico ${ }^{895}$.

Pero, al margen de las interpretaciones y del horizonte comprensivo abierto por Villarroel, conviene destacar, en referencia a su forma de comprender a Foucault, cómo el filósofo de Poitiers le habría concedido

un protagonismo fundamental al dispositivo biomédico desplegado a partir de la época moderna, en la constitución de aquel fenómeno que más o menos por los mismos años en que concibió su obra Vigilar y castigar, comenzó a denominar "anatomopolítica del cuerpo", por referencia a la conjunción de saber y poder desplegado sobre los individuos, al micropoder dejado caer sobre los cuerpos; al tiempo que denominó "biopolítica de la

\footnotetext{
${ }^{892}$ Foucault, ob. cit., 271.

893 Cfr. Raúl Villarroel, Interesarse por la vida. Ensayos bioéticos y biopolíticos (Santiago de Chile: Universitaria, 2014), 29.

${ }^{894}$ Villarroel, ob. cit., 30.

${ }^{895}$ Cfr. Villarroel, ob. cit., 30.
} 
población" al complejo de saber y poder ejercido sobre el cuerpo social entero o los grupos tomados en su conjunto, desde entonces. ${ }^{896}$

El cuerpo como objeto de la práctica médica y el cuerpo como objeto de la práctica jurídico-penitenciaria contribuyen a la transfiguración de la imagen corporal, merced a la incidencia de un poder que articula una figura anatómica uniforme para todos los cuerpos individuales, a su vez, sobre esta imagen del cuerpo se levantó la imagen de otro cuerpo que no hacía ya referencia a un individuo sino a toda una colectividad. Esa imagen biopolítica del cuerpo iba destinada a impeler el despliegue regulado de las prácticas de dominación sobre las poblaciones, en otras palabras, una dominación sobre el dinamismo biológico de toda una amalgama de comunidades humanas. La clínica dispersa los cuerpos y los administra dentro de un espacio, no de acuerdo a la anatomía complexa de los individuos, sino a una anatomía de la enfermedad que sobrepone el cuerpo patológico sobre el cuerpo de los individuos, haciendo de la enfermedad una potencia extensible a la totalidad del cuerpo social, aunque todavía en la clínica operan los mecanismos disciplinarios de individuación abstracta desde una anatomía supuesta y prefijada para una multitud de singularidades corporales contingentes.

El cuerpo de la biopolítica, del polo de poder biológico, no se corresponde con la corporalidad de un individuo concreto, sino con procesos vitales que afectan a una población, a un conjunto gregario de cuerpos. La población, en cuanto cuerpo, solo puede ser entendida como soma social, es decir, la reunión de los cuerpos formando una espesura somático-poblacional cuya inherencia alberga procesos biológicos masivos. Por tanto, estos procesos biológicos van a ser controlados no mediante una mecánica de individuación de los cuerpos, sino tomándolos bajo un mismo tejido somático. En Defender la sociedad, texto que reproduce el curso de 1975-1976 en el Collége de France, Foucault asegura que la tecnología de poder aplicada sobre el cuerpo de la población, o sobre los cuerpos amasados que forman distintos grupos, no es un tipo de poder disciplinario, pues abarca unas dimensiones que van más allá de la anatomopolítica. El poder de la biopolítica actúa sobre una capa disciplinar previa, pero la trasciende: <<no suprime la técnica disciplinaria, simplemente porque es de otro nivel, de otra escala, tiene otra superficie de sustentación y se vale de instrumentos completamente distintos $>{ }^{897}$. El poder biopolítico toma el cuerpo de los hombres en

\footnotetext{
${ }^{896}$ Villarroel, ob. cit., 86.

${ }^{897}$ Michel Foucault, Defender la sociedad (Buenos Aires: Fondo de Cultura Económica, 2000), 219.
} 
cuanto componentes de una especie, se dirige a los seres humanos como "especie" y no como individuos de "anatomía uniforme". La tecnología de poder biopolítico <<está destinada a la multiplicidad de los hombres, pero no en cuanto se resumen en cuerpos sino en la medida en que se forma, al contrario, una masa global, afectada por procesos de conjunto que son propios de la vida $>{ }^{898}$. La tecnología dispuesta por el poder biopolítico hace a la población su objeto, de manera que este nivel de objetualización de lo corporal opera sobre toda una población que se presenta como una masa somática viva.

La nueva tecnología de poder no tiene que vérselas exactamente con la sociedad (o, en fin, con el cuerpo social tal como lo definen los juristas); tampoco con el individuo/cuerpo. Se trata de un nuevo cuerpo: cuerpo múltiple, cuerpo de muchas cabezas, si no infinito, al menos necesariamente innumerables. Es la idea de población. ${ }^{899}$

La imagen de la población como un cuerpo informe, como cúmulo somático de una multitud de cuerpos individuales reunidos, no sigue, entonces, la misma categorización universal de la dominación anatomopolítica o disciplinaria, pues no abstrae el concepto de la sociedad ni lo vuelve universalizable, como sí hace la disciplina antes de acceder al dominio de los cuerpos concretos. Ante todo, el cuerpo de la población no tiene ni una sola alma ni una sola espina dorsal. El poder biopolítico va dirigido sobre unos procesos vitales, controla los tiempos en que se desenvuelve la sociedad, no está ante una silueta prefijada. La anatomopolítica suponía cuerpos con dos brazos, dos manos, dos piernas, dos pies, un tronco y una cabeza; sin embargo, la biopolítica habrá de suponer unos procesos regulares en la vida de una población $\mathrm{y}$, dentro de estas regularidades, habrá de controlar su desarrollo siempre y cuando logre imponer unas constantes susceptibles de regularizar a toda una sociedad.

La permeabilidad y movilidad del cuerpo de la biopolítica requiere, entonces, de unos parámetros que pongan en marcha una gubernamentación que aúne a los individuos en población, solo así puede llegar a surgir el biopoder en cuanto integración tecnológico-gubernamental de disciplina sobre el cuerpo individual y control sobre el cuerpo poblacional. En el biopoder, la abstracción del cuerpo individual se ve entrelazada a abstracciones extraídas de aspectos concretos que tienen que ver con la raza y la salud. Aunque aspectos de este tipo sean concreciones relativas a los cuerpos

\footnotetext{
${ }^{898}$ Foucault, ob. cit., 220.

${ }^{899}$ Foucault, ob. cit., 222.
} 
de determinadas poblaciones, sin embargo, en las clasificaciones de los cuerpos por raza y salud pueden llegar a operar abstracciones que tiendan a universalizar a individuos según su raza y estado de salud. Cuerpo individual y cuerpo poblacional mantendrían una alianza en la que abstracciones de distinta índole determinarían criterios de selección en los procesos de gobernanza. Solo una clasificación de los cuerpos que siguiera esta tendencia podría llegar a justificar la exclusión de grupos sociales determinados, y solo así un poder soberano apartaría a quienes no coincidieran con ciertos cánones raciales y de salud; el Estado, en nombre de la raza, decidiría qué cuerpos son aptos y cuáles no, qué lugar deberían ocupar y cuál no, así como qué cuerpos viven y qué cuerpos mueren. A este respecto, Foucault asegura que con el nazismo

el tema de la sociedad binaria, dividida entre dos razas, dos grupos extranjeros por la lengua, el derecho, etcétera, va a ser reemplazado por el de una sociedad que será, al contrario, biológicamente monista. Esa sociedad se distinguirá simplemente por lo siguiente: la amenaza de una serie de elementos heterogéneos, pero que no le son esenciales, que no dividen el cuerpo social, el cuerpo viviente de la sociedad, en dos partes, sino que en cierto modo son accidentales. Surgirá así la idea de los extranjeros infiltrados y el tema de los desviados, que son los subproductos de esa sociedad. ${ }^{900}$

Estos problemas han sido introducidos por la biopolítica; no se trata de que antes, en la historia de la humanidad, no se hubieran dado, es que la biopolítica es el término que hace referencia a estas vicisitudes en sus concreciones problemáticas. Agamben, en $E l$ poder soberano y la nuda vida, hace una lectura muy acorde con los elementos teóricos que Foucault le designó a la biopolítica: dice que en el siglo XX el nazismo y el fascismo fueron los dos movimientos biopolíticos del momento, pues tomaron aspectos propios de la vida natural como centro de las decisiones sobernas. Una vez acontecida la Gran Guerra que sacudió Europa y otros lugares del mundo, se hizo patente la crisis del concepto Estado-Nación, puesto que el nacimiento de un individuo ya no garantizaba unos derechos de ciudadanía subyacentes a una nacionalidad; así, Rosenberg testimoniaba que la visión de mundo nacionalsocialista parte de que lo alemán equivale a la "sangre" y al "suelo"901, es decir, se nace alemán independientemente del lugar, al ser la herencia sanguínea la que otorga la germanidad.

\footnotetext{
${ }^{900}$ Foucault, ob. cit., 80-81.

901 Cfr. Giorgio Agamben, Homo Sacer. El poder soberano y la nuda vida. I (Valencia: Pre-Textos, 2003), 163-164.
} 
Una de las cuestiones que, a ojos de Agamben, mejor representa el declive de la categoría nacimiento-nación, propia del Estado moderno, es la figura del refugiado ${ }^{902}$. El refugiado se halla fuera de la jurisdicción, en él se realiza la excepcionalidad extrajurídica que pone en marcha los mecanismos de la "nuda vida", esa vida aherrojada a decisiones que no responden a ningún marco jurídico, sino a una situación que pone a los individuos bajo la indefinición de la excepcionalidad. Agamben señala que el escenario Europeo de post-Primera Guerra Mundial hizo más evidente la indefinición acerca de los apátridas y los refugiados, como es el caso de los $\quad<1.500 .000$ rusos blancos, 700.000 armenios $>>$, etc., lo que trajo consigo <<la contemporánea introducción en el orden jurídico de muchos Estados europeos de normas que permiten la desnaturalización y la desnacionalización en masa de los propios ciudadanos $>>903$. Los hechos acecidos en aquel momento en Francia, Bélgica, la Italia fascista, Austria, así como las leyes de Núrenberg promulgadas y aplicadas durante el Tercer Reich, pusieron en entredicho el vínculo nacimiento-nación ${ }^{904}$.

El problema que la visión agambeniana de la biopolítica pone de relieve, y en lo que se refiere al problema de la corporalidad en relación con las categorías tradicionales del derecho, es que la imagen de los cuerpos humanos a partir de comienzos del siglo XX deambula en medio de la desintegración de las categorías políticas tradicionales. Los cuerpos se hallan anudados a fuerzas no legitimadas debido a la ruptura de la jurisdicción clásica, lo corporal no absorbe elementos de poder externos que lo protegen o lo castigan a partir de un marco jurídico perpetuo, la pérdida de esta perpetuidad suspende a los cuerpos en medio de la incertidumbre política y los avoca a valerse de sus propias fuerzas en una vida "pinzada" por poderes de gran envergadura. La inmanencia del poder corporal sigue siendo un problema político, la constitución de las fuerzas que componen esta inmanencia va a tratar de ser atajada, aprovechada o reprendida, pero ahora lo va a ser sin mediaciones legales, sin cálculos jurídicos, sin horizontes contractuales y sin entornos institucionales con una dirección clara sobre cómo hacerlo. Agamben advierte que no cabe olvidar que el "cuerpo biopolítico" $<<$ constituye al nuevo sujeto político fundamental $>>$, que no es una cuestión de hecho (questio facti) ni una cuestión de derecho (questio iuris), $<<$ sino el producto de una

\footnotetext{
902 Cfr. Agamben, ob. cit., 166-167.

903 Agamben, ob. cit., 167.

${ }^{904}$ Cfr. Agamben, ob. cit., 168.
} 
decisión política soberana que opera sobre la base de una absoluta indiferencia entre hecho y derecho >>905.

\subsubsection{REALIZACión DEL BIOPODER: ESPACIOS DE PODER MÁS ALLÁ DE LA JURISDICCIÓN}

En la entrevista que Manuel Osorio le realizó a Foucault en 1977 en Madrid, el filósofo francés aseveraba que el poder no se reduce exclusivamente a los mecanismos empleados por el aparato jurídico. Puede que en otras épocas bastara con analizar los procedimientos jurídicos para entender el funcionamiento del poder, pero, en un momento histórico en el que, por ejemplo, la psiquiatría aporta un discurso de saber susceptible de generar formas de veridicción en materia penal, los procedimientos de dominación se hallan dispersos en otras dinámicas y ordenamientos de saber además del Derecho $^{906}$. Cuando el entrevistador le pregunta a Foucault acerca de la vinculación entre lo jurídico y lo extrajurídico en lo relativo al poder, el pensador de Poitiers responde:

Como usted sabe, las relaciones de poder son las que los aparatos de Estado ejercen sobre los individuos, pero asimismo la que el padre de familia ejerce sobre su mujer y sus hijos, el poder ejercido por el médico, el poder ejercido por el contable, el poder que el dueño ejerce en su fábrica sobre sus obreros..$^{907}$

El poder que concibe Foucault goza de un carácter polifacético, dadas las varias capas en que se encuentran indicios de su paso y presencia, tanto en lo que respecta al dominio como también a la resistencia. En Historia de la sexualidad el filósofo francés reconoce que el término "poder" es propenso a causar malentendidos, pues a menudo se lo identifica con la formalidad de las leyes jurídicas o con la represión, cuando, ciertamente, no se halla específicamente en ninguno de estos aspectos, no siempre aparece en los aparatos de Estado, ni en la sujeción ${ }^{908} .<<$ El poder está en todas partes; no es que lo englobe todo, sino que viene de todas partes>>; así entonces, el poder no se halla asociado a <<una institución, y no es una estructura, no es cierta potencia de la que algunos estarían dotados: es el hombre que se presta a una situación estratégica

\footnotetext{
905 Agamben, ob. cit., 218.

${ }^{906}$ Cfr. Michel Foucault, El poder, una bestia magnífica (Buenos Aires: Siglo Veintiuno Editores, 2012), 40-41.

907 Foucault, ob. cit., 42.

908 Cfr. Michel Foucault, Historia de la sexualidad. 1. La voluntad de saber (Buenos Aires: Siglo Veintiuno Editores, 2005), 112.
} 
compleja en una sociedad $>>009$. Cabalmente Foucault encuentra que el poder no se circunscribe a entornos limitados o concretos en los que actúan potencias arraigadas a una exclusividad social, sino que el poder responde a juegos estratégicos configurados a partir de correlaciones de fuerzas. La concepción foucaultiana del poder desplaza los privilegios que la legalidad, la prohibición y la soberanía, adquieren en correspondencia con los objetivos estratégicos, la eficiencia táctica y la pluralidad heterogénea de las fuerzas. Las relaciones de poder, por tanto, no fijan dominaciones y subyugaciones sólidas, son móviles, están expuestas al tactismo de las fuerzas que entran en correlación. Foucault asegura que esta noción del poder sustituye lo estratégico por el derecho, una suplantación que se produjo en las sociedades occidentales al primar en ellas las relaciones de fuerza ${ }^{910}$.

La sexualidad es una de las dimensiones de la vida en que mayor alcance tiene el biopoder, ya que, tal como comentan Milena Cevallos y Bernardita Serra en el artículo La materialidad del poder: una reflexión en torno al cuerpo, la sexualidad une tanto el dominio sobre sí mismo por parte del individuo como los aspectos referidos al control de las poblaciones, en la medida en que <<hay una imbricación de esas dos instancias (la del uno mismo y la de los otros), a la que Foucault llama gubernamentalidad $>>11$. Las autoras del mencionado artículo concluyen que las prácticas de dominación aminoran su intervención directa sobre los cuerpos en tanto en cuanto se dan <<unas relaciones de poder-saber sobre un cuerpo fabricado en prácticas de autocuidado, autocontrol, autodisciplinamiento >>, consecuentemente <<estamos frente a cuerpos que se autoconstruyen, interviniendo sobre sí mismos, pero sometidos a la movilidad constante de unas reglas a las cuales deben adaptarse continuamente para poder subsistir $>>^{912}$.

Foucault hace ostensible cómo el $\ll<$ sexo es, a un tiempo, acceso a la vida del cuerpo y a la vida de la especie >>913. Para el filósofo francés, la sociedad occidental está inmersa en el sexo, el poder se encuentra presente en los procesos que lleva consigo la

\footnotetext{
${ }^{909}$ Foucault, ob. cit., 113.

${ }^{910}$ Cfr. Foucault, ob. cit., 124-125.

911 Milena Cevallos y Bernardita Serra, "La materialidad del poder: una reflexión en torno al cuerpo", $A$ Parte Rei, no. 47 (2006), http://serbal.pntic.mec.es/ cmunoz11/cevallos47.pdf [consultado el 1/9/2017], 9.

912 Milena Cevallos y Bernardita Serra, ob. cit., 11.

${ }^{913}$ Michel Foucault, Historia de la sexualidad. 1. La voluntad de saber (Buenos Aires: Siglo Veintiuno Editores, 2005), 176.
} 
sexualidad, tales procesos son utilizados por el poder para implementar el dominio del cuerpo, el poder subyacente a los discursos de la sexualidad son utilizados para promover sistemas de control somático-sociales ${ }^{914}$. El cuerpo es tomado por el poder como objeto de la sexualidad, así, todas las acciones que regulan la vida sexual de los individuos y las sociedades acuden al cuerpo, en consecuencia,

lejos de que el cuerpo haya sido borrado, se trata de hacerlo aparecer en un análisis donde lo biológico y lo histórico no se sucederían (...), sino que se ligarían con arreglo a una complejidad creciente conformada al desarrollo de las tecnologías modernas de poder que toman como blanco suyo la vida. Nada, pues, de una "historia de las mentalidades" que solo tendría en cuenta los cuerpos según el modo de percibirlos y de darles sentido y valor, sino, en cambio, una "historia de los cuerpos" y de la manera en que se invadió lo que tienen de más material y viviente. ${ }^{915} 916$

Lo que Foucault viene a decir es que el estudio de los cuerpos tomados como contenido de subjetividad, como formas conceptuales internalizadas en las "mentalidades", no intercepta el modo en que el poder ha trastocado de manera efectiva la corporalidad del individuo humano y de las poblaciones, ya que la sexualidad en este ámbito no se reduce solo a un mero conglomerado de instintos y pulsiones, el poder desplegado en el sexo y vertebrado a lo largo del desarrollo histórico de las relaciones sexuales también causa efectos en los cuerpos, pues genera sistemas de presión directa sobre ellos. La sexualidad está lejos de conformar un espacio de liberación.

La emergencia y proliferación de todo lo que tiene que ver con el sexo, incluso el interés por parte de los intelectuales hacia la cuestión sexual, es, para Foucault, desde finales del siglo XVIII en adelante, un señuelo más del poder. Dicho de otro modo: el desvelamiento de la sexualidad, de ese mundo inexplorado de la sexualidad, y la quiebra

\footnotetext{
${ }^{914}$ Cfr. Foucault, ob. cit., 178-179.

915 Foucault, ob. cit., 184.

916 Bryan Turner utiliza las palabras de Foucault en el último párrafo de la cita mencionada para demostrar su posición sobre el supuesto carácter contradictorio en el tratamiento foucaultiano del cuerpo. Ver en: Bryan Turner, El cuerpo y la sociedad (México D.F: Fondo de Cultura Económica, 1989), 77. Pero la defensa que hace Turner de su propia interpretación a través de las mencionadas palabras de Foucault es refutable si se comprende que el filósofo francés hace alusión a la forma subjetiva de valorar el cuerpo, una imagen de la corporalidad que no sale de los posos de la conciencia. Por eso, lo que Foucault reclama es una historicidad que vea cómo <<se invadió lo que tienen de más material y viviente $>$ los cuerpos, hay que acceder a lo viviente de la corporalidad y examinar su carne, su capacidad, su arrojo y fuerza, solo así se sabrá cómo interaccionan las posiciones del poder con respecto al cuerpo y cómo este último se ve afectado según qué régimen de dominación o sistema de resistencia se despliega en torno a él. Lo corporal foucaultiano no es una entidad mecánica, ni pasiva, es una entidad viva, cuyo dinamismo se escapa a cualquier consideración sólida hecha desde el concepto abstracto con un sentido estrictamente fijado.
} 
de los prejuicios que la acompañaban tradicionalmente, así como también el interés intelectual por el sexo, no es una tendencia ni espontánea ni empecinada en liberar a la humanidad de la represión, sino que, muy por el contrario, Foucault establece que lo sexual viene a ser un motivo de interés a nivel social e intelectual porque trae aparejados dispositivos de poder. Así, de manera muy contundente, Foucault dice que allí donde nosotros vemos hoy la historia de una censura difícilmente vencida, se reconocerá más bien el largo ascenso, a través de los siglos, de un dispositivo complejo para hacer hablar del sexo, para afincar en él nuestra atención y cuidado, para hacernos creer en la soberanía de su ley cuando en realidad estamos trabajando por los mecanismos de poder de la sexualidad. ${ }^{917}$

Foucault enmienda esa idea tan arraigada en ciertos sectores intelectuales que encontraron en la sexualidad una vía de liberación, un medio para escapar de todos esos lugares donde se ejerce un control represivo sobre la totalidad de la vida social e individual, laboral e íntima. El sexo no solo es un vértice corporal y genital cuya potencia avanza en un margen paralelo a todas las formas de dominación que avasallan la vida, tampoco la sexualidad como tal podría concentrar todos los contenidos de resistencia política depositados en la inmanencia de la corporalidad. El autor francés está renegando de todas esas ensoñaciones que creyeron localizar en la genitalidad corporal la senda subversiva que terminaría liberando a los individuos de las cargas de la represión. Podría advertirse, a raíz de la manera en que Foucault comprende el poder, que todos aquellos espacios propuestos o concebidos para la realización de la libertad humana no se hallan exentos de la sospecha de que en ellos también actúan correlaciones de fuerza susceptibles de configurar juegos de dominaciones $\mathrm{y}$ resistencias. La confianza liberal en el mercado como espacio de libertad económicopolítica y el abanderamiento contemporáneo de la sexualidad en cuanto potencial espacio de liberación ante los exabruptos del sistema productivo y político, dejaron pasar inadvertidos los dispositivos que en ellos actúan, dispositivos que fueron obviados u omitidos, ya fuera consciente o inconscientemente, en los discursos favorables a estos espacios como ámbitos de liberación para la humanidad.

En lo relativo a la relación corporalidad-sexo, sostiene Foucault que es habitual ver cómo se <<evocan los innumerables procedimientos con los cuales el cristianismo

${ }^{917}$ Michel Foucault, Historia de la sexualidad. 1. La voluntad de saber (Buenos Aires: Siglo Veintiuno Editores, 2005), 192. 
antiguo nos habría hecho detestar el cuerpo>>, pero insta a que se tengan presentes también las <<astucias con las cuales, desde hace varios siglos, se nos ha hecho amar el sexo, con las cuales se nos tornó deseable conocerlo y valioso todo lo que de él se dice $>{ }^{918}$. La sociedad contemporánea y sus más notables artistas y pensadores consideraron oportuno rebuscar en el terreno de la sexualidad verdades que consideraban soterradas y forzosamente resguardadas por una tradición propiamente "represiva", pero no supieron ver en sus descubrimientos, indagaciones y prácticas, el sello de un dispositivo de dominación que de hecho ya estaba integrándose en los pensamientos y movilizando los cuerpos. <<Ironía del dispositivo: nos hace creer que en ello reside nuestra "liberación" $>>919$.

\subsubsection{ESCISIONES DE LAS FUERZAS CORPORALES}

Las lecciones que pueden extraerse acerca de las observaciones de Foucault sobre la repentina inclinación social hacia la sexualidad ponen de relieve que, en primer lugar, para el filósofo francés cuerpo y poder siempre guardan algún tipo de relación y, en segundo lugar, que los distintos espacios aparentemente favorables a la liberación de los hombres no estaban exentos de la presencia de relaciones de poder: la sexualidad, el espacio productivo y laboral, así como el entorno clínico y otros espacios diferenciados ${ }^{920}$. El poder emana de correlaciones de fuerzas albergadas en el seno de la sociedad. El poder es una relación y necesita de las relaciones humanas para gestarse, no es que las relaciones de poder involucren a los cuerpos, es que estos están ya involucrados en ellas, dado que todos los individuos y grupos de individuos que interactúan portan consigo una corporalidad susceptible de concurrir con otras corporalidades y entrar en juegos de fuerzas que pongan a prueba su resistencia.

Acudiendo a la lectura que Deleuze hace del pensamiento foucaultiano, resulta especialmente destacable -en lo que compete al aspecto tratado en el párrafo anteriorla definición del poder como una "relación de fuerzas". De tal definición Deleuze extrae una consecuencia primordial: que para Foucault el poder no es una forma sino una

\footnotetext{
${ }^{918}$ Foucault, ob. cit., 193.

${ }^{919}$ Foucault, ob. cit., 194.

${ }^{920}$ En Nietzsche, Freud Marx Foucault dice: <<A partir del siglo XIX (Freud. Marx y Nietzsche), los signos se han sobrepuesto en un espacio mucho más diferenciado, según una dimensión que se podría llamar de profundidad, pero a condición de no entender por ella la interioridad sino, al contrario, la exterioridad $\gg, \quad($ ePub base v2.1), http://ceiphistorica.com/wp-content/uploads/2016/02/mfn.pdf [consultado el 21/11/2017], 17. Foucault se hace cargo del legado que encuentra en los planteamientos de estos tres autores cuando examina los elementos del poder en distintos espacios diferenciados.
} 
relación, por lo que las fuerzas no pueden aparecer en singular ${ }^{921}$. Según Deleuze, Foucault está próximo a Nietzsche y a Marx cuando ve en la correlación de fuerzas un rebasamiento de la mera violencia, ya que $<<$ la violencia tiene por objeto cuerpos, objetos o seres determinados a los que destruye o cambia de forma, mientras que el único objeto de la fuerza son otras fuerzas, y su único ser la relación $>>{ }^{922}$. A ojos de Deleuze, el poder en Foucault no tiene un carácter represivo, ya que retroalimenta las fuerzas, es una actividad más que una posesión y, además, se procesa tanto en los dominantes como en los dominados ${ }^{923}$. La característica que distingue al poder de la violencia es que el primero crea verdad, este proceso productivo de veridicción es de lo que se vale Deleuze para explicar la vinculación foucaultiana entre el saber y el poder.

Si el poder no es una simple violencia, no solo es porque en sí mismo pasa por categorías que expresan la relación de la fuerza con la fuerza (incitar, inducir, producir un efecto útil, etc.), sino también porque, con relación al saber, produce verdad, en la medida en que hace ver y hace hablar. Produce lo verdadero como problema. ${ }^{924}$

La interpretación de Deleuze, lejos de echar por tierra la idea de que el poder en Foucault realmente modifica, trastoca y varía los movimientos de los cuerpos, logra llevar a término una noción de dominación hasta un terreno argumentativo que se eleva sobre la insípida y superficial asociación del poder con la violencia, o, en su defecto, con lo represivo y, en rasgos generales, con todo aquello que pudiera suponer una concepción del poder únicamente como fuerza física o modo de presión agresivotransgresora. La concepción del poder ante la que nos sitúa la interpretación de Deleuze, por ende, genera una importante sutileza entre la violencia como desgarramiento y la tensión relacional de fuerzas, que no por ello pretende -bajo nuestro punto de vistaexcluir a la violencia como un discurso más dentro del lenguaje de la dominación; la violencia sería un efecto del poder más que su causa sui.

Para Deleuze, el poder es una relación, ahora bien, esta relación también tiene capacidad de asociarse con otras relaciones de fuerzas: ¿cuál sería entonces el epicentro del cuerpo? Siguiendo las directrices de los argumentos del autor, y en lo que a la empresa de responder a la anterior pregunta se refiere, hay que hacer patente cómo las fuerzas siempre afectan desde un "afuera" a otras fuerzas, la posibilidad de afectar o de

\footnotetext{
${ }^{921}$ Cfr. Gilles Deleuze, Foucault (Barcelona: Paidós, 1987), 99.

${ }^{922}$ Deleuze, ob. cit., 99.

${ }^{923}$ Cfr. Deleuze, ob. cit., 100.

${ }^{924}$ Deleuze, ob. cit., 112.
} 
ser afectado siempre constituye un poder, poder que es ocupado pero no poseído; por tanto, la posición del poder también podrá ser desocupada y esta posibilidad marca la tensión inherente y la constante reactivación de las fuerzas en pugna. Justo en este punto es cuando Deleuze menta la noción foucaultiana de diagrama ${ }^{925}$ :

$<<$ El diagrama como determinación de un conjunto de relaciones de fuerza jamás agota la fuerza, que puede entrar en otras relaciones y en otras composiciones $>>{ }^{926}$.

Las fuerzas nunca son singulares porque no hay fuerza alguna que exista por sí misma. El poder, sin embargo, que es relación, sí alcanza una singularidad, y lo hace precisamente en un diagrama. Los diagramas están en un afuera pero su singularidad es esencialmente distinta de ese afuera. Al respecto, Deleuze argumenta que los diagramas presentan relaciones de poder invariables y que por eso $<<$ la última palabra del poder es que la resistencia es primero >>, dado que la resistencia está en relación con el afuera del que proceden los diagramas, pero no incrustada en ninguno de ellos particularmente; entonces, <<un campo social, más que estrategizar, resiste, y el pensamiento del afuera es un pensamiento de la resistencia $>>{ }^{927}$. La resistencia es una fuerza a-diagramática, una fuerza no instaurada dentro de una relación de poder ya dada, sino una fuerza que se relaciona directamente con un afuera y que desafía a las relaciones de fuerza producidas en su exterioridad. En sintonía con los razonamientos de Deleuze, se puede afirmar que el cuerpo no puede ser considerado como fuerza singular, sino que su contenido político es posible solo en la medida en que la fuerza corporal entra, bien en un diagrama, bien en una parcela social de resistencia. Conduciendo hasta las últimas consecuencias los argumentos deleuzeanos se podría afirmar que, cuando un poder constituido como diagrama pone a prueba la resistencia de unos cuerpos reunidos en sociedad, este tendrá que sopesar las fuerzas de resistencia para instaurar un orden diagramático determinado. No se trata única y exclusivamente de instaurar un régimen represivo, sino de calibrar

\footnotetext{
925 < C Cuando Foucault invoca la noción de diagrama, lo hace en relación con nuestras sociedades modernas de disciplina, en las que el poder efectúa un control de todo el campo: si existe un modelo, ése es el modelo de la «peste», que controla la ciudad enferma y se extiende hasta el más mínimo detalle. Ahora bien, cuando se consideran las antiguas sociedades de soberanía, se ve que no carecen de diagrama, aunque las materias y las funciones sean otras: también en ellas una fuerza se ejerce sobre otras fuerzas, pero más bien para extraer que para combinar o componer: más bien para fraccionar masas que para fragmentar el detalle; más bien para exiliar que para controlar (es el modelo de la «lepra»)〉>. Gilles Deleuze, Foucault (Barcelona: Paidós, 1987), 61.

926 Deleuze, ob. cit., 118-119.

${ }^{927}$ Deleuze, ob. cit., 119.
} 
las fuerzas subyacentes a los cuerpos dominados para que modulen sus fuerzas según unos parámetros que intensifican o disminuyen su poder.

Deleuze detecta que en la filosofía foucaultiana las relaciones de poder no se derivan del dominio de las instituciones, tal como como comenta Maurizio Lazzarato, el poder viene caracterizado por unas relaciones de fuerzas que son agenciadas por las instituciones, las cuales, <<fijan las fuerzas y sus relaciones en formas precisas al dotarles de una función reproductora. El Estado, el Capital y las diferentes instituciones no son la fuente de las relaciones de poder, sino que derivan de ellas $>>{ }^{928}$. Las instituciones estratifican las fuerzas que intervienen en las relaciones de poder, estas relaciones originariamente son inestables, ya que sus diferencias resultan móviles y reversibles; son las instituciones las que estratifican y singularizan estas fuerzas, las que perpetúan sus diferencias, haciéndolas irreversibles ${ }^{929}$.

Al margen de las indicaciones de Deleuze y Lazzarato acerca de las claves interpretativas de la filosofía del poder en Foucault, es posible confirmar cómo el poder, para Foucault, siempre se produce dentro de la inmanencia de las relaciones, es decir, no hay relaciones de poder que puedan ser extrínsecas a las confrontaciones, procesos y prácticas sociales ${ }^{930}$. Todas las resistencias son inherentes a las relaciones de poder, de hecho, el autor de Poitiers considera que allí donde hay poder también tiene que haber resistencia. La resistencia es la muestra de la forma relacional del poder, de modo que las resistencias <<desempeñan, en las relaciones de poder, el papel de adversario, de blanco, de apoyo, de saliente para una aprehensión. Los puntos de resistencia están presentes en todas partes dentro de la red de poder $>>931$.

El poder que domina a los cuerpos no solo debilita sus fuerzas, así, el dominio de las corporalidades no se limita únicamente a la reducción o envilecimiento de los cuerpos, sino que ha de implantarse una administración de las fuerzas. El poder intensifica y reduce las fuerzas de los cuerpos en función de unas finalidades estratégicas. La fortaleza de los cuerpos ha de fragmentarse, el poder escinde la utilidad productiva inherente a los cuerpos y la incrementa en su provecho, por ende, la disciplina organiza los cuerpos según el valor de su capacidad laboral, o sea, según los diferentes

\footnotetext{
${ }^{928}$ Maurizio Lazzarato, Por una política menor (Madrid: Traficantes de Sueños, 2006), 77.

${ }^{929}$ Cfr. Lazzarato, ob. cit., 77.

${ }^{930}$ Cfr. Michel Foucault, Historia de la sexualidad. 1. La voluntad de saber (Buenos Aires: Siglo Veintiuno Editores, 2005), 114.

${ }^{931}$ Foucault, ob. cit., 116.
} 
rendimientos que aportan en las escalas de las distintas actividades económicas. En Vigilar y castigar, Foucault establece que el mecanismo de poder disciplinario consiste en descomponer las fuerzas del cuerpo para dividirlas y administrarlas, solo de este modo la disciplina produce "cuerpos dóciles", políticamente obedientes y productivamente útiles:

La disciplina fabrica así cuerpos sometidos y ejercitados, cuerpos "dóciles". La disciplina aumenta las fuerzas del cuerpo (en términos de utilidad económica) y disminuye esas mismas fuerzas (en términos de obediencia política). En una palabra: disocia el poder del cuerpo; por una parte, hace de este poder una "aptitud", una "capacidad" que trata de aumentar, y cambia por otra parte la energía, la potencia que de ello podría resultar, y la convierte en una relación de sujeción estricta. Si la explotación económica separa la fuerza y el producto del trabajo, la coerción disciplinaria establece en el cuerpo el vínculo de coacción entre una aptitud aumentada y una dominación acrecentada. ${ }^{932}$

Foucault supone la presencia de una "potencia corporal" inicial sobre la que actúa el poder disciplinario. El poder disciplinario fragmenta $\mathrm{y}$ divide ese poder original subyacente a la corporalidad. Cuando Foucault comenta que la disciplina "disocia el poder del cuerpo", lo hace como si en un principio el cuerpo y el poder tuvieran una naturaleza común. Podría decirse que el filósofo francés está suponiendo un cuerpo que de por sí alberga un poder e, incluso, más allá de su propia morfología terminológica, podría interpretarse que el cuerpo guarda en su inmanencia un tipo de "poder natural", en cuanto que poder originario de sus fuerzas naturales. Este "poder natural" no consta de una diagramación externa, sino que se expresa en la fortaleza de los propios cuerpos. Las corporalidades sometidas son aquellas cuya sociabilidad política queda suspendida en virtud de una productividad intensificada, de modo que el debilitamiento del compromiso político implicaría una disminución de la capacidad de resistencia de los cuerpos.

El origen del poder - tal como menciona el autor en Historia de la sexualidad- no responde a ninguna posición binaria entre dominantes y dominados, arriba y abajo, sino que todo poder se inicia en un abajo ${ }^{933}$; Foucault parte de la suposición de <<que las relaciones de fuerza múltiples que se forman y actúan en los aparatos de producción, las familias, los grupos restringidos y las instituciones, sirven de soporte a amplios efectos

\footnotetext{
${ }^{932}$ Michel Foucault, Vigilar y castigar (Madrid: Biblioteca Nueva, 2012), 160.

${ }_{933}$ Cfr. Michel Foucault, Historia de la sexualidad. 1. La voluntad de saber (Buenos Aires: Siglo Veintiuno Editores, 2005), 114.
} 
de escisión que recorren el conjunto del cuerpo social $>>{ }^{934}$. Para que la disciplina logre someter y arrancar la capacidad productiva de la corporalidad debe disociar el poder inicial de la dimensión corporal que integra, en vistas a generar una división de las fuerzas presentes en esa unidad inicial cuerpo-poder.

La disciplina sustrae las fuerzas útiles de los cuerpos a costa de debilitar aquellas que tienen que ver con lo que sería una suerte de compromiso político entre individuos, ese compromiso promotor de toda forma de resistencia. La administración de las fuerzas corporales introduce un diagrama en los cuerpos que contribuye a doblegarlos. El poder disciplinario sustituye a otro poder que ya formaba parte del cuerpo, una potencia que unificaba lo productivo y lo social, lo laboral y lo político. El poder disciplinario genera unas asimetrías allí donde primaba una composición simétrica de las fuerzas, dado que la capacidad productiva y el compromiso político-social no eran diferentes el uno del otro, sino que se complementaban. Entonces, la disciplina disuelve esta complementariedad y produce una asimetría en el interior de la composición de fuerzas de los cuerpos dóciles: aumenta la capacidad productiva mientras disminuye la resistencia política; esta es la asimetría fundamental que busca contusionar el equilibrio de fuerzas de los cuerpos todavía no docilizados. La escisión del poder corporal deriva en un nuevo reparto de las fuerzas del cuerpo, un reparto asimétrico articulado a través de un implante invisible e inmaterial que se deposita sobre los cuerpos, y que procede de una configuración de poder extrínseca a estos, pero que, en ningún momento, los pierde de referencia.

\subsubsection{LA ESTRUCTURA ECONÓMICA DEL PODER}

El pensamiento de Foucault admite y desarrolla una problematización clave en muchos de los pensadores contemporáneos que tomaban como clave del desarrollo de la civilización los procesos productivos; la generación de escisiones en las fuerzas naturales de los individuos articula todo un sistema económico-productivo. Por ejemplo: Marcuse vio en las relaciones de producción el inicio de la estructura represiva de la civilización; también, podría hacerse ostensible cómo en el pensamiento de Hayek hay una escisión histórica entre el atavismo hermético tribal de las sociedades menos desarrolladas y el aperturismo de las sociedades de mercado, más desarrolladas tanto tecnológica como políticamente. En el caso de Foucault, ni la represión de la sexualidad

\footnotetext{
${ }^{934}$ Cfr. Foucault, ob. cit., 114-115.
} 
ni el libre mercado simbolizan, en concreto, la bifurcación que trajo el desarrollo del sistema productivo y el posterior avance de la civilización occidental. Foucault encuentra que la primera manifestación del poder en la época clásica iba enfocada al dominio de un poder latente en la inmanencia de las fuerzas corporales de individuos y comunidades. La dominación anatomopolíca escinde la capacidad productiva individual de la fortaleza política que subyace a la corporalidad social. Esta escisión procuraría envilecer el compromiso de los individuos con su comunidad política, deteriorando la resistencia cohesiva de los diferentes grupos que forman la sociedad, pero, paralelamente, aumentaría la escala de sus índices productivos (intensifica la división del trabajo, especializa actividades, controla los rendimientos, etc.).

El poder disciplinario atraviesa los cuerpos de los sujetos y los cosifica, los transforma en objetos de explotación, en “cuerpos dóciles”. El balance inicial de la administración de las fuerzas corporales parte del principio económico que promueve el mayor aumento de los recursos productivos haciendo el menor gasto posible, una máxima fundamental para la optimización de los rendimientos económicos. Por eso la disciplina sopesa los medios destinados a la dominación y, precisamente por eso, el poder disciplinario tiende a inmaterializarse ${ }^{935}$. Podría decirse, estableciendo una analogía con la terminología marxiana, que la disciplina en Foucault es como una especie de "infraestructura" del poder, puesto que sobre ella se levantan el poder biopolítico y las posteriores acciones gubernamentales. En el pensamiento de Foucault el poder consta de una base que cimienta la construcción de la biopólica y del biopoder, dicha base es la anatomopolítica o el poder disciplinario; y su origen tiene connotaciones económicas puesto que responde al desarrollo material de la civilización occidental:

Si el despliegue económico de occidente ha comenzado con los procedimientos que permitieron la acumulación del capital, puede decirse, quizá, que los métodos para dirigir la acumulación de los hombres han permitido un despegue político respecto de las formas de poder tradicionales, rituales, costosas, violentas, y que, caídas pronto en desuso, han sido sustituidas por toda una tecnología fina y calculada del sometimiento. De hecho los dos procesos, acumulación de los hombres y acumulación del capital, no pueden separarse; no habría sido posible resolver el problema de la acumulación de los hombres sin el crecimiento de un aparato de producción capaz a la vez de mantenerlos y de

${ }^{935}$ Cfr. Michel Foucault, Vigilar y castigar (Madrid: Biblioteca Nueva, 2012), 235. 
utilizarlos; inversamente, las técnicas que hacen útil la multiplicidad acumulativa de los hombres aceleran el movimiento de acumulación de capital. ${ }^{936}$

La disciplina erige un cerco político sobre el cuerpo, dice el autor que puede existir un "saber" del cuerpo, que no es exactamente la ciencia de su funcionamiento, y un dominio de sus fuerzas que es más que la capacidad de vencerlas: este saber y este domino constituyen lo que podría llamarse la tecnología política del cuerpo. (...), en sus mecanismos y en sus efectos, se sitúa en un nivel muy distinto. Se trata en cierto modo de una microfísica del poder que los aparatos y las instituciones ponen en juego, aunque su campo de validez se sitúa en cierto modo entre esos grandes funcionamientos y los propios cuerpos con su materialidad y sus fuerzas. ${ }^{937}$

El espacio penitenciario que surgió a finales del siglo XVIII es tomado por Foucault como un claro ejemplo de dispositivo disciplinario. El encierro de los presos y la obligación de hacerlo económicamente útil generó toda una tecnología de poder sobre el cuerpo. El castigo cambió el sistema de signos que rondaba la corporalidad de los castigados, consistente en los suplicios y la exhibición pública, dando paso al encierro así como al aprovechamiento económico de los presidiarios a finales de la época clásica en adelante. $<<$ La práctica penitenciaria, tecnología sabia, rentabiliza el capital invertido en el sistema penal y en la construcción de las grandes prisiones $>>{ }^{938}$. La finalidad del castigo no era ya el suplicio, no era ya causar dolor físico, sino la corrección del delincuente por medio de ocupaciones laborales. En el espacio penitenciario la exposición de los castigados no es pública, sus cuerpos solo se hacen visibles ante la mirada de los vigilantes, se ponen en marcha articulaciones <<que imponen una transformación del individuo entero, de su cuerpo y de sus hábitos por el trabajo cotidiano a que está obligado, de su espíritu y de su voluntad >>939. Este proceso de transformación y modificación de los individuos requería de una disposición de los medios materiales suficiente para desarrollar una tecnología política alrededor de sus cuerpos, para ello la dimensión subjetiva de los individuos también debía ser "apresada", a fin de garantizar el estado de sumisión del cuerpo sin incurrir en una estructura física de poder demasiado costosa.

\footnotetext{
${ }^{936}$ Foucault, ob. cit., 254.

${ }^{937}$ Foucault, ob. cit., 35-36.

${ }^{938}$ Foucault, ob. cit., 290.

${ }^{939}$ Foucault, ob. cit., 146.
} 
El anudamiento de la dimensión subjetiva de los individuos convoca un diagrama de visibilidades consistente en crear una asimetría en el juego de las miradas, un juego análogo a las asimetrías que la disciplina produce en las fuerzas corporales. Foucault asegura que el poder disciplinario <<se ejerce haciéndose invisible y, por el contrario, impone a aquellos a quienes somete un principio de visibilidad $>>{ }^{940}$. El campo de visibilidad de los espacios disciplinarios ha de instalar un punto de visión vertical entre la mirada vigilante y los cuerpos vigilados. Foucault encuentra en el panóptico ${ }^{941}$ de Bentham el sistema de vigilancia más paradigmático del disciplinamiento, de hecho, el panóptico nació en un momento histórico en el que las técnicas de disciplina habían alcanzado una latencia perenne. Foucault define el panóptico como

el diagrama de un mecanismo de poder referido a su forma ideal; su funcionamiento, abstraído de todo obstáculo, resistencia o rozamiento, puede muy bien ser representado como un puro sistema arquitectónico y óptico: es, de hecho, una figura de tecnología política que se puede, y se debe, desprender de todo uso específico. ${ }^{942}$

En realidad, en el panóptico se pueden distinguir dos diagramas solapados, a saber, el diagrama que verticaliza la mirada para generar una forma de poder óptico y el diagrama de fuerzas que somete a los cuerpos políticamente pero intensifica su potencia productiva. Además, Foucault reafirma la versatilidad útil que Bentham encontró en el panóptico, aunque su mecanismo dióptrico-político resultara de especial aplicabilidad en el ámbito de las prisiones, -como bien es sabido- el jurisconsulto británico concibió el panóptico como medio de vigilancia para muchos otros espacios de la sociedad. Foucault elevó la tecnología política del panóptico a un concepto arquitectónico y óptico, diríase, a un concepto tecnológico que aúna un "diagrama de visibilidad" y un “diagrama de fuerzas" en una cuadratura de espacio-poder. El espacio-poder del panóptico permite aplicar una misma mirada a unos cuerpos hacinados cuya visibilidad es accesible para cualquier inspector o miembro de la sociedad que quisiera hacer las veces de inspector, de este modo se soliviantaba el riesgo de tiranía, pues este espaciopoder crea una instancia de control que trasciende, incluso, el ejercicio cotidiano del

\footnotetext{
${ }^{940}$ Foucault, ob. cit., 218.

${ }^{941}$ El capítulo tercero de la segunda parte de la presente tesis está íntegramente dedicado al panóptico, en él ya se encuentran comentarios de Foucault respecto a este invento y, por supuesto, se especifica en qué consistió la propuesta de los hermanos Bentham con respecto a este innovador sistema de vigilancia; por cierto que sería más oportuno hablar de los "hermanos Bentham", aunque Foucault en sus amplios comentarios sobre el panóptico solo se refiere al filósofo y jurisconsulto Jeremy Bentham.

${ }^{942}$ Foucault, ob. cit., 237-238.
} 
propio poder, dado que también pone a los vigilantes menores bajo el dominio pupilar del foco de la vigilancia ${ }^{943}$; este es un foco -cabe recordar- que hace invisible al "vigilante central" tras las paredes de la torre de guardia.

El panóptico aplica ese mecanismo disciplinario que oculta e inmaterializa el poder para hacerlo más efectivo, para hacerlo presente en la subjetividad de los individuos sin requerir medios físicos muy costosos con qué producir este efecto. Una vez la asimetría visual del poder panóptico ha sido introducida en la mente de los sujetos vigilados, y una vez se han reducido las tentativas de sublevación e imposibilitado la comunicación que las alimenta, el siguiente paso va dirigido a consumar el objetivo por excelencia de la disciplina: aumentar las fuerzas productivas de los hacinados. Por ello, dice Foucault que el panóptico

tiene un poder de amplificación; si acondiciona el poder, si quiere hacerlo más económico y más eficaz, no es por el poder en sí, ni por la salvación inmediata de una sociedad amenazada: se trata de volver más fuertes las fuerzas sociales -aumentar la producción, desarrollar la economía, difundir la instrucción, elevar el nivel de la moral pública; hacerlas crecer y multiplicar-.${ }^{944}$

Primero, la maquinaria económica del panoptismo genera los medios y las disposiciones óptimas para la inspección: "diagrama de visibilidad" que anula la resistencia política de los cuerpos. Segundo, seguido del diagrama de visibilidad, se completa la maquinaria tecnológico-política sobre el cuerpo a través del diagrama de fuerzas por medio del que se intensifican los rendimientos productivos. En el nivel de estos dos diagramas, todavía el panoptismo foucaultiano cubre nada más que la esfera anatomopolítica, es decir, la del funcionamiento interno de la disciplina. Ahora bien, asimismo, Foucault contempla el panóptico en su esfera biopolítica; una vez la arquitectura espacio-poder ha articulado sus diagramas, una vez está planteada la “infraestructura del poder", el funcionamiento del panóptico se adentra en los diversos ámbitos de la sociedad, por tanto, se eleva sobre su funcionamiento interno y explora la topografía social sobre la que va a ser aplicado. Deleuze da buena cuenta de ello cuando afirma que en determinadas ocasiones el panoptismo foucaultiano aparece <<como un agenciamiento óptico o luminoso que caracteriza a la prisión $>$, mientras que en <<otras lo determina abstractamente como una máquina que no solo se aplica a una

\footnotetext{
${ }^{943}$ Cfr. Foucault, ob. cit., 239-240.

${ }^{944}$ Foucault, ob. cit., 240.
} 
materia visible en general (taller, cuartel, escuela, hospital en tanto que prisión), sino que en general también atraviesa todas las funciones enunciables >>945.

Según Foucault, el propio Bentham tenía en mente <<proyectar una institución disciplinaria perfecta〉>, pero, a su vez, tenía también el ambicioso propósito de $<<$ demostrar cómo se puede "desencerrar" las disciplinas y hacerlas funcionar de manera difusa, múltiple y polivalente en el cuerpo social entero $>>{ }^{946}$. El filósofo francés denota en su interpretación del proyecto benthamita una clara tendencia por parte de la vigilancia panoptista a abarcar aspectos de la vida de las poblaciones. La necesidad de gestionar el desarrollo vital de la población, de utilizar las fuerzas sociales para la proliferación de una producción y un mercado eficientes, equivaldría al plano biopolítico del panoptismo, en tanto en cuanto se trascienden las funciones disciplinarias inherentes al espacio del edificio. Una vez fuera del espacio interno panoptista, el funcionamiento de la vigilancia se integra en los vértices gubernamentales desde los que se plantea la administración, dirección y control del cuerpo social. Foucault observa que en el orden jurídico liberal de finales del siglo XVIII, allí donde la gubernamentación promueve el libre comercio, el mercado de trabajo demanda un amplio número de trabajadores mínimamente calificados y con frágiles o inexistentes $<<$ armas política para que no puedan ejercer presión $>>947$. En este contexto histórico, precisamente, el panóptico aportaba mecanismos de control social que intensifican los índices de producción en las distintas actividades económicas, en virtud de un volumen de oferta más amplio; es por ello que Foucault ve en el panóptico una formulación del sistema de gubernamentación liberal ${ }^{948}$. La gubernamentalidad articula las tecnologías disciplinarias con los dispositivos biopolíticos, es decir, conecta y le da continuidad al poder sobre el individuo y al poder sobre la población, de manera que la gubernamentalidad sincroniza estas nivelaciones del poder. El panoptismo, en cuanto fórmula gubernamental pensada por un liberal, va destinado a limitar los quehaceres políticos gracias al ejercicio de la vigilancia, el gobierno <<solo deberá intervenir cuando vea que algo no pasa como lo quiere la mecánica general de los

\footnotetext{
${ }^{945}$ Gilles Deleuze, Foucault (Barcelona: Paidós, 1987), 60.

${ }^{946}$ Michel Foucault, Vigilar y castigar (Madrid: Biblioteca Nueva, 2012), 241.

947 Michel Foucault, Nacimiento de la biopolítica (Buenos Aires: Fondo de Cultura Económica de Argentina, 2007), 85.

${ }^{948}$ Cfr. Foucault, ob. cit., 88-89.
} 
comportamientos, de los intercambios, de la vida económica. El panoptismo no es solo una mecánica regional y limitada a instituciones >>949.

En el estudio de Kevin D. Haggerty, titulado Derribar los muros: sobre la demolición del panóptico ${ }^{950}$, se menciona que los estudios de la gubernamentalidad no se reducen a las operaciones del aparato estatal, la legislación o la representación institucional-política. La actividad gubernamental tiene un extrarradio de agentes encarnados en corporaciones no gubernamentales, cuerpos internacionales $\mathrm{y}$ comunidades, todos ellos no expuestos a la estatalidad pero, sin embargo, con aspiraciones a promover prácticas que en última instancia afectan a la gubernamentalidad. La racionalidad gubernamental requiere de la vigilancia en tanto en cuanto esta es una actividad necesaria para acceder a informaciones acerca de los gobernados, por tanto, la gobernanza de una determinada población precisará de la observación y acopio de información sobre sus particularidades ${ }^{951}$. Haggerty sostiene que $<<$ la vigilancia es reconocida entre las formas más importantes de las tecnologías de gobernanza, como una nueva manera de 'ver' a una población que puede extender nuevas formas de conceptualización de los propósitos de gobernanza y sus posibilidades prácticas $>{ }^{952}$. Aunque el autor lamenta que muchas formas metodológicas y epistemológicas sobre la vigilancia no entran a investigar con profundidad los diferentes modos de sometimiento, reconoce que muchas de las ideas aportadas por Foucault despejaron el camino de las investigaciones acerca de las políticas de vigilancia y la experiencia de los propios vigilados ${ }^{953}$.

Efectivamente, uno de los méritos que la posteridad le debe a los estudios realizados por el filósofo francés es haber encontrado un punto de sutura para las modulaciones entre los planos de aplicación del poder: individuos y poblaciones. La concepción foucaultiana de la vigilancia en su expresión panoptista conecta las tecnologías disciplinarias como sistemas de dominio aplicados a la individualidad de los cuerpos con los sistemas de control sobre todo un cuerpo social, cuya complementación última

\footnotetext{
${ }^{949}$ Foucault, ob. cit., 89.

${ }^{950}$ Kevin D. Haggerty, Tear down the walls: on demolishing the panopticon; en Theorizing Surveillance, David Lyon (Portland, Oregon, USA: William Publishing, 2006).

951 Cfr. Kevin D. Haggerty, Tear down the walls: on demolishing the panopticon; en Theorizing Surveillance, David Lyon (Portland, Oregon, USA: William Publishing, 2006), 40.

952 <<surveillance in various forms is recognized as being among the most important technologies of governance, as new way of 'seeing' a population can open up new ways of conceptualizing the aims of governance and its practical possibilities>>. Haggerty, ob. cit, 41 (traducción propia).

${ }^{953}$ Cfr. Haggerty, ob. cit., 42.
} 
compete a la gubernamentalidad. En este último registro del poder, la vigilancia sigue teniendo su vigencia no ya solo como tecnología anatomopolítica ni como estrategia biopolítica de ordenamiento de una población, sino como práctica gubernamental que distribuye los cuerpos en los espacios de producción e institucionalización de un modo eficiente y rentable. El poder anatomopolítico presenta unos esquemas económicos basales para la aplicación de dispositivos dirigidos a todo un complejo de grupos y organismos sociales. La vigilancia es una estrategia de poder que mantiene su latencia tanto en la anatomopolítica como en la biopolítica, en la medida en que se presenta como la forma de gobierno más óptima.

\subsubsection{El PROBLEMA DE LA DESUBJETIVACIÓN Y SUBJETIVACIÓN DE LOS DISPOSITIVOS}

En ¿Qué es un dispositivo? Agamben dilucida el origen del término "dispositivo", interpreta el sentido que dicho término tomó en la filosofía de Foucault y trata de anticipar el carácter que los dispositivos adquieren de cara al porvenir. Para Agamben los dispositivos van dirigidos a capturar la vida humana, por ello establecen una red que bien puede desenvolverse a través de elementos discursivos, legales, institucionales, arquitectónicos, etc.; los dispositivos también cuentan con funciones estratégicas en la medida en que están inmersos en relaciones de poder y su formación se debe a la articulación de un orden de saber/poder ${ }^{954}$.

El dispositivo foucaultiano tendría su raigambre en el término "positividad". Agamben sustenta esta afirmación atribuyéndole a Foucault una determinada interpretación de los textos de Hyppolite: a partir de la lectura que Hyppolite hizo del joven Hegel, en la que la historia como desarrollo de positividades es opuesta a la naturaleza; positividad y naturaleza aparecen como dos principios opuestos. Agamben matiza que a Foucault no le interesaba reconciliar lo histórico-positivo con la naturaleza, pero tampoco profundizar más en sus contrastes, sino que perseguía hacer un estudio de cómo estas positividades forman parte de las correlaciones de poder ${ }^{955}$. Valiéndose de la concepción que Hyppolite hace de la positividad, Agamben sostiene que Foucault empleaba el término "dispositivo" como concepto operativo que suplanta el lugar de lo universal, pero sin el ánimo de ocupar esa dimensión totalizadora que sí

\footnotetext{
${ }^{954}$ Cfr. Giorgio Agamben, ¿Qué es un dispositivo? seguido de El amigo y de La Iglesia y el Reino (Barcelona: Anagrama, 2015), 11.

${ }^{955}$ Cfr. Agamben, ob. cit., 13-15.
} 
ocupaban las categorías universales clásicas; el término dispositivo, en definitiva, habría sido empleado por el pensador francés como estrategia metodológica para hablar de lo general sin recurrir a lo universal ${ }^{956}$-esto iría muy en la línea de las precisiones realizadas en el primer apéndice del presente capítulo a propósito de la metodología empleada por Foucault-.

El legado que Foucault dejó en torno al término "dispositivo" no solo se remonta al sentido conceptual que Hegel le atribuyó a la positividad -según el modo en que lo entendió Hyppolite-, sino que la génesis de la semántica del dispositivo parte de la palabra latina Dispositio, traducción a su vez del concepto oikonomía (que en griego significa la "administración de la casa” y más en general se refiere a la gestión) ${ }^{957}$. Así que el dispositivo aparece estrechamente asociado con el sentido de oikonomía, o lo que comúnmente hoy en día se entiende como "economía". Agamben da cuenta de cómo en la Edad Media hubo una línea de pensamiento teológico que consideró a la oikonomía como el logos con que Dios administra la Creación. Si bien Dios no deja de ser considerado como una sola sustancia, el resultado del mundo creado requiere de una organización trinitaria, por tanto, Jesucristo sería el "hombre de la economía" para estos teólogos, porque es él quien distribuye el $\log o s$ que le fue cedido por Dios y que es diferente del logos teológico ${ }^{958}$. Asegura el autor italiano que este reparto de competencias entre lo celestial y lo terrenal, entre el ser y la actio, produjo una fisura entre la ontología y la praxis que llega a nuestros días. Esta concepción teológicocristiana de la oikonomia desde Clemente de Alejandría en adelante pasaría a ser traducida por los Padres Latinos, precisamente, mediante el término Dispositio, consecuentemente, la palabra "dispositivo" $<<$ nombra aquello en lo cual y a través de lo cual se realiza una actividad pura de gobierno sin ningún fundamento en el ser. Por esa razón, los dispositivos siempre deben implicar un proceso de subjetivación, es decir, deben producir su sujeto $>>959$.

El campo problemático de los dispositivos, a ojos de Agamben, y según el recorrido argumentativo que va tomando su discurso acerca del tema, se encuentra en el poder de subjetivación que adquieren. El autor divide el mundo en seres vivos por un lado y en dispositivos por el otro, o, como él mismo asevera: <<la ontología de las criaturas >> y

\footnotetext{
${ }^{956}$ Cfr. Agamben, ob. cit., 16.

957 Cfr. Agamben, ob. cit., 18.

${ }^{958}$ Cfr. Agamben, ob. cit., 19.

${ }^{959}$ Agamben, ob. cit., 20.
} 
$<<$ la oikonomía de los dispositivos que tratan de gobernarlas y guiarlas hacia el bien $>{ }^{960}$. Remarca Agamben que los dispositivos de los que hablaba Foucault iban enfocados <<a la creación de cuerpos dóciles pero libres que asumen su identidad y "libertad" de sujetos en el proceso mismo de su sometimientos $>>961$, pero, para el autor italiano estos dispositivos son muy diferentes de esos otros que han ido apareciendo en nuestras sociedades tecnológicas, una diferencia que radicaría en que los primeros producen todavía algún tipo de subjetivación durante el proceso de dominación mientras que los dispositivos del capitalismo de hoy <<actúan a través de procesos que podríamos llamar de desubjetivación $>>{ }^{962}$. Agamben asevera:

Las sociedades contemporáneas se presentan así como cuerpos inertes atravesados por gigantescos procesos de desubjetivación a los que no les corresponde ninguna subjetivación real. De ahí el eclipse de la política que presuponía sujetos e identidades reales (el movimiento de los trabajadores, la burguesía, etc.) y el triunfo de la oikonomía, de una actividad pura de gobierno que solo busca su propia reproducción. ${ }^{963}$

Sin la pretensión de entrar al abordaje de cuestiones que atañen a las primeras décadas del recién iniciado siglo XXI -que no es una etapa que competa a los márgenes históricos de la presente tesis-, sí cabría hacer hincapié en que el hecho de la desubjetivación que acometen, según Agamben, los dispositivos del presente histórico manan de esa fisura fundamental entre la ontología y la acción, por tanto, a tenor de ello, la primacía de la función dispositiva sobre lo existente se habría ido gestando durante un largo periodo que en el siglo XX tuvo un momento de inflexión fundamental. Ya en El poder soberano y la nuda vida se aprecia cómo a partir de la experiencia de los campos de concentración

no hay retorno posible a la política clásica; en ellos ciudad y casa se han hecho indiscernibles y la posibilidad de distinguir entre nuestro cuerpo biológico y nuestro cuerpo político, entre lo que es incomunicable y queda mudo y lo que es comunicable y expresable, nos ha sido arrebatada de una vez por todas. Y no somos solo, por emplear las palabras de Foucault, animales en cuya política está puesta en entredicho su vida de seres

\footnotetext{
${ }^{960}$ Agamben, ob. cit., 23.

961 Agamben, ob. cit., 29-30.

962 Agamben, ob. cit., 30.

963 Agamben, ob. cit., 32.
} 
vivientes, sino también, a la inversa, ciudadanos en cuyo cuerpo natural está puesta en entredicho su propia vida política. ${ }^{964}$

La vida del cuerpo o, mejor dicho, la vida que solo puede desplegarse, contraerse, realizarse, desvanecerse, persistir y aferrarse en el soporte biológico de un cuerpo $-\mathrm{y}$ nadie hasta ahora ha podido demostrar lo contrario- es esa misma vida que queda acorralada en la política sobre los cuerpos. Ya desde hace tiempo el dominio y control de los cuerpos, que se concreta en el ejercicio del poder sobre lo corporal, había sido practicado tomando interesadamente una imagen de la corporalidad que la categorizara como máquina o, en su defecto, como una parte animal inexpugnable de la condición humana que debía disimularse mediante una incesante aplicación de "técnicas de domesticación”. El profesor Germán Osvaldo Prósperi, en La cuestión del cuerpo en las filosofías de A. Kojève, G. Bataille, G. Deleuze y G. Agamben, se refiere a la expresión agambesiana "máquina antropológica" como un dispositivo en cuya definición, el autor italiano, estaría confrontando lo humano y lo no-humano. Estas escisiones dejan al hombre acorralado en un espacio límbico entre lo terrenal y lo celestial, lo que provoca una ironía en el dispositivo del humanismo, puesto que este no encuentra $<<$ a una naturaleza o a una esencia inalterable, sino a un vacío, a una zona neutra en donde el "combate" entre lo humano y lo inhumano no deja de producirse $>>965$. Además, Prósperi señala que para Agamben el ocaso de la historia se corresponde con el gobierno de la economía y el biopoder, lo que significaría que el animal de la especie Homo sapiens ejecuta una política que convierte en objeto a su propia especie y a la vida en general $^{966}$.

El cuerpo-objeto de la economía, el cuerpo desplazado y arrebatado a la ontología, así como el cuerpo arrinconado hacia el vacío de lo no-humano pero también de lo noanimal, es un "cuerpo imaginado" por los dispositivos de poder. Los dispositivos anatomopolíticos funcionan a través de la contracción y minimización de la individualidad subjetiva y corporal que le permite a los cuerpos concurrir para formar identidades gregarias, mientras, entretanto, estos dispositivos maximizan las

\footnotetext{
${ }^{964}$ Giorgio Agamben, Homo Sacer. El poder soberano y la nuda vida. I (Valencia: Pre-Textos, 2003), 238.

965 Germán Osvaldo Prósperi, La cuestión del cuerpo en las filosofías de A. Kojève, G. Bataille, G. Deleuze y G. Agamben (Tesis presentada para la obtención del grado de doctor en Filosofía, Universidad Nacional de la Plata, 2012), http://www.memoria.fahce.unlp.edu.ar/tesis/te.809/te.809.pdf [consultado el 8/5/2017], 330.

${ }^{966}$ Cfr. Prósperi, ob. cit., 332.
} 
capacidades de la fuerza de trabajo de esos cuerpos aislándoles de su dimensión política. La contracción y minimización es procurada para mitigar las fuerzas políticas de estos cuerpos, por medio de una imagen abstracta de la anatomía humana fijada en la dimensión subjetiva de los individuos. Esta operación requiere instalar unos diagramas en la subjetividad de los individuos que redistribuya sus fuerzas, modifique el reparto de habilidades, capacidades y compromisos de los sujetos; para ello, los dispositivos asestan una fragmentación de las subjetividades operantes, es decir, articularán mecanismos desubjetivadores. Agamben enfatiza el carácter subjetivador $^{967}$ de los dispositivos foucaultianos $\mathrm{y}$, ciertamente, lo tienen, pero no examina el modo concreto en que los dispositivos foucaultianos acuden a desahuciar la subjetividad de los individuos, una operación que tiene unos costes y que implica necesariamente algún instrumento desubjetivizador.

El objeto de los dispositivos es el cuerpo, su finalidad, acorralarlo. La manera más económica de hacerlo es controlar a los cuerpos indirectamente, asaltar a las subjetividades en ellos contenidas sin necesidad de recurrir a mecanismo de presión directa que supondrían gastos insostenibles. Los dispositivos operan sobre la dimensión corporal humana aunque, preferentemente, resulta más favorable para ellos hacerlo indirectamente apelando a la subjetividad. Tomar la dimensión subjetiva de los individuos implica ya de por sí tener que vaciarles de sus contenidos subjetivos previos, entendiendo con ello que anteriormente estos cuerpos se movían por mecanismos de poder subjetivador diferentes y que respondían, por tanto, a compromisos de otro tipo.

\footnotetext{
${ }^{967}$ En ¿QQué es un dispositivo? Agamben remarca que la concepción foucaultiana de dispositivo es una máquina de gobierno que produce subjetividad, y resalta como ejemplo la confesión como forma adherente al dispositivo penitenciario, en el que el sujeto niega su "yo pecador"; con el caso del dispositivo de la prisión se <<produce la constitución de un sujeto y de un milieu delincuente que se vuelve el sujeto de nuevas- y, esta vez, perfectamente calculadas- técnicas de gobierno > (Barcelona: Anagrama, 2015), 30. Este argumento se aprecia de forma muy clara cuando en Vigilar y castigar Foucault dice <<que la prisión ha logrado muy bien producir la delincuencia, tipo especificado, forma política o económicamente menos peligrosa -en el límite utilizable- de ilegalismo; producir delincuentes, medio aparentemente marginado pero centralmente controlado; producir al delincuente como sujeto patologizado. El éxito de la prisión: en la lucha en torno a la ley de los ilegalismos, especificar una "delincuencia">> (Madrid: Biblioteca Nueva, 2012), 322. Asimismo, en Historia de la sexualidad el filósofo francés afirma que el <<discurso trasporta y produce poder; lo refuerza pero también lo mina, lo expone, lo torna frágil y permite detenerlo. Del mismo modo, el silencio y el secreto abrigan el poder, anclan sus prohibiciones; pero también aflojan sus apresamientos y negocian tolerancias más o menos oscuras > (Buenos Aires: Siglo Veintiuno Editores, 2005), 123. El poder contiene opacidades y genera vacíos de utilidad dentro de sus tácticas de sujeción de los seres humanos, así que la producción de subjetividad organizada por el poder tiene que calcular, en su "orquestación", determinadas consecuencias y posibles respuestas entre las que se halla la desubjetivación, igualmente, la desubjetivación permite que los contenidos subjetivos que trae consigo la dominación puedan rellenar esos "huecos" de desubjetivación a favor de la dominancia.
} 
Realmente, lo que subraya Agamben acerca de la producción de contenidos subjetivos en los dispositivos de Foucault no deja de ser un procedimiento "positivo" en la ingeniería de poder subyacente a cualquier dispositivo. Hay otro procedimiento que es anterior y que se correspondería con el momento "negativo", el de la desubjetivación, un procedimiento que no solo operaría en los dispositivos actuales, pese a que Agamben se lo atribuya a ellos como una peculiaridad propiamente suya.

La desubjetivación equivale a provocar una renuncia en las convicciones del individuo, un proceso que equivale a poner bajo amenaza a los cuerpos, de modo que la desubjetivación exige asestar un "choque" directo sobre los cuerpos, por lo que el ahorro en el ejercicio del poder queda puntualmente en la indiferencia; la desubjetivación exige derrochar recursos físicos. Los cauces para desubjetivizar a los individuos despliega medios con que infundir terror, ha de existir la causa directa por la que los sujetos desconfíen en su propia resistencia: al estilo en que el protagonista de la novela 1984 de George Orwell es torturado hasta tener que renunciar a sus ideales. Este personaje, llamado Winston, al final de una larga tortura, recibe una amenaza que le obliga a traicionar a la mujer que ama, llamada Julia. La escena en que Winston es puesto bajo la amenaza de unas ratas preparadas para devorar su cabeza se corresponde con el momento en que tiene lugar su traición ${ }^{968}$. Resulta que Winston siente una repulsa incontrolable hacia las ratas, algo que el régimen totalitario bajo el que vive incesantemente vigilado descubrió. Pues bien, este pasaje de la novela simboliza un poder que recurre a temores del propio personaje para aplicar una desubjetivización de sus sentimientos amorosos, puesto que anular sus sentimientos hacia Julia consistía en hacerle comprender que el de ella era el único <<cuerpo que podía arrojar entre las ratas y él $>969$.

De la novela de Orwell es posible desprender una metáfora sobre el modo en que operan los dispositivos: estos llevan a cabo técnicas de desubjetivación mediante elementos que hostigan la propia subjetividad que pretenden desactivar, una vez consiguen reducir los contenidos subjetivos de los individuos, llega el momento de producir nuevos contenidos de subjetividad que respondan a los intereses de los dominadores. En las palabras del torturador de Winston se encuentra esta misma idea de generar vacuidades con que hacer controlables a los hombres:

\footnotetext{
${ }^{968}$ Cfr. George Orwell, 1984 (Barcelona: Austral, 2011), 342-344.

${ }^{969}$ Orwell, ob. cit., 344.
} 
Nosotros, Winston, controlamos la vida en todos sus niveles. Te figuras que existe algo llamado naturaleza humana, que se irritará por lo que hacemos y se resolverá contra nosotros. Pero no olvides que nosotros creamos la naturaleza humana. Los hombres son infinitamente maleables. Quizá hayas vuelto a tu antigua idea de que los proletarios o los esclavos se levantarán contra nosotros y nos derribarán. Desecha esta idea. Están indefensos, como animales. ${ }^{970}$

Los dispositivos de poder han de desahuciar a los sujetos de todos esos elementos susceptibles de otorgarles algún tipo de poder, de todo cuanto integre y unifique las fuerzas que activan la corporalidad desde sus entrañas hasta su espacio social, y que los resuelve en resistencia. La desubjetivación es el paso necesario para asestar el vaciamiento de contenidos subjetivos, principios como la libertad, el derecho, la naturaleza, la Humanidad, la dignidad, etc., antes de llegar a ser utilizados a favor de "formas positivas" de dominación, habrán de perder la figura originaria que tomaron en una integridad corporal-subjetiva, aquella que los empleaba para vivir y reivindicarse políticamente. El dispositivo no solo "positiviza", sino que también evacúa contenidos subjetivos y le da nuevas formas a esos principios universales y esenciales útiles y necesarios para dirigir la vida de los hombres. Muy perspicazmente, Agamben localiza en la desubjetivación la práctica por excelencia de los dispositivos del presente, mas no vio lo propio en los dispositivos del pasado y en los dispositivos en general, de hecho, piensa que estos no se caracterizaron por asestar tal desubjetivación, cuando, sin embargo, su aplicación es un momento fundamental en su funcionamiento. La desubjetivización nunca podría ser el fin último de los dispositivos, no puede constituir su forma acabada, puesto que el dominio de los individuos precisa de contenidos subjetivos que pongan en movimiento sus cuerpos con arreglo a unos intereses determinados por instancias de poder extrínsecas.

La temporalidad de los procesos de desubjetivación-subjetivación de los dispositivos biopolíticos es un "tiempo geológico" en comparación con los dispositivos anatomopolíticos, pues estos últimos, al dirigirse a los hombres en cuanto individualidades, operan con mayor dinamismo y hacen menos evidente la desubjetivación, dado que su poder se despliega sobre la duración de la vida de un individuo. En cambio, los dispositivos biopolíticos actúan sobre poblaciones y generaciones, de modo que los procesos de desubjetivación-subjetivación que articulan

${ }^{970}$ Orwell, ob. cit., 326-327. 
gozan de un tránsito temporal más amplio. La desubjetivación aplicada a las sociedades requiere de tecnologías que alteren el orden social y cuyos cambios se hagan extensibles a toda una población, por lo que infundir terror mediante procesos selectivos que bien matan o dejan vivir, el secuestro selectivo de determinadas poblaciones o la extensión del odio hacia una facción determinada de la población, son tecnologías biopolíticas que operan desfragmentando las formas habituales de subjetivación social. Las políticas económicas basadas en la difusión de datos macroeconómicos con el fin de generar urgencias en la sociedad también resulta un método gubernamental habitual y tristemente eficaz; la propagación de datos macroeconómicos que faciliten ciertas medidas e intervenciones de carácter político, social y económico, a través de los que se suplantan las relaciones laborales habituales, los hábitos de consumo, las costumbres culturales e incluso las propias relaciones familiares, es una práctica de gobierno con una larga trayectoria en el último tercio del siglo XX. Estos procesos del biopoder, aun tratando de realizarse rápidamente, desubjetivan con mayor lentitud que la desubjetivación que pueda sufrir un individuo concreto cuando es torturado, engañado, inducido, etc., pero, a cambio, cuentan con una docilización de los cuerpos a largo plazo mucho más solvente.

\subsubsection{ESPACIOS DOMINADOS: MUROS Y REJAS}

Canetti, en Masa y poder, recurre a los dientes como elemento metafórico del poder: dice que los dientes están <<a mitad de camino entre el miembro natural del cuerpo y la herramienta; el hecho de que se caigan o que puedan ser extraídos los aproximaba a la herramienta aún más $>>{ }^{971}$. Esta metáfora conduce al autor por la senda de la analogía entre las fauces de las fieras y las cárceles:

$<<$ Los dientes son los guardas armados de la boca. Este espacio de veras estrecho es la imagen primigenia de todas las cárceles $>>{ }^{972}$.

Aunque las cárceles contemporáneas hayan modificado las condiciones de vida en su interior, pues, en su origen, cuando el encierro iba aparejado a las cámaras de tortura y a las mazmorras, las cárceles eran un vivo retrato de espacio hostil, a pesar de ello, la cárcel moderna se advierte como una extensión de la agonía de la presa en las "fauces" de la fiera.

\footnotetext{
${ }^{971}$ Elías Canetti, Masa y poder (Barcelona: Muchnik Editores, 1985), 204.

972 Canetti, ob. cit., 205.
} 
Canetti afirma que la amenaza de las fauces de las bestias salvajes que tanto atemorizaron a la imaginación humana suscita la misma sensación de absorción en quienes, cual una presa agonizando en el interior de una boca, se hallan bajo el control y dominio procedimental del poder. El autor sugiere que el poder accede al dominio de un cuerpo al modo en que se produce la digestión del alimento, dado que hay una <<presión constante bajo la que se encuentra la presa hecha alimento durante su larga peregrinación>>, una peregrinación que tiene lugar dentro de un organismo, un cuerpo que se descompone dentro de otro cuerpo, <<todo ello puede considerarse como lo más central, si bien lo más oculto del proceso del poder $>>{ }^{973}$. Para Canetti el poder es una extensión que aplaza la aplicación de la fuerza, pero que mantiene latente la sujeción forzada del sometido. Así, entonces, la relación de fuerzas que engendra el poder surgiría de una cota temporal merced a la que está agonizante el dominado. Canetti supone que el poder surge de la relación entre una fuerza que atrapa y un cuerpo que es atrapado, al que se le deja un espacio y un intervalo de tiempo para perseverar en su esperanza de ser liberado:

Hemos formulado precedentemente la suposición de que la prisión podría derivar de las fauces; la relación entre ambas expresa la relación entre el poder y la fuerza. En las fauces no quedan esperanzas, no hay tiempo y no hay espacio. Desde este punto de vista la prisión es como una ampliación de las fauces. En ella se pueden dar algunos pasos de ida y vuelta, como los da el ratón bajo los ojos del gato; y a veces se sienten los ojos del guardián clavados en la espalda. El prisionero tiene tiempo por delante y esperanza de escapar o de ser liberado; y durante todo el tiempo percibe el interés destructivo del aparato en cuya prisión se encuentra, aún cuando parezca haber cesado. ${ }^{974}$

Canetti menciona casos muy concretos de relaciones humanas en las que se puede detectar el brote del poder, una situación particular es el interrogatorio. La pregunta es una incursión de un individuo en otro individuo, <<se practica como modo del poder, corta como una navaja en el cuerpo del interrogado $>>975$. El medio de defensa contra la pregunta es el secreto; el secreto utiliza al cuerpo como su armadura, aquella que protege la respuesta como si fuera una segunda corporalidad. Quien calla en un interrogatorio, quien enmudece para protegerse frente al interrogador, se vuelve

\footnotetext{
973 Canetti, ob. cit., 206.

974 Canetti, ob. cit., 277-278.

975 Canetti, ob. cit., 280.
} 
peligroso porque oculta algo y, entonces, se expone a la tortura ${ }^{976}$. El cuerpo es el único medio del que dispone el interrogador para extraer una respuesta. La función del interrogador será, por tanto, destruir esa corporalidad cuya superficie hace las veces de armadura. Interrogar es una forma de asaltar al otro, de extraer sus secretos para desvelar aquello que con tanto celo guarda. Quienes poseen poder crean una relación asimétrica con los otros: el poderoso no puede permitir que sus subordinados averigüen las intenciones y pensamientos que tiene, por eso su gestualidad ha de ser fría, mostrándose inaccesible e implacable, a su vez, el poderoso siempre tiene que percatarse de cuáles son las intenciones de los otros. $<<$ Es característico del poder una desigual distribución del calar las intenciones. El poderoso cala, pero no permite que se le cale. El más reservado debe ser él mismo. Nadie debe conocer su convicción ni sus intenciones $>>977$. De este modo, la capacidad del cuerpo para ocultar secretos le concede un poderío a quien brega contra un interrogador, porque la capacidad de ocultar es un poder dado por la natural opacidad interior del cuerpo.

En Canetti el encerrado se convierte en el objeto "devorado" por las fauces del poder, el encierro cerca y atranca al cuerpo en un espacio calculado y administrado. El autor acentúa el carácter opaco del poder y, por ende, su capacidad para encriptar, pero, por ello, toda dominación habrá de acceder a los cuerpos a fin de extraer los secretos más interesantes para quienes pretenden perpetuarse en una posición dominante. Todo cuanto se pliega y oculta posee poder, pues se hace inaccesible e intransitable, consecuentemente, quien aspire a dominar mediante el poder tratará de trasparentar esos pensamientos encriptados en los cuerpos. Más allá de los planteamientos de Canetti, pero asumiendo su comprensión del poder, es preciso poner de relieve que en el encierro contemporáneo se dan dos actividades fundamentales: una, ocultar cuerpos, la otra, transparentarlos. Estas son dos facetas del poder que se encarnan en dos de los elementos constitutivos del encierro, cuyos símbolos más fehacientes son las rejas y los muros.

Prácticamente siempre los muros y las rejas convergen y se complementan, pero conviene encontrar las particularidades que cada uno de ellos tiene por separado. Las rejas son un elemento que economiza el hacinamiento y la reclusión de los cuerpos: permiten que el vigilante mantenga visibilizado al vigilado y que la exposición del

\footnotetext{
${ }^{976}$ Cfr. Canetti, ob. cit., 282.

${ }^{977}$ Canetti, ob. cit., 288.
} 
cuerpo del vigilado sea tan evidente que produzca su sumisión automática. Las rejas, además, y al igual que los muros, encierran a los cuerpos, limitan su espacio de movilidad envolviéndolos, pero, a diferencia de los muros, permiten articular un juego de miradas asimétrico. Las rejas son un elemento físico suficiente para retener a los cuerpos y, a la vez, hacen posible la penetración de la mirada exterior, procuran un encierro ligero, sin la necesidad de incurrir en grandes gastos. Sin embargo, los muros clausuran los cuerpos encerrados frente a las miradas exteriores y, a su vez, impiden cualquier acceso externo a su interior; los muros aíslan y hacen de la reclusión un secreto, lo que ocurre tras ellos se vuelve no confesable; se podría decir que los muros actúan como la "coraza" del poder. Las rejas son un elemento de encierro destinado a trasparentar el espacio donde los cuerpos son recluidos, mientras ellas permiten entrever el interior del lugar donde se ubican los cuerpos encerrados, los muros, por el contrario, opacan y encriptan todo cuanto atrapan en su interior. Las rejas clarifican la mirada del vigilante, hacen posible la inspección, pero los muros prescinden de la trasparencia requerida por las actividades de vigilancia, su propósito consiste en esconder las prácticas de los cuerpos aherrojados por el poder. Los muros esconden los cuerpos que encierran incluso ante los guardias dedicados a la supervisión y vigilancia de las instalaciones; en los espacios destinados a actividades de alto secreto ni siquiera sus guardianes corrientes saben lo que allí se hace, cuantos menos testigos haya mejor.

En Foucault, la prisión, el colegio, la clínica y, en general, todos los lugares de hacinamiento donde los cuerpos son observados como estando en un laboratorio requieren de estructuras arquitectónicas que trasparenten la cuadratura que encierra a las corporalidades. La cárcel es un espacio cuyo mecanismo de vigilancia más paradigmático viene encarnado por el edificio panóptico. En el pensamiento foucaultiano la arquitectura panóptica no se revela como <<una especie de máquina oscura donde espiar a los individuos $>>$ sino que $<<$ se convierte en un edificio trasparente donde la sociedad entera puede controlar el ejercicio del poder $>>978$. El preso, en consecuencia, se ve expuesto al "ojo institucional” y al "ojo público", su celda es el "escaparate" en el que toda una sociedad descubre la colección de ilegalismos que la amenazan diariamente. Los cuerpos de los presos son clasificados y consecuentemente organizados de acuerdo a la gravedad de sus delitos. A este respecto, Lazzarato caracteriza a la prisión foucaultiana como <<un espacio de visibilidad que

${ }^{978}$ Michel Foucault, Vigilar y castigar (Madrid: Biblioteca Nueva, 2012), 240. 
hace ver y emerger una mezcla de cuerpos, un agenciamiento corporal (los detenidos)>>979. Las corporalidades visibilizadas son expuestas a una maquinaria de expresión que produce los enunciados de la delincuencia, de este modo, los cuerpos se hallan sometidos a procesos incorpóreos de agenciamiento ${ }^{980}$.

Para Foucault, la prisión produce la delincuencia, es una fábrica de ilegalismos que permite un control gubernamental de lo ilícito (tráfico de armas, tráfico de drogas, proxenetismo, etc.), un control de todas aquellas prácticas que permiten instrumentalizar la delincuencia haciéndola calculable y gestionable dentro de un marco de gubernamentación ${ }^{981}$. La delincuencia se vuelve controlable en el espacio social, es decir, fuera de los espacios penitenciarios, a raíz, precisamente, del juego de trasparencias con que los ilegalismos entran en el cálculo de consecuencias instaurado por el poder. Supuestamente, las instituciones están llamadas a neutralizar la delincuencia, pero, en realidad, cumplen la función de dosificar sus efectos y limitarla a un circuito expuesto a visibilidad. Sobre la sociedad se cierne un tejido carcelario que permite aplicar una administración de los cuerpos, el medio para someterlos es la mirada de los vigilantes, la mirada de las instituciones y la mirada pública, que propale una expiación social de los delitos por medio de castigos y espacios previstos para ello, a su vez, esta tecnología social produce las condiciones que permiten incrementar el saber sobre el funcionamiento de la sociedad. El panoptismo produce subjetividades que tienden a incrementar su potencia dentro de los espacios de confinamiento, la función del saber es observar y captar los puntos fuertes de estas subjetividades, en vistas a implementar un dominio más contundente y eficaz sobre ellas ${ }^{982}$.

No se trata de decir que de la prisión hayan salido las ciencias humanas. Pero, si han podido formarse y producir en la episteme todos los efectos de trastorno que conocemos, es porque han sido llevadas por una modalidad específica y nueva de poder: una determinada política del cuerpo, una determinada manera de volver dócil y útil la acumulación de los hombres. ${ }^{983}$

En el biopoder aplicado sobre las sociedades disciplinarias las "sombras de las rejas" que encierran a la población se proyectan en el cuerpo social, la anatomía uniforma,

\footnotetext{
${ }^{979}$ Maurizio Lazzarato, Por una política menor (Madrid: Traficantes de Sueños, 2006), 79.

980 Cfr. Lazzarato, ob. cit., 79.

${ }^{981}$ Cfr. Michel Foucault, Vigilar y castigar (Madrid: Biblioteca Nueva, 2012), 325.

982 Cfr. Foucault, ob. cit., 355.

${ }^{983}$ Foucault, ob. cit., 356.
} 
dispone un ropaje que envuelve tanto al soma individual como al social. Los claroscuros de las rejas, de su sombra proyectada en los cuerpos, permiten arrojar destellos de luz que visibilizan los cuerpos y los someten al control constante de los mecanismos de saber/poder. Foucault concibe un poder disciplinario que asciende a una biopolítica por medio de la que un biopoder reactualiza constantemente los dispositivos gubernamentales, su centro de observación comienza en el plano anatomopolítico y, en la medida en que el saber va alumbrando nuevos contenidos de la subjetivación, los dispositivos gubernamentales actualizan las estrategias con que observarlas y controlarlas, de manera que el <<problema actualmente está más bien en el incremento de la importancia de estos dispositivos de normalización y toda la extensión de los efectos de poder que suponen, a través del establecimiento de nuevas objetividades $>>984$.

Entonces, la de Foucault es una sociedad alumbrada y visible, entre rejas, pero con buena iluminación en el interior de los espacios donde operan los dispositivos. Esta consideración del domino sobre el cuerpo social vendría marcada por una impugnación teórica de los abultados muros, esa impugnación propiamente dieciochesca, emprendida por el "Siglo de las luces" contra todo lo oscuro, lo opaco, lo coactivo. Los muros son costosos, requieren de mucha mano de obra, tiempo, dinero, etc., sobredimensionan el poder hasta el punto de hacerlo inoperante. El más vivo retrato de este poder era La Bastilla, de hecho, la liberación de La Bastilla es todo un hito en la historia del poder disciplinario. Con su caída, llegó una arquitectura racionalizada, económica, eficiente y trasparente de los espacios públicos, llegó, por tanto, la idea arquitectónica del panóptico, un edificio que marca un nuevo paradigma en la organización, administración y vigilancia de los lugares de hacinamiento. El poder del que habla Foucault tiene su simiente en ese contexto, con él, se traslada la fundamental necesidad de promover un saber mediante una irradiación de luz constante sobre los cuerpos, es la transparencia de "las luces", allí donde las sombras de las rejas tan solo son un efecto resultante de un esquema predeterminado, un efecto casi ornamental dentro del nuevo ejercicio del poder. La opacidad producida por las moles de piedra hace inaccesible a la mirada pública lo que las rejas, aun obstruyendo el paso, sí permiten ver. Solo la torre central del panóptico se advierte como una excepción fundamental para que toda la tecnología arquitectónica del poder funcione, el interior de esta torre es un nicho de

${ }^{984}$ Foucault, ob. cit., 357. 
opacidad dentro de un plan arquitectónico llamado a producir accesos de visibilidad; la opacidad en la torre central del panóptico es un requisito necesario para la interiorización de la disciplina en los vigilados. No hay accesos visibles en el interior del ojo que todo lo ve. Este "no-saber" irradiado por la presencia de la torre central, que no permite ver quién vigila, ni siquiera si hay o no vigilante, es imprescindible para las asimetrías que funcionan en el ejercicio de la dominación. El reducto de la torre central del panóptico, la pieza excepcional del poder disciplinario, deja deambulando un problema al que Foucault no atendió debidamente: la articulación de opacidades en el poder.

Los muros esconden, los muros no permiten ver qué hay detrás de ellos, por lo que el espacio que recubren se vuelve inexistente para aquellos que ocupan el afuera, este espacio tan solo puede ser supuesto o imaginado, pero nunca accesible. El biopoder tiene que tratar con los mecanismos de ocultación a una escala que va más allá de la anatomopolítica. La filosofía foucaultiana está bastante obstinada en comprender el poder como una tendencia a lo ligero, a la inmaterialización y a la producción de trasparencias, es decir, ese poder que surge en la arquitectura dieciochesca y que, por tanto, impugna al muro. La impugnación del muro como un tipo de construcción fuera de toda racionalidad termina asumiéndose implícitamente en la consideración que Foucault tiene del poder. La enmienda ilustrada contra los muros ha tenido y tiene aún hoy fuertes repercusiones, de tal forma que muchos intelectuales, juristas, filósofos, periodistas y artistas se empeñan en representar estos dispositivos como el más vivo retrato de los "irracionalismos" procedentes de mentalidades recalcitrantes, que preconizan y vitorean una bárbara obstrucción de los derechos. Sin embargo, la mayoría de estas diatribas contra los muros no se detienen en examinar la lógica que opera tras su establecimiento, cuya causa se remonta a una racionalidad económico-biopolítica que selecciona, excluye y obstruye según las urgencias de la competencia mercantil.

Entonces, los muros no son exactamente el producto de una irracionalidad, son una consecuencia directa de la lógica económica del capitalismo vigente. Las funciones del biopoder en la gubernamentación económica van dirigidas a decidir qué cuerpos son excluidos, hasta qué proporción es admisible la cantidad de población inmigrante, qué cuerpos son aptos para realizar determinados trabajos y cuáles no, qué organismos merecen una asistencia más urgente y cuáles no, etc. Todo este sistema de obstrucciones 
requiere de muros explícitos o implícitos que determinen el espacio público en función de criterios provenientes de un saber económico que gestiona el cuerpo poblacional.

A Foucault se le puede reprochar el haberse dejado guiar demasiado por esos órdenes lumínicos abiertos, por esa iluminación de lo corporal que aspira a formar saberes tras los que, tal como él mismo considera, actúan intereses de poder. Pero por su pensamiento no pasa el Muro de Berlín ni las opacidades y secretos que deambulaban entre sistemas, los cuales marcaron la gobernanza global durante las décadas de la Guerra Fría, de hecho, cuando trató cuestiones relacionadas con las instituciones psiquiátricas soviéticas, lo hizo desde el marco teórico del poder disciplinario, común en su origen a la cultura occidental y soviética ${ }^{985}$. Por otro lado, dicho sea de paso que el rigor de un intelectual de la talla de Foucault no piensa el poder desde las pugnas ideológicas sobresaturadas y superficiales de la Guerra Fría; Foucault estudia los dispositivos desde una metodología genealógica aplicada sistemáticamente a la comprensión de la facticidad. No obstante, el problema se halla en que Foucault no profundizó en el estudio de la opacidad del encierro, en la ocultación de los cuerpos sometidos como propagación de un poder que no manifiesta su actuar y que se hace más potente a través de esta operación, al contrario, se preocupa de cómo se desmaterializan los cuerpos que realizan la agencia del poder. Los rincones opacos de la sociedad, según el filósofo francés, no serían más que nichos controlables por el poder gubernamental siempre y cuando el discurso sobre lo que sucede en su interior traiga efectos útiles para la dominación, pero la potencia desubjetivadora que esconden estos espacios crípticos parece pasar desapercibida para el autor.

También en el siglo XX se simbolizó el muro como expresión del poder represor, en esta simbología se halla toda una estética del dominio irracional y el aislamiento agobiante. Man Ray, artista surrealista, representó el rostro de Sade como una mole de

\footnotetext{
${ }^{985}$ Un ejemplo de que Foucault encuentra que los métodos del poder disciplinario fueron interiorizados, articulados y perfeccionados por la Unión Soviética lo hallamos en su diálogo con David Cooper, MarieOdile Faye, Jean-Pierre Faye y Marine Zecca, publicado en los números 32 y 33 de Change en el año 1977. En un momento de dicho diálogo Foucault afirma que tras la Revolución Francesa la psiquiatría nace con el propósito de justificar científicamente un nuevo orden social de marcado carácter secular, el encierro psiquiátrico se practica como una forma de reparación de todas aquellas conductas anormales generadas en los espacios públicos; de modo que el psiquiatra se advierte como un funcionario que preserva el orden social. Cfr. Un diálogo sobre el poder (Madrid: Alianza, 2012), 126-127. A este respecto, prosigue Foucault diciendo que <<la psiquiatría nunca abandonó este sueño ni esta vecindad. De tal modo que lo que ocurre en la Unión Soviética no es el apareamiento monstruoso de una función médica y una función policíaca, que no tendrían nada que ver la una con la otra. Sino que es simplemente la intensificación, la solidificación de un parentesco reticular que no había dejado de funcionar >>, ob. cit., 127.
} 
piedra mientras a lo lejos aparece La Bastilla en llamas. Según Mahon, esta obra, titulada Retrato imaginario del marqués de Sade, habría inspirado el cuadro que Hans Bellmer realizó tras su experiencia en el Camp de Milles, fábrica de ladrillos reconvertida en campo de concentración durante los años de la "Francia ocupada"986, un cuadro titulado Subterráneo, en el que el pintor simboliza la experiencia angustiosa del encierro. El artista imagina, a través de las paredes de ladrillos, la habitación en que estuvo encerrado el Marqués de Sade; trata de recrear alegóricamente el desarrollo de los pensamientos eróticos del marqués pese a su encierro ${ }^{987}$; combina las formas uniformes de la arquitectura con la desfiguración del cuerpo y de los órganos sexuales, estos últimos, segregados en el interior de la habitación.

Cabe añadir que la representación del muro y de los ladrillos o losas que lo componen como elementos metafóricos de privación y represión es un recurso estético que también fue reproducido en el filme The Wall, de 1982, inspirado en la historia conceptuada en los dos álbumes del grupo británico Pink Floyd. El muro de ladrillos refleja la contención, la represión y la frustración del protagonista de la historia, un hombre que es una estrella de Rock pero cuya vida arrastra varios traumas: la falta de su padre debido a su fallecimiento en la Segunda Guerra Mundial, la sobreprotección materna, los métodos educativos conductistas y represivos, los fracasos amorosos y los excesos en el consumo de drogas. El muro aísla al protagonista, las losas y los ladrillos encarnan esos traumas que el protagonista padece y que perturban su vida, provocándole serios desvaríos en su conducta y en el trato con otras personas. Los deseos reprimidos le llevan a ejercer la violencia contra su mujer, al aislamiento y a la autolesión. Pink Floyd "subjetiviza" el muro, ya no solo ve en él un obstáculo físico para el tránsito y un medio de coacción agresivo, sino también la desubjetivación del individuo, la destrucción de la vida interior de los sujetos, que lleva consigo efectos devastadores de cara al exterior y que desfigura la imagen que uno mismo tiene del cuerpo. La corrosión de la subjetividad mediante el efecto desubjetivador del muro provoca una violencia desmesurada, como es el caso de la escena en que el protagonista sueña que es un dictador fascista y arenga a las masas a tomar el poder mediante la fuerza. Pink Floyd juega con los efectos devastadores de la desubjetivación provocada por los muros cuya presencia lleva aparejada la privación, la prohibición y la

\footnotetext{
${ }^{986}$ Cfr. Alyce Mahon, Surrealismo, Eros y política 1938-1968 (Madrid: Alianza editorial, 2009), 94.

${ }^{987}$ Cfr. Mahon, ob. cit., 96.
} 
impotencia. Los muros contribuyen a transformar por completo el comportamiento y la conducta de los (des)sujetos que generan, su instauración implica también el deseo de su destrucción, a la vez que esa avidez tiende a ocupar todos los ámbitos de las relaciones humanas.

La opacidad de los muros, las divisiones de las poblaciones a través de ellos, pero, sobre todo, el uso político de un encierro que recurre a los muros como elemento de terror y disuasión social ejerce efectos desubjetivizadores en los individuos que destierran el poder albergado en sus cuerpos; estas desubjetivaciones descomponen tradiciones políticas, fragmentan vínculos sociales e incluso provocan una "amnesia social" con respecto a los relatos que vertebran el acceso de los pueblos a su historia.

Enjaular crea una limitación más o menos estrecha del movimiento físico del encerrado, pero el encierro entre muros, además de una coacción física y una limitación espacial, también, recluye a los encerrados y les impide mirar a su exterior, la pérdida de una referencia externa juega un papel muy efectivo en el encerrado. El secuestro consiste en esconder los cuerpos, en utilizar muros y recurrir a cualquier cobertizo que los cubra y opaque. Al no estar expuestos al público, los cuerpos opacados son anulados de la vida pública, sus personalidades desaparecen pues pierden cualquier posibilidad de actualizar su existencia social a través del contacto con los otros.

El encerramiento opaco (el encerramiento entre muros), entendido como secuestro, elimina la corporalidad de los individuos que lo sufren, y con ello, su facticidad social desaparece. Los efectos de desubjetivación producidos por este tipo de encierro opaco fueron investigados por la periodista y escritora Naomi Klein en la Doctrina del Shock. La autora da cuenta de cómo, tras la Segunda Guerra Mundial y en el albor de la Guerra Fría, el psiquiatra Ewen Cameron llevó a cabo unos experimentos que pretendían "vaciar la mente" de los individuos a través de prácticas que recurrían al electroshock y al aislamiento. Naomi Klein señala que por aquel entonces era bien sabido que los electroshocks provocaban estados de amnesia y que podían llevar a los pacientes a experimentar momentos de regresión ${ }^{988}$. La celda de aislamiento era el espacio requerido para causar la ruptura del paciente con el exterior y alterar su memoria y hábitos. El vaciamiento de la memoria era, entonces, una desubjetivación que, por supuesto, precisaba del aislamiento. De este modo, Klein, a raíz de uno de los

${ }^{988}$ Cfr. Naomi Klein, La doctrina del Shock (Madrid: Espasa Libros, 2007), 56. 
testimonios anónimos sobre cómo funcionaba esta macabra terapia, sostiene que en el momento en que $<<$ la vida se reduce a las cuatro paredes de una celda, el ritmo de sonidos del exterior es una especie de cuerda de salvavidas, la prueba de que el prisionero aún es humano, de que existe un mundo más allá de la tortura $>{ }^{989}$. Sin el ánimo de especular acerca de qué entiende concretamente la autora por "humano", se destaca de sus palabras cómo ese sistema de aislamiento opaco se hace efectivo en la desubjetivación causada por el aislamiento y el electroshock.

El encubrimiento de las prácticas que recurren al terror, que asestan tortura y muerte sobre el cuerpo social mediante procesos completamente arbitrarios y no supervisados por cauces democráticos y jurisdiccionales, impide la construcción de testimonios capaces de sacar a la luz pública actos reprobables cometidos por determinadas instancias de poder. La ocultación de las actividades gubernamental-terroríficas obstaculizan la denuncia de las irregularidades y vulneraciones cometidas por las instancias de poder que las practican. La imposibilidad de inculpar a los verdugos responsables es un problema que pone en evidencia el escaso ahínco con que se ha estudiado ese reverso críptico del poder de dominación, el cual llega a trascender las propias técnicas de dominación habituales. En el siglo XX los dispositivos de visibilización y subjetivación han tratado de funcionar en paralelo a los dispositivos de ocultación y desubjetivación, pero el no-saber tiene tanta influencia en la configuración del poder como lo tiene el saber, así es que tanto la visibilidad de los cuerpos como su opacidad en los espacios de dominación forman parte de las estrategias posicionales del poder. La subjetivación mediante la creación de "cuerpos vigilados" es tan útil y necesaria para el ejercicio de la dominación como la desubjetivación del cuerpo, un medio con que inactivar lo corporal y derribar sus capas de resistencia. La desubjetivación de los individuos implica la necesaria aniquilación de las imágenes del cuerpo configuradas en el seno del sujeto.

El abandono de la vida a las arbitrariedades de las fuerzas gubernamentales, que ya no eran propiamente instituciones ni representantes del orden legal, implantaba sistemas de invisibilidad que transfiguraban las posiciones del poder con respecto a los cuerpos. La gubernamentalidad también consiste en vedar la desfiguración transgresiva de los cuerpos, no exponerlos a la mirada pública con el fin de instaurar, bien la ignorancia acrítica, bien la ambigüedad y la incertidumbre en la población. El panóptico recurre a

${ }^{989}$ Klein, ob. cit., 64. 
esconder los cuerpos dominantes como táctica de sometimiento, opaca al cuerpo que porta el "ojo del poder". Por el contrario, cubrir y opacar a los cuerpos dominados es una táctica de sometimiento que invierte los términos de ocultación operantes en el panoptismo: en lugar de instaurar la imagen de un "cuerpo vigilado", instaura la noimagen de un "cuerpo encerrado" que públicamente pasa a una situación de total nulidad.

Los muros son el recurso con que las fuerzas de dominación se esconden para generar terror, pero, también para eludir responsabilidades. En ocasiones la autoridad funciona como el testaferro con que ocultar la culpa, tal como hacían los nazis cuando se les juzgaba, exculpaban sus acciones aludiendo a las órdenes que recibían. La orden, como dice Canetti, durante su ejecución forma un aguijón en los hombres que se clava en su carne haciéndose un cuerpo invisible y extraño al hombre que lo posee ${ }^{990}$. <<El aguijón es un intruso, nunca se naturaliza. Es indeseable, uno quiere deshacerse de él. Él es lo que uno ha cometido, él tiene, como se sabe, la semblanza exacta de la orden. Como instancia ajena sigue viviendo en el destinatario y le quita todo sentimiento de culpa $\gg{ }^{991}$. El descubrimiento de esos "aguijones" ocultos en los cuerpos puede hacerse extensible a todo un conjunto de materiales que han actuado bajo las directrices de un poder que aspira a esconder por siempre sus huellas.

De cara a la posteridad, y en lo referente a los estudios biopolítcos, no puede dejarse pasar por alto esta otra faceta del poder que genera políticas de encriptación mediante la instrumentalización de los cuerpos naturales, sociales e institucionales, una faceta del cuerpo biopolítico aun no suficientemente develada, que forma también parte de la institucionalización en el contexto histórico de lo que Agamben llama la "nuda vida", en la que los espacios de indeterminación jurídica, espacios donde opera la misma mecánica del campo de concentración, es imposible <<decidir entre hecho y derecho, entre norma y aplicación, entre excepción y regla >>992. Todavía no se ha iniciado una reflexión filosófica que insista en "exhumar" los contenidos de las relaciones cuerpopoder que permanecen soterrados en los oscuros contubernios de la dominación.

\footnotetext{
${ }^{990}$ Cfr. Elías Canetti, Masa y poder (Barcelona: Muchnik Editores, 1985), 324.

${ }^{991}$ Canetti, ob. cit., 328.

992 Giorgio Agamben, Homo Sacer. El poder soberano y la nuda vida. I (Valencia: Pre-Textos, 2003), 221.
} 


\section{CONCLUSIONES}


Pensar la corporalidad como simiente y vértice troncal del poder, localizar en el cuerpo el origen de lo político en cuanto eje de las relaciones sociales, investigar el crisol de variables que halla la relación cuerpo-poder en el pensamiento político y tratar su desarrollo desde los albores de la modernidad hasta la penúltima década del siglo $\mathrm{XX}$, ha supuesto transitar un terreno pantanoso y repleto de suelos poco firmes. En medio de un "territorio conceptual" tan abrupto para el filosofar, fue necesario aplicarse en el montaje de un aparato metodológico que actuara cual si fuera una máquina de drenaje, presta a aclarar aquellas aguas turbias que impedían acceder a la visión del suelo que nos propusimos investigar y transitar. Así, entonces, los preparativos de nuestra travesía tomaron su inicio en la elaboración del aparato metodológico, la "máquina de drenaje", gracias a la que pudo cartografiarse el terreno de nuestra investigación.

Mientras iban siendo observadas las estrategias de dominación sobre el cuerpo, estrategias que posicionan al poder en un lugar extrínseco con respecto al lugar natural de la corporalidad, fue posible advertir la presencia de algún tipo de poder original en ese cuerpo imaginado como un objeto, bien obtuviera la imagen de máquina, de animal o de cualquier otra entidad. Vimos que lo corporal ejerce una resistencia, una fuerza, un arrojo vital que habría de ser dominado o, en su defecto, envilecido u obliterado en vistas a que nunca llegare a ocupar un lugar prominente en la política; pudimos constatar cómo el hecho de implantar todo este orden estratégico para relegar al cuerpo de las prácticas de poder ya implicaba presuponerle una capacidad de cara a lo político: el cuerpo alberga un poderío intrínseco de modo que, por sí mismo, se erige como un factum de poder.

Una vez fue localizada esta controversia en los textos filosóficos, pudo hacerse patente la cartografía de "los puntos claros" del terreno pantanoso que queríamos transitar, consiguientemente, se hizo practicable la construcción de accesos por medio de los que atravesar el "terreno pantanoso" ante el que nos encontrábamos. Nos resolvimos a construir los caminos y puentes sobre los que circular y avanzar en el itinerario de nuestra investigación. De acuerdo con esta descripción metafórica que venimos empleando para describir a grandes rasgos los pormenores y momentos de nuestro trabajo, cabe añadir, en el tono alegórico que estilamos, que el uso de las páginas leídas para la redacción de nuestra tesis, con sus respectivas frases, fragmentos y textos citados, han actuado como los adoquines con que se fueron construyendo los 
soportes de los caminos creados para emprender nuestro tránsito. La cara de una página puesta como un adoquín -imaginemos un suelo hecho de páginas de libros-, precisamente, evoca el paso a través de circuitos argumentativos por los que se extienden las temáticas que hemos propuesto. Estas páginas, adoquinadas entre sí, permiten atender a los argumentos y a las razones que se hacen patentes para tratar la cuestión de las relaciones entre el cuerpo y el poder; dichas páginas encajadas extienden un plano cómodamente caminable, dejándonos a salvo de los obstáculos abruptos del territorio sobre el que fueron puestas.

Nuestro tránsito de un tema a otro no siempre pisa sobre una misma superficie, también, en virtud del relieve original del terreno, hubo que crear pasos a nivel que marcaran los acotamientos y, por supuesto, trazaran la forma de los circuitos por los que debían ser conducidos nuestros discursos a fin de componer el mosaico discursivo pertinente. Este mosaico es observado como desde un caleidoscopio, si se pretende atender a los puntos concretos de la problematización filosófica en torno a las relaciones cuerpo-poder. Asimismo, desde un punto de vista "aéreo", es posible contemplar un conjunto de relieves y una composición policromática que aspira a formular unos accesos interpretativos de extensa variedad en las relaciones cuerpo-poder. Dichos accesos interpretativos pretenden trasparentar el "esqueleto" específico que componen las relaciones cuerpo-poder en el pensamiento político, sin por ello renunciar a los contenidos procedentes de otras áreas de especialidad filosófica (ontología, epistemología, estética, antropología, filosofía de la historia y filosofía de la ciencia), ya que estas contribuyen a procurarle una densidad consistente a la temática que abordamos.

El cuerpo, al ser el hecho común a todos los seres humanos y al ser el portador de la vida, ocupa prácticamente todas las dimensiones de desarrollo de la filosofía, por ello, las cuestiones que el asunto del cuerpo convoca no se dejan retener fácilmente en una sola área específica del pensamiento filosófico. Pese a que esta empresa conlleva que las líneas perfiladas en el contorno de la reflexión política tiendan a difuminarse, nuestra reflexión siempre necesitó complementarse con las visiones filosóficas acerca de la corporalidad, una complementación a la que nunca pretendimos renunciar, puesto que el tema del cuerpo evoca cuestiones que apuntan a lo político de manera insospechada. Nuestro empeño, en todo momento, ha sido no perder la referencia de los perfiles implantados para pensar el cuerpo en clave de filosofía política, es decir, en su relación 
con el poder, lo que, por otro lado, no implicó necesariamente desestimar determinadas concepciones acerca de lo corporal más generales o tangenciales con respecto a las cuestiones y problemas estrictamente políticos.

A la luz de estas indicaciones, pasemos a concluir cada uno de los temas sustraídos de las relaciones cuerpo-poder, temas que trazan los circuitos por los que ha ido transitando nuestro discurso:

\section{i) LA INMANENCIA ORIGINARIA DEL PODER EN LA CORPORALIDAD}

El cuerpo está inmerso en la facticidad de las relaciones humanas, es la agencia desde la que se erige el carácter relacional que acompaña al poder. La corporalidad ocupa un espacio en la composición de las relaciones sociales, alberga unas capacidades y potencialidades así como, también, proyecta unas necesidades vitales en el marco donde se desenvuelve la vida. Bien sea a través de mecanismos de resistencia, bien sea a través de unos estilos de vida que se mantienen y propagan, las fuerzas corporales entrañan algún tipo de poder en la medida en que los organismos vivos de los seres humanos pueden participar e irrumpir en el espacio donde se desarrollan las relaciones políticas. Los cuerpos participan dentro de un orden social cuya concurrencia conforma, ya sea activa o pasivamente, un espacio político. Los cuerpos tienen capacidad para determinar o transformar el porvenir de las relaciones sociales (agitación, desobediencia civil, participación en elecciones, movilizaciones públicas, afluencia de consumidores en espacios mercantiles, etc.).

Hemos observado que hay una gran variedad de autores en cuyos planteamientos se puede interpretar la presencia de un poder inmanente a la corporalidad, es decir, un poder que mana de las fuerzas (físicas, intelectuales y psicomotrices) intrínsecas a los cuerpos. Hemos considerado que estas orientaciones filosóficas vienen representadas por pensadores que reflexionaron sobre lo corporal ligado inextricablemente a lo político. Pese a que entre dichos pensadores se dan notables diferencias derivadas de enfoques muy distintos, sí es importante señalar que en sus argumentos, críticas o puntos de vista teóricos, la imagen conceptual de lo corporal traza una ligazón indeleble con el poder (Spinoza, La Mettrie, Marx, Nietzsche, etc.). El poderío del cuerpo y el carácter originario de tal poder aparecen de forma implícita en los análisis críticos de la dominación sobre los seres humanos, a saber, la concepción del cuerpo como una resistencia capaz de alterar unas determinaciones políticas, o, también, el cuerpo como 
contenido de un conjunto de capacidades, destrezas y potencialidades susceptibles de crear nuevos devenires en las sociedades.

En los planteamientos filosóficos que presentan al poder como dominación sobre el cuerpo, aquellos en los que el poder aparece como una instancia situada fuera de la corporalidad natural de individuos y multitudes, se aprecia cómo hay una potencia inherente a la dimensión corporal humana que tiene que ser desfragmentada, socavada, disimulada, desplazada o reorientada hacia formas de vida preferibles para los agentes que realizan la dominación sobre los cuerpos. Las fuerzas corporales tienen un recorrido y una extensión en el espacio político donde se congregan las corporalidades; detener estas fuerzas ha sido la empresa de muchos pensadores modernos y analizar cómo se produce este detenimiento la de otros, pero es fundamentalmente entre los primeros donde se hace ostensible un silencio sobre este poder corporal al que casi inconscientemente apartan de lo político. Nosotros, desde un principio, hemos abrazado la hipótesis que favorece la existencia de un poder inmanente a las fuerzas de la corporalidad, por ello, siempre hemos presupuesto la presencia de un cuerpo-poder como origen de las relaciones políticas.

La relación cuerpo-poder conforma una mismidad indisociable, no serían admisibles instancias de poder que no tuvieran como referencia última a los cuerpos. La relación cuerpo-poder o, lo que es lo mismo, tratar de identificar el poder con el cuerpo natural de los sujetos, no supone una irracionalidad ni trata de implantar una noción de poder en términos de fuerza bruta, sino que, al contrario, esta identificación reivindica una posición central del cuerpo, una posición desde la que hacer interpretables aquellas razones sobre las que se fundan e instauran asuntos que afectan a la vida humana, no solo como derecho, sino también como posibilidad. De este modo, en la convivencia humana se articulan razones en cuya convergencia y divergencia se compone una determinada racionalidad organizativa.

\section{ii) GOBIERNO DE LA INDIVIDUALIDAD}

Todo individuo es un cuerpo. Este es un primer factum ineludible en la vida, de modo que todos los seres vivientes son una corporalidad; dicho negativamente: la muerte del cuerpo supone la desaparición del individuo en su estado viviente. Este aspecto fundamental hace del cuerpo una realidad irrenunciable e indeleble en las relaciones que entablan los seres humanos y, por tanto, también en el entorno donde se 
desarrolla la política. Los problemas vitales son corporales en la medida en que no pueden originarse en otro lugar distinto al que ocupan o pretenden ocupar los cuerpos.

No se ha concebido a la individualidad en sinonimia con el individualismo, la individualidad determina los márgenes del sujeto, del individuo humano en cuanto vida que integra subjetividad y cuerpo natural. Pero el individualismo apunta a una visión predeterminada de la individualidad, prescribe una manera de dirigir la vida en la que se promueve la soberanía de sí como unidad atómico-política y atómico-económica. El individualismo carga sobre el individuo humano toda la responsabilidad del porvenir de las configuraciones sociales y políticas: el mérito económico depende del individuo, las decisiones son individuales, la ejecución del interés particular es un principio de soberanía individual, etc. El cuerpo está involucrado en el individualismo como aquello que individualiza, pues a través del cuerpo unos hombres pueden distinguirse de otros y reivindicar su irrepetible singularidad; solo esta operación sitúa al cuerpo como objeto genuino desde el que implementar las diferencias.

La procedencia y el desarrollo de los poderes dispuestos en el individuo para la dirección de su vida, sitúan al cuerpo como fuente de esta potencia, dadas las fuerzas que alberga por naturaleza. Pero las destrezas físicas e intelectuales que forman parte de la composición psicofísica del individuo suelen situar a la corporalidad como un simple ente material al servicio de los intereses de una individualidad. Una estrategia de dominación sobre el cuerpo natural del individuo ha consistido en suponer o idear figuras conceptuales que le otorguen al sujeto una verdadera humanidad: si el individuo no actúa de una determinada forma, ese individuo es catalogado como alguien que no sabe dirigir su cuerpo, alguien que no sabe gobernarse a sí mismo, que permanece en un estado infantil o más cercano a la animalidad que a la humanidad.

Las imágenes que describen a los cuerpos naturales de los individuos como entidades no susceptibles de formar un poder político por sí, conducen a una concepción del cuerpo natural que pretende destacar su supuesta imposibilidad a la hora de causar lo político, de modo que las fuerzas corporales solo podrán ser utilizadas, administradas, controladas y ponderadas por una inteligencia escindida de la corporalidad, una inteligencia caracterizada como proactiva e independiente con respecto al cuerpo. Desde esta perspectiva, la potencia corporal no cuenta con una resolución política, de hecho, tal potencia únicamente se compondría de fuerzas naturales. Los cánones sobre qué debe ser un individuo y cómo ha de actuar y comportase son establecidos desde afuera 
de la corporalidad, el cuerpo pasa a ser, por tanto, un objeto de dominación para el propio individuo.

El problema del dominio sobre los individuos le concede al cuerpo una centralidad muy explícita si nos fijamos en el gobierno de las multitudes. La atomización del cuerpo de la multitud debilita la potencia de esta masa, que pierde capacidad de influencia en el espacio público y en la política institucional. El aislamiento de los individuos divide la potencia que tiene la sociedad para actuar como masa, de hacerse poderosa en cuanto multitud, de coordinar a la población para la consecución de objetivos políticos. Las figuras de dominación producidas por el individualismo político y económico trasladan el centro de poder fuera del cuerpo social, situándolo en el seno de la individualidad, es decir, se configura al individuo como un átomo que supuestamente tiene dominio sobre sí, cuyo afectado más inmediato es el cuerpo, que pasa a ser visto como la propiedad del individuo y no como el individuo mismo.

\section{iii) LA FISURA SUJETO Y OBJETO EN EL SENO DE LA RELACIÓN CUERPO-PODER}

El poder escindido de la corporalidad en el individuo bifurca, por un lado, la dimensión subjetiva y, por el otro, la dimensión corporal; esta bifurcación, establecida por una buena parte de la filosofía moderna, traía consigo la caída de la corporalidad al lado del objeto, mientras que el poder pasaba a ocupar el lado del sujeto. El cuerpo visto bajo la categoría de objeto es representado como un ente pasivo y expuesto al control de una agencia externa a él. El cuerpo es cosificado en tanto en cuanto es visualizado como un objeto, este queda expuesto a la observación, la administración y la intervención de un sujeto que se eleva sobre la dimensión corporal del individuo.

La fisura del sujeto con respecto al cuerpo bifurca subjetividad y corporalidad. La condición de "objeto" instaurada en la concepción del cuerpo impone una determinada imagen sobre la corporalidad, imagen que está implícita en buena parte de las filosofías modernas, ya sea en la propagación de sus líneas maestras de pensamiento o en la crítica de tales supuestos. La noción de objeto justifica la articulación de formas de dominación sobre lo corporal, en la medida en que se advierte necesaria la presencia de un sujeto inteligible, activo y racional que mueva y dirija al cuerpo según una voluntad auto-regularizada y no una voluntad supuestamente animalizada, emanada de instintos, pulsiones, inclinaciones, etc. 
El cuerpo es valorado como un objeto natural más, bajo caracterizaciones como la pasividad, la contingencia, la materialidad, la irracionalidad, etc. Las funciones y fuerzas corporales pasan a ser visibilizadas como las funciones y fuerzas de un ente mecánico o de un ser bestial. Aquello que distinguiría a los seres humanos de otros seres naturales serían esencialidades como la libertad, la razón o lo estrictamente político; la presencia de tales esencialidades no se da naturalmente como objeto material. El cuerpo, en tanto en cuanto guarda una naturaleza común con los objetos físicos, no fue acompañado de los términos con que el ser humano se dignifica y se distingue del resto de seres. Pero en las estrategias corporalistas que configuran un poder corpóreo la división entre el sujeto y el objeto no se fundamenta en diferencias de este tipo, pues, más bien, en estas estrategias el poder que se corporifica es una configuración artificial, y no natural, que se erige como sujeto político; de tal forma que esta corporalidad artificial desplaza el lugar del sujeto a su lado, dejando a los cuerpos naturales como el soporte y compuesto del cuerpo político formado. Bien sean corporalidades artificiales, o bien instancias inmateriales diferentes de los objetos físicos, ambas instancias representan formas de subjetivación constituyentes de figuras de poder que instalan un sistema de dominación sobre los cuerpos.

La división entre el sujeto y el objeto distribuye los términos poder y cuerpo correspondientemente; además de operar en la individualidad, también esta división se proyecta en el espacio público, donde la sociedad es cosificada merced a justificar el dominio sobre ella. La población se ve atravesada por una fisura conceptual que relega su dimensión física a la zona lateral del objeto, al lugar donde los cuerpos quedan expuestos a observación, gestión y control por parte del sujeto. Existe, por tanto, un orden análogo entre la operación practicada sobre la individualidad, que escinde al cuerpo natural de su poder, y la fisura practicada sobre el cuerpo social, que desvertebra las corporalidades poblacionales para presentar a la sociedad como una masa carente de capacidad propia a la hora de adquirir una forma; en virtud de ello, se estaría legitimando el dominio de un poder externo a la dimensión somático-social de la multitud. El cuerpo objetificado aparece como una entidad expuesta al dominio de un sujeto escindido. La fisura entre el sujeto y el objeto referida a la individualidad y a la sociedad guarda tras de sí una relación de índole política, la del domino del sujeto sobre el objeto, la del dominio del poder sobre el cuerpo. 


\section{iv) LA PROducción de ASIMETRías EN EL DOMINIO SOBRE LOS CUERPOS NATURALES Y LA HIBRIDACIÓN DEL PODER}

La división sujeto-objeto, con todas sus connotaciones y variables individuales y sociales, impone un régimen asimétrico en el que lo corporal es planteado como objeto de dominación. Extirpar el poder original del cuerpo requiere de estrategias -como fue precisado en el punto anterior- en las que el poder se corresponda con instancias externas a la corporalidad. El poder, entonces, se instala como una realidad externa a la naturaleza de los cuerpos humanos y de sus concurrencias sociales. Este primer procedimiento estratégico que sustrae al poder de la inmanencia corporal conforma una figura de dominio que bien puede ser el cogito, el Estado, el mercado, la razón, la torre de vigilancia del panóptico, la represión sexual, etc.; de esta forma, los cuerpos se ven expuestos ante poderes ajenos a su naturaleza originaria, a saber, el cuerpo viviente con que aparece y existe todo ser humano. Precisamente, el primer paso de las estrategias por medio de las que se configuran formas de poder externas a los cuerpos consiste en articular polaridades asimétricas. En tales polaridades, la corporalidad cae bajo el espectro dominante de poderes diferentes al poder originario del cuerpo natural.

Las asimetrías generan una desigualdad categórica entre el cuerpo natural humano y otra instancia que, ya sea material, inmaterial o híbrida, recoge el poderío que le otorga potestad para erigirse en gobierno de los cuerpos. De este modo, en la polarización instaurada entre la corporalidad natural y una instancia ajena a esta, el poder se desplaza hacia el segundo lado de dicha polarización, dejando al cuerpo natural desprovisto de la potencia que le legitima políticamente. Es así cómo se produce una gobernanza vertical sobre el cuerpo de individuos y sociedades; cualquiera que sea la figura de poder extrínseca a la dimensión corporal, esta se verá respaldada por una forma de poder dominante.

Las asimetrías pueden articularse en un espacio físico cuyos relieves generan sometimiento en aquellos cuerpos a los que se pretende dominar; a través del ejercicio de presión directa, las asimetrías producen la disposición de los cuerpos con respecto a instancias de dominación con potencia física. También, en las asimetrías se distingue entre un poder incorporal intangible y un poder corporal que domina a los cuerpos naturales desde un afuera. El poder incorporal e invisible no comparte carácter alguno con la corporalidad natural humana, su exterioridad con respecto al mundo natural es el principio que legitima su capacidad para dirigir los cuerpos humanos, mientras que, en 
el caso del poder corporificado, se produce una asimetría visible sobre el terreno que dispone a los cuerpos naturales en estado de sometimiento.

Los poderes de dominación actúan como hibridaciones de contenidos subjetivos y elementos físicos; en nuestro recorrido por la historia de la filosofía moderna se hizo más hincapié en formas de poder corporales o incorporales según los parámetros establecidos por cada autor, que en algunos casos solo reforzaban o consideraban una de las dos formas de poder. Un poder corpóreo "puro" es el del Estado en Hobbes, probablemente no haya uno parecido y ha quedado demostrado que no hemos podido contemplar otro semejante, en parte, también, porque la modernidad tomó un rumbo en el que el poder y el domino sobre el cuerpo pasó a ser más valorado y efectivo si se hacía a través de la subjetividad. La modernidad promovía que los hombres pensaran, actuaran y dirigieran sus cuerpos en virtud de su voluntad, pues así los individuos actuarían de acuerdo a la libertad antes que debido a la presión directa sobre sus cuerpos. Estas preferencias se dan al menos en una parte de la historia del pensamiento político donde se estaba tratando de evitar el ejercicio del poder a través de un Estado corporificado como un gran mecanismo de coacción y represión sobre los cuerpos, la imagen de este poder estatal vino representada por el absolutismo del Antiguo Régimen. En esta situación, el Estado-cuerpo que avalaba la teoría hobbesiana fue sumando rechazos por parte de muchos filósofos modernos. No obstante, la estrategia que recurría al poder corporal fue hibridándose con estrategias de dominación indirectas. Precisamente, hemos visto cómo autores de gran envergadura han planteado el poder dominante como combinación de ambas formas estratégicas: Bentham, con su panóptico y por medio de un balance del poder corporal e incorporal propio de un economista, hibridó el cuerpo del edificio con la invisibilización e inmaterialización de los vigilantes; Marx, en su análisis del capitalismo, también dio muestras de cómo el capital actúa como un poder incorporal y corporal simultáneamente; Marcuse, a través de sus estudios sobre la civilización y la crítica de las sociedades modernas avanzadas, tuvo en cuenta tanto la producción de subjetividad como el acecho encubierto de medios coactivos; o el propio Foucault, que muestra las articulaciones que se perfilan en la subjetivación y materialización de las tecnologías de poder.

\section{v) COMPLEXIÓN POLÍTICA DEL SOMA SOCIAL}

El carácter político del soma social, al que también hemos denominado "multitud", "masa”, "población", "tropel”, "cuerpo social” etc., se ha advertido como uno de los 
temas más controvertidos en cuanto a las posiciones del poder con respecto a la corporalidad se refiere. El cuerpo social, en analogía con el cuerpo natural, mantiene una misma inmanencia de poder, lo que no ha sido reconocido por buena parte de los autores de la modernidad. Muchos de ellos, han concebido a la sociedad como un cuerpo expuesto al domino de formas de poder externas a él, en la medida en que entienden que la corporalidad social por sí sola no puede conformar un espacio político y un ordenamiento civil.

El cuerpo social ha sido despojado de su poder originario en la medida en que los grupos que lo forman fueron considerados como asociaciones producidas por la contingencia, la inercia irracional, la impulsión fisiológica, el empuje brutal de la libido o la pasividad de las pasiones; ni tampoco se reconoció orden inteligible o racional allí donde los cuerpos se reunían bien por instinto de supervivencia bien por la tradición comunitaria. El reúso a reconocer la politicidad que subyace a la vida de los grupos humanos en cuanto cuerpos justifica que lo social sea visto como un molde expuesto a instancias de poder exteriores. La reunión de los cuerpos vendría mediada por principios racionales o nómicos exteriores a la propia naturaleza corporal, de modo que el soma social carecería de forma previa.

La consideración de que la sociedad es una masa informe respalda la idea de que su dimensión somática requiera de mecanismos extrínsecos, ya sean materiales o inmateriales, que le atribuyan una complexión determinada. De este modo, se despoja a los cuerpos sociales de sus posibilidades creativas a la hora de institucionalizar y plantear como prioridades asuntos que tienen que ver con la vida pública. Las abstracciones provenientes del quehacer científico, muy especialmente de la economía como ciencia social, anteponen aspectos alejados de la vitalidad inherente a los cuerpos e ignoran el poderío que todavía contienen estos cuerpos en su inmanencia, un poder capaz de incrementarse en su resolución social y que hace de los tropeles y las multitudes formaciones corporales con potencia para cambiar las relaciones políticas y económicas.

Las filosofías que han planteado la corporalidad social en términos de poder político, es decir, aquellas filosofías que no han desechado o devaluado el conjunto de fuerzas y necesidades que surgen de los cuerpos naturales colegidos en sociedad, proporcionan una imagen de la masa somático-social más próxima a los asuntos de la vida, porque toman lo social como un cuerpo vivo capaz de adquirir expresión propia en el espacio 
político, un espacio que se le había reservado a ciertas instancias desprendidas de los cuerpos y de los problemas que afectan a la vida. Esas instancias recurren a abstracciones tanto políticas como económicas que ejercen un domino de índole general sobre toda una población, excluyendo las peculiaridades, las condiciones singulares y particularidades locales específicas de uno u otro cuerpo social.

El individualismo, reforzado por ciertas tendencias de la teoría política y económica, así como por ciertos derroteros de la cultura occidental, ha generado un abandono de la soberanía política de los cuerpos sociales en virtud de la soberanía del individuo como puntal de lo social. Se han enfatizado y mejorado aspectos que tienen que ver con la salud del cuerpo o la estética corporal de los sujetos, pero el modo en que se han enfocado estas cuestiones en la mayoría de las ocasiones contribuye a distorsionar la ligazón entre los cuerpos y su potencial político.

Las corporalidades tienen la posibilidad de concurrir en la política, de hacerse presentes en su espacio de desarrollo e interferir a fin de generar nuevas organizaciones y estilos de vida pública; ignorar este hecho, supone darle rienda suelta a tendencias políticas que tratan de empoderar de manera selectiva un tipo de corporalidades muy concretas y solo en función de determinadas características, lo que es un movimiento en falso en lo que se refiere a la recuperación del poder albergado en el cuerpo social, pues esta recuperación equivale a no incluir a todos los cuerpos presentes en un mismo espacio socio-económico y soberano. Empoderar ciertos cuerpos de la población a costa de excluir a corporalidades con otras características que bien podrían formar parte de poblaciones minoritarias o en situación de indefensión es un problema creciente que resulta de la impotencia implantada en las sociedades modernas y contemporáneas, que han mostrado graves dificultades para recuperar el poder inmanente a su corporalidad social, en buena medida, porque ha habido una política práctica y teórica que ha minusvalorado, desestimado y deslegitimado el poderío que habita en la masa. Tan solo con imaginar al soma social como un tropel o masa descontrolada, con una fuerza natural no inscrita a una inteligibilidad, se produce el pánico en el aparato conceptual individualista inserto en una buena parte de los sujetos, que ven peligrar su soberanía individual. Pero el soma social viene formado por unas relaciones sociales que lo integran, este no es un cuerpo invertebrado, sino que trae consigo una estructura relacional en la que los cuerpos cooperan y se administran a expensas de la intervención de poderes extrínsecos. 
La potencia que alberga una sociedad en cuanto cuerpo multitudinario resulta insospechada. Cabe cuestionarse, en los mismos términos en que Spinoza se preguntó por el poder del cuerpo de los hombres: ¿cuánto puede el cuerpo de la multitud? La respuesta sería que hoy, por el momento, todavía las sociedades no han tomado conocimiento de ello. Hay varias líneas de filosofía que podrían ayudarnos a comprender cómo el cuerpo social fue despojado de su poder original y proporcionarnos algunas pistas sobre cómo instituirlo, dado que el devenir de nuestro tiempo presente exige urgentemente retomar el problema de la vida tanto en su forma social como en el entorno natural donde se desenvuelve, lo que apunta a pensar cómo desarrollar la convivencia de los humanos, también en lo relativo a la implantación de una nueva adecuación a las posibilidades del planeta que habitamos y en el que coexistimos con otras formas de vida.

\section{vi) DESFIGURACIÓN DE LA IMAGEN POLÍTICA DE LO CORPORAL EN LA HISTORIA}

La suposición de que los cuerpos naturales de los hombres albergan un poderío que origina lo político, una potencia que consta de una extensión y trayectoria en el espacio donde se desarrolla la política, trajo como consecuencia emprender una reflexión sobre la corporalidad en los tránsitos históricos producidos por la filosofía moderna. Nuestra atención se ha centrado en estudiar la fragmentación del poder originario que subyace a la corporalidad, que no marca exactamente un inicio desde el punto de vista temporal porque habría que remontarse a un origen muy remoto para localizarlo-, sino que se trata de un principio sintético de la vida que aúna e identifica al cuerpo y al poder en los seres humanos. A través de este principio, hemos accedido al estudio de la historia de la modernidad como el intento de romper esta síntesis de la vida humana, por ello, destacamos la desfiguración que sufrió la imagen conceptual del cuerpo en diversos sistemas de pensamiento político y filosófico.

Nuestro análisis genealógico ha versado sobre una historia de la desfiguración de la imagen conceptual del cuerpo en la filosofía. La historia de la dominación, cuya consecuencia lateral es la resistencia, son los elementos claves del proceso de desfiguración de la imagen conceptual de los cuerpos. Aquello que los individuos y las comunidades no se verían forzados a hacer, de no ser por la presencia y persistencia de una dominación que invoca un poder o poderes exteriores al cuerpo, nos permite acceder a la comprensión de un poder-dominación que transfigura la unidad cuerpopoder. Hemos partido de que todo plan estratégico de dominación requiere de unos 
cuerpos sobre los que recaigan los controles y métodos de presión con que dominar a individuos y grupos humanos; el despliegue de estas estrategias deja tras de sí las huellas de una historia. La configuración de las imágenes conceptuales del cuerpo es el resultado de una historia de la dominación y colateralmente de la resistencia, historicidad que relata el proceso de escisión del poder con respecto al cuerpo; pero la inmanencia corporal vuelve a atraer al poder hacia el lugar de su origen, el cuerpo, de ahí que se forme una gravitación de los conceptos políticos en torno a la corporalidad. Dicha gravitación compone los escenarios por los que va a transitar la historia de la dominación, con su respectivo juego de resistencias.

La política, pensada en los márgenes de las relaciones sociales que afectan al modo de vivir, le otorga al inmanentismo corporal un poder original, puntal y necesario para pensar la dominación y la resistencia en términos históricos. Nos hemos valido de perspectivas filosóficas que preconizaban un trascendentalismo del poder con respecto a los cuerpos y que formulaban estrategias de dominación basadas en la exteriorización del poder con respecto a los cuerpos. Por otra parte, la línea de filósofos a los que hemos clasificado como "corporalistas-inmanentistas" por haber hallado una conjugación cuerpo-poder unitaria, precisamente ellos, tuvieron que desplegar un filosofar en medio de una tradición moderna que hacía del cuerpo el lugar privilegiado sobre el que verter los planes estratégico-trascendentales de dominación. No obstante, estos filósofos que defendieron de alguna u otra manera el poder olvidado y soterrado de la corporalidad, no dejaron por ello de distorsionar la imagen del cuerpo a través de las figuras de ese poder inmanente a la corporalidad, puesto que lo corporal queda a merced de las operaciones subyacentes a la inmanencia del poder.

La historia del cuerpo es la historia de la dominación y de la resistencia humana, es el tránsito sucesivo de posiciones de poder con respecto al cuerpo, donde se producen formas de dominación o formas de resistencia. Nuestra historia filosófica del cuerpo únicamente ha tratado de visibilizar la desfiguración del cuerpo en virtud de su relación con el poder, el inmanentismo corporalista se ha advertido en todas sus facetas como una manera de resistencia, es decir, una relación que unifica la identidad cuerpo-poder. Sin embargo, las desfiguraciones que sobre la imagen de la corporalidad implantan tanto la dominación como la resistencia son inevitables. En consecuencia, el siguiente paso -el propósito que resulta de esta investigación- será estudiar la situación cuerpopoder como una forma de transgresión contra los órdenes impuestos sobre los márgenes 
de la corporalidad humana, tanto en el registro de la individualidad, como en el de la sociedad y sus respectivas articulaciones. La desfiguración que la modernidad implantó sobre la imagen de la corporalidad es una transgresión sobre la unidad originaria cuerpo-poder, unidad que hemos supuesto como principio de la vida política, lo que abre una ligadura entre la potencia corporal y los márgenes público-institucionales y económicos en los que ella se encuentra inserta. 


\section{BIBLIOGRAFÍA}


Agamben, Giorgio. Estado de excepción. Homo sacer, II, I. Traducción de Flavia Costa e Ivana Costa. Buenos Aires: Adriana Hidalgo, 2005.

AgAmben, Giorgio. Homo Sacer. El poder soberano y la nuda vida. I. Traducción de Antonio Gimeno Cuspinera. Valencia: Pre-Textos, 2003.

AgAmBen, Giorgio. ¿Qué es un dispositivo? seguido de El amigo y de La Iglesia y el Reino. Traducción de Mercedes Ruvituso. Barcelona: Anagrama, 2015.

BACON, Francis. Novum Organum. Traducción de Francisco Gallach. Madrid: EspasaCalpe Palés, 1933.

BAtAille, Georges. El erotismo. Traducción de Antoni Vicens (primera parte) y Marie Paule Sarazin (segunda parte). Barcelona: Tusquets Editores, 2002.

BAtaille, Georges. Las lágrimas de Eros. Traducción de David Fernández. Barcelona: Tusquets, 2002.

Bataille, Georges. Para leer a Georges Bataille. Editado por glenn Gallardo. México D.F: Fondo de Cultura Económica, 2015.

Belaval, Yvon (dir.). Historia de la filosofía. Siglo XIX. Traducción de Eduardo Bustos, José Jiménez Jiménez, Pilar López Máñez, José Miguel Marinas, Trinidad R. Maestú. Madrid: Siglo Veintiuno Editores, 1979.

Bentham, Jeremy. El Panóptico [incluye además: El ojo del poder de Michel Foucault y Bentham en España de María Jesús Miranda]. Madrid: La Piqueta, 1979.

Bentham, Jeremy. Escritos económicos. Traducción de Francisco J. Pimentel. México D.F.: Fondo de Cultura Económica, 1965.

Bentham, Jeremy. Falacias políticas. Traducción de Javier Ballarin. Madrid: Centro de Estudios Constitucionales, 1990.

BENTHAM, Jeremy. Los principios de la moral y la legislación. Traducción de Margarita Costa. Buenos Aires: Editorial Claridad, 2008.

Bentham, Jeremy. Panóptico. Traducción de David Cruz Acevedo. Madrid: Círculo de Bellas Artes, 2011.

Bentham, Jeremy. Un fragmento sobre el gobierno. Traducción de Enrique Bocardo Crespo. Madrid: Tecnos, 2010. 
BERKElEy, George. Comentarios filosóficos, Ensayo de una nueva teoría de la visión, Tratado sobre los principios del conocimiento humano, Tres diálogos entre Hilas y Filonús, Alcifón. Traducción de José Antonio Robles, Manuel Fuentes Benot, Carlos Mellizo, Gerardo López Sastre, Pablo García Castillo. Madrid: Gredos, 2013.

BobBio, Norberto. Liberalismo y democracia. Traducción de José F. Fernández Santillán. Buenos Aires: Fondo de Cultura Económica, 1989.

BobBIO, Norberto. Locke y el derecho natural. Traducción de Rachele Facchi. Valencia: Tirant Humanidades, 2017.

BODEI, Remo. Geometría de las pasiones. Miedo, esperanza, felicidad: filosofía y uso político. Traducción de Isidro Rosas. México: Fondo de Cultura Económica, 1995.

Bueno Morales, Rafael. "Velázquez: un pintor científico del siglo XVII. Una aproximación a su técnica en el IV centenario de su nacimiento". Spin cero. Cuadernos de ciencias, no. 4 (1999): 44-46.

Brentano, Francisco. Psicología. Traducción de José Gaos. Argentina: Editorial Schapire, 1951.

CAlderón de la BARCA, Pedro. La vida es sueño. El Alcalde de Zalamea. Madrid: Espasa-Calpe, 1979.

CAnetTi, Elías. Masa y poder. Traducción de Horst Vogel. Barcelona: Muchnik Editores, 1985.

CANTILlON, Richard. Ensayo sobre la naturaleza del comercio en general. Traducción de Manuel Sánchez Sarto. Biblioteca de la libertad. http://biblioteca.libertyfund.org/sites/default/files/naturaleza-del-comercioelectronico.pdf [consultado el 29/10/2016].

CARdoso, José Luís. "El terremoto de Lisboa de 1755 y la política de regulación económica del Marqués de Pombal”. Traducción de Pablo Dopico. Historia y política, no. 16 (2006): 209-236.

Cevallos, Milena; Serra, Bernardita. "La materialidad del poder: una reflexión en torno al cuerpo", A Parte Rei, no. 47 (2006). http://serbal.pntic.mec.es/ cmunoz11/cevallos47.pdf [consultado el 1/9/2017]. 
CladAKIS, Maximiliano Basilio. "Merleau-Ponty y la ontología de la naturaleza: intercorporalidad, negatividad y dialéctica”. Diánoia 61. no. 77 (2016): 83-108.

ConCEIÇÃo, Cláudio de. Notícia do Terramoto. Lisboa: Frenesi, 2005.

Constant, Benjamin. Del espíritu de conquista y de la usurpación. Traducción de Ana Portundo Pérez. Madrid: Tecnos, 2008.

Constant, Benjamin. Escritos políticos. Traducción de María Luisa Sánchez-Mejía Rodríguez. Madrid: Centro de Estudios Constitucionales, 1989.

COnStant, Benjamin. Principios de política aplicables a todos los gobiernos. Traducción de Víctor Goldstein. Madrid: Katz, 2010.

Corbin, Alain. El perfume o el miasma. Traducción de Carlota Vallée Lazo. México D.F: Fondo de Cultura Económica, 1987.

Corbin, Alain; Courtine, Jean-Jacques; Vigarello, Georges (dir.). Historia del cuerpo. (II) De la Revolución francesa a la Gran Guerra. Traducción de Paloma Gómez, María José Hernández y Alicia Martorell. Buenos Aires: Taurus, 2005.

DARWIN, Charles. El origen de las especies. Traducción de Antonio de Zuleta. Madrid: Espasa-Calpe, 1988.

DARWIN, Charles. El origen del hombre. Traducción de Julián Aguirre. Madrid: EDAF, 1989.

DARWIn, Charles. Teoría de la evolución. Traducción de Jaume Fuster y Maria Antònia Oliver. Barcelona: Ediciones Península, 1971.

Deleuze, Gilles. En medio de Spinoza. Traducción del Equipo Editorial Cactus. Buenos Aires: Cactus, 2008.

Deleuze, Gilles. Foucault. Traducción de José Vázquez Pérez. Barcelona: Paidós, 1987.

Deleuze, Gilles. Nietzsche y la filosofía. Traducción de Carmen Arta. Barcelona: Anagrama, 1998.

Deleuze, Gilles. Spinoza: filosofía práctica. Traducción de Antonio Escohotado. Buenos Aires: Fábula, 2004.

DESCARTES, René. Correspondencia con Isabel de Bohemia y otras cartas. Traducción de María Teresa Gallego Urrutia. Barcelona: Alba Editorial, 1999. 
Descartes, René. Discurso del método, Dióptrica, Meteoros y Geometría. Traducción de Guillermo Quintás Alonso. Madrid: Alfaguara, 1981.

Descartes, René. Discurso del método. Traducción de Manuel García Morente. Madrid: Espasa-Calpe, 1973.

DesCARTES, René. Oeuvres de Descartes XI [contiene: Le monde, Description du corps humain, Passions de l'ame, Anatomica, varia]. Publiees par Charles Adam \& Paul Tannery. Paris: Léopold Cerf, Imprimeur-editeur, 1909.

Descartes, René. Obras completas de Renato Descartes. Traducción de Manuel Machado. París: Casa editorial Garnier hermanos, 1921-1938.

Dumas, Alexandre. El conde de Montecristo. Traducción del equipo "Página/12". Buenos Aires: La Página, 2006.

El Redactor Del Congreso nacional. Acta de la Declaración de la Independencia de Argentina (1816). № 6.

http://www.historiadelderecho.es/h\%20dcho/docencia/hce/TEXTOS/AMERICA NAS/LATINOAMERICANAS/ARGENTINA.pdf [consultado el 10/01/2017].

Incluye: Presidente Dr. SÁenz, Antonio; Diputado-Secretario Serrano, José Mariano. Estatuto provisional. "Sección primera. Del hombre en sociedad" (1816).

ENRÍQueZ SÁnCHEZ, José María. Desgracia e injusticia. Madrid: Sequitur, 2015.

ESCRIBANO LÓPEZ, Francesc Xavier. "Maurice Merleau-Ponty: el anclaje corpóreo en el mundo". Thémata, no. 22 (1999): 67-79.

EsPinOSA Rubio, Luciano. “La política como física del poder”. Res Publica. Revista de Historia de las Ideas Políticas 17, no. 1 (2014): 33-57.

EsPosito, Roberto. Bíos. Biopolítica y filosofía. Traducción de Carlo R. Molinari Marotto. Buenos Aires: Amorrortu, 2006.

EsPosito, Roberto. Communitas. Origen y destino de la comunidad. Traducción de Carlo R. Molinari Marotto. Buenos Aires: Amorrortu, 2007.

EsPOSITO, Roberto. Inmunitas. Protección y negación de la vida. Traducción de Luciano Padilla López. Buenos Aires: Amorrortu, 2009. 
EsPosito, Roberto. Las personas y las cosas. Traducción de Federico Villegas. Buenos Aires: Eudeba, 2016.

FERNÁNDEZ LERMA, Fernando. Algo más que belleza. Madrid: Biblioteca Nueva, 2015.

Foucault, Michel. Arqueología del saber. Traducción de Aurelio Garzón del Camino. Madrid: Siglo Veintiuno Editores, 1979.

Foucault, Michel. Defender la sociedad. Traducción de Horacio Pons. Buenos Aires: Fondo de Cultura Económica, 2000.

Foucault, Michel. El nacimiento de la clínica. Traducción de Francisco Perujo. Buenos Aires: Siglo Veintiuno Editores, 2004.

Foucault, Michel. El poder, una bestia magnífica. Traducción de Horacio Pons. Buenos Aires: Siglo Veintiuno Editores, 2012.

FoucAult, Michel. Historia de la sexualidad. 1. La voluntad de saber. Traducción de Traducción de Ulises Guiñazú. Buenos Aires: Siglo Veintiuno Editores, 2005.

Foucault, Michel. Nacimiento de la biopolítica. Traducción de Horacio Pons. Buenos Aires: Fondo de Cultura Económica de Argentina, 2007.

Foucault, Michel. Nietzsche, Freud, Marx. Traducción de Carlos Rincón. ePub base v2.1. http://ceiphistorica.com/wp-content/uploads/2016/02/mfn.pdf [consultado el 21/11/2017]

Foucault, Michel. Nietzsche, la genealogía, la historia. Traducción de José Vázquez Pérez. Valencia: Pre-textos, 2014.

Foucault, Michel. Seguridad, territorio, población. Traducción de Horacio Pons. Buenos Aires: Fondo de Cultura Económica de Argentina, 2004.

FouCAUlT, Michel. Un diálogo sobre el poder. Traducción de Miguel Morey. Madrid: Alianza, 2012.

FouCAult, Michel. Vigilar y castigar. Traducción de Aurelio Garzón del Camino. Madrid: Biblioteca Nueva, 2012.

FREUD, Sigmund. El malestar en la cultura. Traducción de Alfredo Brotons Muñoz. Madrid: Ediciones Akal, 2017.

FREUD, Sigmund. Obras completas (volumen 19). "El yo y el ello y otras obras". Traducción de José Luis Etcheverry. Buenos Aires: Amorrortu, 1992. 
Gaos, José. Historia de nuestra idea del Mundo. México D.F: Fondo de Cultura Económica, 1992.

GIDDENS, Anthony. La transformación de la intimidad. Traducción de Benito Herrero Amaro. Madrid: Cátedra, 2000.

HAN, Byung-Chul. Sobre el poder. Traducción de Alberto Ciria. Barcelona: Herder, 2016.

HANSEN Roses, Christian. Ensayo sobre el pensamiento político del Padre Juan de Mariana. Santiago de Chile: Universidad Católica de Chile, 1959.

HAYEK, Friedrich August von. Camino de servidumbre. Traducción de José Vergara. Madrid: Alianza, 1978.

HAYEK, Friedrich August von. Derecho, legislación y libertad. Una nueva formulación de los principios liberales de la justicia y de la economía política. Traducción de Luis Reig Albiol. Madrid: Unión Editorial, 1985.

HAYEK, Friedrich August von. Derecho, legislación y libertad. Volumen II: El espejismo de la justicia social. Traducción de Luis Reig Albiol. Madrid: Unión Editorial, 1988.

HAYEK, Friedrich August von. Individualismo: el verdadero y el falso. Traducción de Juan Marcos de la Fuente. Madrid: Unión Editorial, 2009.

HAYEK, Friedrich August von. Selección de textos de Friedrich A. von Hayek. Traducción de Eliana M. Santanatoglia y Federico G.M. Sosa Valle. Buenos Aires: Estudios Públicos, 2010.

HeGEL, Georg Wilhelm Friedrich. Fenomenología del espíritu. Traducción de Manuel Jiménez Redondo. Valencia: Pre-textos, 2006.

HEGEL, Georg Wilhelm Friedrich. Lecciones sobre la filosofía de la historia universal. Traducción de José Ortega y Gassett y José Gaos. Madrid: Alianza Editorial, 2004.

Hegel, Georg Wilhelm Friedrich. Principios de la Filosofía del Derecho. Traducción de Juan Luis Vermal. Barcelona: Edhasa, 1999.

HÉNAFF, Marcel. Sade. La invención del cuerpo libertino. Traducción de Antoni Vicens. Barcelona: Ediciones Destino, 1980. 
HobBes, Thomas. Leviatán. Traducción de Manuel Sánchez Sarto. Buenos Aires: Fondo de Cultura Económica de Argentina, 1992.

HobBes, Thomas. Tratado sobre el ciudadano, Leviatán, Vida de Thomas Hobbes de Malmesbury escrita por él mismo. Traducción de Joaquín Rodríguez Feo, Carlos Mellizo, José Rafael Hernández Arias. Madrid: Gredos, 2012.

Hobbes, Thomas. Tratado sobre el cuerpo. Traducción de Joaquín Rodríguez Feo. Madrid: Trotta, 2000.

Holbach, Barón de. Sistema de la naturaleza. Traducción de Nerina Bacín, José Manuel Bermudo, Miguel Estapé y Alín Solom. Madrid: Editora Nacional, 1982.

Hume, David. Del amor y del matrimonio. Traducción de Carlos Mellizo. Madrid: Alianza Editorial, 2006.

Hume, David. Ensayos morales, politicos y literarios. Traducción de Carlos Martín Ramírez. Madrid: Trotta, 2011.

HUSSERL, Edmund. Ideas relativas a una fenomenología pura y una filosofía fenomenológica. Traducción de José Gaos. México D.F: Fondo de Cultura Económica, 1949.

JARA, José. Nietzsche, un pensador póstumo. Barcelona: Anthropos, 1998.

KANT, Immanuel. "Un texto de Immanuel Kant sobre las causas de los terremotos (1756)". Traducción de Maximiliano Hernández Marcos. Cuadernos dieciochistas, no. 6 (2005): 215-224.

KLEIN, Naomi. La doctrina del Shock. Traducción de Isabel Fuentes García (agradecimientos, introducción, partes 1 y2, y conclusión), Albino Santos (partes 3 y 4), Remedios Diéguez (partes 5 y 6) y Ana Caerols (parte 7). Madrid: Espasa Libros, 2007.

KLEIST, Heinrich von. El terremoto de Chile. Traducción de José Luis Ribas, Miguel Sáenz, Juan José del Solar. Girona: Ediciones Atalanta, 2008.

KoJÈVE, Alexandre. Introducción a la lectura de Hegel. Traducción de Andrés Alonso Martos. Madrid: Trotta, 2013. 
KropotKin, Piotr. El apoyo mutuo. Traducción de Luis Orsetti (revisada y corregida por Julio Monteverde y Maila Lema). Logroño: Pepitas de calabazas, 2016.

KunderA, Milan. La insoportable levedad del ser. Traducción de Fernando Valenzuela. Barcelona: Fabula Tusquets Editores, 2005.

LA MetTRIE, Julien-Offray. Obra filosófica. Edición prepara por Menene Gras Balaguer. Madrid: Editora Nacional, 1983.

La Mettrie, Julien-Offray. Discurso sobre la felicidad. Traducción de Diego Taitán. Buenos Aires: El cuenco de plata, 2010.

Lazzarato, Maurizio. Por una política menor. Traducción de Pablo Rodríguez. Madrid: Traficantes de Sueños, 2006.

LeIBNIZ, Gottfried W. Discurso de metafísica. Traducción de Julián Marías. Madrid: Alianza, 2002.

LOCKE, John. Ensayo sobre el entendimiento humano. Traducción de Luis Rodríguez Arana. Buenos Aires: Aguilar, 1967.

LOCKE, John. Ensayos sobre la ley natural. Traducción de Isabel Ruiz Gallardón. Madrid: Universidad Complutense de Madrid, 1998.

Locke, John. Ensayo y Carta sobre la tolerancia. Traducción de Carlos Mellizo. Madrid: Alianza Editorial, 1999.

LocKE, John. Escritos monetarios. Traducción de María Olaechea. Madrid: Pirámide, 1999.

LOCKE, John. Segundo tratado sobre el gobierno. Traducción de Carlos Mellizo. Madrid: Biblioteca Nueva, 1999.

LongÁs URAngA, Fernando Daniel. La libertad en el laberinto del minotauro. Santiago de Chile: Editorial Cuarto Propio, 2005.

LYON, David (ed.). Theorizing Surveillance. Portland, Oregon, USA: William Publishing, 2006.

MACPHERSON, Crawford Brough. La teoría política del individualismo posesivo. Traducción de Juan-Ramón Capella. Barcelona: Editorial Fontanella, 1970.

MaHon, Alyce. Surrealismo, Eros y política 1938-1968. Traducción de Alejandro Pradera. Madrid: Alianza editorial, 2009. 
MALAMUD, Carlos, coord. Ruptura y reconciliación. España y el reconocimiento de las independencias latinoamericanas. Madrid: [como coeditores] Fundación MAPFRE y Santillana Ediciones Generales S.L., 2012.

MARCUSE, Herbert. El carácter afirmativo de la cultura. Comentado por Claudia Kozak y dirigido por Daniel Link. Buenos Aires: El Cuenco de Plata, 2011.

MARCuSE, Herbert. El hombre unidimensional. Traducción de Juan García Ponte. México D.F: Editorial Joaquín Mortiz S.A., 1968.

Marcuse, Herbert. Eros y civilización. Traducción de Juan García Ponce. Barcelona: Seix Barral, 1968.

MaRiana, Juan de. Del rey y de la institución real (Libro Primero). Valencia: CCM, 2009.

MARIANA, Juan de. Tratado y discurso sobre la Moneda de Vellón. Madrid: Instituto de Estudios Fiscales, 1987.

MARTín, Daniel. "El terremoto y tsunami de Lisboa de 1755". Pangeados. http://www.pangeados.com/2012/02/el-terremoto-y-tsunami-de-lisboa-de.html [consultado el 2/11/2016].

MARX, Karl. Crítica de la filosofía del Estado de Hegel. Traducción de José María Ripalda. Madrid: Biblioteca Nueva, 2010.

MARX, Karl. El capital. I. Traducción de Wenceslao Roces. México D. F: Fondo de Cultura Económica, 1946.

MARX, Karl. Introducción general a la crítica de la economía política/1857. Traducción de Miguel Murmis, Pedro Scaron y José Aricó. Córdoba, Argentina: Ediciones Pasado y Presente, 1974.

MARX, Karl. La ideología alemana. Traducción de Wenceslao Roces. Madrid: Akal, 2014.

MARX, Karl. Manuscritos de economía y filosofía. Traducción de Francisco rubio Llorente. Madrid: Alianza Editorial, 2013.

MARX, Karl. Resultados del proceso inmediato de producción. Libro I. Capítulo VI inédito de El Capital. Traducción de Pedro Scaron. México D.F: Siglo XXI Editores, 2009. 
Mercado, Tomás de. Suma de tratos y contratos. Edición de Nicolás Sánchez Albornoz. http://www.hacer.org/pdf/Tratos.pdf [consultado el 10/04/2015].

Merleau-Ponty, Maurice. El ojo y el espíritu. Traducción de Alejandro del Río Herrmann. Madrid: Trotta, 2013.

Merleau-Ponty, Maurice. Fenomenología de la percepción. Traducción de Jem Cabanes. Barcelona: Ediciones Península, 1994.

Merleau-Ponty, Maurice. La institución. La pasividad: Notas en cursos del Collège de France (1954-1955). I. La institución en la historia personal y pública. Traducción de María Larison. Barcelona: Anthropos, 2012

Merleau-Ponty, Maurice. Lo visible y lo invisible. Traducción de José Escudé. Barcelona: Editorial Seix Barral, 1966.

MiLl, John Stuart. Sobre la libertad. Traducción de Josefa Sainz Pulido. Buenos Aires: Aguilar, 1962.

NIETZSCHE, Friedrich. El Nacimiento de la tragedia. Traducción de Andrés Sánchez Pascual. Madrid: Alianza, 2000.

NIETZSCHE, Friedrich. Consideraciones intempestivas. Traducción de Eduardo Ovejero y Maury. Buenos Aires: Aguilar, 1949.

NIETZSCHE, Friedrich. Fragmentos póstumos. Volumen IV. Traducción de Juan Luis Vermal y Joan B. Llinares. Madrid: Tecnos, 2008.

NIETZSCHE, Friedrich. Fragmentos póstumos sobre politica. Traducción de José Emilio Esteban Enguita. Madrid: Trotta, 2004.

NIETZSCHE, Friedrich. La ciencia jovial <<la gaya scienza >>. Traducción de José Jara. Valparaíso: Universidad de Valparaíso Ediciones, 2013.

NiETZSCHE, Friedrich. Obras completas. Volumen IV. Traducción de Jaime Aspiunza, Manuel Barrios Casares, Kilian Lavernia, Joan B. Linares, Alejandro Martín Navarro y Diego Sánchez Meca. Madrid: Tecnos, 2016.

NIETZSCHE, Friedrich. Sobre verdad y mentira en sentido extramoral y otros fragmentos de filosofía del conocimiento. Traducción de Luis Manuel Valdés (Sobre verdad y mentira en sentido extramoral), Luis E. de Santiago Guervós (Sobre el pathos de la verdad), Joan B. Llinares (La leyenda de Edipo), Manuel Garrido (Más 
allá del bien y del mal y Primer ditirambo dionisíaco), Teresa Orduña (La voluntad de ilusión en Nietzsche). Madrid: Tecnos, 2012.

Ortega y Gasset, José; Gaos, José; Xirau, Joaquín; Palacios, Leopoldo-Eulogio; SERRANo de Haro, Agustín. Cuerpo vivido. Madrid: Ediciones encuentro, 2010.

ORwEll, George. 1984. Traducción de Rafael Vázquez Zamora. Barcelona: Austral, 2011.

PeÑa ECheverría, Francisco Javier. "Cómo se ordena la potencia de la multitud. Instituciones y derecho de la ciudad en la teoría política de Spinoza”. Revista Laguna, no. 31 (2012): 45-66.

PEÑA ECHEVERRÍA, Francisco Javier. La filosofía política de Espinosa. Valladolid: Secretariado de Publicaciones Universidad de Valladolid, 1989.

PeÑa ECHEVERría, Francisco Javier. "Rousseau y la idea de comunidad política". Isegoría, no. 11 (1995): 126-143.

PezoA, Álvaro. Política y economía en el pensamiento de John Locke. Pamplona: Ediciones Universidad de Navarra, 1997.

PigafetTA, Antonio. Navegación y descubrimiento de la India Superior Libro I. Archivo de la Frontera, 2013. http://www.archivodelafrontera.com/wpcontent/uploads/2013/05/Antonio-Pigafetta-1-con-plantilla.pdf [consultado el 12/10/2015].

PIgAFRTTA, Antonio. Navegación y descubrimiento de la India Superior Libro III. Archivo de la Frontera, 2013. http://www.archivodelafrontera.com/wpcontent/uploads/2013/05/Antonio-Pigafetta-3-con-plantilla.pdf [consultado el $15 / 10 / 2015]$.

PolANYI, Karl. La gran transformación. Traducción de Eduardo L. Rubio. México D.F.: Fondo de Cultura Económica, 1992.

POPPER, Karl Raimund. Conjeturas y refutaciones. Traducción de Néstor Míguez. Barcelona: Paidós, 1967.

PRÓSPERI, Germán Osvaldo. La cuestión del cuerpo en las filosofías de A. Kojève, G. Bataille, G. Deleuze y G. Agamben. Tesis presentada para la obtención del grado de doctor en Filosofía, Universidad Nacional de la Plata, 2012. 
http://www.memoria.fahce.unlp.edu.ar/tesis/te.809/te.809.pdf $\quad$ [consultado el 8/5/2017].

RoOver, Raymond de. "Economía escolástica". Estudios públicos, no. 9 (1983): 89121.

RousSEAU, Jean-Jacques. Discurso sobre el origen de la desigualdad entre los hombres. Edición de Eduardo Maura y Clara Navarro. Madrid: Biblioteca Nueva, 2014.

RousSEAU, Jean-Jacques. Discursos sobre la economía política. Traducción de José E. Candela. Madrid: Tecnos, 2001.

Rousseau, Jean-Jacques. El contrato social. Traducción de Consuelo Berges. Madrid: Aguilar, 1970.

Rosset, Clément. La fuerza mayor. Traducción de Rafael del Hierro. Madrid: Acuarela Editorial, 2000.

SADE, Marqués de. La filosofía en el tocador. Traducción de Ricardo Pochtar. Barcelona: Tusquets, 2009.

SAdE, Marqués de. Los infortunios de la virtud. Traducción de Juana Bignozzi. Barcelona: Fontana, 2016.

SÁEZ RuEDA, Luis. Movimientos filosóficos actuales. Madrid: Trotta, 2009.

SÁnCHEZ ARTEAGA, Juanma. "La antropología física y los 'zoológicos humanos': exhibiciones de indígenas como práctica de popularización científica en el umbral del siglo XX". Asclepio. Revista de historia de la medicina y de la ciencia 62, no. 1 (2010), 269-292.

SEnNETT, Richard. Carne y piedra. Traducción de César Vida. Madrid: Alianza Editorial, 1997.

SEnNETT, Richard. El declive del hombre público. Traducción de Gerardo Di Masso. Barcelona: Anagrama, 2011.

Smith, Adam. La riqueza de las naciones. Traducción de Carlos Rodríguez Braun. Madrid: Alianza Editorial, 2001.

SKINNER, Quentin. Hobbes y la libertad republicana. Traducción de Juliana Udi. Buenos Aires: Universidad Nacional de Quilmes, 2010. 
SPENCER, Herbert. El hombre contra el Estado. Traducción de Luis Rodríguez Aranda. Buenos Aires: Aguilar, 1963.

SPENCER, Herbert. Los primeros principios. Traducción de Eugenio López. Granada: Comares, 2009.

SPINOZA, Baruj. Ética demostrada según el orden geométrico. Traducción de Atilano Domínguez. Madrid: Trotta, 2000.

SpINOZA. Tratado político. Traducción de Atilano Domínguez. Madrid: Alianza Editorial, 1986.

SPINOZA. Tratado teológico-político. Traducción de Atilano Domínguez. Madrid: Alianza editorial, 1986.

Steadman, Philip. "Samuel Bentham's Panopticon”. Journal of Bentham Studies 14, no. 1 (2012): 1-30.

STIRnER, Max. El único y su propiedad. Traducción de José Rafael Hernández Arias. Madrid: Valdemar, 2004.

TocQueville, Alexis de. La democracia en América. Traducción de Marcelo ArroitaJáuregui. Madrid: Orbis, 1985.

TOCQueviLle, Alexis de. Tocqueville. Igualdad social y libertad política. Traducción de Joaquín Esteban Perruca. Barcelona: Página indómita, 2015.

TURNER, Bryan. El cuerpo y la sociedad. Traducción de Eric Herrán Salvatti. México D.F: Fondo de Cultura Económica, 1989.

Valencia Avaria, Luis. La Declaración de la Independencia de Chile. Santiago de Chile: Imp. El Esfuerzo, 1943.

VEGA, Lope de. Fuente Ovejuna. Edición de Juan María Martín. Madrid: Cátedra, 1983.

VILLAR, Alicia. Voltaire-Rousseau. En torno al mal natural. Selección y traducción de textos de Alicia Villar. Madrid: Alianza Editorial, 1995.

Villarroel, Raúl. La naturaleza como texto. Hermenéutica y crisis medioambiental. Santiago de Chile: Editorial Universitaria, 2006.

VILlarRoel, Raúl. Interesarse por la vida. Ensayos bioéticos y biopolíticos. Santiago de Chile: Universitaria, 2014. 
VIRILIO, Paul. La máquina de la visión. Traducción de Mariano Antolín Rato. Madrid: Cátedra, 1998.

Voltaire. Cándido y otros cuentos. Traducción de Carlos Pujol. Barcelona: RBA Editores, 1993.

Watson, Richard. Descartes. El filósofo de la luz. Traducción de Carlos Gardini. Barcelona: Ediciones B, S.A., 2003.

WELls, Herbert George. El hombre invisible. Traducción de Jenis Ochoa. Barcelona: Olmak Trade, 2016.

WERRETT, Simon. "El panóptico en el jardín: La casa de inspección de Samuel Bentham y la teatralidad de la nobleza en la Rusia del siglo XVIII". Traducción de Alejandro Recio Sastre. Scientia Helmántica 2, no. 4 (2014): 32-59. 